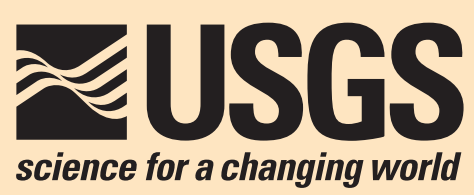

Global Mineral Resource Assessment

\title{
Porphyry Copper Assessment of East and Southeast Asia- Philippines, Taiwan (Republic of China), Republic of Korea (South Korea), and Japan
}

Prepared in cooperation with the Coordinating Committee for Geoscience Programmes in East and Southeast Asia

Scientific Investigations Report 2010-5090-P 



\section{Global Mineral Resource Assessment}

\section{Porphyry Copper Assessment of East and Southeast Asia-Philippines, Taiwan (Republic of China), Republic of Korea (South Korea), and Japan}

By Jane M. Hammarstrom, Arthur A. Bookstrom, Michael W. DeMarr, Connie

L. Dicken, Steve Ludington, Gilpin R. Robinson, Jr., and Michael L. Zientek with contributions from Dennis P. Cox, Claro Jose C. Manipon, Lilian A. Rollan, Takehiro Sakimoto, Tetsuichi Takagi, and Yasushi Watanabe

Prepared in cooperation with the Coordinating Committee for Geoscience

Programmes in East and Southeast Asia

Scientific Investigations Report 2010-5090-P 


\title{
U.S. Department of the Interior SALLY JEWELL, Secretary
}

\section{U.S. Geological Survey \\ Suzette M. Kimball, Acting Director}

\author{
U.S. Geological Survey, Reston, Virginia: 2014
}

For more information on the USGS - the Federal source for science about the Earth, its natural and living resources, natural hazards, and the environment, visit http://www.usgs.gov or call 1-888-ASK-USGS.

For an overview of USGS information products, including maps, imagery, and publications, visit http://www.usgs.gov/pubprod

To order this and other USGS information products, visit http://store.usgs.gov

Any use of trade, firm, or product names is for descriptive purposes only and does not imply endorsement by the U.S. Government.

Although this information product, for the most part, is in the public domain, it also may contain copyrighted materials as noted in the text. Permission to reproduce copyrighted items must be secured from the copyright owner.

Suggested citation:

Hammarstrom, J.M., Bookstrom, A.A., DeMarr, M.W., Dicken, C.L., Ludington, S., Robinson, Jr., G.R., and Zientek, M.L., with contributions from Cox, D.P., Manipon, C.J.C., Rollan, L.A., Sakimoto, T., Takagi, T., and Watanabe, Y., 2014, Porphyry copper assessment of East and Southeast Asia-Philippines, Taiwan (Republic of China), Republic of Korea (South Korea), and Japan: U.S. Geological Survey Scientific Investigations Report 2010-5090-P, 241 p., and spatial data, http://dx.doi.org/10.3133/sir20105090P.

ISSN 2328-0328 (online 


\section{Contents}

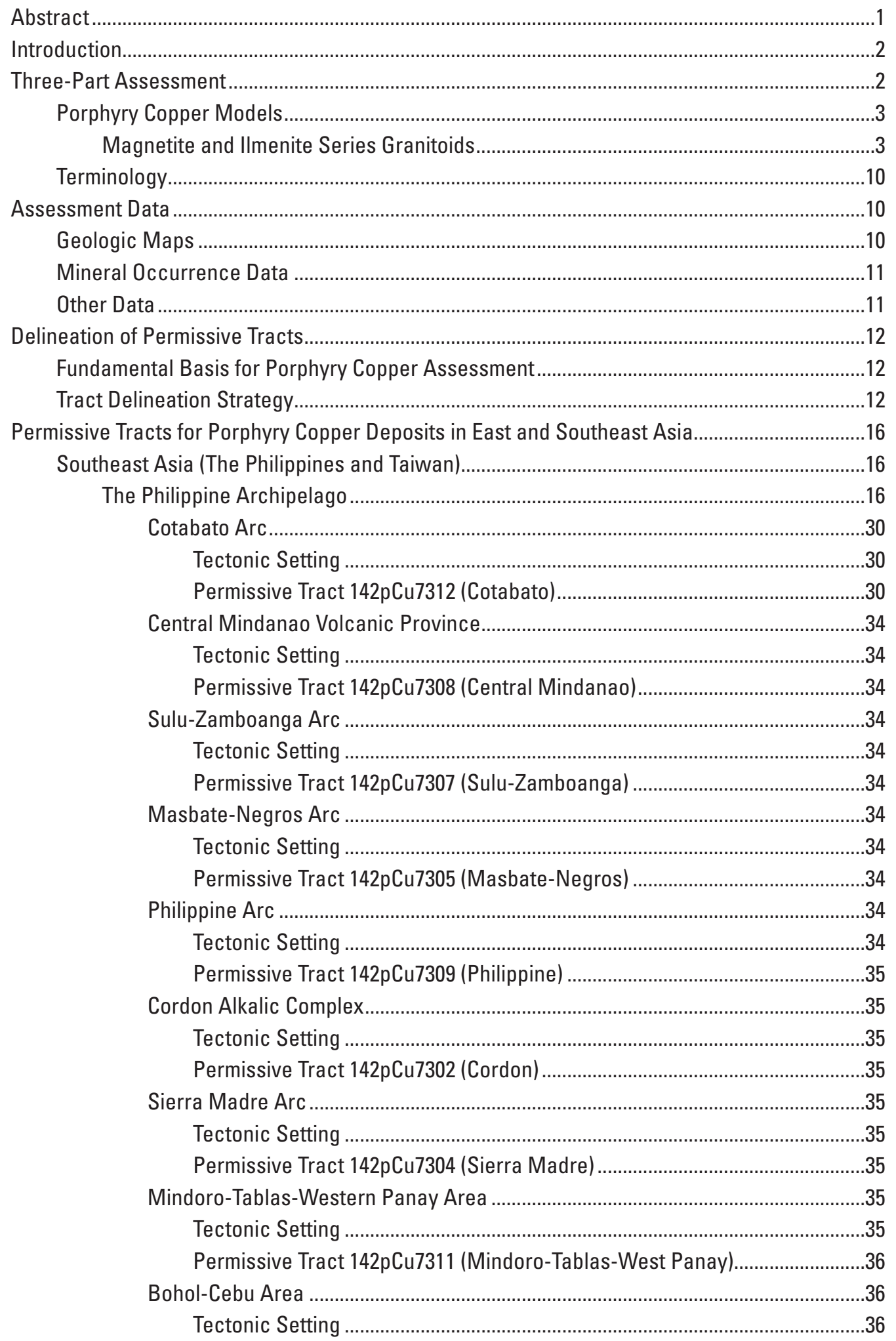


Permissive Tract 142pCu7306 (Bohol-Cebu Area) ............................................36

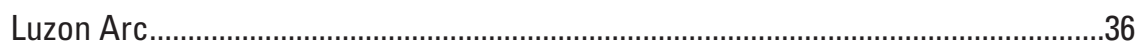

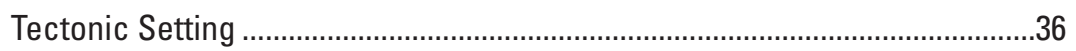

Permissive Tract 142pCu7301 (Luzon)............................................................36

East Asia (South Korea and Japan) .....................................................................................

Mesozoic to Holocene Evolution of the East Asian Continental Margin .........................38

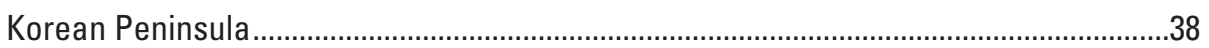

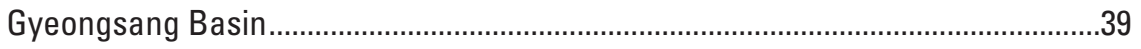

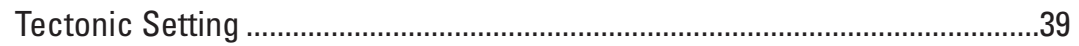

Permissive Tract 142pCu7313 (Gyeongsang Basin) ………...........................39

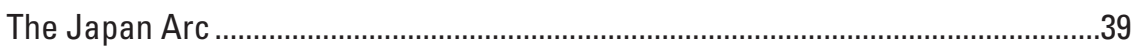

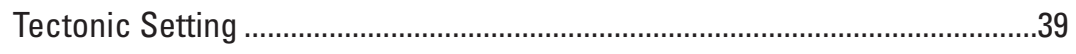

Permissive Tract 142pCu7314 (Western Honshu) ..............................................42

Japan and South Korea ..................................................................................................

Neogene Volcanic Arcs ................................................................................5

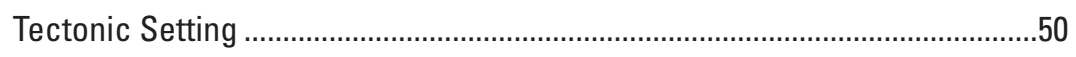

Permissive Tract 142pCu7315 (Subaerial Neogene Arcs of

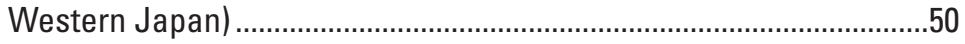

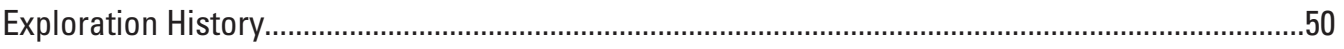

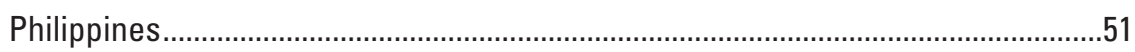

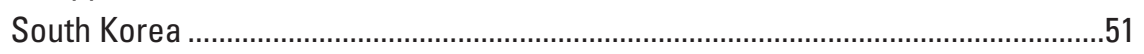

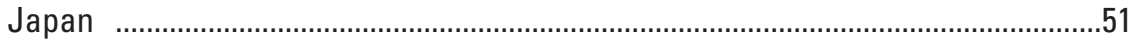

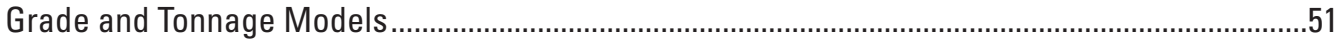

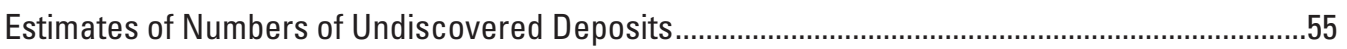

Simulation of Undiscovered Resources in Southeast Asia .........................................................56

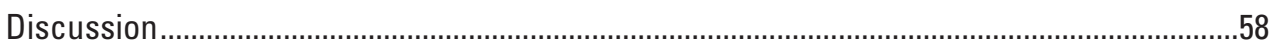

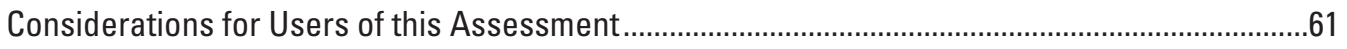

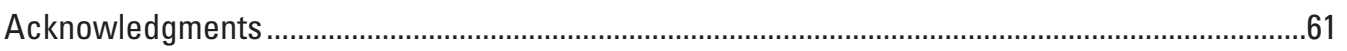

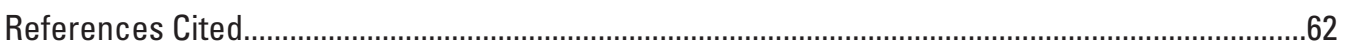

Appendix A. Porphyry Copper Assessment for Tract 142pCu7312,

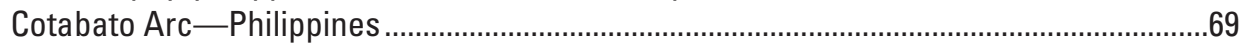

Appendix B. Porphyry Copper Assessment for Tract 142pCu7308,

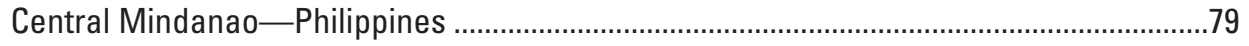

Appendix C. Porphyry Copper Assessment for Tract 142pCu7307,

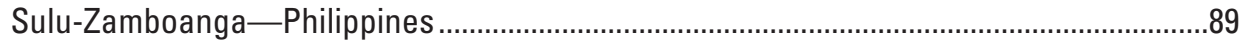

Appendix D. Porphyry Copper Assessment for Tract 142pCu7305,

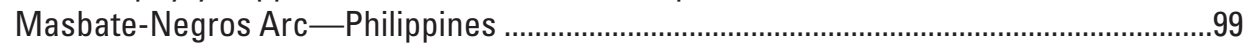

Appendix E. Porphyry Copper Assessment for Tract 142pCu7309,

Philippine Arc-Philippines ......................................................................................111

Appendix F. Porphyry Copper Assessment for Tract 142pCu7302,

Cordon Alkalic Complex —Philip pines ........................................................................129

Appendix G. Porphyry Copper Assessment for Tract 142pCu7304,

Sierra Madre Arc-Philippines

Appendix H. Porphyry Copper Assessment for Tract 142pCu7311,

Mindoro-Tablas-West Panay Area—Philippines ..............................................................155

Appendix I. Porphyry Copper Assessment for Tract 142pCu7306,

Bohol-Cebu Area-Philippines 
Appendix J. Porphyry Copper Assessment for Tract 142pCu7301, Luzon Arc-Philippines and Taiwan (Republic of China)

Appendix K. Porphyry Copper Assessment for Tract 142pCu7313,

Gyeongsang Basin Area—Republic of Korea (South Korea) .............................................213

Appendix L. Porphyry Copper Assessment for Tract 142pCu7314,

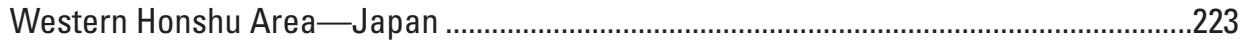

Appendix M. Porphyry Copper Assessment for Tract 142pCu7315,

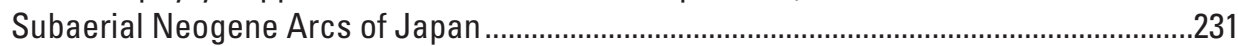

Appendix N. Description of Spatial Data Files .................................................................................241

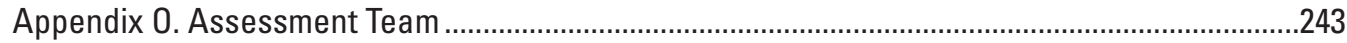




\section{Figures}

1. Map showing location of the study area in East and Southeast Asia

2. Maps showing the principal magmatic arcs and belts of East and Southeast Asia

3. Maps of permissive tracts for porphyry copper deposits in countries covered in this report

4. Maps showing physiographic features and locations of porphyry copper deposits (named) and prospects in the Philippines and Taiwan

5. Map showing the tectonic setting of the Philippines

6. Graph showing the age and deposit-type distribution of post-Cretaceous porphyry copper deposits across the Philippine Archipelago as a function of longitude across the islands, from west to east.....

7. Map showing the Luzon Arc segments.

8. Map showing physiographic features and locations of porphyry copper prospects and copper occurrences in the Republic of Korea and Japan, along with province boundaries for North and South Korea and prefecture boundaries for Japan

9. Simplified map showing the distribution of Cretaceous granitoids of the northern Eurasian continental margin

10. Map showing tectonic setting of the Eurasian continental margin.

11. Maps showing tectonic divisions and Mesozoic igneous rocks of the Korean Peninsula

12. Maps showing metallogenic provinces and igneous rocks of Japan ............................47

13. Tonnage model analysis for the Philippines.....

14. Graphical summary of results as bar charts comparing identified copper resources with mean and median estimated copper in undiscovered porphyry copper deposits on a tract by tract basis for the Philippines

A1. Map showing tract location, known deposits, and significant prospects and occurrences for tract 142pCu7312, Cotabato Arc-Philippines

A2. Map showing the distribution of permissive igneous rocks for tract 142pCu7312, Cotabato Arc-Philippines

A3. Cumulative frequency plot showing the results of Monte Carlo computer simulation of undiscovered resources in 142pCu7312, Cotabato Arc-Philippines .......76

B1. Map showing tract location and significant porphyry copper prospects for tract 142pCu7308, Central Mindanao-Philippines

B2. Map showing the distribution of permissive igneous rocks for tract 142pCu7308, Central Mindanao-Philippines.

B3. Cumulative frequency plot showing the results of Monte Carlo computer simulation of undiscovered resources in 142pCu7308, Central Mindanao-Philippines .....

C1. Map showing tract location and significant porphyry copper prospects for tract 142pCu7307, Sulu-Zamboanga Arc-Philippines

C2. Map showing the distribution of permissive igneous rocks for tract 142pCu7307, Sulu-Zamboanga Arc-Philippines.

C3. Cumulative frequency plot showing the results of Monte Carlo computer simulation of undiscovered resources in 142pCu7307, Sulu-Zamboanga Arc-Philippines.

D1. Map showing tract location, porphyry copper deposits, and porphyry copper prospects for tract 142pCu7305, Masbate-Negros Arc-Philippines 
D2. Map showing the distribution of permissive igneous rocks for tract 142pCu7305, Masbate-Negros Arc-Philippines.

D3. Cumulative frequency plot showing the results of Monte Carlo computer simulation of undiscovered resources in tract 142pCu7305, Masbate-Negros Arc-Philippines.

E1. Map showing tract location and significant porphyry copper prospects for tract 142pCu7309, Philippine Arc-Philippines

E2. Map showing the distribution of permissive igneous rocks for tract 142pCu7309, Philippine Arc-Philippines.

E3. Cumulative frequency plot showing the results of Monte Carlo computer simulation of undiscovered resources in 142pCu7309, Philippine Arc-Philippines

F1. Map showing tract location and significant porphyry copper prospects for tract 142pCu7302, Cordon Alkalic Complex-Philippines

F2. Map showing the distribution of permissive igneous rocks for tract 142pCu7302, Cordon Alkalic Complex-Philippines

F3. Cumulative frequency plot showing the results of Monte Carlo computer simulation of undiscovered resources in 142pCu7302, Cordon Alkalic Complex-Philippines.

G1. Maps showing tract location, deposits, and significant porphyry copper prospects for tract 142pCu7304, Sierra Madre Arc-Philippines

G2. Maps showing the distribution of permissive igneous rocks for tract $142 \mathrm{pCu} 7304$, Sierra Madre Arc-Philippines.

G3. Cumulative frequency plot showing the results of Monte Carlo computer simulation of undiscovered resources in tract 142pCu7304, Sierra Madre Arc-Philippines.

H1. Map showing tract location and porphyry copper prospects for tract 142pCu7311, Mindoro-Tablas-West Panay Area-Philippines

H2. Map showing the distribution of permissive igneous rocks for tract 142pCu7311, Mindoro-Tablas-West Panay Area-Philippines

H3. Cumulative frequency plot showing the results of Monte Carlo computer simulation of undiscovered resources in tract 142pCu7311, Mindoro-Tablas-West Panay Area-Philippines

11. Map showing tract location and significant porphyry copper prospects for tract 142pCu7306, Bohol-Cebu Area-Philippines

12. Map showing the distribution of permissive igneous rocks for tract 142pCu7306, Bohol-Cebu Area-Philippines.

13. Sketch map of the historical Atlas Mine on Cebu Island

14. Cumulative frequency plot showing the results of Monte Carlo computer simulation of undiscovered resources in 142pCu7306, Bohol-Cebu Area-Philippines

J1. Maps showing tract location, deposits, and significant prospects for tract 142pCu7301, Luzon Arc-Philippines and Taiwan (Republic of China).

J2. Map showing the distribution of permissive igneous rocks for tract 142pCu7301, Luzon Arc - the Philippines and Taiwan.

J3. Map showing the relation of porphyry copper deposits and prospects to major faults in the Luzon Central Cordillera, northern Luzon—Philippines

J4. Cumulative frequency plot showing the results of Monte Carlo computer simulation of undiscovered resources in tract 142pCu7301, Luzon Arc - the Philippines and Taiwan (Republic of China)

K1. Map showing tract location and significant prospects and occurrences for tract 142pCu7313, Gyeongsang Basin Area-Republic of Korea 
K2. Map showing igneous rocks used to delineate tract 142pCu7313, Gyeongsang Basin Area-Republic of Korea...

K3. Map showing the distribution of copper, molybdenum, gold, tungsten and lead occurrences in South Korea

L1. Map showing the location of permissive tract 142pCu7314, Western Honshu Area-Japan

L2. Map showing the distribution of Cretaceous and Paleogene permissive rocks in the Inner Zone of southwest Japan

M1. Map showing the location of permissive tract 142pCu7315, Neogene arcs of Japan.

M2. Map showing the distribution of Miocene and younger permissive rocks associated with Neogene arcs in Japan.

\section{Tables}

1. Summary of identified resources in porphyry copper deposits in the Philippines............6

2. Principal magmatic arcs of East and Southeast Asia .................................................15

3. Permissive tracts for porphyry copper deposits in East and Southeast Asia .................19

4. Grade and tonnage model selections for simulations of undiscovered resources ........54

5. Estimates of numbers of undiscovered porphyry copper deposits in East and Southeast Asia

6. Summary of simulations of undiscovered resources in porphyry copper deposits in East and Southeast Asia

A1. Summary of selected resource assessment results for tract 142pCu7312, Cotabato Arc-Philippines

A2. Map units that define tract 142pCu7312, Cotabato Arc_-Philippines ............................73

A3. Porphyry copper deposits in tract 142pCu7312, Cotabato Arc-Philippines ...................73

A4. Significant prospects and occurrences in tract 142pCu7312, Cotabato Arc-Philippines

A5. Principal sources of information used for tract 142pCu7312, Cotabato

Arc-Philippines.

A6. Undiscovered deposit estimates, deposit numbers, and tract area for tract 142pCu7312, Cotabato Arc-Philippines.

A7. Results of Monte Carlo simulation of undiscovered resources for tract 142pCu7312, Cotabato Arc-Philippines

B1. Summary of selected resource assessment results for tract 142pCu7308,

Central Mindanao-Philippines

B2. Map units that define tract 142pCu7308, Central Mindanao-Philippines .......................83

B3. Significant prospects and occurrences in tract 142pCu7308, Central Mindanao-Philippines

B4. Principal sources of information used for tract 142pCu7308, Central Mindanao-Philippines

B5. Undiscovered deposit estimates, deposit numbers, tract area, and deposit density for tract 142pCu7308, Central Mindanao-Philippines

B6. Results of Monte Carlo simulation of undiscovered resources for tract 142pCu7308, Central Mindanao-Philippines 
C1. Summary of selected resource assessment results for tract 142pCu7307,

Sulu-Zamboanga Arc—Philippines ...........................................................................89

C2. Map units that define tract 142pCu7307, Sulu-Zamboanga Arc-Philippines ................93

C3. Significant prospects and occurrences in tract 142pCu7307, Sulu-Zamboanga

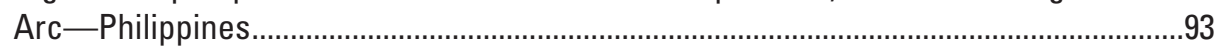

C4. Principal sources of information used for tract 142pCu7307, Sulu-Zamboanga Arc_-Philippines.................................................................................................94

C6. Results of Monte Carlo simulation of undiscovered resources for tract 142pCu7307, Sulu-Zamboanga Arc_Philippines .................................................95

C5. Undiscovered deposit estimates, deposit numbers, tract area, and deposit density for tract 142pCu7307, Sulu-Zamboanga Arc_Philippines ..................................95

D1. Summary of selected resource assessment results for tract 142pCu7305, Masbate-Negros Arc_Philippines .............................................................................

D2. Map units that define tract 142pCu7305, Masbate-Negros Arc-Philippines...............103

D3. Porphyry copper deposits in tract 142pCu7305, Masbate-Negros Arc-Philippines .103

D4. Significant prospects and occurrences in tract 142pCu7305, Masbate-Negros

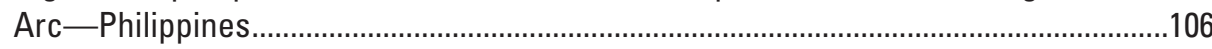

D5. Principal sources of information used for tract 142pCu7305, Masbate-Negros Arc-Philippines.

D6. Undiscovered deposit estimates, deposit numbers, tract area, and deposit density for tract 142pCu7305, Masbate-Negros Arc-Philippines

D7. Results of Monte Carlo simulation of undiscovered resources for tract 142pCu7305, Masbate-Negros Arc-Philippines

E1. Summary of selected resource assessment results for tract 142pCu7309, Philippine Arc-Philippines.

E2. Map units that define tract 142pCu7309, Philippine Arc-Philippines ..........................116

E3 Porphyry copper deposits in tract 142pCu7309, Philippine Arc-Philippines................117

E4. Significant prospects and occurrences in tract 142pCu7309, Philippine Arc-Philippines.

E5. Principal sources of information used for tract 142pCu7309, Philippine Arc-Philippines.

E6. Undiscovered deposit estimates, deposit numbers, tract area, and deposit density for tract 142pCu7309, Philippine Arc-Philippines

E7. Results of Monte Carlo simulation of undiscovered resources for tract 142pCu7309, Philippine Arc-Philippines

F1. Summary of selected resource assessment results for tract 142pCu7302, Cordon Alkalic Complex-Philippines

F2. Map units that define tract 142pCu7302, Cordon Alkalic Complex-Philippines ..........133

F3. Porphyry copper deposits in tract 142pCu7302, Cordon Alkalic Complex-Philippines.

F4. Significant prospects and occurrences in tract 142pCu7302, Cordon Alkalic Complex-Philippines.

F5. Principal sources of information used for tract 142pCu7302, Cordon Alkalic Complex-Philippines.

F6. Undiscovered deposit estimates, deposit numbers, tract area, and deposit density for tract 142pCu7302, Cordon Alkalic Complex-Philippines

F7. Results of Monte Carlo simulation of undiscovered resources for tract 142pCu7302, Cordon Alkalic Complex-Philippines 
G1. Summary of selected resource assessment results for tract 142pCu7304,

Sierra Madre Arc-Philippines.

G2. Map units that define tract 142pCu7304, Sierra Madre Arc-Philippines.

G3. Porphyry copper deposits in tract 142pCu7304, Sierra Madre Arc_Philippines .........147

G4. Significant prospects and occurrences in tract 142pCu7304, Sierra

Madre Arc-Philippines.

G5. Principal sources of information used for tract 142pCu7304, Sierra

Madre Arc-Philippines.

G6. Undiscovered deposit estimates, deposit numbers, tract area, and deposit density for tract 142pCu7304, Sierra Madre Arc-Philippines

G7. Results of Monte Carlo simulation of undiscovered resources for tract 142pCu7304, Sierra Madre Arc-Philippines.

H1. Summary of selected resource assessment results for tract 142pCu7311, Mindoro-Tablas-West Panay Area-Philippines.

H2. Map units that define tract 142pCu7311, Mindoro-Tablas-West Panay Area-Philippines

H3. Significant prospects and occurrences in tract 142pCu7311, Mindoro-Tablas-West Panay Area-Philippines.

H4. Principal sources of information used for tract 142pCu7311, Mindoro-Tablas-West Panay Area-Philippines.

H5. Undiscovered deposit estimates, deposit numbers, tract area, and deposit density for tract 142pCu7311, Mindoro-Tablas-West Panay Area-Philippines

H6. Results of Monte Carlo simulation of undiscovered resources for tract 142pCu7311, Mindoro-Tablas-West Panay-Philippines.

11. Summary of selected resource assessment results for tract 142pCu7306 Bohol-Cebu Area-Philippines 167

12. Map units that define tract 142pCu7306, Bohol-Cebu Area-Philippines 170

13. Porphyry copper deposits in tract 142pCu7306, Bohol-Cebu Area-Philippines ..........173

14. Significant prospects and occurrences in tract 142pCu7306 Bohol-Cebu Area-Philippines

15. Principal sources of information used for tract 142pCu7306 Bohol-Cebu Area-Philippines

16. Undiscovered deposit estimates, deposit numbers, and tract area for tract 142pCu7306 Bohol-Cebu Area-Philippines.

17. Results of Monte Carlo simulation of undiscovered resources for tract 142pCu7306 Bohol-Cebu Area-Philippines.

J1. Summary of selected resource assessment results for tract 142pCu7301, Luzon Arc-Philippines and Taiwan (Republic of China)

J2. Map units that define tract 142pCu7301, Luzon Arc-Philippines and Taiwan (Republic of China)

J3 Porphyry copper deposits in tract 142pCu7301, Luzon Arc—Philippines and Taiwan (Republic of China).

J4. Significant prospects and occurrences in tract 142pCu7301, Luzon

Arc-Philippines and Taiwan (Republic of China)

J5. Principal sources of information used for tract 142pCu7301, Luzon

Arc-Philippines and Taiwan (Republic of China).

J6. Undiscovered deposit estimates, deposit numbers, tract area, and deposit density for tract 142pCu7301, Luzon Arc-Philippines and Taiwan (Republic of China) 
J7. Results of Monte Carlo simulation of undiscovered resources for tract 142pCu7301, Luzon Arc_-Philippines and Taiwan (Republic of China) ..................206

K1. Summary of selected resource assessment results for tract 142pCu7313, Gyeongsang Basin Area-Republic of Korea ............................................................213

K2. Map units that define tract 142pCu7313, Gyeongsang Basin Area-Republic

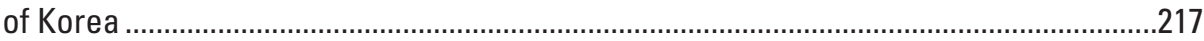

K3. Significant prospects and occurrences in tract 142pCu7313, Gyeongsang Basin Area-Republic of Korea ............................................................217

K4. Principal sources of information used for tract 142pCu7313, Gyeongsang Basin Area-Republic of Korea ................................................................................220

L1. Summary of selected resource assessment results for tract 142pCu7314, Western Honshu Area_Japan..................................................................................223

L2. Map units that define tract 142pCu7314, Western Honshu Area-Japan ......................227

L3. Principal sources of information used for tract 142pCu7314, Western Honshu Area-Japan .228

M1. Summary of selected resource assessment results for tract 142pCu7315, Subaerial Neogene Arcs of Western Japan

M2. Map units that define tract 142pCu7315, Subaerial Neogene Arcs of Western Japan.

M3. Principal sources of information used for tract 142pCu7315, Subaerial Neogene Arcs of Western Japan 


\section{Conversion Factors, Abbreviations and Acronymns, and Chemical Symbols}

\section{Conversion Factors}

Inch/Pound to SI

\begin{tabular}{|c|c|c|}
\hline Multiply & By & To obtain \\
\hline \multicolumn{3}{|c|}{ Length } \\
\hline inch (in) & 2.54 & centimeter $(\mathrm{cm})$ \\
\hline foot $(\mathrm{ft})$ & 0.3048 & meter $(\mathrm{m})$ \\
\hline mile (mi) & 1.609 & kilometer (km) \\
\hline yard (yd) & 0.9144 & meter $(\mathrm{m})$ \\
\hline \multicolumn{3}{|c|}{ Area } \\
\hline acre & 4,047 & square meter $\left(\mathrm{m}^{2}\right)$ \\
\hline square foot $\left(\mathrm{ft}^{2}\right)$ & 0.09290 & square meter $\left(\mathrm{m}^{2}\right)$ \\
\hline square mile $\left(\mathrm{mi}^{2}\right)$ & 259.0 & hectare (ha) \\
\hline square mile $\left(\mathrm{mi}^{2}\right)$ & 2.590 & square kilometer $\left(\mathrm{km}^{2}\right)$ \\
\hline \multicolumn{3}{|c|}{ Mass } \\
\hline ounce, avoirdupois (oz) & 28.35 & $\operatorname{gram}(\mathrm{g})$ \\
\hline pound, avoirdupois (lb) & 0.4536 & kilogram (kg) \\
\hline ton, short $(2,000 \mathrm{lb})$ & 0.9072 & megagram (Mg) \\
\hline \multicolumn{3}{|l|}{ SI to Inch/Pound } \\
\hline Multiply & By & To obtain \\
\hline \multicolumn{3}{|c|}{ Length } \\
\hline centimeter $(\mathrm{cm})$ & 0.3937 & inch (in) \\
\hline meter $(\mathrm{m})$ & 3.281 & foot $(\mathrm{ft})$ \\
\hline kilometer (km) & 0.6214 & mile (mi) \\
\hline $\operatorname{meter}(\mathrm{m})$ & 1.094 & yard (yd) \\
\hline \multicolumn{3}{|c|}{ Area } \\
\hline square meter $\left(\mathrm{m}^{2}\right)$ & 0.0002471 & acre \\
\hline square meter $\left(\mathrm{m}^{2}\right)$ & 10.76 & square foot $\left(\mathrm{ft}^{2}\right)$ \\
\hline hectare (ha) & 0.003861 & square mile $\left(\mathrm{mi}^{2}\right)$ \\
\hline square kilometer $\left(\mathrm{km}^{2}\right)$ & 0.3861 & square mile $\left(\mathrm{mi}^{2}\right)$ \\
\hline \multicolumn{3}{|c|}{ Mass } \\
\hline $\operatorname{gram}(\mathrm{g})$ & 0.03527 & ounce, avoirdupois (oz) \\
\hline kilogram (kg) & 2.205 & pound avoirdupois (lb) \\
\hline megagram (Mg) & 1.102 & ton, short $(2,000 \mathrm{lb})$ \\
\hline megagram (Mg) & 0.9842 & ton, long $(2,240 \mathrm{lb})$ \\
\hline
\end{tabular}




\section{Acronyms and Abbreviations Used}

\begin{tabular}{ll}
\hline ANOVA & analysis of variance \\
GIS & geographic information system \\
$\mathbf{g} / \mathbf{t}$ & grams per metric ton \\
$\mathbf{k t}$ & thousand metric tons \\
IP & induced polarization geophysical technique \\
LILE & large ion lithophile elements \\
$\mathbf{M a}$ & million of years before the present \\
$\mathbf{M t}$ & million metric tons \\
PGE & platinum-group elements \\
REE & rare-earth elements \\
SHRIMP & sensitive high resolution ion microprobe \\
SSIB & small-scale digital international boundaries \\
$\mathbf{t}$ & metric ton (tonne) or megagram (Mg) \\
USGS & U.S. Geological Survey \\
\hline
\end{tabular}

\section{Chemical Symbols Used}

\begin{tabular}{ll}
$\mathbf{A g}$ & silver \\
$\mathbf{A u}$ & gold \\
$\mathbf{B i}$ & bismuth \\
$\mathbf{C o}$ & cobalt \\
$\mathbf{C u}$ & copper \\
$\mathbf{M o}$ & molybdenum \\
$\mathbf{P b}$ & lead \\
$\mathbf{Z n}$ & zinc \\
\hline
\end{tabular}


This page left intentionally blank. 


\title{
Porphyry Copper Assessment of East and Southeast Asia-Philippines, Taiwan (Republic of China), Republic of Korea (South Korea), and Japan
}

\author{
By Jane M. Hammarstrom', Arthur A. Bookstrom², Michael W. DeMarr',Connie L. Dicken', Steve Ludington³, \\ Gilpin R. Robinson, Jr. ${ }^{1}$, and Michael L. Zientek ${ }^{2}$ with contributions from Dennis P. Cox ${ }^{3}$, Claro J. Manipon ${ }^{4}$, \\ Lilian A. Rollan ${ }^{4}$, Takehiro Sakimoto ${ }^{5}$, Tetsuichi Takagi ${ }^{5}$, and Yasushi Watanabe ${ }^{5}$
}

\section{Abstract}

The U.S. Geological Survey collaborated with member countries of the Coordinating Committee for Geoscience Programmes in East and Southeast Asia (CCOP) on an assessment of the porphyry copper resources of East and Southeast Asia as part of a global mineral resource assessment. The assessment covers the Philippines in Southeast Asia, and the Republic of Korea (South Korea), Taiwan (Province of China), and Japan in East Asia. The Philippines host world class porphyry copper deposits, such as the Tampakan and Atlas deposits. No porphyry copper deposits have been discovered in the Republic of Korea (South Korea), Taiwan (Province of China), or Japan.

Thirteen geographic areas were delineated as tracts that are permissive for porphyry copper deposits in the assessed area. Individual tracts range from about 3,000 to 100,000 square kilometers in area. Permissive tracts are delineated on the basis of mapped distributions of igneous rocks of specific age ranges that define subduction-related magmatic arcs or magmatic belts that might contain porphyry copper deposits. Most of these magmatic arcs are subduction related, although some porphyry deposits and prospects are present in back-arc or poorly understood tectonic settings. Maps at various scales were used in the compilation; however, the final tract boundaries are intended for use at a scale of 1:1,000,000.

Numbers of undiscovered deposits were estimated at different levels of confidence for 10 permissive tracts in the Philippines including one area that extends to eastern Taiwan

${ }^{1}$ U.S. Geological Survey, Reston, Virginia, United States.

${ }^{2}$ U.S. Geological Survey, Spokane, Washington, United States.

${ }^{3}$ U.S. Geological Survey, Menlo Park, California, United States.

${ }^{4}$ Philippine Department of Environment and Natural Resources, Mines and Geosciences Bureau, Quezon City, Philippines.

${ }^{5}$ Geological Survey of Japan, National Institute of Advanced Industrial Science and Technology (AIST), Ibaraki, Japan.
(Republic of China); permissive tracts in South Korea and Japan are discussed qualitatively. Estimates of numbers of undiscovered deposits were combined with grade and tonnage models using Monte Carlo simulation to estimate amounts of undiscovered resources. Grades and tonnages of known porphyry copper deposits in the study area were compared with global grade and tonnage models to determine the appropriate model for simulation of undiscovered resources. Most of the known deposits are best described as copper-gold subtypes of porphyry copper deposits. For some permissive tracts, a general porphyry copper-gold-molybdenum model was used.

Thirty-eight porphyry copper deposits are known in the Philippines; the mean number of undiscovered deposits was estimated to be 28. Mean (arithmetic) resources that could be associated with the undiscovered deposits are 90 million metric tons of copper and 5,800 metric tons of gold, as well as byproduct molybdenum and silver. Additional resources that could be discovered in extensions to known deposits were not evaluated. Assessment results, presented in tables and graphs, indicate expected amounts of total contained metal and mineralized rock in undiscovered deposits at different quantile levels, as well as the arithmetic mean for each tract.

The Philippines have a long history of porphyry exploration cycles and mine development, interrupted at times by political and social unrest, environmental concerns, and natural disasters. Changes in mining laws within the region and the recent high price of gold on the world market have prompted renewed interest in porphyry copper deposits in the region. South Korea and Japan have been thoroughly explored for many types of mineral deposits. Available data suggest that the permissive rocks in South Korea typically are too deeply eroded to preserve porphyry copper deposits. Porphyry copper systems may be present in Japan, but are likely to lie at depths greater than the 1 kilometer from the surface protocol adopted for this study.

Descriptions of the geologic basis for delineating each tract, the data used, the geologic criteria and rationale for the assessment, and results of the assessment are included in 
appendixes along with the description of a geographic information system (GIS) that includes tract boundaries, known porphyry copper deposits and significant prospects, and assessment results.

\section{Introduction}

The Southeast Asia region hosts world-class examples of porphyry copper deposits, including Tampakan, Atlas, and six other deposits in the Philippines (fig. 1, table 1). Porphyry copper deposits provide approximately 60 percent of the world copper supply and produce gold, molybdenum, and silver (Singer, 1995). In recent years, new target areas have been recognized in Southeast Asia, historical mining districts continue to be explored, and new deposits continue to be discovered through greenfields exploration (that is, exploration targets away from known deposits). Permissive geologic settings for porphyry copper deposits also exist in the East Asia countries of the Republic of Korea (South Korea), Taiwan (Republic of China), and Japan although no such deposits have been discovered.

A probabilistic assessment of undiscovered mineral resources in porphyry copper deposits in East and Southeast Asia was undertaken as part of a global mineral resource assessment (Schulz and Briskey, 2003). The purpose of the assessment was to (1) delineate permissive areas (tracts) for undiscovered porphyry copper deposits at a scale of $1: 1,000,000$, (2) provide a database of known porphyry copper deposits and significant prospects, (3) estimate numbers of undiscovered deposits within those permissive tracts, and (4) provide probabilistic estimates of amounts of copper $(\mathrm{Cu})$, molybdenum (Mo), gold $(\mathrm{Au})$, and silver $(\mathrm{Ag})$ that could be contained in undiscovered deposits for each permissive tract. The U.S. Geological Survey (USGS) collaborated with the Coordinating Committee for Geoscience Programmes in East and Southeast Asia (CCOP) on the joint assessment project for East and Southeast Asia.

$\mathrm{CCOP}^{6}$ is an intergovernmental organization founded to facilitate and coordinate applied geoscience projects. The CCOP mission is to contribute to economic development and improve the quality of life in the region. CCOP has 11 member countries - Cambodia, China, Indonesia, Japan, Malaysia, Papua New Guinea, Philippines, Singapore, South Korea, Thailand, and Vietnam. Fourteen other countries, including the United States, participate in CCOP activities as cooperating countries.

The large area that covers CCOP member countries was divided into broadly defined geographic/geologic areas for assessment. This assessment report covers parts of the CCOP-member countries of the Philippines, Taiwan (Province of China), Republic of Korea (South Korea), and Japan (fig. 1). A separate report on the porphyry copper assessment of Southeast Asia covered Cambodia, Indonesia, Lao People's

${ }^{6}$ http://www.ccop.or.th/
Democratic Republic, Malaysia, Myanmar, Papua New Guinea, Singapore, Thailand, parts of India, and the Melanesian island nations of the Solomon Islands, Vanuatu, and Fiji (Hammarstrom and others, 2013).

Several workshops were held between CCOP and USGS authors, in which CCOP representatives gave country reports, provided data, and participated in tract delineation and estimation of undiscovered resources. Project workshops were held in Bangkok, Thailand (2003, 2004), Kunming, China (2005), and Busan, South Korea (2010). Preliminary results from the early workshops were updated for the 2010 meeting, and refined after formal reviews.

The assessment data and results for each permissive tract are presented in a standardized format in appendixes A through $\mathrm{M}$ of this report. Permissive tract boundaries and point locations of significant deposits and prospects are included in a geographic information system (GIS) that accompanies this report (appendix N). Appendix O lists the assessment participants, along with their particular expertise, affiliation, and role in the assessment. Political boundaries are based on data maintained by the U.S. Department of State (2009).

The assessment was based primarily on data compiled through 2010, although deposit and prospect data were updated where possible to reflect new information available through the first quarter of 2012. Many active exploration projects are large concession areas that attracted attention due to reported gold associated with historical workings. Epithermal gold deposits are the initial targets of many projects owing to the current high price of gold. Company reports mention porphyry systems associated with some of these targets, and the association of these deposit types with porphyry copper deposits is well-known in Southeast Asia (see, for example, Cooke and others, 1998). Such comments may be speculative, however, and delineation of a porphyry copper deposit, if present, awaits further exploration in most cases.

\section{Three-Part Assessment}

The three-part approach to mineral resource assessment is based on mineral deposit models (Singer 1993, 2007a, b; Singer and Berger, 2007; Singer and Menzie, 2005). In applying this approach, geographic areas (permissive tracts) are delineated on the basis of geologic, geochemical, and geophysical features typically associated with the type of deposit under consideration. The amount of metal contained in undiscovered deposits is estimated using grade and tonnage models ${ }^{7}$. Estimates of numbers of undiscovered porphyry copper deposits are made at different confidence levels using a variety of estimation strategies to express the degree of

\footnotetext{
${ }^{7}$ Grade and tonnage models are frequency distributions of tonnages and grades of well-explored deposits, based on total production, reserves, and resources at the lowest available cutoff grade. For porphyry copper deposit models, a spatial rule is used to group grade and tonnage information to represent deposits as geologic entities - all mineralized rock or alteration within 2 kilometers is combined as one deposit for model construction (Singer and others, 2008).
} 
belief that some fixed but unknown number of deposits exists within the tract. A crucial step in the estimation process is selecting an appropriate grade and tonnage model; 80 percent of the undiscovered deposits should lie between the 90th and 10th percentile model values and half of the deposits should be above the model median in grade or tonnage (Singer and Menzie, 2010). The probabilistic estimates are a measure of the favorability of the tract and the estimator's uncertainty about what may exist (Singer, 2007a).

\section{Porphyry Copper Models}

Porphyry copper deposits are large-tonnage (hundreds of millions of metric tons), low-to moderate-grade ( $0.3-2$ percent copper) deposits of disseminated copper minerals (John and others, 2010). The most common ore minerals in porphyry copper deposits are chalcopyrite $\left(\mathrm{CuFeS}_{2}\right)$ and bornite $\left(\mathrm{Cu}_{5} \mathrm{FeS}_{4}\right)$, distributed in stockwork veinlets and disseminations in hydrothermally altered intrusions and adjacent wallrock. Secondary copper minerals, such as chalcocite $\left(\mathrm{Cu}_{2} \mathrm{~S}\right)$, in oxidized, supergene enrichment zones comprise a major part or all of the ore in some deposits. Molybdenum, silver, and gold are important coproducts or byproducts in many deposits.

Mineral deposit models describe the characteristics and environments of formation of a specific type of mineral deposit. Porphyry copper mineral deposit models used for the assessment described here include those of Singer and others (2008), Cox (1986a, b), Berger and others (2008), and John and others (2010). In addition, models for the porphyry copper in the Philippines (Sillitoe and Gappe, 1984) and porphyry copper-gold deposits in Australia and the western Pacific also apply (Cooke and others, 1998). These latter two models are appropriate for use in many of the tectonic settings of Southeast Asia. Conceptual exploration models for southwest Pacific Rim gold-copper systems, including porphyry copper deposits, are included in Corbett and Leach (1998). A comprehensive overview of porphyry copper systems by Sillitoe (2010) discussed features to consider in exploration.

Although porphyry copper deposits typically form in subduction-related magmatic arcs, other tectonic settings also are recognized as permissive environments. These include collisional and extensional back-arc settings for the formation of porphyry copper (typically gold-rich) deposits, where processes such as postsubduction lithosphere thickening or extension, delamination, slab rollback, and asthenospheric upwelling may have facilitated remelting of lithosphere (Richards, 2009). Postsubduction porphyry copper-gold deposits generally are associated with mildly alkaline, rather than calc-alkaline, magmas, and may form isolated complexes in contrast to volcanoplutonic arcs (Richards, 2009).

Porphyry copper deposits in the western Pacific region typically are gold-rich in island arcs but tend to be molybdenum-rich where they formed in continental margin arcs or within cratons (Cooke and others, 1998). Intrusive rocks associated with many Cenozoic western Pacific porphyry deposits are calc-alkalic to shoshonitic in composition, were emplaced at shallow (1-2 kilometer, $\mathrm{km})$ depths, have distinctive steep-sided, cylindrical form ("pencil porphyries"), and are spatially associated with diatremes, epithermal gold deposits, and, if carbonate rocks are present, skarn deposits. Gold-rich porphyry copper deposits associated with alkaline (high-K) rocks, typically syenites, also are present in Southeast Asia. Characteristic settings for these deposits include subductionrelated oceanic arcs within or along calderas at lineament or fault intersections. Associated rocks typically have elevated $\mathrm{K}_{2} \mathrm{O}$ contents, are enriched in chlorine, fluorine, and light rareearth elements, and have oxidized, magnetite-bearing magma sources (Müller and Groves, 1999).

\section{Magnetite and IImenite Series Granitoids}

Worldwide, porphyry copper deposits are associated with magnetite-series rocks. The classification of granitoids into magnetite- and ilmenite-series rocks based on redox state and the relation of those series to associated mineral deposit type was established by Ishihara's landmark studies of the Cretaceous-Paleogene metallogenic provinces of Japan (Ishihara, 1979, 1981, 2004). Those studies showed that magnetite-series granitoids are correlated with I-type granitoids and associated with sulfide-rich base-metal, preciousmetal, and molybdenum deposits, including porphyry, skarn, and kuroko-type massive sulfide deposits. In Japan, however, no porphyry copper deposits have been discovered. Ilmeniteseries granitoids can be correlated with both I- and S-type granitoids and are associated with sulfide-poor tin and tungsten deposits. The boundary between the reduced ilmeniteseries rocks and the more oxidized magnetite series rocks is 0.1 percent modal magnetite.

Differences between the granitoid series reflect differences in the redox state of the magma chamber, which is related to the sulfur content (Takagi and Tsukirma, 1997). During late-magmatic stages, sulfur dioxide $\left(\mathrm{SO}_{2}\right)$ gas oxidizes silicate melts such that at $\mathrm{SO}_{2}$ concentrations greater than 250 parts per million (ppm) magnetite-series granitoids form. The magnetite-series granitoid magmas in Japan likely acquired sulfate by subduction of altered oceanic crust that reacted with seawater whereas the ilmenite-series magmas assimilated sedimentary sulfide, in which most of the $\mathrm{SO}_{2}$ was reduced to $\mathrm{H}_{2} \mathrm{~S}$ (hydrogen sulfide). Increases in subduction erosion and sediment assimilation rates due to increases in plate convergence rates and (or) climate effects that promoted erosion in Cretaceous time may explain the distribution of the magnetite and ilmenite series in Japan (Takagi, 2004) and may have application elsewhere. 


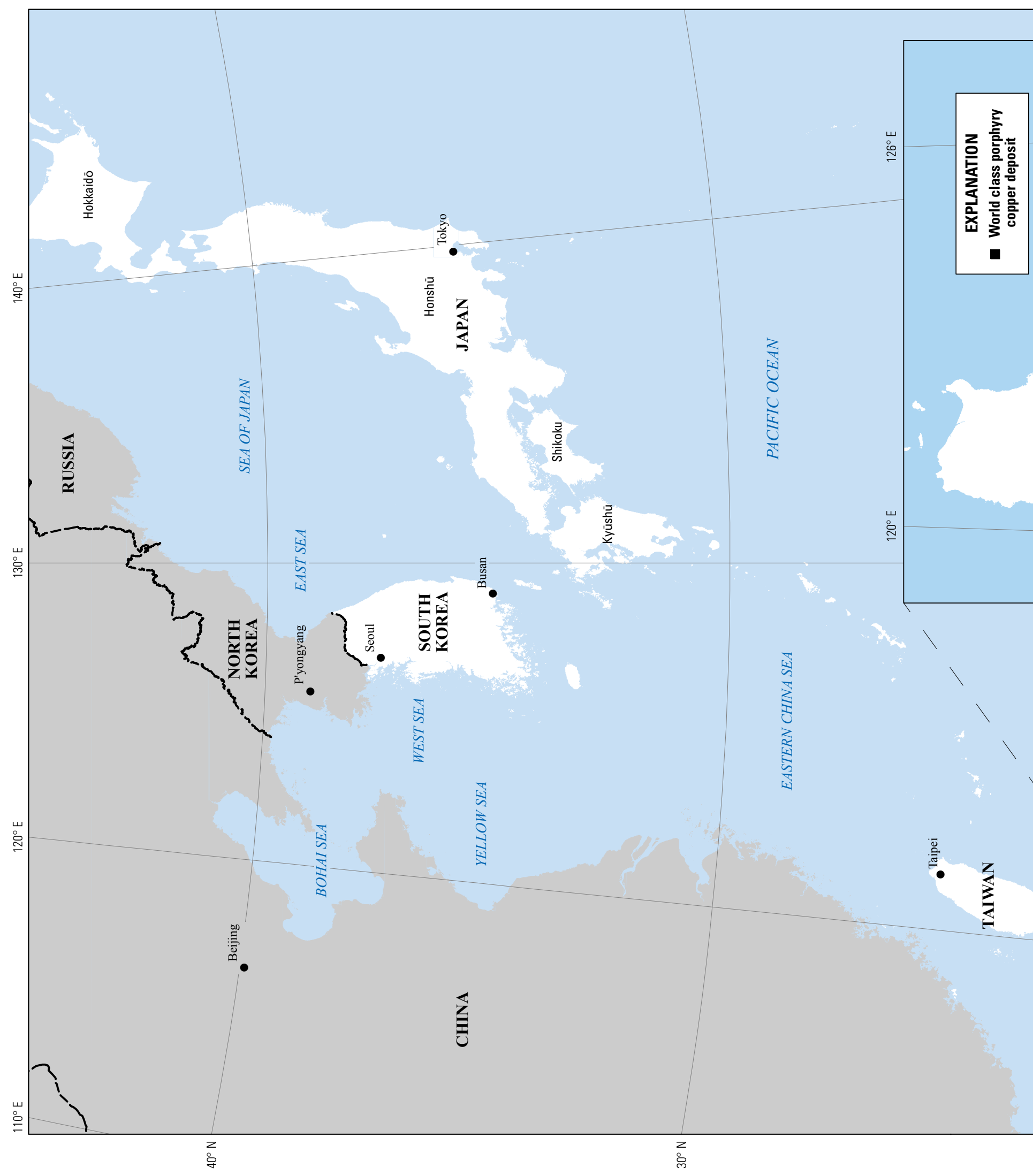



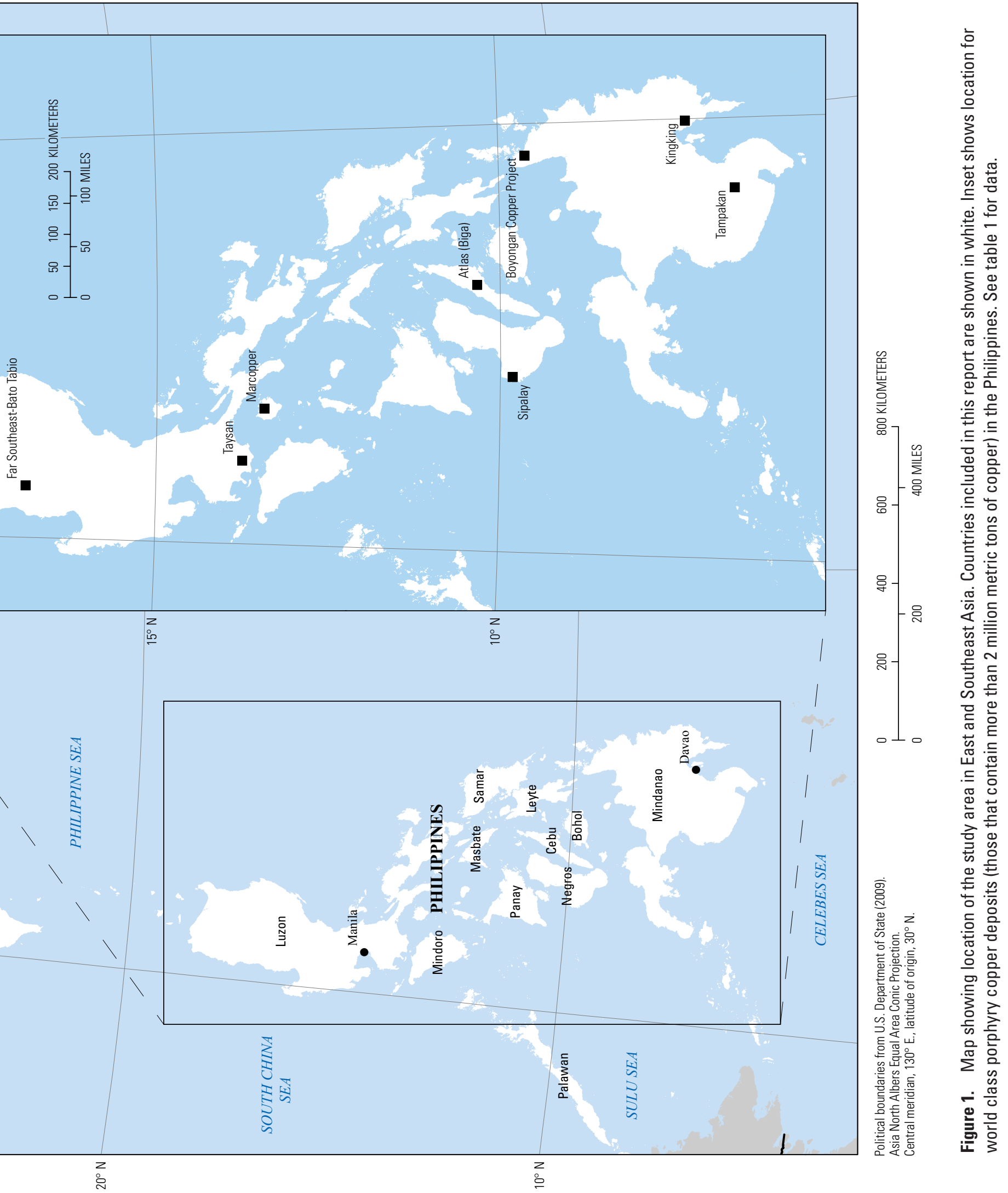


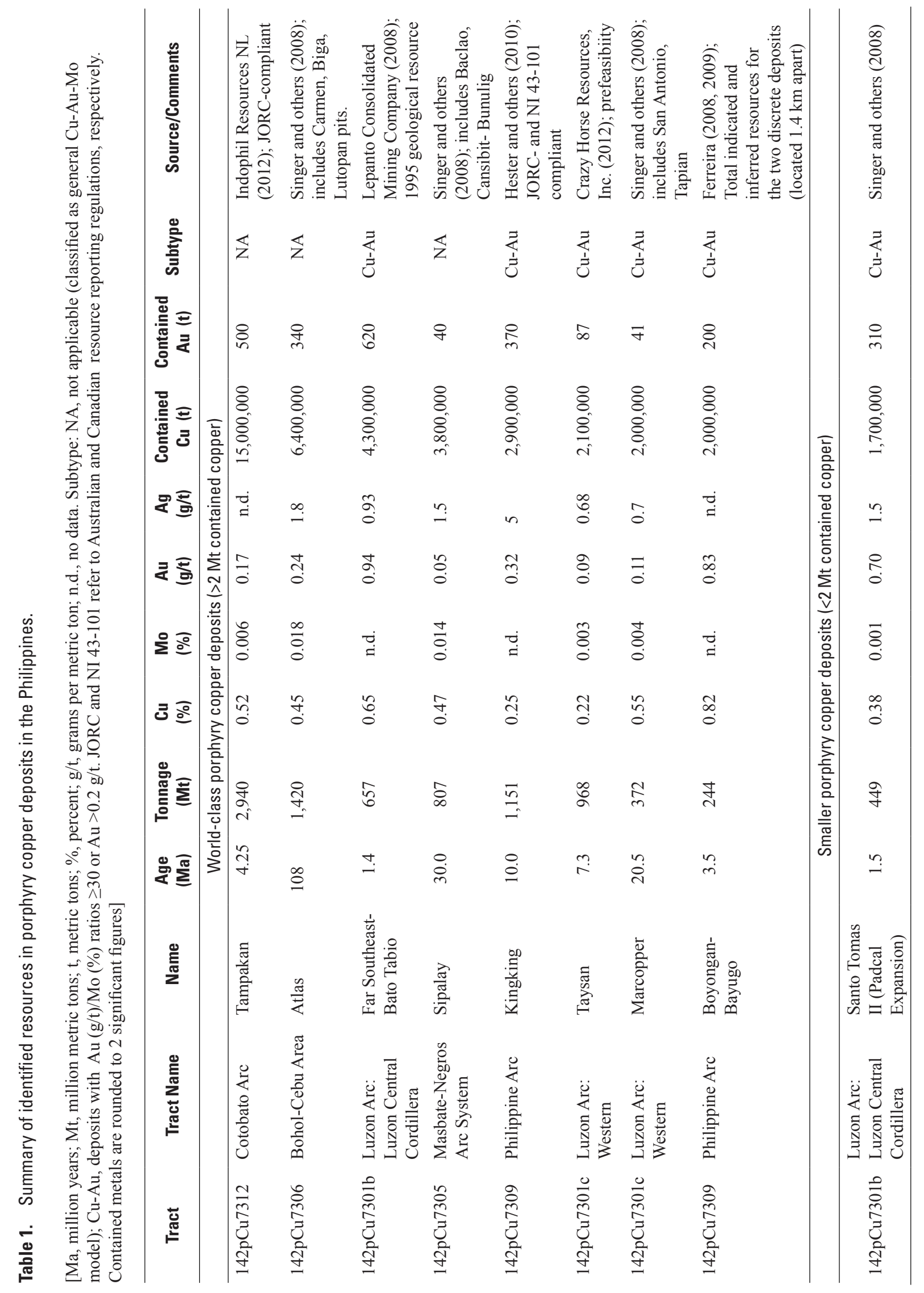




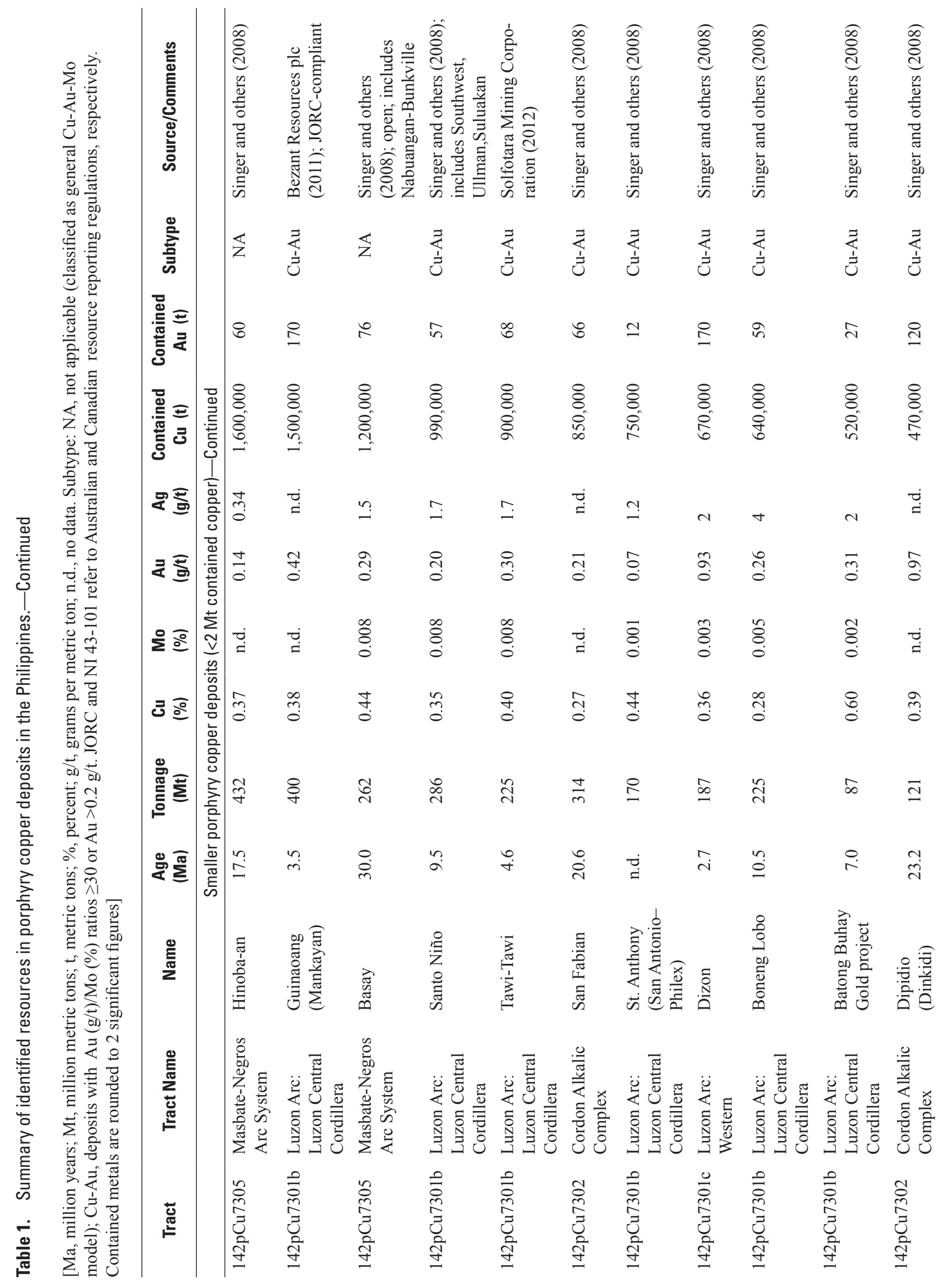




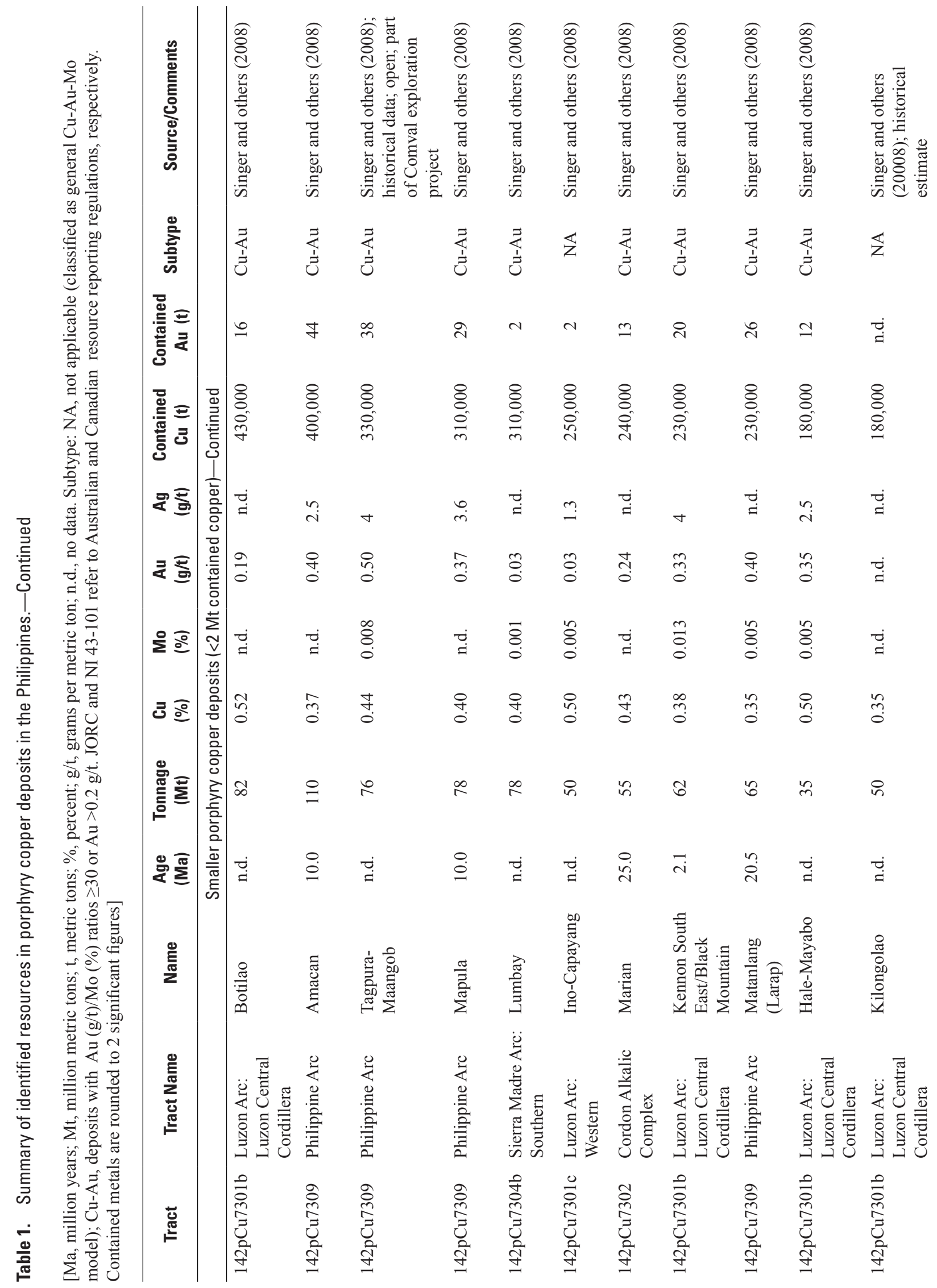




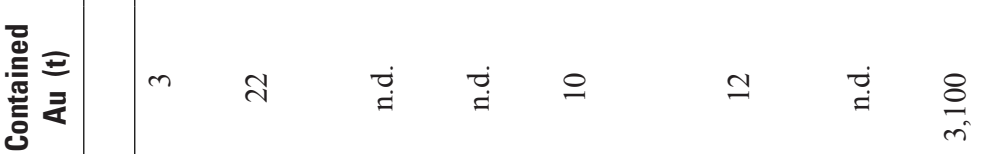

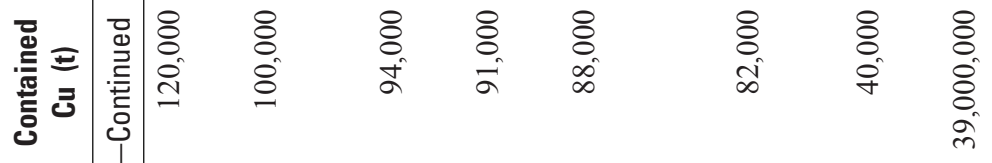

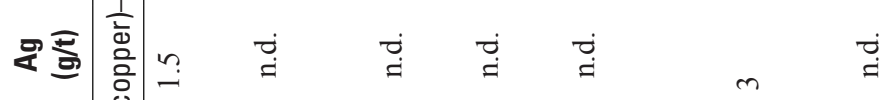

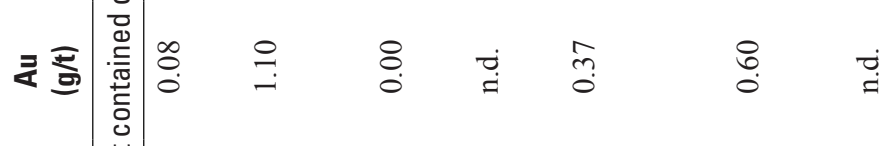

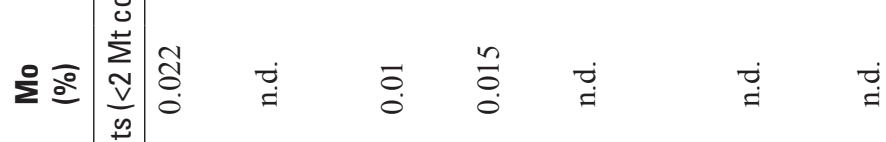

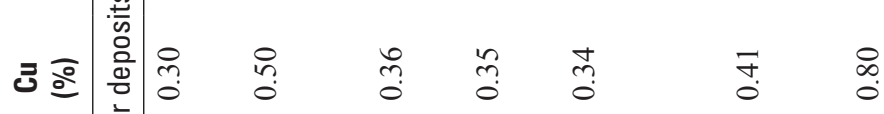

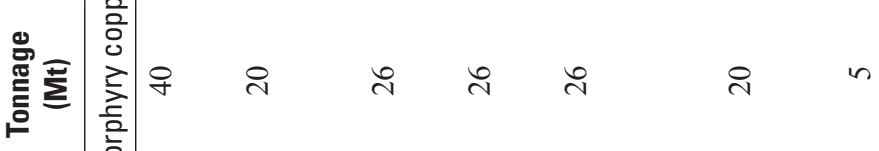

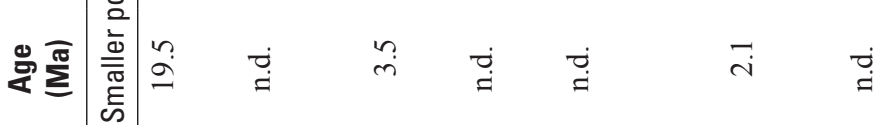

政

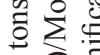

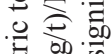

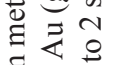

乎

更

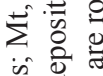

कृ च

至

E

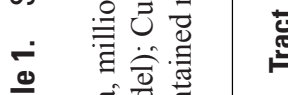

|

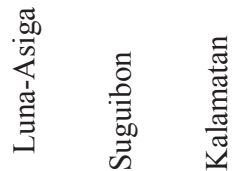

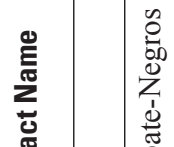

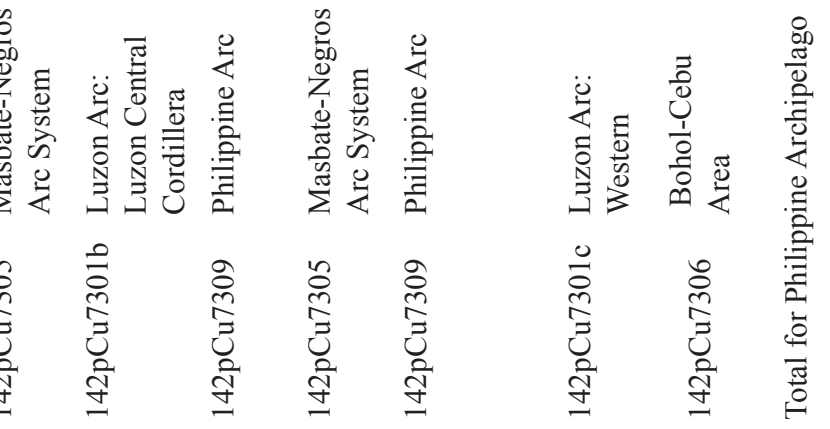




\section{Terminology}

The terminology used in this report follows the definitions used in the 1998 U.S. Geological Survey assessment of undiscovered deposits of gold, silver, copper, lead, and zinc in the United States (U.S. Geological Survey National Mineral Resource Assessment Team, 2000). This terminology is intended to represent standard definitions that reflect general usage by the minerals industry and the resource assessment community.

- Mineral deposit - A mineral concentration of sufficient size and grade that it might, under the most favorable of circumstances, be considered to have potential for economic development.

- Undiscovered mineral deposit-A mineral deposit believed to exist $1 \mathrm{~km}$ or less below the surface of the ground, or an incompletely explored mineral occurrence or prospect that could have sufficient size and grade to be classified as a deposit.

- Mineral prospect - A mineral concentration that is being actively examined to determine whether a mineral deposit exists.

- Mineral occurrence - A locality where a useful mineral or material is found.

- Permissive tract - The surface projection of a volume of rock where the geology permits the existence of a mineral deposit of a specified type. The probability of deposits of the type being studied occurring outside the boundary is negligible.

- Resource-A mineral concentration of sufficient size and grade, and in such form and amount, that economic extraction of a commodity from the concentration is currently or potentially feasible.

- Identified resources - Resources whose location, grade, quality, and quantity are known or can be estimated from specific geologic evidence. For this report, known resources are those in the porphyry copper deposits that are included in the grade and tonnage models used in the assessment. In addition, deposits that are not included in the models used for the assessment are considered to contain identified resources if they are characterized well enough by deposit type, grade, and tonnage to meet commonly used reporting guidelines, such as those established by the U.S. Securities and Exchange Commission, JORC ${ }^{8}$, or CRIRSCO 9 .

- Calc-alkaline, calc-alkalic; alkaline, alkalic-These terms are used in a general, nonrigorous manner to refer

\footnotetext{
${ }^{8}$ The Australasian Code for Reporting of Exploration results, Mineral Resources and Ore Reserves (http://www.jorc.org/jorc_code.asp).

${ }^{9}$ Committee for Mineral Reserves International Reporting Standards (2006) (http://www.crirsco.com/welcome.asp).
}

to plutonic igneous rocks of granitoid composition (calcalkaline or calc-alkalic) and of syenitoid through dioritoid to gabbroid composition (alkaline or alkalic) and their volcanic equivalents (see provisional field classifications, figures 2.10 and 2.19 of Le Maitre and others, 2002). In the igneous literature, the terms "-alkaline" and "-alkalic" are defined and used in multiple and inconsistent ways (see Arculus, 2003). For this assessment, the term calcalkalic is used synonymously for calc-alkaline, and alkalic is used synonymously for alkaline, as well as for their associated deposits, which are classified as calc-alkaline (or calc-alkalic) $\mathrm{Cu} \pm \mathrm{Mo} \pm \mathrm{Au}$ or alkaline (or alkalic) porphyry copper subtypes.

- Adakite - The term "adakite" appears in much of the recent literature on igneous rocks associated with porphyry copper deposits, including studies of deposits in East and Southeast Asia (John and others, 2010; Sajona and Maury, 1998; Sajona and others, 2000). The term "adakite" was introduced by Defant and Drummond (1990) to describe the magnesian andesite near Adak Island in the Aleutian Arc in the North Pacific Ocean described by Kay (1978) as a possible product of reacting partially melted subducted oceanic crust with asthenospheric mantle. The term has become problematic because in addition to the geochemical criteria used to define adakites, an unequivocal origin by melting of a subducted slab of oceanic crust may be implied. Richards and Kerrich (2007) showed that processes other than slab melting also could produce "adakite" and proposed the use of the term "adakite-like rocks" to describe the suite of rocks that have the following general characteristics: $\mathrm{SiO}_{2}$ $\geq 56$ percent, $\mathrm{Al}_{2} \mathrm{O}_{3} \geq 15$ percent, $\mathrm{MgO}<3$ percent, $\mathrm{Sr} \geq 400$ ppm, $\mathrm{Y} \leq 18 \mathrm{ppm}, \mathrm{Yb} \leq 1.9 \mathrm{ppm}, \mathrm{Ni} \geq 20 \mathrm{ppm}, \mathrm{Cr} \geq 30 \mathrm{ppm}, \mathrm{Sr} /$ $\mathrm{Y} \geq 20, \mathrm{La} / \mathrm{Yb} \geq 20$, and ${ }^{87} \mathrm{Sr} /{ }^{86} \mathrm{Sr} \leq 0.7045$. They showed that these compositions can result from crustal processes involving normal tholeiitic to calc-alkalic arc magmas, such as melting-assimilation-storage-homogenization (MASH) and assimilation-fractional crystallization (AFC), and cannot be unambiguously ascribed to slab melts. The term adakite-like is used in this report for rocks that meet the geochemical criteria for adakite; no particular origin is implied.

\section{Assessment Data}

\section{Geologic Maps}

Geologic maps at several scales were used as information sources during this assessment. Maps included proprietary data provided by CCOP country representatives, commercially available digital geologic compilations, and paper geologic maps. These included a 1:2,000,000-scale digital geologic map of East and Southeast Asia (Coordinating Committee for Coastal and Offshore Geoscience Programmes in 
East and Southeast Asia (CCOP) and Geological Survey of Japan, 1997), a 1:1,000,000-scale digital geologic map of Japan (Geological Survey of Japan, 2003), geologic maps of the Philippines at scales of 1:1,000,000, 1:1,500,000, and 1:2,500,000 and selected 1:200,000-scale maps (Philippine Bureau of Mines and Geosciences, 1963, 2004a; Balace and others, 1974), a 1:800,000-scale neotectonic map of the Philippines (Pubellier and others, 1993), a 1:500,000-scale map of Taiwan (Wei and others, 2006), and a series of 1:1,000,000scale maps of South Korea (Korea Institute of Geology, Mining and Materials [in 2001, the name was changed to the Korea Institute of Geoscience and Mineral Resources, KIGAM], 1995a-d).

Paper maps were scanned and georectified to incorporate as images in GIS projects, including some 1:50,000-scale geologic maps for the Philippines (see http://www.mgb.gov.ph/ lgmp.aspx for available maps; Philippine Mines and Geosciences Bureau, undated index map). Page-size figures from a variety of publications were used as references to identify tectonic features and the extent of magmatic arcs. Specific data used for each tract are listed in the appendixes.

\section{Mineral Occurrence Data}

A global database of porphyry copper deposits and prospects by Singer and others (2008) was supplemented with other global and regional mineral occurrence databases, including those maintained by the Geological Survey of Canada (Dunne and Kirkham, 2003), a mineral resource map of Asia (Kamitani and Naito, 1998), and proprietary data from CCOP. The Philippine Bureau of Mines and Geosciences provided a digital database of mineral occurrences for their country (Philippine Bureau of Mines and Geosciences, 2004b). In addition, commercially available databases (InfoMine $^{10}$, Intierra ${ }^{11}$, Metals Economic Group ${ }^{12}$ ), metallogenic maps, technical reports, company Web sites, publications and Web sites of geological surveys, and geological literature were consulted. The USGS (2012) On-Line Mineral Resources Data (MRDS) ${ }^{13}$ includes information on mines, prospects, and mineral occurrences worldwide. The 1984 CCOP report on Philippine porphyry copper deposits summarizes the results of a project on porphyry copper deposits initiated by the Philippine Bureau of Mines and Geology (Sillitoe and Gappe, 1984). The CCOP report includes a comparative study of 48 porphyry copper deposits and prospects in the Philippines, 20 of which were mined. Divis (1983) summarized the geology and geochemistry of Philippine porphyry copper deposits. Dr. Claro Manipon (a contributor to this report) provided additional data on porphyry copper deposits and prospects in the Philippines (written commun., 2006).

\footnotetext{
${ }^{10} \mathrm{http}: / / \mathrm{www}$. infomine.com/

${ }^{11}$ http://www.intierra.com/Homepage.aspx

${ }^{12} \mathrm{http}: / /$ www.metalseconomics.com/default.htm

${ }^{13} \mathrm{http}: / /$ mrdata.usgs.gov/
}

The assessment team classified sites as either deposits or prospects. The term "deposit" is limited to sites where the location, deposit characteristics and type, and resource grades and tonnages are thoroughly characterized. Some prospects reported in data sources could not be unambiguously classified as porphyry copper deposit types. Deposits and prospects that the assessment team could classify as porphyry copper or porphyry-copper-related are discussed in the appendixes and included in the database for this report (appendix N).

Many islands of the Philippines were being actively explored during the course of this study, owing primarily to recent high gold prices. Many prospects change hands, new exploration data become available, and identified resources for deposits may change over time. We attempted to update information on deposits and prospects during final report preparation, but because of the dynamic exploration environment, still newer data may be available.

Spatial rules are used in mineral resource assessment to define consistent sampling units for constructing tonnage and grade models. For porphyry copper deposits, all mineralized rock or alteration within $2 \mathrm{~km}$ of each other are combined as one deposit. In this study, prospects that lie within a $2-\mathrm{km}$ distance of known deposits are grouped with those deposits because they are likely to represent extensions of identified resources. For example, the tonnage and grade reported for the Atlas deposit (table 1) include data for the Carmen, Biga, and Lutopan pit areas. Similarly, clusters of prospects within $2 \mathrm{~km}$ of each other are grouped to avoid over-representing numbers of prospects that could, if fully explored, meet reporting criteria for identified resources.

Distributions of gold placers, skarns, and epithermal deposits, as well as unclassified copper and gold occurrences, were considered during the assessment but generally are not included in the database. Skarns and epithermal deposits may be included if the assessment team considered it likely that a porphyry system is associated.

\section{Other Data}

Other types of data were available for some areas. Mining tenement maps, geologic information, and updates on mining in the Philippines are available on the Web site of the Mines and Geosciences Bureau of the Department of Natural Resources, Republic of the Philippines (http://www. $m g b . g o v . p h /$ ). A two-volume summary of the geology and mineral resources of the Philippines (Philippine Bureau of Mines and Geosciences, 1981, 1986) and maps therein were also used. The second edition of the geology of the Philippines was released in 2010 (Philippine Mines and Geosciences Bureau, 2010).

Satellite imagery proved helpful for confirming mine and prospect locations and for locating and identifying topographic and structural features such as lineaments and faults. In many areas, vegetation and cloud cover were too dense to allow identification of altered rocks on the images. 
A regional magnetic anomaly map at a scale of 1:4,000,000 covers much of the study area (Geological Survey of Japan, 1996). Global-scale magnetic data are available but are of limited use at the scale of the assessment (National Geophysical Data Center, 2009). Site-specific magnetic data are available on some exploration company Web sites or in published reports. A database of radiometric ages for Southeast Asia provided locations of dated samples of igneous rocks and information about rock type (Malaihollo and others, 2002).

\section{Delineation of Permissive Tracts}

\section{Fundamental Basis for Porphyry Copper Assessment}

The fundamental geologic feature that is used to delineate a permissive tract for porphyry copper deposits is a subductionrelated magmatic arc or a postsubduction or postcollisional magmatic belt of a given age. Porphyry copper deposits form in hydrothermal systems that are spatially and temporally associated with apical, generally porphyro-aphanitic parts of felsic to intermediate stocks that were emplaced at shallow depths, typically less than $4 \mathrm{~km}$.

Permissive tracts for porphyry copper deposits are delineated as geographic areas that include volcanic and intrusive rocks of a specified age range that typically can be related to a particular tectonic setting (such as a subduction-boundary zone). Tracts are based primarily on geologic map units that define the magmatic arc or belt.

A complex collage of island arcs and continental-arc fragments developed in response to subduction and plate reorganization related to the geodynamic evolution of the borders of the Eurasian and Indian-Australian continents, the lifecycle of seas in the region, and the movement of the Pacific Plate over time. This complex tectonic evolution has led to the development of arc fragments, microcontinents, accreted terranes, and sea basins, many of which are of uncertain origin. Building on the work of Hamilton (1979) and Mitchell and Leach (1991), Garwin and others (2005) described the tectonic setting, the geology, and the characteristics of gold and copper deposits of the principal Cenozoic magmatic arcs in the southeast Asia-western Pacific region. Their delineation of arcs provided the basic framework for delineation of most of the permissive tracts in this assessment. A new regionalscale compilation of geodynamic maps prepared for the global assessment also was used to document the extent and nature of arcs (D. Alexeiev, Russian Academy of Science, written commun., 2011). The magmatic arcs and belts that were used as the basis for delineating permissive tracts for porphyry copper deposits are outlined on figure 2 .

\section{Tract Delineation Strategy}

The first step in delineating a permissive tract for porphyry copper deposits is identifying appropriate tectonic settings based on characteristics described in mineral deposit models. In East and Southeast Asia, the initial framework for delineating permissive tracts was established by identifying subduction-related magmatic arcs in the region (fig. 2, table 2). Many of the arcs are composite systems that include oceanicas well as continental-arc segments, or arcs that formed on accretionary basement or deformed ophiolites; these latter arc systems developed on thin, immature crust lacking granitoids in the basement in contrast to continental arcs that typically are underlain by older granitoids complexes (D. Alexeiev, 2010, written commun.). Some of the arcs include submarine arc segments that are not included in permissive tracts; most of the Izu-Bonin Arc is submerged.

Once the main tectonic elements and age ranges were identified, the tracts were delineated by selecting the igneous rocks that define the terrestrial extent of the arcs based primarily on geologic maps. The geology-based strategy for permissive tract delineation used in this assessment is described here. Tracts may consist of multiple segments. The appendixes contain detailed descriptions for individual tracts, along with figures that show the intrusive and extrusive rocks that define the tract and tables listing the maps used, and the map units included, for each tract. 
A

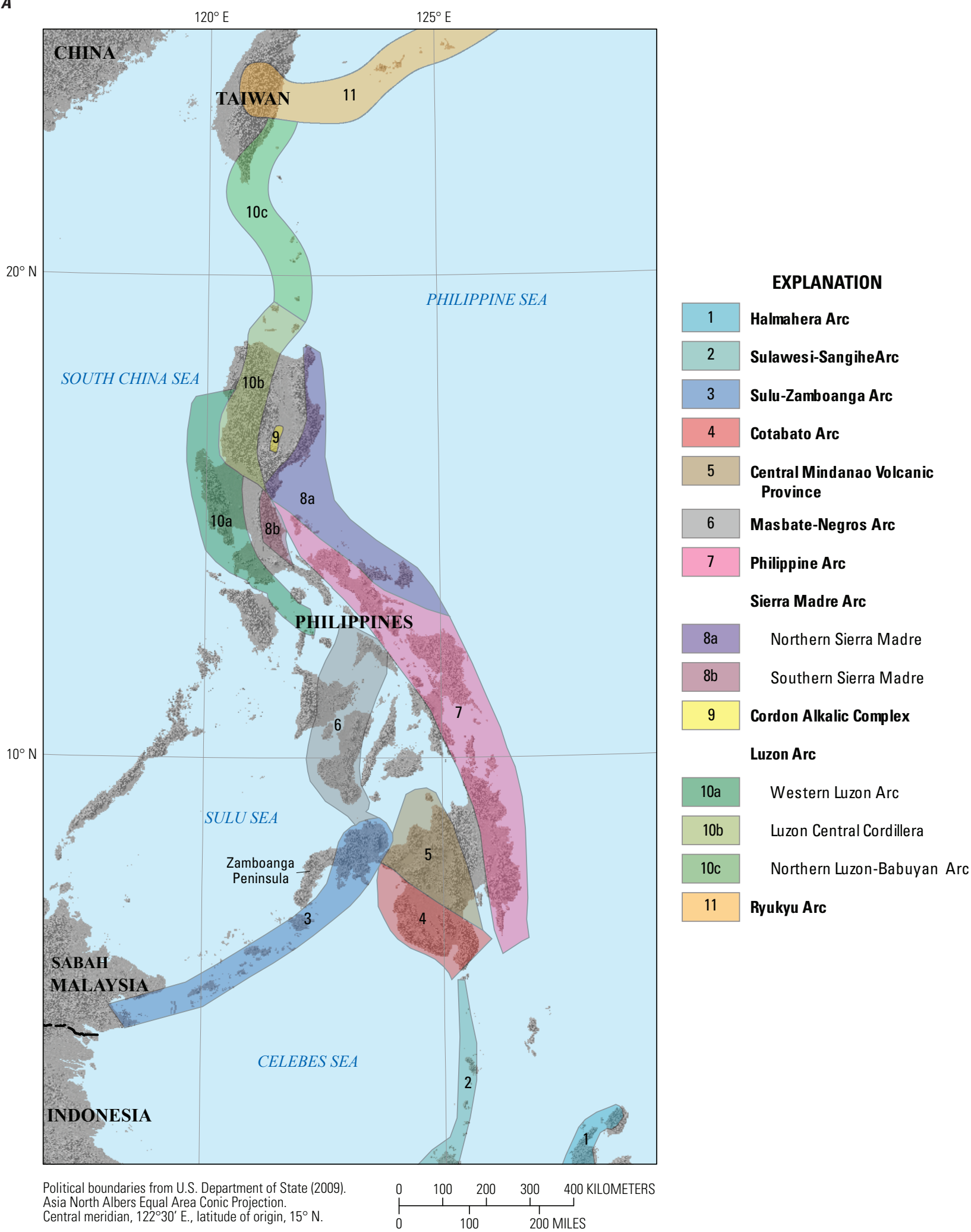

Figure 2. Maps showing the principal magmatic arcs and belts of East and Southeast Asia. A, Southeast AsiaPhilippines and Taiwan (Republic of China); B, East Asia-Republic of Korea (South Korea) and Japan. 

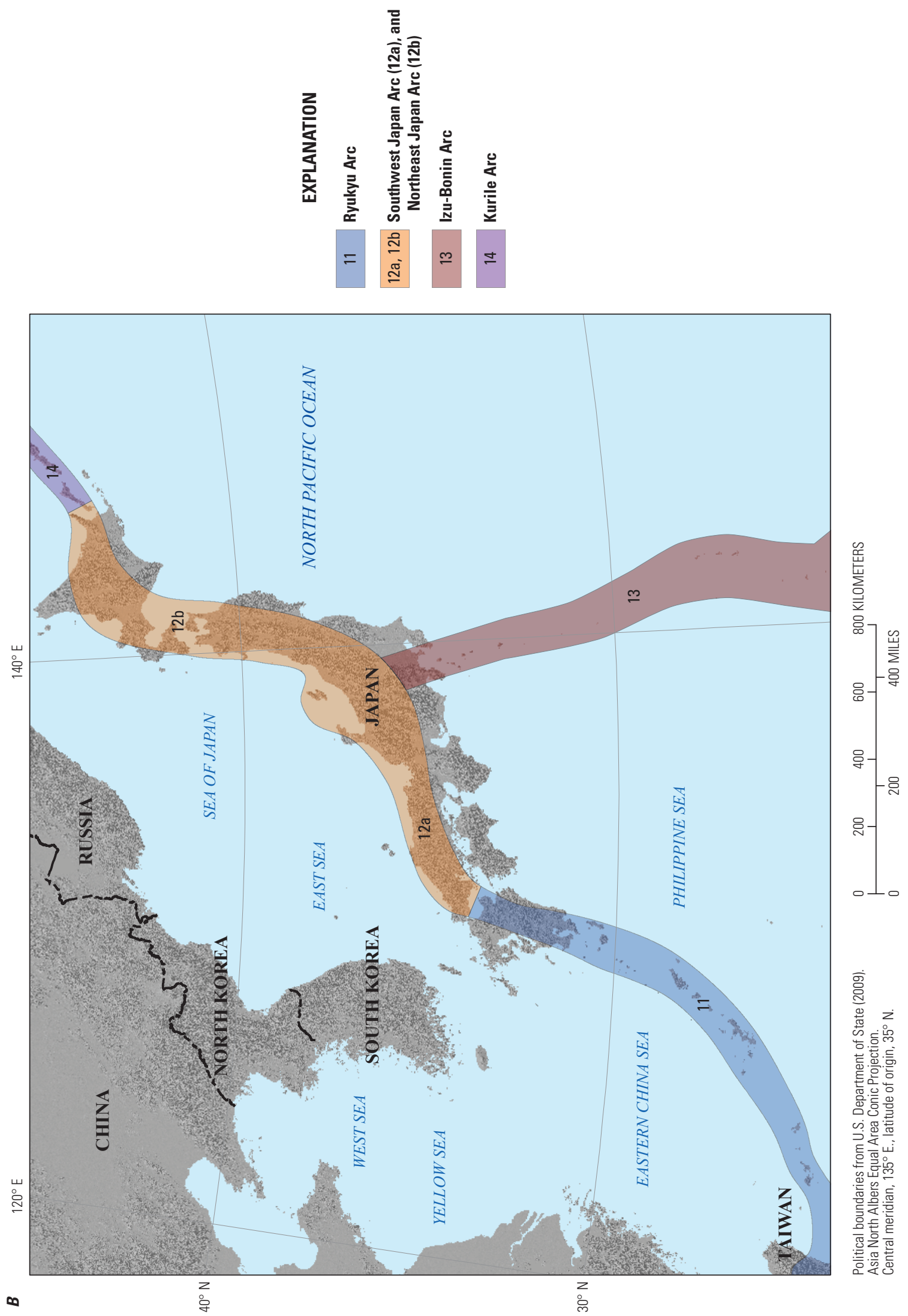

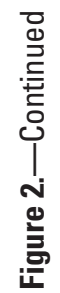


Table 2. Principal magmatic arcs of East and Southeast Asia.

[Map key for figure 2; arcs and magmatic provinces based on Garwin and others (2005), Mitchell and Leach (1991), and D. Alexeiev (written commun., 2010)]

\begin{tabular}{|c|c|c|c|c|c|}
\hline Map key & Magmatic arcs and belts & Age range & $\begin{array}{c}\text { Arc } \\
\text { Length } \\
(\mathbf{k m})\end{array}$ & Arc /crust type & Key reference \\
\hline 1 & Halmahera Arc & Neogene to Holocene & 400 & oceanic $(\mathrm{N})$; continental $(\mathrm{S})$ & Garwin and others (2005) \\
\hline 2 & Sulawesi-SangiheArc & Miocene to Pliocene & 1,200 & oceanic (NE); continental (SW) & Garwin and others (2005) \\
\hline 3 & Sulu-Zamboanga Arc & Miocene to Holocene & 400 & oceanic (NE); continental (SW) & Garwin and others (2005) \\
\hline 4 & Cotabato Arc & Miocene to Holocene & 300 & $\begin{array}{l}\text { oceanic/ accretionary } \\
\text { basement }\end{array}$ & Garwin and others (2005) \\
\hline 5 & $\begin{array}{l}\text { Central Mindanao Volcanic } \\
\text { Province }\end{array}$ & Miocene to Holocene & 350 & residual arc? & Garwin and others (2005) \\
\hline 6 & Masbate-Negros Arc & Eocene to Holocene & 400 & $\begin{array}{l}\text { oceanic/ accretionary } \\
\text { basement }\end{array}$ & Garwin and others (2005) \\
\hline 7 & Philippine Arc & Oligocene to Holocene & 1,000 & $\begin{array}{l}\text { oceanic/ accretionary } \\
\text { basement }\end{array}$ & Garwin and others (2005) \\
\hline & Northern Sierra Madre Arc & Eocene-Oligocene & 200 & $\begin{array}{l}\text { oceanic/ accretionary } \\
\text { basement }\end{array}$ & Mitchell and Leach (1991) \\
\hline $8 b$ & Southern Sierra Madre Arc & & & & \\
\hline 9 & Cordon Alkalic Complex & $\begin{array}{l}\text { Late Oligocene to Early } \\
\text { Miocene }\end{array}$ & $<100$ & back-arc rift & Garwin and others (2005) \\
\hline $10 \mathrm{a}$ & Western Luzon Arc & & & & \\
\hline $10 \mathrm{~b}$ & Luzon Central Cordillera & Oligocene to Holocene & 1,200 & oceanic/ accretionary & Garwin and others (2005) \\
\hline $10 \mathrm{c}$ & $\begin{array}{l}\text { Northern Luzon-Babuyan } \\
\text { Arc }\end{array}$ & & & & \\
\hline 11 & Ryukyu Arc & $\begin{array}{l}\text { Eocene, Miocene to } \\
\text { Holocene }\end{array}$ & 1,200 & continental (no porphyry copper) & Garwin and others (2005) \\
\hline $12 \mathrm{a}$ & Southwest Japan Arc & Late Cretaceous- & & & \\
\hline $12 \mathrm{~b}$ & Northeast Japan Arc & $\begin{array}{l}\text { Paleogene; Miocene to } \\
\text { Holocene }\end{array}$ & 1,800 & continental (no porphyry copper) & Garwin and others (2005) \\
\hline 13 & Izu-Bonin Arc & Eocene to Holocene & 1,200 & oceanic (no porphyry copper) & Garwin and others (2005) \\
\hline 14 & Kurile Arc & Miocene to Holocene & 2,200 & continental (no porphyry copper) & Garwin and others (2005) \\
\hline
\end{tabular}


Digital geologic data were processed in a GIS using Esri ArcGIS software, as follows:

- Regional-scale geologic maps, geodynamic maps, and geologic literature were used to identify fundamental units for tract delineation, which were defined as magmatic arcs, belts, or large complexes of igneous rocks of a given age range.

- Digital geologic maps were then used to select map units to define preliminary permissive tracts for porphyry copper deposits. Igneous map units were separated by age groups and classified as permissive or nonpermissive based on lithology. Permissive rocks include calc-alkalic and alkalic plutonic and volcanic rocks. Types of igneous rocks that are unlikely to be associated with porphyry copper deposits were classified as nonpermissive. Examples of nonpermissive lithologies include ultramafic rocks, ophiolite complexes, highly evolved granites, peraluminous granites, rhyolites, and pillow basalts.

- Buffers were applied to polygons that represent permissive rocks. A $10-\mathrm{km}$ buffer was applied to plutonic rock polygons and a $2-\mathrm{km}$ buffer to volcanic rock polygons; this generally expanded the area of the tract to include all known porphyry copper deposits and significant associated prospects.

- Available data on mineral deposits and occurrences, locations of dated igneous rock samples, structural, geophysical, and geochemical information were examined to ensure that the tract included any other evidence of unmapped permissive rocks or hydrothermal systems.

- An aggregation and smoothing routine was applied to the resulting buffered polygons, followed by editing by hand to honor postmineral fault boundaries. In some cases, more detailed geologic maps were acquired to resolve tract boundary issues or page-size map illustrations from the literature were incorporated to fill in gaps.

- Volcanic centers and other areas of volcanic cover where the thickness of cover was known to exceed $1 \mathrm{~km}$ were excluded from tracts, either by using a buffer zone of $10 \mathrm{~km}$ around the volcano or based on topography. Intrusions younger than the designated tract age and ophiolitic and ultramafic rocks were also excluded. Volcanic rocks younger than the designated tract age, but inferred to be less than 1-km thick, may be present as cover and included in permissive areas.
- Resulting tract boundaries were clipped to shorelines to eliminate undersea areas by using small-scale digital international land boundary polygon files from the U.S. Department of State (2009), which incorporate high tide coastline data from the U.S. National GeospatialIntelligence Agency's World Vector Shoreline ${ }^{14}$ dataset.

\section{Permissive Tracts for Porphyry Copper Deposits in East and Southeast Asia}

Thirteen permissive tracts for porphyry copper deposits were delineated within the study area (fig. 3, table 3). Probabilistic estimates of numbers of undiscovered porphyry copper deposits were made for the 10 tracts in the Philippines. Three other tracts, one in South Korea and two in Japan, are discussed qualitatively. These three tracts delineate permissive lithologies; however, no porphyry copper deposits are known in Japan, and only a few porphyry-type prospects are known in South Korea, although future discoveries cannot be ruled out. The geologic rationales that have been proposed for the lack of significant porphyry-style deposits in these areas are discussed.

Permissive tracts are listed by geographic area, along with the countries included within each tract and the fundamental geologic feature used as a basis for each tract (table 3). Porphyry copper deposits with reliable identified resources are listed in table 1, in order of decreasing contained copper content. The following discussion provides an overview of the geodynamic settings for porphyry copper deposits in the study area and brief descriptions of the permissive tracts, starting with the Southeast Asia area.

\section{Southeast Asia (The Philippines and Taiwan)}

\section{The Philippine Archipelago}

The Philippine archipelago consists of more than 7,000 islands that cover a land area of about 300,000 square kilometers $\left(\mathrm{km}^{2}\right)$ (fig. 1). Locations of porphyry copper deposits and prospects in the Philippines and Taiwan (Republic of China) are plotted in figure $4 A-E$ along with physiographic features mentioned in this report.

\footnotetext{
${ }^{14} \mathrm{http}: / /$ shoreline.noaa.gov/data/datasheets/wvs.html
} 
$\boldsymbol{A}$

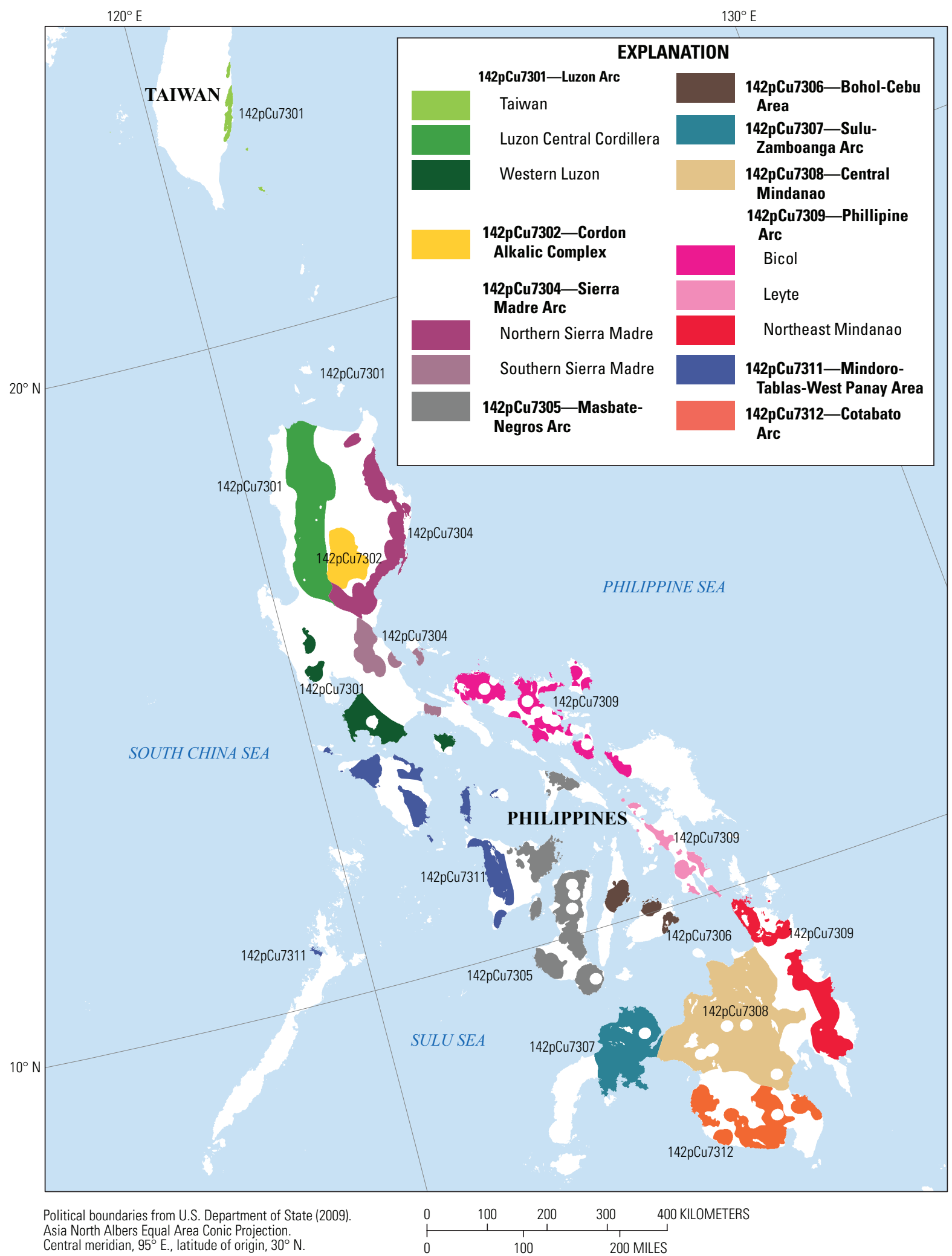

Figure 3. Maps of permissive tracts for porphyry copper deposits in countries covered in this report. A, Southeast Asia-Philippines and Taiwan (Republic of China); B, East Asia-Republic of Korea (South Korea) and Japan. 
B

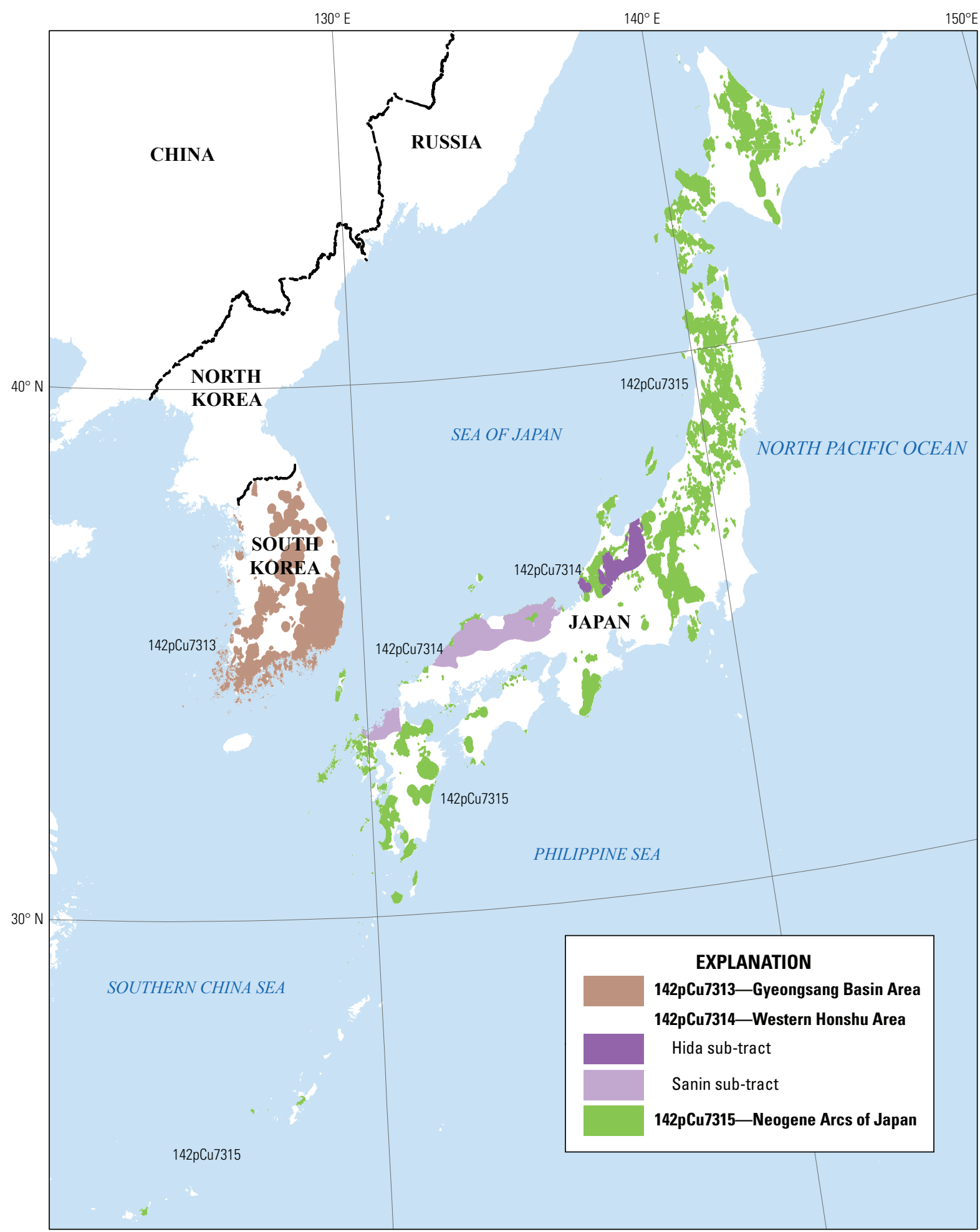

Political boundaries from U.S. Department of State (2009). Asia North Albers Equal Area Conic Projection.

Central meridian, $125^{\circ} \mathrm{E}$., latitude of origin, $30^{\circ} \mathrm{N}$.

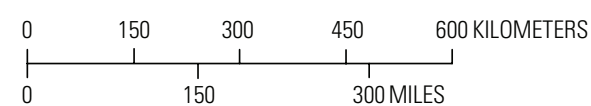

Figure 3.-Continued 
Table 3. Permissive tracts for porphyry copper deposits in East and Southeast Asia.

$\left[\mathrm{km}^{2}\right.$, square kilometers $]$

\begin{tabular}{|c|c|c|c|c|c|}
\hline Coded_Id & Tract Name & Countries & Geologic feature assessed & $\begin{array}{c}\text { Tract area } \\
\left(\mathbf{k m}^{2}\right)\end{array}$ & Appendix \\
\hline \multicolumn{6}{|c|}{ Philipine Archipelago } \\
\hline $142 \mathrm{pCu} 7312$ & Cotabato Arc & Philippines & Miocene to Pleistocene Colobato Arc & 9,700 & A \\
\hline $142 \mathrm{pCu} 7308$ & $\begin{array}{l}\text { Central Mindanao } \\
\text { Volcanic Province }\end{array}$ & Philippines & Pliocene Central Mindanao Volcanic Province & 29,320 & $\mathrm{~B}$ \\
\hline $142 \mathrm{pCu} 7307$ & Sulu-Zamboanga Arc & Philippines & $\begin{array}{l}\text { Northern late Miocene to Holocene Sulu- } \\
\text { Zamboanga Arc }\end{array}$ & 10,180 & $\mathrm{C}$ \\
\hline $142 \mathrm{pCu} 7305$ & $\begin{array}{l}\text { Masbate-Negros Arc } \\
\text { System }\end{array}$ & Philippines & $\begin{array}{l}\text { Masbate- Negros island arc system ( Eocene to } \\
\text { Miocene W, Miocene to Holocene E) }\end{array}$ & 12,230 & $\mathrm{D}$ \\
\hline $142 \mathrm{pCu} 7309$ & Philippine Arc & Philippines & Oligocene to Pleistocene Philippine Arc & 23,700 & $\mathrm{E}$ \\
\hline $142 \mathrm{pCu} 7302$ & Cordon Alkalic Complex & Philippines & $\begin{array}{l}\text { Late Oligocene to early Miocene K-alkaline } \\
\text { magmatic province at south end of Cagayan } \\
\text { rift basin. }\end{array}$ & 4,860 & $\mathrm{~F}$ \\
\hline $142 \mathrm{pCu} 7304(\mathrm{a}, \mathrm{b})$ & Sierra Madre Arc & Philippines & Eocene-Oligocene Sierra Madre Arc & 14,000 & G \\
\hline $142 \mathrm{pCu} 7311$ & $\begin{array}{l}\text { Mindoro-Tablas-West } \\
\text { Panay Area }\end{array}$ & Philippines & $\begin{array}{l}\text { Neogene Mindoro-Tablas-Western Panay } \\
\text { magmatic arc }\end{array}$ & 9,170 & $\mathrm{H}$ \\
\hline $142 \mathrm{pCu} 7306$ & Bohol-Cebu Area & Philippines & Miocene Bohol Arc; Cretaceous rocks on Cebu & 2,600 & I \\
\hline 142pCu7301(a,b,c,d) & Luzon Arc & $\begin{array}{l}\text { Philippines, } \\
\text { Taiwan }\end{array}$ & Oligocene to Holocene Luzon Arc & 23,700 & $\mathrm{~J}$ \\
\hline \multicolumn{6}{|c|}{ South Korea } \\
\hline $142 \mathrm{pCu} 7313$ & Gyeongsang Basin & South Korea & $\begin{array}{l}\text { Late Cretaceous calc-alkalic igneous rocks of } \\
\text { the southeastern Korean Peninsula }\end{array}$ & 46,300 & $\mathrm{~K}$ \\
\hline \multicolumn{6}{|c|}{ Japan Archipelago } \\
\hline $142 \mathrm{pCu} 7314$ & Western Honshu Area & Japan & $\begin{array}{l}\text { Late Cretaceous to Paleogene magnetite-series } \\
\text { igneous rocks of the Japan Arc }\end{array}$ & 27,600 & $\mathrm{~L}$ \\
\hline $142 \mathrm{pCu} 7315$ & $\begin{array}{l}\text { Subaerial Neogene Arcs } \\
\text { of Western Japan }\end{array}$ & Japan & $\begin{array}{l}\text { Subaerial parts of the Miocene and younger } \\
\text { Kurile, Northeast Japan, Izu, Southwest } \\
\text { Japan, and Ryukyu volcanic arcs }\end{array}$ & 120,590 & M \\
\hline
\end{tabular}



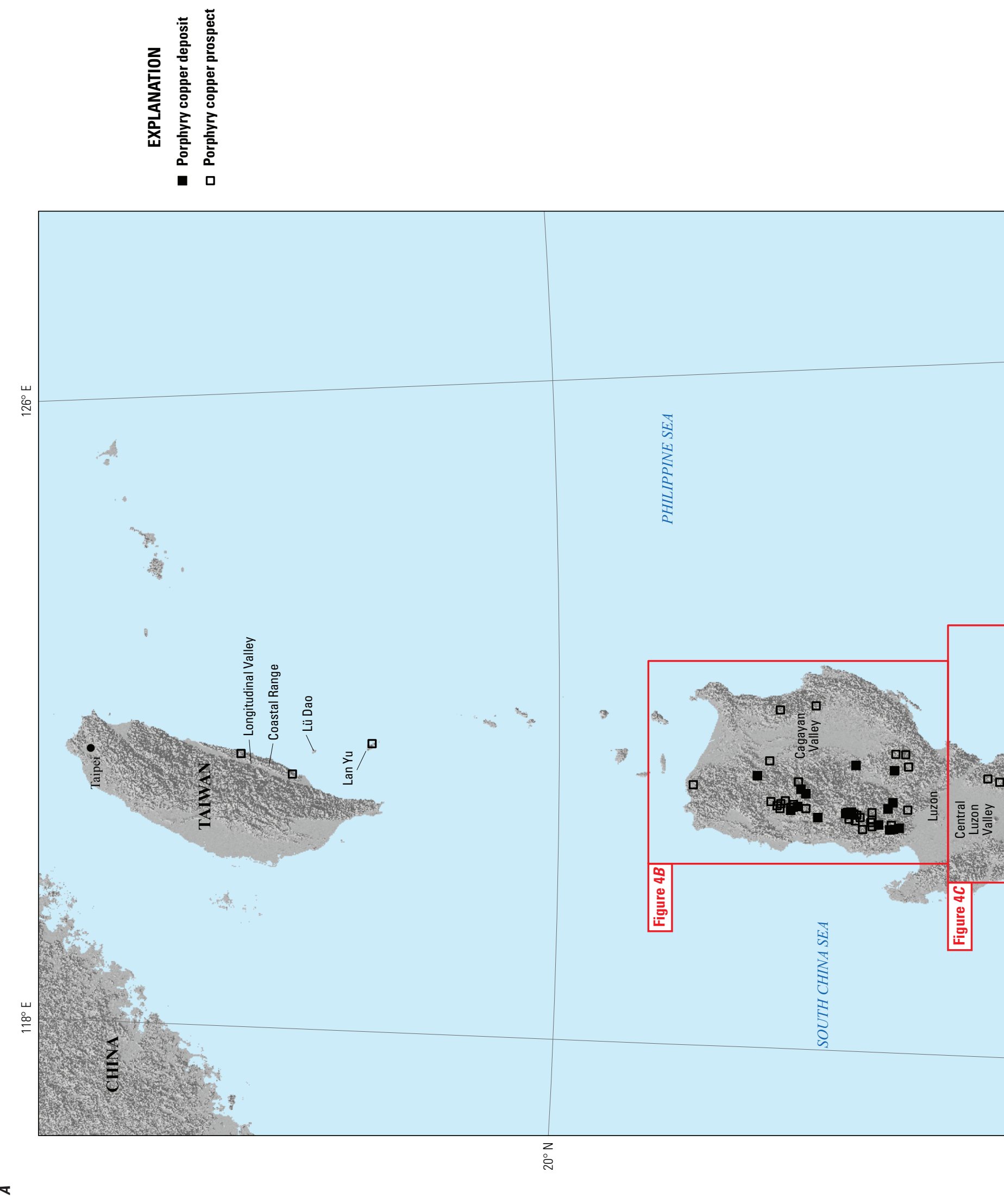


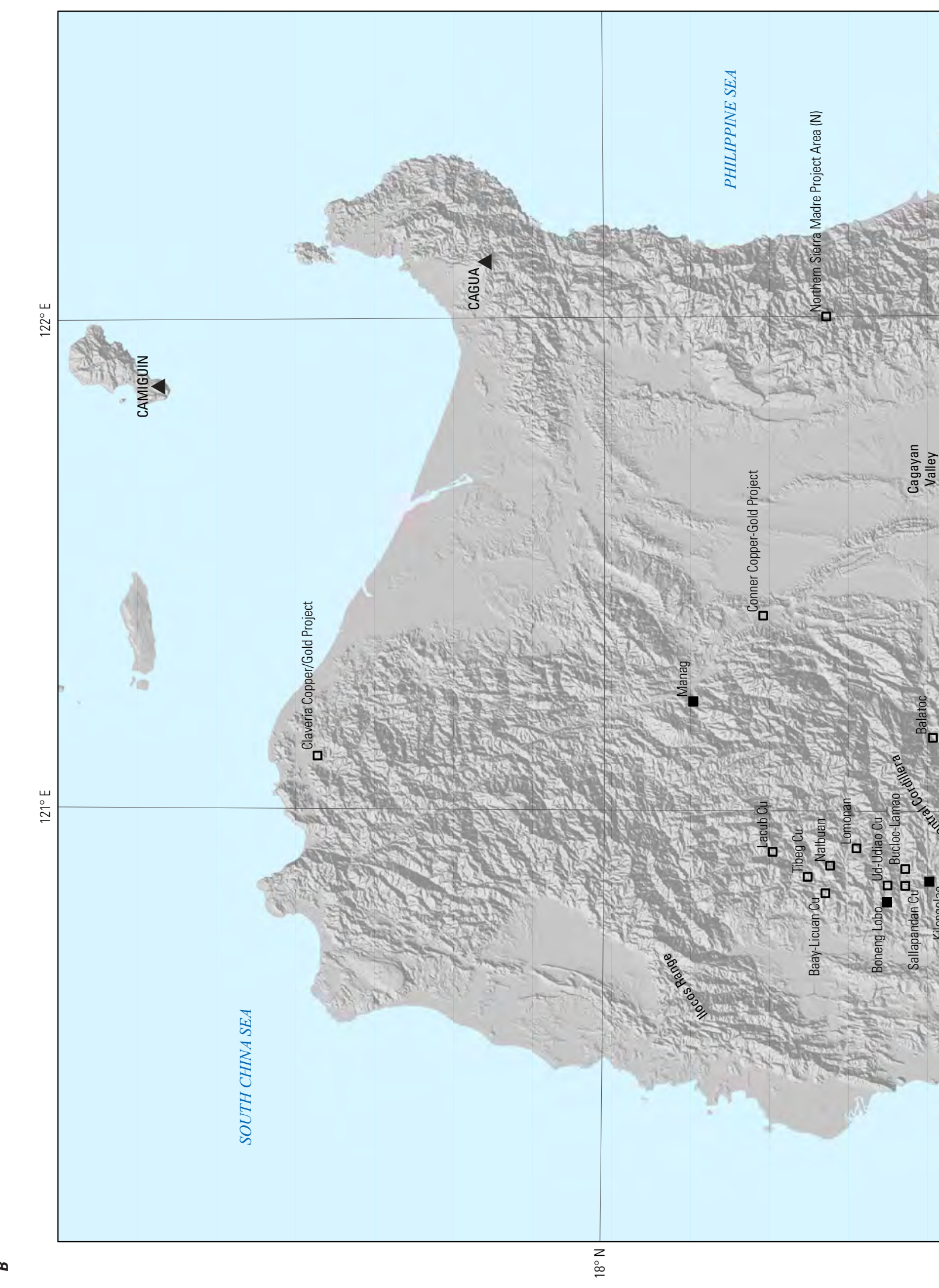




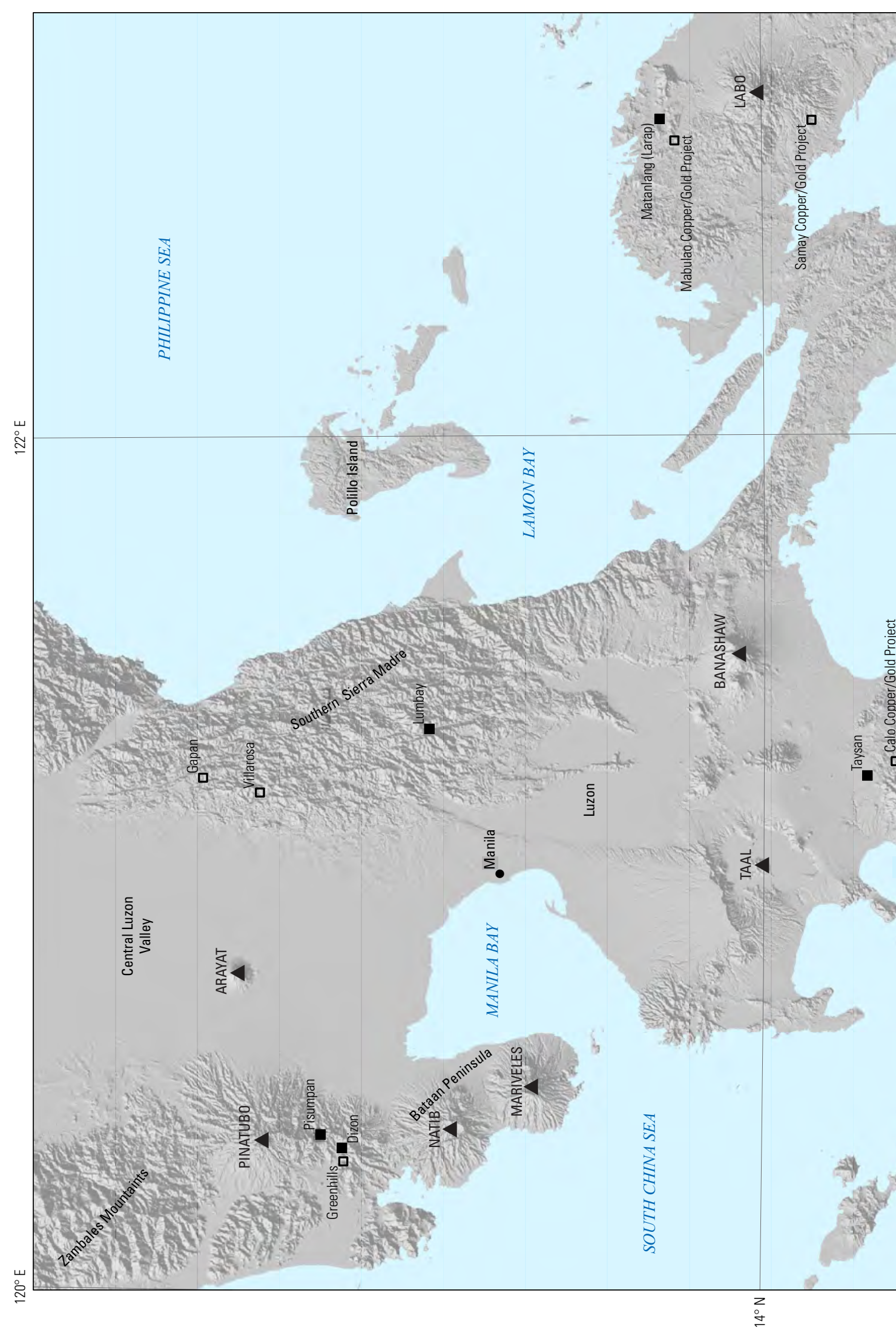


D

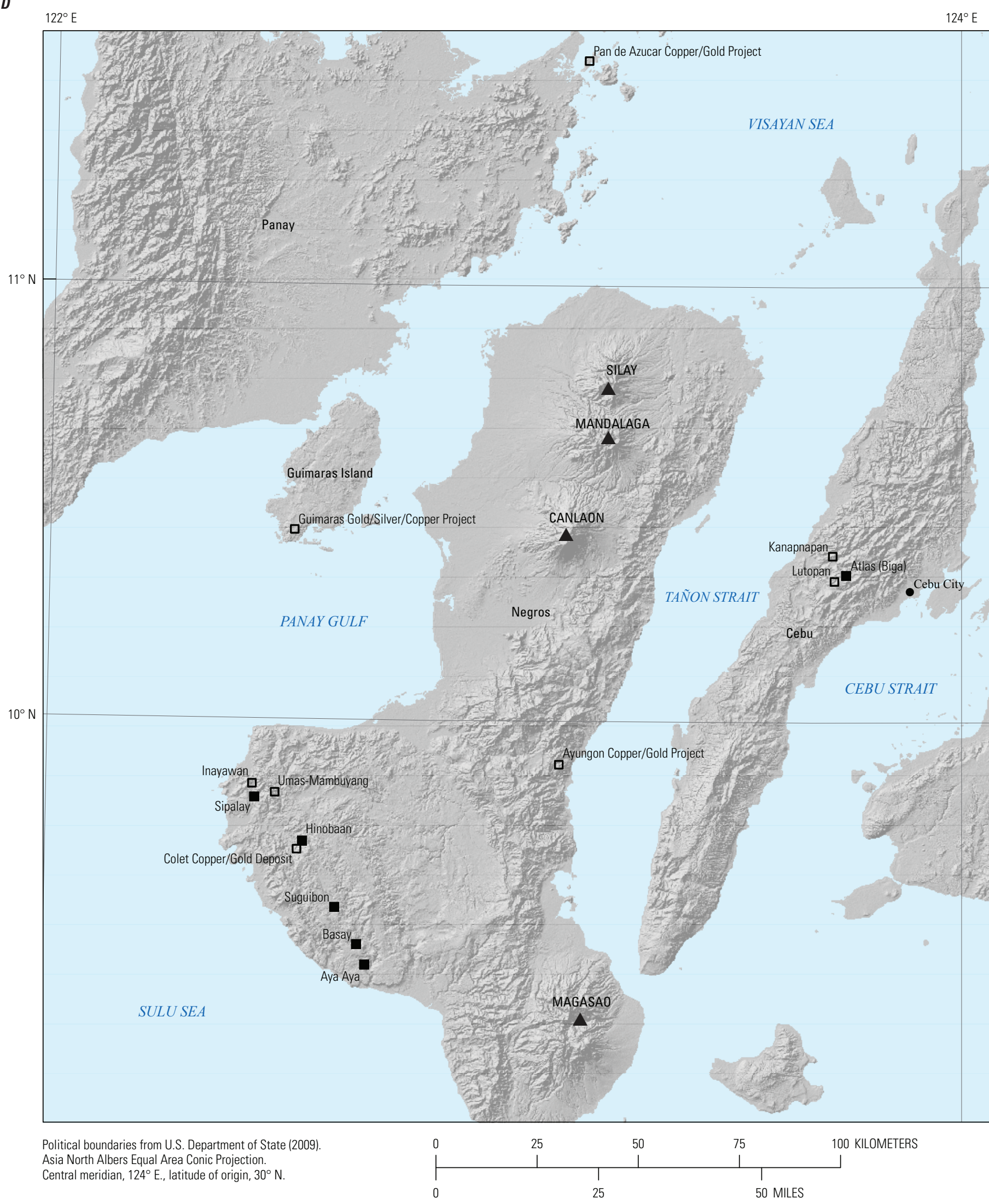

Figure 4.-Continued 
E

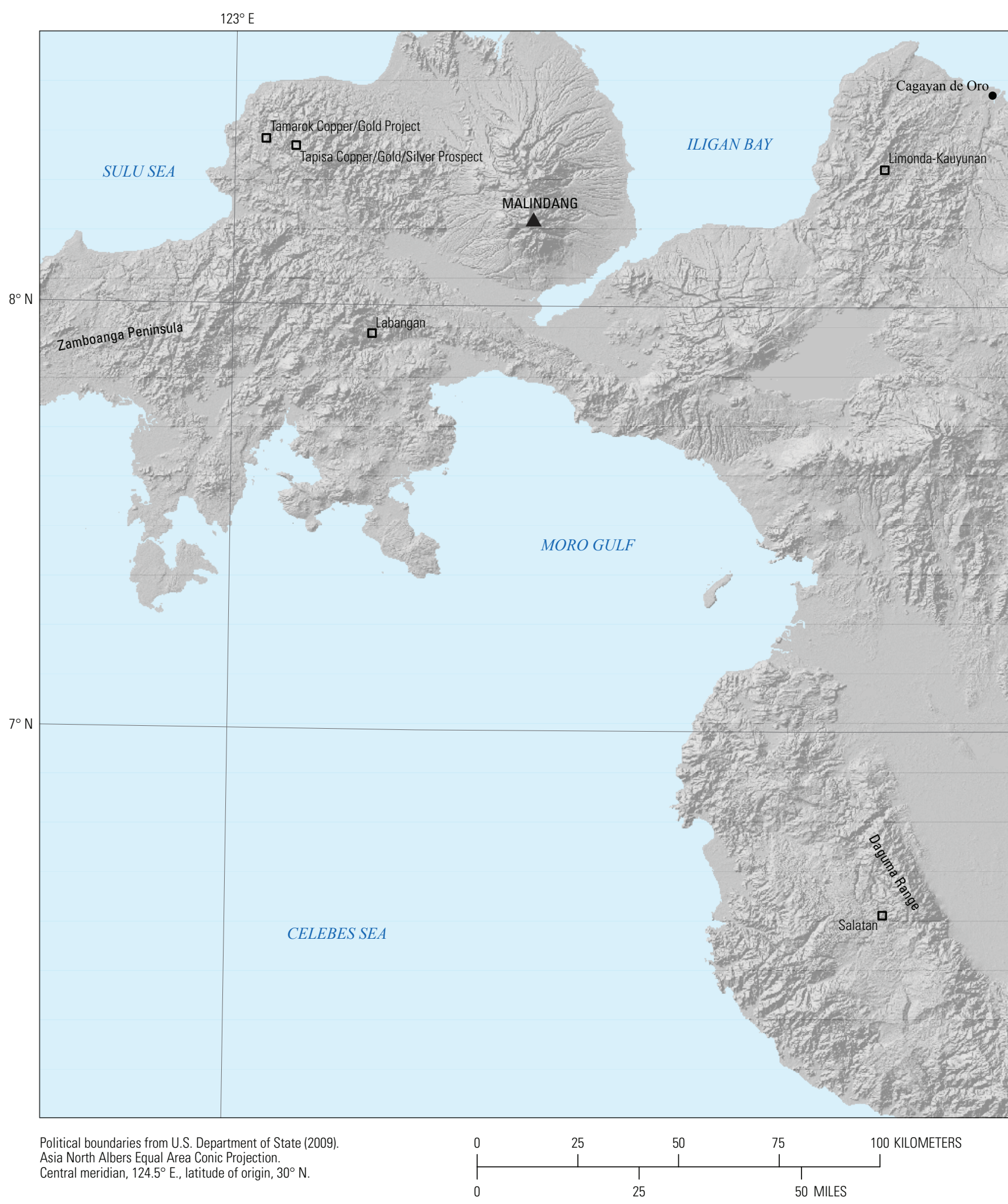

Figure 4.-Continued 
$125^{\circ} \mathrm{E}$

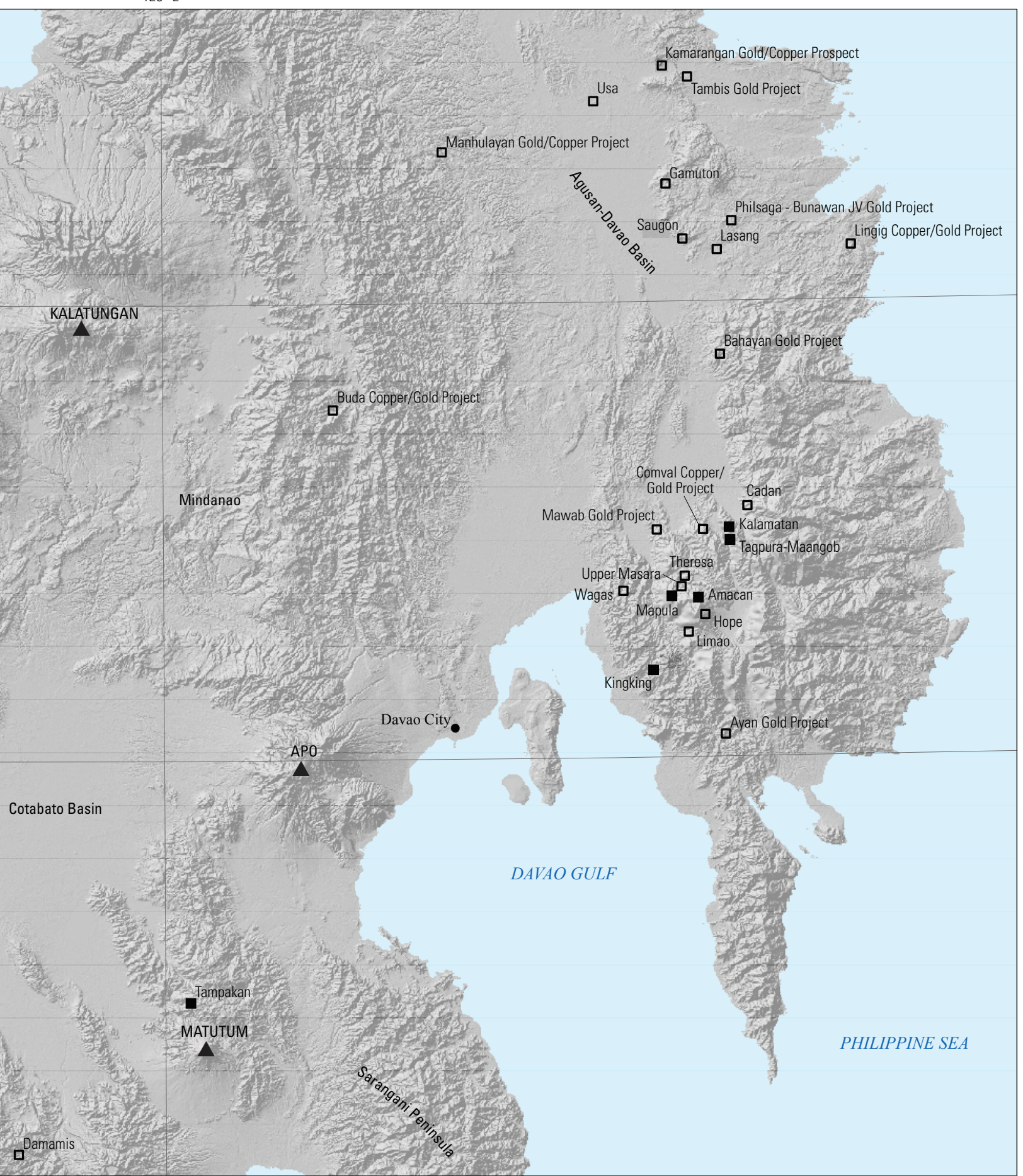

\section{EXPLANATION}

- Porphyry copper deposit

口 Porphyry copper prospect

- Volcano 
The Philippine island arc system is at the intersection of the oceanic Pacific Plate to the east, the continental Eurasian Plate to the west, and the oceanic and continental Indo-Australian Plate to the south (fig. $5 \mathrm{~A}$ ). The archipelago is a complex collage of subduction and collision zones, island arcs, marginal basins, and rifted and accreted microcontinental blocks (Philippine Mines and Geosciences Bureau, 2010). Arcs range in age from Cretaceous to Quaternary (table 2).

The Cretaceous was a period of oceanic crust formation, documented by Cretaceous ophiolite complexes containing fragmentary preserved evidence of arc magmatism. Cretaceous igneous rocks reported on Cebu, southeastern Luzon, and northeastern Luzon have subduction-related geochemical signatures (Dimalanta and Yumul, 2006). These rocks host the oldest porphyry copper deposit known in the Philippines, the 108-Ma (million-year-before-present/mega-annum) Atlas (Biga) deposit on Cebu (fig. 4D).

The Oligocene-Miocene magmatic arcs of the Philippines are preserved as more coherent belts that extend from Luzon to Mindanao. The majority of the porphyry copper and epithermal gold deposits of the Philippines are associated with Oligocene-Miocene arcs (Philippine Mines and Geosciences Bureau, 2010).

The Miocene collision of a microcontinent with an oceanic island arc formed the two major geologic blocks that constitute the Philippines. The Philippines Mobile Belt (fig. $5 B$ ) is a seismically active block characterized by faulting, earthquakes, and active volcanoes. The aseismic Palawan microcontinental block (fig. $5 B$ ) is a rifted fragment of an Asian Andean-type continental margin that drifted southward as the South China Sea opened in late Eocene to early Miocene time (37-16 Ma). The Palawan block (referred to as the Palawan indenter) collided with the northwestward-moving Philippine Mobile Belt near Mindoro Island in the central part of the archipelago about 20-16 Ma (Yumul and others, 2009). Studies of ophiolites, accretionary prisms and mélanges, and paleomagnetics indicate that different islands in the central Philippines rotated in different directions, and that multiple collisions may have occurred (Yumul and others, 2009).

Some data contradict the generally accepted interpretation of a northwest-southeast initial orientation of the central Philippines islands (Yumul and others, 2003, 2009).

The modern archipelago is situated between two opposing subduction zones. To the west, the South China Sea, Sulu Sea, and Celebes Sea are subducting eastward along the Manila-Negros-Sulu and Cotabato Trenches (fig. 5B). On the east side of the archipelago, the Philippine Sea Plate is subducting westward along the East Luzon Trough-Philippine trench system (fig. 5B). A 1,200-km-long sinistral strike-slip fault system, the northwest-trending Philippine Fault accommodates strain from convergence of surrounding subduction zones (Dimalanta and Yumul, 2006; Yumul and others, 2008a).

Most of the Cenozoic arcs can be directly related to specific subduction zones; some arcs are composite or longlived (table 2). The Luzon, Negros-Masbate, and Cotabato arc systems (fig. $2 A$ ) were formed by subduction along the eastdipping Manila-Negros-Cotabato trench system (fig. $5 B$ ); the Bicol and Philippine arc systems are related to west-dipping subduction of the Philippine Sea Plate along the Philippine Trench. Interpretations of the tectonic settings of some arcs continue to evolve as more data become available.

With the exception of the Atlas Mine on Cebu Island (fig. 4D), all of the known porphyry copper deposits of the Philippines are Oligocene or younger. Deposits include both porphyry copper-molybdenum-gold and porphyry copper-gold subtypes. Miocene and younger deposits are present in the western and eastern parts of the archipelago, whereas Miocene and Oligocene deposits mainly are confined to a central belt (fig. 6). As noted by Yumul and others (2003), the distribution of porphyry copper deposits in the Philippines is approximately coextensive with the distribution of epithermal gold systems, and the main magmatic episodes for porphyry copper emplacement are Cretaceous (95-110 Ma on Cebu), Oligocene (30 Ma on Negros), Miocene (15-20 Ma on Marinduque), and Pliocene (Baguio district on Luzon) (figs. 4A, $B$ ).

The major arc systems of the region (fig. 2, table 2) and the permissive tracts delineated by the assessment team (fig. 3, table 3) are described below, from south to north. Most of the arcs in the Philippines developed on older accretionary basement or on deformed ophiolites on thin, immature crust devoid of granitoid basement (D. Alexeiev, written commun., 2010).

\section{Cotabato Arc}

\section{Tectonic Setting}

The 300-km-long Miocene to Holocene Cotabato composite arc system in western Mindanao is the northern extension of the Sangihe Arc, and may be coextensive with the Masbate-Negros Arc to the north (fig. 2). The modern Cotabato Arc is associated with subduction of oceanic crust of the Celebes Sea at the Cotabato Trench (fig. 5). The Pliocene to Quaternary calc-alkalic and adakitic arc overlies Oligocene tholeiitic diorites and Miocene calc-alkalic andesites developed on older accretionary basement (Pubellier and others, 1991). The Cotabato Fault (fig. 5) forms the boundary between the northern part of the arc and the Central Mindanao Volcanic Belt to the east.

\section{Permissive Tract 142pCu7312 (Cotabato)}

The Cotabato tract, $142 \mathrm{pCu} 7312$, delineates arc-related calc-alkalic igneous rocks in southwestern Mindanao (fig. 3A). The tract hosts the Pliocene (3.5 Ma) Tampakan deposit (fig. 4E). The Tampakan porphyry copper-gold deposit, with 2,940 million metric tons ( $\mathrm{Mt}$ ) of 0.52 percent copper, is considered to be one of the largest undeveloped deposits in Southeast Asia (Middleton and others, 2004).Tampakan represents an epithermal system telescoped on a porphyry copper deposit. A feasibility study and mining plan were completed; however, plans for development of a mine were impeded by legislation passed in 2010. Porphyry copper-gold prospects, epithermal gold deposits, and skarns are associated with Neogene diorite stocks, hypabyssal porphyries, and eroded stratovolcanoes in the tract area. 


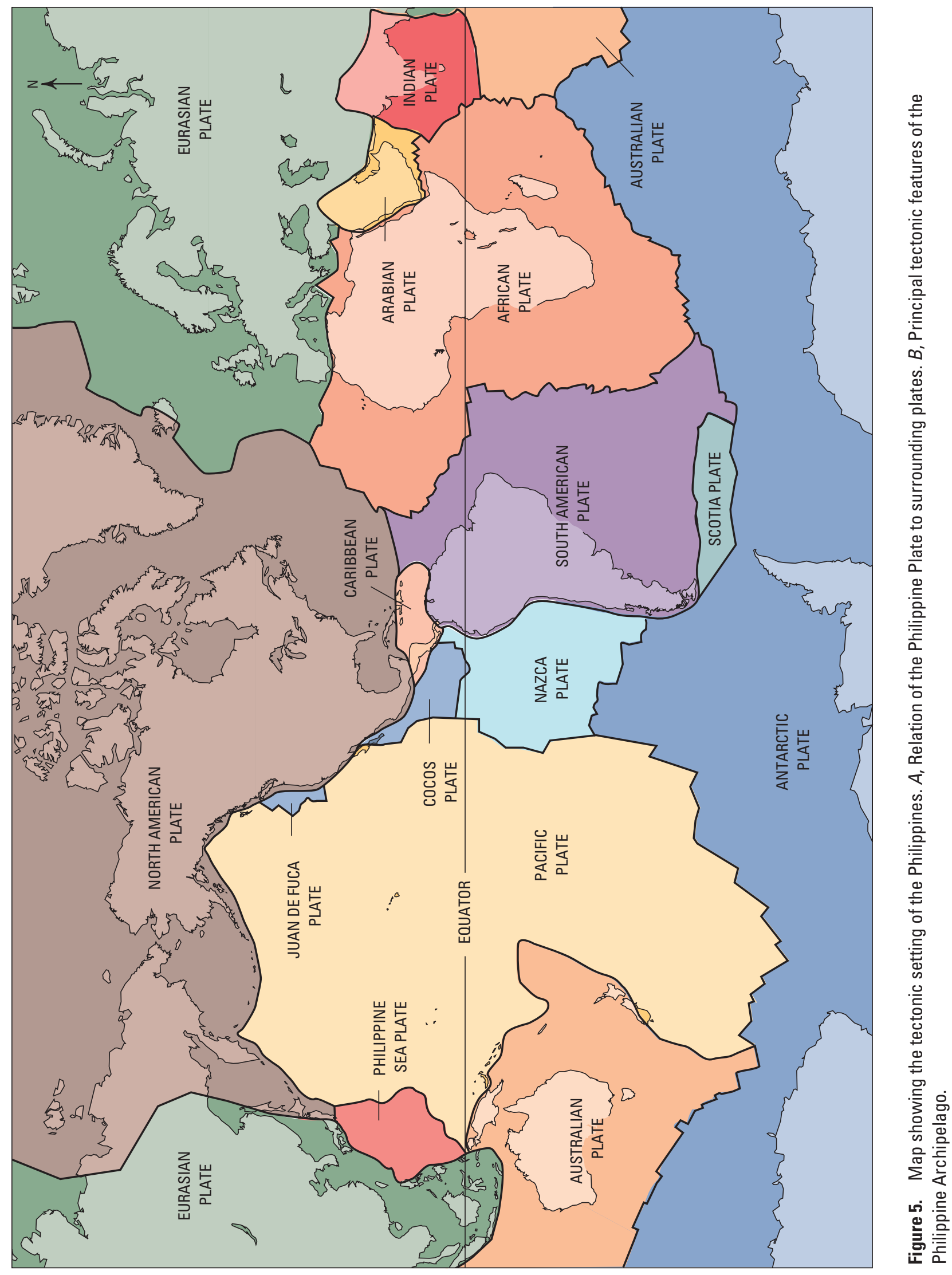


B

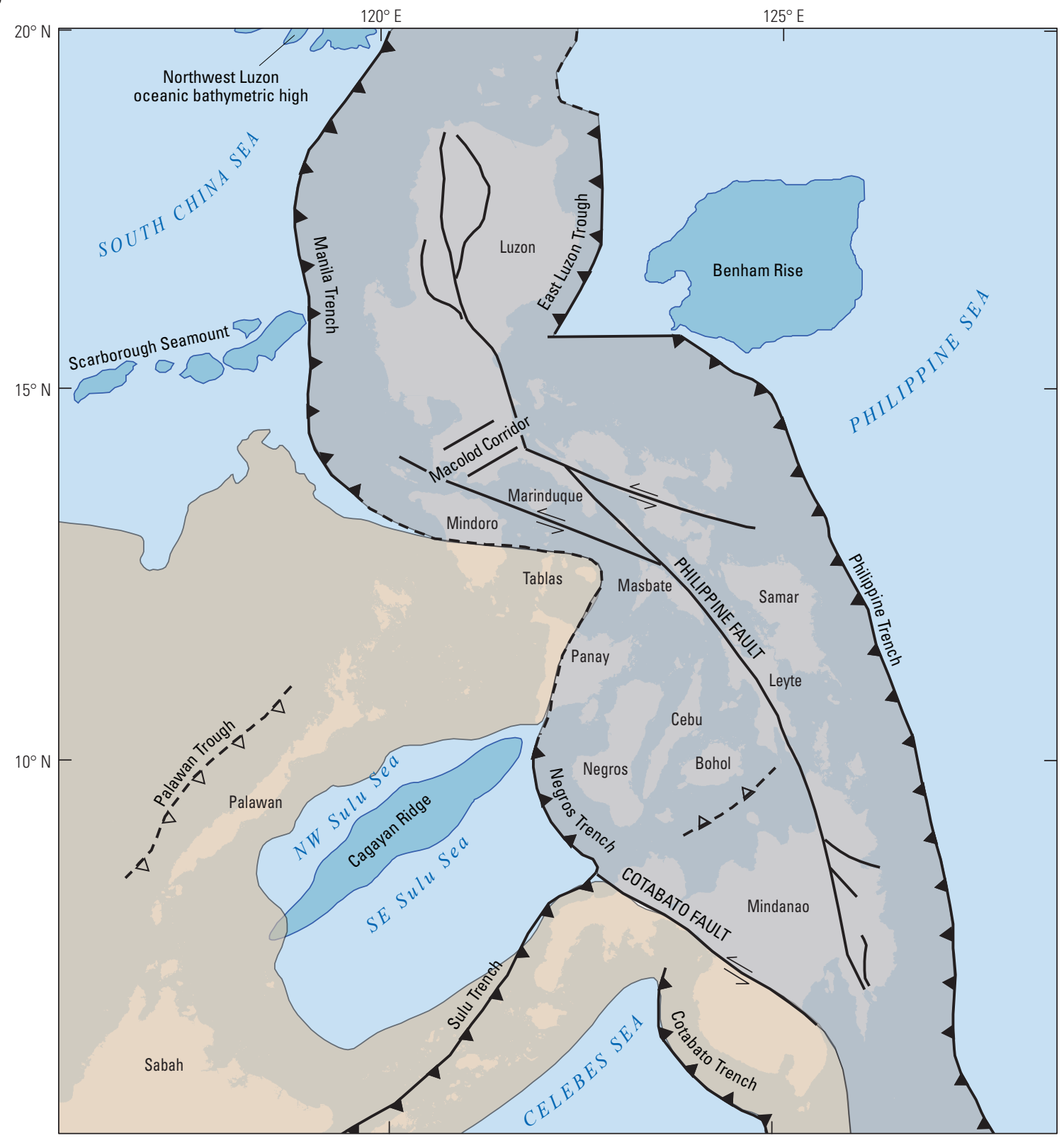

Political boundaries from U.S. Department of State (2009). Asia South Albers Equal Area Conic Projection.

Central meridian, $122^{\circ} \mathrm{E}$., latitude of origin, $15^{\circ} \mathrm{S}$.
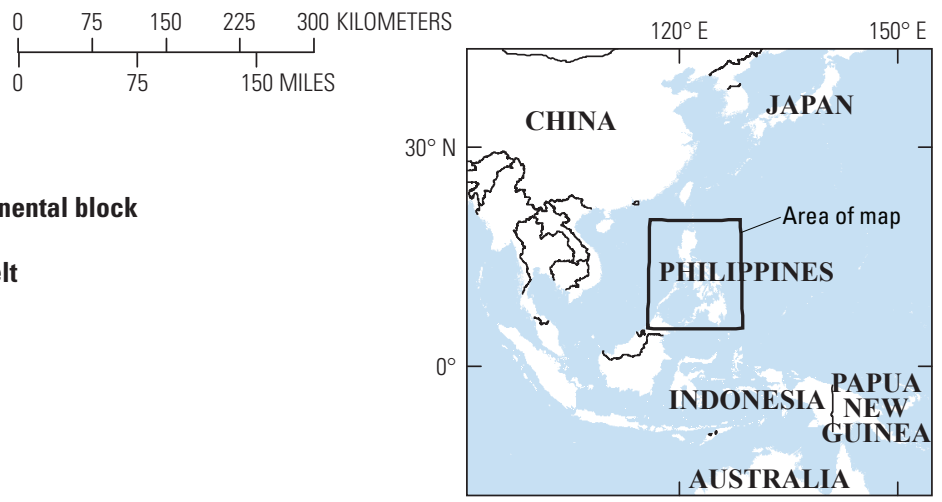

Figure 5.-Continued 


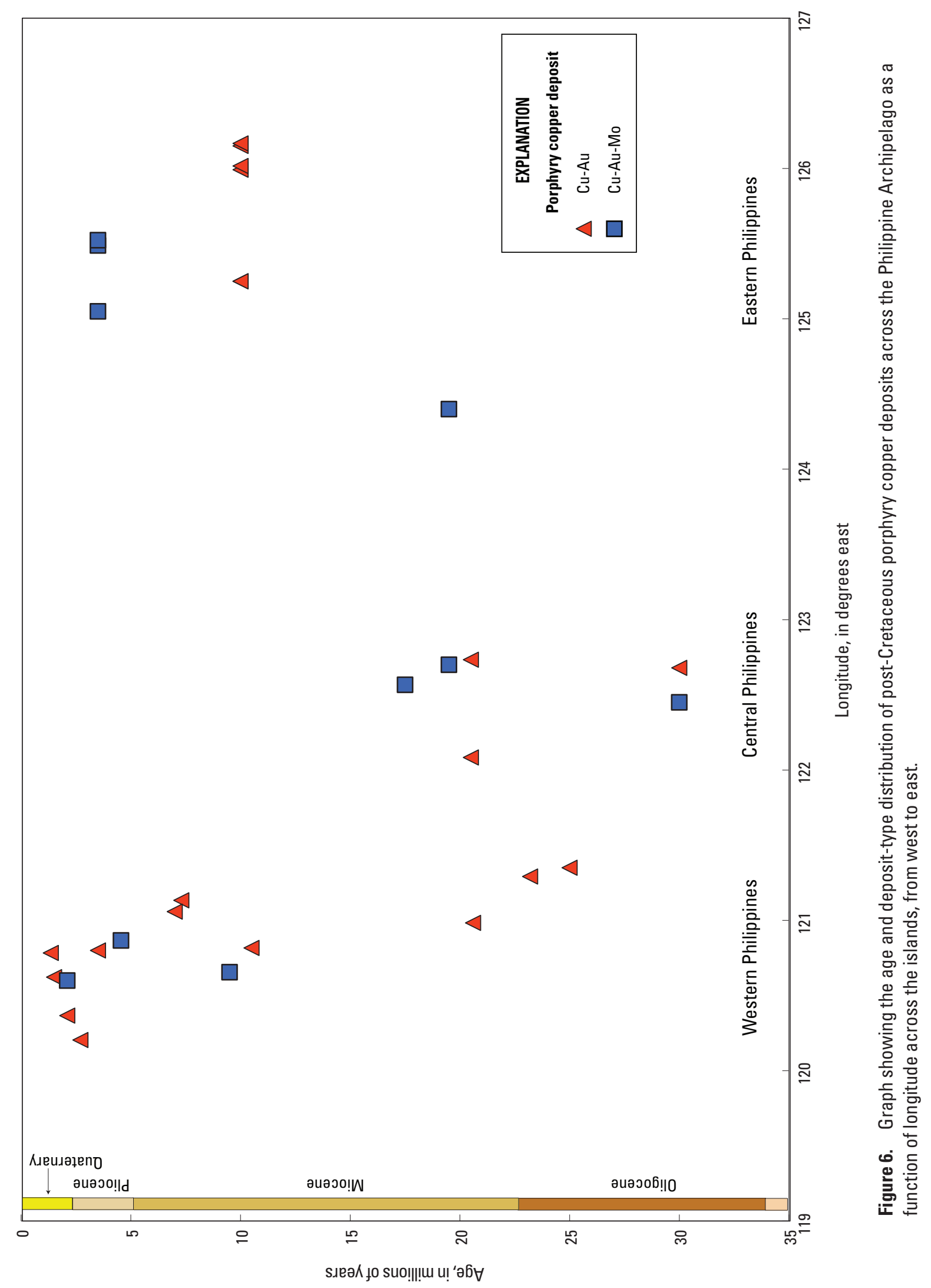




\section{Central Mindanao Volcanic Province}

\section{Tectonic Setting}

The Central Mindanao Volcanic Province (fig. 4E) is an area of Pliocene (4-5 Ma) collision of two island arcs, followed by postcollisional calc-alkalic to shoshonitic magmatism (2-3 Ma) that produced the largest volcanic field in the Philippines (Pubellier and others, 1996; Sajona and others, 2000). Western and eastern Mindanao constitute the northernmost extents of the Sangihe and Halmahera Arcs (figs. 1, $2 A$ ), respectively. These parts of present-day Mindanao were discrete oceanic arcs from the Paleogene until the Pliocene collision event (Sajona and others, 2000; Rangin and others, 1990). The collision event is ongoing to the south, where the Halmahera and Sangihe Arcs are colliding and consuming the intervening Molucca Sea (Sajona and others, 2000).

\section{Permissive Tract 142pCu7308 (Central Mindanao)}

The highlands west of the Philippine Fault (fig. 5B) in Central Mindanao within the Central Mindanao Volcanic Province are delineated as tract $142 \mathrm{pCu} 7308$ (fig. $3 A$ ). The eastern boundary of this tract is the margin of a basin filled with more than $5 \mathrm{~km}$ of Cenozoic sediments (the Agusan-Davao Trough). The western boundary of the Central Mindanao tract is the Cotabato Fault (fig. $5 B$ ), which forms the eastern boundary of the Cotabato Arc, tract 143pCu7312. There are three porphyry prospect areas within the tract, but no known deposits. Any porphyry copper deposits are likely to be concealed under volcanic cover.

\section{Sulu-Zamboanga Arc}

\section{Tectonic Setting}

The Sulu-Zamboanga Arc extends for $400 \mathrm{~km}$ from eastern Sabah, Malaysia, to the Zamboanga Peninsula of the southern Philippines (fig. 2A). Miocene collision between the northeastern island-arc terrane and a continental fragment that makes up the southwestern part of the peninsula is recorded by a mélange zone (Garwin and others, 2005; Jimenez and others, 2002).

\section{Permissive Tract 142pCu7307 (Sulu-Zamboanga)}

Paleogene and Neogene intrusions, and late Miocene to Pliocene volcanic rocks in the northern part of the SuluZamboanga Arc are assessed as tract 142pCu7307 (fig. 3A). Porphyry copper prospects and precious- and base-metal occurrences are associated with Pliocene to Pleistocene andesites and hypabyssal intrusions in the northeastern Zamboanga Peninsula, south of the Cotabato Fault (fig. 5B). The tract includes three significant porphyry copper prospect areas, including the undrilled, abandoned Labangan porphyry $\mathrm{Cu}-\mathrm{Au}$ prospect associated with diorite porphyry, andesitic to basaltic flows, and northwest-striking faults (Sillitoe and Gappe, 1984).

\section{Masbate-Negros Arc}

\section{Tectonic Setting}

The 400-km-long Masbate-Negros arc system includes an older Eocene to Miocene western arc, and a younger Miocene to Holocene eastern arc, all developed on oceanic arc accretionary crust (Garwin and others, 2005). The younger arc, which overprints the older arc, is related to the subduction of the Sulu Sea basin beneath Negros along the Negros Trench (fig. $5 B$ ). The polarity of subduction for the older western arc is not well-established (west- or east-dipping). The younger arc is interpreted as a product of east-dipping subduction associated with a slab at $100 \mathrm{~km}$ depth (Gudmundson and Sambridge, 1998).

\section{Permissive Tract 142pCu7305 (Masbate-Negros)}

The Masbate-Negros tract (fig. $3 A$ ) was delineated on the distribution of the Neogene igneous rocks that lie within the arc system, as bounded by the Philippine Fault (fig. $5 B$ ) on the north, and by the Sulu-Zamboanga Arc (fig. $2 A$ ) on the south. The Oligocene arc on Negros includes the Pagatban Batholith (38.4-34.4 Ma) that has intruded andesitic and dacitic rocks (Mitchell and Leach, 1991). On eastern Panay, the pre-Miocene arc rocks include diorites that intrude andesites (Mitchell and Leach, 1991). The mid-Miocene arc is defined by dacite porphyry stocks and dikes that intrude Oligocene diorites associated with porphyry copper deposits on southwestern Negros and andesites in eastern Panay (Mitchell and Leach, 1991). The tract includes Quaternary volcanic rocks in Central and Western Visayas that may cover buried porphyry deposits at shallow depths. The 30-Ma Sipalay deposit (807 Mt, 0.473 percent copper) lies within the tract (fig. $4 D$ ).

\section{Philippine Arc}

\section{Tectonic Setting}

The 1,000-km-long Philippine oceanic arc extends from Bicol to eastern Mindanao, parallel to the Philippine Fault (fig. 2A). The 1,200-km-long, left lateral Philippine strikeslip fault (fig. 5B), which spans the length of the Philippine Archipelago, has been active since the mid-Miocene. Different segments of the arc have been active since the Oligocene. Post-Pliocene arc magmatism was related to west-directed subduction of the Philippine Sea Plate at the Philippine Trench (fig. 5B). Pre-Pliocene magmatism may have been related to east-dipping subduction from the west (Garwin and others, 2005). From north to south, arc segments identified along the fault (fig. $5 B$ ) include the following (Yumul and others, 2008a):

- Bicol segment-Medium- to high-K calc-alkalic rocks, high-Al basalts, and andesites. 
- Leyte segment-A 250-km-long, southeast-trending belt of Plio-Pleistocene volcanoes characterized as medium- to high-K calc-alkalic rocks, Miocene andesitic rocks.

- Northeastern Mindanao segment-Early Oligocene-early Miocene rocks and Pliocene-Quaternary andesites.

\section{Permissive Tract 142pCu7309 (Philippine)}

The Philippine tract (142pCu7309) outlines the mapped extent of Paleogene and Neogene intrusions, including diorite complexes, and Oligocene-Miocene andesitic volcanic rocks along the Philippine Arc (fig. 2A). The tract includes late Pliocene intrusions associated with porphyry deposits in northeastern Mindanao. Parts of the tract are overlain by PlioceneQuaternary volcanic cover. The Philippine Fault forms the western boundary of the tract, which extends to the coast of eastern Mindanao. The tract includes eight porphyry copper deposits that range in age from $21 \mathrm{Ma}$ at Matanlang to $4 \mathrm{Ma}$ at Boyangan. These include the 1,151-Mt Kingking porphyry copper-gold deposit, several smaller deposits such as the 110-Mt Amacan deposit, and recent discoveries of the approximately 2.5-Ma concealed deposits at Boyungun (fig. 4D). The Boyungun deposit in northeastern Mindanao is remarkable because of the deep ( 600 meters, $\mathrm{m}$ ) oxidation zone that developed in a humid tropical climate, whereas supergene zones typically are $100 \mathrm{~m}$ thick or less (Braxton and others, 2009). More than 30 prospect areas lie within the tract, which may be underexplored relative to some other areas of the Philippines, such as the Luzon Central Cordillera (fig. $4 B$ ).

\section{Cordon Alkalic Complex}

\section{Tectonic Setting}

The Cordon Alkalic Complex is a late Oligocene to early Miocene alkalic province at the southern end of the Cagayan Valley in the Caraballo Mountains of Northern Luzon (fig. 4B). Proposed origins for the distinctive alkalic province, the only one recognized in the Philippines, include back- or intra-arc rifting that occurred after westward subduction along the East Luzon Trench ceased in the late Oligocene and before middle Miocene, east-directed subduction began along the Manila Trench. Intraplate magmatism, partial melting of a subducted slab, or intra-arc extension also have been proposed to explain these rocks. Geochemical data support a large ion lithophile elements (LILE) enriched mantle source that became increasingly enriched over time and a back-arc setting relative to eastward subduction along the western Luzon Arc (Wolfe and others, 2010). In a recent geochemical study, Hollings and others (2011) concluded that the potassic igneous rocks in the Cordon area formed in a back arc associated with the main calc-alkalic Miocene arc that produced the igneous activity in the Central Cordillera, where the arc formed by eastward subduction along the Manila Trench (fig. 5).
Permissive Tract 142pCu7302 (Cordon)

The Cordon tract (142pCu7302) outlines the Cordon Alkalic Complex at south end of the Cagayan Valley rift basin on Luzon (fig. $3 A$ ). The tract includes alkali syenites, monzonites, and trachyandesites of the Dipidio Igneous Complex, Palali batholith, Cordon Syenite Complex, and alkaline volcanic rocks (Knittel and Cundari, 1990; Knittel and Defant, 1988). The 23.2 Ma Dinkidi deposit (fig. $4 B$ ) is notable as it is one of the few recognized alkaline porphyry deposits outside of British Columbia, Canada (Wolfe and others, 2010). Dinkidi contains measured, indicated, and inferred resources of $121 \mathrm{Mt}$ of 0.39 percent copper, 0.97 grams per metric ton $(\mathrm{g} / \mathrm{t})$ gold with mining reserves of $23.7 \mathrm{Mt}$ at 0.65 percent copper and $1.8 \mathrm{~g} / \mathrm{t}$ gold (Joyce and Thomson, 2002). The tract also includes the 340-Mt San Fabian deposit.

\section{Sierra Madre Arc}

\section{Tectonic Setting}

Oligocene igneous rocks of intermediate composition along the Pacific coastal area of eastern Luzon in the Sierra Madre (fig. 4B,C) define the Sierra Madre Arc. The northern Sierra Madre is separated from the Luzon Central Cordillera by the Cagayan Valley (fig. 4B), an 8-km-deep sedimentary basin developed on pre-Tertiary ophiolite and CretaceousPaleogene arc rocks. Mitchell and Leach (1991) referred to the northern Sierra Madre as the Northeastern Luzon-Polillo-Catuandanes Arc, noting that a large 31-Ma granodiorite pluton that intruded Oligocene(?) volcanic rocks in northeastern Luzon may be coextensive with Oligocene plutons on Catuandanes Island (fig. $4 A$ ) and Polillo Island (fig. $4 C$ ). The rocks in the northern Sierra Madre may be coextensive with the Oligocene rocks in the southern Sierra Madre (fig. 4C).

\section{Permissive Tract 142pCu7304 (Sierra Madre)}

The Sierra Madre tract, $142 \mathrm{pCu} 7304$, consists of two segments (fig. $3 A$ ). The northern segment delineates Oligocene igneous rocks exposed in a discontinuous belt parallel to the east coast of Luzon; no porphyry deposits are known. The southern segment delineates Oligocene quartz diorite and diorites in southeastern Luzon and Miocene quartz diorite. The tract contains the 78-Mt Lumbay porphyry copper-gold deposit and four prospect areas (fig. $4 C$ ).

\section{Mindoro-Tablas-Western Panay Area}

\section{Tectonic Setting}

Rocks in northeastern Mindoro Island have the island-arc characteristics of the Philippine Mobile Belt, whereas rocks in southwestern Mindoro are linked to the Palawan microcontinent. Miocene arc rocks on Tablas and western Panay extend offshore to the Cagayan Ridge (fig. 5). The Tablas-Cagayan arc segment may represent a mid-Miocene continuation of the western Luzon Arc that existed before the Palawan collision (Mitchell and Leach,1991). 


\section{Permissive Tract 142pCu7311 (Mindoro-Tablas-West Panay)}

The Neogene Mindoro-Tablas-Western Panay tract (fig. $3 A$ ) is delineated on the extent of mapped Neogene igneous rocks in the collisional area between the Palawan microcontinent and the Philippine Mobile Belt on Mindoro Island, the Romblon Islands, Western Visayas (Panay), and a small area of exposed quartz monzonite in Palawan. The tract is composed of several parts due to the geography of the islands, all west of the Philippine Fault system. No porphyry deposits are known within the tract area; two porphyry-related copper prospects are reported in the tract area.

\section{Bohol-Cebu Area}

\section{Tectonic Setting}

The geodynamic setting(s) for the calc-alkalic igneous rocks on Bohol and Cebu Islands in the Central Philippines is poorly understood. Cretaceous, Paleogene, and Miocene ages are all reported. A northwest-trending Cretaceous arc fragment extends from northwestern Bohol through central Cebu Island (Philippine Mines and Geosciences Bureau, 2010). The relation of the Cretaceous rocks to subduction is unknown. Mitchell and Leach (1991) described Miocene diorite plutons and andesitic and dacitic volcanic rocks on Bohol Island as the Northwestern Bohol Arc, possibly related to an early Miocene trench that lay to the east of Bohol.

\section{Permissive Tract 142pCu7306 (Bohol-Cebu Area)}

Pre-Pliocene igneous rocks associated with known porphyry copper deposits and prospects in Bohol Island and nearby Cebu Island (fig. $4 D$ ) are assessed as tract $142 \mathrm{pCu} 7306$ (fig. $3 A$ ). The tract includes the Balak deposit on Bohol Island that has supergene reserves of $5 \mathrm{Mt}$ of 0.80 percent copper, the Cretaceous Atlas (Biga) mine on Cebu Island, and several prospects. Before the discovery of the Tampakan deposit, the Atlas Mine was the largest porphyry copper deposit in the Philippines (greater than $6 \mathrm{Mt}$ contained copper). The Atlas Mine operated from 1955 to 1995 with production from three separate pits (Biga, Carmen, and Lutopan). Production was restarted in 2007 along with exploration activities to assess historical mine waste dumps (1.2 billion metric tons) for copper recovery and to evaluate partially explored prospects for concealed extensions and satellites of the identified resources (Atlas Consolidated Mining and Development Corporation, 2012).

\section{Luzon Arc}

\section{Tectonic Setting}

The Neogene Luzon composite arc system extends from the Coastal Range of eastern Taiwan southward for a distance of 1,200 km to Mindoro in the Philippines (fig. 7). The arc became active in the early Miocene and is now underlain by an east-dipping Benioff zone related to the Manila Trench. In northern Luzon, an early to middle Miocene reversal in arc polarity may have shifted the locus of arc activity from east to west as the geodynamics switched from subduction of the proto-Philippine Sea Plate along the proto-East Luzon Trough to subduction of the South China Sea Plate along the Manila Trench (Yumul and others, 2008a). The 900-km-long Manila Trench marks Plio-Pleistocene eastward subduction of the South China Sea on the Eurasian Plate beneath the Luzon Arc of the Philippine Mobile Belt (figs. 5B, 7). The trench trends approximately north-south from the Taiwan collision zone in the north to Mindoro in the south, where the Palawan block collides with southwestern Luzon. Subduction of the Scarborough seamounts, the aseismic mid-ocean ridge of the South China Sea (fig. 5B), at 5-4 Ma may have caused a change in subduction angle (buoyancy) that interrupted subduction, caused regional uplift and erosion, and led to a gap in magmatic activity expressed as an approximately $50-\mathrm{km}$-wide gap between the western and eastern volcanic zones of the double island arc between Luzon and Taiwan to the north.

The Luzon Arc is a chain of active and extinct stratovolcanoes and volcanic necks that erupted tholeiitic through calcalkalic to shoshonitic and adakitic rocks (Yumul and others, 2008a). The oldest rocks associated with the Luzon Arc occur in the north (30-9 Ma on Taiwan); south of Taiwan, the arc is made up of several Miocene to Holocene segments (Yang and others, 1996; Garwin and others, 2005). The Luzon Central Cordillera segment contains 13 porphyry copper deposits, including the 1.5-Ma Far Southeast deposit, with more than $4 \mathrm{Mt}$ contained copper and the 3.5-1-Ma Baguio district, the most important gold-producing area in the Philippines (fig. $4 B$ ). The Baguio district hosts the Black Mountain and Santo Tomas II porphyry copper-gold deposits and at least eight porphyry copper-gold prospects (fig. $4 B$ ), as well as copper-gold skarns skarn and giant epithermal gold and base-metal vein deposits (Waters and others, 2011).

\section{Permissive Tract 142pCu7301 (Luzon)}

The 1,200-km-long Luzon Arc was assessed as a single tract (fig. $3 A$ ), but is described as four geographically separate segments. The northernmost segment of the Luzon Arc delineates permissive rocks along the Coastal Range of eastern Taiwan and adjacent islands, and includes the Chimei porphyry copper prospect. The Luzon Central Cordillera segment contains 13 copper-gold porphyry deposits that range in age from 11-1 Ma, including the world class Baguio and Mankayan mining districts (fig. 4B). The 657-Mt Far Southeast-Bato 


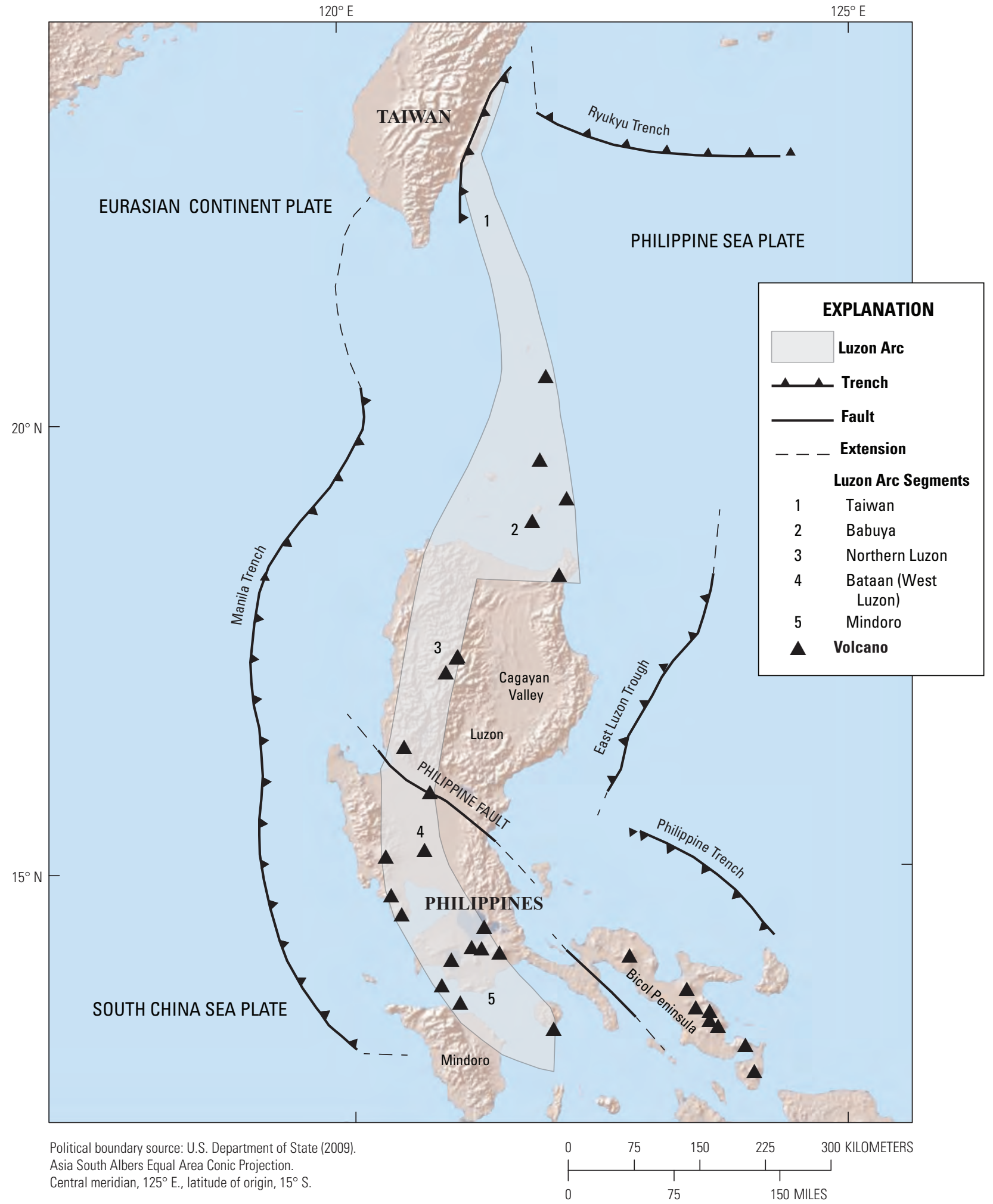

Figure 7. Map showing the Luzon Arc segments (after Defant and others, 1989; Yang and others, 1996). The Northern Luzon segment includes the Luzon Central Cordillera. 
Tabio deposit in the Mankayan district contains more than $4 \mathrm{Mt}$ of copper (Lepanto Consolidated Mining Company, 2008). The deposit was discovered in 1980 by drilling beneath the Lepanto epithermal deposit. Recognition of coupled, coeval K-silicate alteration in the Far Southeast porphyry deposit and advanced argillic (quartz-alunite) alteration in the spatially associated Lepanto high-sulfidation epithermal veins established a genetic relation between porphyry and epithermal deposit types (Sillitoe, 1983; Arribas and others, 1995; Hedenquist and others, 1998). Further studies in the Mankayan district showed that the presence of a lithocap, such as the one at Lepanto, indicated a level of erosion characteristic of the epithermal zone and that detailed alteration mapping can provide vectors to causative intrusions as an exploration tool for concealed porphyry and epithermal deposits (Chang and others, 2011).

The Western Luzon segment of the arc contains three copper-gold porphyry deposits (7-2 Ma), including the Taysan deposit (fig. 4C) with $968 \mathrm{Mt}$ of ore and 2.1 Mt contained copper. The Babuyan arc segment (number 2 on fig. 7) includes the northeasternmost tip of Luzon Island and offshore islands to the north; no deposits are known.

\section{East Asia (South Korea and Japan)}

The complete absence of known economic porphyry copper deposits associated with magmatic arcs in South Korea and Japan is in stark contrast to the arcs of Southeast Asia, though these countries do have significant mineralized belts of copper-tungsten and lead-zinc-molybdenum, as well as goldsilver and polymetallic deposits. Mesozoic arcs may be too deeply exhumed to preserve porphyry deposits, or arc magmas may have been insufficiently copper-rich or insufficiently oxidized to result in porphyry copper formation. Neogene arcs may be too immature or insufficiently eroded to expose porphyry copper systems subaerially. The following discussion includes an overview of the geologic setting of the East Asia magmatic arcs, descriptions of permissive tracts for porphyry copper deposits, and discussion of possible explanations for the apparent lack of porphyry copper deposits in the region. Locations of prospects in South Korea are plotted in figure 8, along with physiographic features mentioned in this report.

\section{Mesozoic to Holocene Evolution of the East Asian Continental Margin}

Following the Late Triassic collision and suturing of the North and South China cratons along the Qinling-Dabie suture (fig. 9), westward subduction of Paleopacific oceanic plates along the eastern margin of the amalgamated continent produced large volumes of Mesozoic granitic intrusions and volcanic rocks. Subduction of mid-ocean ridges, northward (along arc) migration of triple junctions, acceleration in plate velocities, and shifts in sea plate orientation produced the belts of Jurassic and Cretaceous continental arc magmas that characterize the Korean Peninsula and Japan (fig. 9). Figure $10 \mathrm{~A}$ shows a paleogeographic reconstruction of the Late Cretaceous Eurasian margin. During the Cretaceous, southern Korea was part of an active, Andean-type continental margin along East Asia that encompassed what is now southeastern China, western Japan, and the Sikhote-Alin area of Russia (fig. 9). Northward passage of the Pacific-Izanagi mid-ocean ridge along the Asian margin formed the fore-arc Ryoke granitoid belt and the Sanbagawa metamorphic belt (fig. 10A, based on Maruyama and others, 1997). Paleogene clockwise rotation of about 23 degrees affected both Korean and Japan (Lee, 2008). By the Eocene, the Izanagi Plate was completely subducted and the Pacific Plate came into contact with protoJapan. An extensional regime developed along the northern Asian continental margin in Eocene time as the convergence rate decreased. Continued extension led to the Miocene opening of the Japan Sea as a back-arc basin and resulted in the separation of Japan from the continent. Further clockwise rotation of southwestern Japan and counterclockwise rotation of the northeastern Japan in the Miocene led to the modern configuration of the archipelago (fig. 10B), parts of which are situated on four different tectonic plates-Eurasia, Okhotsk (North America), the Philippine Sea Plate, and the Pacific Sea Plate (Maruyama and others, 1997). The Japan Arc evolved from a Cretaceous Eurasian continental margin arc through a continental rifting stage (approximately $24 \mathrm{Ma}$ ), followed by an arc rifting stage (16-13 Ma), and then to the modern island arc (less than $14 \mathrm{Ma})$.

Quaternary volcanic fronts parallel the trenches that mark present-day subduction of the Pacific and Philippine Sea Plates. The Philippine Sea Plate is moving towards the northwest and subducting beneath the Southwest Japan and Ryukyu Arcs; the Pacific Plate is moving west-northwest and subducting beneath the Kurile and Izu-Bonin Arcs (fig. 10B). For a more detailed overview of the tectonic setting and evolution of Japan, see Maruyama and others (1997) and NUMO (2004).

\section{Korean Peninsula}

The Korean Peninsula is a collage of continental blocks that amalgamated in the late Paleozoic to early Triassic. Basement rocks include Precambrian massifs of high-grade schists and gneisses that are unconformably overlain by younger rocks and intervening belts of mainly Paleozoic metasedimentary and metavolcanic rocks (fig. 11A). Correlations among the major pre-Mesozoic tectonic provinces in Korea with those in China vary. For example, the entire Korean Peninsula historically has been interpreted to be part of the North China (Sino-Korea) crustal block, but some studies link the Gyeongii and Yeongnam Massifs (fig. 11A) to the South China Craton (Oh, 2006; Ernst and Liou, 1995; Zhang and others, 2012) and regard the Imjingang Belt (fig. 11A) as an extension of the Qinling-Dabie suture belt (fig. 9) between the North China (Sino-Korea) Craton and the South China Craton in China (Chough and others, 2000; Kim, 1996). 
Phanerozoic magmatism in the Korean Peninsula is associated with three major tectonic events - (1) the Late Permian to Triassic Songnim orogeny that marked the collision between the North and South China Cratons (Qinling-DabieSulu Indosinian orogeny in China), (2) the Jurassic Daebo orogeny, and (3) the Late Cretaceous to early Tertiary magmatism associated with the Bulguksa (Bulgugsa) ${ }^{15}$ orogeny (Kim, 1996). The Songnim magmatism mainly is preserved in North Korea as deeply eroded batholiths with no coeval volcanic rocks. The Daebo orogeny ended with intrusion of S-type granites.

Jurassic granites are widespread in southern Korea as deep-seated batholiths; deeply exhumed Triassic stocks are less common, and coeval volcanic rocks are absent (fig. 11B). Cretaceous, calc-alkalic I-type magnetite-series granites are preserved mainly as volcano-plutonic complexes in the Gyeongsang Basin (fig. 11B), the largest of the northeastsouthwest-oriented strike-slip basins that developed as a result of oblique subduction of the Paleopacific Plate beneath the Eurasian Plate (Choi and Lee, 2011). No plutonic rocks younger than Paleogene are known in South Korea.

No porphyry copper deposits are known on the Korean Peninsula. Porphyry-type mineralization has been recognized at a few prospects in the Gyeongsang Basin associated with Cretaceous to early Tertiary calc-alkalic rocks, and some exploration was done in the 1970s (Sillitoe, 1980). Intrusionrelated copper-tungsten skarn and polymetallic vein and carbonate replacement deposits are aligned with a series of northeast-southwest-striking metallogenic zones recognized within the Gyeongsang Basin. From southeast to northwest across the basin, the zones define belts of copper, iron, copperzinc-lead, tungsten-molybdenum, and lead-zinc mineralization. Yang and Bodnar (1994) concluded that although the geodynamic setting and lithologies in the basin are similar to productive porphyry settings elsewhere in the circum-Pacific region, the exposed permissive rocks represent the root zones of porphyry copper systems where any ore deposit that existed higher in the system has eroded off. Their study of silicate melt and fluid inclusions in granitoid intrusions in the Gyeongsang Basin showed that the high pressure of emplacement (1.9-2.5 kilobars, kbar), very late-stage attainment of magma water saturation, lack of veining and fracturing, and shapes of intrusions are characteristics of low-grade, deeper parts of porphyry systems.

The assessment team delineated one qualitative permissive tract in South Korea on the basis of distributions of permissive rocks for porphyry copper deposits. Yanshanian (Jurassic and Cretaceous) igneous rocks in North Korea are included in the Manchuride tract (142pCu8509) in the porphyry copper assessment of the Mesozoic of East Asia by Ludington and others (2012).

\footnotetext{
${ }^{15}$ The South Korean Ministry of Culture adopted a revised Romanization of the Korean language in 2000. As a result, many place names appear with slightly different spellings depending on the date of the publication. For example, the city of Busan formerly was known as Pusan.
}

\section{Gyeongsang Basin}

\section{Tectonic Setting}

Before the opening of the Sea of Japan in the Miocene, southeastern Korea and Japan were joined and formed an active continental margin on the Eurasian Plate. The Gyeongsang Basin preserves Late Cretaceous volcano-sedimentary complexes and calc-alkalic I-type subvolcanic intrusions (Bulguksa magmatism) that have been interpreted as marking the trace of a subduction-related continental arc system that extends from eastern China through southeastern Korea to the Japan Arc (Zhang and others, 2012).

\section{Permissive Tract 142pCu7313 (Gyeongsang Basin)}

The Late Cretaceous igneous and volcanic rocks of South Korea were delineated as permissive tract $142 \mathrm{pCu} 7313$ (fig. $3 B$ ). Most of these rocks are preserved in the Gyeongsang Basin and along the Ogcheon Belt (fig. 11A). Rocks of the Gyeongsang Supergroup, a 9-km-thick sequence of volcanic and sedimentary rocks, including the 2,000-3,000-m-thick volcanic-dominant Yucheon Group, fill the basin. The Yucheon Group is comprised of andesitic and rhyolitic subgroups of high-K calc-alkalic volcanic rocks. The granitoids in the basin range in age from 120-40 Ma. Zhang and others (2012) described volcanic rocks (94.4-78.4 Ma) and associated intrusions (72 Ma) in an area in the southern part of the basin. Small stocks and volcano-plutonic complexes are predominantly porphyritic, I-type diorites to granodiorites that have textures and miarolitic cavities indicative of a shallow level of emplacement (Zhang and others, 2012). The deeply eroded intrusions studied by Yang and Bodnar (1994) lie to the east of the area studied by Zhang and others (2012). These two study areas are on opposite sides of a major north-northeast-trending strike-slip fault system and may record different ages or different tectonic histories. The tract includes porphyry copper prospects (Sillitoe, 1980), copper-tungsten breccia-pipe deposits (Yang and Bodnar, 2004), skarns, and polymetallic deposits as well as copper occurrences, but no economic porphyry copper deposits have been documented to date.

\section{The Japan Arc}

\section{Tectonic Setting}

The 1,800-km-long Japan Arc records a long and complex geodynamic history. Cretaceous and Paleogene I-type granitoids intruded Permian-Triassic gneiss, schist, and Jurassic accretionary complexes on the Eurasian continental margin before Miocene separation of Japan from the craton as the Sea of Japan opened as a back-arc spreading center (Garwin and others, 2005).

Mesozoic granitoids formed during the continental-arc stage are present in western Honshu in the Inner Zone of southwest Japan along the eastern margin of the Sea of Japan 


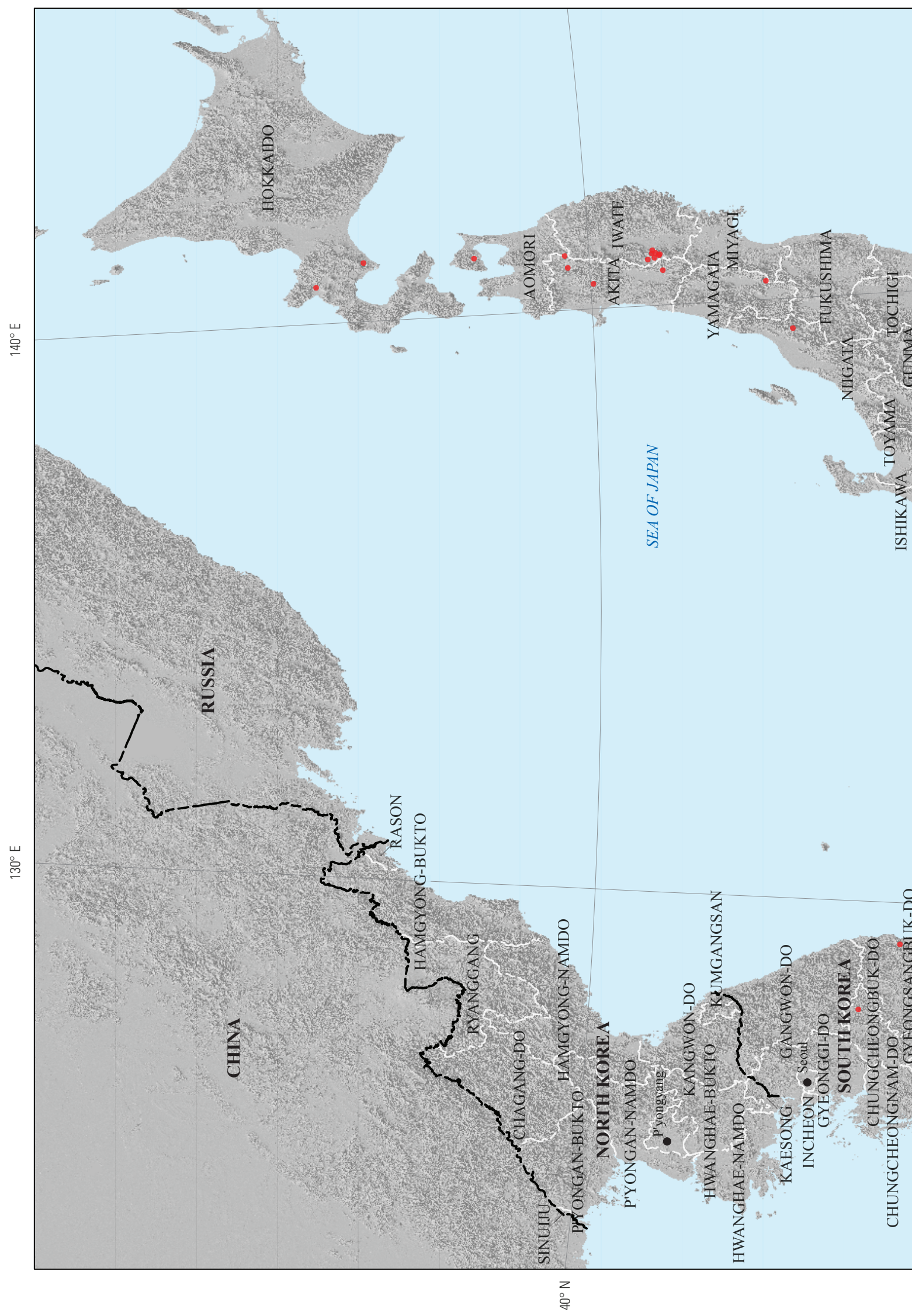




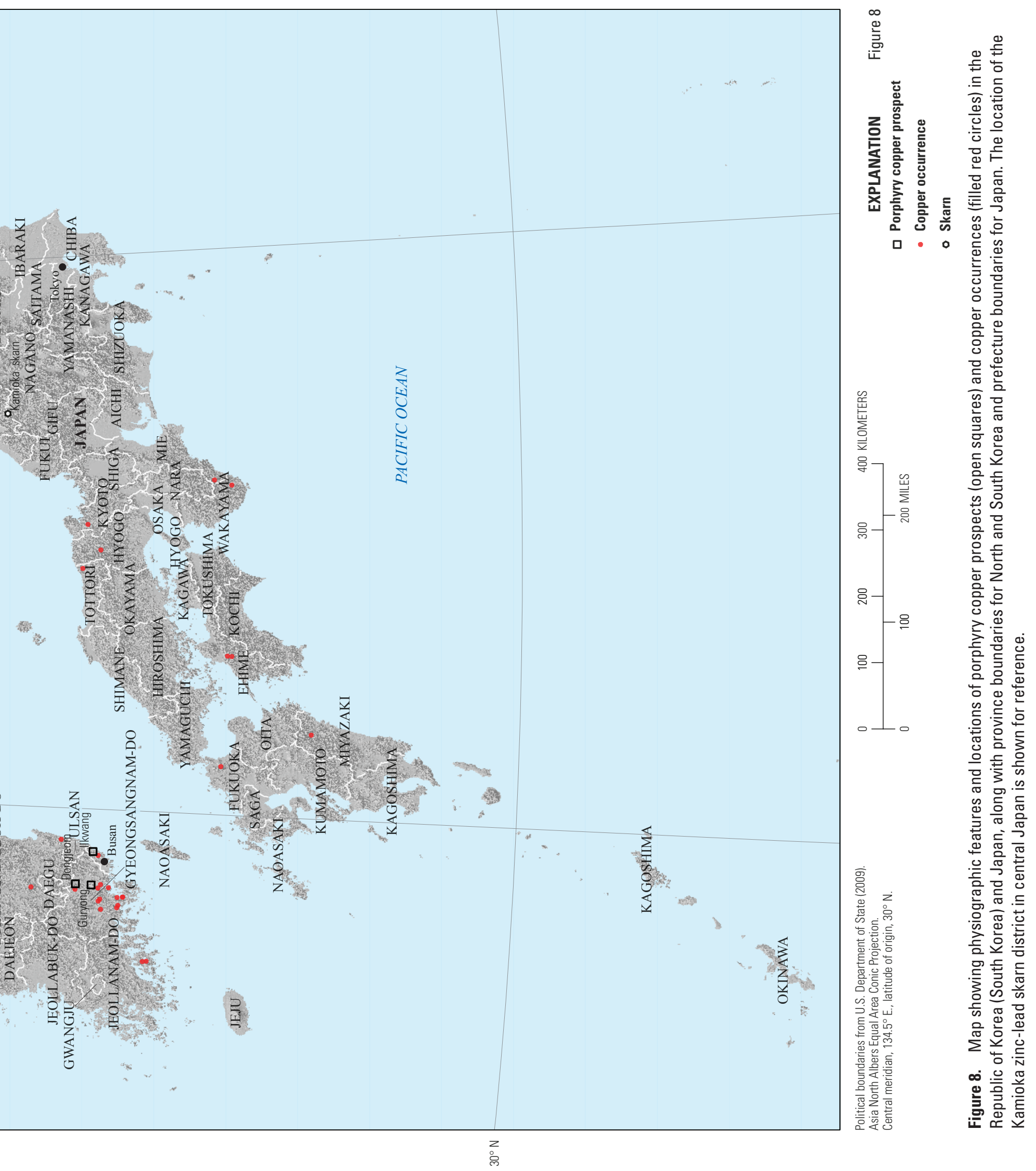




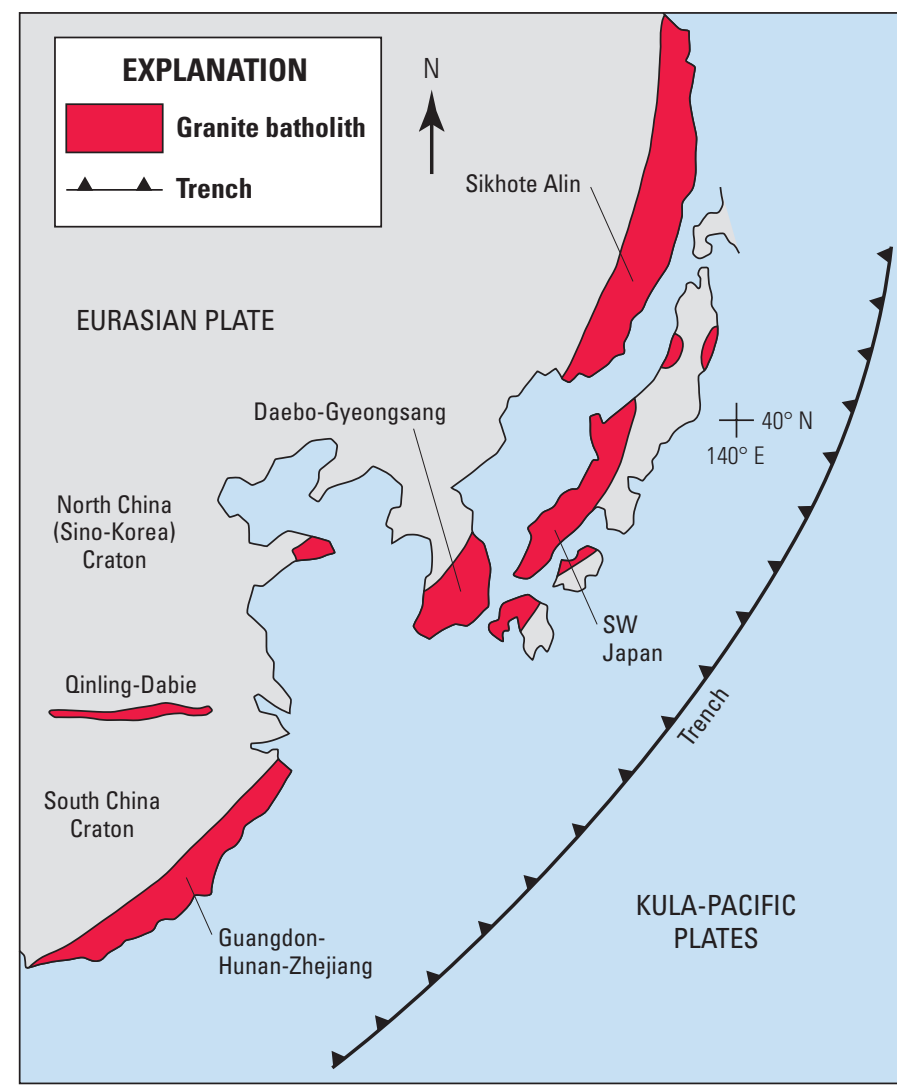

Figure 9. Simplified map showing the distribution of Cretaceous granitoids of the northern Eurasian continental margin, modified from Takagi (2004). SW, southwest.

and in northeast Japan (fig. 12A, B). Jurassic to Quaternary granitoids occur in narrow ( $80-100 \mathrm{~km}$ wide) belts in southern Japan (Ishihara, 1998), where back-arc magnetite series rocks characterize the Sanin Belt and fore-arc ilmenite series rocks characterize the Sanyo-Ryoke Belts (fig. 12A).

\section{Permissive Tract 142pCu7314 (Western Honshu)}

The Late Cretaceous to Paleogene calc-alkalic magnetiteseries igneous and volcanic rocks of Western Honshu were delineated as permissive tract 142pCu7314 (fig. 3B), which includes the western Sanin segment and the Hida segment to the northeast. Molybdenum quartz vein deposits and skarns are found in the Sanin molybdenum province (fig. 12A), but no economic porphyry copper deposits have ever been found. The Kamioka zinc-lead skarn deposits (fig. 8), Japan's largest zinclead producer, lies within the Hida tract segment. In a study that documented hydrothermal alteration patterns associated with igneous rocks in Japan, Utada (1980) defined alteration zones as acidic (alunite-rich), intermediate (approximately propylitic), and alkaline (Ca- and Na-zeolites). Propylitic and acidic alteration are most common; the potassic alteration stage typical of porphyry copper systems was not observed.
The absence of porphyry copper deposits in the magnetiteseries rocks of Japan has been a subject of extensive study and speculation; negative factors put forth include absence of thick crust, an extensional setting that produced volcanogenic massive sulfide deposits rather than a compressional setting that would favor porphyry formation, low copper abundance in granitoids, a low percentage of magnetite-series relative to ilmenite-series granitoids, and insufficient erosion to expose tops of porphyry systems (Qin and Ishihara, 1998). The lack of porphyry copper deposits most likely reflects the fact the oxygen and sulfur fugacities of magnetite-series magmas in Japan were not high enough to form porphyry copper deposits; that is, the magmas were less oxidized than those that formed deposits in the porphyry-rich areas elsewhere, such as in North and South America (Takagi and Tsukimura, 1997; Takagi, 2004). Differences in source magma $\mathrm{SO}_{2}$ and $\mathrm{H}_{2} \mathrm{~S}$ content and redox effects of assimilation of subducted sediment (promoted by increasing subduction-erosion accompanying increasing plate convergence rates) can explain the origin of the two series in Japan; contamination of granitic magmas with 15 percent subducted sediment or more could have produced the ilmenite-series rocks (Takagi, 2004). Both Utada (1980) and Qin and Ishihara (1998) suggested that porphyry copper deposits might lie at depth below acid-sulfate alteration.

\section{Japan and South Korea}

In Japan, Cretaceous granitoids are more abundant than older Mesozoic granitoids, in contrast to South Korea, where, with the exception of the Cretaceous magmatism preserved in the Gyeongsang Basin, Jurassic granitoids are more abundant (compare figs. $11 B$ and $12 B$ ). The 50-million-year magmatic gap from Late Jurassic to Early Cretaceous in both Japan and South Korea might have resulted from changes in subduction angle or changes in plate convergence rates (Sagong and others, 2005).

A number of authors have compared the Cretaceous igneous rocks of the Gyeongsang Basin of South Korean with the Sanin Belt rocks, given that they formed along the same continental margin (Ishihara, 1981; Sillitoe, 1980; Jwa, 1998; Koh and others, 2003; Sagong and others, 2005). Intrusive rocks in both areas were emplaced mainly between 100 and $50 \mathrm{Ma}$, have similar ${ }^{87} \mathrm{Sr} /{ }^{86} \mathrm{Sr}$ values of about 0.706 , and lead isotopes for galena from ore deposits in both areas have similar ranges. Intrusions were emplaced at high levels in the crust with coeval volcanism in both areas. Jwa's (2004) comparison of Cretaceous to Paleogene granitoids of the Gyeongsang Basin with those in Japan indicated that the South Korean rocks are more oxidized and richer in alkali elements.

Major differences are observed in the arrangement of age trends, metal zones, and the distributions of Cretaceous to Paleogene magnetite and ilmenite series rocks. In general, 


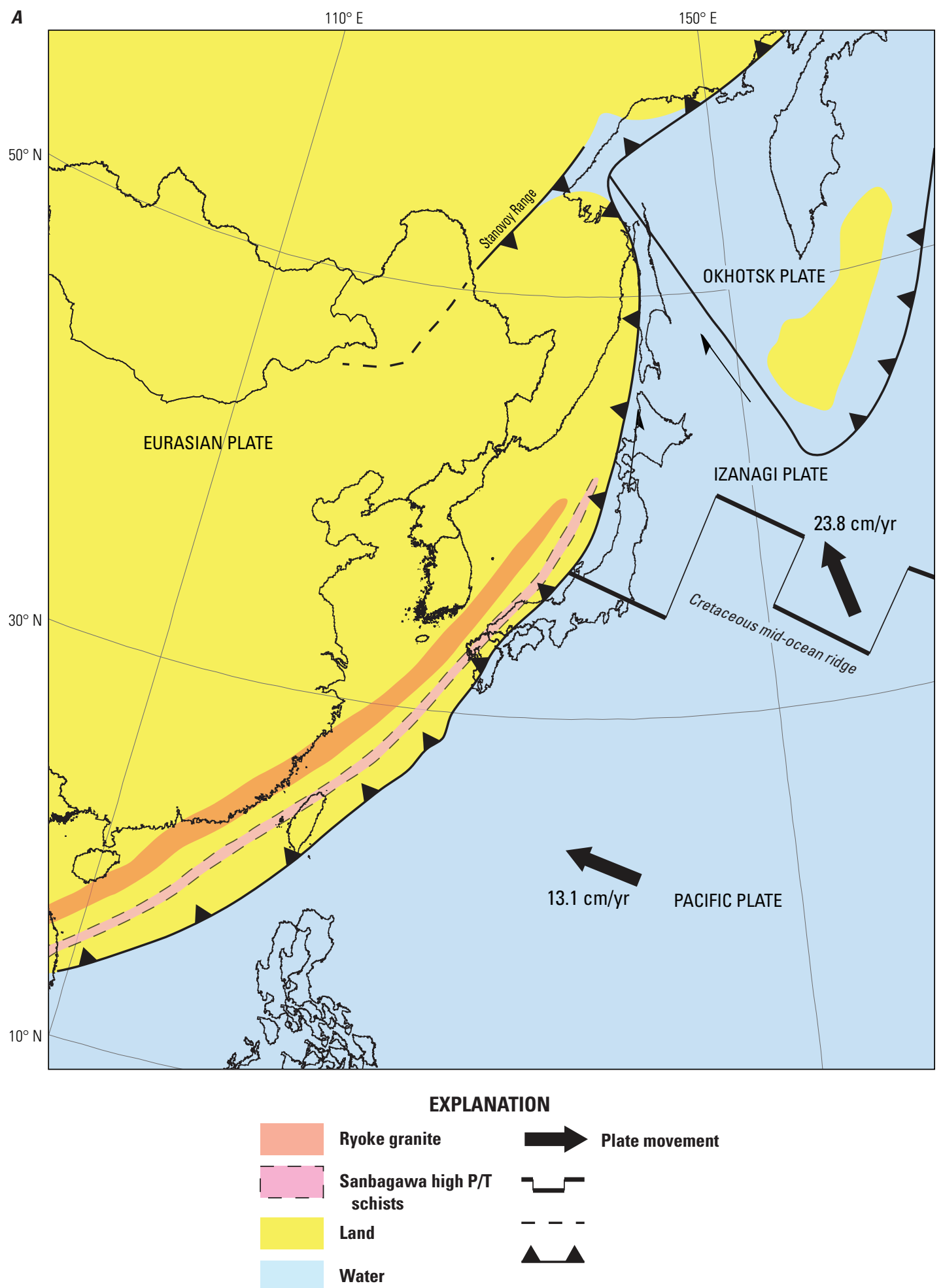

Figure 10. Map showing tectonic setting of the Eurasian continental margin (modified from Maruyama and others, 1997). A, Late Cretaceous. $B$, present day. Dark yellow, land areas; blue, sea areas; white, Okhotsk Plate. Arrows show directions and speed of plate motions. Thin black lines show country boundaries. $\mathrm{cm} / \mathrm{yr}$, centimeters per year; N., North; $\mathrm{P} / \mathrm{T}$, pressure/temperature. 


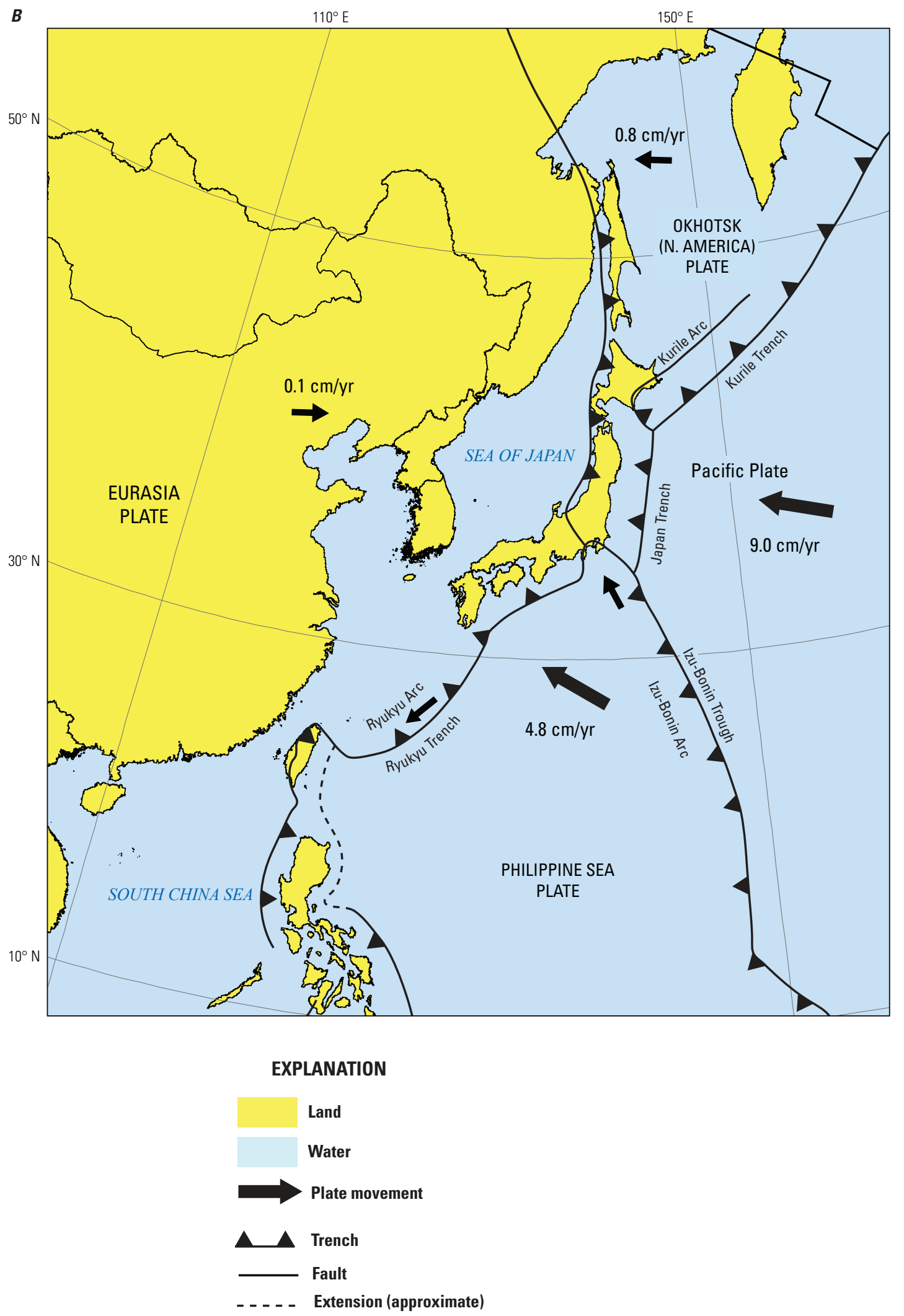

Figure 10.-Continued 
$\boldsymbol{A}$

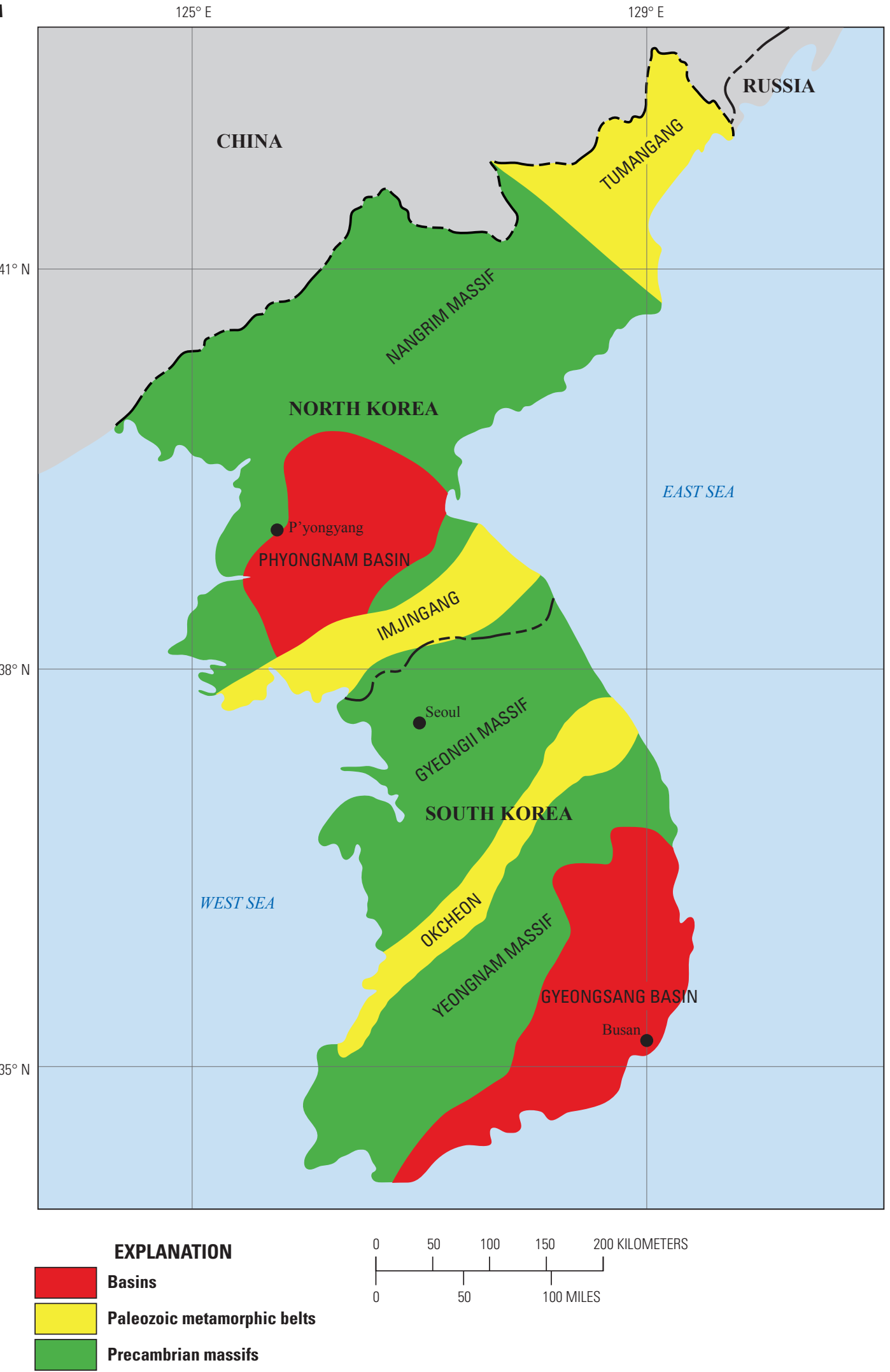

Figure 11. Maps showing tectonic divisions and Mesozoic igneous rocks of the Korean Peninsula. $A$, Major tectonic divisions of the Korean Peninsula, based on Paek and others (1996). B, Distribution of Mesozoic igneous rocks in the Korean Peninsula, based on the 1:1,000,000-scale geologic map of Korea (Korea Institute of Geology, Mining and Materials (KIGAM), 1995a). 


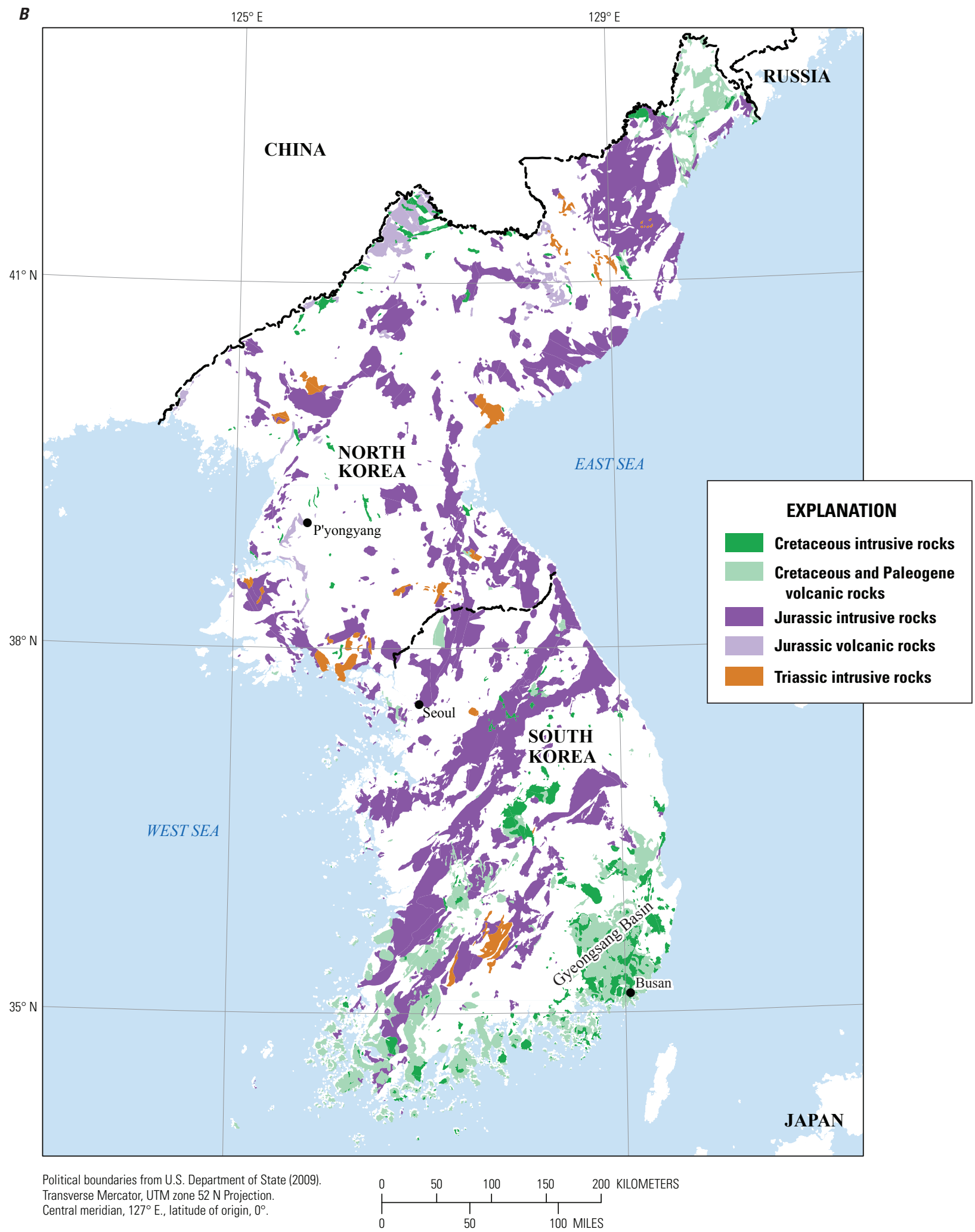

Figure 11.-Continued 


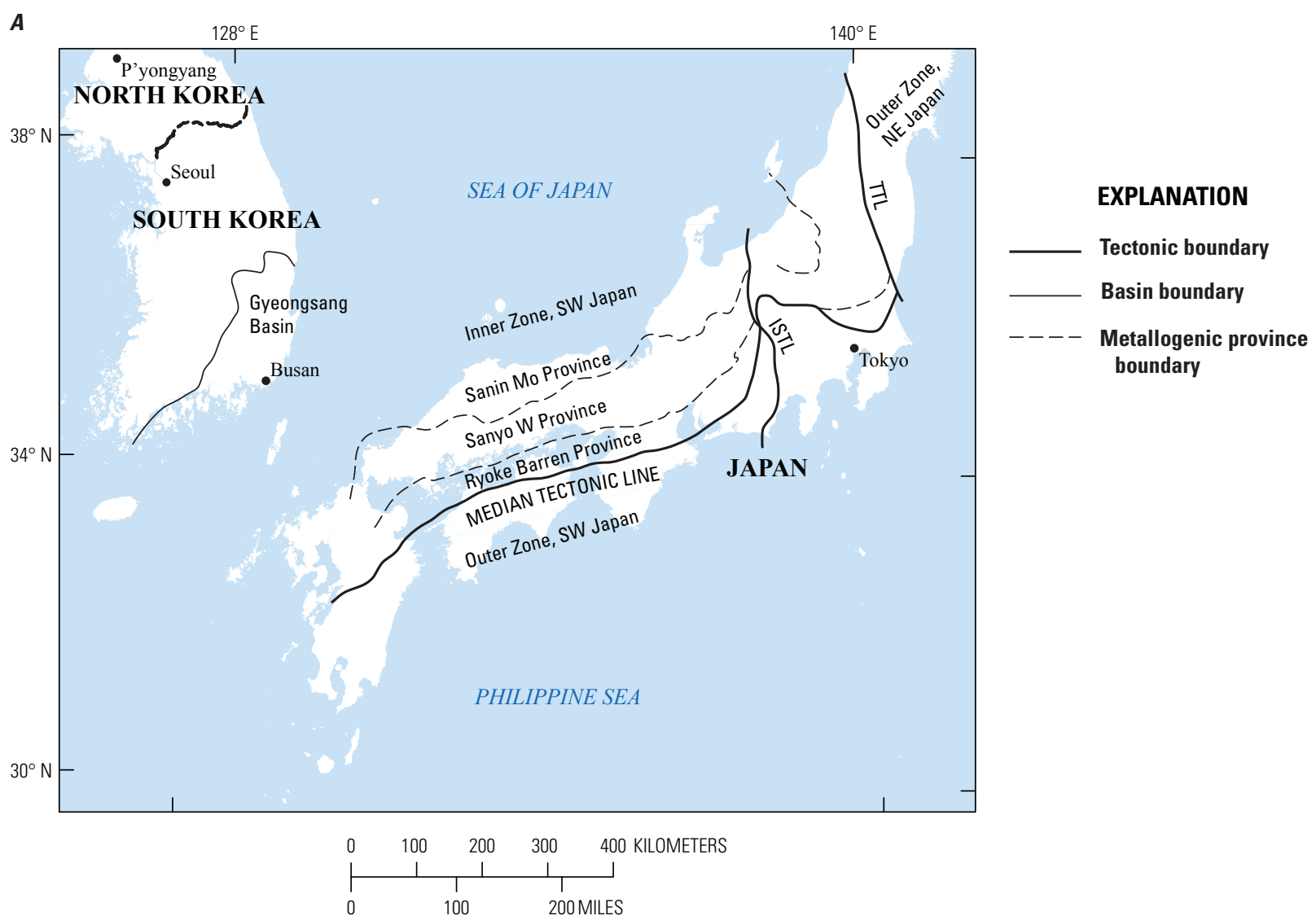

Figure 12. Maps showing metallogenic provinces and igneous rocks of Japan. $A$, Cretaceous to Paleogene metallogenic provinces of southwest Japan (Mo, molybdenum; W, tungsten). The Median Tectonic Line separates the Inner (Sea of Japan side) and Outer (Pacific Ocean side) Zones of southwest Japan. The ItoigawaShizuoka Tectonic Line (ISTL) separates the southwest (SW) and northeast (NE) segments of the Japan Arc and marks the western boundary of a depression along the Eurasian and North American Plate boundaries. The Tanakuru Tectonic Line (TTL) separates pre-Cretaceous basement terranes of northeast and southwest Japan. $B$, Distribution of Mesozoic and Tertiary igneous rocks in Japan, based on the 1:1,000,000-scale geologic map of Japan (Geological Survey of Japan, 2003). 


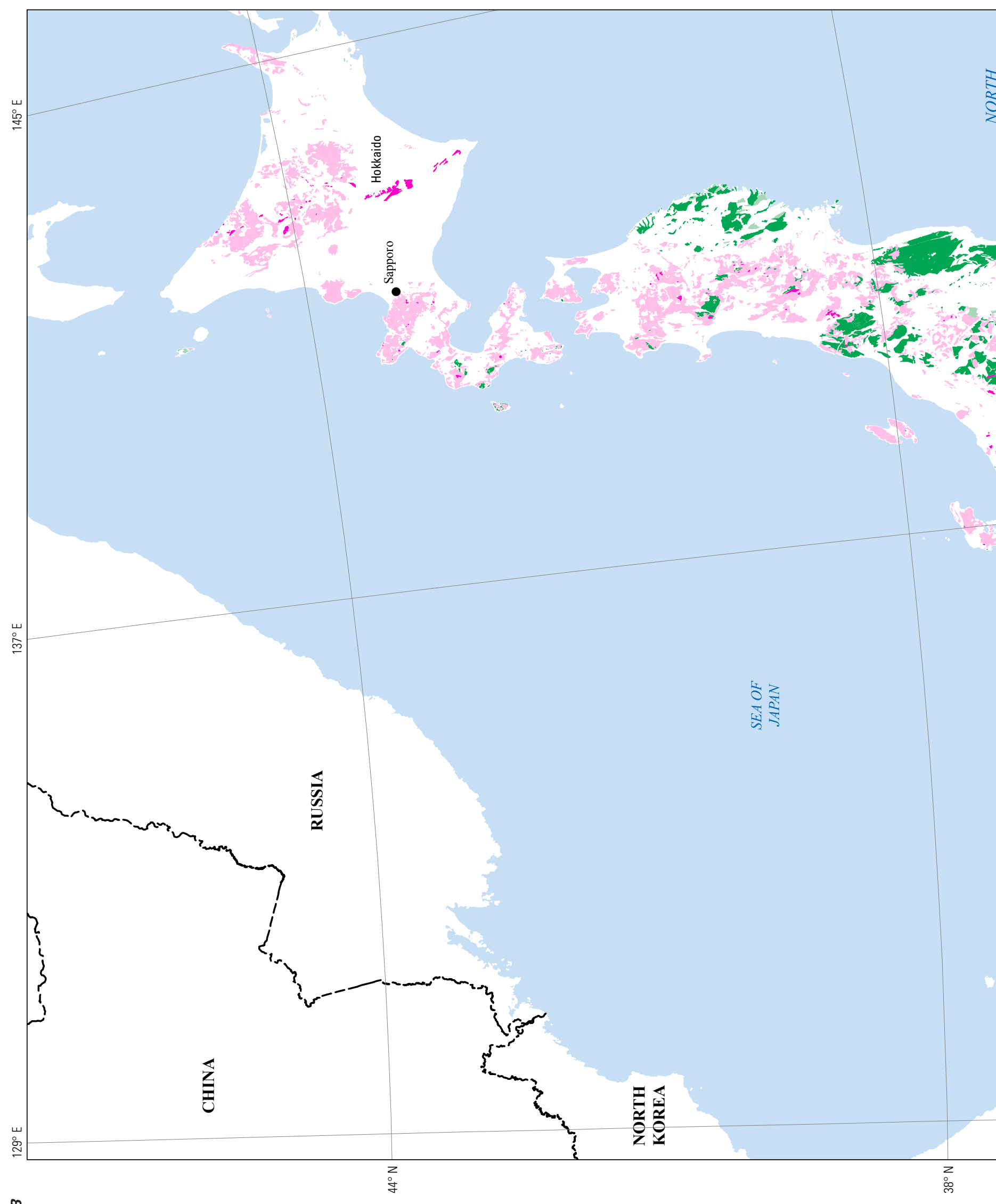




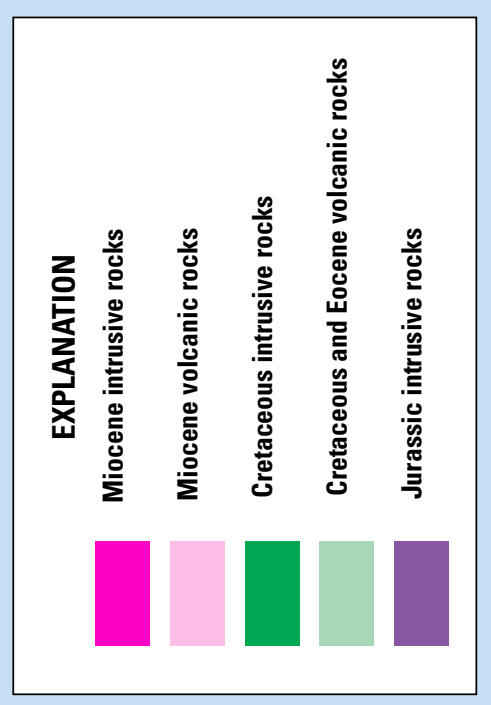

施

$\therefore$

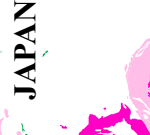

$-4=2+\frac{1}{2}$

$-a^{2}+y^{9}$

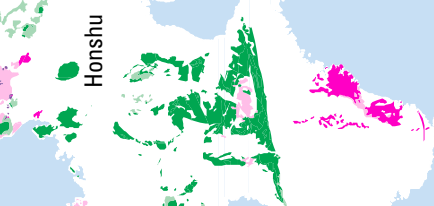

the

I.

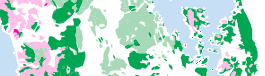

3) : Snitio

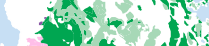

$1-x^{2}$

tiven

15:

in

量空
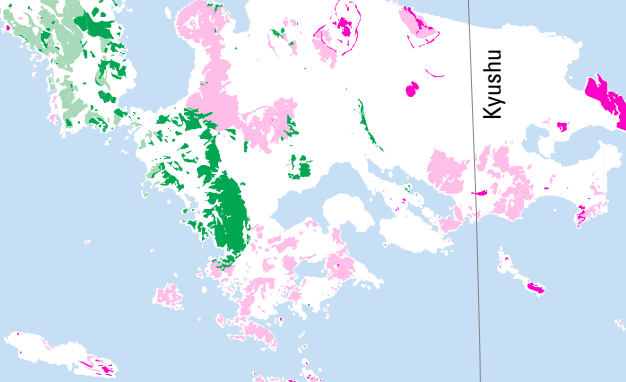
ages of mineralized zones decrease across the Gyeongsang Basin from 100-80 in the northwest to 60-40 Ma in the southeast (Koh and others, 2003). Magnetic susceptibility increases from the interior towards the coast across the basin and nearly all of the intrusions are magnetite-series rocks (Jin and others, 2001). From northwest to southeast across the Gyeongsang Basin, metallogenic subprovinces include the following zones: lead-zinc, tungsten-molybdenum, copper-zinc-lead, iron and copper; the most common deposits are tungsten-molybdenum skarns and polymetallic veins (Jwa, 2004). In Japan, the Sanin Belt (magnetite series) along the east coast of the Sea of Japan is a Tertiary (65-46 Ma) molybdenum-lead-zinc province, whereas copper is present in the tungsten-tin province of the 96-64 Ma Sanyo Belt (ilmenite>magnetite series). It was originally postulated that South Korean rocks were correlative with the molybdenum-lead-zinc Sanin Province of Japan, based on distributions of magnetite-rich rocks (Sillitoe, 1980). Any porphyry copper systems would likely be associated with the younger magnetite-series rocks in both areas; the Gyeongsang Basin has more evidence of porphyry-type mineralization, albeit at deep levels, as noted above. The Sanin Belt rocks, like the rocks in South Korea, may be too deeply eroded to preserve any porphyry systems that may have formed.

The occurrence of copper with lead-zinc skarns in both areas suggests that depth may be a factor. Alternatively, exploration for concealed porphyry systems beneath volcanic cover has not been extensive or optimum redox conditions for development of porphyry systems may never have obtained along this particular continental margin.

\section{Neogene Volcanic Arcs}

\section{Tectonic Setting}

Japan lies at a crossroads of a number of active arc systems that produced volcanogenic massive sulfide deposits and epithermal deposits from the middle Miocene through the Pliocene and into the Pleistocene. No porphyry copper deposits are known within these arcs. The Neogene arcs include the Japan Arc, the Ryukyu Arc, the Izu-Bonin Arc, and the Kurile Arc (figs. 2 and 10B). Rift-related bi-modal arc volcanism (opening of the Sea of Japan) continued in the southwestern Japan Arc through the early and middle Miocene, followed by subduction-related andesite-dacite volcanism starting in the late Miocene (Garwin and others, 2005). The northeastern and southwestern segments of the Japan Arc are separated by a fault zone (Itoigawa-Shizuoka tectonic line, ISTL on fig. 12A) that forms the boundary between the North American and Eurasian Plates (Garwin and others, 2005; Uyeda, 1991). The northeastern Japan Arc is related to subduction of the Pacific Plate beneath the North America Plate along the Japan Trench. The 1,800-km-long modern continental Japan Arc connects the Ryukyu Arc to the south with the Kurile Arc to the north (figs. 2 and 10B). The Ryukyu Arc, an island chain related to subduction of the Philippine Sea Plate beneath Eurasia, extends from southern Japan to Taiwan. The Kurile Arc is formed by subduction of the Pacific Plate beneath the Okhotsk Plate along the Kurile Trench. The oceanic Izu-Bonin Arc results from northwestward subduction of the Pacific Plate along the
Philippine Sea Plate (fig. 10B). During the middle Miocene, the Okhotsk (North America) continental block and the IzuBonin Arc collided with the Japan Arc. Most of the Izu-Bonin Arc is submerged.

\section{Permissive Tract 142pCu7315 (Subaerial Neogene Arcs of Western Japan)}

The tract delineates subaerial parts of the Miocene (fig. 12B) and younger-age Kurile (Chishma) volcanic arc and the subaerial parts of the Northeast Japan, Izu, Southwest Japan, and Ryukyu volcanic arcs. All of these arc systems contain Miocene to Quaternary volcanic rocks, including calc-alkalic andesite and dacite with minor rhyolite and basalt. Miocene and Pliocene shallow-level intrusions are variable in size, ranging from a few meters to several kilometers in diameter. The Miocene to Quaternary volcanic rocks in the Inner Zone of southwestern Japan (fig. 12A), known as the Green Tuff region, typically are more than $1 \mathrm{~km}$ thick; this area is the type locality for kuroko-type massive sulfide deposits. Although no porphyry copper deposits or occurrences are known in the tract, abundant advanced argillic alteration occurs around late Miocene and Pliocene shallow intrusions in some areas suggesting that the porphyry granitoid systems may occur beneath the epithermal deposits. Highsulfidation epithermal gold provinces associated with Tertiary volcanic rocks, such as in southern Kyushu and central Honshu, are the most likely target areas for concealed porphyry copper deposits (T. Takagi, contributor to this report, written commun., 2004).

A submerged porphyry-copper type system associated with a 7-Ma back-arc seamount chain in the Izu-Bonin Arc in the Pacific Ocean off the coast of Honshu is the first documentation of this deposit type in the arc (Ishizuka and others, 2002). The evidence for a porphyry system includes chalcopyrite-bearing altered tonalite porphyry (potassic and propylitic alteration) with stockwork quartz-magnetite veins containing hypersaline high-temperature $\left(600^{\circ} \mathrm{C}\right)$ fluid inclusions in quartz. Although offshore occurrences are not included in the assessment tract, the occurrence demonstrates that processes that produced porphyry systems were active in the back-arc region before the present rift setting.

\section{Exploration History}

Porphyry copper exploration in the Philippines has been cyclic, driven largely by global metal prices, government policies, and accessibility of the region. Although the area is considered among the most copper- and gold-endowed regions on Earth, parts of the area remain relatively underexplored (Feebrey, 1999). As noted by Waters and others (2011), despite the interest in gold and the long history of mining in the Luzon Central Cordillera, the area has not been thoroughly evaluated for porphyry potential. Political, social, cultural, and environmental issues as well as mining laws affect exploration in the region. Downturns in copper prices led to mine closures in the 
Philippines in the 1990s. In addition, steep topography, lack of infrastructure, tropical climate and vegetation, and natural hazards, such as earthquakes, tsunamis, and volcanic eruptions, complicate exploration and development in the region. An example of porphyry copper exploration cycles for the Philippines is described below, based on information provided in country reports presented at the 2010 CCOP-USGS Workshop in Busan, South Korea, by coauthors of this assessment.

\section{Philippines}

The Philippine copper industry dates back to the country's pre-Spanish period. In the 1800s, during the Spanish period, the Cariwisan Mine in Antique Province in western Panay (fig. 4A) opened in 1842, followed by work on the Mankayan Mine in the Mankayan district in western Luzon (fig. 4B) in 1865. The Mankayan Mine reopened in 1936 during the American period, and the Atlas Mine on Cebu (fig. 1), the Sipalay Mine on Negros (fig. 1), and Santo Tomas II in the Baguio district of Luzon (fig. 4B) opened in the 1950s. A boom period in copper exploration and mine development in the 1960s and 1970s was followed by a period of declining production and mine closures from the early 1980s to 1990 s. Factors that contributed to the decline of the copper industry were ore depletion; global economics, including decreasing metal prices and demand; inflation; the Gulf War crisis; and domestic problems, including labor problems, power shortages, natural disasters, the mine tailings spill on Marinduque Island (Plumlee and others, 2000; Wnuk and others, 2006), and heightened local resistance to mining. The decline has continued into the 2000s. Passage of the Mining Act of 1995, which was challenged but upheld in 2004, resulted in a policy shift to the promotion of mining. Since 1990, several new discoveries were made, and some mining projects were expanded. As of 2009, four porphyry copper projects were producing in the Philippines, four porphyry copper-gold projects were in the feasibility stage, and at least eight other baseand precious-metal projects were in exploration for massive sulfide and epithermal gold deposits.

\section{South Korea}

The few porphyry copper, copper-molybdenum, and molybdenum prospects identified in South Korea were discovered during exploration programs of the Korea Mining Promotion Corporation and other groups in the 1970s (Sillitoe, 1980). A few prospects were drilled, and geophysical and geochemical surveys were done. Anomalous copper and molybdenum concentrations associated with advanced argillic alteration apparently are stratigraphically controlled and are not clearly related to plutons.

In 2009, the Korea Institute of Geoscience and Mineral Resources (KIGAM) initiated a 3-year domestic exploration project for epithermal gold deposits in hydrothermally altered Cretaceous volcanic rocks in the Haenam area, which hosts the Moisan Mine, an epithermal gold-silver vein system (Korea Institute of Geoscience and Mineral Resources,
2011). KIGAM is also assessing domestic metallic resources; their work includes stream-sediment surveys and drilling for extension of tungsten skarns in the Gangweon Province (KIGAM, 2011).

\section{Japan}

Japan has been explored for minerals for well over 100 years. Various epithermal gold-silver deposits have been drilled at depths of hundreds to thousands of meters. Small volcanic islands in the middle and northeastern parts of the Kurile Arc have not been well explored.

Japan explores and invests in mining internationally, but there is no domestic copper exploration, and Japan is the one of the world's largest importers of copper. Very little copper is produced domestically; the Kamioka lead-zinc-copper skarn produced copper until 2001, when operations ceased owing to low grade and high mining costs (Wu, 2001).

\section{Grade and Tonnage Models}

The global porphyry copper grade and tonnage models of Singer and others (2008) were used for the simulation of undiscovered resources. Available models include a coppergold subtype model based on data for 115 deposits, a coppermolybdenum subtype model based on data for 51 deposits, a copper subtype model based on data for 256 deposits, and a general porphyry copper-gold-molybdenum model based on all 422 deposits. The subtypes are based on grade criteria defined by Singer and others (2008). Deposits are classified as the copper-gold subtype if (1) the gold (in $\mathrm{g} / \mathrm{t}$ ) to molybdenum (in percent) ratio is greater than or equal to 30 or (2) if no molybdenum grade is reported and the gold grade is greater than $0.2 \mathrm{~g} / \mathrm{t}$. Deposits are classified as the coppermolybdenum subtype if (1) the gold (in $\mathrm{g} / \mathrm{t}$ ) to molybdenum (in percent) ratio is less than or equal to 3 or (2) if no gold grade is reported and the molybdenum grade is greater than 0.03 percent. Otherwise, the deposits are classified as the porphyry copper subtype. The general model that includes all subtypes is recommended for most settings, in particular where no deposits are known (Singer and others, 2008).

The tonnages for the 38 deposits in the Philippines are plotted on the global general model of Singer and others (2008) in figure 13A. Most (29 out of 38) of the deposits in the Philippines (table 4) meet the criteria for the coppergold subtype. No gold grades are available for four of the deposits and no molybdenum grades are reported for 16 of the deposits. Four deposits that have both gold and molybdenum grades reported meet the criteria for the copper subtype (that is, gold to molybdenum ratios between 3 and 30). The tracts that host three of those four deposits (Ino-Capayang in the Southern Sierra Madre Arc; Aya Aya, and Sipalay in the Masbate-Western Negros Arc) also host copper-gold deposits. The fourth deposit, the Atlas deposit on Cebu, is the oldest, and before the Tampakan discovery was the largest, porphyry deposit in the Philippines. The Atlas deposit historically produced both molybdenum and gold. 


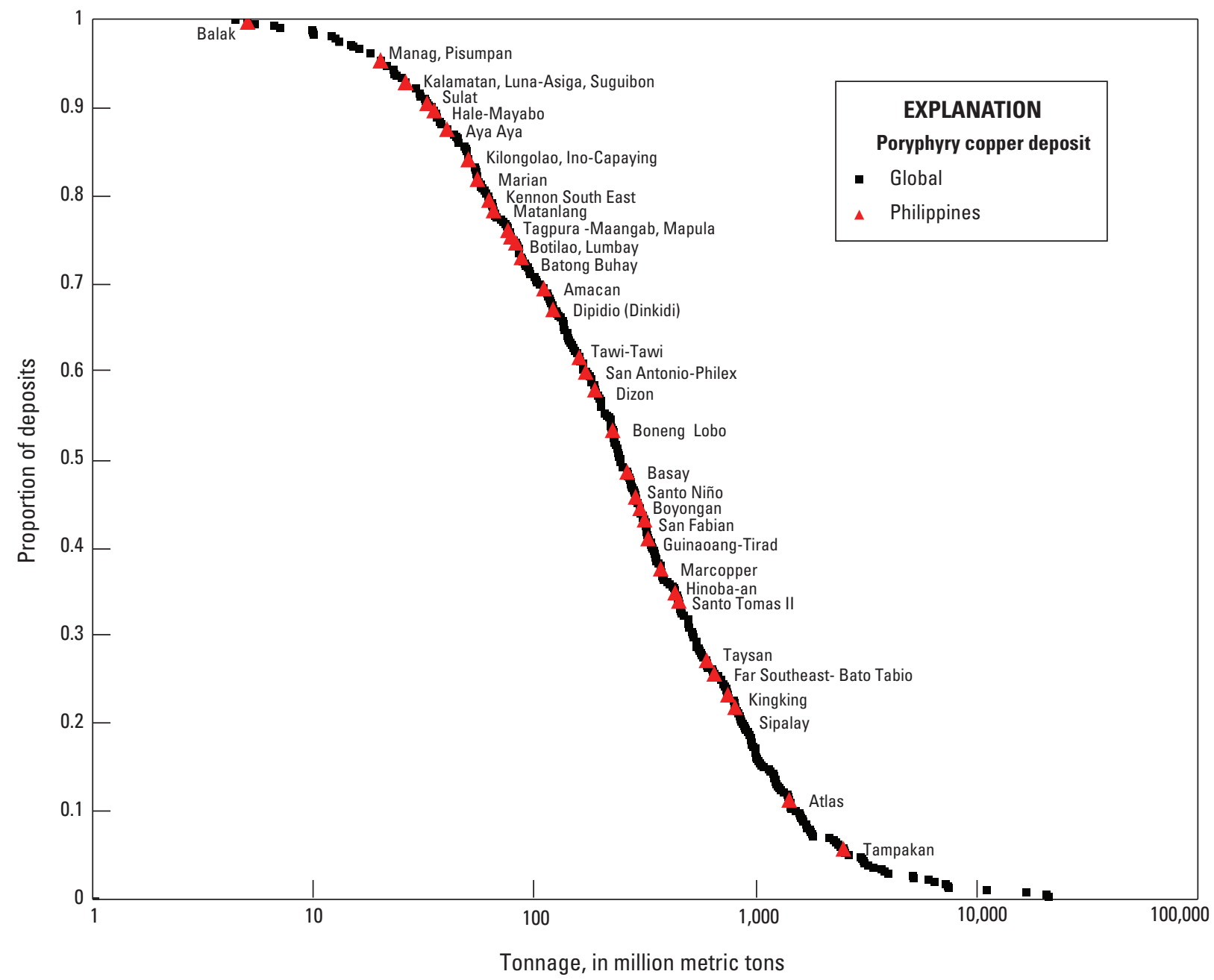

Figure 13. Tonnage model analysis for the Philippines. A, Global porphyry copper tonnage model of Singer and others (2008). Philippine porphyry copper deposits (red triangles) are labeled. $B$, $t$-test comparison of the tonnages of the 38 porphyry copper deposits in the Philippines with tonnages of deposits in the global porphyry copper-molybdenum-gold model of Singer and others (2008). C, Explanation of the elements of the graphs shown in $B$. 
B

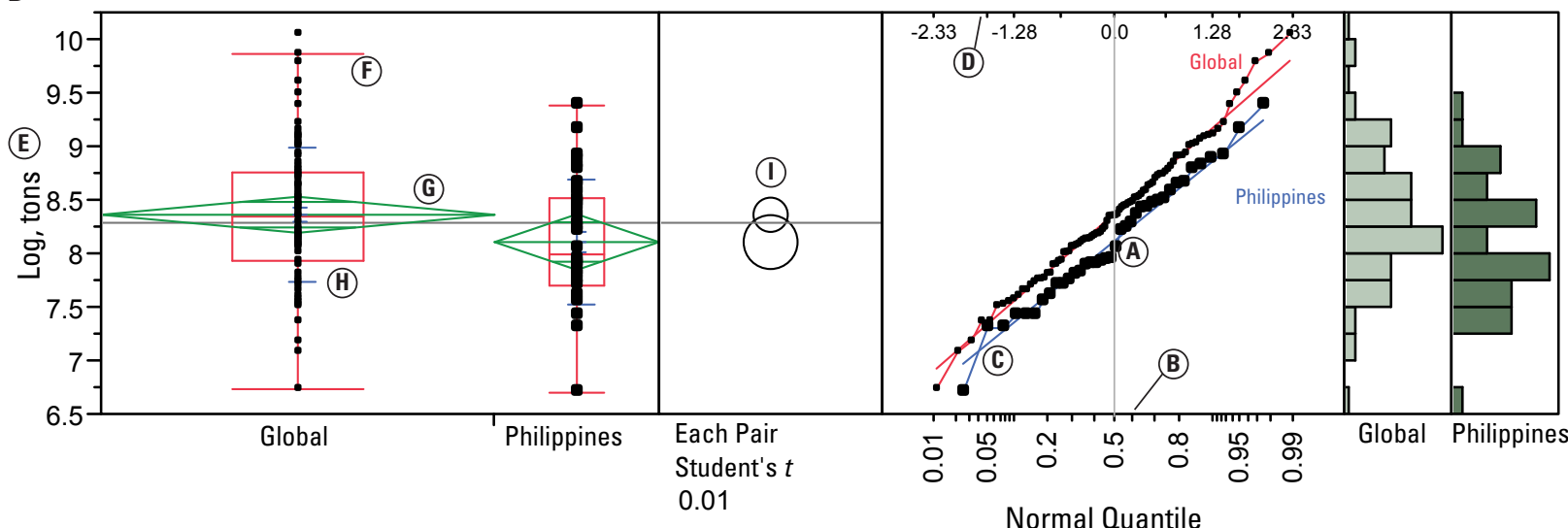

c
A. Mean is intersection of line with normal quantile score $=$ zero
B. Probability score
C. Slope is standard deviation
D. Normal quantile score
E. Data values

F. Box plots are schematics that illustrate how data are distributed as measured by percentiles.

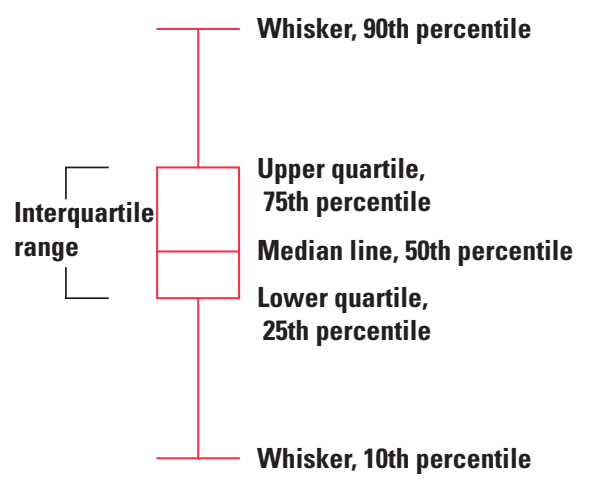

$G$. The means diamonds are a graphical illustration of the $t$ test. If the overlap marks do not vertically separate the groups, the groups are probably not significantly different. The groups appear separated if there is vertical space between the top overlap mark of one diamond and the bottom overlap of the other.

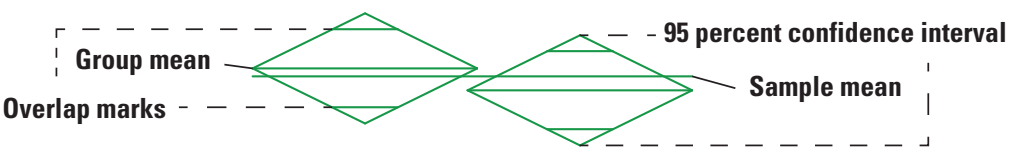

H. Graph that illustrates how data are distributed using estimates of the measured standard deviation.

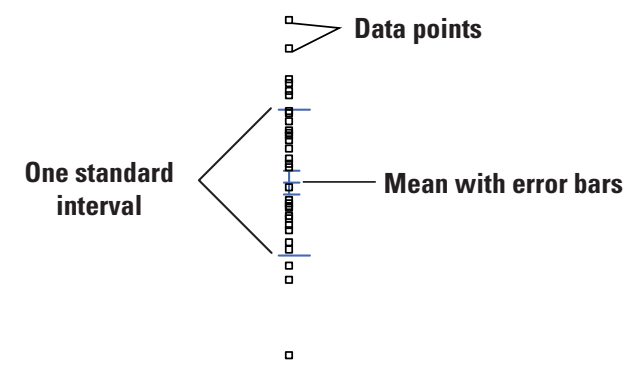

I. Comparison circles are a graphical technique that illustrate signficant separation among means in terms of how circles intersect.

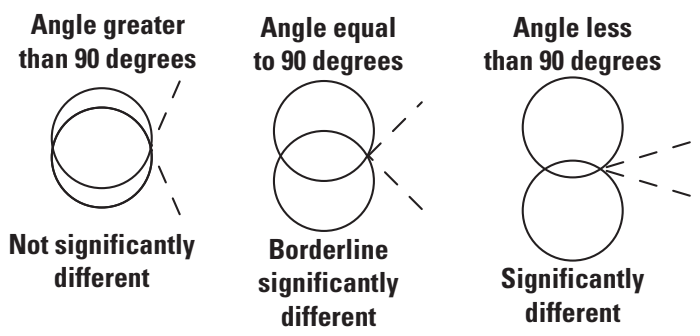

Figure 13.-Continued 


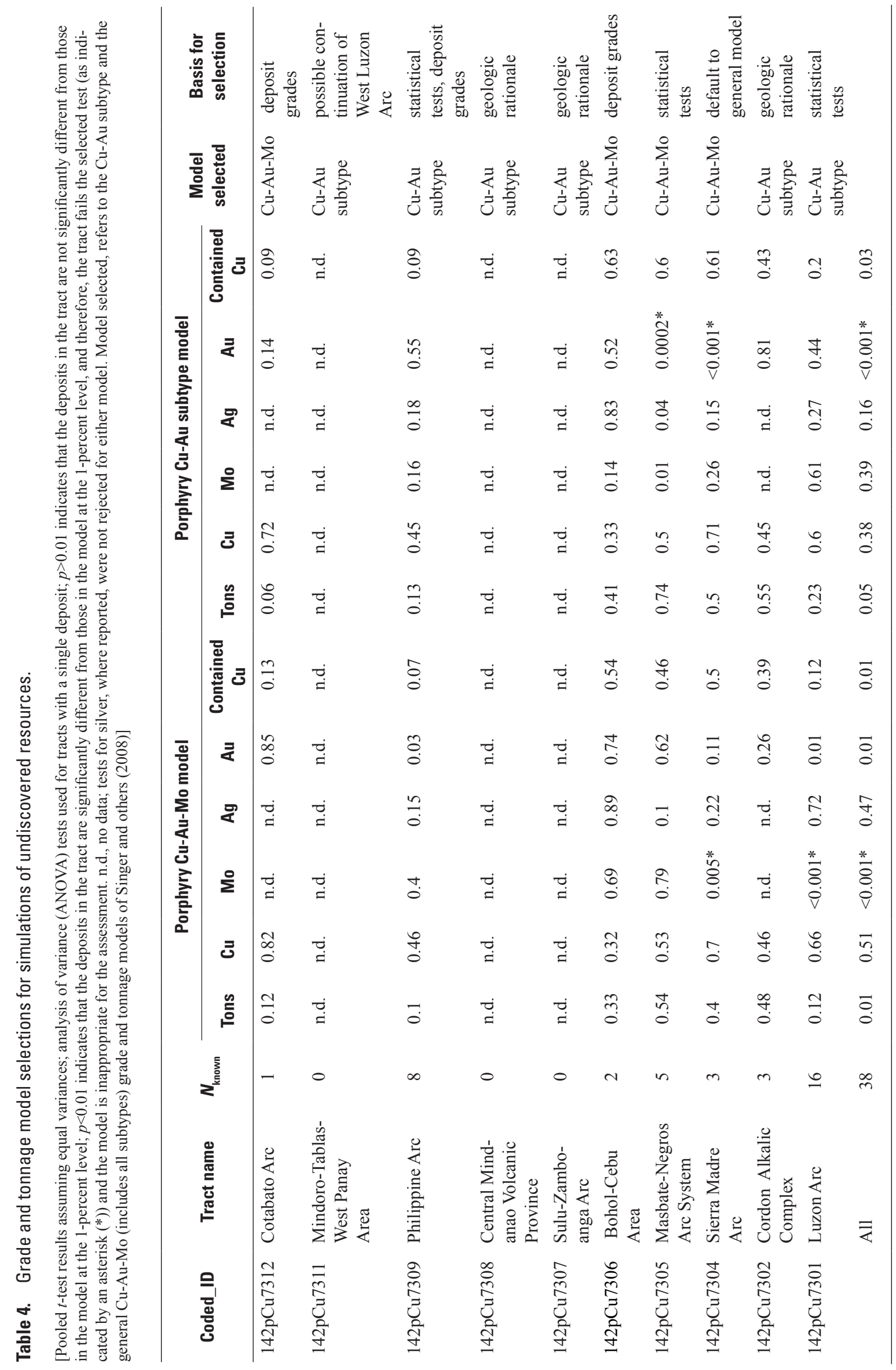


A $t$-test or analysis of variance (ANOVA) was done for each assessed permissive tract to compare the log-transformed tonnages and grades of any known deposits in the tract with the global models using a $p$-value (significance probability) of 0.01 to test for significant differences in the means of the two groups. Results of these tests on a tract by tract basis for the deposits in the Philippines are listed in table 4.

As a group, the 38 deposits in the Philippines have lower tonnages than those in all the global models but do not fail the $t$-test for the porphyry copper-gold subtype model at the 1-percent screening level, although the $p$-value of 0.03 for the test indicates that the test would barely pass at a 3-percent screening level and would fail at a 5-percent level (fig. 13B). In a previous analysis of appropriate model selection for Southeast Asia, Drew and Singer (2005) used a slightly older dataset (2005) to conclude that a copper-gold model might be appropriate for assessing the Philippines region. The general model was used for the tracts that failed the $t$-test for gold using the copper-gold model.

\section{Estimates of Numbers of Undiscovered Deposits}

The assessment team evaluated the available data and, using expert judgment, made individual, subjective estimates of the numbers of undiscovered porphyry copper deposits. The distribution of known deposits, prospects, related deposit types, alteration, depth of erosion, thickness of cover, and level of exploration were factors considered in making estimates. Sites were ranked informally using the following numeric scale:

$5=$ deposit (identified resources)

4=prospect in Singer and others (2008) or less than 16,000 $t$ of ore established by drilling

$3=$ drilled, with greater than $20 \mathrm{~m}$ of 0.2 -percent copper or more

$2=$ drilled, or trenched, with less than $20 \mathrm{~m}$ of 0.2 percent copper; past or ongoing exploration

$1=$ stream sediment, magnetic anomaly, or mineralized structural trend

Sites ranked at 3 or 4 typically were considered to represent significant prospects that, if fully explored, might have grades and tonnages represented by the deposit model. Sites ranked as 2 may or may not be significant, and sites ranked as 1 generally were considered as occurrences that could be compatible with, although not necessarily indicative of, porphyry copper formation.

In addition, the distribution of reported copper and gold occurrences of unknown type and placer gold workings were considered. Other considerations included the fact that some areas are heavily vegetated and have been inaccessible for exploration for 20 years or more because of environmental concerns and local opposition to mineral development. Particular weight was given to sites classified as porphyry copperrelated in published literature and recent exploration reports. The location, number, deposit type, and relative importance of other prospects, such as skarns and epithermal deposits, were also considered. Recent literature, company Web sites, and technical reports for exploration projects were reviewed for descriptions of geology, mineralogy, deposit type, rock alteration, and sampling results to evaluate the likelihood that a particular prospect might be associated with a porphyry copper system similar to those in the grade and tonnage models. In some cases, team members provided information about prospects based on personal observations from site visits. The rationales for individual tract estimates are discussed in the appendixes.

Estimates are expressed in terms of different levels of certainty. Estimators are asked for the least number of deposits of a given type that they believe could be present at three levels of certainty ( 90 percent, 50 percent, and 10 percent). For example, on the basis of all the available data, a team member might estimate that there was a 90 -percent chance (or better) of the presence of at least one deposit, a 50-percent chance of at least three deposits, and a 10-percent chance of at least five undiscovered deposits in a permissive tract. In some cases, the number and characteristics of porphyry copper prospects within a tract were the primary basis for estimates at the 90th and 50th quantiles. The individual estimates were discussed as a group, and a single team estimate was agreed upon for each tract. The estimates are converted to a mean number of deposits and standard deviation based on an algorithm developed by Singer and Menzie (2005). The algorithm can be described by the following general equations to calculate an expected (mean) number of deposits $(\lambda)$ and a standard deviation $\left(s_{x}\right)$ based on estimates of numbers of undiscovered deposits predicted at different quantile levels ${ }^{16}\left(N_{90}=90\right.$ percent level, $N_{50}=50$ percent level, etc.):

$$
\begin{gathered}
\lambda=0.233 N_{90}+0.4 N_{50}+0.225 N_{10}+0.045 N_{05}+0.04 N_{01} \\
s_{x}=0.121-0.237 N_{90}-0.093 N_{50}+0.183 N_{10}+0.073 N_{05}+0.123 N_{01}
\end{gathered}
$$

These equations were programmed in a simple spreadsheet to allow the team to quickly evaluate estimates. The spread in the number of deposits associated with the 90th percentile to the 10th percentile or 1 percentile reflects uncertainty; large differences in number suggest great uncertainty. The expected number of deposits for the permissive tract, or the numbers associated with a given probability level, reflect favorability. Another useful parameter for reporting

\footnotetext{
${ }^{16}$ To use the equation in cases where three nonzero quantiles (90-50-10) are estimated, use the $N_{10}$ values for $N_{05}$ and $N_{01}$; where four quantiles (90-50-10-5) are estimated, use the $N_{05}$ value for $N_{01}$
} 
uncertainty associated with an estimate is the coefficient of variation $\left(C_{v}\right)$, defined as:

$$
C_{v}=s_{x} / \lambda
$$

The coefficient of variation is often reported as percent relative variation:

$$
\% C_{v}=100 \times C_{v}
$$

Team estimates reflect both the uncertainty in what may exist and the favorability of the tract (Singer, 1993). Final team estimates of numbers of undiscovered deposits are summarized in table 5, along with statistics that describe mean expected numbers of undiscovered deposits, the standard deviation and coefficient of variation associated with the estimate, the number of known deposits, and the implied deposit density for each tract.

\section{Simulation of Undiscovered Resources in Southeast Asia}

Estimates of numbers of undiscovered deposits for each permissive tract (table 5) are combined with the selected grade and tonnage models (table 4) in a Monte Carlo simulation using the EMINERS computer program (Duval, 2012; Bawiec and Spanski, 2012). EMINERS is based on the original Mark3 computer program that was developed to provide a probabilistic estimate of amounts of resources that could be contained in undiscovered deposits (Root and others, 1992). Probability distributions based on known grades and tonnages and the estimates of numbers of undiscovered deposits at different quantiles are used to predict the metal endowment. Results of 4,999 Monte Carlo simulations are sorted and ranked, and estimates of contained metal are reported at selected quantile levels and as a mean for each commodity (copper, molybdenum, gold, and silver) and for the total amount of mineralized rock.

Simulation results for mean and median ${ }^{17}$ estimates of contained copper and gold in undiscovered deposits are reported in table 6 along with total identified resources in known deposits in each tract. Identified resources (table 1) are based on total production, if any, and published data for measured, indicated, and inferred reserves and resources at the lowest cutoff grade reported. Identified resources may include substantial amounts of metal that have already been produced.

Three of the assessed permissive tracts contain no identified resources. Some tracts may contain porphyry copper systems that are currently, or have been, explored, but no

\footnotetext{
${ }^{17}$ Amount of metal at the 0.5 quantile; 50 -percent chance of occurrence of that amount of metal or more, based on simulation for the estimated numbers of undiscovered deposits.
}

Table 5. Estimates of numbers of undiscovered porphyry copper deposits in East and Southeast Asia.

$\left[N_{\mathrm{XX}}\right.$, estimated number of deposits associated with the xxth percentile; $N_{\text {und }}$, expected number of undiscovered deposits; $s$, standard deviation; $C_{v} \%$, coefficient of variance; $N_{\text {known }}$, number of known deposits in the tract that are included in the grade and tonnage model; $N_{\text {total }}$, total of expected number of deposits plus known deposits; area, area of permissive tract in square kilometers $\left(\mathrm{km}^{2}\right)$; density, deposit density reported as the total number of deposits per $100,000 \mathrm{~km}^{2} . N_{\text {und }}, s$, and $C_{v} \%$ are calculated using a

\begin{tabular}{|c|c|c|c|c|c|c|c|c|c|c|c|c|c|c|}
\hline \multirow{2}{*}{ Appendix } & \multirow{2}{*}{ Coded_id } & \multirow{2}{*}{ Tract name } & \multicolumn{5}{|c|}{$\begin{array}{l}\text { Consensus undiscovered deposit } \\
\text { estimates }\end{array}$} & \multicolumn{5}{|c|}{ Summary statistics } & \multirow{2}{*}{$\begin{array}{l}\text { Tract area } \\
\quad\left(\mathbf{k m}^{2}\right)\end{array}$} & \multirow{2}{*}{$\begin{array}{c}\text { Deposit } \\
\text { density } \\
\left(N_{\text {total }} /\right. \\
\left.100,000 \mathrm{~km}^{2}\right)\end{array}$} \\
\hline & & & $N_{90}$ & $N_{50}$ & $N_{10}$ & $N_{05}$ & $N_{01}$ & $\boldsymbol{N}_{\text {und }}$ & $s$ & $C_{v} \%$ & $N_{\text {known }}$ & $N_{\text {total }}$ & & \\
\hline A & $142 \mathrm{pCu} 7312$ & Cotabato Arc & 1 & 1 & 2 & 2 & 2 & 1.2 & 0.55 & 45 & 1 & 2.2 & 9,700 & 23 \\
\hline $\mathrm{B}$ & $142 \mathrm{pCu} 7308$ & $\begin{array}{l}\text { Central Mindanao } \\
\text { Volcanic Province }\end{array}$ & 0 & 1 & 5 & 5 & 5 & 1.9 & 1.9 & 100 & 0 & 1.9 & 29,320 & 6 \\
\hline $\mathrm{C}$ & $142 \mathrm{pCu} 7307$ & $\begin{array}{l}\text { Sulu-Zamboanga } \\
\text { Arc }\end{array}$ & 0 & 1 & 1 & 2 & 3 & 0.8 & 0.7 & 90 & 0 & 0.8 & 10,180 & 8 \\
\hline $\mathrm{D}$ & $142 \mathrm{pCu} 7305$ & $\begin{array}{l}\text { Masbate-Negros Arc } \\
\text { System }\end{array}$ & 0 & 2 & 4 & 4 & 4 & 2 & 1.5 & 73 & 5 & 7 & 12,230 & 57 \\
\hline $\mathrm{E}$ & $142 \mathrm{pCu} 7309$ & Philippine Arc & 3 & 7 & 14 & 14 & 14 & 7.7 & 4.1 & 53 & 8 & 15.7 & 23,700 & 66 \\
\hline $\mathrm{F}$ & $142 \mathrm{pCu} 7302$ & $\begin{array}{l}\text { Cordon Alkalic } \\
\text { Complex }\end{array}$ & 0 & 1 & 4 & 5 & 5 & 1.7 & 1.7 & 100 & 3 & 4.7 & 4,860 & 97 \\
\hline G & $142 \mathrm{pCu} 7304$ & Sierra Madre Arc & 0 & 0 & 1 & 1 & 3 & 0.36 & 0.75 & 210 & 1 & 1.36 & 14,000 & 10 \\
\hline $\mathrm{H}$ & $142 \mathrm{pCu} 7311$ & $\begin{array}{l}\text { Mindoro-Tablas- } \\
\text { West Panay Area }\end{array}$ & 0 & 1 & 2 & 3 & 3 & 1.1 & 0.98 & 91 & 0 & 1.1 & 9,170 & 12 \\
\hline I & $142 \mathrm{pCu} 7306$ & Bohol-Cebu Area & 0 & 1 & 3 & 3 & 3 & 1.3 & 1.2 & 90 & 2 & 3.3 & 2,600 & 127 \\
\hline $\mathrm{J}$ & $142 \mathrm{pCu} 7301$ & Luzon Arc & 2 & 9 & 20 & 20 & 20 & 10 & 6.4 & 63 & 18 & 28 & 23,700 & 118 \\
\hline
\end{tabular}
regression equation (Singer and Menzie, 2005)] 


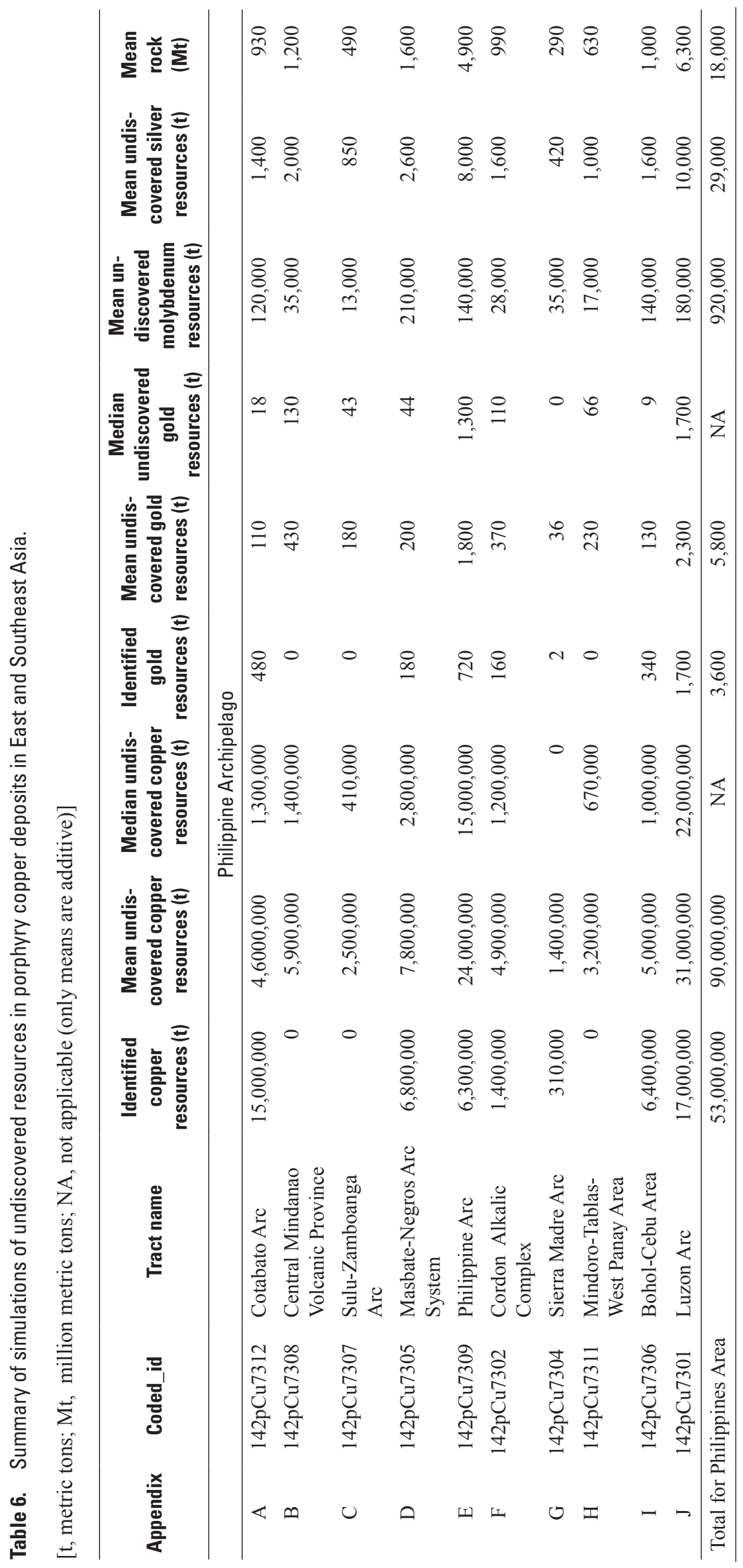


reliable grade and tonnage estimates are yet available; these were considered as significant prospects with a high probability of representing deposits like those in the grade and tonnage models.

The amounts of metal reported at different quantiles are included in the appendix tables, along with the mean value, the probability associated with the mean, and a cumulative graph of the results. Note that the probability associated with the mean typically is on the order of 30 percent or more and that the median value is less than the mean. The quantiles are linked to each tract simulation and, therefore, should not be added. Mean estimates, however, can be added to obtain total amounts of metal and mineralized rock in undiscovered deposits.

\section{Discussion}

This probabilistic assessment of the metal resources associated with undiscovered porphyry copper deposits in the Philippines indicates that additional resources may be present (table 6). The mean estimate of undiscovered copper resources in the study area $(90 \mathrm{Mt})$ is about twice the amount of copper present in identified resources $(52 \mathrm{Mt})$. If present, however, these resources may be either inaccessible or otherwise uneconomic to develop. Results should be interpreted with due caution pending application of economic filters to evaluate what portion of the estimated undiscovered resources might be economic under various conditions such as mining method, metal prices, capital development costs, and so forth. Identified resources are compared with mean and median estimates of undiscovered copper resources by area, and by tract, in figure 14.

Cases in which the mean estimates of undiscovered copper resources in a permissive tract far exceed the identified resources in that tract, such as for the Luzon Arc and Philippine Arc permissive tracts (table 6), raise concerns about the appropriateness of the global models used for the simulation. As noted in the discussion on grade and tonnage models, the deposits in the Philippines as a group appear to have smaller tonnages than most of the deposits in global models, which may be attributed to the underlying resource estimates or to some geologic factors. Much of the tonnage and grade data for the Philippines deposits represents 1980s-era historical estimates with unspecified cutoff grades and cannot be considered compliant with modern reporting standards. Renewed exploration in the Philippines in the 21st century, with a focus on more extensive and deeper drilling than was done in past, is providing updated resource information for some deposits. Table 1 includes updates to the tonnage and grade data reported by Singer and others (2008) for five deposits in the Philippines. For example, the 2008 data for the Tawi Tawi deposit listed historical data of $159 \mathrm{Mt}$ at 0.39 percent copper, whereas Solfotara Mining Corporation (2012) reported $225 \mathrm{Mt}$ at 0.4 percent copper, an approximately 50 -percent increase in contained copper. The $159 \mathrm{Mt}$ estimate is from Sillitoe and Gappe (1984); the larger estimate (non-JORC compliant) was calculated in 1975 based on 58 drill holes, and a 2006 computer-generated block model estimates resources of $261 \mathrm{Mt}$ at 0.4 percent copper. These data illustrate the difficulties in combining older and more recent data in models, which ideally should capture information on cutoff grade and meet modern reporting standards where possible. In many cases, the recent exploration and development focus is on copper and gold, and molybdenum and silver grades are not always reported. Most of the known deposits in the Philippines are considered to be open in one or more directions indicating that further exploration is likely to increase identified resources.

The broader question of whether there are important regional differences in size and quality of deposits remains open. No geologic explanations for the apparent differences in the Philippines are obvious; the deposits formed in multiple geodynamic settings on oceanic, continental, and accreted arc basement.

The Philippines Mines and Geosciences Bureau's 2009 resource estimates for the country include 7.1 billion metric tons at 1.00 weight percent copper (approximately $71 \mathrm{Mt}$ contained copper) and 4.3 billion metric tons at $0.94 \mathrm{~g} / \mathrm{t}$ gold (approximately 4,000 t), in addition to chromite, nickel, iron, and manganese (L.A. Rollan, a coauthor of this report, written commun., 2010). Porphyry copper deposits represent more than 97 percent of the identified copper reserves, and 26 percent of the annual gold production as a byproduct. The remaining copper resources are present in volcanogenic massive sulfide deposits, copper veins, and skarns. The predicted mean amounts of copper in undiscovered porphyry copper deposits from this assessment (approximately $90 \mathrm{Mt}$ copper) and gold ( 5,800 t gold) are somewhat higher than the Bureau's estimates for copper, although much of the Philippine gold production is likely to come from epithermal deposits which may, or may not, be associated with a porphyry deposit at depth.

The magmatic arc systems preserved in South Korea and Japan lack known porphyry copper deposits, although a few partly explored prospects are present in South Korea. Although the possible occurrence of porphyry copper deposits in these settings is of academic interest, no exploration has occurred in recent years and the likelihood of near-surface porphyry discoveries large enough to warrant development in the foreseeable future is negligible. 
$\boldsymbol{A}$

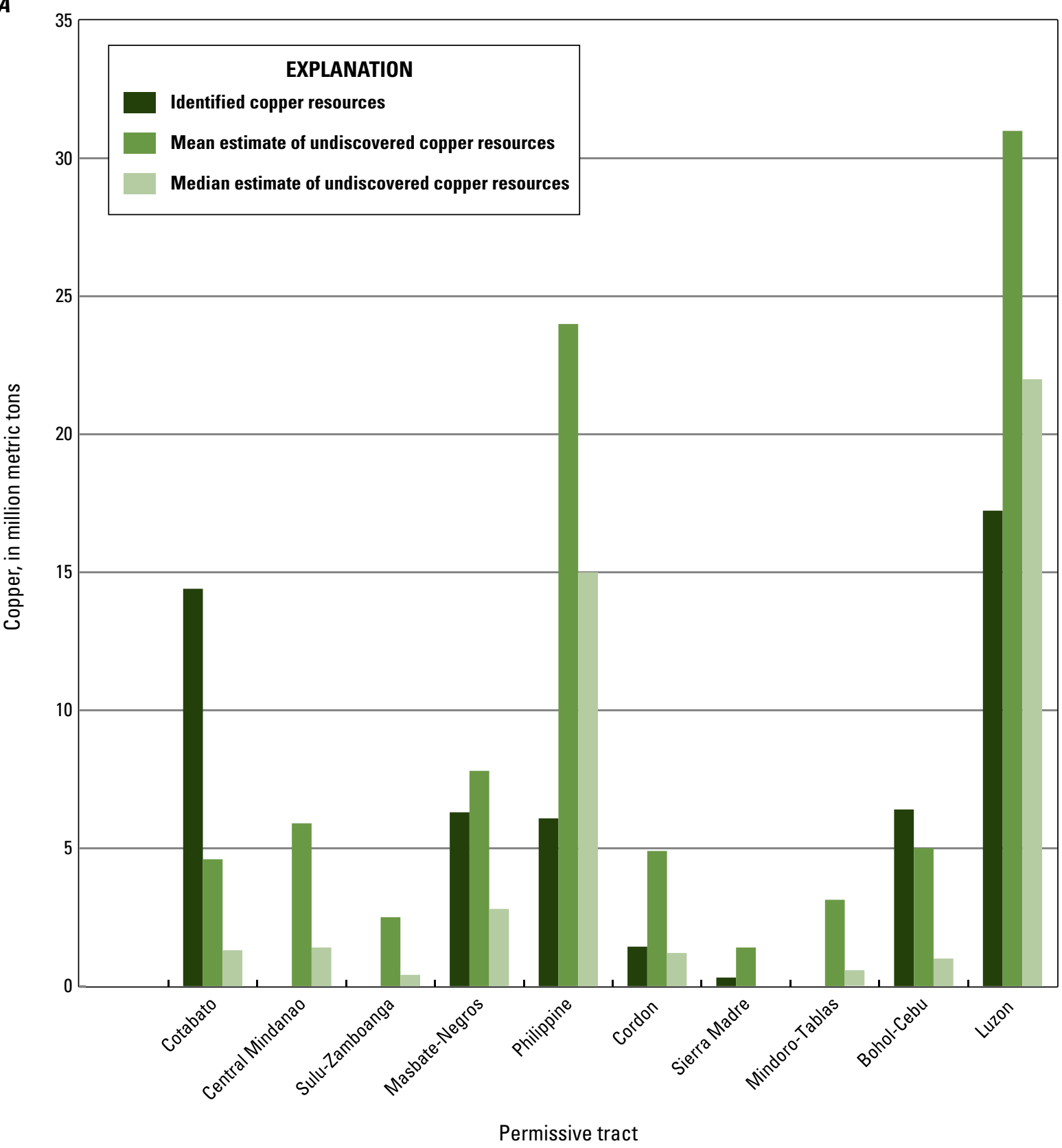

Figure 14. Graphical summary of results as bar charts comparing identified copper resources with mean and median estimated copper in undiscovered porphyry copper deposits on a tract by tract basis for the Philippines. A, Copper. $B$, Gold. 
B

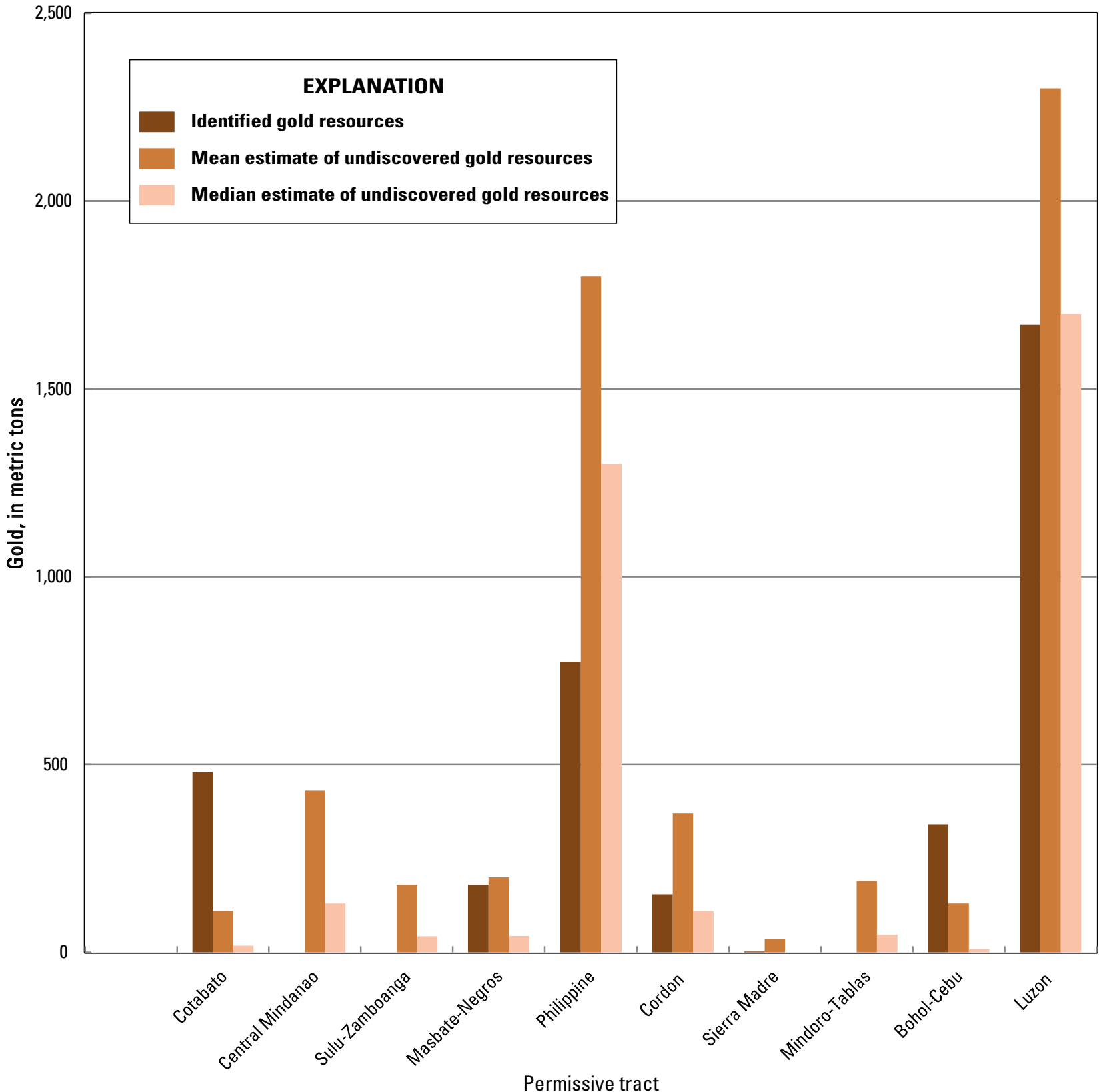

Figure 14.-Continued 


\section{Considerations for Users of this Assessment}

GMRAP products represent a synthesis of current, readily available information. Ideally, assessments are made on a recurring basis, at a variety of scales, because available data change over time. This assessment is based on the descriptive and grade-tonnage data contained in published mineral deposit models. Data in the grade and tonnage models represent average grades of each commodity of possible economic interest and tonnages based on the total of production, reserves, and resources at the lowest cutoff grade for which data were available when the model was constructed. The present-day economic viability of the deposits used to construct the models varies widely, so care must be exercised when using the results of this assessment to answer questions that involve economics. Furthermore, these estimates are for numbers of deposits that are likely to exist, not necessarily those likely to be discovered (Singer, 2007b). Prospects, revealed by past or current exploration efforts, may become deposits when further drilling and characterization takes place. These probable deposits are treated here as undiscovered deposits, albeit ones with a high degree of certainty of existence. The mineral industry explores for extensions of identified resources, as well as for greenfields projects in new exploration areas. Extensions of identified resources are not considered in this assessment. This assessment addresses the potential for concealed deposits that have upper parts within $1 \mathrm{~km}$ of the surface. Very high-grade deposits may be exploited at greater depths. However, exploration for, and exploitation of such deposits may be so expensive that deposits, if present, may not be discovered in the near term. If they are discovered, the costs and logistics related to mining a deeply buried porphyry deposit might prohibit their development into mines given current or near-term metal prices and technology.

Permissive tracts are based on geology, irrespective of political boundaries. Therefore, tracts may cross country boundaries or include lands that already have been developed for other uses, or have been withdrawn from mineral development as protected areas. The tracts are constructed at a scale of $1: 1,000,000$ and are not intended for use at larger scales.

\section{Acknowledgments}

This joint USGS-CCOP project has a long history, with many people involved at different times. Klaus Schulz and Joseph Briskey initiated the USGS project and participated in planning workshops in Bangkok in 2003 and 2004. Stephen G. Peters coordinated and led the original assessment activities for the USGS, including the 2005 workshop in Kunming, China. Preliminary tracts and estimates were made at the Kunming workshop, which was attended by CCOP representatives Dr. Yasushi Watanabe (Geological Survey of Japan, AIST), Dr. Duk Hwan Hwang (Korea Institute of Geoscience and Minerals Resources), Mr. Claro Jose C. Manipon (Philippines Mines and Geosciences Bureau), and Professor Ochir Gerel (Mongolian University of Science and Technology). CCOP member countries generously participated in assessment meetings and provided data that would not have been available otherwise. The final CCOP-USGS workshop in Busan, South Korea, in 2010 was attended by CCOP representatives Dr. Sang-Mo Koh (Korea Institute of Geoscience and Minerals Resources), Dr. Tetsuichi Takagi (Geological Survey of Japan, AIST), and Ms. Lilian A. Rollan (Philippines Mines and Geosciences Bureau). Dr. Lee Young-Joo (Executive Director of the Korea Institute of Geoscience and Minerals Resources) and Dr. Hee-Young Chun (2010 Director of the CCOP Technical Secretariat) greatly facilitated the Busan meeting. We would like to thank past and present CCOP directors and staff, especially Nguyen Nhu Trung (CCOP Geo-Resources Sector Coordinator) and Ms. Sansanee Wudhiwanich for their assistance in completing the project. The Geological Survey of China hosted the Kunming meeting, the Geological Survey of Thailand hosted Dr. Peters in Bangkok, and the Korea Institute of Geoscience and Mineral Resources (KIGAM) hosted the final workshop in Busan in 2010. At the workshops, CCOP representatives presented talks on the status of mining and exploration and the geological framework for mineral deposits in their countries and participated in preliminary delineation of permissive tracts and estimation of undiscovered resources.

USGS colleagues Walter J. Bawiec, Joseph A. Briskey, Warren J. Nokleberg, Robert J. Miller, Donald A Singer, and W. David Menzie participated in the early phases of the assessment and provided expertise on mineral resource assessment.

USGS colleagues David John, Peter Vikre, Byron Berger, Lawrence Drew, Thomas Light, and Mark Mihalasky served on assessment oversight committees to vet assessment results. Steve Peters provided data, expertise, and reviews of preliminary drafts of some assessment tracts. Technical reviews of the manuscript were provided by David John, Klaus Schulz, and Niki Wintzer. Pamela Cossette reviewed the GIS. Avery Drake (USGS emeritus) and Suzanne Nicholson (USGS) provided a helpful edits of the manuscript. Jack Medlin, as USGS representative to CCOP, facilitated joint project activities. Kathleen Johnson, as USGS Mineral Resources Program Coordinator, provided constant support over the life of the project and contributed to the final version of the report as a series editor. Sewit Yenie, John Wallace, Paul Schruben, Pamela Dunlap, Deborah Briggs, and Mukul Sonwalker provided technical support. 


\section{References Cited}

Arculus, R.J., 2003, Use and abuse of the terms calc-alkaline and calcalkalic: Journal of Petrology, v. 44, p. 925-935.

Arribas, A., Jr., Hedenquist, J.W., Itaya, T., Okada, T., Concepción, R.A., and Garcia, J.S., Jr., 1995, Contemporaneous formation of adjacent porphyry and epithermal $\mathrm{Cu}-\mathrm{Au}$ deposits over $300 \mathrm{ka}$ in northern Luzon, Philippines: Geology, v. 23, p. 333-340.

Atlas Consolidated Mining and Development Corporation, 2012, Carmen Copper Corporation's Toledo Copper Mine: Atlas Consolidated Mining and Development Corporation Web page, accessed June 1, 2012, at http:// atlasphilippines.com/.

Balace, G.R., Alcantara, P.M., and Morante, E.M., compilers, 1974, Geological map of the Philippines, Plate-1: Philippine Bureau of Mines, scale 1:2,500,000.

Bawiec, W.J., and Spanski, G.T., 2012, Quick-start guide for version 3.0 of EMINERS-Economic Mineral Resource Simulator: U.S. Geological Survey Open-File Report 2009-1057, 26 p., accessed June 30, 2012, at http://pubs. usgs.gov/of/2009/1057/. (This report supplements USGS OFR 2004-1344.)

Berger, B.R., Ayuso, R.A., Wynn, J.C., and Seal, R.R., 2008, Preliminary model of porphyry copper deposits: U.S. Geological Survey Open-File Report 2008-1321, 55 p., accessed May 15, 2009, at http://pubs.usgs.gov/ of $/ 2008 / 1321 /$.

Bezant Resources plc, 2011, Positive independent conceptual study completed on the Mankayan copper.gold project, Philippines: Bezant Resources plc, Web site, accessed April 5, 2013, at http://online.hemscottir.com/ir/bzt/ ir.jsp?page $=$ news-item\&item $=583915836281158$.

Braxton, D.P., Cooke, D.R., Ignacio, A.M., Rye, R.O., and Waters, P.J., 2009, Ultra-deep oxidation and exotic copper formation at the Late Pliocene Boyongan and Bayugo porphyry copper-gold deposits, Surigao, Philippines - Geology, mineralogy, paleoaltimetry, and their implications for geologic, physiographic, and tectonic controls: Economic Geology, v. 104, p. 333-349.

Chang, Zhaoshan, Hedenquist, J.W., White, N.C., Cooke, D.R., Roach, M., Deyell, C.L., Garsia, J., Jr., Gemmell, J.B., McKnight, S., and Cuison, A.L., 2011, Exploration tools for linked porphyry and epithermal deposits-Example from the Mankayan intrusion-centered $\mathrm{Cu}-\mathrm{Au}$ district, Luzon, Philippines: Economic Geology, v. 106, no. 8, p. 1365-1398.
Choi, Taejin, and Lee, Yong Il, 2011, Thermal histories of Cretaceous basins in Korea-Implications for response of the East Asian continental margin to subduction of the PaleoPacific Plate: Island Arc, v. 20, p. 371-385.

Chough, S.K., Kwon, S.-T., Ree, J.-H., and Choi, D.K., 2000, Tectonic and sedimentary evolution of the Korean peninsula-A review and new view: Earth-Science Reviews, v. 52 , p. $175-235$.

Cooke, D.R., Heithersay, P.S., Wolfe, R., and Calderon, A.L., 1998, Australian and western Pacific porphyry $\mathrm{Cu}-\mathrm{Au}$ deposits: Journal of Australian Geology and Geophysics, v. 17 , no. 4 , p. $97-104$.

Coordinating Committee for Coastal and Offshore Geoscience Programmes in East and Southeast Asia (CCOP) and Geological Survey of Japan, 1997, Digital geologic map of East and Southeast Asia: Geological Survey of Japan, Digital Geoscience Map G-2 scale 1:2,000,000, CD-ROM.

Corbett, G.J., and Leach, T.M., 1998, Southwest Pacific Rim gold-copper systems - Structure, alteration and mineralization: Society of Economic Geologists Special Publication 6, $240 \mathrm{p}$.

Cox, D.P., 1986a, Descriptive model of porphyry Cu (Model 17), in Cox, D.P., and Singer, D.A., eds., 1986, Mineral deposit models: U.S. Geological Survey Bulletin 1693, p. 76. (Also available at http://pubs.usgs.gov/bul/b1693/.)

Cox, D.P., 1986b, Descriptive model of porphyry $\mathrm{Cu}-\mathrm{Au}$, in Cox, D.P., and Singer, D.A., eds., 1986, Mineral deposit models: U.S. Geological Survey Bulletin 1693, p. 110. (Also available at http://pubs.usgs.gov/bul/b1693/.)

Crazy Horse Resources, Inc., 2012, Taysan copper-gold project: Crazy Horse Resources, Inc., Web site accessed March 15, 2012, at http://crazyhorseresources.com/s/ TaysonProject.asp.

Defant, M.J., and Drummond, M.S., 1990, Derivation of some modern arc magmas by melting of young subducted lithosphere: Nature, v. 347, p. 662-665.

Defant, M.J., Jacques, D., Maury, R.C., de Boer, J., and Joron, J.-L., 1989, Geochemistry and tectonic setting of the Luzon arc, Philippines: Geological Society of America Bulletin, v. 101, p. 663-672.

Dimalanta, C.B., and Yumul, G.P., Jr., 2006, Magmatic and amagmatic contributions to crustal growth in the Philippine island arc system - Comparison of the Cretaceous and post-Cretaceous periods: Geosciences Journal, v. 10, no. 3, p. 321-329. 
Divis, A.F., 1983, The geology and geochemistry of Philippine porphyry copper deposits, in Hayes, D.E., ed., The tectonic and geologic evolution of Southeast Asia seas and islandsPart 2: Washington, D.C., American Geophysical Union, Geophysical Monograph 27, p. 173-216.

Drew, L.J., and Singer, D.A., 2005, Identifying the appropriate porphyry-copper deposit grade-tonnage model for a largescale mineral resource assessment in South East Asia, in Chen, Qiuming, and Bonham-Carter, Graeme, eds., Proceedings of IAMG-The annual conference of the International Association for Mathematical Geology: Toronto, Canada, York University Geomatics Research Laboratory, p. 1034-1039.

Dunne, K.P.E, and Kirkham, R.V., compilers, 2003, World distribution of porphyry, porphyry-related skarn, and bulk-mineable epithermal deposits: Geological Survey of Canada, unpublished. (Available at http://gdr.nrcan.gc.ca/ minres/metadata_e.php?id=6.)

Duval, J.S., 2012, Version 3.0 of EMINERS-Economic Mineral Resource Simulator: U.S. Geological Survey Open-File Report 2004-1344, accessed June 30, 2012, at http://pubs. usgs.gov/of/2004/1344/.

Ernst, W.G., and Liou, J.G., 1995, Contrasting plate-tectonic styles of the Qinling-Dabie-Sulu and Franciscan metamorphic belts: Geology, v. 23, p. 353-356.

Feebrey, C.A., 1999, Copper and gold exploration in Southeast Asia: Society for Geology Applied to Mineral Deposits (SGA) News, no. 7, accessed March 1, 2010, at https:// www.e-sga.org/fileadmin/sga/newsletter/news $7 /$ art1.html.

Ferreira, D.S., 2008, Technical report on the Boyongan porphyry deposit: Report prepared for Philex Gold Incorporated by Independent Resource Estimations cc., 114 p.

Ferreira, D.S., 2009, Technical report on the Bayugo deposit in the province of Surigao del Norte, Island of Mindanao, Philippines: Report prepared for Philex Gold Incorporated by Independent Resource Estimations cc., 155 p.

Garwin, S., Hall, R., and Watanabe, Y., 2005, Tectonic setting, geology, and gold and copper mineralization in Cenozoic magmatic arcs of southeast Asia and the west Pacific, in Hedenquist, T.W., Thompson, J.F.H., Goldfarb, R.J., and Richards, J.P., eds., One hundredth anniversary volume 1905-2005: Littleton, Colorado, Society of Economic Geologists, p. 891-930.

Geological Survey of Japan, 1996, Magnetic anomaly map of East Asia: Geological Survey of Japan Digital Geoscience Map 2 (P-1) scale 1:4,000,000, CD-ROM version.

Geological Survey of Japan, 2003, Geological map of Japan, (3rd ed.): Geological Survey of Japan Digital Geoscience Map G-1, scale 1:1,000,000, 2nd CD-ROM version.
Hamilton, Warren, 1979, Tectonics of the Indonesian region: U.S. Geological Survey Professional Paper 1078, 345 p.

Hammarstrom, J.M., Bookstrom, A.A., Dicken, C.L., Drenth, B.J., Ludington, S., Robinson, G.R., Jr., Setiabudi, B.T., Sukserm, W., Sunuhadi, D.N., Wah, A.Yan Sze, and Zientek, M.L., with contributions from Cox, D.P., Jarnyaharn, P., Kopi, G., Ngoc, N.T.M., Otarawanna, P., Pei, C.S., Phany, U., Van Quy, N.V., Sakimoto, T., Saroa, D., Soares da Costa, N., Sotham, S., Sim, I.M., Trung, N.N., Wongsomasak, S., Yokarti, B., Zaw, K., 2013, Porphyry copper assessment of Southeast Asia and Melanesia: U.S. Geological Survey Scientific Investigations Report 2010-5090-D, 332 p. and GIS data, available at http://pubs.usgs.sir/2012/5090/d/.

Hedenquist, J.W., Arribas, A., Jr., and Reynolds, T.J., 1998, Evolution of an intrusion-centered hydrothermal systemFar Southeast-Lepanto porphyry and epithermal $\mathrm{Cu}-\mathrm{Au}$ deposits, Philippines: Economic Geology, v. 93, p. 373-404.

Hester, M.G., Earnert, D.F., and Aronson, J.G., 2010, Kingking copper-gold project, Mindanao, Philippines: Technical Report (NI 43-101) prepared for Ratel Gold Limited and Russell Mining and Minerals, Inc., prepared by Independent Mining Consultants, Inc., 288 p., accessed April 15, 2013, at http://sagcmining.com/.

Hollings, Pete, Wolfe, R., Coke, D.R., and Waters, P.J., 2011, Geochemistry of Tertiary igneous rocks of Northern Luzon, Philippines-Evidence for a back-arc setting for alkali porphyry copper-gold deposits and a case for slab roll-back?: Economic Geology, v. 106, p. 1257-1277.

Indophil Resources NL, 2012, Tampakan copper-gold project, resources/reserves: Indophil Resources NL, Web site, accessed April 5, 2013, at http://www.indophil.com/ projects/tampakan/resources-reserves.

Ishihara, Shunso, 1979, Lateral variation of magnetic susceptibility of the Japanese granitoids: Journal of the Geological Society of Japan, v. 263, p. 173-208.

Ishihara, Shunso, 1981, The granitoid series and mineralization, in Skinner, B.J., ed., Economic Geology, 75th anniversary volume 1905-1980: Lancaster, Pennsylvania, Lancaster Press, Inc., p. 458-484.

Ishihara, Shunso, 1998, Granitoid series and mineralization in the circum-Pacific Phanerozoic granitic belts: Resource Geology, v. 48, no. 4, p. 219-224.

Ishihara, Shunso, 2004, The redox state of granitoids relative to tectonic setting and earth history-The magnetite-ilmenite series 30 years later: Transactions of the Geological Society of Edinburgh, Earth Sciences, v. 95, p. 23-33. 
Ishizuka, Osamu, Yuasa, Makoto, and Uto Kozo, 2002, Evidence of porphyry copper-type hydrothermal activity from a submerged remnant back-arc volcano of the Izu-Bonin arc-Implications for the volcanotectonic history of backarc seamounts: Earth and Planetary Science Letters, v. 198, p. 381-399.

Jimenez, F.A., Jr., Yumul, G.P., Jr., Maglambayan, V.B., and Tamayo, R.A., Jr., 2002, Shallow to near-surface, vein-type epithermal gold mineralization at Lalab in the Sibutad gold deposit, Zamboanga del Norte, Mindanao, Philippines: Journal of Asian Earth Sciences, v. 21, p. 119-133.

Jin, M.S., Lee. Y.S., and Ishihara, S., 2001, Granitoids and their magnetic susceptibility in South Korea: Resource Geology, v. 51, p. 189-203.

John, D.A., Ayuso, R.A., Barton, M.D., Blakely, R.J., Bodnar, R.J., Dilles, J.H., Gray, Floyd, Graybeal, F.T., Mars, J.C., McPhee, D.K., Seal, R.R., Taylor, R.D., and Vikre, P.G., 2010, Porphyry copper deposit model, chap. B of Mineral deposit models for resource assessment: U.S. Geological Survey Scientific Investigations Report 2010-5070-B, 169 p., accessed September 8, 2010, at http://pubs.usgs.gov/ $\operatorname{sir} / 2010 / 5070 / b /$.

Joyce, Paul, and Thomson, Robert, 2002, Dipidio gold-copper project-Moving towards development: Sydney Mineral Exploration Discussion Group Web site, accessed June 21, 2010, at http://www.smedg.org.au/Tiger/Dipidio.htm.

Jwa, Y.-J., 1998, Temporal, spatial and geochemical discriminations of granitoids in South Korea: Resource Geology, v. 48 , p. $273-284$.

Jwa, Y.-J., 2004, Mesozoic granites and associated mineralization in South Korea, in Blevin, Phil, Jones, Mel, and Chappell, Bruce, eds., The Ishihara Symposium - Granites and Associated Metallogenesis, 22-24 July 2003, Macquarie University: Geoscience Australia, Record 2003/14, p. 81-83.

Kamitani, M., and Naito, K., eds., 1998, Mineral resource map of Asia: Metal Mining Agency of Japan, 1 sheet, scale $1: 35,000,000$.

Kay, R.W., 1978, Aleutian magnesian andesites-Melts from subducted Pacific Ocean crust: Journal of Volcanology and Geothermal Research, v. 4, p. 117-132.

Kim, J.H., 1996, Mesozoic tectonics in Korea: Journal of Southeast Asian Earth Sciences, v. 13, no. 3-5, p. 251-265.

Knittel, U., and Cundari, A., 1990, Mineralogical evidence for the derivation of metaluminous, potassic rocks from peralkaline precursors-The Cordon Syenite Complex (Philippines): Mineralogy and Petrology ,v. 41, p. 163-183.
Knittel, U., and Defant, M.J., 1988, Sr isotopic and trace element variations in Oligocene to Recent igneous rocks from then Philippine island arc_Evidence for Recent enrichment in the sub-Philippine mantle: Earth and Planetary Science Letters, v. 87, p. 87-99.

Koh, Sang-Mo, Ryoo, Chung-Ryul, and Song, Min-Sub, 2003, Mineralization characteristics and structural controls of hydrothermal deposits in the Gyeongsang Basin, South Korea: Resource Geology, v. 53, no. 3, p. 175-192.

Korea Institute of Geology, Mining and Materials (KIGAM), 1995a, Geological map of Korea: KIGAM, Taejeon, Korea, scale 1:1,000,000. [In Korean and English.]

Korea Institute of Geology, Mining and Materials (KIGAM), 1995b, Isotope age map of volcanic rocks in Korea: Taejeon, Korea, KIGAM, scale 1:1,000,000. [In Korean |and English.]

Korea Institute of Geology, Mining and Materials (KIGAM), 1995c, Isotope age map of plutonic rocks in Korea: Taejeon, Korea, KIGAM, scale 1:1,000,000. [In Korean and English.]

Korea Institute of Geology, Mining and Materials (KIGAM), 1995d, Isotope age map of ore deposits in Korea: Taejeon, Korea, KIGAM, scale 1:1,000,000. [In Korean and English.]

Korea Institute of Geosciences and Mineral Resources (KIGAM), 2011, Annual Report 2011: KIGAM, accessed May 1, 2012, at http://www.kigam.re.kr/Contents/mboard. asp?strBoardID=B028.

Korea Institute of Geosciences and Mineral Resources (KIGAM), 2012, KIGAM: KIGAM, Web site accessed May 1, 2012, at http://www.kigam.re.kr/.

Lee, Y.I., 2008, Paleogeographic reconstructions of the East Asia continental margin during the middle to late Mesozoic: Island Arc, v. 17, p. 458-470.

Le Maitre, R.W., ed., Streckeisen, A., Zanettin, B., Le Bas, M.J., Bonin, B., Bateman, P., Bellieni, G., Dudel, A., Efremova, S., Keller, A.J., Lameyre, J., Sabine, P.A., Schmid, R., Sørensen, H., and Woolley, A.R., 2002, Igneous rocksA classification and glossary of terms ( $2 \mathrm{~d}$ ed.): Cambridge University Press, $236 \mathrm{p}$.

Lepanto Consolidated Mining Company, 2008, Far Southeast: Lepanto Consolidated Mining Company Web page, accessed May 15, 2012, at http://www.lepantomining.com/ far_southeast.html. 
Ludington, Steve, Mihalasky, M.J., Hammarstrom, J.M., Robinson, G.R., Jr., Frost, T.P., Gans, K.D., Light, T.D., and Miller, R.J., and Alexeiev, D., 2012, Porphyry copper assessment of the Mesozoic of East Asia-China, Vietnam, North Korea, Mongolia, and Russia: U.S. Geological Survey Scientific Investigations Report 2010-5090-G, $53 \mathrm{p}$. and GIS data, available at http://pubs.usgs.gov/ $\operatorname{sir} / 2010 / 5090 / \mathrm{g} /$.

Malaihollo, J.F.A., Hall, R., and Macpherson, C.G., 2002, SE Asia radiometric ages - GIS database: Southeast Asia Research Group, Department of Earth Sciences, Royal Holloway University of London, accessed January 15, 2010, at http://searg.rhul.ac.uk/current_research/isotopic_ages/ SEAsia_GIS.pdf.

Maruyama, Shigenori, Isozaki, Yukio, Kimura, Gaku, and Taerbayshi, Masuru, 1997, Paleogeographic maps of the Japanese Islands-Plate tectonic synthesis from $750 \mathrm{Ma}$ to the present: The Island Arc, v. 6, p. 121-142.

Middleton, C., Buenavista, A., Rohrlach, B., Gonzalez, J., Subang, L., and Molreno, G., 2004, A geological review of the Tampakan copper-gold deposit, Southern Mindanao, Philippines: Australasian Institute of Mining and Metallurgy, Proceedings of PACRIM 2004 Congress, 19-22 September 2004, Adelaide, South Australia, p. 172-187.

Mitchell, A.H.G, and Leach, T.M., 1991, Epithermal gold in the Philippines-Island arc metallogenesis, geothermal systems and geology: London, Academic Press, $457 \mathrm{p}$.

Müller, D., and Groves, D.I., 1999, Potassic igneous rocks and associated gold-copper mineralization: Berlin, SpringerVerlag, $252 \mathrm{p}$.

National Geophysical Data Center, 2009, EMAG2-Earth Magnetic Anomaly Grid (2-arc-minute resolution): National Oceanic and Atmospheric Administration, National Geophysical Data Center, accessed March 17, 2014, at http:// catalog.data.gov/dataset/emag2-earth-magnetic-anomalygrid-2-arc-minute-resolution.

NUMO (Nuclear Waste Management of Japan), 2004, Tectonic setting and evolution of Japan: NUMO Technical Report NUMO-TR-04-04, chap. 6, p. 29-39, accessed April 10, 2012, at http://www.numo.or.jp/en/reports/pdf/Level3 SF_Final-06.pdf.

Oh, C.W., 2006, A new concept on tectonic correlation between Korea, China and Japan-Histories from the late Proterozoic to Cretaceous: Gondwana Research, v. 9, p. 47-61.

Paek, R.J., Gap, K.H., and Jon, G.P., eds., 1996, Geology of Korea: Pyongyang, Foreign Languages Publishing House, $631 \mathrm{p}$.
Philippine Bureau of Mines, 1963, Geological map of the Philippines: Philippine Bureau of Mines, 1 map on 8 sheets, scale $1: 1,000,000$.

Philippine Bureau of Mines and Geosciences, 1981, Geology and mineral resources of the Philippines, v. 1-Geology: Philippine Bureau of Mines and Geosciences, $406 \mathrm{p}$.

Philippine Bureau of Mines and Geosciences, 1986, Geology and mineral resources of the Philippines, v. 2-Mineral resources: Manila, Philippines, Philippine Bureau of Mines and Geosciences, $446 \mathrm{p}$.

Philippine Geological Survey Division, 1964, Mineral distribution map of the Philippines-Base metals: Philippine Geological Survey Division, sheet 2 of 6 maps, scale $1: 2,500,000$.

Philippine Mines and Geosciences Bureau, [n.d.], Geology and mineral distribution map of the Philippines: Philippine Mines and Geosciences Bureau, 1 map on 4 sheets, scale $1: 1,400,000$.

Philippine Mines and Geosciences Bureau, [n.d.], Index to 1:50,000 scale geological maps: Philippine Mines and Geosciences Bureau, scale 1:50,000.

Philippine Mines and Geosciences Bureau, 2004a, Digital geological map of the Philippines: Philippine Mines and Geosciences Bureau, scale 1:1,000,000. [Proprietary data.]

Philippine Mines and Geosciences Bureau, 2004b, Digital database of mineral occurrences of the Philippines: Philippine Mines and Geosciences Bureau. [Proprietary report.]

Philippine Mines and Geosciences Bureau, 2009, Tenement control map of region 10: Philippine Mines and Geosciences Bureau, accessed June 15, 2010, at http://www.mgb. gov.ph/Maps/Tenement/mgb-X\%20map-3rd_qtr.jpg.

Philippine Mines and Geosciences Bureau, 2010, Geology of the Philippines ( $2 \mathrm{~d}$ ed.): Philippines Mines and Geosciences Bureau, $532 \mathrm{p}$.

Plumlee, G.S., Morton, R.A., Boyle, T.P., Medlin, J.H., and Centeno, J.A., 2000, An overview of mining-related environmental and human health issues, Marinduque Island, Philippines - Observations from a joint U.S. Geological Survey-Armed Forces Institute of Pathology reconnaissance field evaluation, May 12-19, 2000: U.S. Geological Survey Open-File Report 00-397, accessed June 15, 2010, at http:// pubs.usgs.gov/of/2000/ofr-00-0397/.

Pubellier, M., Quebrel, R., Rangin, C., Deffontaines, B., Muller, C., Butterlin, J., and Manzano, J., 1991, The Mindanao collision zone-A soft collision event within a continuous Neogene strike-slip setting: Journal of Southeast Asian Earth Sciences, v. 6, no. 3-4, p. 239-248. 
Pubellier, M., Quebral, R., Deffontaines, B., and Rangin, C., 1993, Neotectonic map of Mindanao (Philippines): Quezon City, Philippines, Asia Geodyne Corporation, scale 1:800,000.

Pubellier, M., Quebral, R. Aurelii, M., and Rangin, G., 1996, Docking and post-docking escape tectonics in the southern Philippines, in Hall, R., and Blundell, D., eds., Tectonic evolution of southeast Asia: Geological Society of London Special Publication, no. 106, p. 511-523.

Qin, Kezhang, and Ishihara, Shunso, 1998, On the possibility of porphyry copper mineralization in Japan: International Geology Review, v. 40, no. 6, p. 539-551.

Rangin, C., Jolivet, L., and Pubellier, M., 1990, A simple model for the tectonic evolution of Southeast Asia and Indonesia regions for the past $43 \mathrm{Ma}$ : Bulletin de la Société géologique de France, v. 8, p. 889-905.

Richards, J.P., 2009, Postsubduction porphyry $\mathrm{Cu}-\mathrm{Au}$ and epithermal Au deposits-Products of remelting subductionmodified lithosphere: Geology, v. 37, no. 3, p. 247-250.

Richards, J.P., and Kerrich, Robert, 2007, Adakite-like rocksTheir diverse origins and questionable role in metallogenesis: Economic Geology, v. 102, p. 537-576.

Root, D.H., Menzie, W.D., and Scott, W.A., 1992, Computer Monte Carlo simulation in quantitative resource estimation: Natural Resources Research, v. 1, no. 2, p. 125-138.

Sagong, Hee, Kwon, Sung-Tack, and Ree, Jin-Han, 2005, Mesozoic episodic magmatism in South Korea and its tectonic implication: Tectonics, v. 24, p. 1-18.

Sajona, F.G., and Maury, R.C., 1998, Association of adakites with gold and copper mineralization in the Philippines: Comptes rendus de l'Academie des sciences Serie II, Sciences de la terre et des planets, v. 326, p. 27-34.

Sajona, F.G., Maury, R.C., Pubellier, M., Leterrier, J., Bellon, H., and Cotton, J., 2000, Magmatic source enrichment by slab-derived melts in a young post-collision setting, central Mindanao (Philippines): Lithos, v. 54, p. 173-206.

Schulz, K.J., and Briskey, J. A., 2003, The global mineral resource assessment project: U.S. Geological Survey Fact Sheet 053-03, available online at http://pubs.usgs.gov/fs/ fs $053-03 /$.

Sillitoe, R.H., 1980, Evidence for porphyry-type mineralization in South Korea: Mining Geology Special Issue 8, p. 205-214.

Sillitoe, R.H., 1983, Enargite-bearing massive sulfide deposits high in porphyry copper systems: Economic Geology, v. 78, p. 348-352.
Sillitoe, R.H., 2010, Porphyry copper systems: Economic Geology, v. 105, p. 3-41.

Sillitoe, R.H., and Gappe, I.M., Jr., 1984, Philippine porphyry copper deposits - Geologic setting and characteristics: Committee for Co-ordination of Joint Prospecting for Mineral Resources in Asian Offshore Areas (CCOP), CCOP Technical Publication 14, 89 p.

Singer, D.A., 1993, Basic concepts in three-part quantitative assessments of undiscovered mineral resources: Nonrenewable Resources, v. 2, no. 2, p. 69-81.

Singer, D.A., 1995, World-class base and precious metal deposits-A quantitative analysis: Economic Geology, v. 99 , p. $88-104$.

Singer, D.A., 2007a, Short course introduction to quantitative mineral resource assessments: U.S. Geological Survey Open-File Report 2007-1434, accessed May 15, 2009, at http://pubs.usgs.gov/of/2007/1434/.

Singer, D.A., 2007b, Estimating amounts of undiscovered resources, in Briskey, J.A., and Schulz, K.J., eds., Proceedings for a workshop on deposit modeling, mineral resource assessment, and their role in sustainable development, 31st International Geological Congress, Rio de Janeiro, Brazil, August 18-19, 2000: U.S. Geological Survey Circular 1294, p. 79-84. (Also available online at http://pubs.usgs.gov/ circ/2007/1294/.)

Singer, D.A., and Berger, V.I., 2007, Deposit models and their application in mineral resource assessments, in Briskey, J.A., and Schulz, K.J., eds., Proceedings for a workshop on deposit modeling, mineral resources assessment, and their role in sustainable development, 31st International Geological Congress, Rio de Janeiro, Brazil, August 18-19, 2000 : U.S. Geological Survey Circular 1294, p. 71-78. (Also available online at http://pubs.usgs.gov/circ/2007/1294/.)

Singer, D.A., Berger, V.I., and Moring, B.C., 2008, Porphyry copper deposits of the World-Database and grade and tonnage models, 2008: U.S. Geological Survey Open-File Report 2008-1155, accessed June 1, 2011, at http://pubs. usgs.gov/of/2008/1155/.

Singer, D.A., and Menzie, W.D., 2005, Statistical guides to estimating the number of undiscovered mineral deposits-An example with porphyry copper deposits, in Cheng, Qiuming, and Bonham-Carter, Graeme, eds., Proceedings of IAMG-The annual conference of the International Association for Mathematical Geology: Toronto, Canada, York University, Geomatics Research Laboratory, p. 1028-1033.

Singer, D.A., and Menzie, W.D., 2010, Quantitative mineral resource assessments - An integrated approach: New York, Oxford University Press, New York, 219 p. 
Solfotara Mining Corporation, 2012, Tawi-Tawi copper-gold porphyry deposit: Solfotara Mining Corporation Web page, accessed May 1, 2012, at http://solfotara.com/.

Takagi, Tetsuichi, 2004, Origin of magnetite- and ilmeniteseries granitic rocks in the Japan Arc: American Journal of Science, v. 304, p. 169-202.

Takagi, Tetsuichi, and Tsukitmura, Katsuhiro, 1997, Genesis of oxidized- and reduced-type granites: Economic Geology, v. 92, p. 81-86.

U.S. Department of State, 2009, Small-scale digital international land boundaries (SSIB)_-Lines, edition 10, and polygons, beta edition 1, in Boundaries and sovereignty encyclopedia (B.A.S.E.): U.S. Department of State, Office of the Geographer and Global Issues.

U.S. Geological Survey, 2012, U.S. Geological Survey on-line mineral resources spatial data: U.S. Geological Survey Web site, accessed April 15, 2013, at http://mrdata.usgs.gov/.

U.S. Geological Survey National Mineral Resource Assessment Team, 2000, 1998 assessment of deposits of gold, silver, copper, lead, and zinc in the United States: U.S. Geological Survey Circular 1178, 21 p. (Also available at http:// pubs.usgs.gov/circ/c1178/.)

Utada, Minotu, 1980, Hydrothermal alterations related to igneous activity in Cretaceous and Neogene formations of Japan: Mining Geology Special Issue 8, p. 67-83.

Uyeda, Seiya, 1991, The Japanese island arc and the subduction process: Episodes, v.14, p. 190-198.

Waters, P.J., Cooke, D.R., Gonzales, R.I, and Phillips, D., 2011, Porphyry and epithermal deposits and ${ }^{40} \mathrm{Ar} /{ }^{39} \mathrm{Ar}$ geochronology of the Baguio District, Philippines: Economic Geology, v. 106, p. 1335-1363.

Wei, Chi-Sheng, Yen, Chih-Min, Lin, Yung-Hsiang, Chen, Po-Psun, Wang, Yunshuen, and Fei, Li-Yuan, compilers, 2006, Resources map of metallic minerals of Taiwan: Central Geological Survey, Ministry of Economic Affairs, scale 1:500,000.

Wnuk, Christopher, Boyle, T., Centeno, J., David, C.P., Gibb, H., Logsdon, M., and others, 2006, Social, environmental and health impacts of a large-scale tailings spill on Marinduque Island, the Philippines [abs.]: Geological Society of America Abstracts, accessed June 15, 2010, at http://gsa.confex.com/gsa/2006AM/finalprogram/ abstract_114371.htm.
Wolfe, Rohan, Hollings, Peter, and Cooke, D.C., 2010, Mineralisation and geochemistry associated with the Dinkidi alkali $\mathrm{Cu}-\mathrm{Au}$ porphyry, Northern Luzon, Philippines: GeoCanada 2010-Working with the Earth, Calgary, Canada, May 10-13, 2010, accessed March 17, 2014, at http://www.cspg.org/documents/Conventions/ Archives/Annual/2010/0531 GC2010 Mineralisation and geochemistry_associated_with_the_Dinkidi_alkalic.pdf.

Wu, J.C., 2001, The mineral industry of Japan, in Area reports-International-Asia and the Pacific: U.S. Geological Survey Minerals Yearbook 2002, v. III, p. 13.1-13.15, accessed May 15, 2012, at http://minerals.usgs.gov/ minerals/pubs/country/2001/jamyb01.pdf.

Yang, Kyounghee, and Bodnar, R.J., 1994, Magmatichydrothermal evolution in the "bottoms" of porphyry copper systems - Evidence from silicate melt and aqueous fluid inclusions in granitoids intrusions in the Gyeongsang Basin, South Korea: International Geology Review, v. 36, p. 608-628.

Yang, Kyounghee, and Bodnar, R.J., 2004, Orthomagmatic origin for the Ilkwang $\mathrm{Cu}-\mathrm{W}$ breccia-pipe deposit, southeastern Kyongsang Basin, South Korea: Journal of Asian Earth Sciences, v. 24, p. 259-270.

Yang, T.F., Lee, T., Chen, C.H., Cheng, S.N., Knittel, U., Punongbayan, R.S., and Rasda, A.R., 1996, A double island arc between Taiwan and Luzon-Consequence of ridge subduction: Tectonophysics, v. 258, p. 85-101.

Yumul, G.P., Jr., Dimalanta, C.B., Maglambayan, V.B., and Tamayo, R.A., Jr., 2003, Mineralization controls in island arc settings - Insights from Philippine metallic deposits: Gondwana Research, v. 6, no. 4, p. 767-776.

Yumul, G.P., Jr., Dimalanta, C.B., Maglambayan, V.B., and Marquez, E.J., 2008a, Tectonic setting of a composite terrane-A review of the Philippine island arc system: Geosciences Journal, v. 12, no. 1, p. 7-17.

Yumul, G.P., Jr., Dimalanta, C.B., Marquez , E.J., and Queano, K.L., 2009, Onland signatures of the Palawan microcontinental block and Philippine Mobile Belt collision and crustal growth process-A review: Journal of Asian Earth Sciences, v. 34, p. 610-623.

Zhang, Yan-Bin, Zhai, M., Hou, Q.-L., Li, T.-SA., Liu, F., and Hu, B., 2012, Late Cretaceous volcanic rocks and associated granites in Gyeongsang Basin, SE Korea-Their chronological ages and tectonic implications for cratonic destruction of the North China craton: Journal of Asian Earth Sciences, v. 47 , p. $252-264$. 
This page left intentionally blank. 


\section{Appendix A. Porphyry Copper Assessment for Tract 142pCu7312, Cotabato Arc-Philippines}

By Jane M. Hammarstrom ', Arthur A. Bookstrom², Connie L. Dicken', Steve Ludington ${ }^{3}$, Gilpin R. Robinson, Jr.', and Michael L. Zientek ${ }^{2}$ with contributions from Sevillo (Bill) D. David, Jr. ${ }^{4}$ Claro J. Manipon ${ }^{4}$, Lilian A. Rollan ${ }^{4}$, and Yasushi Watanabe ${ }^{5}$

\section{Deposit Type Assessed: Porphyry copper}

Descriptive model: Porphyry copper (Berger and others, 2008; Cox, 1986; John and others, 2010; Sillitoe and Gappe, 1984) Grade and tonnage model: Porphyry copper (Singer and others, 2008)

Table A1 summarizes selected assessment results.

Table A1. Summary of selected resource assessment results for tract 142pCu7312, Cotabato Arc-Philippines.

[km, kilometers; $\mathrm{km}^{2}$, square kilometers; $\mathrm{t}$, metric tons; identified copper rounded to two significant figures]

\begin{tabular}{cccccc}
\hline $\begin{array}{c}\text { Date of assess- } \\
\text { ment }\end{array}$ & $\begin{array}{c}\text { Assessment depth } \\
(\mathbf{k m})\end{array}$ & Tract area $\left(\mathbf{k m}^{2}\right)$ & $\begin{array}{c}\text { Identified copper } \\
\text { resources }(\mathbf{t})\end{array}$ & $\begin{array}{c}\text { Mean estimate of } \\
\text { undiscovered copper } \\
\text { resources }(\mathbf{t})\end{array}$ & $\begin{array}{c}\text { Median estimate of } \\
\text { undiscovered copper } \\
\text { resources }(\mathbf{t})\end{array}$ \\
\hline 2010 & 1 & 9,700 & $15,000,000$ & $4,600,000$ & $1,300,000$ \\
\hline
\end{tabular}

\section{Location}

Southwestern Mindanao (fig. A1).

\section{Geologic Feature Assessed}

Miocene to Holocene Cotabato Arc.

${ }^{1}$ U.S. Geological Survey, Reston, Virginia, United States.

${ }^{2}$ U.S. Geological Survey, Spokane, Washington, United States.

${ }^{3}$ U.S. Geological Survey, Menlo Park, California, United States.

${ }^{4}$ Philippine Department of Environment and Natural Resources, Mines and Geosciences Bureau, Quezon City, Philippines.

${ }^{5}$ Geological Survey of Japan, National Institute of Advanced Industrial Science and Technology (AIST), Ibaraki, Japan. 

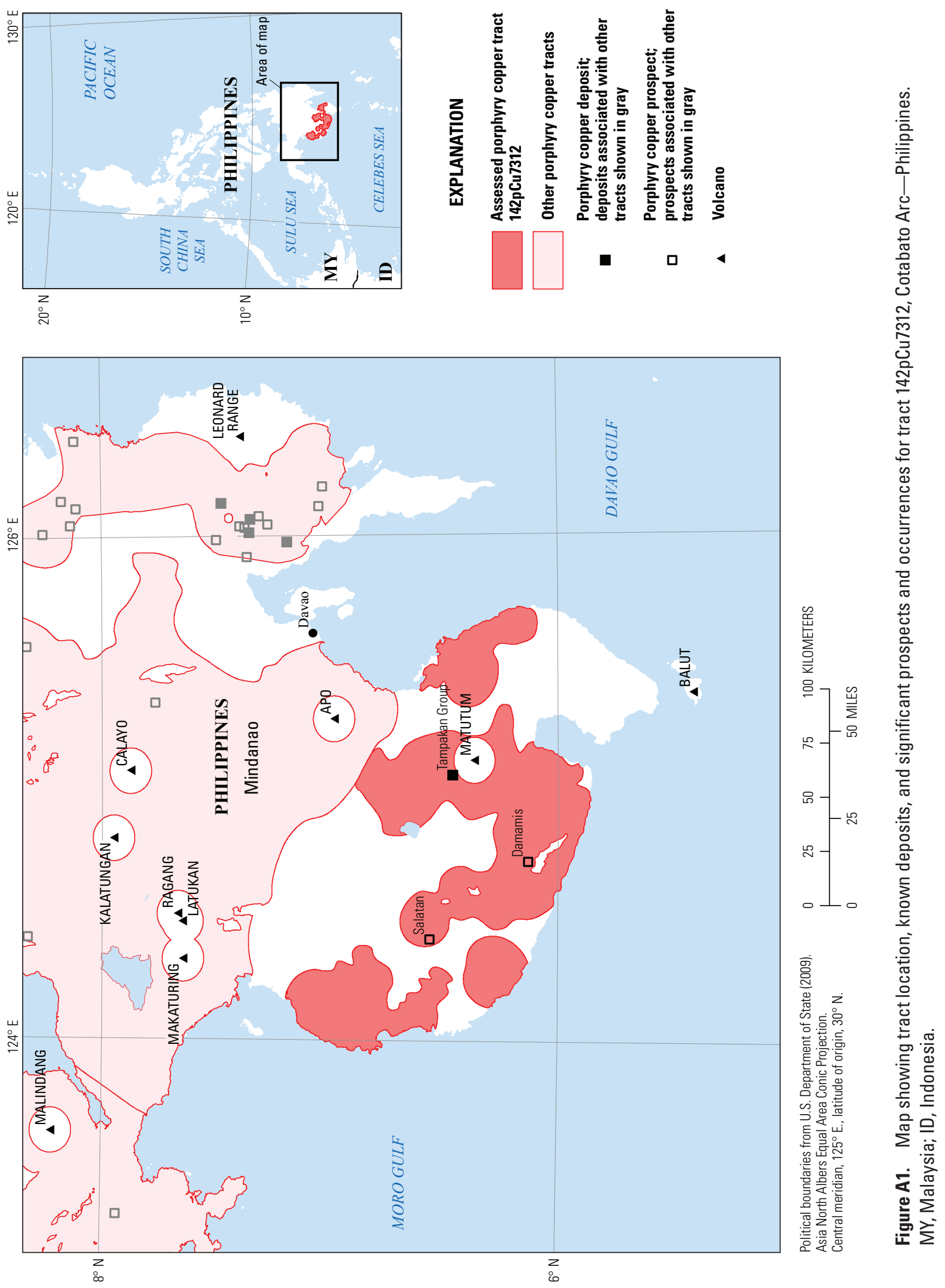


\section{Delineation of the Permissive Tract}

\section{Tectonic Setting}

The tract delineates calc-alkalic intrusive rocks within the 300-km-long Miocene to Holocene Cotabato Arc in southwestern Mindanao (fig. $2 A^{6}$ ) as outlined by Garwin and others (2005) and Mitchell and Leach (1991). The arc formed by northeast-directed subduction of oceanic crust in the Cotabato Trench (fig. $5 B$ ). The Cotabato Arc is built on a Paleogene (50-30 Ma) basement of volcanic rocks characterized by island-arc tholeiitic compositions; these rocks are attributed to an older arc (Daguma) related to subduction of a proto-Molucca Sea along a proto-Sangihe trench (Sajona and others, 1997). The Cotabato Arc may be coextensive with the Masbate-Negros Arc to the north and with the North SulawesiSangihe Arc to the south (fig. $2 A$ ); its continuation across the intervening Sulu-Zamboanga Arc has not been established (Garwin and others, 2005).

\section{Geologic Criteria}

The permissive tracts were constructed by selecting igneous rocks from a digital version of the 1:1,000,000scale geologic map of the Philippines (Philippine Mines and Geosciences Bureau, 2004a). Map units were classified by age groups, and subdivided into intrusive and volcanic subgroups. Lithologies were examined, and rock types that are not considered permissive for porphyry copper deposits, such as pillow basalts, ultramafic rocks, and rhyolites were excluded. Permissive rocks used to delineate the tract are shown in figure A2 and listed in table A2. A 10-km buffer was created around intrusive rocks, and a 2-km buffer was created around volcanic rocks. These distances are considered appropriate to allow for inaccuracies in mapped contacts and extensions under adjacent cover rock. The buffered map unit polygons were aggregated, smoothed, and edited by hand to honor fault boundaries and to include known prospects and permissive igneous rocks shown on larger scale maps (fig. 7 of Sajona and others, 1997; Middleton and others, 2004).

The tract primarily is based on the pre-Pleistocene intrusive and volcanic rocks shown on the 1:1,000,000-scale geologic map of the Philippines. Site locations for dated and classified igneous rocks were also used to ensure that permissive rocks that did not appear on the map were included within the tract (Malaihollo and others, 2002). Calc-alkalic and high$\mathrm{K}$ calc-alkalic andesite and dacite flows, andesitic necks, and intrusions within the tract area are dated at 23.6 Ma to Holocene (Sajona and others, 1997). The Cotabato Fault bounds the tract on the north and separates it from the Central Mindanao Volcanic Province (tract 142pCu7308). A circular cutout in the tract represents a 10-km area around the 8.4-Ma Mount Matutum active stratovolcano (fig. A1); other excluded areas within the tract outline ophiolite complexes along the Daguma Range (fig. 4E). Tract boundaries were clipped to shorelines based on political boundaries established by the U.S. Department of State (2009).

\section{Known Deposits}

The Tampakan Group (fig. A1) include the Tampakan deposits and the adjacent Sodaco exploration project. The 3.5-Ma Tampakan deposit in southern Mindanao has been described as the largest undeveloped copper-gold deposit in Southeast Asia (Middleton and others, 2004). As of January 2012, resources were reported to be 2,940 Mt of ore having an average grade of 0.52 percent copper and $0.17 \mathrm{~g} / \mathrm{t}$ gold (table A3). The porphyry system underlies a high-sulfidation epithermal deposit and is associated with intermediate argillic alteration (sericite-chlorite-clay (SCC) type alteration) of andesite and diorite. The andesite overlies early to middle Miocene basaltic basement intruded by hornblende diorite porphyry stocks. The main copper mineral in the porphyry is chalcopyrite, which occurs as disseminations and stringers. In the epithermal system, the main copper mineral is enargite (Philippine Mines and Geosciences Bureau, 2005). Feasibility studies were completed with plans for open-pit mining and production to begin approximately 2016 , with a $20-40$ year mine life. However, a ban on open-pit mining in South Cotabato was enacted in July of 2010, which may affect mine development (Aguiba, 2010).

Tampakan is near intersections of faults that strike westnorthwest and north-northeast. The Sodaco exploration project, $900 \mathrm{~m}$ from Tampakan, lies within the $90-\mathrm{km}^{2}$ lithocap of advanced argillically altered volcanic rocks and is considered as an extension of the Tampakan deposit. Drilling $400 \mathrm{~m}$ south of the Sodaco project intercepted $158 \mathrm{~m}$ of rock containing $0.52 \mathrm{~g} / \mathrm{t}$ gold and 0.41 percent copper.

\section{Prospects, Mineral Occurrences, and Related Deposit Types.}

Two porphyry copper prospects are known within the tract area: Salatan and Damamis (fig. A1, table A4). The main ore-bearing intrusive rock at the Salatan prospect is an argillically altered biotite-hornblende dacite porphyry and associated dikes (Sillitoe and Gappe, 1984). The maximum depth of oxidation at Salatan is less than $10 \mathrm{~m}$, and supergene enrichment is minor. Little is known about the Damamis copper prospect, a reported porphyry-type copper-gold occurrence (C. Manipon, a coauthor of this report, written commun., 2004). Several iron and copper occurrences are associated with Miocene quartz diorite in the Daguma Range (fig. $4 E$ ). 

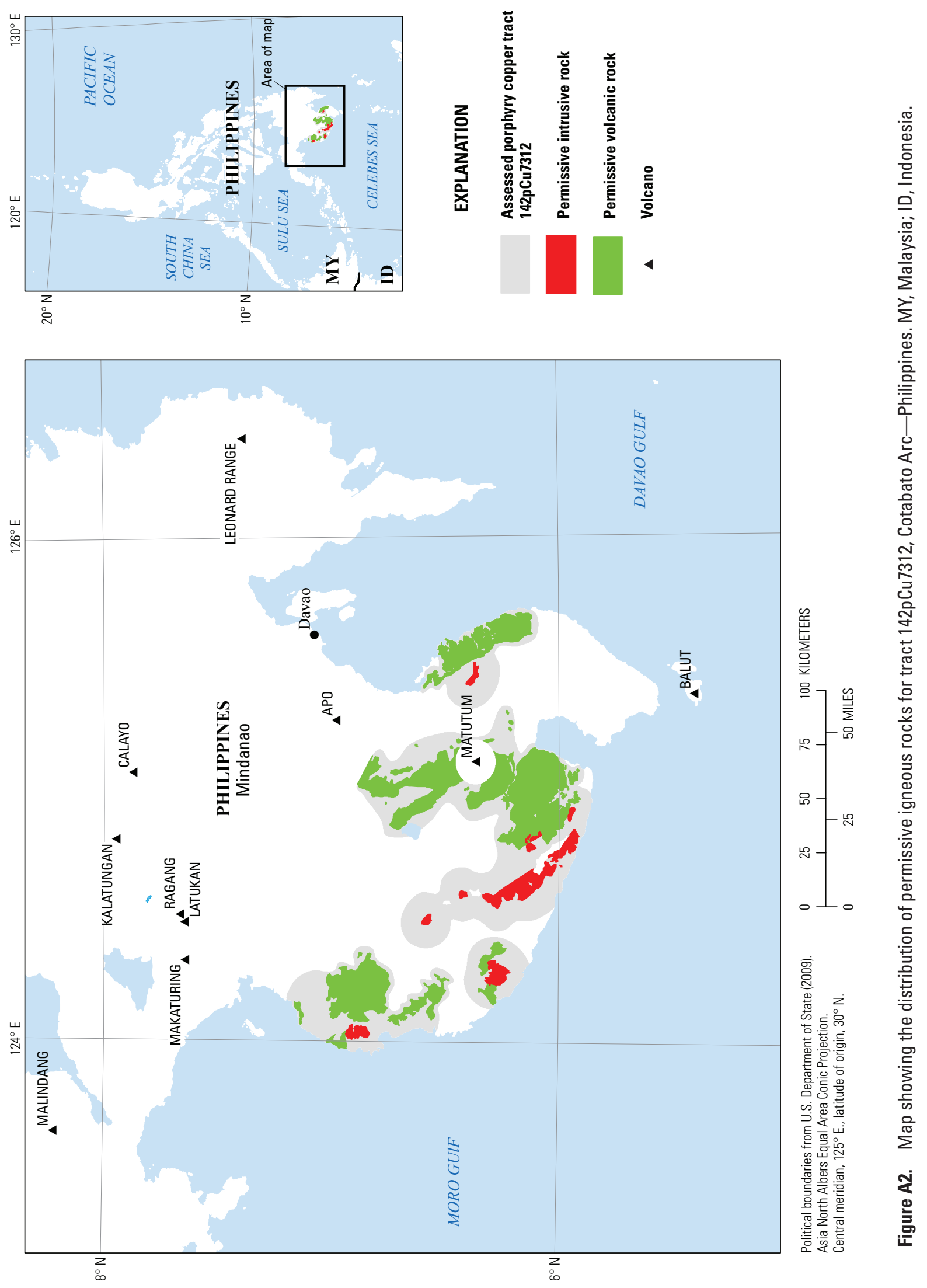
Table A2. Map units that define tract 142pCu7312, Cotabato Arc—Philippines.

[Map unit, age range, and principal lithologies are based on a digital compilation of maps listed in table A5]

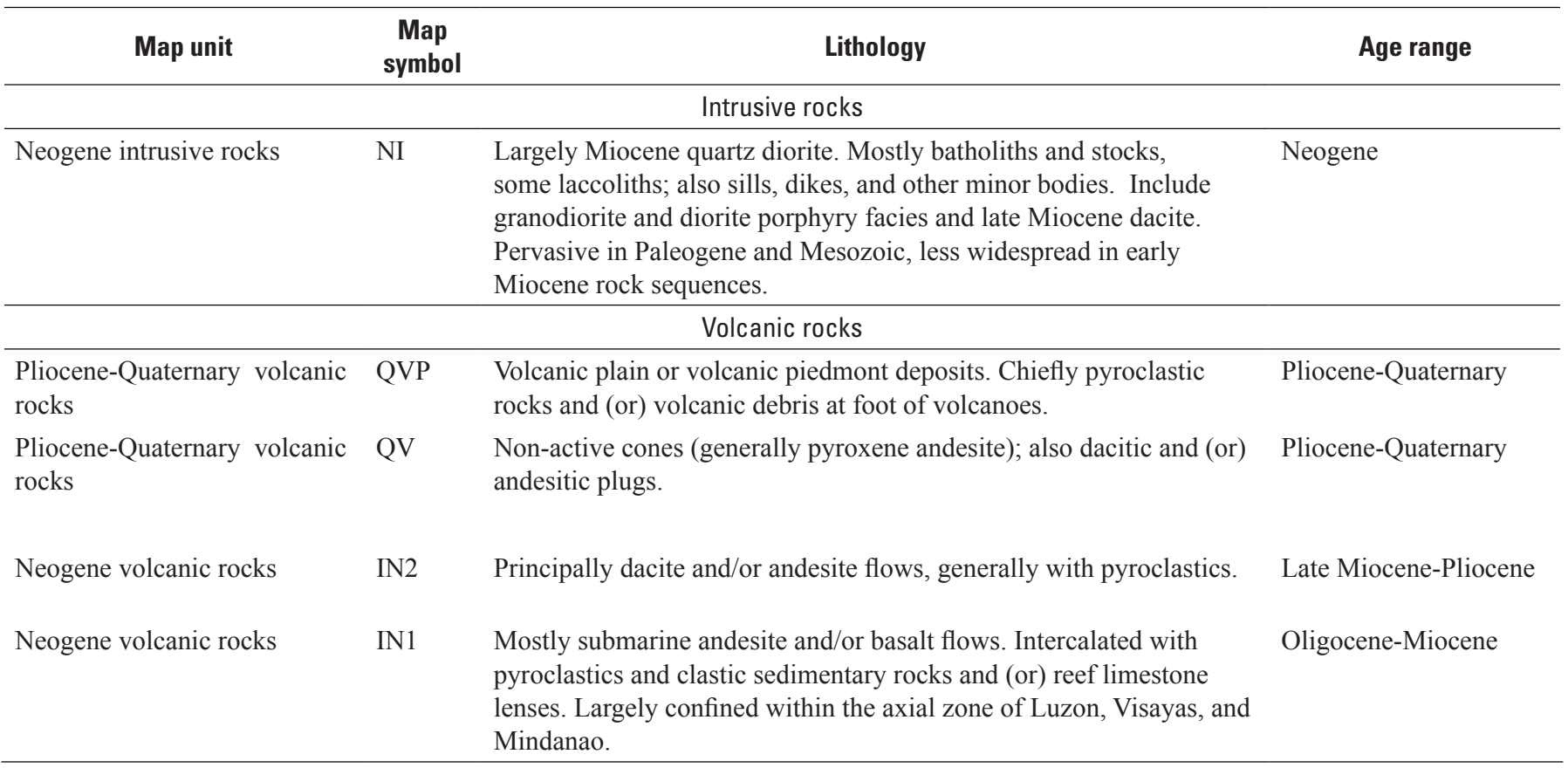

Table A3. Porphyry copper deposits in tract 142pCu7312, Cotabato Arc-Philippines.

[Ma, million years; Mt, million metric tons; $\mathrm{t}$, metric ton; $\mathrm{g} / \mathrm{t}$, gram per metric ton; \%, percent; NA, not applicable; n.d., no data. Contained Cu in metric tons is computed as $(\mathrm{Mt} \times 1,000,000) \times(\mathrm{Cu}$ grade, $\% \div 100)]$

\begin{tabular}{|c|c|c|c|c|c|c|c|c|c|c|c|}
\hline Name & Latitude & Longitude & Subtype & $\begin{array}{l}\text { Age } \\
\text { (Ma) }\end{array}$ & $\begin{array}{c}\text { Tonnage } \\
\text { (Mt) }\end{array}$ & $\mathrm{Cu}(\%)$ & Mo (\%) & $A u(g / t)$ & $\underset{(g / t)}{\mathrm{Ag}}$ & $\begin{array}{c}\text { Contained } \\
\text { Cu (t) }\end{array}$ & Reference \\
\hline $\begin{array}{l}\text { Tampakan } \\
\text { Group }\end{array}$ & 6.467 & 125.050 & NA & 4.25 & 2,940 & 0.52 & 0.006 & 0.17 & n.d. & $15,288,000$ & $\begin{array}{l}\text { Middleton and } \\
\text { others (2004), Mills } \\
\text { (2007), Mitchell } \\
\text { and Leach (1991), } \\
\text { Rohrlach (2002), } \\
\text { Rohrlach and oth- } \\
\text { ers (1999), Singer } \\
\text { and others }(2008) \text {, } \\
\text { WMC (1999, 2000) }\end{array}$ \\
\hline
\end{tabular}

Table A4. Significant prospects and occurrences in tract 142pCu7312, Cotabato Arc—Philippines.

[Ma, million years. Rank 4=prospect listed in global database of Singer and others (2008) or $<16,000$ metric tons (t) of ore established by drilling. Rank $1=$ copper occurrence that may be related to porphyry-type mineralization based on stream sediment or magnetic anomaly or location along structural trend]

\begin{tabular}{cccclcc}
\hline \multicolumn{1}{c}{ Name } & Latitude & Longitude & \multicolumn{1}{c}{ Age (Ma) } & \multicolumn{1}{c}{ Comments } & \multicolumn{1}{c}{ Reference } \\
\hline Damamis & 6.133 & 124.708 & $\begin{array}{l}\text { Early Miocene } \\
(\sim 19.5)\end{array}$ & $\begin{array}{l}\text { South Cotabato copper pros- } \\
\text { pect. Chalcopyrite, bornite. }\end{array}$ & $\begin{array}{l}\text { U.S. Geological Survey (2012) } \\
\text { Salatan }\end{array}$ \\
& 6.567 & 124.400 & $\begin{array}{l}\text { Early Miocene } \\
(\sim 19.5)\end{array}$ & $\begin{array}{l}\text { Prospect explored by Gold } \\
\text { Fields Asia, Ltd. in 1982. }\end{array}$ & $\begin{array}{l}\text { Almogela (1974), Sillitoe and Gappe } \\
(1984), \text { Singer and others (2008) }\end{array}$ \\
\hline
\end{tabular}




\section{Exploration History}

In the 1960s-1980s, a minor amount of gold prospecting was done and small alluvial gold deposits were worked within the tract area. The Salatan prospect was explored in 1982 by Gold Fields Asia, Ltd. (Sillitoe and Gappe, 1984). Reconnaissance exploration within the district began in 1990, and Tampakan was discovered in 1992 (Indophil Resources, Ltd., 2010). Geochemical and geophysical surveys followed, and the deposit was characterized by 85 drill holes that led to geological resource estimates and plans for development. The May 2012 mining tenement map for Central Mindanao showed more than 25 exploration permit applications, permits, or mineral protection sharing agreements for copper and gold that overlap parts of the tract area (http://www.mgb.gov.ph/ lmtp.aspx).

\section{Sources of Information}

Principal sources of information for the Tampakan deposit are listed in table A5.

\section{Grade and Tonnage Model Selection}

The gold to molybdenum ratio of reported grades for the Tampakan deposit is 28 , which categorizes the deposit as a porphyry copper subtype deposit according to the model criteria of Singer and others (2008). An analysis of variance (ANOVA) test for the deposit (table 4) also supports selection of general global porphyry copper model.

\section{Estimate of the Number of Undiscovered Deposits}

\section{Rationale for the Estimate}

The small size of the tract (less than $10,000 \mathrm{~km}^{2}$ ) limits the numbers of undiscovered deposits that could be present.
The project area for Tampakan, the one known deposit in the tract, is about $300 \mathrm{~km}^{2}$. The tract contains two porphyry copper prospects, one of which (Salatan) was explored in the past. A favorable structural setting, epithermal gold deposits associated with the Tampakan deposit, alluvial gold occurrences, and alteration of diorites in the Daguma Range (Philippine Mines and Geosciences Bureau, 2010) are all positive indications for additional deposits. Also, the extensive Quaternary volcanic cover could conceal deposits. On the basis of these factors, the assessment team estimated a 90-percent chance for one or more additional deposits and a 10-percent chance of two or more deposits within the tract. The mean number of undiscovered deposits is $1.2 \pm 0.5$ (table A6).

\section{Probabilistic Assessment Simulation Results}

Undiscovered resources for the tract were estimated by combining consensus estimates for numbers of undiscovered porphyry copper deposits with the general porphyry copper model of Singer and others (2008) using the EMINERS program (Root and others, 1992; Duval, 2012; Bawiec and Spanski, 2012). Selected simulation results are reported in table A7. Results of the Monte Carlo simulation are presented as a cumulative frequency plot (fig. A3). The cumulative frequency plot shows the estimated resource amounts associated with cumulative probabilities of occurrence, as well as the mean, for each commodity and for total mineralized rock. The mean amount of undiscovered copper within the tract, 4.6 $\mathrm{Mt}$, represents about a third of the amount of copper identified at Tampakan (15.3 Mt).

\section{References Cited}

Aguiba, M.M., 2010, Tampakan copper-gold project to yield \$37B over mine life: Manila Bulletin Publishing Corporation, accessed September 20, 2010, at http://www. mb.com.ph/articles/277647/tampakan-coppergold-projectyield-37-b-over-mine-life. 
Table A5. Principal sources of information used for tract 142pCu7312, Cotabato Arc-Philippines.

[NA, not applicable]

\begin{tabular}{|c|c|c|c|}
\hline Theme & Name or Title & Scale & Citation \\
\hline \multirow[t]{3}{*}{ Geology } & $\begin{array}{l}\text { Geology and mineral resources of the Philippines, } \\
\text { v. } 1 \text { - Geology }\end{array}$ & $1: 1,000,000$ & $\begin{array}{l}\text { Philippine Bureau of Mines and Geosciences (1981), } \\
\text { Philippine Mines and Geosciences Bureau (2010) }\end{array}$ \\
\hline & $\begin{array}{l}\text { Geology and mineral distribution map of the } \\
\text { Philippines }\end{array}$ & $1: 1,400,000$ & Philippine Bureau of Mines (undated) \\
\hline & Geologic map of the Philippines & $1: 1,000,000$ & Philippine Bureau of Mines (1963) \\
\hline \multirow{4}{*}{$\begin{array}{l}\text { Mineral } \\
\text { occurrences }\end{array}$} & $\begin{array}{l}\text { Geology and mineral resources of the Philippines, } \\
\text { v. } 2 \text { - Mineral Resources }\end{array}$ & NA & Philippine Bureau of Mines and Geosciences (1986) \\
\hline & Mineral distribution map of the Philippines & $1: 2,500,000$ & Philippine Geological Survey Division (1964) \\
\hline & $\begin{array}{l}\text { Digital data base of mineral occurrences of the } \\
\text { Philippines }\end{array}$ & NA & Philippine Mines and Geosciences Bureau (2004b) \\
\hline & $\begin{array}{l}\text { U.S. Geological Survey On-Line Mineral } \\
\text { Resources Spatial Data }\end{array}$ & NA & U.S. Geological Survey (2012) \\
\hline \multirow[t]{2}{*}{ Exploration } & $\begin{array}{l}\text { Philippine Mines and Geosciences Bureau } \\
\text { Web site }\end{array}$ & NA & http://www.mgb.gov.ph/ \\
\hline & Company Web sites and technical reports & NA & Indophil Resources (2010), WMC $(1999,2000)$ \\
\hline
\end{tabular}

Table 6. Undiscovered deposit estimates, deposit numbers, and tract area for tract 142pCu7312, Cotabato Arc-Philippines.

$\left[N_{\mathrm{XX}}\right.$, estimated number of deposits associated with the xxth percentile; $N_{\text {und }}$, expected number of undiscovered deposits; $s$, standard deviation; $C_{v} \%$, coefficient of variance; $N_{\text {known }}$, number of known deposits in the tract that are included in the grade and tonnage model; $N_{\text {total }}$, total of expected number of deposits plus known deposits; area, area of permissive tract in square kilometers $\left(\mathrm{km}^{2}\right)$; density, deposit density reported as the total number of deposits per $100,000 \mathrm{~km}^{2}$. $N_{\text {und }} S$, and $C_{v} \%$ are calculated using a regression equation (Singer and Menzie, 2005)]

\begin{tabular}{|c|c|c|c|c|c|c|c|c|c|c|c|}
\hline$N_{90}$ & $N_{50}$ & $N_{10}$ & $N_{05}$ & $N_{01}$ & $\boldsymbol{N}_{\text {und }}$ & $s$ & $\boldsymbol{C}_{v} \%$ & $\boldsymbol{N}_{\text {known }}$ & $N_{\text {total }}$ & $\begin{array}{l}\text { Tract } \\
\text { Area } \\
\left(\mathrm{km}^{2}\right)\end{array}$ & $\begin{array}{c}\text { Deposit } \\
\text { density }\left(N_{\text {total }} /\right. \\
\left.100,000 \mathrm{~km}^{2}\right)\end{array}$ \\
\hline 1 & 1 & 2 & 2 & 2 & 1.2 & 0.55 & 45 & 1 & 2.2 & 9,700 & 23 \\
\hline
\end{tabular}

Table A7. Results of Monte Carlo simulation of undiscovered resources for tract 142pCu7312, Cotabato Arc-Philippines.

[Cu, copper; Mo, molybdenum; Au, gold; and Ag, silver; in metric tons; Rock, in million metric tons]

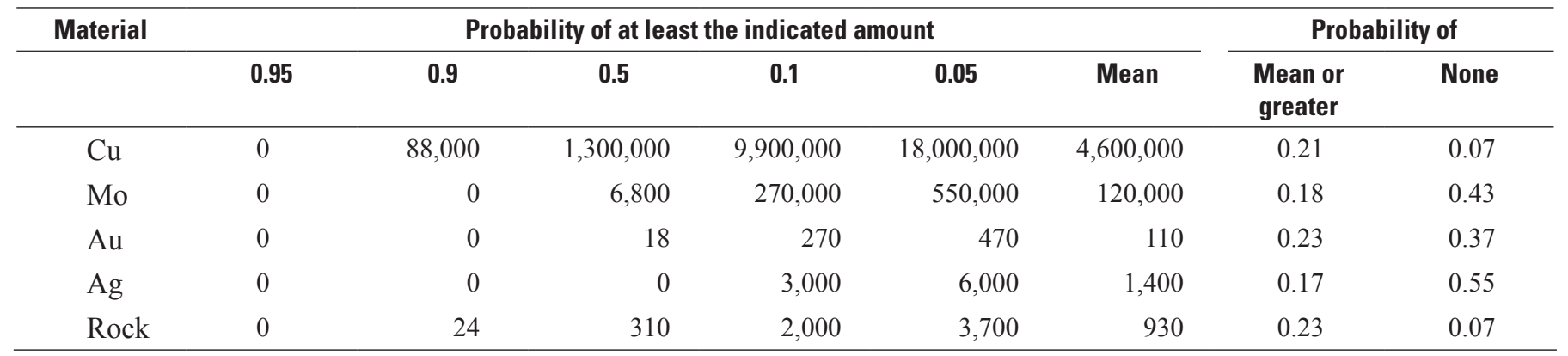




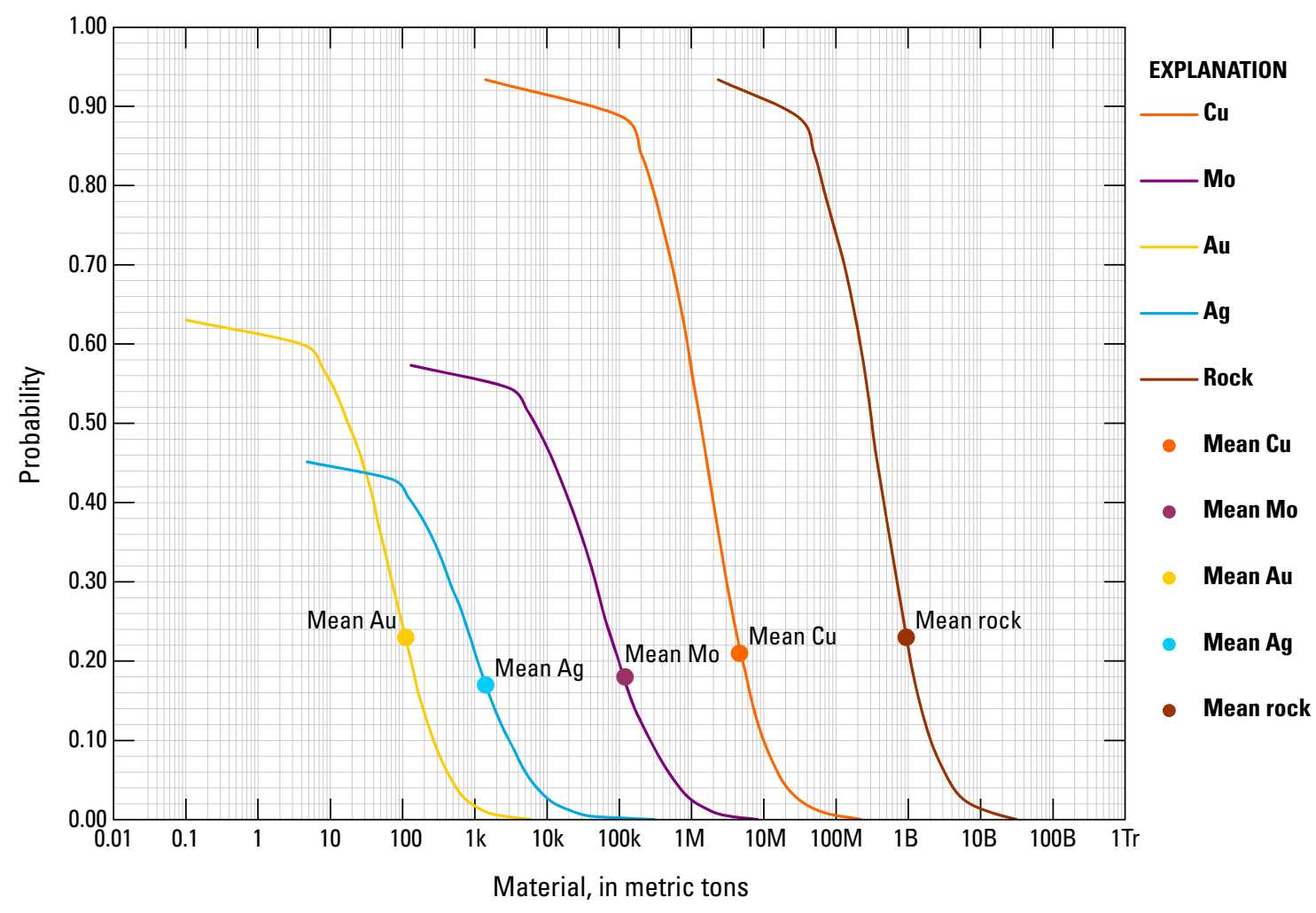

Figure A3. Cumulative frequency plot showing the results of Monte Carlo computer simulation of undiscovered resources in 142pCu7312, Cotabato Arc-Philippines. k, thousands; M, millions; $B$, billions; Tr, trillions. 
Almogela, D.H., 1974, Geologic environment and economic possibilities of porphyry copper deposits in the Philippines: Journal of the Geological Society of the Philippines, v. 28, no. 3, p. 1-16.

Bawiec, W.J., and Spanski, G.T., 2012, Quick-start guide for version 3.0 of EMINERS-Economic Mineral Resource Simulator: U.S. Geological Survey Open-File Report 2009-1057, 26 p., accessed July 15, 2012, at http://pubs. usgs.gov/of/2009/1057/. (This report supplements USGS OFR 2004-1344.)

Berger, B.R., Ayuso, R.A., Wynn, J.C., and Seal, R.R., 2008, Preliminary model of porphyry copper deposits: U.S. Geological Survey Open-File Report 2008-1321, 55 p., accessed May 15, 2009, at http://pubs.usgs.gov/ of $/ 2008 / 1321 /$.

Cox, D.P., 1986, Descriptive model of porphyry $\mathrm{Cu}$, in Cox, D.P., and Singer, D.A., eds., 1986, Mineral deposit models: U.S. Geological Survey Bulletin 1693, p. 76. (Also available at http://pubs.usgs.gov/bul/b1693/.)

Duval, J.S., 2012, Version 3.0 of EMINERS-Economic Mineral Resource Simulator: U.S. Geological Survey Open-File Report 2004-1344, accessed July 15, 2012, at http://pubs. usgs.gov/of/2004/1344/.

Garwin, S., Hall, R., and Watanabe, Y., 2005, Tectonic setting, geology, and gold and copper mineralization in Cenozoic magmatic arcs of southeast Asia and the west Pacific, in Hedenquist, T.W., Thompson, J.F.H., Goldfarb, R.J., and Richards, J.P., eds., One hundredth anniversary volume 1905-2005: Littleton, Colorado, Society of Economic Geologists, p. 891-930.

Google Earth ${ }^{\circledR}$, 2013, Mining places in the Philippines: Google Earth, accessed April 5, 2013, at http://www.google. com/url? sa $=\mathrm{t} \& \mathrm{rct}=\mathrm{j} \& \mathrm{q}=\&$ esrc $=\mathrm{s} \& \mathrm{frm}=1 \&$ source $=$ web $\&$ $\mathrm{cd}=2 \&$ sqi $=2 \&$ ved $=0$ CEAQFjAB\&url $=$ http $\% 3 \mathrm{~A} \% 2 \mathrm{~F} \% 2$ Fgeocommons.com\%2Foverlays\%2F16366.kml\&ei $=\mathrm{kf}$ NeUZTVE8nO2gXb2IGYAQ\&usg=AFQjCNFLq8CrnK 4OBdTHR81Aka9fzvm3zg\&sig2=dDS9CIwjKLhyq28Ifqtmw\&bvm=bv.44770516,d.b2.

Indophil Resources, Ltd., 2010, Tampakan project: Indophil Resources, Ltd., Web site, accessed May 15, 2010, at http://www.indophil.com/tampakan.asp.
John, D.A., Ayuso, R.A., Barton, M.D., Blakely, R.J., Bodnar, R.J., Dilles, J.H., Gray, Floyd, Graybeal, F.T., Mars, J.C., McPhee, D.K., Seal, R.R., Taylor, R.D., and Vikre, P.G., 2010, Porphyry copper deposit model, chap. B of Mineral deposit models for resource assessment: U.S. Geological Survey Scientific Investigations Report 2010-5070-B, 169 p., accessed September 8, 2010, at http://pubs.usgs.gov/ $\operatorname{sir} / 2010 / 5070 / \mathrm{b} /$.

Malaihollo, J.F.A., Hall, R., and Macpherson, C.G., 2002, SE Asia radiometric ages - GIS database: Southeast Asia Research Group, Department of Earth Sciences, Royal Holloway University of London, accessed February 1, 2010, at http://searg.rhul.ac.uk/current_research/isotopic_ages/ SEAsia_GIS.pdf.

Middleton, C., Buenavista, A., Rohrlahh, B., Gonzalez, J., Subang, L., and Molreno, G., 2004, A geological review of the Tampakan copper-gold deposit, Southern Mindanao, Philippines: PACRIM 2004, p. 172-187, accessed September 10, 2010, at http://www.indophil.com/pdf/Middleton.pdf.

Mills, R., 2007, Asia Pacific mining conference: The Northern Miner, July 16-22, p. 15.

Mitchell, A.H.G, and Leach, T.M., 1991, Epithermal gold in the Philippines-Island arc metallogenesis, geothermal systems and geology: London, Academic Press, $457 \mathrm{p}$.

Philippine Bureau of Mines, 1963, Geological map of the Philippines: Manila, Philippines, Philippine Bureau of Mines, 1 map on 8 sheets, scale 1:1,000,000.

Philippine Geological Survey Division, 1964, Mineral distribution map of the Philippines-Base metals: Manila, Philippines, Philippine Bureau of Mines, sheet 2 of 6 maps, scale 1:2,500,000.

Philippine Bureau of Mines and Geosciences, 1981, Geology and mineral resources of the Philippines, v. 1-Geology: Manila, Philippines, Philippine Bureau of Mines and Geosciences, $406 \mathrm{p}$.

Philippine Bureau of Mines and Geosciences, 1986, Geology and mineral resources of the Philippines, v. 2-Mineral resources: Manila, Philippines, Philippine Bureau of Mines and Geosciences, $446 \mathrm{p}$.

Philippine Mines and Geosciences Bureau, [n.d.], Geology and mineral distribution map of the Philippines: Philippine Mines and Geosciences Bureau, 1 map on 4 sheets, scale $1: 1,400,000$.

Philippine Mines and Geosciences Bureau, 2004a, Digital geological map of the Philippines: Philippine Mines and Geosciences Bureau, scale 1:1,000,000. [Proprietary data.] 
Philippine Mines and Geosciences Bureau, 2004b, Digital database of mineral occurrences of the Philippines: Philippine Mines and Geosciences Bureau. [Proprietary report.]

Philippine Mines and Geosciences Bureau, 2005, Copper: Philippine Mines and Geosciences Bureau, Mineral Resource Information Series, no. 5, 23 p.

Philippine Mines and Geosciences Bureau, 2010, Geology of the Philippines (2d ed.): Philippine Mines and Geosciences Bureau, $532 \mathrm{p}$.

Philippine Mines and Geosciences Bureau, 2010, Geology of the Philippines ( $2 \mathrm{~d}$ ed.): Philippine, Mines and Geosciences Bureau, $532 \mathrm{p}$.

Rohrlach, B.D., Madera, A., Watt, R., 1999, Geology, alteration and mineralization of the Tampakan copper deposit, in Weber, G., ed., Pacrim ' 99 Congress Proceedings, International Congress on earth science, exploration and mining around Pacific rim: Australasian Institute of Mining and Metallurgy Publication Series no. 4/99, p. 517-525.

Rohrlach, B.D., 2002, Tectonic evolution, petrochemistry, geochronology and paleohydrology of the Tampakan porphyry and high sulfidation epithermal $\mathrm{Cu}-\mathrm{Au}$ deposit Mindanao, Philippines: Canberra, Australian National University, Ph.D. dissertation.

Root, D.H., Menzie, W.D., and Scott, W.A., 1992, Computer Monte Carlo simulation in quantitative resource estimation: Natural Resources Research, v. 1, no. 2, p. 125-138.

Sajona, F.G., Bellon, H., Maury, R.C., Pubellier, M., Quebreal, R.D., Cotton, J., Bayon, F.E., Pagado, E., and Pamatian, P., 1997, Tertiary and Quaternary magmatism in Mindanao and Leyte (Philippines) - Geochronology, geochemistry, and tectonic setting: Journal of Asian Earth Sciences, v. 15, no. 2-3, p. 121-153.
Sillitoe, R.H., and Gappe, I.M., Jr., 1984, Philippine porphyry copper deposits - Geologic setting and characteristics: Committee for Co-ordination of Joint Prospecting for Mineral Resources in Asian Offshore Areas (CCOP), CCOP Technical Publication 14, 89 p.

Singer, D.A., and Menzie, W.D., 2005, Statistical guides to estimating the number of undiscovered mineral deposits-An example with porphyry copper deposits, in Cheng, Qiuming, and Bonham-Carter, Graeme, eds., Proceedings of IAMG-The annual conference of the International Association for Mathematical Geology: Toronto, Canada, York University, Geomatics Research Laboratory, p. 1028-1033.

Singer, D.A., Berger, V.I., and Moring, B.C., 2008, Porphyry copper deposits of the World-Database and grade and tonnage models, 2008: U.S. Geological Survey Open-File Report 2008-1155, accessed June 1, 2011, at http://pubs. usgs.gov/of/2008/1155/.

U.S. Department of State, 2009, Small-scale digital international land boundaries (SSIB) - Lines, edition 10, and polygons, beta edition 1, in Boundaries and sovereignty encyclopedia (B.A.S.E.): U.S. Department of State, Office of the Geographer and Global Issues.

U.S. Geological Survey, 2012, U.S. Geological Survey on-line mineral resources spatial data: U.S. Geological Survey Web site, accessed April 15, 2013, at http://mrdata.usgs.gov/.

WMC (Western Mining Corporation), 1999, Annual report, form 20-F, exploration and new business: WMC, p. 40, accessed June 15, 2009, at http://www.altavista.com/cgibin $/$ query $\mathrm{pg}=\mathrm{q} \&$ stype $=$ stext $\& \mathrm{sc}=\mathrm{on} \& \mathrm{q}=$ Tampakan $\&$ stq $=0$.

WMC (Western Mining Corporation), 2000, WMC's Tampakan copper project in the Philippines: WMC Information Paper no. 1, chap. 2, accessed June15, 2009, at http://www. wmc.com,au/pubpres/philippines/contents.htm. 


\section{Appendix B. Porphyry Copper Assessment for Tract 142pCu7308, Central Mindanao-Philippines}

By Jane M. Hammarstrom ', Arthur A. Bookstrom², Connie L. Dicken', Steve Ludington³, Gilpin R. Robinson, Jr.', and Michael L. Zientek ${ }^{2}$ with contributions from Sevillo (Bill) D. David, Jr. ${ }^{4}$ Claro J. Manipon ${ }^{4}$, Lilian A. Rollan ${ }^{4}$, and Yasushi Watanabe ${ }^{5}$

\section{Deposit Type Assessed: Porphyry copper, copper-gold subtype}

Descriptive model: Porphyry copper (Berger and others, 2008; Cox, 1986; John and others, 2010; Sillitoe and Gappe, 1984) Grade and tonnage model: Porphyry copper, copper-gold subtype (Singer and others, 2008)

Table B1 summarizes selected assessment results.

Table B1. Summary of selected resource assessment results for tract 142pCu7308, Central Mindanao-Philippines.

[km, kilometers; $\mathrm{km}^{2}$, square kilometers; $\mathrm{t}$, metric tons]

\begin{tabular}{|c|c|c|c|c|c|}
\hline $\begin{array}{c}\text { Date of } \\
\text { assessment }\end{array}$ & $\begin{array}{l}\text { Assessment depth } \\
\qquad(\mathrm{km})\end{array}$ & Tract area $\left(\mathbf{k m}^{2}\right)$ & $\begin{array}{l}\text { Identified copper } \\
\text { resources }(t)\end{array}$ & $\begin{array}{l}\text { Mean estimate of } \\
\text { undiscovered copper } \\
\text { resources }(t)\end{array}$ & $\begin{array}{l}\text { Median estimate of } \\
\text { undiscovered copper } \\
\text { resources }(t)\end{array}$ \\
\hline 2010 & 1 & 29,320 & 0 & $5,900,000$ & $1,400,000$ \\
\hline
\end{tabular}

\section{Location}

Central part of Mindanao Island (fig. B1).

\section{Geologic Feature Assessed}

Central Mindanao Volcanic Province.

${ }^{1}$ U.S. Geological Survey, Reston, Virginia, United States.

${ }^{2}$ U.S. Geological Survey, Spokane, Washington, United States.

${ }^{3}$ U.S. Geological Survey, Menlo Park, California, United States.

${ }^{4}$ Philippine Department of Environment and Natural Resources, Mines and Geosciences Bureau, Quezon City, Philippines.

${ }^{5}$ Geological Survey of Japan, National Institute of Advanced Industrial Science and Technology (AIST), Ibaraki, Japan. 

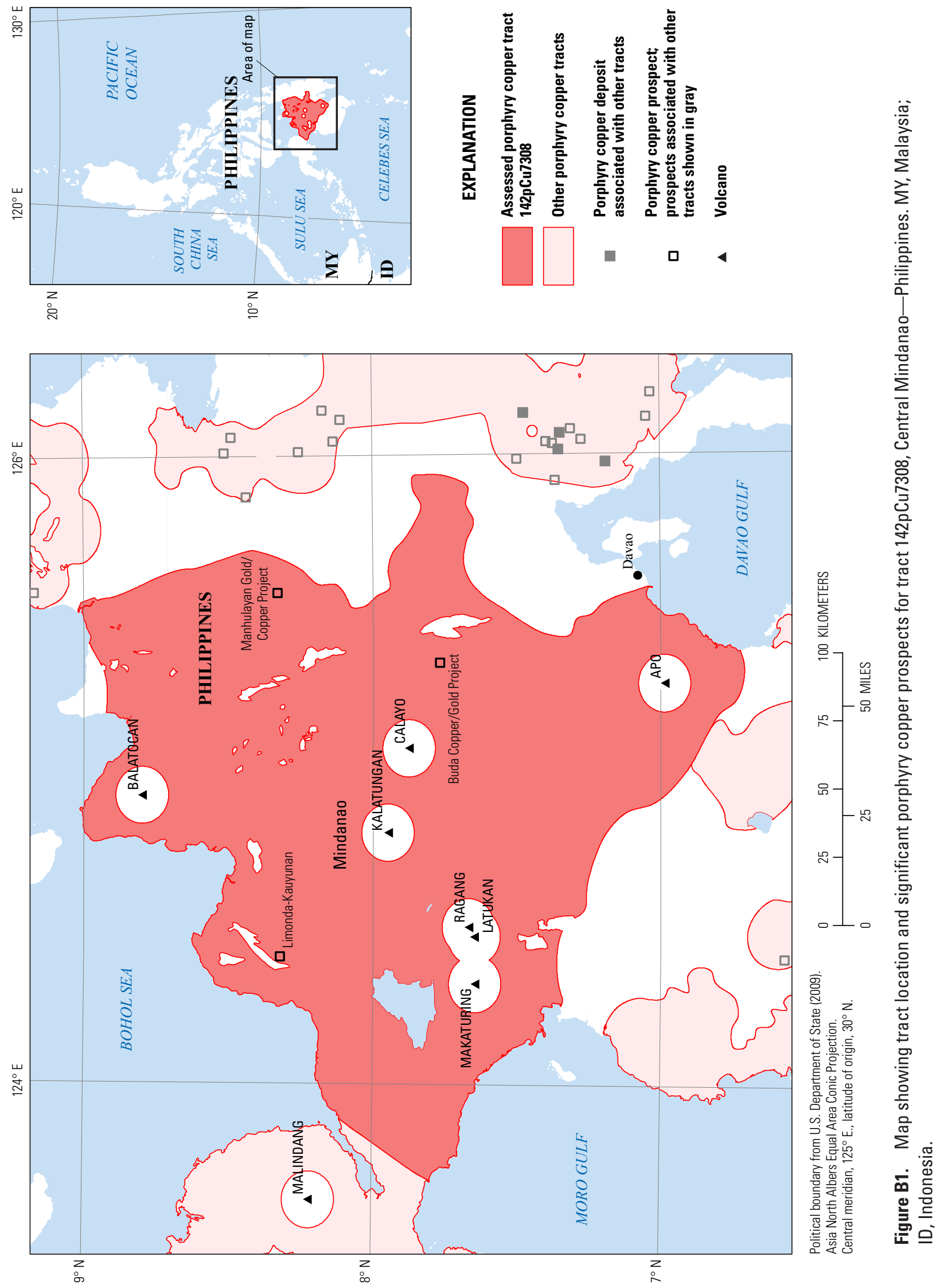


\section{Delineation of the Permissive Tract}

\section{Tectonic Setting}

The Central Mindanao Volcanic Province (fig. $2 A^{6}$ ) represents an area of soft collision of two arcs in the Pliocene (4-5 Ma), followed by postcollisional calc-alkalic to shoshonitic magmatism (2-3 Ma) that produced the largest volcanic field in the Philippines (Pubellier and others, 1991, 1996; Sajona and others, 1997, 2000). Sajona and others (2000) noted that deep seismic studies refute a linkage with subduction along any of the trenches that surround Mindanao (Philippine Trench to the east, Sulu Trench to the west, or Cotabato Trench to the southwest, fig. 5B). They describe the island arcs that collided as northern continuations of the Neogene Sulawesi-Sangihe (western Mindanao) and Halmahera Arcs (eastern Mindanao) (fig. 2A). Other studies ascribed Quaternary volcanism to a Central Mindanao Volcanic Arc, an arc parallel to, and related to, subduction along the Philippine Trench, or to a detached slab; the volcanoes in western Mindanao were probably related to east-dipping subduction along the extension of the Sulawesi-Sangihe Arc (Corpuz, 1992 and references therein).

\section{Geologic Criteria}

The tract is based on the distribution of Neogene intrusive and volcanic rocks (fig. B2, table B2) in the highlands of Central Mindanao, as shown on the 1:1,000,0000-scale geologic map of the Philippines (Philippine Mines and Geosciences Bureau, 2004a). Much of the area is covered by Pliocene-Quaternary andesitic volcanic rocks and pyroclastic rocks. Permissive rock units were selected from the digital geologic map using GIS tools, and 10- and 2-km buffers were created around intrusive and volcanic rocks, respectively. These distances are considered appropriate to allow for inaccuracies in mapped contacts and extensions under adjacent cover rock. The map-unit polygons were buffered, aggregated, smoothed, and edited by hand to honor fault boundaries and include known prospects and permissive igneous rocks shown on maps included in topical studies (Sajona and others, 1997; Corpuz, 1992; Malaihollo and others, 2002). PlioceneQuaternary volcanic rocks were not used to delineate the tract, but comprise cover that could conceal deposits. Areas within approximately $10 \mathrm{~km}$ of Quaternary volcanic centers are excluded from the tract because the volcanic cover is likely to be greater than $1 \mathrm{~km}$ thick.

The northern boundary of the tract follows the Cotabato Fault (fig. 5B). The northeastern boundary of tract parallels the Philippine Fault (fig. $5 B$ ), which is a Neogene feature that cuts through the Agusan-Davao Basin (fig. 4E). The basin is underlain by at least $5 \mathrm{~km}$ of Cenozoic clastic rocks. Therefore, the

${ }^{6}$ Refer to figures and tables in main report. basin is excluded from the tract because any buried porphyry systems in that area are likely to be deeper than the 1-km depth limit chosen for this study. The final tract boundary was clipped to the Mindanao shoreline (U.S. Department of State, 2009).

Miocene andesites in Central Mindanao are dated at 20-16 Ma. Pliocene volcanic rocks include calc-alkalic basalts and basaltic andesites. Postcollisional volcanic rocks vary from calc-alkalic (2.3-0.6 Ma) to shoshonitic (0.5-0.4 Ma) to calc-alkalic (0.3 to the present). The geochemistry of these rocks $\left(\mathrm{OIB}^{7}\right.$-like enrichments in niobium $(\mathrm{Nb})$, high $\mathrm{La} / \mathrm{Nb}$ ratios) include typical arc as well as adakite-like compositions and may reflect contributions of upwelled mantle (Sajona and others, 1997, 2000), possibly related to sinking of a detached slab of the Molucca Sea Plate ${ }^{8}$. Any porphyry systems are likely to be related to the pre-collisional rocks. Although collisional and postcollisional settings are known for porphyry copper deposits elsewhere in the world, any deposits associated with the younger rocks are likely to lie below $1 \mathrm{~km}$ of the surface under the thick volcanic cover.

\section{Known Deposits}

None.

\section{Prospects, Mineral Occurrences, and Related Deposit Types}

Two porphyry copper prospects are being explored in the eastern part of the tract (fig. B1, table B3). At the Manhulayan prospect, drilling intercepted a potassically altered porphyry stock ( $185 \mathrm{~m}$ of 0.33 percent copper, $0.16 \mathrm{~g} / \mathrm{t}$ gold) associated with a magnetic anomaly and adjacent to epithermal veins (Oceana Gold Corporation, 2010). The Buda copper-gold prospect is part of Indophil Resources NL (2010) Central Mindanao project area. Copper and gold are reported in veins in andesite at the Limonda-Kauyunan occurrence in the northwestern part of the tract.

\section{Exploration History}

The eastern side of the tract area, to the west of the Philippine Fault, recently has been explored for porphyry copper (table B3). Porphyry copper deposits and larger prospects are known to the east of fault zone (within tract 142pCu7309). Recent exploration data collected within the tract (aeromagnetic and radiometric surveys, regional geologic mapping, and geochemical sampling) were interpreted as surface expressions of buried porphyry systems overprinted by epithermal gold and base-metal veins (Oceana Gold Corporation, 2010; Indophil Resources NL, 2010). Paleogene volcanic rocks and

\section{${ }^{7} \mathrm{OIB}$, oceanic island basalt.}

${ }^{8}$ Molucca Sea Plate: a microplate in Indonesia that is subducting to the west under the Eurasian Plate and to the east under the Philippine Sea Plate. 

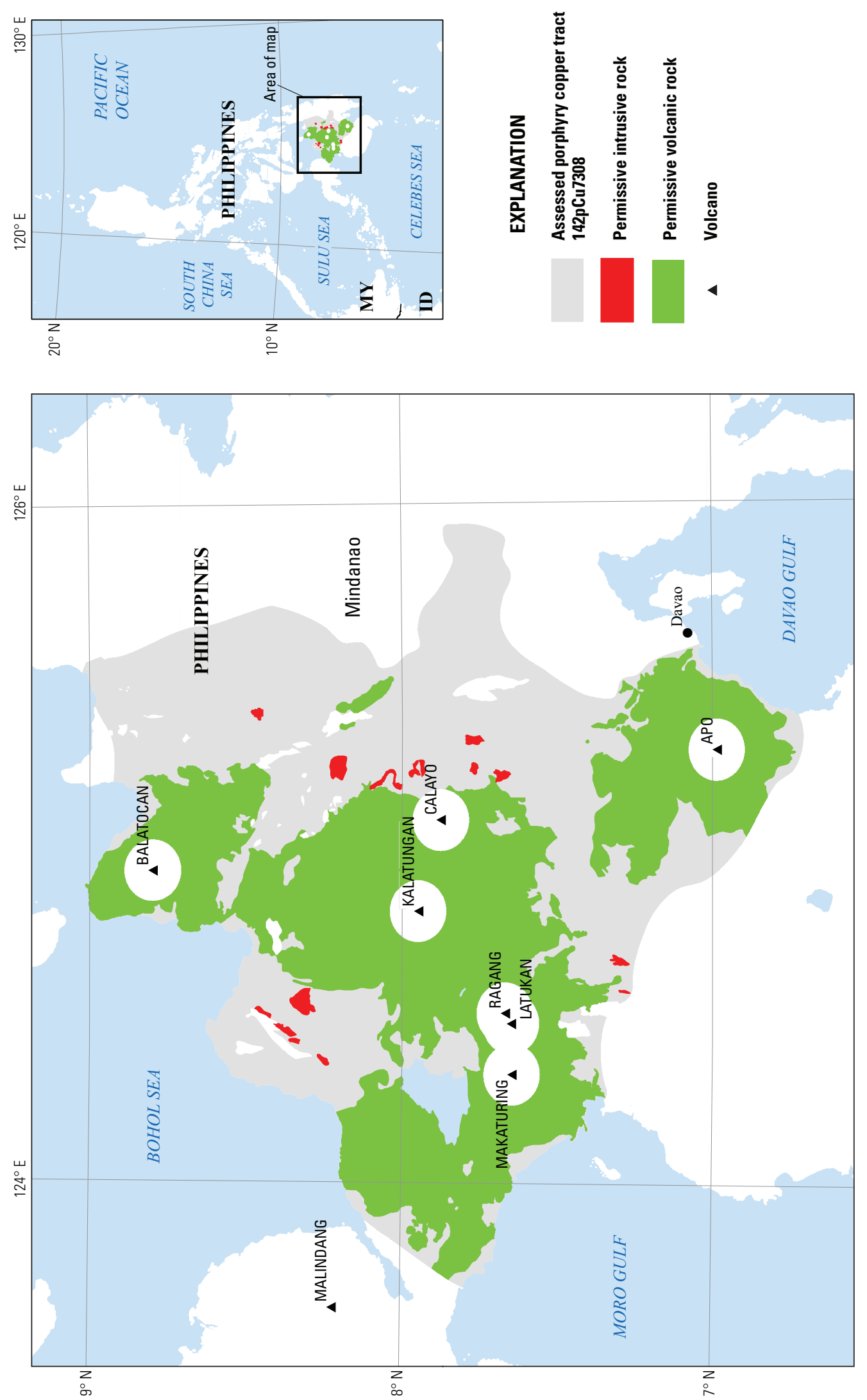

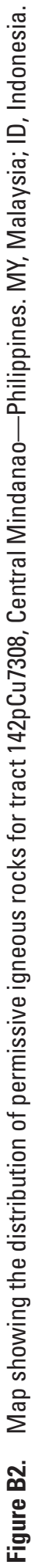


Table B2. Map units that define tract 142pCu7308, Central Mindanao-Philippines.

[Map unit, age range, and principal lithologies are based on a digital geologic map of the Philippines (Philippine Mines and Geosciences Bureau, 2004a)]

\begin{tabular}{|c|c|c|c|}
\hline Map unit & Map symbol & Lithology & Age range \\
\hline \multicolumn{4}{|c|}{ Intrusive rocks } \\
\hline Neogene intrusive rocks & NI & $\begin{array}{l}\text { Largely intra-Miocene quartz diorite. Mostly batholiths and stocks, } \\
\text { some laccoliths; also sills, dikes, and other minor bodies. Includes } \\
\text { granodiorite and diorite porphyry facies and late Miocene dacite. Per- } \\
\text { vasive in Paleogene and Mesozoic, less widespread in early Miocene } \\
\text { sequences. }\end{array}$ & Neogene \\
\hline \multicolumn{4}{|c|}{ Volcanic rocks } \\
\hline Neogene volcanic rocks & $\mathrm{IN}_{2}$ & Principally dacite and/or andesite flows, generally with pyroclastics. & Late Miocene-Pliocene \\
\hline Neogene volcanic rocks & $\mathrm{IN}_{1}$ & $\begin{array}{l}\text { Mostly submarine andesite and (or) basalt flows. Intercalated with } \\
\text { pyroclastics and clastic sedimentary rocks and/or reef limestone } \\
\text { lenses. Largely confined within the axial zone of Luzon, Visayas, and } \\
\text { Mindanao. }\end{array}$ & Oligocene-Miocene \\
\hline
\end{tabular}

Table B3. Significant prospects and occurrences in tract 142pCu7308, Central Mindanao_Philippines.

[Ma, million years; n.d., no data; \%, percent; g/t, grams per metric ton; km, kilometers; $\mathrm{m}$, meters. Rank $1=$ copper occurrence that may be related to porphyry-type mineralization based on stream sediment or magnetic anomaly or location along structural trend. Rank $3=$ drilled prospect, with $>20 \mathrm{~m}$ of $0.2 \%$ or more $\mathrm{Cu}]$

\begin{tabular}{|c|c|c|c|c|c|c|}
\hline Name & Latitude & Longitude & Age (Ma) & Comments & Reference & Rank \\
\hline $\begin{array}{l}\text { Buda Copper/ } \\
\text { Gold Project }\end{array}$ & 7.770 & 125.340 & n.d. & $\begin{array}{l}\text { Southern block of Indophil's Central } \\
\text { Mindanao Project area. Porphyry } \mathrm{Cu}-\mathrm{Au} \\
\text { target area; } \mathrm{Au}, \mathrm{Cu} \text {, and } \mathrm{Ag} \text { in sulfide } \\
\text { outcrop along a major fault at Bangan } \\
\text { prospect within the project area. }\end{array}$ & $\begin{array}{l}\text { Indophil Resources } \\
\text { NL (2010) }\end{array}$ & 1 \\
\hline $\begin{array}{l}\text { Limonda- } \\
\text { Kauyunan }\end{array}$ & 8.324 & 124.403 & n.d. & $\mathrm{Cu}$ and $\mathrm{Au}$ veins in andesite & $\begin{array}{l}\text { U.S. Geological } \\
\text { Survey (2012) }\end{array}$ & 1 \\
\hline $\begin{array}{l}\text { Manhulayan } \\
\text { Gold/Copper } \\
\text { Project }\end{array}$ & 8.331 & 125.564 & n.d. & $\begin{array}{l}\mathrm{Cu} \text {-Au porphyry prospect adjacent to low } \\
\text { sulfidation epithermal gold and base- } \\
\text { metal sulfide veins. Drilling ( } 4 \text { holes) } \\
\text { intercepted } \mathrm{K} \text { - altered porphyry ( } 185 \mathrm{~m} \\
\text { of } 0.33 \% \mathrm{Cu}, 0.16 \mathrm{ppm} \mathrm{Au} \text { and } 300 \mathrm{~m} \\
\text { of } 0.32 \% \mathrm{Cu}, 0.15 \mathrm{ppm} \mathrm{Au} \text { ). Prospect is } \\
\text { associated with a } 900 \text { by } 200 \mathrm{~m} \text { miner- } \\
\text { alized porphyry stock within a } 2.5 \text { by } \\
0.8 \mathrm{~km} \text { positive magnetic anomaly. }\end{array}$ & $\begin{array}{l}\text { Oceana Gold Cor- } \\
\text { poration }(2010)\end{array}$ & 3 \\
\hline
\end{tabular}


Neogene andesites and intrusions are mapped within $25 \mathrm{~km}$ of the prospects on the east side of Mount Kalatungan volcano (fig. 4E). Mining tenement maps for northern Mindanao (Philippine Bureau of Mines and Geosciences, 2009) show that recent exploration activity is concentrated along a 140-km-long belt in the eastern part of the tract that trends north-south and includes both the Manhulayan and Buda prospects.

\section{Sources of Information}

Table B4 lists the principal sources of information used for the assessment.

\section{Grade and Tonnage Model Selection}

No deposits are known within the tract. The copper-gold subtype model was selected for the assessment on the basis of characteristics of the partially explored prospects and the model selected for the permissive tracts in the southern arc counterparts - the Halmahera and Sulawesi-Sangihe Arcs

(fig. 2A; Hammarstrom and others, 2012).

\section{Estimate of the Number of Undiscovered Deposits}

\section{Rationale for the Estimate}

On the basis of the facts that the tract has not been thoroughly explored, the possibility that if fully explored, the Mahulayan project could represent undiscovered resources, the possibilities for buried deposits, and the occurrence of porphyry copper deposits in the Sangihe and Halmahera Arcs to the south, the assessment team estimated a 50-percent chance for one or more undiscovered deposits and a 10-percent chance for 5 or more deposits (table B5). The expected number of deposits based on this distribution of estimates is 1.9 deposits, with a relatively high uncertainty $\left(C_{v}=100\right.$ percent $)$.

Table B4. Principal sources of information used for tract 142pCu7308, Central Mindanao-Philippines.

[NA, not applicable]

\begin{tabular}{|c|c|c|c|}
\hline Theme & Name or Title & Scale & Citation \\
\hline \multirow[t]{2}{*}{ Geology } & Digital geologic map of the Philippines & $1: 1,000,000$ & $\begin{array}{l}\text { Philippine Mines and Geosciences } \\
\text { Bureau (2004a) }\end{array}$ \\
\hline & Geologic map of the Philippines & $1: 1,000,000$ & Philippine Bureau of Mines (1963) \\
\hline \multirow[t]{3}{*}{ Mineral occurrences } & $\begin{array}{l}\text { Porphyry copper deposits of the world-Database, map, and } \\
\text { grade and tonnage models }\end{array}$ & NA & Singer and others (2008) \\
\hline & Digital data base of mineral occurrences of the Philippines & NA & $\begin{array}{l}\text { Philippine Mines and Geosciences } \\
\text { Bureau (2004b) }\end{array}$ \\
\hline & $\begin{array}{l}\text { U.S. Geological Survey On-Line Mineral Resources Spatial } \\
\text { Data }\end{array}$ & NA & U.S. Geological Survey (2012) \\
\hline \multirow[t]{2}{*}{ Exploration } & Philippine Mines and Geosciences Bureau Web site & NA & http://www.mgb.gov.ph/ \\
\hline & Company Web sites and technical reports & NA & $\begin{array}{l}\text { Oceana Gold (2010), Indophil } \\
\text { Resources NL (2010) }\end{array}$ \\
\hline
\end{tabular}




\section{Probabilistic Assessment Simulation Results}

Undiscovered resources for the tract were estimated by combining the team's estimate for numbers of undiscovered porphyry copper deposits with the porphyry copper-gold model of Singer and others (2008) using the EMINERS program (Root and others, 1992; Duval, 2012; Bawiec and
Spanski, 2012). Selected simulation results are reported in table B6. Results of the Monte Carlo simulation are presented as a cumulative frequency plot (fig. B3). The cumulative frequency plot shows the estimated resource amounts associated with cumulative probabilities of occurrence, as well as the mean, for each commodity and for total mineralized rock. See table 6 for comparisons with other tracts.

Table B5. Undiscovered deposit estimates, deposit numbers, tract area, and deposit density for tract 142pCu7308, Central Mindanao-Philippines.

[ $N_{\mathrm{xx}}$, estimated number of deposits associated with the xxth percentile; $N_{\text {und }}$, expected number of undiscovered deposits; $s$, standard deviation; $C_{v} \%$, coefficient of variance; $N_{\text {known }}$, number of known deposits in the tract that are included in the grade and tonnage model; $N_{\text {total }}$ total of expected number of deposits plus known deposits; area, area of permissive tract in square kilometers $\left(\mathrm{km}^{2}\right)$; density, deposit density reported as the total number of deposits per $100,000 \mathrm{~km}^{2} . N_{\text {und }}, s$, and $C_{v} \%$ are calculated using a regression equation (Singer and Menzie, 2005)]

\begin{tabular}{|c|c|c|c|c|c|c|c|c|c|c|c|}
\hline \multicolumn{5}{|c|}{ Consensus undiscovered deposit estimates } & \multicolumn{5}{|c|}{ Summary statistics } & \multirow{2}{*}{$\begin{array}{c}\text { Tract Area } \\
\left(\mathbf{k m}^{2}\right)\end{array}$} & \multirow{2}{*}{$\begin{array}{l}\text { Deposit density } \\
\left(N_{\text {total }} / 100,000 \text { km }^{2}\right.\end{array}$} \\
\hline$N_{90}$ & $N_{50}$ & $N_{10}$ & $N_{05}$ & $N_{01}$ & $N_{\text {und }}$ & $s$ & $C_{v} \%$ & $N_{\text {known }}$ & $N_{\text {total }}$ & & \\
\hline 0 & 1 & 5 & 5 & 5 & 1.9 & 1.9 & 100 & 0 & 1.9 & 29,320 & 6 \\
\hline
\end{tabular}

Table B6. Results of Monte Carlo simulation of undiscovered resources for tract 142pCu7308, Central Mindana0—Philippines.

[Cu, copper; Mo, molybdenum; Au, gold; and Ag, silver; in metric tons; rock, in million metric tons]

\begin{tabular}{|c|c|c|c|c|c|c|c|c|}
\hline \multirow[b]{2}{*}{ Material } & \multicolumn{6}{|c|}{ Probability of at least the indicated amount } & \multicolumn{2}{|c|}{ Probability of } \\
\hline & 0.95 & 0.9 & 0.5 & 0.1 & 0.05 & Mean & $\begin{array}{l}\text { Mean or } \\
\text { greater }\end{array}$ & None \\
\hline $\mathrm{Cu}$ & 0 & 0 & $1,400,000$ & $16,000,000$ & $27,000,000$ & $5,900,000$ & 0.25 & 0.30 \\
\hline Mo & 0 & 0 & 0 & 77,000 & 190,000 & 35,000 & 0.18 & 0.56 \\
\hline $\mathrm{Au}$ & 0 & 0 & 130 & 1,200 & 1,900 & 430 & 0.28 & 0.30 \\
\hline $\mathrm{Ag}$ & 0 & 0 & 67 & 3,900 & 8,300 & 2,000 & 0.18 & 0.49 \\
\hline Rock & 0 & 0 & 310 & 3,300 & 5,900 & 1,200 & 0.26 & 0.30 \\
\hline
\end{tabular}




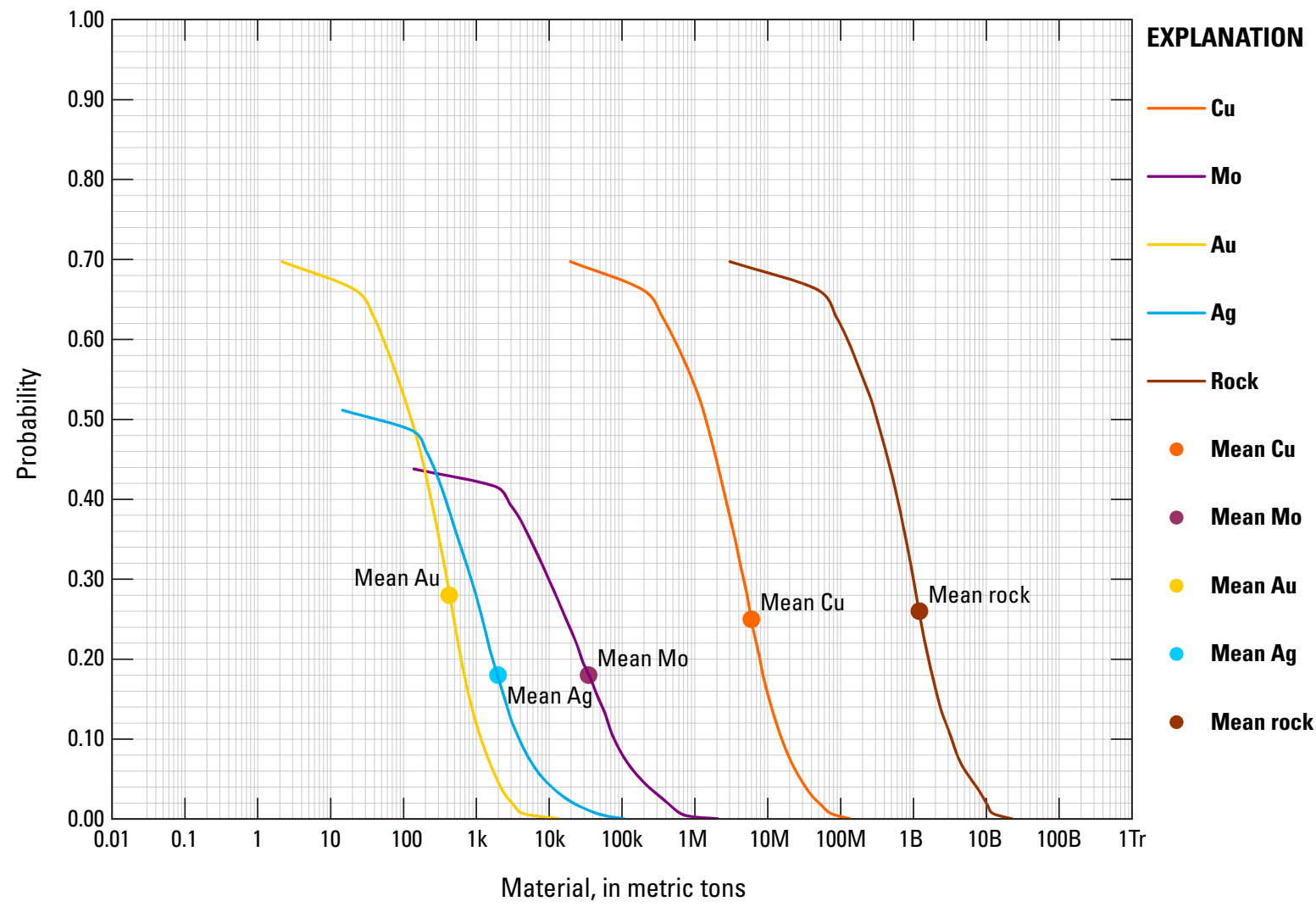

Figure B3. Cumulative frequency plot showing the results of Monte Carlo computer simulation of undiscovered resources in 142pCu7308, Central Mindanao-Philippines. k, thousands; M, millions; B, billions; Tr, trillions.

\section{References Cited}

Bawiec, W.J., and Spanski, G.T., 2012, Quick-start guide for version 3.0 of EMINERS-Economic Mineral Resource Simulator: U.S. Geological Survey Open-File Report 2009-1057, 26 p., accessed July 15, 2012, at http://pubs. usgs.gov/of/2009/1057/. (This report supplements USGS OFR 2004-1344.)

Berger, B.R., Ayuso, R.A., Wynn, J.C., and Seal, R.R., 2008, Preliminary model of porphyry copper deposits: U.S. Geological Survey Open-File Report 2008-1321, 55 p., accessed May 15, 2009, at http://pubs.usgs.gov/ of $/ 2008 / 1321 /$.

Corpuz, E.S.G., 1992, Petrology and geochemistry of the Central Mindanao Volcanic Arc, Southern Philippines: Canterbury, University of Canterbury, Ph.D. dissertation, $330 \mathrm{p}$.
Cox, D.P., 1986, Descriptive model of porphyry $\mathrm{Cu}$, in $\mathrm{Cox}$, D.P., and Singer, D.A., eds., 1986, Mineral deposit models: U.S. Geological Survey Bulletin 1693, p. 76. (Also available at http://pubs.usgs.gov/bul/b1693/.)

Duval, J.S., 2012, Version 3.0 of EMINERS-Economic Mineral Resource Simulator: U.S. Geological Survey Open-File Report 2004-1344, accessed July 15, 2012, at http://pubs. usgs.gov/of/2004/1344/.

Hammarstrom, J.M., Bookstrom, A.A., Dicken, C.L., Drenth, B.J., Ludington, S., Robinson, G.R., Jr., Setiabudi, B.T., Sukserm, W., Sunuhadi, D.N., Wah, A.Yan Sze, and Zientek, M.L., with contributions from Cox, D.P., Jarnyaharn, P., Kopi, G., Ngoc, N.T.M., Otarawanna, P., Pei, C.S., Phany, U., Van Quy, N.V., Sakimoto, T., Saroa, D., Soares de Costa, N., Sotham, S., Sim, I.M., Trung, N.N., Wongsomasak, S., Yokarti, B., Zaw, K., 2012, Porphyry copper assessment of Southeast Asia and Melanesia: U.S. Geological Survey Scientific Investigations Report 2010-5090-D, 324 p. and spatial data, available at http://pubs.usgs.sir/2012/5090/d/. 
Indophil Resources NL, 2010, Buda \& Mt. Kinabalin, Central Mindanao Cordillera [Philippines]: Indophil Resources NL Web page, accessed April 8, 2010, at http://www.indophil. com/buda.asp.

John, D.A., Ayuso, R.A., Barton, M.D., Blakely, R.J., Bodnar, R.J., Dilles, J.H., Gray, Floyd, Graybeal, F.T., Mars, J.C., McPhee, D.K., Seal, R.R., Taylor, R.D., and Vikre, P.G., 2010, Porphyry copper deposit model, chap. B of Mineral deposit models for resource assessment: U.S. Geological Survey Scientific Investigations Report 2010-5070-B, 169 p., accessed September 8, 2010, at http://pubs.usgs.gov/ $\operatorname{sir} / 2010 / 5070 / \mathrm{b} /$.

Malaihollo, J.F.A., Hall, R., and Macpherson, C.G., 2002, SE Asia Radiometric ages - GIS database: Southeast Asia Research Group, Department of Earth Sciences, Royal Holloway University of London, accessed February 1, 2010, at http://searg.rhul.ac.uk/current_research/isotopic_ages/ SEAsia_GIS.pdf.

Oceana Gold Corporation, 2010, Manhulayan, Mindanao [Philippines]: Oceana Gold Corporation Web page, accessed April 8, 2010, at http://premium.infomine.com/ scripts/advanced/infodbweb/ChargePropertyReport. asp?SearchID $=33045$.

Philippine Bureau of Mines, 1963, Geological map of the Philippines: Philippine Bureau of Mines, 1 map on 8 sheets, scale 1:1,000,000.

Philippine Bureau of Mines and Geosciences, 1981, Geology and mineral resources of the Philippines, v. 1-Geology: Philippine Bureau of Mines and Geosciences, $406 \mathrm{p}$.

Philippine Bureau of Mines and Geosciences, 1986, Geology and mineral resources of the Philippines, v. 2-Mineral resources: Philippine Bureau of Mines and Geosciences, $446 \mathrm{p}$.

Philippine Mines and Geosciences Bureau, 2004a, Digital geological map of the Philippines: Philippine Mines and Geosciences Bureau, scale 1:1,000,000. [Proprietary data.]
Philippine Mines and Geosciences Bureau, 2004b, Digital database of mineral occurrences of the Philippines: Philippine Mines and Geosciences Bureau. [Proprietary report.]

Philippine Mines and Geosciences Bureau, 2009, Tenement control map of region 10: Philippine Bureau Mines and Geosciences Bureau, accessed June 15, 2010, at http://www. mgb.gov.ph/Maps/Tenement/mgb-X\%20map-3rd_qtr.jpg.

Philippine Mines and Geosciences Bureau, 2010, Geology of the Philippines ( $2 \mathrm{~d}$ ed.): Philippine Mines and Geosciences Bureau, $532 \mathrm{p}$.

Pubellier, M., Quebral, R., Deffontaines, B., and Rangin, C., 1993, Neotectonic map of Mindanao (Philippines): Quezon City, Philippines, Asia Geodyne Corporation, scale $1: 800,000$.

Pubellier, M., Quebrel, R., Rangin, C., Deffontaines, B., Muller, C., Butterlin, J., and Manzano, J., 1991, The Mindanao collision zone-A soft collision event within a continuous Neogene strike-slip setting: Journal of Southeast Asian Earth Sciences, v. 6, no. 3-4, p. 239-248.

Pubellier, M., Quebral, R. Aurelii, M., and Rangin, G., 1996, Docking and post-docking escape tectonics in the southern Philippines, in Hall, R., and Blundell, D., eds., Tectonic evolution of southeast Asia, Geological Society Special Publication, no. 106, p. 511-523.

Root, D.H., Menzie, W.D., and Scott, W.A., 1992, Computer Monte Carlo simulation in quantitative resource estimation: Natural Resources Research, v. 1, no. 2, p. 125-138.

Sajona, F.G., Bellon, H., Maury, R.C., Pubellier, M., Quebral, R.D., Cotton, J., Bayon, F.E., Pagadi, E., and Pamatian, P., 1997, Tertiary and Quaternary magmatism in Mindanao and Leyte (Philippines) - Geochronology, geochemistry and tectonic setting: Journal of Asian Earth Sciences, v. 15, no. $2-3$, p. 121-153. 
Sajona, F.G., Maury, R.C., Pubellier, M., Leterrier, J., Bellon, H., and Cotton, J., 2000, Magmatic source enrichment by slab-derived melts in a young post-collision setting, central Mindanao (Philippines): Lithos, v. 54, p. 173-206.

Sillitoe, R.H., and Gappe, I.M., Jr., 1984, Philippine porphyry copper deposits - Geologic setting and characteristics: Committee for Co-ordination of Joint Prospecting for Mineral Resources in Asian Offshore Areas (CCOP), CCOP Technical Publication 14, 89 p.

Singer, D.A., and Menzie, W.D., 2005, Statistical guides to estimating the number of undiscovered mineral deposits-An example with porphyry copper deposits, in Cheng, Qiuming, and Bonham-Carter, Graeme, eds., Proceedings of IAMG - The annual conference of the International Association for Mathematical Geology: Toronto, Canada,
York University, Geomatics Research Laboratory, p. 1028-1033.

Singer, D.A., Berger, V.I., and Moring, B.C., 2008, Porphyry copper deposits of the World-Database and grade and tonnage models, 2008: U.S. Geological Survey Open-File Report 2008-1155, accessed June 1, 2011, at http://pubs. usgs.gov/of/2008/1155/.

U.S. Department of State, 2009, Small-scale digital international land boundaries (SSIB)_-Lines, edition 10, and polygons, beta edition 1, in Boundaries and sovereignty encyclopedia (B.A.S.E.): U.S. Department of State, Office of the Geographer and Global Issues.

U.S. Geological Survey, 2012, U.S. Geological Survey on-line mineral resources spatial data: U.S. Geological Survey Website, accessed April 15, 2013, at http://mrdata.usgs.gov/. 


\section{Appendix C. Porphyry Copper Assessment for Tract 142pCu7307, Sulu-Zamboanga-Philippines}

By Jane M. Hammarstrom ', Arthur A. Bookstrom², Connie L. Dicken', Steve Ludington³, Gilpin R. Robinson, Jr.', and Michael L. Zientek ${ }^{2}$ with contributions from Sevillo (Bill) D. David, Jr. ${ }^{4}$ Claro J. Manipon ${ }^{4}$, Lilian A. Rollan ${ }^{4}$, and Yasushi Watanabe ${ }^{5}$

\section{Deposit Type Assessed: Porphyry copper, copper-gold subtype}

Descriptive model: Porphyry copper (Cox, 1986; Cooke and others, 1998; Berger and others, 2008; John and others, 2010; Sillitoe and Gappe, 1984)

Grade and tonnage model: Porphyry copper, copper-gold subtype (Singer and others, 2008)

Table $\mathrm{C} 1$ summarizes selected assessment results.

Table C1. Summary of selected resource assessment results for tract 142pCu7307, Sulu-Zamboanga Arc_-Philippines.

[km, kilometers; $\mathrm{km}^{2}$, square kilometers; $\mathrm{t}$, metric tons $]$

\begin{tabular}{cccccc}
\hline $\begin{array}{c}\text { Date of } \\
\text { assessment }\end{array}$ & $\begin{array}{c}\text { Assessment depth } \\
(\mathbf{k m})\end{array}$ & Tract area $\left(\mathbf{k m}^{2}\right)$ & $\begin{array}{c}\text { Identified copper } \\
\text { resources }(\mathbf{t})\end{array}$ & $\begin{array}{c}\text { Mean estimate of } \\
\text { undiscovered copper } \\
\text { resources }(\mathbf{t})\end{array}$ & $\begin{array}{c}\text { Median estimate of } \\
\text { undiscovered copper } \\
\text { resources }(\mathbf{t})\end{array}$ \\
\hline 2010 & 1 & 10,180 & 0 & $2,500,000$ & 410,000 \\
\hline
\end{tabular}

\section{Location}

Zamboanga Peninsula, Western Mindanao (fig. C1).

\section{Geologic Feature Assessed}

Northeastern (oceanic arc) part of the Miocene to Holocene Sulu-Zamboanga Arc.

${ }^{1}$ U.S. Geological Survey, Reston, Virginia, United States.

${ }^{2}$ U.S. Geological Survey, Spokane, Washington, United States.

${ }^{3}$ U.S. Geological Survey, Menlo Park, California, United States.

${ }^{4}$ Philippine Department of Environment and Natural Resources, Mines and Geosciences Bureau, Quezon City, Philippines.

${ }^{5}$ Geological Survey of Japan, National Institute of Advanced Industrial Science and Technology (AIST), Ibaraki, Japan. 

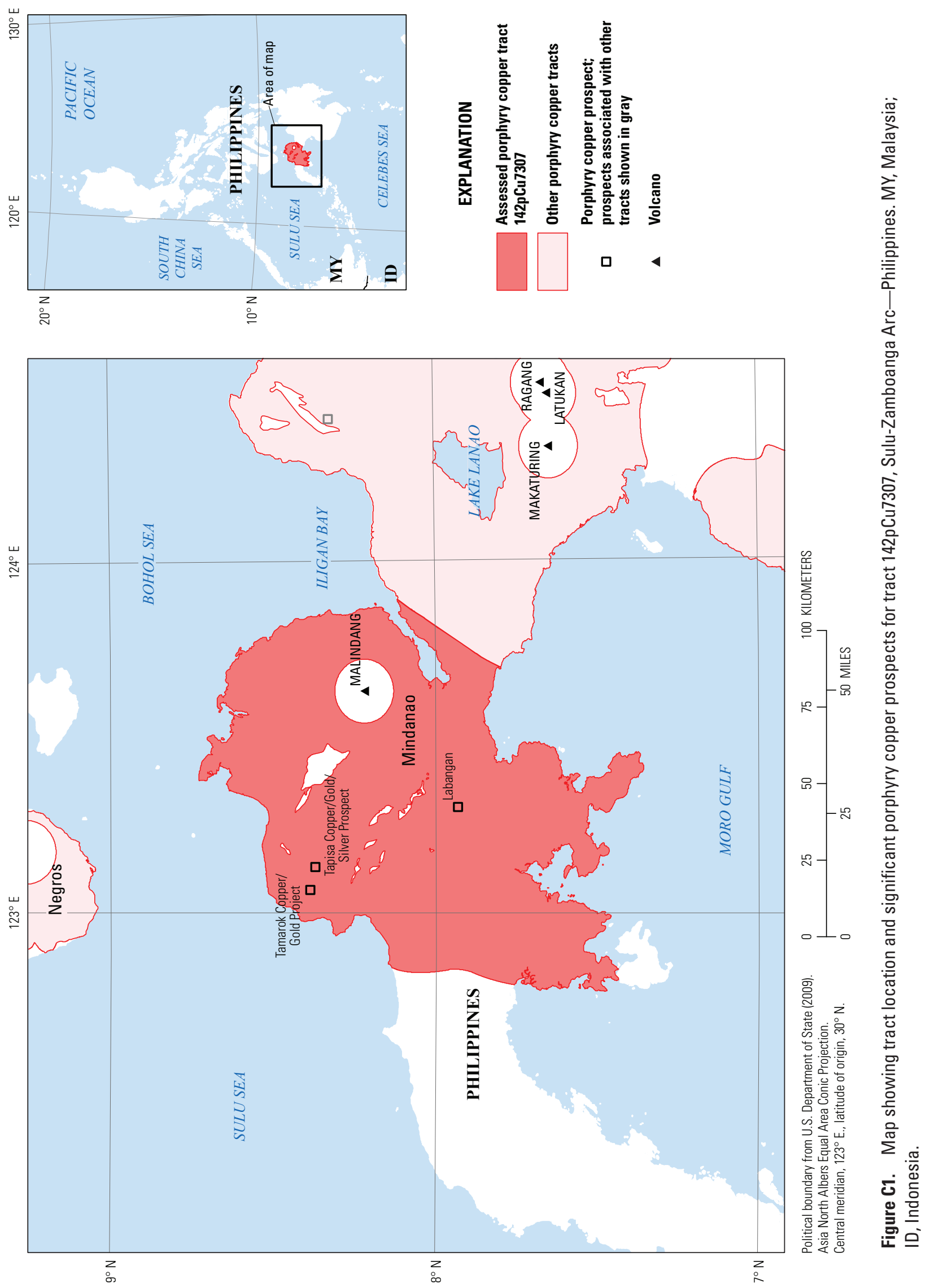


\section{Delineation of the Permissive Tract}

\section{Tectonic Setting}

The tract is the northern part of the late Miocene to Holocene, 400-km-long Sulu-Zamboanga Arc that extends from eastern Sabah to the Zamboanga Peninsula of the Philippines (fig. 2A). The arc was formed by subduction at the Sulu Trench (fig. $5 B^{6}$ ). The Celebes Sea Basin (fig. $5 B$ ), located southeast of the Sulu-Zamboanga Arc, consists of Eocene oceanic crust (Weissel, 1980; 1981; Lee and McCabe, 1986). The SuluZamboanga Arc separates the Sulu Sea Basin from the Celebes Sea Basin (fig. $5 B$ ) and includes a group of Quaternary islands with one active volcano (Cruz, 1987). Subduction beneath the arc is from the Sulu Trench to the northwest. Although there is no well-defined seismic zone along the Sulu Trench, the volcanic arc is considered to be in a waning (fumarolic) stage (Pubellier and others, 1991).

The northern part of the arc lies north of a mid-Miocene collisional boundary (Siayan-Sindangan Suture Zone and its continuation as the tectonically active Sindingan-CotabatoDaguma Lineament on fig. C2) that separates island-arc rocks to the north and continental rocks related to Sundaland on the south (Anonymous, 1995; Pubellier and others, 1993). The Sulu-Zamboanga Peninsula collided with central Mindanao in the middle Miocene; subduction gave way to strike-slip motion along the suture zone (Yumul and others, 2008). The Cotabato and Masbate-Negros arc systems (fig. 2A) cut off the Sulu-Zamboanga Arc at its northern end (Garwin and others, 2005).

\section{Geologic Criteria}

The tract (fig. C1) is based on the distribution of Paleogene and Neogene intrusions and late Miocene to Pliocene volcanic rocks as shown on the 1:1,000,0000-scale geologic map of the Philippines (Philippine Mines and Geosciences Bureau, 2004a). Plio-Pleistocene volcanic rocks in the northeastern part of the Zamboanga Peninsula at Maundang volcano, where volcanic cover is likely to be greater than $1 \mathrm{~km}$ thick, are excluded from the tract.

Permissive rock units (fig. C2, table C2) were selected from the digital geologic map using GIS tools, and 10- and 2-km buffers were created around intrusive and volcanic rocks, respectively. These distances are considered appropriate to allow for inaccuracies in mapped contacts and extensions under adjacent cover rock. The buffered map unit polygons were aggregated, smoothed, and edited by hand to honor fault boundaries and include known prospects and permissive igneous rocks shown on maps included in topical studies (Pubellier and others, 1993; Malaihollo and others, 2002). Quaternary volcanic rocks were not used as criteria to delineate the tract but are included as cover that could conceal deposits. A northwest-striking belt of ophiolitic complexes was excluded from the tract; these appear as irregularly shaped holes in the tract (fig. C1). The western boundary of the tract is based on a series of north-striking faults; no permissive rocks are mapped south of the faults.

\section{Known Deposits}

None.

\section{Prospects, Mineral Occurrences, and Related Deposit Types}

The tract includes three significant porphyry copper prospect areas (fig. C1, table C3). Labangan is an undrilled, abandoned porphyry copper-gold prospect associated with diorite porphyry, andesitic to basaltic flows, and northwesterly faults. Pleistocene volcanic cover is present at Labangan (Sillitoe and Gappe, 1984). Tamarok and Tapisa are part of an ongoing exploration program; initial channel sampling for Tamarok, characterized as chalcopyrite and bornite disseminations and in sheeted quartz veins in altered hornblende diorite, indicate grades compatible with the porphyry copper system (table C3). A porphyry copper outcrop (Malachite Hill), described as a 50-m exposure of altered hornblende diorite (chlorite-claysericite overprinting magnetite-biotite-K-feldspar-silica alteration), was drilled in 2011. Drilling was suspended pending further structural analysis (TVI Pacific, Inc., 2012).

Porphyry copper prospects are associated with andesitic to basaltic lava flows, diorite porphyry, and northweststriking faults. Other deposit types on the peninsula include epithermal gold veins, copper-iron skarn, and volcanogenic massive sulfides. 

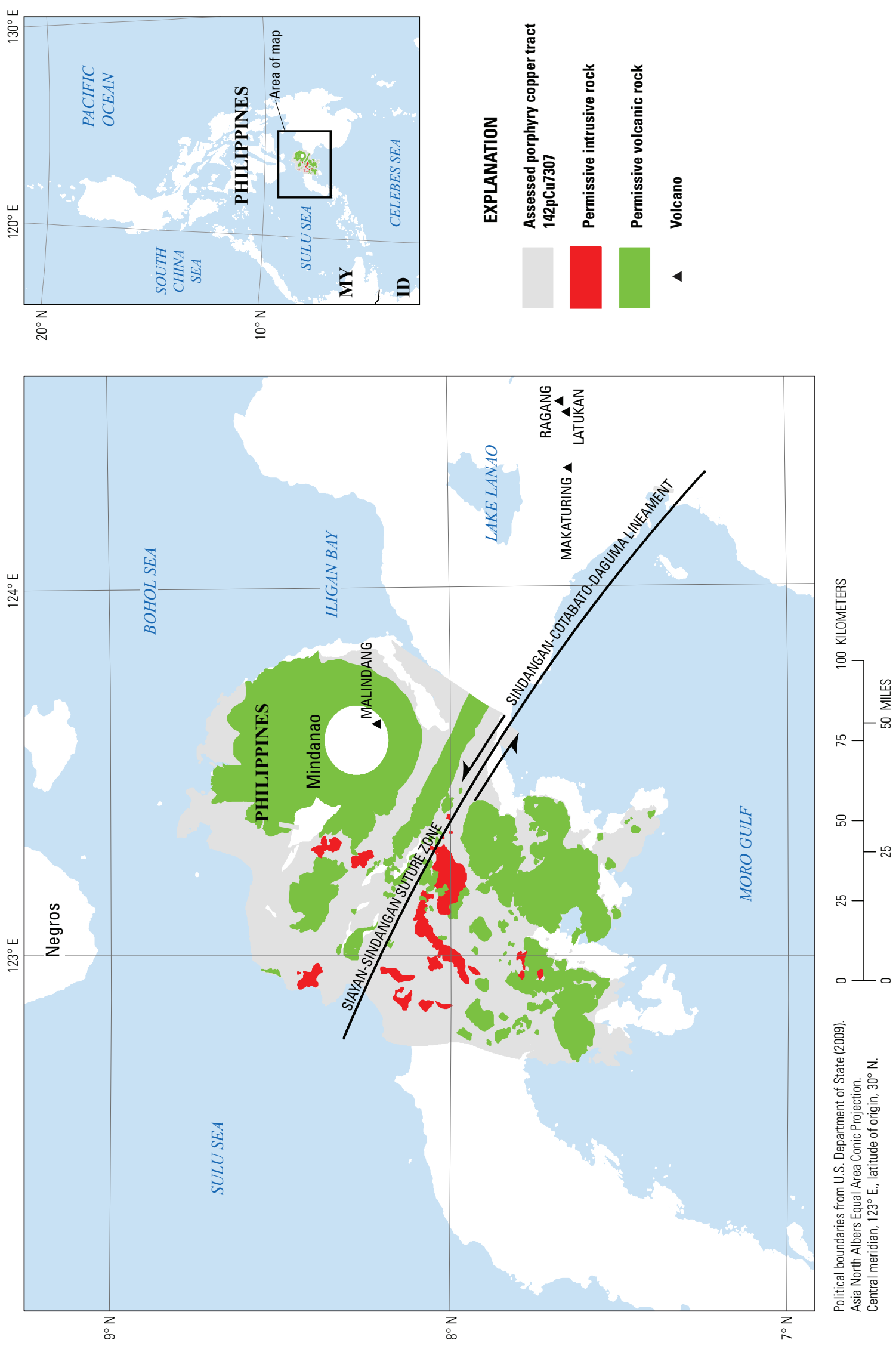
Table C2. Map units that define tract 142pCu7307, Sulu-Zamboanga Arc-Philippines.

[Map unit, age range, and principal lithologies are based on a digital version of the 1:1,000,000-scale geological map of the Philippines (Philippine Bureau of Mines, 1963).

\begin{tabular}{|c|c|c|c|}
\hline Map unit & Map symbol & Lithology & Age range \\
\hline \multicolumn{4}{|c|}{ Intrusive rocks } \\
\hline Neogene intrusive rocks & NI & $\begin{array}{l}\text { Largely intra-Miocene quartz diorite. Mostly batholiths and stocks, } \\
\text { some laccoliths; also sills, dikes, and other minor bodies. Include } \\
\text { granodiorite and diorite porphyry facies and late Miocene dacite. } \\
\text { Pervasive in Paleogene and Mesozoic, less widespread in early Mio- } \\
\text { cene sequences. }\end{array}$ & Neogene \\
\hline Paleogene intrusive rocks & $\mathrm{Pg}_{1}$ & Mostly quartz diorite. & Paleogene \\
\hline \multicolumn{4}{|c|}{ Volcanic rocks } \\
\hline Neogene volcanic rocks & $\mathrm{IN}_{2}$ & $\begin{array}{l}\text { Principally dacite and (or) andesite flows, generally with pyroclastics. } \\
\text { Locally thick and associated with reef limestone lenses in southern } \\
\text { Zamboanga. }\end{array}$ & Late Miocene-Pliocene \\
\hline
\end{tabular}

Table C3. Significant prospects and occurrences in tract 142pCu7307, Sulu-Zamboanga Arc—Philippines.

[Rank 4= Prospect listed in global database of Singer and others (2008) or $<16,000 \mathrm{t}$ of ore established by drilling. Rank $2=$ drilled or trenched with $<20 \mathrm{~m}$ of $0.2 \% \mathrm{Cu}$, or past or ongoing exploration. Rank $1=$ copper occurrence that may be related to porphyry-type mineralization based on stream sediment or magnetic anomaly or location along structural trend. Ma, miilion years; n.d., no data; \%, percent; g/t, grams per metric ton; km, kilometers; m, meters]

\begin{tabular}{|c|c|c|c|c|c|c|}
\hline Name & Latitude & Longitude & Age (Ma) & Comments & Reference & Rank \\
\hline Labangan & 7.933 & 123.300 & $\begin{array}{c}\text { Late } \\
\text { Miocene } \\
\text { to early } \\
\text { Pliocene } \\
\text { (?) }\end{array}$ & $\begin{array}{l}\text { Porphyry } \mathrm{Cu}-\mathrm{Au} \text { prospect associated with } \\
\text { diorite porphyry, andesitic to basaltic } \\
\text { flows, northwest-southeast faults. Chalco- } \\
\text { pyrite, bornite, sphalerite, galena (+gold), } \\
\text { silver, covellite, chalcocite, azurite, mala- } \\
\text { chite. Alteration: silicification. }\end{array}$ & $\begin{array}{l}\text { Jimenez and others } \\
\text { (2002), Mercado } \\
\text { (1975), Sillitoe } \\
\text { and Gappe (1984), } \\
\text { Singer and others } \\
\text { (2008) }\end{array}$ & 4 \\
\hline
\end{tabular}




\section{Exploration History}

The Labangan prospect (fig. C1) was explored by the Marcopper Mining Corp. in the 1970s (Sillitoe and Gappe, 1984). A resurgence in exploration activity starting about 2000 in the northern part of the Zamboanga Peninsula led to discovery of the other two prospect areas. Airborne magnetic surveys, mapping, and channel and rock sampling at Tamarok were completed in 2011; drilling was scheduled to resume in 2012 (TVI Pacific, Inc., 2012).

\section{Sources of Information}

Table C4 lists the principal sources of information used for assessment of the tract.

\section{Grade and Tonnage Model Selection}

Based on the gold-rich character of porphyry deposits in the Philippines, associations of epithermal gold in the region, and recommendations of a regional analysis (Drew and Singer, 2005), the copper-gold subtype model was used for the assessment of the tract.

\section{Estimate of the Number of Undiscovered Deposits}

\section{Rationale for the Estimate}

The assessment team considered the Labangan, and Tamarok-Tapisa porphyry prospects as potential deposits. Preliminary results from recent exploration support the likelihood of additional targets in the tract area. Sillitoe and Gappe (1984) speculated that areas along strike from the Labangan prospect in the northern part of the Sulu-Zamboanga Arc have significant potential for discoveries. In addition, the numerous gold prospects, general lack of thorough exploration and volume of Quaternary cover were considered favorable for

Table C4. Principal sources of information used for tract 142pCu7307, Sulu-Zamboanga Arc—Philippines.

[NA, not applicable; n.d., no data]

\begin{tabular}{|c|c|c|c|}
\hline Theme & Name or Title & Scale & Citation \\
\hline \multirow[t]{4}{*}{ Geology } & $\begin{array}{l}\text { Geology and mineral resources of the Philippines, } \\
\text { v. } 1 \text { - Geology }\end{array}$ & $1: 1,000,000$ & $\begin{array}{l}\text { Philippine Bureau of Mines and Geo- } \\
\text { sciences (1981), Philippine Mines and } \\
\text { Geosciences Bureau ( 2010) }\end{array}$ \\
\hline & Digital geologic map of the Philippines & $1: 1,000,000$ & $\begin{array}{l}\text { Philippine Mines and Geosciences Bureau } \\
\text { (2004a) }\end{array}$ \\
\hline & Digital geologic map of the East and Southeast Asia & $1: 2,000,000$ & $\begin{array}{l}\text { Coordinating Committee for Coastal and } \\
\text { Offshore Geoscience Programmes in East } \\
\text { and Southeast Asia (CCOP) and Geologi- } \\
\text { cal Survey of Japan (1997) }\end{array}$ \\
\hline & Geologic map of the Philippines & $1: 1,000,000$ & Philippine Bureau of Mines (1963) \\
\hline \multirow[t]{5}{*}{$\begin{array}{l}\text { Mineral } \\
\text { occurences }\end{array}$} & $\begin{array}{l}\text { Porphyry copper deposits of the world-Database, map, and } \\
\text { grade and tonnage models }\end{array}$ & NA & Singer and others (2008) \\
\hline & Philippine porphyry copper deposits and prospects & NA & $\begin{array}{l}\text { Database (C. Manipon, 2004, written } \\
\text { commun., compiled from Philippine Mines } \\
\text { and Geosciences Bureau records) }\end{array}$ \\
\hline & Mineral resource map of Asia & $1: 35,000,000$ & Kamitani and Naito (1998) \\
\hline & Philippine porphyry copper deposits & NA & Sillitoe and Gappe (1984) \\
\hline & $\begin{array}{l}\text { U.S. Geological Survey On-Line Mineral Resources Spatial } \\
\text { Data }\end{array}$ & NA & U.S. Geological Survey (2012) \\
\hline \multirow[t]{2}{*}{ Exploration } & Philippine Mines and Geosciences Bureau Web site & NA & http://www.mgb.gov.ph/ \\
\hline & Commercial databases & NA & http://www.infomine.com/ \\
\hline
\end{tabular}


the occurrence of undiscovered porphyry copper deposits. The Labangan and Tamarok-Tapisa prospect areas lie along the northwest-striking Sindangan-Cotabato-Daguma Lineament (fault system), which may represent a mineralized corridor. The area is poorly explored relative to more thoroughly explored parts of the Philippines such as western Luzon.

The team estimated a 50-percent chance of one or more undiscovered deposits, a 5-percent chance of two or more and a 1-percent chance of three or more deposits based on the occurrence of three known prospect areas. The mean result is 0.8 deposits with a high degree $\left(C_{v}=90\right.$ percent $)$ of uncertainty (table C5). One consideration is that although near-surface epithermal systems may be present, porphyry copper deposits may be present at depths greater than the $1-\mathrm{km}$ maximum depth for undiscovered deposits specified for the assessment.

\section{Probabilistic Assessment Simulation Results}

Estimates of undiscovered resources for the tract were made by combining the team's estimate for numbers of undiscovered porphyry copper deposits with the porphyry coppergold model of Singer and others (2008) using the EMINERS program (Root and others, 1992; Duval, 2012; Bawiec and Spanski, 2012). Selected simulation results are reported in table C6. Results of the Monte Carlo simulation are presented as a cumulative frequency plot (fig. C3). The cumulative frequency plot shows the estimated resource amounts associated with cumulative probabilities of occurrence, as well as the mean, for each commodity and for total mineralized rock. See table 6 in the main text of this report for comparisons with other tracts.

Table C5. Undiscovered deposit estimates, deposit numbers, tract area, and deposit density for tract 142pCu7307, Sulu-Zamboanga Arc-Philippines.

$\left[N_{\mathrm{XX}}\right.$, estimated number of deposits associated with the xxth percentile; $N_{\text {und, }}$ expected number of undiscovered deposits; $s$, standard deviation; $C_{v} \%$, coefficient of variance; $N_{\text {known }}$, number of known deposits in the tract that are included in the grade and tonnage model; $N_{\text {total }}$, total of expected number of deposits plus known deposits; area, area of permissive tract in square kilometers $\left(\mathrm{km}^{2}\right)$; density, deposit density reported as the total number of deposits per $100,000 \mathrm{~km}{ }^{2}$. $N_{\text {und }}, s$, and $C_{v} \%$ are calculated using a regression equation (Singer and Menzie, 2005)]

\begin{tabular}{|c|c|c|c|c|c|c|c|c|c|c|c|}
\hline \multicolumn{5}{|c|}{ Consensus undiscovered deposit estimates } & \multicolumn{5}{|c|}{ Summary statistics } & \multirow{2}{*}{$\begin{array}{c}\text { Tract Area } \\
\quad\left(\mathbf{k m}^{2}\right)\end{array}$} & \multirow{2}{*}{$\begin{array}{c}\text { Deposit } \\
\text { density }\left(N_{\text {total }} \text { (100,000 } \mathrm{km}^{2}\right)\end{array}$} \\
\hline$N_{90}$ & $N_{50}$ & $N_{10}$ & $N_{05}$ & $N_{01}$ & $N_{\text {und }}$ & $s$ & $C_{v} \%$ & $N_{\text {known }}$ & $N_{\text {total }}$ & & \\
\hline 0 & 1 & 1 & 2 & 3 & 0.81 & 0.73 & 90 & 0 & 0.81 & 10,180 & 8 \\
\hline
\end{tabular}

Table C6. Results of Monte Carlo simulation of undiscovered resources for tract 142pCu7307, Sulu-Zamboanga Arc—Philippines.

[Cu, copper; Mo, molybdenum; Au, gold; and Ag, silver; in metric tons; Rock, in million metric tons]

\begin{tabular}{|c|c|c|c|c|c|c|c|c|}
\hline \multirow[b]{2}{*}{ Material } & \multicolumn{6}{|c|}{ Probability of at least the indicated amount } & \multicolumn{2}{|c|}{ Probability of } \\
\hline & 0.95 & 0.9 & 0.5 & 0.1 & 0.05 & Mean & $\begin{array}{c}\text { Mean or } \\
\text { greater }\end{array}$ & None \\
\hline $\mathrm{Cu}$ & 0 & 0 & 410,000 & $5,000,000$ & $11,000,000$ & $2,500,000$ & 0.19 & 0.30 \\
\hline Mo & 0 & 0 & 0 & 20,000 & 54,000 & 13,000 & 0.12 & 0.74 \\
\hline $\mathrm{Au}$ & 0 & 0 & 43 & 410 & 780 & 180 & 0.21 & 0.30 \\
\hline $\mathrm{Ag}$ & 0 & 0 & 0 & 1,400 & 2,900 & 850 & 0.14 & 0.65 \\
\hline Rock & 0 & 0 & 100 & 1,000 & 2,300 & 490 & 0.20 & 0.30 \\
\hline
\end{tabular}




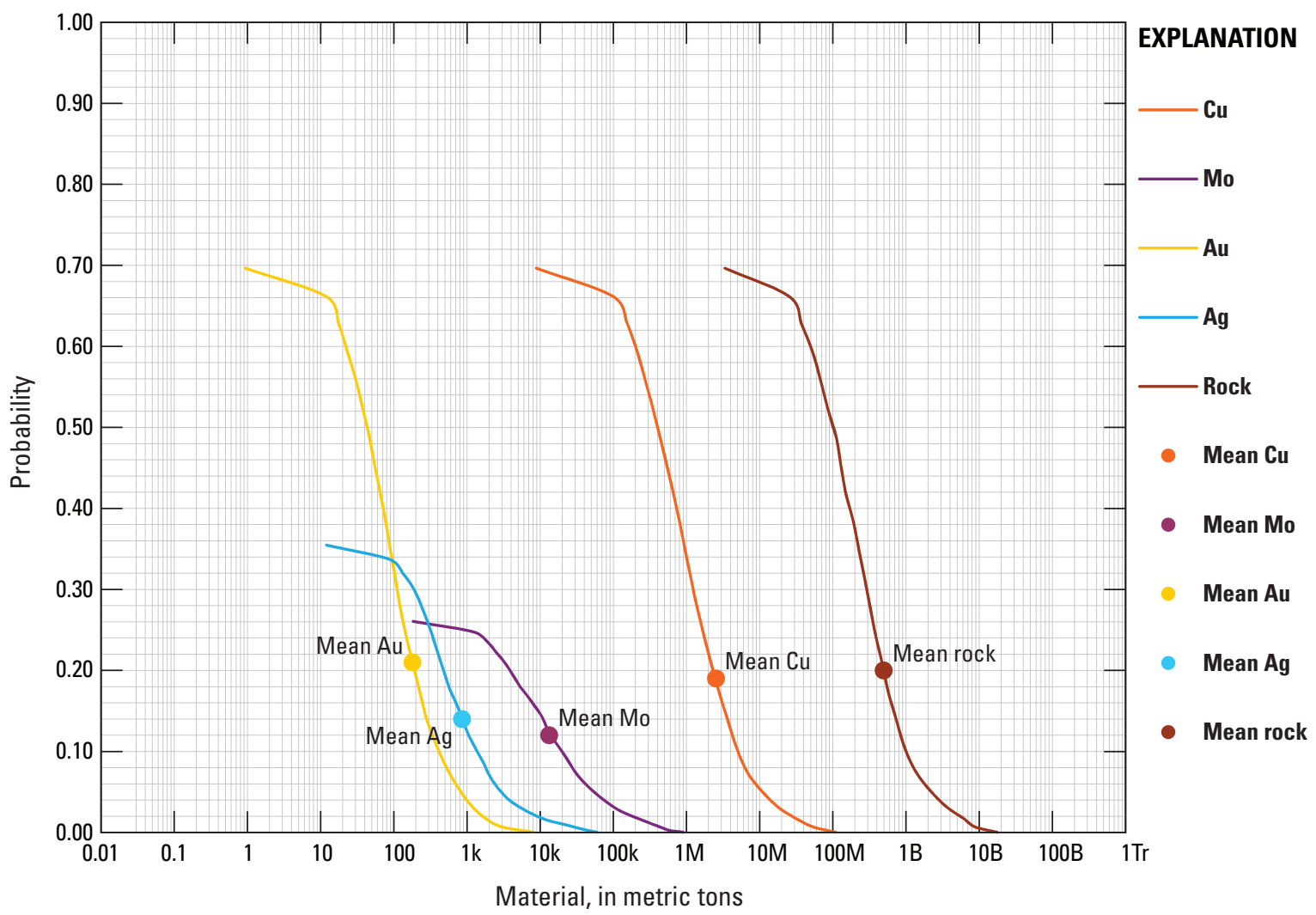

Figure C3. Cumulative frequency plot showing the results of Monte Carlo computer simulation of undiscovered resources in 142pCu7307, Sulu-Zamboanga Arc_Philippines. $k$, thousands; M, millions; $\mathrm{B}$, billions; $\mathrm{Tr}$, trillions.

\section{References Cited}

Anonymous, 1995, Tectonic map of the Philippines: scale $1: 2,000,000$.

Bawiec, W.J., and Spanski, G.T., 2012, Quick-start guide for version 3.0 of EMINERS-Economic Mineral Resource Simulator: U.S. Geological Survey Open-File Report 2009-1057, 26 p., accessed June 30, 2012, at http://pubs. usgs.gov/of/2009/1057/. (This report supplements USGS OFR 2004-1344.)

Berger, B.R., Ayuso, R.A., Wynn, J.C., and Seal, R.R., 2008, Preliminary model of porphyry copper deposits: U.S. Geological Survey Open-File Report 2008-1321, 55 p., accessed May 15, 2009, at http://pubs.usgs.gov/ of $/ 2008 / 1321 /$.

Cooke, D.R., Heithersay, P.S., Wolfe, Rohan, and Calderon, A.L., 1998, Exploration models for major Australian mineral deposit types-Australian and western Pacific porphyry $\mathrm{Cu}-\mathrm{Au}$ deposits: Journal of Australian Geology and Geophysics, v.17, no. 4, p. 97-104.
Coordinating Committee for Coastal and Offshore Geoscience Programmes in East and Southeast Asia (CCOP) and Geological Survey of Japan, 1997, Digital geologic map of East and Southeast Asia, 1:2,000,000: Geological Survey of Japan, Digital Geoscience Map G-2.

Cox, D.P., 1986, Descriptive model of porphyry $\mathrm{Cu}-\mathrm{Au}$, in Cox, D.P. and Singer, D.A., eds., Mineral deposit models: U.S. Geological Survey Bulletin 1693, p. 110. (Also available at http://pubs.usgs.gov/bul/b1693/.)

Cruz, J.B., 1987, Volcanism and associated hazards in the Philippine setting, in Geologic Hazards and Preparedness Systems: Manila, Philippines, Philippine Institute of Volcanology and Seismology, National Science and Technology Authority, p. 22-37.

Drew, L.J., and Singer, D.A., 2005, Identifying the appropriate porphyry-copper deposit grade-tonnage model for a largescale mineral resource assessment in South East Asia, in Chen, Qiuming, and Bonham-Carter, Graeme, eds., Proceedings of IAMG-The annual conference of the International Association for Mathematical Geology: Toronto, Canada, York University, Geomatics Research Laboratory, p. 1034-1039. 
Duval, J.S., 2012, Version 3.0 of EMINERS-Economic Mineral Resource Simulator: U.S. Geological Survey OpenFile Report 2004-1344, available at http://pubs.usgs.gov/ of/2004/1344/.

Garwin, S., Hall, R., and Watanabe, Y., 2005, Tectonic setting, geology, and gold and copper mineralization in Cenozoic magmatic arcs of southeast Asia and the west Pacific, in Hedenquist, T.W., Thompson, J.F.H., Goldfarb, R.J., and Richards, J.P., eds., One hundredth anniversary volume 1905-2005: Littleton, Colorado, Society of Economic Geologists, p. 891-930.

Jiminez, F.A., Jr., Yumul, G.P., Jr., Maglambayan, V.B., and Tamayo, R.A., Jr., 2002, Shallow to near-surface, vein-type epithermal gold mineralization at Lalab in the Sibutad gold deposit, Zamboanga del Norte, Mindanao, Philippines: Journal of Asian Earth Sciences, v. 21, p.119-133.

John, D.A., Ayuso, R.A., Barton, M.D., Blakely, R.J., Bodnar, R.J., Dilles, J.H., Gray, Floyd, Graybeal, F.T., Mars, J.C., McPhee, D.K., Seal, R.R., Taylor, R.D., and Vikre, P.G., 2010, Porphyry copper deposit model, chap. B of Mineral deposit models for resource assessment: U.S. Geological Survey Scientific Investigations Report 2010-5070-B, 169 p., accessed September 8, 2010, at http://pubs.usgs.gov/ $\operatorname{sir} / 2010 / 5070 / b /$.

Kamitani, M., and Naito, K., eds., 1998, Mineral resource map of Asia: Metal Mining Agency of Japan, 1 sheet 1:35,000,000-scale. (Also available at www.mmaj.go.jp/ mric_web/deposit/index.htm.)

Lee, C.S., and McCabe, R., 1986, The Banda-Celebes-Sulu Basin, a trapped piece of Cretaceous-Eocene oceanic crust?: Nature, v. 322, no. 3, p. 51-53.

Malaihollo, J.F.A., Hall, R., and Macpherson, C.G., 2002, SE Asia Radiometric ages-GIS database: Southeast Asia Research Group, Department of Earth Sciences, Royal Holloway University of London, accessed February 1, 2010, at http://searg.rhul.ac.uk/current_research/isotopic_ages/ SEAsia_GIS.pdf.

Mercado, V.O., 1975, Preliminary report on the geology and mineralization of the Labangan copper-gold property, Dipaya, Labangan, Zamboanga del Sur: Unpublished report of the Victoria Consolidated Resources Corp., 10 p.

Philippine Bureau of Mines, 1963, Geological map of the Philippines: Philippine Bureau of Mines, 1 map on 8 sheets, scale 1:1,000,000.

Philippine Bureau of Mines and Geosciences, 1981, Geology and mineral resources of the Philippines, v. 1-Geology: Philippine Bureau of Mines and Geosciences, 406 p.
Philippine Bureau of Mines and Geosciences, 1986, Geology and mineral resources of the Philippines, v. 2-Mineral Resources: Philippine Bureau of Mines and Geosciences, 446 p.

Philippine Mines and Geosciences Bureau, 2004a, Digital geological map of the Philippines: Philippine Mines and Geosciences, scale 1:1,000,000. [Proprietary data.]

Philippine Mines and Geosciences Bureau, 2004b, Digital database of mineral occurrences of the Philippines: Philippine Mines and Geosciences Bureau. [Proprietary report.]

Philippine Mines and Geosciences Bureau, 2010, Geology of the Philippines (2d. ed.): Philippine Mines and Geosciences Bureau, 532 p.

Pubellier, M., Quebrel, R., Rangin, C., Deffontaines, B., Muller, C., Butterlin, J., and Manzano, J., 1991, The Mindanao collision zone-A soft collision event within a continuous Neogene strike-slip setting: Journal of Southeast Asian Earth Sciences, v. 6, no. 3-4, p. 239-248.

Pubellier, M., Quebral, R., Deffontaines, B., and Rangin, C., 1993, Neotectonic map of Mindanao (Philippines): Quezon City, Philippines, Asia Geodyne Corporation, scale $1: 800,000$.

Root, D.H., Menzie, W.D., and Scott, W.A., 1992, Computer Monte Carlo simulation in quantitative resource estimation: Natural Resources Research, v. 1, no. 2, p. 125-138.

Sillitoe, R.H., and Gappe, I.M., Jr., 1984, Philippine porphyry copper deposits - Geologic setting and characteristics: Committee for Co-ordination of Joint Prospecting for Mineral Resources in Asian Offshore Areas (CCOP), CCOP Technical Publication 14, 89 p.

Singer, D.A., and Menzie, W.D., 2005, Statistical guides to estimating the number of undiscovered mineral deposits - An example with porphyry copper deposits, in Cheng, Qiuming, and Bonham-Carter, Graeme, eds., Proceedings of IAMG - The annual conference of the International Association for Mathematical Geology: Toronto, Canada, York University, Geomatics Research Laboratory, p. 1028-1033.

Singer, D.A., Berger, V.I., and Moring, B.C., 2008, Porphyry copper deposits of the World-Database and grade and tonnage models, 2008: U.S. Geological Survey Open-File Report 2008-1155, accessed June 1, 2011, at http://pubs. usgs.gov/of/2008/1155/.

TVI Pacific, Inc., 2010, Tamarok-Tapisa, Mindanao [Philippines]: TVI Pacific, Inc., Web page, accessed April 8, 2010, at http://premium.infomine.com/scripts/advanced/ infodbweb/ChargePropertyReport.asp?SearchID=37763. 
TVI Pacific, Inc., 2012, Tamarok copper and gold prospect: TVI Pacific, Inc., Web page, accessed May 15, 2012, at http://www.tvipacific.com/Operations/MiningAssets/ Exploring/Tamarok-Tapisa/default.aspx.

U.S. Department of State, 2009, Small-scale digital international land boundaries (SSIB) - Lines, edition 10, and polygons, beta edition 1, in Boundaries and sovereignty encyclopedia (B.A.S.E.): U.S. Department of State, Office of the Geographer and Global Issues.

U.S. Geological Survey, 2012, U.S. Geological Survey on-line mineral resources spatial data: U.S. Geological Survey Web site, accessed April 15, 2013, at http://mrdata.usgs.gov/.
Weissel, J.K., 1980, Evidence for Eocene oceanic crust in the Celebes Sea Basin, in Hayes, D.E., ed., The tectonic and geologic evolution of southeast Asian seas and islands: America Geophysical Union Monograph 23, p. 37-48.

Weissel, J.K., 1981, Magnetic lineations in marginal basins of the West Pacific: Philosophical Transactions Royal Society London, Series A, v. 300, p. 223-247.

Yumul, G.P., Jr., Dimalanta, C.B., Maglambayan, V.B., and Marquez, E.J., 2008, Tectonic setting of a composite terrane-A review of the Philippine island arc system: Geosciences Journal, v. 12, no. 1, p. 7-17. 


\section{Appendix D. Porphyry Copper Assessment for Tract 142pCu7305, Masbate-Negros Arc-Philippines}

By Jane M. Hammarstrom ', Arthur A. Bookstrom², Connie L. Dicken', Steve Ludington³, Gilpin R. Robinson, Jr.', and Michael L. Zientek ${ }^{2}$ with contributions from Sevillo (Bill) D. David, Jr., Claro J. Manipon ${ }^{4}$, Lilian A. Rollan ${ }^{4}$, and Yasushi Watanabe ${ }^{5}$

\section{Deposit Type Assessed: Porphyry copper}

Descriptive model: Porphyry copper (Cox, 1986; Berger and others, 2008; John and others, 2010; Sillitoe and Gappe, 1984) Grade and tonnage model: Porphyry copper (Singer and others, 2008)

Table D1 summarizes selected assessment results.

Table D1. Summary of selected resource assessment results for tract 142pCu7305, Masbate-Negros Arc-Philippines.

[km, kilometers; $\mathrm{km}^{2}$, square kilometers; $\mathrm{t}$, metric tons; identified copper rounded to two significant figures]

\begin{tabular}{cccccc}
\hline $\begin{array}{c}\text { Date of } \\
\text { assessment }\end{array}$ & $\begin{array}{c}\text { Assessment depth } \\
(\mathbf{k m})\end{array}$ & Tract area $\left(\mathbf{k m}^{2}\right)$ & $\begin{array}{c}\text { Identified copper } \\
\text { resources }(\mathbf{t})\end{array}$ & $\begin{array}{c}\text { Mean estimate of } \\
\text { undiscovered copper } \\
\text { resources }(\mathbf{t})\end{array}$ & $\begin{array}{c}\text { Median estimate of } \\
\text { undiscovered copper } \\
\text { resources }(\mathbf{t})\end{array}$ \\
\hline 2010 & 1 & 12,230 & $6,800,000$ & $7,800,000$ \\
\hline
\end{tabular}

\section{Location}

Central and Western Visayas region, including the islands of Negros, Masbate, and Panay, Philippines (fig. D1).

\section{Geologic Feature Assessed}

Masbate-Negros Arc.

${ }^{1}$ U.S. Geological Survey, Reston, Virginia, United States.

${ }^{2}$ U.S. Geological Survey, Spokane, Washington, United States.

${ }^{3}$ U.S. Geological Survey, Menlo Park, California, United States.

${ }^{4}$ Philippine Department of Environment and Natural Resources, Mines and Geosciences Bureau, Quezon City, Philippines.

${ }^{5}$ Geological Survey of Japan, National Institute of Advanced Industrial Science and

Technology (AIST), Ibaraki, Japan. 

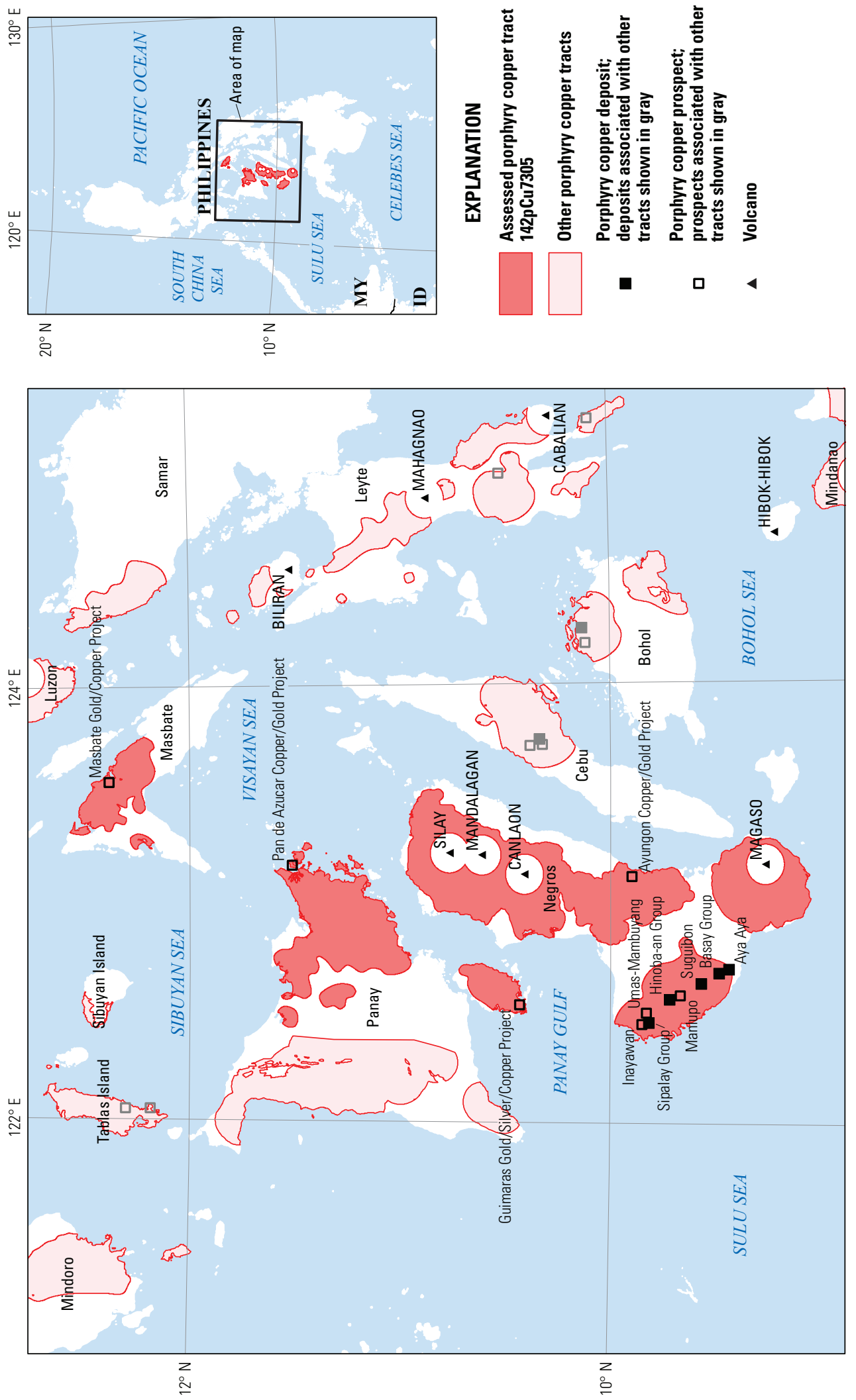

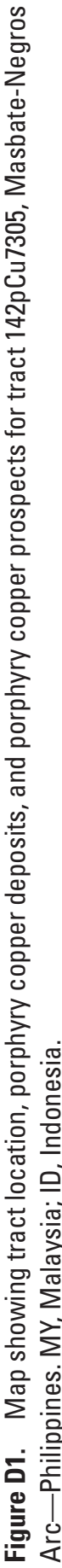




\section{Delineation of the Permissive Tract}

\section{Tectonic Setting}

The 400-km-long Masbate-Negros composite arc system (fig. $2 A^{6}$ ) includes an Eocene to Miocene western arc and a Miocene to Holocene eastern arc, both a result of subduction beneath Negros (Garwin and others, 2005). The older western arc, which was built on oceanic and accretionary basement, extends across several islands from southwestern Negros through east Panay to Masbate (fig. 5B). The polarity of subduction (west or east dipping) for the older arc is unknown, but it may be a northern extension of the Daguma Arc, which forms the older basement for the Cotabato Arc (appendix A) in Mindanao (Pubellier and others, 1991; Sajona and others, 1997, 2000). The younger arc overprints the older arc and is also related to east-dipping subduction at the Negros Trench (fig. 5B). The Masbate-Negros arc system is bounded by the Philippine Fault (fig. 5B) on the north, and by the SuluZamboanga Arc (fig. $2 A$ ) on the south.

\section{Geologic Criteria}

The tract was delineated by selecting Neogene intrusions, including mid-Miocene dacite porphyry stocks and dikes and Eocene to Oligocene diorite stocks and andesitic to dacitic volcanic rocks (fig. D2, table D2) that lie within the MasbateNegros Arc as defined by Garwin and others (2005). These permissive rock units were selected from a digital version of the 1:1,000,000-scale geologic map of the Philippine (Philippine Mines and Geosciences Bureau, 2004a) using GIS tools. and 10- and 2-km buffers were created around intrusive and volcanic rocks, respectively. These distances are considered appropriate to allow for inaccuracies in mapped contacts and extensions under adjacent cover rock. The buffered map unit polygons were aggregated, smoothed, and edited by hand and tract boundaries were checked to include known prospects and permissive igneous rocks shown on maps included in topical studies (Malaihollo and others, 2002). Circular cutouts in the tract represents $10-\mathrm{km}$ areas around the Quaternary stratovolcanoes, where the volcanic cover is likely to be about $1 \mathrm{~km}$ thick above any undiscovered porphyry systems. Final tract boundaries were edited by hand to honor fault boundaries and include prospects and dated igneous-rock localities (Malaihollo and others, 2002). As a last step, the tracts were clipped to coastlines (U.S. Department of State, 2009).
In this composite arc system, the mid-Miocene arc rocks intruded and overprinted the Oligocene arc. The Oligocene arc rocks on Negros include the Pagatban Batholith (38.4 and 34.4 Ma ages of diorite) that intrudes andesitic and dacitic rocks (Mitchell and Leach, 1991). On eastern Panay, the preMiocene arc rocks include diorites that have intruded andesites (Mitchell and Leach, 1991). The mid-Miocene arc is defined by dacite porphyry stocks and dikes that intrude Oligocene porphyry-copper-related diorites in southwestern Negros and andesites in eastern Panay (Mitchell and Leach, 1991).

\section{Known Deposits}

Five porphyry copper deposits are known within the tract area (fig. D1, table D3). The deposits are aligned along the Southwest Negros mineral district, a mineralized corridor that extends for about $60 \mathrm{~km}$ from the Sipalay Group in the northwest to the Basay Group in the southeast (fig. D1). Intersections of two major faults in the district, north-northwest arc-parallel faults and northeast arc-normal faults, may control deposit locations (Vigar and others, 2011). The Aya Aya and Suguibo deposits are relatively small $(\leq 120,000 \mathrm{t}$ contained copper) and the authors are unaware of any recent activity at these sites.

\section{Sipalay Group}

The largest deposit in the tract is the 30 Ma Sipalay deposit ( $807 \mathrm{Mt}, 0.473$ percent copper). Sipalay was discovered in 1936; production started in 1957. The mine was closed in 2002, leaving in-place resources of $642 \mathrm{Mt}$ at 0.41 percent copper (Vigar and others, 2011). In the mine area, multiphase Eocene-Oligocene diorite intrudes metavolcanic rocks. The mine pit area is at the intersection of nearly perpendicular faults. Ore minerals are disseminated in diorite; supergene enrichment is variable within the three ore bodies at Sipalay (Philippines Bureau of Mines and Geosciences, 1986). The Sipalay Group includes Baciao and Cansibat-Bunuliog and also is known as Colet or Maracalum.

\section{Hinoba-an Group}

The 17.5 Ma Hinoba-an deposit lies about $25 \mathrm{~km}$ north of Basay (fig. D1). The Hinoba-an project includes the Colet area that was explored as one of 23 National Priority Projects under the Philippines Revitalization Program of the Minerals Industry. Singer and others (2008) reported resources for the Hinoba-an deposit as $432 \mathrm{Mt}$ at 0.367 percent copper, 

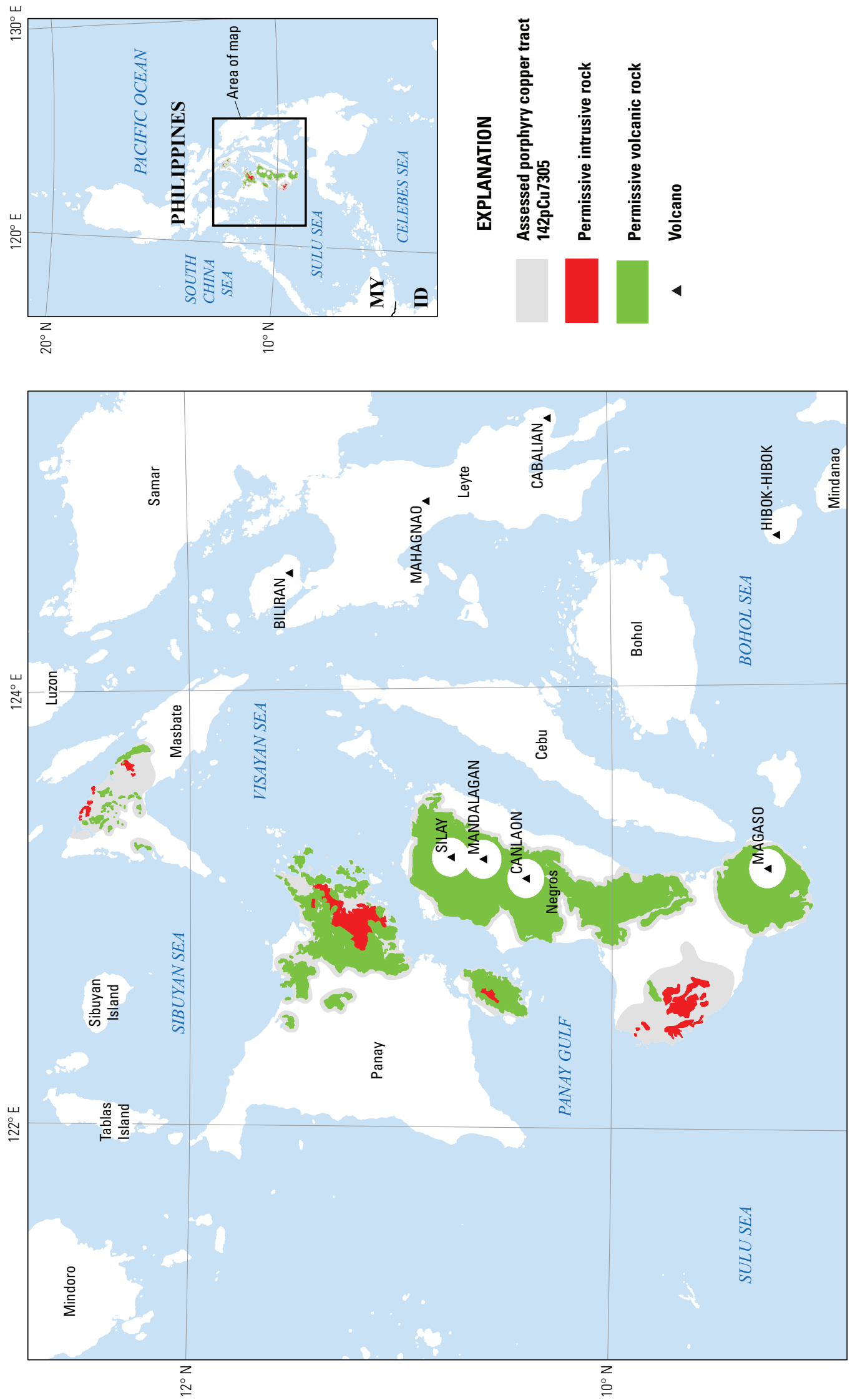

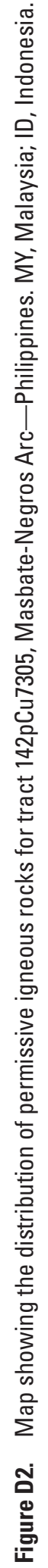


Table D2. Map units that define tract 142pCu7305, Masbate-Negros Arc-Philippines.

[Map unit, age range, and principal lithologies are based on a digital compilation of the 1963 1:1,000,000-scale geologic map of the Philippines (Philippine Bureau of Mines, 1963)]

\begin{tabular}{|c|c|c|c|}
\hline Map unit & $\begin{array}{l}\text { Map } \\
\text { symbol }\end{array}$ & Lithology & Age range \\
\hline \multicolumn{4}{|c|}{ Intrusive rocks } \\
\hline Neogene intrusive rocks & NI & $\begin{array}{l}\text { Largely intra-Miocene quartz diorite. Mostly batholiths and stocks, } \\
\text { some laccoliths; also sills, dikes, and other minor bodies. Includes } \\
\text { granodiorite and diorite porphyry facies and late Miocene dacite. } \\
\text { Pervasive in Paleogene and Mesozoic, less widespread in early } \\
\text { Miocene rock sequences. Neogene }\end{array}$ & Neogene \\
\hline \multicolumn{4}{|c|}{ Volcanic rocks } \\
\hline $\begin{array}{l}\text { Pliocene-Quaternary } \\
\text { volcanic rocks }\end{array}$ & QV & $\begin{array}{l}\text { Nonactive cones (generally pyroxene andesite); also dacitic and (or) } \\
\text { andesitic plugs. }\end{array}$ & Pliocene-Quaternary \\
\hline Neogene volcanic rocks & $\mathrm{IN}_{2}$ & Principally dacite and/or andesite flows, generally with pyroclastics. & Late Miocene-Pliocene \\
\hline Paleogene volcanic rocks & $\mathrm{IPg}_{2}$ & $\begin{array}{l}\text { Essentially keratophyre and andesite flows. Often with pyroclastics } \\
\text { and chert of volcanic origin. Undifferentiated from early Miocene } \\
\text { sedimentary rocks in some areas. }\end{array}$ & Oligocene \\
\hline
\end{tabular}

Table D3. Porphyry copper deposits in tract 142pCu7305, Masbate-Negros Arc—Philippines.

[*, See text for discussion of other resource estimates for these deposits. Ma, million years; Mt, million metric tons; \%, percent; $t$, metric ton; g/t, gram per metric ton; $\mathrm{Cu}-\mathrm{Au}$ subtype, deposits that have $\mathrm{Au} / \mathrm{Mo}$ ratios $>30$ or average $\mathrm{Au}$ grades $>0.2 \mathrm{~g} / \mathrm{t}$; n.d., no data; NA, not applicable. Contained Cu in metric tons is computed as $(\mathrm{Mt} \times 1,000,000) \times(\mathrm{Cu}$ grade, $\% \div 100)$. Age, based on midpoint of age range reported by Singer and others $(2008)]$

\begin{tabular}{|c|c|c|c|c|c|c|c|c|c|c|c|}
\hline Name & Latitude & Longitude & Subtype & $\begin{array}{l}\text { Age } \\
\text { (Ma) }\end{array}$ & $\begin{array}{l}\text { Tonnage } \\
\text { (Mt) }\end{array}$ & $\begin{array}{l}\mathrm{Cu} \\
(\%)\end{array}$ & Mo (\%) & $A u(g / t)$ & $\mathrm{Ag}(\mathrm{g} / \mathrm{t})$ & $\begin{array}{l}\text { Contained } \\
\text { Cu (t) }\end{array}$ & Reference \\
\hline Aya Aya & 9.433 & 122.700 & NA & 19.5 & 40 & 0.30 & 0.022 & 0.08 & 1.5 & 120,000 & $\begin{array}{l}\text { Divis (1983), Sillitoe and } \\
\text { Gappe (1984), Singer and } \\
\text { others (2008) }\end{array}$ \\
\hline \multirow[t]{2}{*}{$\begin{array}{l}\text { Basay } \\
\text { Group* }\end{array}$} & 9.481 & 122.682 & $\mathrm{Cu}-\mathrm{Au}$ & 30.0 & 262 & 0.44 & 0.008 & 0.29 & 1.5 & $1,152,800$ & $\begin{array}{l}\text { Jacinto and Hofilena (1981), } \\
\text { Motton (2009), Saegert and } \\
\text { Lewis (1976), Sevillano and } \\
\text { Fernando (1981), Singer and } \\
\text { others (2008), Vigar and } \\
\text { others (2011) }\end{array}$ \\
\hline & & & & & 131.1 & 0.48 & n.d. & n.d. & n.d. & 629,280 & $\begin{array}{l}\text { Copper Development } \\
\text { Corporation (2012) }\end{array}$ \\
\hline \multirow[t]{2}{*}{$\begin{array}{l}\text { Hinoba-an } \\
\text { Group* }\end{array}$} & 9.719 & 122.562 & NA & 17.5 & 432 & 0.367 & n.d. & 0.14 & 0.34 & $1,585,440$ & $\begin{array}{l}\text { Border and others (2003), } \\
\text { Copper Resources Corp. } \\
\text { (2005), Divis (1983), Malic- } \\
\text { dem (1974), Motegi (1977), } \\
\text { Sillitoe and Gappe (1984), } \\
\text { Singer and others (2008) }\end{array}$ \\
\hline & & & & & 339 & 0.35 & n.d. & n.d. & n.d. & $1,186,500$ & $\begin{array}{l}\text { Copper Development } \\
\text { Corporation (2012) }\end{array}$ \\
\hline
\end{tabular}


Table D3. Porphyry copper deposits in tract 142pCu7305, Masbate-Negros Arc_-Philippines.—Continued

[*, See text for discussion of other resource estimates for these deposits. Ma, million years; Mt, million metric tons; \%, percent; $\mathrm{t}$, metric ton; g/t, gram per metric

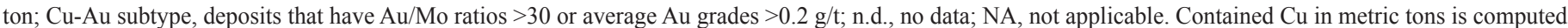
as $(\mathrm{Mt} \times 1,000,000) \times(\mathrm{Cu}$ grade, $\% \div 100)$. Age, based on midpoint of age range reported by Singer and others $(2008)]$

\begin{tabular}{|c|c|c|c|c|c|c|c|c|c|c|c|}
\hline Name & Latitude & Longitude & Subtype & $\begin{array}{l}\text { Age } \\
\text { (Ma) }\end{array}$ & $\begin{array}{l}\text { Tonnage } \\
\text { (Mt) }\end{array}$ & Cu (\%) & Mo (\%) & $A u(g / t)$ & $\mathrm{Ag}(\mathrm{g} / \mathrm{t})$ & $\begin{array}{c}\text { Contained } \\
\mathrm{Cu}(\mathrm{t})\end{array}$ & Reference \\
\hline $\begin{array}{l}\text { Sipalay- } \\
\text { Group }\end{array}$ & 9.818 & 122.456 & NA & 30.0 & 807 & 0.473 & 0.0139 & 0.05 & 1.5 & $3,817,110$ & $\begin{array}{l}\text { Divis (1983), Domingo } \\
\text { (1980), Kinkel and others } \\
\text { (1956), Philippine Mines and } \\
\text { Geosciences Bureau (2007), } \\
\text { Motegi (1977), Philippine } \\
\text { Mines and Geosciences } \\
\text { Bureau (1986), Sillitoe and } \\
\text { Gappe (1984), Singer and } \\
\text { others (2008,) Walther and } \\
\text { others (1981) }\end{array}$ \\
\hline Suguibon & 9.567 & 122.633 & NA & n.d. & 26 & 0.35 & 0.015 & n.d. & n.d. & 91,000 & $\begin{array}{l}\text { Divis (1983), Sillitoe and } \\
\text { Gappe (1984), Singer and } \\
\text { others (2008) }\end{array}$ \\
\hline
\end{tabular}

$0.14 \mathrm{~g} / \mathrm{t}$ gold, and $0.34 \mathrm{~g} / \mathrm{t}$ silver based on a 0.2 percent copper cutoff grade. JORC-compliant total resources announced by Copper Development Corporation (2012) in June 2012 are $339.0 \mathrm{Mt}$ at 0.35 percent copper (also based on a 0.2 percent copper cutoff grade). Table D3 lists the data of Singer and others (2008), because those data include byproduct grades that are not available for the new resource estimates and because of uncertainties in the comparing the areas included in the two different resource estimates. The deposit, which was at the prefeasibility stage of development in 2005, was held by Copper Development Corporation in 2012 and was proposed for development as an open-pit mine with a conventional flotation plant.

The Hinoba-an project area includes two deposits within $1 \mathrm{~km}$ of each other (Don Jose, also known as DJ, and A1,also known as Mantoboy) that are both along a north-northwest fault zone and within a large alteration zone (mainly phyllic and argillic) in quartz diorite of the Pagatban Intrusive Complex. The main ore minerals are disseminated chalcopyrite and minor amounts of bornite and chalcocite (Border and others, 2003). The Luz porphyry, about $2 \mathrm{~km}$ from Hinoba-an, was drilled in 2009 by Vulcan Industrial and Mining Corporation resulting in an announcement of inferred resources of 33.4 Mt at 0.38 percent copper; further exploration may expand this area as a separate development project (Vigar and others, 2011).

\section{Basay Group}

The Basay porphyry copper deposit produced ore from 1979 to 1983 . The property currently (2012) is part of an 18 $\mathrm{km}^{2}$ exploration project by Copper Development Corporation and Solfotara Mining Company. Singer and others (2008) reported the total resources for Basay, including Nabuangan and Bunkville, as $262 \mathrm{Mt}$ at 0.44 percent copper, 0.008 percent molybdenum, $0.29 \mathrm{~g} / \mathrm{t}$ gold, and $1.5 \mathrm{~g} / \mathrm{t}$ silver, citing 1980s-era data (table D3). Historical noncompliant resources estimates for the period 1975-1983 compiled by Vigar and others (2011) vary and do not include data for molybdenum, gold, silver, or rhenium; for example, historical resources of $230 \mathrm{Mt}$ at an average grade of 0.44 percent copper and reserves of $129 \mathrm{Mt}$ of 0.48 percent copper were reported in 1983. Initial JORCcompliant gross inferred mineral resources of $131.1 \mathrm{Mt}$ at 0.48 percent copper ( 0.25 percent copper cutoff grade) were announced in March 2012 for four deposit areas in and around the historical open pit, based on historical and new drilling (Copper Development Corporation, 2012). All four areas are open along strike and at depth, and step-out and deeper work was planned to update resource statements. According to Vigar and others (2011), the areas within the current Basay project area may represent only part of a much larger porphyry system. Table D3 lists of data of Singer and others (2008), with the caveat that the deposit is open and that resource estimates are likely to change.

The Basay deposit(s) are in hornblende diorite, quartz diorite, and monzonite stocks that have intruded andesitic to dacitic volcanic rocks. The primary ore minerals are chalcopyrite and molybdenite. A supergene zone estimated to be about $40 \mathrm{~m}$ thick and containing about $4 \mathrm{Mt}$ of 0.69 percent copper is present at one of the four target areas, the Nabore deposit, which is on an uneroded plateau about $1 \mathrm{~km}$ south of the open pit. The other areas are proximal to the open pit within eroded valleys and apparently lack supergene enrichment zones (Vigar and others, 2011). 


\section{Prospects, Mineral Occurrences, and Related Deposit Types}

The tract includes 7 prospects, some of which have been recently explored (fig. D1, table D4). The Manlupo prospect lies along a northwest trend between the Aya Aya and Basay copper deposit to the south and the Hinoba-an and Sipalay deposits to the north on Negros (fig. D1). The Ayungon and Masbate prospects on Negros are being explored to develop drill targets (Geograce Resources Philippines, Inc., 2010). The Pan de Azucar project area includes a polymetallic target (Valderama) and a potential porphyry copper-gold target at depth at (Asparin Hill); most of the drilling has focused on the Valderama massive pyritic sulfide target (Mindoro Resources, Ltd., 2012; Abrasaldo and Climie, 2003).

\section{Exploration History}

The tract area was explored in the 1980-1990s timeframe. Recent changes in Philippine mining law have encouraged new exploration and reevaluation of previously explored areas. Although there have been several exploration projects in the area, no large-scale mines have been developed. Yumul and others (2008) mention Panay as an attractive exploration area for copper and gold, and a need for further studies and reevaluations in the area. Garwin and others (2005) suggested that there may be potential for buried porphyry copper deposits in the eastern Masbate-Negros Arc where there are indications of upper parts of high-sulfidation epithermal systems. A number of companies were reevaluating properties and drilling the tract area 2010-2012.

\section{Sources of Information}

Table D5 list the principal sources of information used in the assessment.

\section{Grade and Tonnage Model Selection}

The Basay deposit is classified as a copper-gold porphyry deposit (gold greater than $0.2 \mathrm{~g} / \mathrm{t}$ and gold:molybdenum greater than 30). The other four deposits are less gold-rich and could be classified as the general porphyry type using reported grades (Singer and others, 2008). Garwin and others (2005) referred to Sipalay and Hinoba-an as gold-poor, coppermolybdenum deposits. Statistical tests based on the grades and tonnages for the known deposits supported a general model and failed the copper-gold subtype model for both molybdenum and gold grade (table 5). As a result, the general porphyry model was adopted for the simulation of undiscovered resources in the tract.

\section{Estimate of the Number of Undiscovered Deposits}

\section{Rationale for the Estimate}

On the basis of the northwest-trending distribution of the five known deposits in the southern part of Negros (fig. D1), the occurrence of additional prospects there, and along the trend of the arc to the north, the assessment team estimated a 50-percent chance of two or more deposits, a 10-percent chance of four or more deposits, and a 5-percent chance of five or more deposits (table D6). The tract includes the partially explored Ayungon and Manlupo porphyry prospects and five additional known project areas (table D4). Buried deposits may be present under volcanic cover, especially in the younger, eastern parts of the tract.

\section{Probabilistic Assessment Simulation Results}

Undiscovered resources for the tract were estimated by combining the team's estimate for numbers of undiscovered porphyry copper deposits with the general porphyry copper model of Singer and others (2008) using the EMINERS program (Root and others, 1992; Duval, 2012; Bawiec and Spanski, 2012). Selected simulation results are reported in table D7. Results of the Monte Carlo simulation are presented as a cumulative frequency plot (fig. D3). The cumulative frequency plot shows the estimated resource amounts associated with cumulative probabilities of occurrence, as well as the mean, for each commodity and for total mineralized rock. Mean estimated copper resources $(7.8 \mathrm{Mt})$ are about $1 \mathrm{Mt}$ greater than the identified copper resources (approximately $6.8 \mathrm{Mt}$ ) in the tract. See table 6 of the main report for comparisons with identified copper and gold resources and with other tracts. 
Table D4. Significant prospects and occurrences in tract 142pCu7305, Masbate-Negros Arc_Philippines.

[n.d., no data; \%, percent; g/t, grams per metric ton; km, kilometers, m, meters. Rank 4=prospect listed in global database of Singer and others (2008) or $<16,000 \mathrm{t}$ of ore established by drilling. Rank $2=$ drilled or trenched with $<20 \mathrm{~m}$ of $0.2 \% \mathrm{Cu}$, or past or ongoing exploration. Rank $1=$ copper occurrence that may be related to porphyry-type mineralization based on stream sediment or magnetic anomaly or location along structural trend]

\begin{tabular}{|c|c|c|c|c|c|c|}
\hline Name & Latitude & Longitude & Age & Comments & Reference & Rank \\
\hline $\begin{array}{l}\text { Ayungon Copper/ } \\
\text { Gold Project }\end{array}$ & 9.900 & 123.120 & $\begin{array}{l}\text { Oligocene-early } \\
\text { Miocene (?) }\end{array}$ & $\begin{array}{l}\text { Explored 1989-1991; } 2008 \text { re-evaluation } \\
\text { for potential large, low- to medium- } \\
\text { grade porphyry system at depth beneath } \\
\text { hydrothermally-altered andesite. }\end{array}$ & $\begin{array}{l}\text { Geograce Resources } \\
\text { Philippines, Inc. } \\
\text { (2010) }\end{array}$ & 2 \\
\hline $\begin{array}{l}\text { Pan de Azucar } \\
\text { Copper/Gold } \\
\text { Project }\end{array}$ & 11.516 & 123.174 & $\begin{array}{l}\text { Oligocene-early } \\
\text { Miocene (?) }\end{array}$ & $\begin{array}{l}\text { Volcanic caldera. Asparin Hill porphyry } \\
\text { copper-gold prospect. Exploration results } \\
\text { (including drilling) suggest potential buried } \\
\text { porphyry system, but not proven. Propyl- } \\
\text { itized andesite with disseminated chalco- } \\
\text { pyrite, quartz-magnetite alteration, positive } \\
\text { magnetic anomaly. }\end{array}$ & $\begin{array}{l}\text { Abrasaldo and Climie } \\
\text { (2003), Mindoro } \\
\text { Resources, Ltd. } \\
\text { (2010, 2012), Rusina } \\
\text { Mining NL (2010) }\end{array}$ & 2 \\
\hline Manlupo & 9.667 & 122.583 & $\begin{array}{l}\text { Oligocene-early } \\
\text { Miocene (?) }\end{array}$ & $\begin{array}{l}\text { Porphyry copper prospect } 25 \mathrm{~km} \text { north } \\
\text { of Basay; resource estimate of } 81.5 \mathrm{Mt} \text { at } \\
0.42 \% \mathrm{Cu}\end{array}$ & $\begin{array}{l}\text { Vigar and others } \\
\text { (2011) }\end{array}$ & 4 \\
\hline $\begin{array}{l}\text { Guimaras Gold/ } \\
\text { Silver/Copper } \\
\text { Project }\end{array}$ & 10.436 & 122.535 & $\begin{array}{l}\text { Oligocene-early } \\
\text { Miocene (?) }\end{array}$ & $\begin{array}{l}\text { Low-sulfidation epithermal Au-Ag and } \\
\text { porphyry copper prospect area. }\end{array}$ & $\begin{array}{l}\text { Rusina Mining NL } \\
\text { (2010) }\end{array}$ & 1 \\
\hline Inayawan & 9.850 & 122.450 & $\begin{array}{l}\text { Oligocene-early } \\
\text { Miocene (?) }\end{array}$ & $\begin{array}{l}\text { Porphyry copper prospect associated with } \\
\text { volcanoclastic sedimentary rocks. }\end{array}$ & $\begin{array}{l}\text { Philippines Mines } \\
\text { and Geosciences } \\
\text { Bureau ( } 2004 \text {, } \\
\text { written commun.) }\end{array}$ & 1 \\
\hline $\begin{array}{l}\text { Masbate Gold/ } \\
\text { Copper Project }\end{array}$ & 12.380 & 123.560 & $\begin{array}{l}\text { Oligocene-early } \\
\text { Miocene (?) }\end{array}$ & $\begin{array}{l}\text { Cretaceous to early Miocene volcanic and } \\
\text { sedimentary units intruded by dioritic to } \\
\text { andesitic porphyry intrusions west of the } \\
\text { Philippine Fault. Cu hosted in dioritic } \\
\text { intrusions; alteration halos (silicification). }\end{array}$ & $\begin{array}{l}\text { Geograce Resources, } \\
\text { Philippines, Inc. } \\
(2010)\end{array}$ & 1 \\
\hline Umas-Mambuyang & 9.831 & 122.500 & $\begin{array}{l}\text { Oligocene-early } \\
\text { Miocene (?) }\end{array}$ & $\mathrm{Au}, \mathrm{Cu}$ vein occurrence in diorite & $\begin{array}{l}\text { U.S. Geological } \\
\text { Survey (2012) }\end{array}$ & 1 \\
\hline
\end{tabular}


Table D5. Principal sources of information used for tract 142pCu7305, Masbate-Negros Arc_Philippines.

[NA, not applicable]

\begin{tabular}{llcl}
\hline \multicolumn{1}{c}{ Theme } & \multicolumn{1}{c}{ Name or Title } & Scale & \multicolumn{1}{c}{ Citation } \\
\hline Geology & $\begin{array}{l}\text { Geology and mineral resources of the Philippines, } \\
\text { v. 1-Geology }\end{array}$ & $1: 1,000,000$ & $\begin{array}{l}\text { Philippine Bureau of Mines and Geo- } \\
\text { sciences (1981), Philippine Mines and } \\
\text { Geosciences Bureau (2010) }\end{array}$ \\
& Digital geologic map of the Philippines & $1: 1,000,000$ & $\begin{array}{l}\text { Philippine Mines and Geosciences } \\
\text { Bureau (2004a) } \\
\end{array}$ \\
& Geologic map of the Philippines & $1: 1,000,000$ & Philippine Bureau of Mines (1963) \\
\hline Mineral occurrences & $\begin{array}{l}\text { Porphyry copper deposits of the world-Database, } \\
\text { map, and grade and tonnage models }\end{array}$ & NA & Singer and others (2008) \\
& $\begin{array}{l}\text { Geology and mineral resources of the Philippines, } \\
\text { v. 2-Mineral Resources }\end{array}$ & NA & $\begin{array}{l}\text { Philippine Bureau of Mines and } \\
\text { Geosciences (1986) }\end{array}$ \\
& $\begin{array}{l}\text { Digital data base of mineral occurrences of the } \\
\text { Philippines }\end{array}$ & NA & $\begin{array}{l}\text { Philippine Bureau of Mines and } \\
\text { Geosciences (2004b) } \\
\text { Philippine porphyry copper deposits }\end{array}$ \\
& $\begin{array}{l}\text { U.S. Geological Survey On-Line Mineral } \\
\text { Resources Spatial Data (MRDS) }\end{array}$ & NA & Sillitoe and Gappe (1984) \\
& $\begin{array}{l}\text { Philippine Mines and Geosciences Bureau } \\
\text { Region 6 Web site } \\
\text { Company Web sites and technical reports }\end{array}$ & NA.S. Geological Survey (2012) \\
\hline Exploration & NA & NA & Sttp://www.mgb.gov.ph/ \\
\hline
\end{tabular}

Table D6. Undiscovered deposit estimates, deposit numbers, tract area, and deposit density for tract 142pCu7305, Masbate-Negros Arc-Philippines.

[ $N_{\mathrm{xx}}$, estimated number of deposits associated with the xxth percentile; $N_{\text {und }}$, expected number of undiscovered deposits; $s$, standard deviation; $C_{v} \%$, coefficient of variance; $N_{\text {known }}$, number of known deposits in the tract that are included in the grade and tonnage model; $N_{\text {total }}$, total of expected number of deposits plus known deposits; area, area of permissive tract in square kilometers $\left(\mathrm{km}^{2}\right)$; density, deposit density reported as the total number of deposits per $100,000 \mathrm{~km}^{2} . N_{\text {und }}, s$, and $C_{v} \%$ are calculated using a regression equation (Singer and Menzie, 2005)]

\begin{tabular}{|c|c|c|c|c|c|c|c|c|c|c|c|}
\hline \multicolumn{5}{|c|}{ Consensus undiscovered deposit estimates } & \multicolumn{5}{|c|}{ Summary statistics } & \multirow{2}{*}{$\begin{array}{c}\text { Tract Area } \\
\quad\left(\mathbf{k m}^{2}\right)\end{array}$} & \multirow{2}{*}{$\begin{array}{c}\text { Deposit density } \\
\left(N_{\text {total }} / 100,000 \text { km² }^{2}\right.\end{array}$} \\
\hline$N_{90}$ & $N_{50}$ & $N_{10}$ & $\boldsymbol{N}_{05}$ & $N_{01}$ & $N_{\text {und }}$ & $s$ & $C_{v} \%$ & $N_{\text {known }}$ & $N_{\text {total }}$ & & \\
\hline 0 & 2 & 4 & 4 & 4 & 2 & 1.5 & 73 & 5 & 7 & 12,230 & 57 \\
\hline
\end{tabular}

Table D7. Results of Monte Carlo simulation of undiscovered resources for tract 142pCu7305, Masbate-Negros Arc-Philippines.

[Cu, copper; Mo, molybdenum; Au, gold; and Ag, silver; in metric tons; Rock, in million metric tons]

\begin{tabular}{|c|c|c|c|c|c|c|c|c|}
\hline \multirow[b]{2}{*}{ Material } & \multicolumn{6}{|c|}{ Probability of at least the indicated amount } & \multicolumn{2}{|c|}{ Probability of } \\
\hline & 0.95 & 0.9 & 0.5 & 0.1 & 0.05 & Mean & $\begin{array}{c}\text { Mean or } \\
\text { greater }\end{array}$ & None \\
\hline Mo & 0 & 0 & 25,000 & 480,000 & 950,000 & 210,000 & 0.20 & 0.36 \\
\hline $\mathrm{Au}$ & 0 & 0 & 44 & 520 & 850 & 200 & 0.25 & 0.33 \\
\hline
\end{tabular}




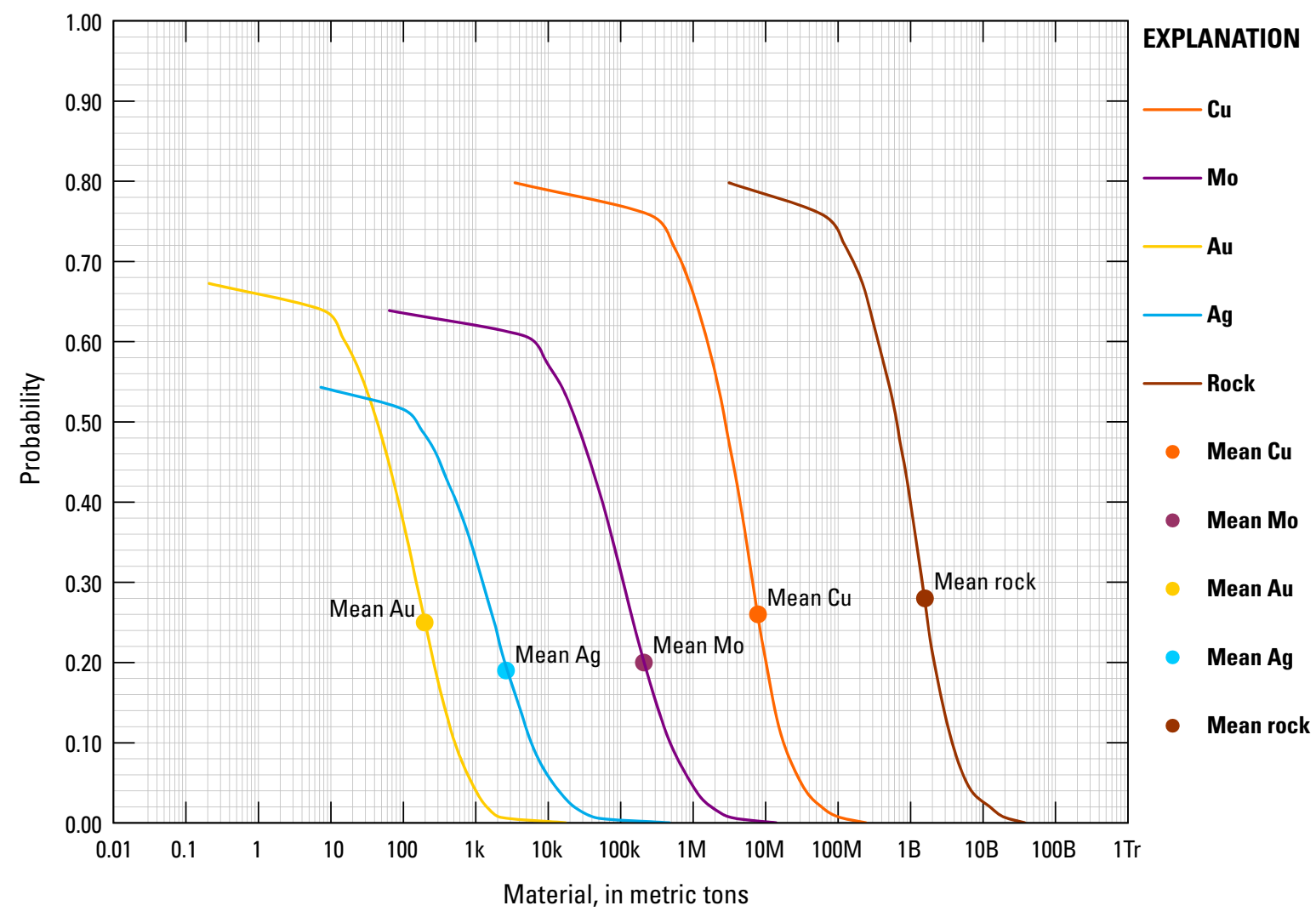

Figure D3. Cumulative frequency plot showing the results of Monte Carlo computer simulation of undiscovered resources in tract 142pCu7305, Masbate-Negros Arc_-Philippines. k, thousands; M, millions; B, billions; Tr, trillions.

\section{References Cited}

Abrasaldo, E.M., and Climie, J.A., 2003, Mindoro Resources, Ltd., Pan de Azucar Project, Iloilo Province, Philippines, Second Stage Drilling Program: accessed July 15, 2010, at http://www.mindoro.com/i/pdf/PandeAzucar_TechReport_03-01-20.pdf.

Bawiec, W.J., and Spanski, G.T., 2012, Quick-start guide for version 3.0 of EMINERS_Economic Mineral Resource Simulator: U.S. Geological Survey Open-File Report 2009-1057, 26 p., accessed June 30, 2012, at http://pubs. usgs.gov/of/2009/1057/. (This report supplements USGS OFR 2004-1344.)

Berger, B.R., Ayuso, R.A., Wynn, J.C., and Seal, R.R., 2008, Preliminary model of porphyry copper deposits: U.S. Geological Survey Open-File Report 2008-1321, 55 p., accessed May 15, 2009, at http://pubs.usgs.gov/ of/2008/1321/.

Border, A., Cavey, G., and Gunning, D., 2003, Technical report on the Hinoba-an Project, Negros Occidental, Republic of the Philippines: Report prepared for Constellation Copper Corporation, 81 p.
Copper Development Corporation, 2012, Copper Development Corporation: Copper Development Corporation Web page, accessed April 15, 2013, at http:// www.copperdevelopmentcorp.com/index.html.

Copper Resources Corporation, 2005, Hinoba-an porphyry copper project: Copper Resources Corporation, 147 p., accessed May 15, 2009, at http://www.copperresources. com/news/documents/CRC-AIM-Admission-Document.pdf.

Cox, D.P., 1986, Descriptive model of porphyry $\mathrm{Cu}$, in Cox, D.P., and Singer, D.A., eds., 1986, Mineral deposit models: U.S. Geological Survey Bulletin 1693, p. 76. (Also available at http://pubs.usgs.gov/bul/b1693/.)

Divis, A.F., 1983, The geology and geochemistry of Philippine porphyry copper deposits, in Hayes, D.E., ed., The tectonic and geologic evolution of Southeast Asian Seas and Islands-Part 2: Washington, American Geophysical Union, p. 173-216.

Domingo, B.B., 1980, Contribution to the geology of the Cansibit-Binuling ore body Sipalay mine, Negros Occidental: Journal of the Geological Society of the Philippines, v. 34 , no. 2 , p. 24-32. 
Duval, J.S., 2012, Version 3.0 of EMINERS-Economic Mineral Resource Simulator: U.S. Geological Survey Open-File Report 2004-1344, accessed July 15, 2012, at http://pubs. usgs.gov/of/2004/1344/.

Garwin, S., Hall, R., and Watanabe, Y., 2005, Tectonic setting, geology, and gold and copper mineralization in Cenozoic magmatic arcs of southeast Asia and the west Pacific, in Hedenquist, T.W., Thompson, J.F.H., Goldfarb, R.J., and Richards, J.P., eds., One hundredth anniversary volume 1905-2005: Littleton, Colorado, Society of Economic Geologists, p. 891-930.

Geograce Resource Philippines, Inc., 2010, Ayungon Project, Island of Negros [Philippines]: Geograce Resource Philippines, Inc., Web page, accessed April 8, 2010, at http:// www.geograce.com/ayungon.php.

Jacinto, R.P., and Hofilena, W.C., 1981, Geological and structural setting of the Muhong ore bodies in Basay, Negros Oriental: Journal of the Geological Society of the Philippines, v. 35, no. 3, p. 1-13.

John, D.A., Ayuso, R.A., Barton, M.D., Blakely, R.J., Bodnar, R.J., Dilles, J.H., Gray, Floyd, Graybeal, F.T., Mars, J.C., McPhee, D.K., Seal, R.R., Taylor, R.D., and Vikre, P.G., 2010, Porphyry copper deposit model, chap. B of Mineral deposit models for resource assessment: U.S. Geological Survey Scientific Investigations Report 2010-5070-B, 169 p., accessed September 8, 2010, at http://pubs.usgs.gov/ $\operatorname{sir} / 2010 / 5070 / \mathrm{b} /$.

Kinkel, A.R., Santos-Yñigon, L.M., Sanmaniego, S., and Crispin, O., eds., 1956, Copper deposits of the Philippines: Manila, Philippines, Bureau of Mines of the Philippines Special Project Series Publication No. 16-Copper, 305 p.

Malaihollo, J.F.A., Hall, R., and Macpherson, C.G., 2002, SE Asia Radiometric Ages: GIS Database accessed February 10, 2010, at http://searg.rhul.ac.uk/current_research/ isotopic_ages/SEAsia_GIS.pdf.

Malicdem, D.G., 1974, Notes of the geology and exploration of Hinobaan copper prospect, Negros Occidental: Journal of the Geological Society of the Philippines, v. 28, no. 3, p. 17-25.

Mindoro Resources, Ltd., 2010, Batangas Projects, [Philippines]: Mindoro Resources, Ltd., Web page, accessed April 8, 2010, at http://www.mindoro.com/s/Calo.asp.

Mindoro Resources, Ltd., 2012, Pan de Azucar: Mindoro Resources, Ltd., Web page, accessed May 15, 2012, at http://www.mindoro.com/s/PandeAzucarOverview.asp.
Mitchell, A.H.G, and Leach, T.M., 1991, Epithermal gold in the Philippines-Island arc metallogenesis, geothermal systems and geology: London, Academic Press, 457 p.

Motegi, M., 1977, Porphyry copper deposits in PhilippinesTheir tectonic setting and present status of development: Mining Geology, v. 27, p. 221-230.

Motton, Neil, 2009, Basay Copper Project: Report prepared for Adanacex Resources, Inc., (Philippines) and Solfotara Mining Corporation (Canada), 74 p., accessed March 17, 2014, at http://www.solfotara.com/project/basay/ basayreport-mar2009.pdf.

Philippine Bureau of Mines, 1963, Geological map of the Philippines: Philippine Bureau of Mines, 1 map on 8 sheets, scale $1: 1,000,000$.

Philippine Bureau of Mines and Geosciences, 1981, Geology and mineral resources of the Philippines, v. 1: Geology: Philippine Bureau of Mines and Geosciences, 406 p.

Philippine Bureau of Mines and Geosciences, 1986, Geology and mineral resources of the Philippines, v. 2-Mineral Resources: Philippine Bureau of Mines and Geosciences, 446 p.

Philippine Mines and Geosciences Bureau, [n.d.], Geology and mineral distribution map of the Philippines: Philippine Mines and Geosciences Bureau, 1 map on 4 sheets, scale $1: 1,400,000$.

Philippine Mines and Geosciences Bureau, 2004a, Digital geological map of the Philippines: Philippine Mines and Geosciences Bureau, scale 1:1,000,000. [Proprietary data.]

Philippine Mines and Geosciences Bureau, 2004b, Digital database of mineral occurrences of the Philippines: Philippine Mines and Geosciences Bureau. [Proprietary report.]

Philippines Mines and Geosciences Bureau, 2006, Region 6: Philippines Mines and Geosciences Bureau Web site, accessed May 15, 2010, at http://www.mgb6.org/revitalization-of-the-minerals-industry/.

Philippine Mines and Geosciences Bureau, 2007, Priority Mineral development projects of the Philippines: Philippine Mines and Geosciences Bureau, 27 p., accessed February 20, 2010, at http://www.mgb.gov.ph/revitalization_files/revi talization_23projectsprofile.pdf.

Pubellier, M., Quebrel, R., Rangin, C., Deffontaines, B., Muller, C., Butterlin, J., and Manzano, J., 1991, The Mindanao collision zone-A soft collision event within a continuous Neogene strike-slip setting: Journal of Southeast Asian Earth Sciences, v. 6, no. 3-4, p. 239-248. 
Root, D.H., Menzie, W.D., and Scott, W.A., 1992, Computer Monte Carlo simulation in quantitative resource estimation: Natural Resources Research, v. 1, no. 2 , p. $125-138$.

Rusina Mining NL., 2010, Pan de Azucar Project, Pan de Azucar Island [Philippines]: Rusina Mining NL. Web page, accessed April 8, 2010, at http://rmwiseresearch. com/wp-content/uploads/RMWise-RML-20080915.pdf.

Saegart, W.E., and Lewis, D.E., 1976, Characteristics of Philippine porphyry copper deposits and summary of current production and resources: American Institute of Mining, Metallurgical, and Petroleum Engineers Annual Meeting, February 22-26, 1976, Las Vegas, preprint no. 76-1-79, $46 \mathrm{p}$.

Sajona, F.G., Bellon, H., Maury, R.C., Pubellier, M., Quebral, R.D., Cotton, J., Bayon, F.E., Pagadi, E., and Pamatian, P., 1997, Tertiary and Quaternary magmatism in Mindanao and Leyte (Philippines) - Geochronology, geochemistry and tectonic setting: Journal of Asian Earth Sciences, v. 15, no. 2-3, p. 121-153.

Sajona, F.G., Maury, R.C., Pubellier, M., Leterrier, J., Bellon, H., and Cotton, J., 2000, Magmatic source enrichment by slab-derived melts in a young postcollision setting, central Mindanao (Philippines): Lithos, v. 54, p. 173-206.

Sevillano, A.C., and Fernando, C.J., 1981, Secondary dispersion pattern in the Basay porphyry copper deposits: Journal of the Geological Society of the Philippines, v. 35 , no. 3 , p. $14-25$.

Sillitoe, R.H., and Gappe, I.M., Jr., 1984, Philippine porphyry copper deposits-Geologic setting and characteristics: Committee for Co-ordination of Joint Prospecting for Mineral Resources in Asian Offshore Areas (CCOP), CCOP Technical Publication 14, 89 p.
Singer, D.A., and Menzie, W.D., 2005, Statistical guides to estimating the number of undiscovered mineral deposits-An example with porphyry copper deposits, in Cheng, Qiuming, and Bonham-Carter, Graeme, eds., Proceedings of IAMG-The annual conference of the International Association for Mathematical Geology: Toronto, Canada, York University, Geomatics Research Laboratory, p. 1028-1033.

Singer, D.A., Berger, V.I., and Moring, B.C., 2008, Porphyry copper deposits of the World-Database and grade and tonnage models, 2008: U.S. Geological Survey Open-File Report 2008-1155, accessed June 1, 2011, at http://pubs. usgs.gov/of/2008/1155/.

U.S. Department of State, 2009, Small-scale digital international land boundaries (SSIB) - Lines, edition 10, and polygons, beta edition 1, in Boundaries and sovereignty encyclopedia (B.A.S.E.): U.S. Department of State, Office of the Geographer and Global Issues.

U.S. Geological Survey, 2012, U.S. Geological Survey on-line mineral resources spatial data: U.S. Geological Survey Web site, accessed April 15, 2013, at http://mrdata.usgs.gov/.

Vigar, A.J., Motton, N.T., and Taylor, I., 2011, Competent person's report on the Basay Copper Project, Negros Oriental Province, Philippines: Report prepared by Mining Associates Limited for Copper Development Corporation, accessed May 15, 2012, at http://www. copperdevelopmentcorp.com/project/basayproject.html, $84 \mathrm{p}$.

Walther, H.W., Förster, H., Harre, W., Kreuzer, H., Lenz, H., Müller, P., and Raschka, H., 1981, Early Cretaceous porphyry copper mineralization on Cebu Island, Philippines, dated with $\mathrm{K}-\mathrm{Ar}$ and $\mathrm{Rb}-\mathrm{Sr}$ methods: Geologische Jahrbuch, Reihe D, Hf. 48, p. 21-35.

Yumul, G.P., Jr., Dimalanta, C.B., Maglambayan, V.B., and Marquez, E.J., 2008, Tectonic setting of a composite terrane-A review of the Philippine island arc system: Geosciences Journal, v. 12, no. 1, p. 7-17. 


\section{Appendix E. Porphyry Copper Assessment for Tract 142pCu7309, Philippine Arc-Philippines}

By Jane M. Hammarstrom ', Arthur A. Bookstrom², Connie L. Dicken', Steve Ludington³, Gilpin R. Robinson, Jr.', and Michael L. Zientek ${ }^{2}$ with contributions from Sevillo (Bill) D. David, Jr., Claro J. Manipon ${ }^{4}$, Lilian A. Rollan ${ }^{4}$, and Yasushi Watanabe ${ }^{5}$

\section{Deposit Type Assessed: Porphyry copper, copper-gold subtype}

Descriptive model: Porphyry copper (Cox, 1986; Berger and others, 2008; John and others, 2010; Sillitoe and Gappe, 1984) Grade and tonnage model: Porphyry copper, copper-gold subtype (Singer and others, 2008)

Table E1 summarizes selected assessment results.

Table E1. Summary of selected resource assessment results for tract 142pCu7309, Philippine Arc_Philippines.

[km, kilometers; $\mathrm{km}^{2}$, square kilometers; t, metric tons; identified copper rounded to two significant figures]

\begin{tabular}{cccccc}
\hline $\begin{array}{c}\text { Date of } \\
\text { assessment }\end{array}$ & $\begin{array}{c}\text { Assessment depth } \\
(\mathbf{k m})\end{array}$ & Tract area $\left(\mathbf{k m}^{2}\right)$ & $\begin{array}{c}\text { Identified copper } \\
\text { resources }(\mathbf{t})\end{array}$ & $\begin{array}{c}\text { Mean estimate of } \\
\text { undiscovered copper } \\
\text { resources }(\mathbf{t})\end{array}$ & $\begin{array}{c}\text { Median estimate of } \\
\text { undiscovered copper } \\
\text { resources }(\mathbf{t})\end{array}$ \\
\hline 2010 & 1 & 23,700 & $6,300,000$ & $24,000,000$ \\
\hline
\end{tabular}

\section{Location}

Eastern Philippines, extending from the Bicol Peninsula of southeastern Luzon Island southwards through Leyte and along eastern Mindanao (fig. E1).

\section{Geologic Feature Assessed}

Oligocene to Holocene Philippine Arc.

${ }^{1}$ U.S. Geological Survey, Reston, Virginia, United States.

${ }^{2}$ U.S. Geological Survey, Spokane, Washington, United States.

${ }^{3}$ U.S. Geological Survey, Menlo Park, California, United States.

${ }^{4}$ Philippine Department of Environment and Natural Resources, Mines and Geosciences Bureau, Quezon City, Philippines.

${ }^{5}$ Geological Survey of Japan, National Institute of Advanced Industrial Science and

Technology (AIST), Ibaraki, Japan. 
$\boldsymbol{A}$

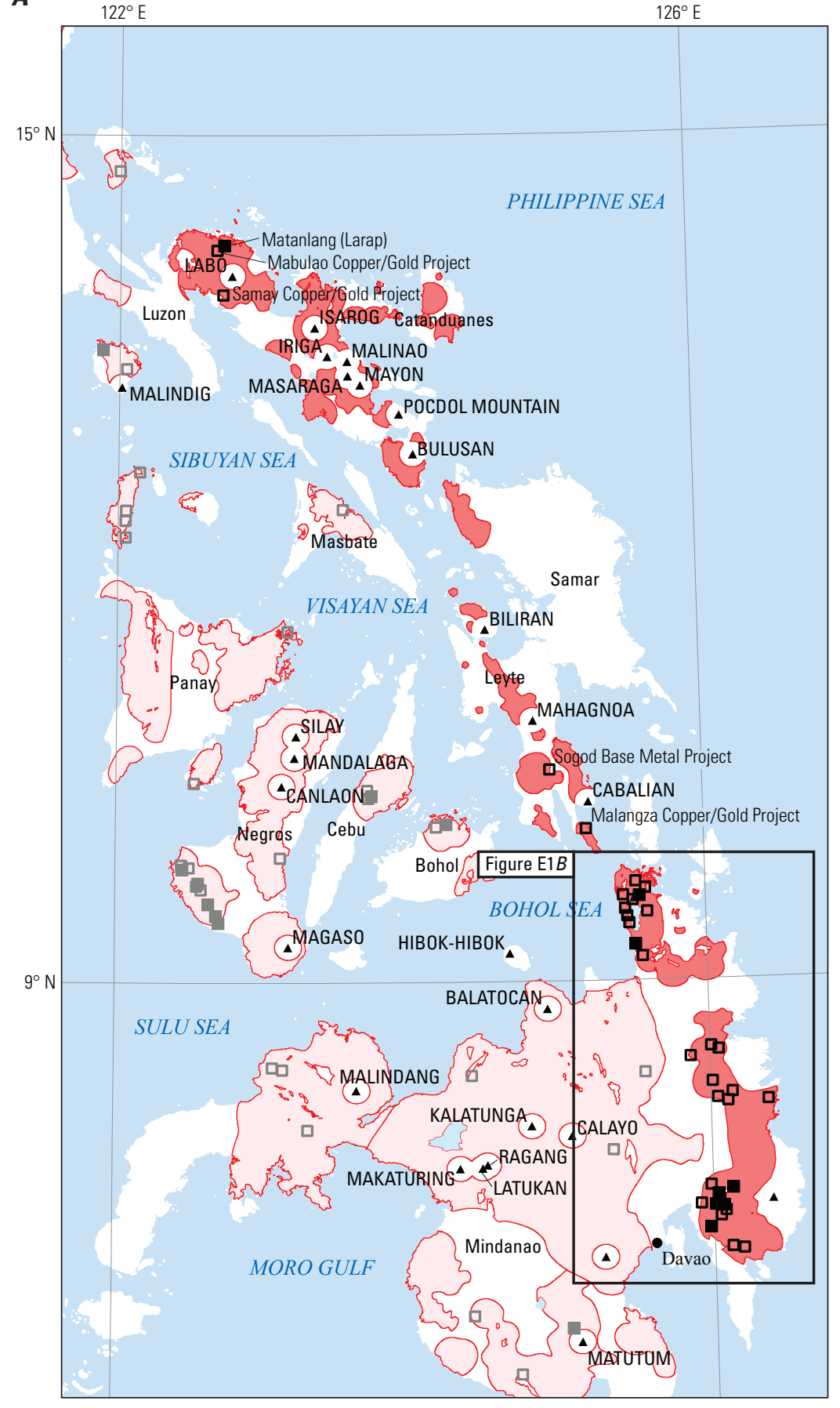

Political boundaries from U.S. Department of State (2009). Asia North Albers Equal Area Conic Projection.

Central meridian, $125^{\circ} \mathrm{E}$., latitude of origin, $30^{\circ} \mathrm{N}$.

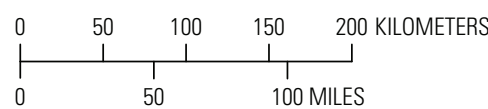

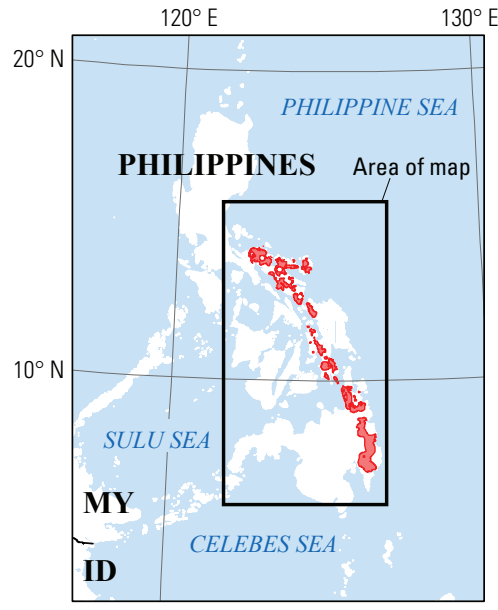

\section{EXPLANATION}

Assessed porphyry copper tract 142pCu7309

Other porphyry copper tracts

Porphyry copper deposit;

- deposits associated with other tracts shown in gray

Porphyry copper prospect;

- prospects associated with other tracts shown in gray

- Volcano

Figure E1. Maps showing tract location and significant porphyry copper prospects for tract 142pCu7309, Philippine Arc-Philippines. $A$, Map of entire tract; $B$, map of eastern Mindanao. MY, Malaysia; ID, Indonesia. 

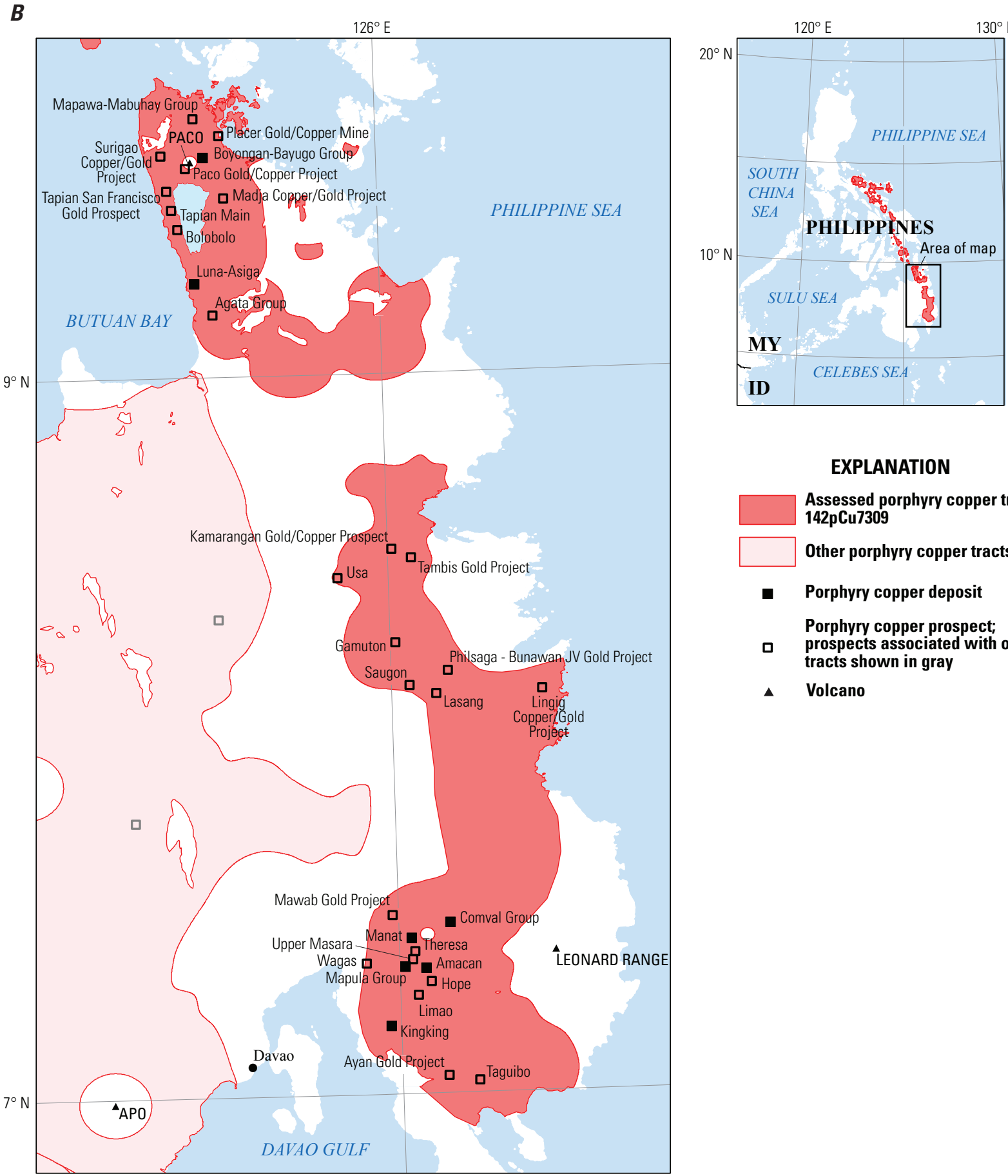

\section{EXPLANATION}

Assessed porphyry copper tract 142pCu7309

Other porphyry copper tracts

- Porphyry copper deposit

Porphyry copper prospect;

- prospects associated with other tracts shown in gray

- Volcano

Political boundaries from U.S. Department of State (2009). Asia North Albers Equal Area Conic Projection.

Central meridian, $125^{\circ} \mathrm{E}$., latitude of origin, $30^{\circ} \mathrm{N}$.

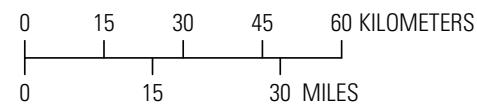

Figure E1.-Continued 


\section{Delineation of the Permissive Tract}

\section{Tectonic Setting}

The 1,000-km-long Oligocene to Holocene Philippine Arc extends from Bicol to eastern Mindanao, parallel to the Philippine Fault (fig. $5 B^{6}$ ). Arc magmatism is related to westdirected subduction of the Philippine Sea Plate at the Philippine Trench (fig. 5B). Arc segments (fig. E2), from north to south, are (Yumul and others, 2008):

- Bicol (northern) segment - medium- to high-K calc-alkalic rocks, high-Al basalts and andesites

- Leyte segment-a 250-km-long, southeast-trending belt of Plio-Pleistocene volcanoes characterized as mediumto high-K calc-alkalic rocks, Miocene andesitic rocks

- Northeastern Mindanao segment-Lower OligoceneLower Miocene rocks and Pliocene-Quaternary andesites

The level of erosion generally increases from north to south on the basis of the relative amounts of mapped volcanic and intrusive rocks (fig. E2). The Bicol arc segment includes several Quaternary volcanoes. The Leyte segment is mostly defined by permissive volcanic rocks, and the northeastern Mindanao segment is mainly defined by scattered intrusions.

\section{Geologic Criteria}

The tract outlines the mapped extent of Paleogene and Neogene intrusions, including diorite complexes, and Oligocene-Miocene andesitic volcanic rocks (fig. E2, table E2). The tract includes Late Pliocene intrusions associated with porphyry deposits in northeastern Mindanao. Parts of the tract are overlain by Pliocene-Quaternary volcanic cover (map units QVP and QV, not shown on fig. E2). The Philippine Fault Zone forms the western boundary of the tract, which extends to the coast of eastern Mindanao.

The tract was constructed by selecting permissive Eocene to Holocene igneous rocks that lie within the Philippine Arc as defined by Garwin and others (2005) from the digital version of the 1:1,000,000-scale geologic map of the Philippines (Philippine Bureau of Mines and Geosciences, 2004a). A preliminary tract was constructed by using GIS tools to make 10- and 2-km buffers around intrusive and volcanic rocks, respectively. These distances are considered appropriate to allow for inaccuracies in mapped contacts and extensions under adjacent cover rock. The buffered map unit polygons were aggregated, smoothed, and edited by hand and tract boundaries were checked to include known prospects and permissive igneous rocks shown on maps included in topical studies (Malaihollo and others, 2002). Circular cutouts in the tract represents areas around the Quaternary stratovolcanoes, where the thickness of volcanic cover is likely to be greater than $1 \mathrm{~km}$ thick above the tops of undiscovered porphyry systems. Final tract boundaries were edited by hand to honor fault boundaries and include prospects and dated igneous-rock localities (Malaihollo and others, 2002). As a last step, the tracts were clipped to coastlines (U.S. Department of State, 2009).

Deposits and prospects (figs. E1, E2) do not always overlie permissive mapped igneous rocks. This is an effect of map scale $(1: 1,000,000)$. Many of the intrusions associated with porphyry copper deposits, if exposed at all, crop out over an area of greater than $1 \mathrm{~km}^{2}$. The 1:50,000-scale geologic maps series for the Philippines shows more detail. Spot checks of available 1:50,000-scale maps show that small intrusions of permissive rocks lie within the tract boundaries based on the smaller scale maps.

\section{Known Deposits}

The tract includes 8 porphyry copper deposits that range in age from $4 \mathrm{Ma}$ at Boyangan to $21 \mathrm{Ma}$ at Matanlang (table E3). Characteristics of the larger deposits in the tract are described below. Data reported for Mapula represent 1963-1980 era drilling; historical data are listed for Kalamatan and Taagpura-Maangob as reported by Singer and others (2008). Taagpura-Maangob was mined by open-pit methods from 1978-1981. However, these two deposits remain open and are currently under exploration as part of the Comval Group (fig. E1, table E4). Inferred resources reported in 2013 for the Comval copper-gold project (32.675 Mt at 0.42 percent copper and $0.13 \mathrm{~g} / \mathrm{t}$ gold for greater than 0.3 percent copper) include the Maangob, Kalamantan, Tagpura West, and Tagpura East target areas within a 4,310 hectare (ha) exploration area (Cadan Resources, 2013). The additional resources suggest that the total contained copper for the group may be on the order of 560,000 t.

\section{Boyongan-Bayugo Group}

The Boyongan deposit has the highest average copper grade ( 0.82 percent copper) of all the deposits within the Philippine Arc. The high grade reflects the ultra-deep oxidation zone (600 m thick), which is the deepest oxidation reported for a porphyry system anywhere in the world (Braxton and others, 2009). This oxidation profile is especially unusual for a humid tropical setting where most oxidation profiles are less than $100 \mathrm{~m}$ thick. The deposit was preserved under $50-350 \mathrm{~m}$ of postmineral cover. The local physiographic conditions allowed a thick supergene zone to form at Boyangan, in contrast to the adjacent Bayugo deposit, where the zone is about $70 \mathrm{~m}$ thick. The deposits are associated with the multiple diorite intrusive complexes and were discovered by exploration in the late 1990s along a belt of intrusion-centered gold-rich porphyry deposits in northeastern Mindanao.

${ }^{6}$ Refer to figures and tables in main report. 

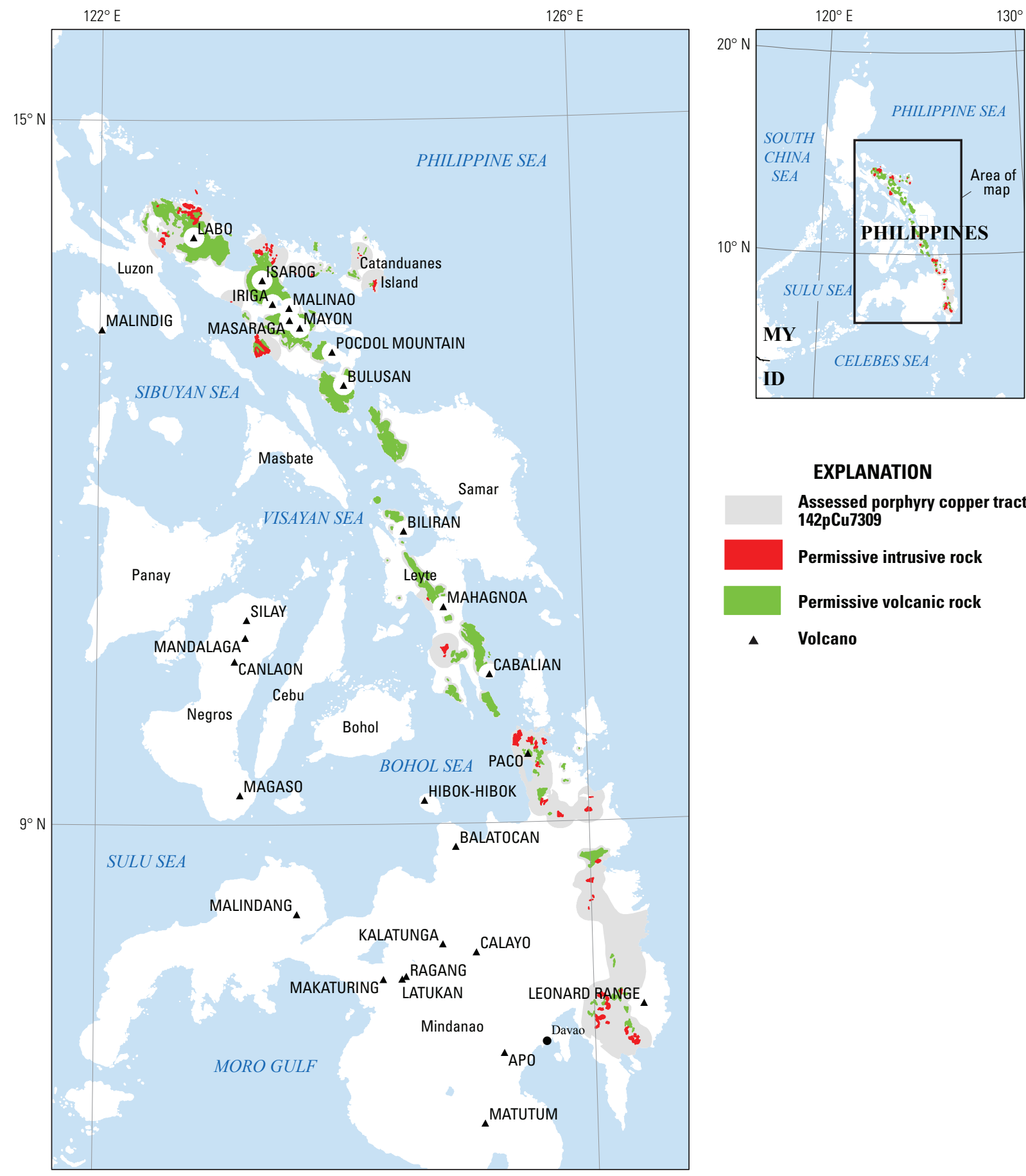

\section{EXPLANATION}

Assessed porphyry copper tract 142pCu7309

Permissive intrusive rock

Permissive volcanic rock

- Volcano

Political boundaries from U.S. Department of State (2009). Asia North Albers Equal Area Conic Projection.

Central meridian, $125^{\circ} \mathrm{E}$., latitude of origin, $30^{\circ} \mathrm{N}$.

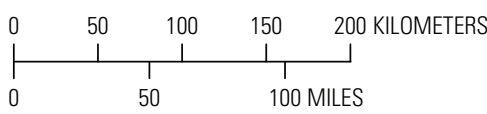

Figure E2. Map showing the distribution of permissive igneous rocks for tract 142pCu7309, Philippine Arc-Philippines. MY, Malaysia; ID, Indonesia. The Philippine arc is divided into three segments - the Bicol segment extends northwestward from Samar Island, the Leyte segment covers the central part of the arc, and the Mindanao segment extends southeastward from northern Mindanao Island. 
Table E2. Map units that define tract 142pCu7309, Philippine Arc—Philippines.

[Map unit, age range, and principal lithologies are based on a digital compilation of the 1963 1:1,000,000 scale geologic map of the Philippines (Philippine Bureau of Mines, 1963)]

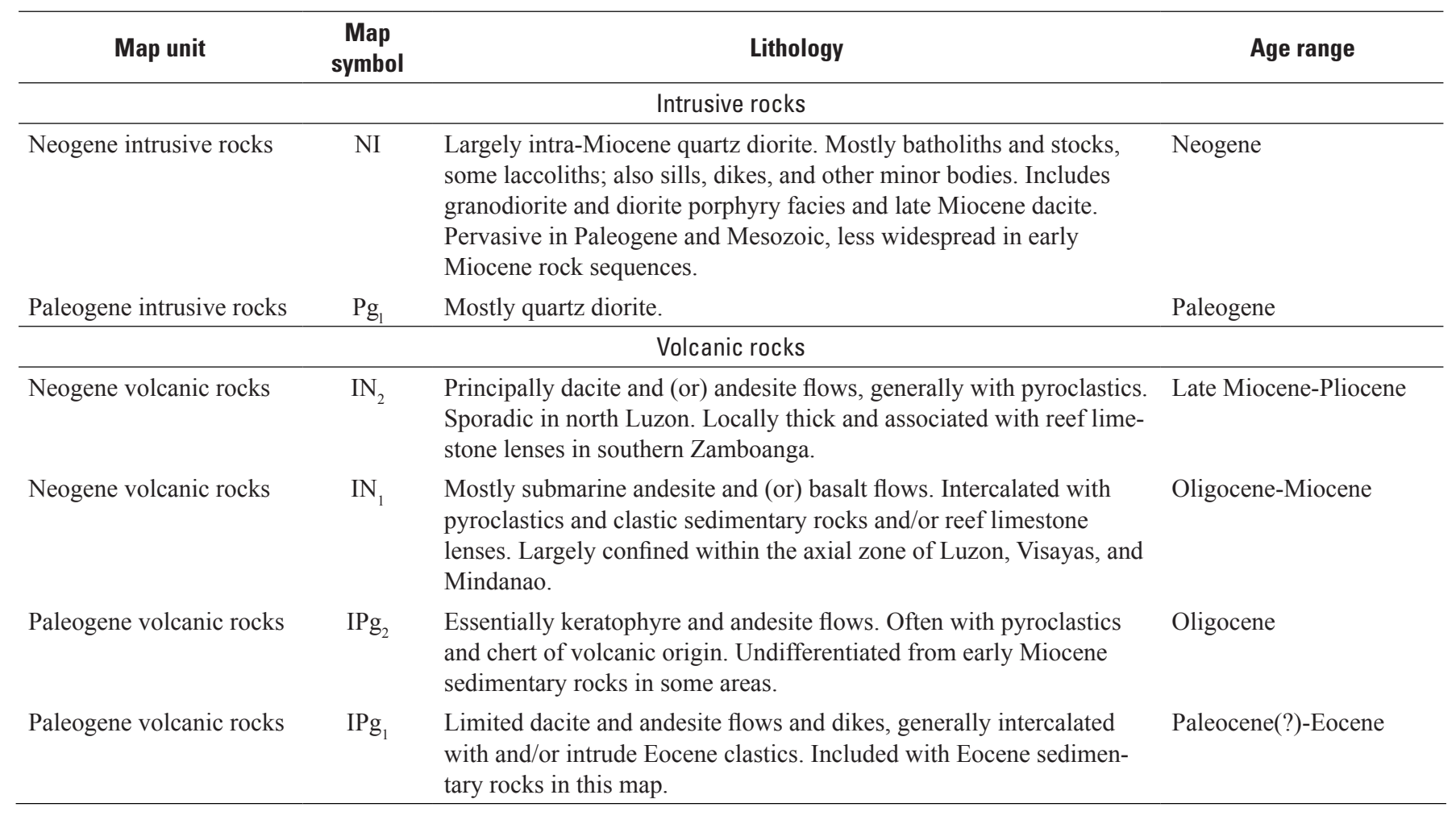

\section{Kingking}

The Kingking deposit, which is exposed at the surface, is located between two splays of the Philippine Fault. Copper and gold are associated with a 1,800 by $400 \mathrm{~m}$, northweststriking, elongated Miocene diorite complex that has intruded pyroclastic rocks, andesite flows, and intercalated sedimentary rocks (Hester and others, 2010). In the main intrusion, a biotite diorite porphyry, the principal ore mineral is bornite. The hydrothermal alteration at Kingking differs from many other Philippine porphyry copper deposits in several aspects (Hester and others, 2010) - (1) biotite and potassic alteration zones are well-developed; (2) a phyllic (quartz-sericite-pyrite) zone is absent and replaced by a quartz-sericite-chlorite, so the deposit has a low pyrite content; (3) epidote occurs in all alteration zones, not only in the propylitic zone; and (4) advanced argillic alteration is only developed locally along structures outside the main ore zone.
The deposit was first drilled in the late 1960s and had a tonnage estimate of $93 \mathrm{Mt}$ at that time. The most recent resources announced are total (measured, indicated, and inferred) resources of $1,151 \mathrm{Mt}$ at 0.25 percent copper and $0.32 \mathrm{~g} / \mathrm{t}$ gold (Hester and others, 2010). About a third of the resource is oxide ore in a $230 \mathrm{~m}$ thick supergene zone with an average grade of 0.62 percent copper (Braxton and others, 2009). As of May 2012, the deposit was in the initial phases of permitting for development (St. Augustine Gold and Copper Limited, 2012).

\section{Amacan}

The exposed Amacan deposit was staked in 1963 and operated as an open-pit mine from 1982 until 1992. The mine produced $50 \mathrm{Mt}$ of ore averaging 0.39 percent copper and $0.30 \mathrm{~g} / \mathrm{t}$ gold. Drill-indicated reserves of $65 \mathrm{Mt}$ at 0.34 percent copper and $0.412 \mathrm{~g} / \mathrm{t}$ gold remain. The mine closed due to low copper prices, decreasing copper grades, and operational issues. 
Table E3. Porphyry copper deposits in tract 142pCu7309, Philippine Arc-Philippines.

[Ma, million years; Mt, million metric tons; $\mathrm{t}$, metric ton; $\mathrm{g} / \mathrm{t}$, gram per metric ton; $\%$, percent. $\mathrm{Cu}$-Au subtype, deposits that have Au/Mo ratios $>30$ or average Au grades $>0.2 \mathrm{~g} / \mathrm{t}$; NA, not applicable; n.d., no data. Contained $\mathrm{Cu}$ in metric tons is computed as $(\mathrm{Mt} \times 1,000,000) \times(\mathrm{Cu}$ grade, $\% \div 100)$. Deposits are listed from north to south.*, Historical resource estimates reported by Singer and others (2008); these are part of the Comval copper-gold prospect area shown on figure E1B. Age, based on mid-point of age range reported by Singer and others, 2008)]

\begin{tabular}{|c|c|c|c|c|c|c|c|c|c|c|c|}
\hline Name & Latitude & Longitude & Subtype & $\begin{array}{c}\text { Age } \\
\text { (Ma) }\end{array}$ & $\begin{array}{c}\text { Tonnage } \\
\text { (Mt) }\end{array}$ & $\mathrm{Cu}(\%)$ & Mo (\%) & $A u(g / t)$ & $\mathrm{Ag}(\mathrm{g} / \mathrm{t})$ & $\begin{array}{c}\text { Contained } \\
\mathrm{Cu}(\mathrm{t})\end{array}$ & Reference \\
\hline $\begin{array}{l}\text { Matanlang } \\
\text { (Larap) }\end{array}$ & 14.233 & 122.733 & $\mathrm{Cu}-\mathrm{Au}$ & 20.5 & 65 & 0.35 & 0.005 & 0.40 & n.d. & 227,500 & $\begin{array}{l}\text { Frost (1959), Mitchell and } \\
\text { Leach (1991), Sillitoe and } \\
\text { Gappe (1984), Singer and } \\
\text { others (2008), Uriate (1972) }\end{array}$ \\
\hline $\begin{array}{l}\text { Boyongan- } \\
\text { Bayugo } \\
\text { Group }\end{array}$ & 9.605 & 125.554 & $\mathrm{Cu}-\mathrm{Au}$ & 3.5 & 244 & 0.82 & n.d. & 0.83 & n.d. & $2,000,800$ & $\begin{array}{l}\text { Anonymous (2001a,b), } \\
\text { Anonymous (2001c), } \\
\text { Anonymous (2002), Braxton } \\
\text { and Cooke (2005), Brax- } \\
\text { ton and others (2009), } \\
\text { Feebrey (2001), Ferreira } \\
\text { (2008, 2009), Josef (2002), } \\
\text { Philippine Mines and Geosci- } \\
\text { ences Bureau (2007), Singer } \\
\text { and others (2008) }\end{array}$ \\
\hline Luna-Asiga & 9.258 & 125.523 & NA & 3.5 & 26 & 0.36 & 0.01 & n.d. & n.d. & 93,600 & $\begin{array}{l}\text { Mitchell and Leach (1991), } \\
\text { Sillitoe and Gappe (1984), } \\
\text { Singer and others (2008) }\end{array}$ \\
\hline Kalamatan* & 7.504 & 126.130 & $\mathrm{Cu}-\mathrm{Au}$ & n.d. & 26 & 0.34 & n.d. & 0.37 & n.d. & 88,400 & $\begin{array}{l}\text { Fernandez (1986), Sillitoe } \\
\text { and Gappe (1984), Singer } \\
\text { and others (2008), Sur } \\
\text { American Gold Corp. (2007) }\end{array}$ \\
\hline $\begin{array}{l}\text { Tagpura- } \\
\text { Maangob* }\end{array}$ & 7.476 & 126.131 & $\mathrm{Cu}-\mathrm{Au}$ & n.d. & 76 & 0.44 & 0.008 & 0.50 & 4 & 332,640 & $\begin{array}{l}\text { Fernandez (1986), Sillitoe } \\
\text { and Gappe (1984), Singer } \\
\text { and others (2008), Society of } \\
\text { Economic Geologists (1999), } \\
\text { Sur American Gold Corp. } \\
\text { (2007) }\end{array}$ \\
\hline $\begin{array}{l}\text { Mapula } \\
\text { Group }\end{array}$ & 7.355 & 126.014 & $\mathrm{Cu}-\mathrm{Au}$ & 10.0 & 78 & 0.40 & n.d. & 0.37 & 3.6 & 312,000 & $\begin{array}{l}\text { Bolaño (2010), Fernandez } \\
\text { (1986), Saegart and Lewis } \\
\text { (1976), Sillitoe and Gappe } \\
\text { (1984), Singer and others } \\
\text { (2008) }\end{array}$ \\
\hline Amacan & 7.350 & 126.067 & $\mathrm{Cu}-\mathrm{Au}$ & 10.0 & 110 & 0.37 & n.d. & 0.40 & 2.5 & 407,000 & $\begin{array}{l}\text { Fernandez (1986), Mercado } \\
\text { and others (1987), Philippine } \\
\text { Mines and Geosciences } \\
\text { Bureau (2007), Mitchell and } \\
\text { Leach (1991), Sillitoe and } \\
\text { Gappe (1984), Singer and } \\
\text { others (2008) }\end{array}$ \\
\hline Kingking & 7.192 & 125.975 & $\mathrm{Cu}-\mathrm{Au}$ & 10.0 & 1,151 & 0.25 & n.d. & 0.32 & 5 & $2,877,500$ & $\begin{array}{l}\text { Almogela (1974), Fernan- } \\
\text { dez (1986), Fortuna (1998), } \\
\text { Philippine Mines and } \\
\text { Geosciences Bureau (2007), } \\
\text { Mitchell and Leach (1991), } \\
\text { Philippine Society of Mining } \\
\text { Engineers (2007), Sillitoe } \\
\text { (1989), Sillitoe and Gappe } \\
\text { (1984), Singer and others } \\
\text { (2008), St. Augustine Gold } \\
\text { and Copper, Ltd. (2012) }\end{array}$ \\
\hline
\end{tabular}




\section{Prospects, Mineral Occurrences, and Related Deposit Types}

The tract contains 34 prospect areas (fig. E1, table E4) most of which lie in the southernmost segment of the Philippine Arc in eastern Mindanao. Many of these prospects are relatively recent, early stage exploration targets that have not been confirmed by drilling. Prospects include partially drilled deposits, grass roots exploration targets, epithermal gold deposits or prospects that have some indications of a possible associated porphyry system, and copper occurrences that reportedly represent porphyry-copper types (C. Manipon, written commun., 2004). For example, the Tapian Main and Tapian San Francisco porphyry prospects are in an area mined for gold before World War II, where 1990s-era stream-sediment and soil geochemical anomalies and mapped alteration prompted further interest. Prospects within the tract are listed from north to south in table E4.

\section{Exploration History}

The tract area was explored in the 1960s and has recently (late 1990s to present) been the focus of another round of exploration. Discovery of the buried Boyongan deposit prompted exploration interest in eastern Mindanao for additional targets. Historical epithermal gold districts described by Mitchell and Leach (1991) in the Eastern Mindanao Gold Province (Surigao, Central, and Masara districts on fig. E1) are a focus of recent exploration for porphyry systems at depth below epithermal vein systems or adjacent to such deposits.

\section{Sources of Information}

Principal sources of information for this assessment are listed in table E5.

\section{Grade and Tonnage Model Selection}

The porphyry copper-gold subtype model is appropriate for the assessment, as indicated by the statistical tests (table 4), although the deposits also fit a the general model. Molybdenum grades are available for only three of the deposits, so the general model was rejected. Historical tonnages reported in the older literature are not compliant with modern reporting standards; some of these "deposits" are being reevaluated and are almost certainly "open" in one or more directions.

\section{Estimate of the Number of Undiscovered Deposits}

\section{Rationale for the Estimate}

The tract contains 34 prospects that include known porphyry copper prospects, exploration projects targeting porphyry copper/gold systems, and some gold exploration targets that may overlie or lie adjacent to porphyry systems. Recent exploration projects are targeting buried systems; the Boyongan deposit, for example, is covered by 50 to $300 \mathrm{~m}$ of lake sediments and lava flows. Indications that additional 
Table E4. Significant prospects and occurrences in tract 142pCu7309, Philippine Arc—Philippines.

$[\%$, percent; g/t, grams per metric ton; km, kilometers; m, meters; ha, hectares; ppm, parts per million; SCC, sericite-chlorire-clay. Rank 4=prospect listed in global database of Singer and others (2008) or $<16,000 \mathrm{t}$ of ore established by drilling. Rank $3=$ drilled, with $>20 \mathrm{~m}$ of $0.2 \%$ or more Cu. Rank $2=$ drilled or trenched with $<20 \mathrm{~m}$ of $0.2 \% \mathrm{Cu}$, or past or ongoing exploration. Rank $1=$ copper occurrence that may be related to porphyry-type mineralization based on stream sediment or magnetic anomaly or location along structural trend]

\begin{tabular}{|c|c|c|c|c|c|c|}
\hline Name & Latitude & Longitude & Age & Comments & Reference & Rank \\
\hline \multicolumn{7}{|c|}{ Bicol arc segment } \\
\hline $\begin{array}{l}\text { Mabulao Copper/ } \\
\text { Gold Project }\end{array}$ & 14.200 & 122.683 & Neogene & $\begin{array}{l}\text { Exploration project in Paracele old } \\
\text { mining district, } \sim 7 \mathrm{~km} \mathrm{SW} \text { of } 20.5 \mathrm{Ma} \\
\text { Matanglan (Larap) porphyry copper-gold } \\
\text { deposit. Explored } 1960 .\end{array}$ & Altai Resources, Inc. (2003) & 3 \\
\hline $\begin{array}{l}\text { Samay Copper/ } \\
\text { Gold Project }\end{array}$ & 13.886 & 122.727 & Neogene & $\begin{array}{l}\text { Exploration on epithermal veins and } \\
\text { potential porphyry copper at depth on } \\
\text { property explored by Phelps/Dodge } \\
\text { in } 2004-2005 \text {. Drill targets in argillic } \\
\text { alteration zones. }\end{array}$ & $\begin{array}{l}\text { RoyalCo Resources, Ltd. } \\
\text { (2006) }\end{array}$ & 2 \\
\hline \multicolumn{7}{|c|}{ Leyte arc segment } \\
\hline $\begin{array}{l}\text { Sogod Base Metal } \\
\text { Project (Leyte) }\end{array}$ & 10.520 & 124.960 & Neogene & $\begin{array}{l}\text { Epithermal gold and porphyry copper- } \\
\text { gold early exploration project on south- } \\
\text { ern Leyte in large areas of hydrothermal } \\
\text { alteration, geochemical anomalies. }\end{array}$ & $\begin{array}{l}\text { Indophil Resources NL } \\
\text { (2002) }\end{array}$ & 1 \\
\hline $\begin{array}{l}\text { Malangza Cop- } \\
\text { per/Gold Project }\end{array}$ & 10.095 & 125.204 & Neogene & $\begin{array}{l}\text { Exploration project for epithermal gold- } \\
\text { porphyry system based on hydrother- } \\
\text { mally-altered area; drilling was targeted } \\
\text { for } 2008 \text {; outcome unknown. }\end{array}$ & $\begin{array}{l}\text { RoyalCo Resources, Ltd. } \\
\text { (2010) }\end{array}$ & 1 \\
\hline \multicolumn{7}{|c|}{ Northeast Mindanao arc segment } \\
\hline $\begin{array}{l}\text { Mapawa- } \\
\text { Mabuhay Group }\end{array}$ & 9.712 & 125.530 & Neogene & $\begin{array}{l}\text { Mapawa exploration target: diorite- } \\
\text { hosted copper-gold porphyry system } \\
\text { with intact cap in altered andesite; drill } \\
\text { intercepts } 53 \mathrm{~m} \text { of } 0.2 \% \mathrm{Cu}, 0.8 \mathrm{~g} / \mathrm{t} \\
\mathrm{Au} \text {, and } 2.4 \mathrm{~g} / \mathrm{t} \mathrm{Ag} \text {. Mabuhay: Old gold } \\
\text { mine (underground } 1957 \text { to } 1953 \text {; open } \\
\text { pit } 1995-2000 \text { ); exploration target for } \\
\text { a deep porphyry copper-gold system } \\
\text { associated with high-sulfidation epi- } \\
\text { thermal gold deposit; drill intercept ( } 1 \\
\text { hole) } 243 \mathrm{~m} \text { of } 0.227 \% \mathrm{Cu}, 0.24 \mathrm{~g} / \mathrm{t} \mathrm{Au} \text {, } \\
\text { and } 0.0088 \% \text { Mo. Drilling to } 770 \text { and } \\
1,000 \mathrm{~m} \text { in other holes encountered only } \\
\text { weakly altered diorite, possible diatreme } \\
\text { breccia. }\end{array}$ & $\begin{array}{l}\text { Red } 5 \text { Limited (2010), } \\
\text { Rugby Mining, Ltd. (2011a, } \\
\text { b; 2012) }\end{array}$ & 3 \\
\hline $\begin{array}{l}\text { Placer Gold/ } \\
\text { Copper Mine }\end{array}$ & 9.664 & 125.595 & Miocene (?) & $\begin{array}{l}\text { Small, low-grade porphyry copper } \\
\text { mineralization in SCC-altered basaltic } \\
\text { to andesitic flows with chalcopyrite } \pm \\
\text { molybdenite, pyrite, magnetite, and } \\
\text { hematite in veinlets. May be mid- to late } \\
\text { Miocene. }\end{array}$ & $\begin{array}{l}\text { Manila Mining Corporation } \\
\text { (2010), Mitchell and Leach } \\
\text { (1991) }\end{array}$ & 1 \\
\hline $\begin{array}{l}\text { Surigao Copper/ } \\
\text { Gold Project } \\
\text { (MAT-I) }\end{array}$ & 9.612 & 125.445 & Neogene & $\begin{array}{l}\text { Exploration project area on Eastern } \\
\text { Mindanao Ridge. } \mathrm{Cu}-\mathrm{Au} \text { soil anomalies. } \\
\text { Historical artisanal gold mining area. }\end{array}$ & $\begin{array}{l}\text { Oz Minerals Ltd. (2010), } \\
\text { Bailey (2003) }\end{array}$ & 2 \\
\hline
\end{tabular}


Table E4. Significant prospects and occurrences in tract 142pCu7309, Philippine Arc—Philippines.—Continued

[\%, percent; g/t, grams per metric ton; km, kilometers; m, meters; ha, hectares; ppm, parts per million; SCC, sericite-chlorire-clay. Rank 4=prospect listed in global database of Singer and others (2008) or $<16,000 \mathrm{t}$ of ore established by drilling. Rank $3=$ drilled, with $>20 \mathrm{~m}$ of $0.2 \%$ or more Cu. Rank $2=$ drilled or trenched with $<20 \mathrm{~m}$ of $0.2 \% \mathrm{Cu}$, or past or ongoing exploration. Rank $1=$ copper occurrence that may be related to porphyry-type mineralization based on stream sediment or magnetic anomaly or location along structural trend]

\begin{tabular}{|c|c|c|c|c|c|c|}
\hline Name & Latitude & Longitude & Age & Comments & Reference & Rank \\
\hline $\begin{array}{l}\text { Kalaya-an } \\
\text { Copper/Gold } \\
\text { Project }\end{array}$ & 9.611 & 125.545 & Neogene & $\begin{array}{l}\text { Exploration area adjacent to (north of) } \\
\text { Boyongan project area. Diorite porphyry } \\
\text { dikes; breccias. }\end{array}$ & $\begin{array}{l}\text { Manila Mining Corporation } \\
\text { (2010) }\end{array}$ & 1 \\
\hline $\begin{array}{l}\text { Paco Gold/ } \\
\text { Copper Project }\end{array}$ & 9.576 & 125.507 & Neogene & $\begin{array}{l}\text { Adjacent to the porphyry copper-gold } \\
\text { deposits at Boyongan and Bayugo. } \\
\text { Geophysical data suggest similar struc- } \\
\text { tural settings at Paco with potential for } \\
\text { porphyry-epithermal systems. Recon- } \\
\text { naissance drilling has so far failed to } \\
\text { penetrate the overlying Quaternary cover } \\
\text { to test targets. }\end{array}$ & $\begin{array}{l}\text { Oceana Gold Corporation } \\
(2010)\end{array}$ & 2 \\
\hline
\end{tabular}

\begin{tabular}{llll}
\hline Tapian San & 9.515 & 125.457 & Neogene \\
Francisco Gold & & & \\
Prospect & & &
\end{tabular}

Porphyry $\mathrm{Cu}-\mathrm{Au}$ prospect along NEtrending lineaments towards Boyangan and Bayugo. Partly overlaps $6 \mathrm{~km}$ intrusive complex (Masgad porphyry and Mayag porphyry). Induced polarization anomalies, drilled intercepts of $>20$ $\mathrm{m}$ of $1.01 \% \mathrm{Cu}, 0.56 \mathrm{~g} / \mathrm{t} \mathrm{Au}, 19.02 \mathrm{~g} / \mathrm{t}$ Ag. $\mathrm{Cu}, \mathrm{Au}, \mathrm{Zn}$ soil anomalies. Altered andesite (propylitic, argillic, phyllic, potassic).

\begin{tabular}{|c|c|c|c|c|c|c|}
\hline $\begin{array}{l}\text { Madja Copper/ } \\
\text { Gold Prospect }\end{array}$ & 9.493 & 125.604 & Neogene & $\begin{array}{l}\text { Exploration project adjacent to Tapian } \\
\text { project area, porphyry } \mathrm{Cu}-\mathrm{Au} \text { target. }\end{array}$ & $\begin{array}{l}\text { Panoro Minerals, Ltd. } \\
\text { (2010) }\end{array}$ & 1 \\
\hline Tapian Main & 9.462 & 125.469 & Neogene & $\begin{array}{l}\text { Exploration project several km S of } \\
\text { Tapian San Francisco property; pre- } \\
\text { WWII underground gold mining. } \\
\text { Soil and stream-sediment Au and Cu } \\
\text { anomalies. }\end{array}$ & $\begin{array}{l}\text { Mindoro Resources, Ltd. } \\
\text { (2010), Rohrlach (2005), } \\
\text { Bailey (2003) }\end{array}$ & 1 \\
\hline Bolobolo & 9.409 & 125.484 & Neogene & $\begin{array}{l}\text { Structural exploration target S of Tapian } \\
\text { Main prospect based on intersections of } \\
\text { northeast- to southwest-trending faults } \\
\text { with northwest splays of the Philippine } \\
\text { Fault. Altered and mineralized float boul- } \\
\text { ders with chalcopyrite and bornite. May } \\
\text { be in propylitic halo. }\end{array}$ & $\begin{array}{l}\text { Mindoro Resources, Ltd. } \\
\text { (2012) }\end{array}$ & 1 \\
\hline Agata Group & 9.172 & 125.568 & Neogene & $\begin{array}{l}\text { Cluster of porphyry copper-gold pros- } \\
\text { pects. Artisinal mining of high-grade } \\
\text { copper ore from six shafts and tunnels. } \\
\text { Multiphase syenite, quartz monzonite. } \\
\text { Monzodiorite, diorite intrusions as dikes, } \\
\text { sills, and small stocks intruding ultra- } \\
\text { mafic rocks. Potassic, phyllic alteration. } \\
\text { Intersections of Philippine Fault splays } \\
\text { and cross-cutting faults. Epithermal gold } \\
\text { mined at American Tunnels; younger } \\
\text { epithermal gold cuts older porphyry- } \\
\text { related alteration. Late phyllic and skarn } \\
\text { overprint early potassic alteration. Note } \\
\text { that there is an Agata nickel laterite } \\
\text { deposit nearby. }\end{array}$ & $\begin{array}{l}\text { Mindoro Resources, Ltd. } \\
\text { (2010), Rohrlach (2005) }\end{array}$ & 2 \\
\hline
\end{tabular}

Mindoro Resources, Ltd. 4
(2010), Rohrlach (2005)

.


Table E4. Significant prospects and occurrences in tract 142pCu7309, Philippine Arc—Philippines.—Continued

[\%, percent; g/t, grams per metric ton; km, kilometers; m, meters; ha, hectares; ppm, parts per million; SCC, sericite-chlorire-clay. Rank 4=prospect listed in global database of Singer and others (2008) or $<16,000 \mathrm{t}$ of ore established by drilling. Rank $3=$ drilled, with $>20 \mathrm{~m}$ of $0.2 \%$ or more $\mathrm{Cu}$. Rank $2=$ drilled or trenched with $<20 \mathrm{~m}$ of $0.2 \% \mathrm{Cu}$, or past or ongoing exploration. Rank $1=$ copper occurrence that may be related to porphyry-type mineralization based on stream sediment or magnetic anomaly or location along structural trend]

\begin{tabular}{|c|c|c|c|c|c|c|}
\hline Name & Latitude & Longitude & Age & Comments & Reference & Rank \\
\hline $\begin{array}{l}\text { Kamarangan } \\
\text { Gold/Copper } \\
\text { Prospect }\end{array}$ & 8.515 & 126.010 & Neogene & $\begin{array}{l}\text { Ten holes drilled below a large area of } \\
\text { variably mineralized magnetite skarn; } \\
\mathrm{Cu}-\mathrm{Au} \text { in diorite and andesite; highest } \\
\text { concentrations in skarn. Mo ( } 244 \mathrm{ppm} \\
\text { max; average } 37,41 \mathrm{ppm} \text { in two holes. } \\
\text { Deep magnetic anomaly; possible pencil } \\
\text { porphyry at depth. }\end{array}$ & $\begin{array}{l}\text { Medusa Mining, Ltd. } \\
(2010,2013)\end{array}$ & 3 \\
\hline $\begin{array}{l}\text { Tambis Gold } \\
\text { Project }\end{array}$ & 8.490 & 126.060 & Neogene & $\begin{array}{l}\text { Intermediate sulfidation epithermal gold } \\
\text { system ( }+\mathrm{Ag}, \pm \mathrm{Zn}, \pm \mathrm{Cu}, \pm \mathrm{Pb}) \text { in and } \\
\text { adjacent to Tambis intrusive breccia } \\
\text { complex. Subvolcanic calc-alkaline } \\
\text { intrusions cut by diatremes and hydro- } \\
\text { thermal breccia. Gold mineralized veins } \\
\text { to } 500 \mathrm{~m} \text {. Porphyry potential at depth? }\end{array}$ & $\begin{array}{l}\text { Medusa Mining, Ltd. (2010, } \\
\text { 2013) }\end{array}$ & 1 \\
\hline Usa & 8.439 & 125.870 & Neogene & $\begin{array}{l}\mathrm{Cu}-\mathrm{Au} \text { diorite porphyry target }(500 \mathrm{~m} \text { by } \\
500 \mathrm{~m} \text { ) along the Baroba fault corridor; } \\
\text { rock chips to } 0.59 \% \mathrm{Cu} \text { and } 0.42 \mathrm{~g} / \mathrm{t} \\
\mathrm{Au} . \mathrm{Cu} \text { and } \mathrm{Au} \text { anomalies overlie three } \\
\text { magnetic highs, interpreted as magne- } \\
\text { tite alteration in the diorite. Pyrite with } \\
\text { bornite, some chalcopyrite. }\end{array}$ & Medusa Mining, Ltd. (2012) & 1 \\
\hline Gamuton & 8.257 & 126.013 & Neogene & $\begin{array}{l}\text { Drilling to test gold-bearing quartz veins } \\
\text { to the west of the Co-O underground } \\
\text { epithermal gold mine (located } 6 \mathrm{~km} \\
\text { north of Banawan) intersected intense } \\
\text { propylitic alteration with epidote, zones } \\
\text { of silicification and hydrothermal brec- } \\
\text { cias associated with strongly anomalous } \\
\text { gold contents of approximately } 0.5 \mathrm{~g} / \mathrm{t} \\
\text { and anomalous silver values accompa- } \\
\text { nied by irregular chalcopyrite veinlets. } \\
\text { Interpreted as indicative of nearby } \\
\text { porphyry copper. }\end{array}$ & Medusa Mining, Ltd. (2012) & 2 \\
\hline $\begin{array}{l}\text { Philsaga- } \\
\text { Bunawan JV } \\
\text { Gold Project }\end{array}$ & 8.175 & 126.145 & Neogene & $\begin{array}{l}\text { Exploration project - stream sediment } \\
\text { sampling }\end{array}$ & $\begin{array}{l}\text { Magnum Mining and Explo- } \\
\text { ration Limited (2006) }\end{array}$ & 1 \\
\hline Saugon & 8.137 & 126.046 & Neogene & $\begin{array}{l}\text { High grade gold-silver vein target in } \\
\text { andesite. Grass roots project for por- } \\
\text { phyry potential. }\end{array}$ & Medusa Mining, Ltd. (2010) & 1 \\
\hline $\begin{array}{l}\text { Lingig Copper/ } \\
\text { Gold Project } \\
\text { (das-Agan) }\end{array}$ & 8.119 & 126.384 & Neogene & $\begin{array}{l}\text { Discovered in } 1970 \mathrm{~s} \text {, mapping and } \\
\text { geochemical surveys, partly drilled } \\
\text { ( } 5 \text { hole). Modern exploration defined two } \\
\text { targets within a thrust zone: (1) Basalt } \\
\text { prospect, thrust-related copper in basalt } \\
\text { and ( } 2 \text { ) Breccia prospect, porphyry style } \\
\text { copper mineralization in diorite below } \\
\text { the thrust. Breccia prospect drill inter- } \\
\text { cept example: } \sim 155 \mathrm{~m} \text { of } 0.19 \% \mathrm{Cu} \text { and } \\
0.03 \mathrm{~g} / \mathrm{t} \mathrm{Au} \text {. }\end{array}$ & $\begin{array}{l}\text { Medusa Mining, Ltd. } \\
(2007,2012)\end{array}$ & 2 \\
\hline Lasang & 8.112 & 126.114 & Neogene & $\begin{array}{l}\text { Conceptual porphyry copper target based } \\
\text { on aeromagnetic data interpretation }\end{array}$ & Medusa Mining, Ltd. (2010) & 1 \\
\hline
\end{tabular}


Table E4. Significant prospects and occurrences in tract 142pCu7309, Philippine Arc—Philippines.—Continued

[\%, percent; g/t, grams per metric ton; km, kilometers; m, meters; ha, hectares; ppm, parts per million; SCC, sericite-chlorire-clay. Rank 4=prospect listed in global database of Singer and others (2008) or $<16,000 \mathrm{t}$ of ore established by drilling. Rank $3=$ drilled, with $>20 \mathrm{~m}$ of $0.2 \%$ or more $\mathrm{Cu}$. Rank $2=$ drilled or trenched with $<20 \mathrm{~m}$ of $0.2 \% \mathrm{Cu}$, or past or ongoing exploration. Rank $1=$ copper occurrence that may be related to porphyry-type mineralization based on stream sediment or magnetic anomaly or location along structural trend]

\begin{tabular}{|c|c|c|c|c|c|c|}
\hline Name & Latitude & Longitude & Age & Comments & Reference & Rank \\
\hline $\begin{array}{l}\text { Mawab Gold } \\
\text { Project }\end{array}$ & 7.500 & 125.985 & Neogene & $\begin{array}{l}\text { Exploration target area; soil } \\
\text { geochemistry }\end{array}$ & Sierra Mining Ltd. (2012) & 1 \\
\hline $\begin{array}{l}\text { Comval Copper/ } \\
\text { Gold Project }\end{array}$ & 7.476 & 126.131 & Neogene & $\begin{array}{l}\text { Diorite with quartz stockworks, skarn, } \\
\text { and epithermal gold quartz veins cut por- } \\
\text { phyry and skarn. Copper and gold along } \\
\text { the margins of quartz diorite intrusions } \\
\text { and associated porphyries. Comval proj- } \\
\text { ect consists of two tenements ( } 4,310 \text { ha). } \\
\text { Inferred resources ( } 2013 \text { ) of } 32.675 \mathrm{Mt} \\
\text { at } 0.42 \% \mathrm{Cu} \text { and } 0.13 \mathrm{~g} / \mathrm{t} \mathrm{Au} \text { (for }>0.3 \% \\
\mathrm{Cu} \text { ) for the Maangob, Kalamantan, Tag- } \\
\text { pura West, and Tagpura East target areas. } \\
\text { Note that this prospect area includes the } \\
\text { historical mines reported in table E3 and } \\
\text { additional target areas. }\end{array}$ & $\begin{array}{l}\text { Cadan Resources Corpora- } \\
\text { tion (2010a, 2013), Mining } \\
\text { Group Limited (2012) }\end{array}$ & 4 \\
\hline Wagas Mapula & 7.467 & 126.083 & Neogene & $\begin{array}{l}\text { Wagas Mapula Copper Project; surface } \\
\text { operation by Apex Exploration and Min- } \\
\text { ing Company, Inc., in the 1970s. }\end{array}$ & $\begin{array}{l}\text { U.S. Geological Survey } \\
\text { (2012) }\end{array}$ & 1 \\
\hline Upper Masara & 7.467 & 126.083 & Neogene & $\begin{array}{l}\text { Copper prospect associated with andes- } \\
\text { ite. Chalcopyrite, bornite. }\end{array}$ & $\begin{array}{l}\text { Philippine Mines and } \\
\text { Geosciences Bureau ( } 2004 \text {, } \\
\text { written commun.) }\end{array}$ & 1 \\
\hline Manat & 7.433 & 126.033 & Neogene & $\begin{array}{l}\text { Hornblende andesite, hornblende diorite } \\
\text { intrusive, basaltic-andesite plagiophyric } \\
\text { andesite, and limestone. Exploration } \\
\text { by Indophil discovered a new porphyry } \\
\text { copper-gold system (drilled } 227 \mathrm{~m} \text { at } \\
0.19 \% \mathrm{Cu} \text { and } 0.30 \mathrm{~g} / \mathrm{t} \mathrm{Au}) \mathrm{S} \text { of the } \\
\text { Magas polymetallic vein system. }\end{array}$ & Indophil Resources (2011) & 2 \\
\hline Theresa Group & 7.398 & 126.040 & Neogene & $\begin{array}{l}\text { Group of } 4 \text { prospects within } 2 \mathrm{~km} \text { of } \\
\text { each other in the Masara District. Loca- } \\
\text { tion given is for Theresa. (1) Theresa: } \mathrm{Cu} \\
\text { prospect associated with quartz diorite. } \\
\text { Chalcopyrite, bornite. (2) Kanarubi Cu } \\
\text { prospect. (3) Maco Au mine: Explora- } \\
\text { tion project west of Philippine Fault; } \\
\text { Miocene diorite and quartz diorite and } \\
\text { late Miocene to Pliocene diorite and } \\
\text { andesitic plugs and dikes. Quartz sulfide } \\
\text { porphyry copper stockworks in mid- } \\
\text { Miocene diorite. (4) Panurao: Porphyry } \\
\text { Cu-Au deposit mined in 1962-1971. } \\
\text { Landslide in } 1972 \text { led to mine closure. } \\
\text { INCO reported that it mined } 200,000 \mathrm{t} \\
\text { of ore at } 0.8 \% \mathrm{Cu} \text { and } 7 \mathrm{~g} / \mathrm{t} \text { Au. May be } \\
\text { open at depth. }\end{array}$ & $\begin{array}{l}\text { Crew Gold (2010), Philip- } \\
\text { pine Mines and Geosciences } \\
\text { Bureau (2004, written com- } \\
\text { mun.), Philippine Mining } \\
\text { Development Corporation } \\
\text { (2010) }\end{array}$ & 3 \\
\hline Hope & 7.312 & 126.079 & Neogene & $\begin{array}{l}\text { Copper prospect associated with quartz } \\
\text { diorite. Chalcopyrite, bornite. }\end{array}$ & $\begin{array}{l}\text { Philippine Mines and } \\
\text { Geosciences Bureau (2004, } \\
\text { written commun.) }\end{array}$ & 1 \\
\hline
\end{tabular}


Table E4. Significant prospects and occurrences in tract 142pCu7309, Philippine Arc—Philippines.—Continued

[\%, percent; g/t, grams per metric ton; km, kilometers; m, meters; ha, hectares; ppm, parts per million; SCC, sericite-chlorire-clay. Rank 4=prospect listed in global database of Singer and others (2008) or $<16,000 \mathrm{t}$ of ore established by drilling. Rank $3=$ drilled, with $>20 \mathrm{~m}$ of $0.2 \%$ or more Cu. Rank $2=$ drilled or trenched with $<20 \mathrm{~m}$ of $0.2 \% \mathrm{Cu}$, or past or ongoing exploration. Rank $1=$ copper occurrence that may be related to porphyry-type mineralization based on stream sediment or magnetic anomaly or location along structural trend]

\begin{tabular}{|c|c|c|c|c|c|c|}
\hline Name & Latitude & Longitude & Age & Comments & Reference & Rank \\
\hline Limao & 7.275 & 126.046 & Neogene & $\begin{array}{l}\text { Copper prospect associated with apha- } \\
\text { nitic volcanic rock. }\end{array}$ & $\begin{array}{l}\text { Philippine Mines and } \\
\text { Geosciences Bureau ( } 2004 \text {, } \\
\text { written commun.) }\end{array}$ & 1 \\
\hline $\begin{array}{l}\text { Ayan Gold } \\
\text { Project }\end{array}$ & 7.050 & 126.117 & Neogene & $\begin{array}{l}\text { Exploration target area along a NW-SE } \\
\text { structural trend between the Kingking } \\
\text { deposit and the Taguibo project area } \\
\text { (artisanal gold and high grade copper } \\
\text { mining). }\end{array}$ & Sierra Mining, Ltd. (2012) & 1 \\
\hline Taguibo & 7.034 & 126.194 & Neogene & $\begin{array}{l}\text { Potential buried porphyry copper explo- } \\
\text { ration target associated with a brecci- } \\
\text { ated, hydrothermally-altered (propylitic, } \\
\text { potassic, argillic) diorite and andesite } \\
\text { (Taguibo volcano-plutonic complex). } \\
\text { Initial drilling reports low-grade } \mathrm{Cu} \text { zone } \\
\text { in two holes }(125.6 \mathrm{~m} \text { at } 0.15 \% \mathrm{Cu} \text { and } \\
111.6 \mathrm{~m} \text { at } 0.15 \% \mathrm{Cu} \text {. ) }\end{array}$ & Sierra Mining, Ltd. (2012) & 2 \\
\hline
\end{tabular}

Table E5. Principal sources of information used for tract 142pCu7309, Philippine Arc—Philippines.

[NA, not applicable]

\begin{tabular}{|c|c|c|c|}
\hline Theme & Name or Title & Scale & Citation \\
\hline \multirow[t]{3}{*}{ Geology } & Digital geologic map of the Philippines & $1: 1,000,000$ & $\begin{array}{l}\text { Philippine Mines and Geosciences Bureau } \\
\text { (2004a) }\end{array}$ \\
\hline & $\begin{array}{l}\text { Geology and mineral resources of the Philippines, } \\
\text { v. } 1 \text { - Geology }\end{array}$ & $1: 1,000,000$ & $\begin{array}{l}\text { Philippine Bureau of Mines and Geo- } \\
\text { sciences (1981), Philippine Mines and } \\
\text { Geosciences Bureau (2010) }\end{array}$ \\
\hline & Geologic map of the Philippines & $1: 1,000,000$ & Philippine Bureau of Mines (1963) \\
\hline \multirow[t]{5}{*}{$\begin{array}{l}\text { Mineral } \\
\text { occurrences }\end{array}$} & $\begin{array}{l}\text { Porphyry copper deposits of the world-Database, } \\
\text { map, and grade and tonnage models }\end{array}$ & NA & Singer and others (2008) \\
\hline & $\begin{array}{l}\text { Geology and mineral resources of the Philippines, } \\
\text { v. } 2 \text { - Mineral Resources }\end{array}$ & NA & $\begin{array}{l}\text { Philippine Bureau of Mines and Geosci- } \\
\text { ences (1986) }\end{array}$ \\
\hline & $\begin{array}{l}\text { Digital data base of mineral occurrences of the } \\
\text { Philippines }\end{array}$ & NA & $\begin{array}{l}\text { Philippine Mines and Geosciences Bureau } \\
\text { (2004b) }\end{array}$ \\
\hline & Mining places in the Philippines ( $\mathrm{kml}$ file) & NA & GoogleEarth ${ }^{\circledR}(2013)$ \\
\hline & Philippine porphyry copper deposits & NA & Sillitoe and Gappe (1984) \\
\hline \multirow[t]{4}{*}{ Exploration } & $\begin{array}{l}\text { U.S. Geological Survey On-Line Mineral Resources } \\
\text { Spatial Data }\end{array}$ & NA & U.S. Geological Survey (2012) \\
\hline & Philipppine Mines and Geosciences Bureau Web site & NA & http://www.mgb.gov.ph/ \\
\hline & Commercial databases & NA & http://www.infomine.com/ \\
\hline & Company Web sites and technical reports & NA & Numerous - see references in table E4 \\
\hline
\end{tabular}


deposits may be present within the tract include the discovery of Boyongan-Bayugo, increased reliance on aeromagnetic data for target selection, the presence of splays of the Philippine Fault that could provide conduits for hydrothermal fluids and localize emplacement of intrusions, and a spatial association with a belt of epithermal gold deposits.

On the basis of these data, the assessment team estimated a 90-percent chance for 3 or more undiscovered deposits, a 50-percent chance for 7 or more, and a 10-percent chance of 14 or more deposits (table E6). The team considered that historically, the tract area may be underexplored relative to some other areas of the Philippines, such as the Luzon Central Cordillera. Note that the assessment was done in 2010. Attempts were made to update prospect information to further validate prospects that were known but less well-delineated in 2010 .

\section{Probabilistic Assessment Simulation Results}

Undiscovered resources for the tract were estimated by combining the team's estimate for numbers of undiscovered porphyry copper deposits with the porphyry copper-gold model of Singer and others (2008) using the EMINERS program (Root and others, 1992; Duval, 2012; Bawiec and Spanski, 2012). Selected simulation results are reported in table E7. Results of the Monte Carlo simulation are presented as a cumulative frequency plot (fig. E3). The cumulative frequency plot shows the estimated resource amounts associated with cumulative probabilities of occurrence, as well as the mean, for each commodity and for total mineralized rock. The mean estimated amount of undiscovered copper is about four times the amount of identified resources in the tract. See table 6 for comparisons with other tracts.

Table E6. Undiscovered deposit estimates, deposit numbers, tract area, and deposit density for tract 142pCu7309,

Philippine Arc—Philippines.

[ $N_{\mathrm{XX}}$, estimated number of deposits associated with the xxth percentile; $N_{\text {und }}$, expected number of undiscovered deposits; $s$, standard deviation; $C_{v} \%$, coefficient of variance; $N_{\text {known }}$, number of known deposits in the tract that are included in the grade and tonnage model; $N_{\text {total }}$, total of expected number of deposits plus known deposits; area, area of permissive tract in square kilometers $\left(\mathrm{km}^{2}\right)$; density, deposit density reported as the total number of deposits per $100,000 \mathrm{~km}^{2} . N_{\text {und }}, s$, and $C_{v} \%$ are calculated using a regression equation (Singer and Menzie, 2005)]

\begin{tabular}{|c|c|c|c|c|c|c|c|c|c|c|c|}
\hline \multicolumn{5}{|c|}{ Consensus undiscovered deposit estimates } & \multicolumn{5}{|c|}{ Summary statistics } & \multirow{2}{*}{$\begin{array}{c}\text { Tract Area } \\
\quad\left(\mathbf{k m}^{2}\right)\end{array}$} & \multirow{2}{*}{$\begin{array}{c}\text { Deposit density } \\
\left(N_{\text {total }} / 100,000 \text { km}^{2}\right)\end{array}$} \\
\hline$N_{90}$ & $N_{50}$ & $N_{10}$ & $N_{05}$ & $N_{01}$ & $N_{\text {und }}$ & $s$ & $\mathbf{C}_{v} \%$ & $N_{\text {known }}$ & $N_{\text {total }}$ & & \\
\hline 3 & 7 & 14 & 14 & 14 & 7.7 & 4.1 & 53 & 8 & 15.7 & 23,700 & 66 \\
\hline
\end{tabular}

Table E7. Results of Monte Carlo simulation of undiscovered resources for tract 142pCu7309, Philippine Arc—Philippines.

[Cu, copper; Mo, molybdenum; Au, gold; and Ag, silver; in metric tons; Rock, in million metric tons]

\begin{tabular}{|c|c|c|c|c|c|c|c|c|}
\hline \multirow[b]{2}{*}{ Material } & \multicolumn{6}{|c|}{ Probability of at least the indicated amount } & \multicolumn{2}{|c|}{ Probability of } \\
\hline & 0.95 & 0.9 & 0.5 & 0.1 & 0.05 & Mean & $\begin{array}{c}\text { Mean or } \\
\text { greater }\end{array}$ & None \\
\hline $\mathrm{Cu}$ & 960,000 & $2,400,000$ & $15,000,000$ & $58,000,000$ & $80,000,000$ & $24,000,000$ & 0.34 & 0.03 \\
\hline Mo & 0 & 0 & 52,000 & 420,000 & 620,000 & 140,000 & 0.27 & 0.12 \\
\hline $\mathrm{Au}$ & 82 & 210 & 1,300 & 4,000 & 5,000 & 1,800 & 0.37 & 0.03 \\
\hline $\mathrm{Ag}$ & 0 & 190 & 3,200 & 22,000 & 38,000 & 8,000 & 0.25 & 0.08 \\
\hline Rock & 210 & 570 & 3,300 & 12,000 & 15,000 & 4,900 & 0.36 & 0.03 \\
\hline
\end{tabular}




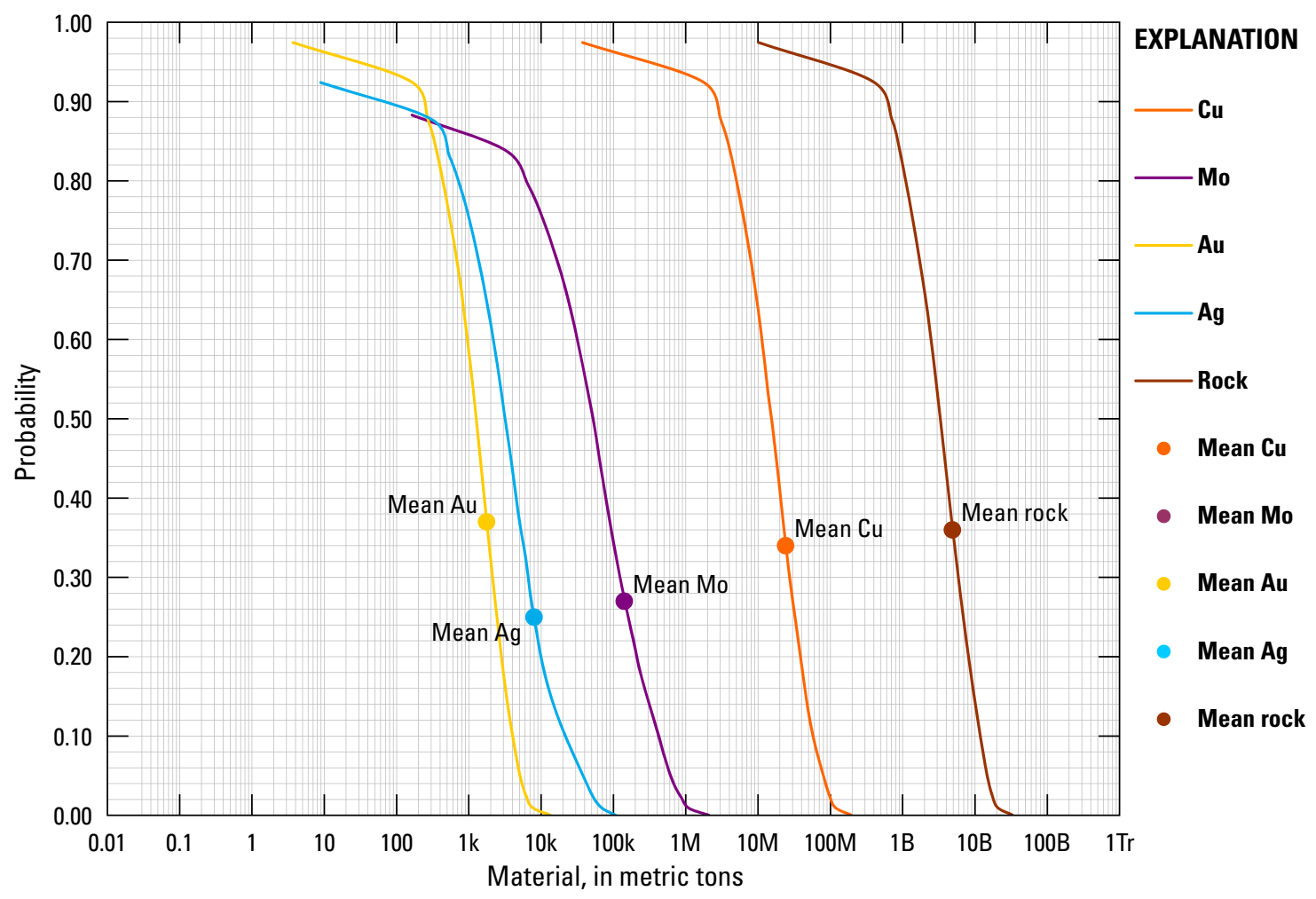

Figure E3. Cumulative frequency plot showing the results of Monte Carlo computer simulation of undiscovered resources in 142pCu7309, Philippine Arc-Philippines. k, thousands; M, millions; $\mathrm{B}$, billions; Tr, trillions.

\section{References Cited}

Almogela, D.H., 1974, Geologic environment and economic possibilities of porphyry copper deposits in the Philippines: Journal of the Geological Society of the Philippines, v. 28, no. 3 , p. $1-16$.

Altai Resources, Inc., 2003, Annual Information Form [dated April 25, 2003]: Altai Resources, Inc., 32 p.

Anonymous, 2001a, Asia-The waking giant: Mining Journal, March, v. 336, no. 8630, p. 12.

Anonymous, 2001b, Exploration success in the Philippines: Mining Journal, v. 336, March 9, p. 173, 175.

Anonymous, 2001c, Philippines eyes exploration revival: The Northern Miner, March 12, Exploration, p. C1, C4.

Anonymous, 2002, More drilling slated for Boyongan: The Northern Miner, Dec.31, 2001-Jan. 6, 2002, Exploration, p. 1.

Bailey, D.G., 2003, Surigao Property Group, Northeastern Mindanao-Geology and exploration potential: Report prepared for Panoro Minerals, Ltd., September 11, 2003, 61 p.
Bawiec, W.J., and Spanski, G.T., 2012, Quick-start guide for version 3.0 of EMINERS-Economic Mineral Resource Simulator: U.S. Geological Survey Open-File Report 2009-1057, 26 p., accessed June 30, 2012, at http://pubs. usgs.gov/of/2009/1057/. (This report supplements USGS OFR 2004-1344.)

Berger, B.R., Ayuso, R.A., Wynn, J.C., and Seal, R.R., 2008, Preliminary model of porphyry copper deposits: U.S. Geological Survey Open-File Report 2008-1321, 55 p., accessed May 15, 2009, at http://pubs.usgs.gov/ of $/ 2008 / 1321 /$.

Bolaño, Marcelo, 2010, 2010 Report for economic assessment and ore reserve estimation of the gold vein deposits of Maco Mines in Maco, Compostela Valley Province, Mindanao Island, Philippines: Technical report, accessed August 20, 2010, at http://www.pse.com.ph/html/ListedCompanies/ pdf/2010/APX_23B_04162010.pdf.

Braxton, D.P. and Cooke, D.R., 2005, The Boyongan porphyry $\mathrm{Cu}$ - $\mathrm{Au}$ deposit: repeated hydrothermal cycles tied to discrete intrusive events, in Mao, J., Bierlein, F.P., eds., Mineral deposits research-Meeting the global challenge, v. 1: Springer, p. 357-360. 
Braxton, D.P., Cooke, D.R., Ignacio, A.M., Rye, R.O., and Waters, P.J., 2009, Ultra-deep oxidation and exotic copper formation at the Late Pliocene Boyongan and Bayugo porphyry copper-gold deposits, Surigao, Philippines - Geology, mineralogy, paleoaltimetry, and their implications for geologic, physiographic, and tectonic controls: Economic Geology, v. 104, p. 333-349.

Cadan Resources Corporation, 2010a, Comval, Mindanao [Philippines]: Cadan Resources Corporation Web page, accessed April 8, 2010, at http://www.infomine. com/companies-roperties/reports/propertyreport. aspx?pid=31604.

Cadan Resources Corporation, 2010b, Tagpura-Kalamantan, Mindanao [Philippines]: Cadan Resources Corporation Web page, accessed April 8, 2010, at http://premium.infomine. com/scripts/advanced/infodbweb/ChargePropertyReport. asp?SearchID=31602.

Cadan Resources Corporation, 2013, Comval copper-gold project: Cadan Resources Corporation Web page, accessed August 16, 2013, at http://www.cadanresources.com/ projects/comval-copper-gold/.

Cox, D.P., 1986, Descriptive model of porphyry $\mathrm{Cu}-\mathrm{Au}$, in Cox, D.P., and Singer, D.A., eds., 1986, Mineral deposit models: U.S. Geological Survey Bulletin 1693, p. 110. (Also available at http://pubs.usgs.gov/bul/b1693/.)

Crew Gold, 2010, Maco project: Crew Gold Web site, accessed September 15, 2010, at http://www.crewdev.com/ ops_maco.php\#.

Duval, J.S., 2012, Version 3.0 of EMINERS-Economic Mineral Resource Simulator: U.S. Geological Survey Open-File Report 2004-1344, accessed July 15, 2012, at http://pubs. usgs.gov/of/2004/1344/.

Fernandez, J.C., 1986, Geology and mineral resources of the Philippines, v. 2: Mineral Resources: Philippine Bureau of Mines and Geosciences, Manila, $446 \mathrm{p}$.

Fortuna, J., 1998, Late porphyry-related gold mineralization at the Kingking porphyry $\mathrm{Cu}-\mathrm{Au}$ deposit, Mindanao, Philippines: SEG (Society of Economic Geologists) Newsletter, no. 35 , p. 5 .

Feebrey, G.A., 2001, Exploration reviews-Asia, Philippines: SEG (Society of Economic Geologists) Newsletter, April, no. 45 , p. 35.

Ferreira, D.S., 2008, Technical report on the Boyongan porphyry deposit: Report prepared for Philex Gold Incorporated by Independent Resource Estimations cc., 114 p.

Ferreira, D.S., 2009, Technical report on the Bayugo deposit in the province of Surigao del Norte, Island of Mindanao, Philippines: Report prepared for Philex Gold Incorporated by Independent Resource Estimations cc., 155 p.
Frost, J.E., 1959, Notes on the genesis of the ore-bearing structures of the Paracale district, Camarines Norte, Philippines: Journal of the Geological Society of the Philippines, v. 13 , no. 2 , p. $31-43$.

Garwin, S., Hall, R., and Watanabe, Y., 2005, Tectonic setting, geology, and gold and copper mineralization in Cenozoic magmatic arcs of southeast Asia and the west Pacific, in Hedenquist, T.W., Thompson, J.F.H., Goldfarb, R.J., and Richards, J.P., eds., One hundredth anniversary volume 1905-2005: Littleton, Colorado, Society of Economic Geologists, p. 891-930.

Google Earth ${ }^{\circledR}, 2013$, Mining places in the Philippines: Google Earth ${ }^{\circledR}$ Web site, accessed April 5, 2013, at http:// www.google.com/url? sa $=t \& r c t=j \& q=\&$ esrc $=s \&$ frm $=1 \&$ sou rce $=$ web $\&$ cd $=2 \&$ sqi $=2 \&$ ved $=0$ CEAQFjAB \&url $=$ http $\% 3 \mathrm{~A}$ $\% 2 \mathrm{~F} \% 2 \mathrm{Fgeocommons} . \mathrm{com} \% 2 \mathrm{Foverlays} \% 2 \mathrm{~F} 16366 . \mathrm{kml} \&$ ei $=\mathrm{kfNeUZTVE} 8 \mathrm{nO} 2 \mathrm{gXb} 2 \mathrm{IGYAQ} \& u s g=A F Q j C N F L q 8 \mathrm{Cr}$ nK4OBdTHR81 Aka9fzvm3zg\&sig2=dDS9CIwjKLhyq28Ifqtmw\&bvm=bv.44770516,d.b2.

Hester, M.G., Earnert, D.F., and Aronson, J.G., 2010, Kingking copper-gold project, Mindanao, Philippines: Technical Report (NI 43-101) prepared for Ratel Gold Limited and Russell Mining and Minerals, Inc., prepared by Independent Mining Consultants, Inc., 288 p., accessed April 5, 2013, at $\mathrm{http}: / /$ sagcmining.com/.

Indophil Resources NL, 2002, Annual report for 2002: Indophil Resources NL, 52 p., accessed June 1, 2012, at www.indophil.com/pdf/204432_indophil_ar_web.pdf.

Indophil Resources NL, 2011, Indophil Resources NL: Indophil Resources NL Web site: accessed June 1, 2012, at http://www.indophil.com/philippines_ex.asp.

John, D.A., Ayuso, R.A., Barton, M.D., Blakely, R.J., Bodnar, R.J., Dilles, J.H., Gray, Floyd, Graybeal, F.T., Mars, J.C., McPhee, D.K., Seal, R.R., Taylor, R.D., and Vikre, P.G., 2010, Porphyry copper deposit model, chap. B of Mineral deposit models for resource assessment: U.S. Geological Survey Scientific Investigations Report 2010-5070-B, 169 p., accessed September 8, 2010, at http://pubs.usgs.gov/ $\operatorname{sir} / 2010 / 5070 / \mathrm{b} /$.

Josef, L.P., 2002, The Boyongan porphyry $\mathrm{Cu}-\mathrm{Au}$ deposit, Philippines: Cordillera Roundup January, 2002, British Columbia and Yukon Chambers of Mines, Asia Exploration Forum, Vancouver, preprint, $4 \mathrm{p}$.

Magnum Mining and Exploration Limited, 2006, Annual financial report for the year ended 31 December 2006: Magnum Mining and Exploration Limited, 46 p., accessed May 15, 2011, at www.mmel.com.au/Pdfs/pdfAnnlReport311206MGU.pdf. 
Malaihollo, J.F.A., Hall, R., and Macpherson, C.G., 2002, SE Asia Radiometric ages - GIS database: Southeast Asia Research Group, Department of Earth Sciences, Royal Holloway University of London, accessed February 1, 2010, at http://searg.rhul.ac.uk/current_research/isotopic_ages/ SEAsia_GIS.pdf.

Manila Mining Corporation, 2010, Manila Mining Corporation: Manila Mining Corporation Web site, accessed May 15, 2012, at http://www.manilamining.com/.

Medusa Mining, Ltd., 2007, 2010, 2012, Medusa Mining: Medusa Mining Web site, last accessed June 15, 2012, at http://www.medusamining.com.au/.

Mercado, A.C., Estoque, J., Lodriqueza, L., and Rebillon, F., 1987, Geology and ore deposits of Masara Mine, Davao del Norte, Philippines: Parkville, Victoria, Australia, Proceedings of Pacific Rim Congress 87, p. 329-332.

Mindoro Resources, Ltd., 2010, Surigao Projects, [Philippines]: Mindoro Resources, Ltd., Web page, accessed April 8, 2010, at http://www.mindoro.com/s/ Agata.asp?ReportID=1956411.

Mindoro Resources, Ltd., 2012, Bolobolo porphyry coppergold prospect: Mindoro Resources, Ltd., Web page, accessed June 15, 2012, at http://www.mindoro.com/s/ Bolobolo.asp.

Mining Group Limited, 2012, Comval copper gold project: Mining Group Limited Web site, accessed May 15, 2012, at http://www.mininggroup.net.au/Projects/comval-coppergold-project.html.

Mitchell, A.H.G, and Leach, T.M., 1991, Epithermal gold in the Philippines-Island arc metallogenesis, geothermal systems and geology: London, Academic Press, 457 p.

Oceana Gold Corporation, 2010, Oceana Gold Corporation: Oceana Gold Corporation Web site, accessed September 26, 2010, at http://www.oceanagold.com/.

Oz Minerals, 2010, Oz Minerals: Oz Minerals Web site, accessed May 15, 2011, at http://www.ozminerals.com.

Panoro Minerals, Ltd., 2010, Agata Project, Mindanao [Philippines]: Panoro Minerals, Ltd., Web page, accessed April 8, 2010, at http://www.panoro.com/i/pdf/2005-11-08_NR.pdf.

Philippine Bureau of Mines, 1963, Geological map of the Philippines: Philippine Bureau of Mines, 1 map on 8 sheets, scale $1: 1,000,000$.

Philippine Bureau of Mines and Geosciences, 1981, Geology and mineral resources of the Philippines, v. 1-Geology: Philippine Bureau of Mines and Geosciences, $406 \mathrm{p}$.
Philippine Bureau of Mines and Geosciences, 1986, Geology and mineral resources of the Philippines, v. 2-Mineral Resources: Philippine Bureau of Mines and Geosciences, $446 \mathrm{p}$.

Philippine Mines and Geosciences Bureau, 2004a, Digital geological map of the Philippines: Philippine Mines and Geosciences Bureau, scale 1:1,000,000. [Proprietary data.]

Philippine Mines and Geosciences Bureau, 2004b, Digital database of mineral occurrences of the Philippines: Philippine Mines and Geosciences Bureau. [Proprietary report.]

Philippine Mines and Geosciences Bureau, 2007, Priority mineral development projects of the Philippines: Philippine Mines and Geosciences Bureau, $27 \mathrm{p}$.

Philippine Mines and Geosciences Bureau, 2010, Geology of the Philippines ( $2 \mathrm{~d}$ ed.): Philippine Mines and Geosciences Bureau, $532 \mathrm{p}$.

Philippine Mining Development Corporation, 2010, Web site: accessed February 15, 2010, at http://pmdc.com.ph/.

Philippine Society of Mining Engineers, 2007, Copper: Philippine Society of Mining Engineers Web site, accessed April 15, 2013, at http://www.psem.ph/articles.php?article_id=29.

Red5Limited, 2010, Mapawa Project: Red5Limited Web page, accessed September 21, 2010, at http://www.red5limited. com/projects/mapawa.html.

Root, D.H., Menzie, W.D., and Scott, W.A., 1992, Computer Monte Carlo simulation in quantitative resource estimation: Natural Resources Research, v. 1, no. 2, p. 125-138.

Rohrlach, B.D., 2005, Independent geological report on the Surigao property group, northern Mindanao, Philippines: Report prepared for MRL Gold Philippines, Inc., and Panoro Minerals, Ltd., accessed May 15, 2012, at http://www. mindoro.com/i/pdf/2005-04-25_RohrlachTechRpt.pdf.

RoyalCo Resources, Ltd., 2006, Philippines drilling and exploration activities: RoyalCo Resources, Ltd., 6 p.

RoyalCo Resources, Ltd., 2010, Malangza, Panoan Island [Philippines]: RoyalCo Resources, Ltd., Web page, accessed April 8, 2010, at http://www.royalco.com.au.

Rugby Mining Limited, 2011a, Rugby discovers gold mineralization at Mabuhay project, Philippines: Rugby Mining Limited press release NR 11-5 dated July 19, 2011, 4 p.

Rugby Mining Limited, 2011b, Drilling update for the Mabuhay project, Philippines: Rugby Mining Limited press release NR 11-7 dated August 24, 2011, 3 p. 
Rugby Mining Limited, 2012, Mabuhay project: Rugby Mining Limited Web site, accessed June 5, 2012, at http://www. rugbymining.com/projects/mabuhay.php.

Saegart, W.E., and Lewis, D.E., 1976, Characteristics of Philippine porphyry copper deposits and summary of current production and resources: American Institute of Mining, Metallurgical, and Petroleum Engineers Annual Meeting, February 22-26, 1976, Las Vegas, preprint no. 76-1-79, $46 \mathrm{p}$.

Sierra Mining Limited, 2012, March 2012 Quarterly Report: Sierra Mining Limited, accessed May 30, 2012, at http:// sierramining.com.au/.

Sillitoe, R.H., 1989, Gold deposits in western Pacific island arcs-The magmatic connection, in Keays, R.R., Ramsay, W.R.H., and Groves, D.I., eds., The geology of gold deposits-The perspective in 1988: Economic Geology Monograph 6, p. 274-291.

Sillitoe, R.H., and Gappe, I.M., Jr., 1984, Philippine porphyry copper deposits-Geologic setting and characteristics: Committee for Co-ordination of Joint Prospecting for Mineral Resources in Asian Offshore Areas (CCOP), CCOP Technical Publication 14, 89 p.

Singer, D.A., and Menzie, W.D., 2005, Statistical guides to estimating the number of undiscovered mineral deposits-An example with porphyry copper deposits, in Cheng, Qiuming, and Bonham-Carter, Graeme, eds., Proceedings of IAMG-The annual conference of the International Association for Mathematical Geology: Toronto, Canada, York University, Geomatics Research Laboratory, p. 1028-1033.

Singer, D.A., Berger, V.I., and Moring, B.C., 2008, Porphyry copper deposits of the World - Database and grade and tonnage models, 2008: U.S. Geological Survey Open-File Report 2008-1155, accessed June 1, 2011, at http://pubs. usgs.gov/of/2008/1155/.
Society of Economic Geologists, 1999, Exploration Reviews, 31 p.: accessed April 5, 2013, at http://gold.prime-tass.com/ documents/files/degold_exploration3Q.pdf.

St. Augustine Gold and Copper Limited, 2011, St. Augustine Gold and Copper Limited announces $21.6 \%$ increase in King-king project total resource containing 5.4 billion lbs copper and 10.3 million oz gold: St. Augustine Gold and Copper Limited press release, August 15, 2011, accessed October 15, 2011, at http://sagcmining.com/en/news/ news_2011/news20110815.pdf.

St. Augustine Gold and Copper Limited, 2012, St. Augustine Gold and Copper Limited: St. Augustine Gold and Copper Limited Web site, accessed June 5, 2012, at http://sagcmining.com/.

Sur American Gold Corp., 2007, Kalamantan copper-gold porphyry exploration update: Sur American Gold Corp., accessed May 15, 2012, at http://www.marketwire.com/ press-release/Sur-American-Gold-Corporation-KalamatanCopper-Gold-Porphyry-Exploration-Update-TSXVENTURE-SUR-650311.htm.

U.S. Department of State, 2009, Small-scale digital international land boundaries (SSIB) - Lines, edition 10, and polygons, beta edition 1, in Boundaries and sovereignty encyclopedia (B.A.S.E.): U.S. Department of State, Office of the Geographer and Global Issues.

U.S. Geological Survey, 2012, U.S. Geological Survey on-line mineral resources spatial data: U.S. Geological Survey Web site, accessed April 15, 2013, at http://mrdata.usgs.gov/.

Uriarte, H. M., 1972, Base metal exploration in Larap, Jose Panganiban and vicinity: Journal of the Geological Society of the Philippines, v. 26, no. 1, p. 37-49.

Yumul, G.P., Jr., Dimalanta, C.B., Maglambayan, V.B., and Marquez, E.J., 2008, Tectonic setting of a composite terrane-A review of the Philippine island arc system: Geosciences Journal, v. 12, no. 1, p. 7-17. 


\section{Appendix F. Porphyry Copper Assessment for Tract 142pCu7302, Cordon Alkalic Complex-Philippines}

By Jane M. Hammarstrom ', Arthur A. Bookstrom², Connie L. Dicken', Steve Ludington³, Gilpin R. Robinson, Jr.', and Michael L. Zientek ${ }^{2}$ with contributions from Sevillo (Bill) D. David, Jr., Claro J. Manipon ${ }^{4}$, Lilian A. Rollan ${ }^{4}$, and Yasushi Watanabe ${ }^{5}$

\section{Deposit Type Assessed: Porphyry copper, copper-gold subtype}

Descriptive model: Porphyry copper (Cox, 1986; Berger and others, 2008; John and others, 2010; Sillitoe and Gappe, 1984) Grade and tonnage model: Porphyry copper, copper-gold subtype (Singer and others, 2008)

Table F1 summarizes selected assessment results.

Table F1. Summary of selected resource assessment results for tract 142pCu7302, Cordon Alkalic Complex-Philippines.

[km, kilometers; $\mathrm{km}^{2}$, square kilometers; $\mathrm{t}$, metric tons; identified copper rounded to two significant figures]

\begin{tabular}{cccccc}
\hline $\begin{array}{c}\text { Date of } \\
\text { assessment }\end{array}$ & $\begin{array}{c}\text { Assessment depth } \\
(\mathbf{k m})\end{array}$ & Tract area $\left(\mathbf{k m}^{2}\right)$ & $\begin{array}{c}\text { Identified copper } \\
\text { resources }(\mathbf{t})\end{array}$ & $\begin{array}{c}\text { Mean estimate of } \\
\text { undiscovered copper } \\
\text { resources }(\mathbf{t})\end{array}$ & $\begin{array}{c}\text { Median estimate of } \\
\text { undiscovered copper } \\
\text { resources }(\mathbf{t})\end{array}$ \\
\hline 2010 & 1 & 4,860 & $1,400,000$ & $4,900,000$ \\
\hline
\end{tabular}

\section{Location}

Caraballo Range, southern end of the Cagayan Basin in North Luzon (fig. F1).

\section{Geologic Feature Assessed}

Late Oligocene to early Miocene K-alkalic magmatic province at the south end of the Cagayan rift basin.

${ }^{1}$ U.S. Geological Survey, Reston, Virginia, United States.

${ }^{2}$ U.S. Geological Survey, Spokane, Washington, United States.

${ }^{3}$ U.S. Geological Survey, Menlo Park, California, United States.

${ }^{4}$ Philippine Department of Environment and Natural Resources, Mines and Geosciences Bureau, Quezon City, Philippines.

${ }^{5}$ Geological Survey of Japan, National Institute of Advanced Industrial Science and

Technology (AIST), Ibaraki, Japan. 

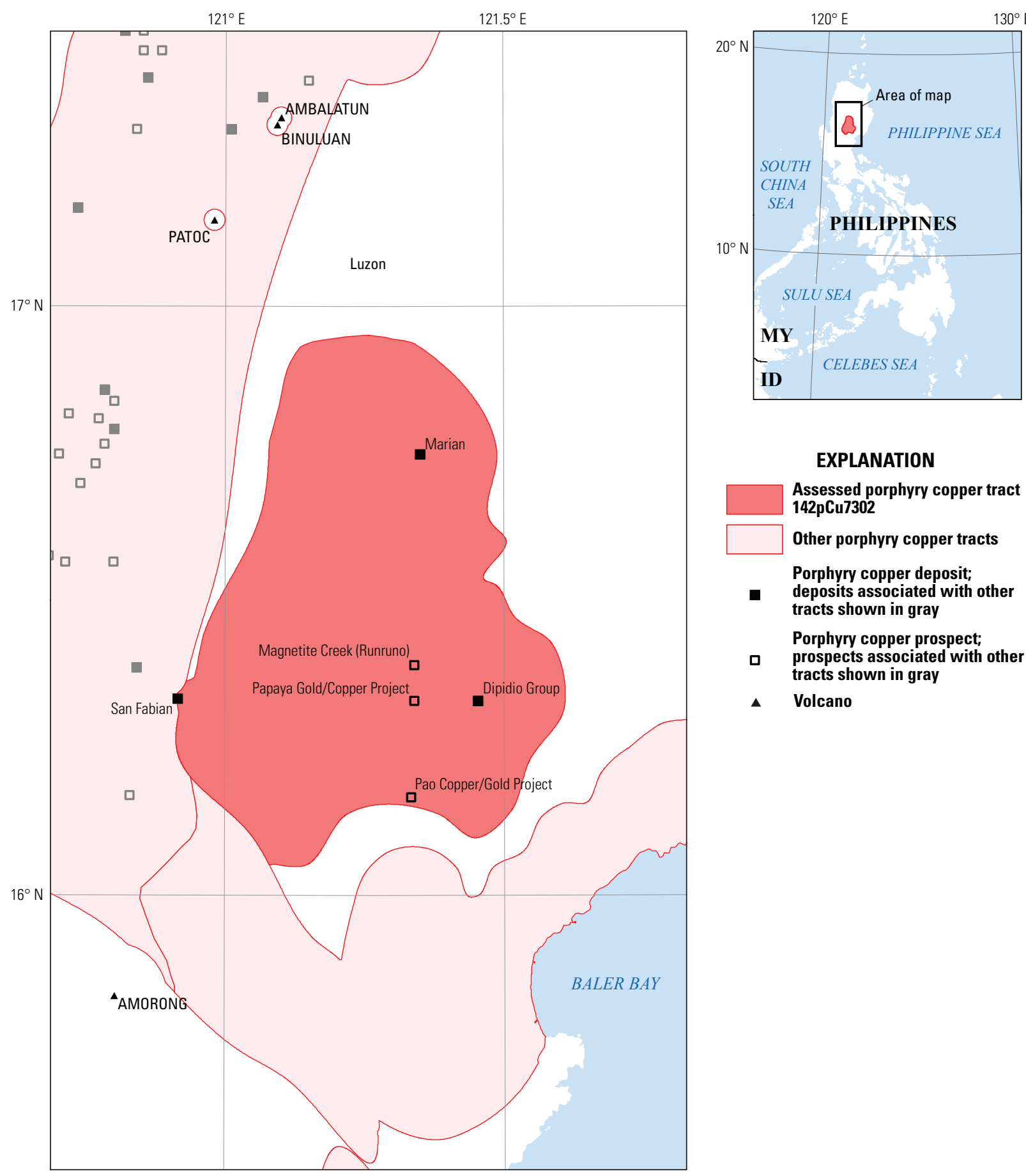

\section{EXPLANATION}

Assessed porphyry copper tract 142pCu7302

Other porphyry copper tracts

Porphyry copper deposit;

- deposits associated with other tracts shown in gray

Porphyry copper prospect;

a prospects associated with other tracts shown in gray

A Volcano

Political boundaries from U.S. Department of State (2009). $\quad 0 \quad 10 \quad 20 \quad 30 \quad 40$ KILOMETERS Asia North Albers Equal Area Conic Projection.

Central meridian, $121.25^{\circ}$ E., latitude of origin, $30^{\circ} \mathrm{N}$

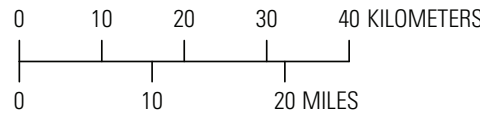

Figure F1. Map showing tract location and significant porphyry copper prospects for tract 142pCu7302, Cordon Alkalic Complex—Philippines. MY, Malaysia; ID, Indonesia. 


\section{Delineation of the Permissive Tract}

\section{Tectonic Setting}

The Cordon Alkalic Complex may be related to intra-arc rifting that occurred after westward subduction along the East Luzon Trench ceased in the late Oligocene and before midMiocene, east-directed subduction began along the Manila Trench (fig. $5 B^{6}$ ). Intraplate magmatism, partial melting of a subducted slab, intra-arc extension, and back-arc rift have all been proposed to explain these rocks (Garwin and others, 2005), and Mitchell and Leach (1991) noted that it was unclear if these rocks are arc-related. More recently, Hollings and others (2011) concluded that the potassic igneous rocks of the Cagayan Valley formed in a back-arc setting coeval with the main arc formed by eastward subduction of the Luzon Arc to the west since the late Eocene. Basement rocks are oceanic, including ophiolite complexes.

\section{Geologic Criteria}

The tract is defined by the occurrence of alkalic rocks (fig. F2, table F2) that constitute the Cordon Alkalic Complex and associated copper prospects. The tract was constructed by selecting Oligocene to Miocene igneous rocks from the digital version of the 1:1,000,000-scale geologic map of the Philippines (Philippine Mines and Geosciences Bureau, 2004a) that lie within the area referred to as the Cordon secondary magmatic arc by Garwin and others (2005). A preliminary tract was constructed using GIS tools to make 10- and 2-km buffers around intrusive and volcanic rocks, respectively. These distances are considered appropriate to allow for inaccuracies in mapped contacts and extensions under adjacent cover rock. The buffered map unit polygons were aggregated, smoothed, and edited by hand, and tract boundaries were checked to include known prospects and permissive igneous rocks shown on maps included in topical studies (Imai, 2005; Wolfe and others, 2010). Point locations for dated alkalic rocks in the database of Malaihollo and others (2002) were plotted to ensure inclusion within the tract area.

The tract includes alkali syenites, monzonites, and trachyandesites of the Dipidio Igneous Complex and Palali batholiths, as well as the Cordon Syenite Complex (Knittel and Cundari, 1990; Knittel and Defant, 1988). The alkalic rocks are characterized by uniformly low initial ${ }^{87} \mathrm{Sr} /{ }^{86} \mathrm{Sr}$ ratios (0.7035-0.7039) and elevated strontium contents (approximately $1,000-3,000 \mathrm{ppm}$ ). The tract also includes the calcalkalic Oligocene-Miocene Dupax batholith (fig. F2), which is not part of the alkalic suite and might be slightly older. Most of the tract area is covered by late Oligocene to middle Miocene sedimentary and volcanic rocks; few intrusive rocks

${ }^{6}$ Refer to figures and tables in main report. are mapped at a scale of 1:1,000,000 (fig. F2). See figure 3 of Hollings and others (2011) for a detailed map of the distribution of alkalic igneous rocks in the Dipidio area.

\section{Known Deposits}

The tract contains three well-characterized Oligocene porphyry copper-gold deposits: Dipidio(Dinkidi), Marian, and San Fabian (table F3). Deposits are plotted as filled squares in figure F1.

\section{Dipidio Group}

The Dipidio (Dinkidi) deposit, notable as one of the few recognized alkaline porphyry deposits outside of British Columbia, Canada, is hosted by the Dipidio Igneous Complex (Wolfe and others, 2010; Wolfe and Cooke, 2011). New $\mathrm{U}-\mathrm{Pb}$ ages on zircon for the Dipidio area reported by Hollings and others (2011) include ages of $24.81 \pm 0.28$ and $24.79 \pm 0.22$ Ma for syenite and monzonite associated with the copper-gold mineralization. The deposit contains measured, indicated, and inferred resources of $101 \mathrm{Mt}$ of 0.36 percent copper, $0.79 \mathrm{~g} / \mathrm{t}$ gold (OceanaGold Corporation, 2011), updated from previous resource estimates (Joyce and Thomson, 2002; Climax Mining Limited, 2010). Mining began in 2012 as an open pit with plans to start underground mining in year 8; estimated mine life is 16 or 17 years (OceanaGold Corporation, 2011, 2013).

The deposit is hosted in the pipe-like, composite Dinkidi stock (monzonite, syenite, porphyry, syenite dike) within the Dipidio igneous complex (gabbro, clinopyroxenite, diorite, monzodiorite, monzonite). The geochemical signature (low $\mathrm{TiO}_{2}$, low $\mathrm{HFSE}^{7}$, high $\mathrm{Al}_{2} \mathrm{O}_{3}$ ) of the alkaline to potassic host rocks is interpreted as representing the final LILE ${ }^{8}$-enriched product of island arc magmatism related to partial melting of a mantle wedge above the eastward-subducting, dehydrating Eurasian Plate (Wolfe and others, 2010). The stock has a potassically altered core, surrounded by a zone of sericite-carbonate-clay alteration. Ore minerals, principally chalcopyrite and electrum, occur in narrow quartz-feldspar-carbonate-sulfide veins in the center of the stock, as peripheral stockworks, and as disseminations with magnetite and pyrite. Bornite is present as rims and along fractures in chalcopyrite. Oxidation (silicification, clay and carbonate mineral, malachite, chrysocolla) extends from the surface to $15-60 \mathrm{~m}$, with an average thickness of $30 \mathrm{~m}$ (Redden and Moore, 2011).

Wolfe and Cooke (2011) published a detailed map showing the distribution of different phases of late Oligocene alkalic rocks at Dinkidi, documented alteration stages as well as sulfur isotope compositions $\left(\delta^{34} \mathrm{~S}\right.$ values of -4.2 to -0.2 per mil) and fluid inclusion characteristics of the deposit. Their study showed that the deposit formed in a multiphase alkali stock that intruded a composite diorite-monzonite pluton at depths of 2.9-4.5 km. Copper-gold ore is associated with both

${ }^{7} \mathrm{HFSE}$, high field strength elements (Y, Hf, Zr, Ti, Nb, Ta).

${ }^{8}$ LILE, large-ion lithophile elements (Cs, $\left.\mathrm{Rb}, \mathrm{K}, \mathrm{Ba}, \mathrm{Sr}, \mathrm{Eu}\right)$. 

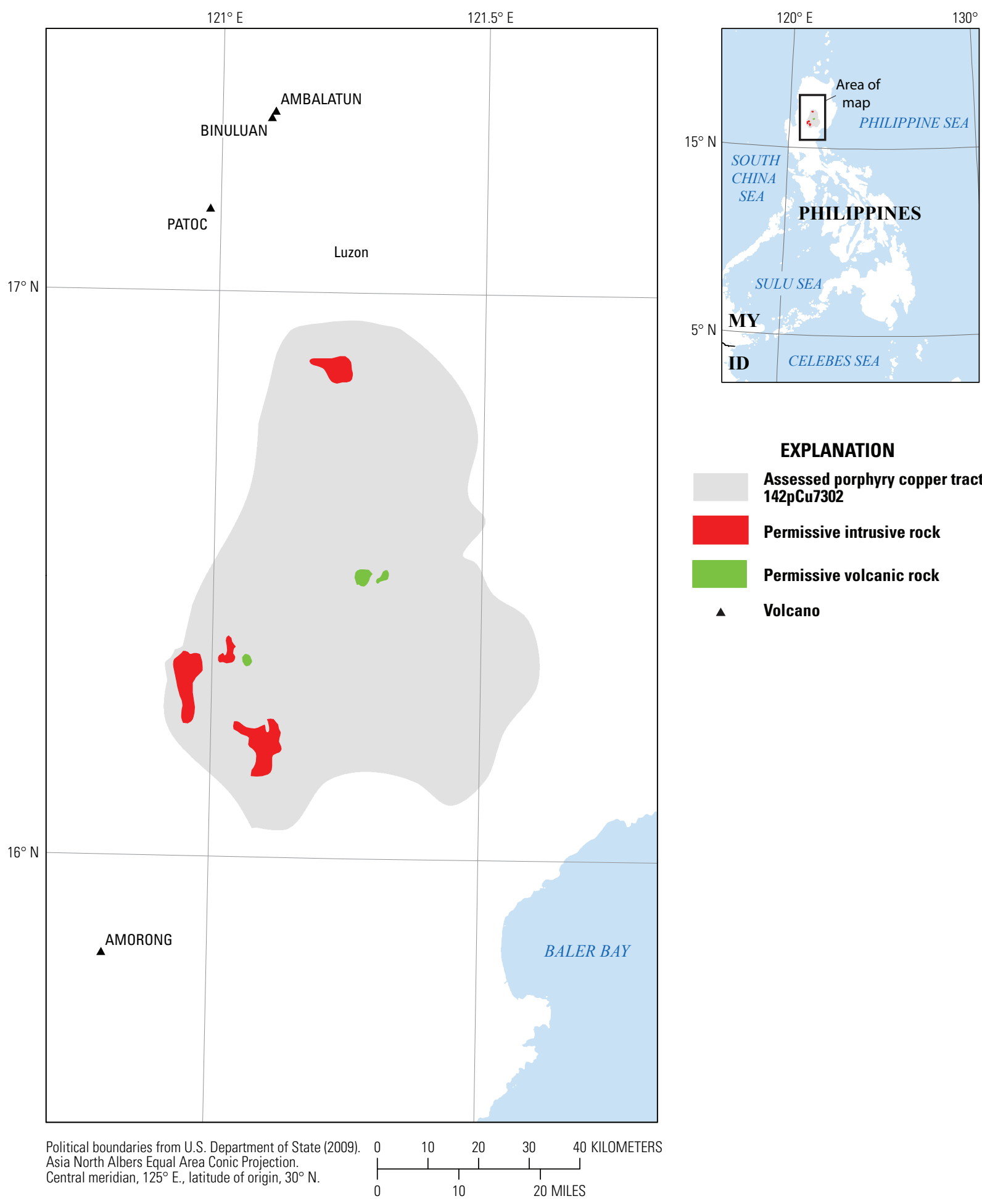

EXPLANATION

Assessed porphyry copper tract 142pCu7302

Permissive intrusive rock

Permissive volcanic rock

$\triangle \quad$ Volcano

Figure F2. Map showing the distribution of permissive igneous rocks for tract 142pCu7302, Cordon Alkalic Complex-Philippines. MY, Malaysia; ID, Indonesia. 
Table F2. Map units that define tract 142pCu7302, Cordon Alkalic Complex-Philippines.

[Map unit, age range, and principal lithologies are based on a digital version of the 1:1,000,000-scale geologic map of the Philippines (Philippine Bureau of Mines, 1963, and references in table F5)]

\begin{tabular}{lcll}
\hline Map unit & $\begin{array}{c}\text { Map } \\
\text { symbol }\end{array}$ & \multicolumn{1}{c}{ Lithology } & Age range \\
\hline Neogene intrusive rocks & NI & $\begin{array}{l}\text { Largely intra-Miocene quartz diorite. Mostly batholiths and stocks, } \\
\text { some laccoliths; also sills, dikes, and other minor bodies. Include } \\
\text { granodiorite and diorite porphyry facies and late Miocene dacite. } \\
\text { Also include Dupax batholith (Aritao quadrangle) and alkalic rocks } \\
\text { mapped around Dipidio. }\end{array}$ & Neogene \\
\hline Neogene volcanic rocks & QV & $\begin{array}{l}\text { Nonactive cones (generally pyroxene andesite); also dacitic and (or) } \\
\text { andesitic plugs. }\end{array}$ & Pliocene-Quaternary \\
\hline
\end{tabular}

Table F3. Porphyry copper deposits in tract 142pCu7302, Cordon Alkalic Complex-Philippines.

[Ma, million years; Mt, million metric tons; $\mathrm{t}$, metric ton; $\mathrm{g} / \mathrm{t}$, gram per metric ton; \%, percent; $\mathrm{Cu}-\mathrm{Au}$ subtype, deposits that have $\mathrm{Au} / \mathrm{Mo}$ ratios $>30$ or average Au grades $>0.2 \mathrm{~g} / \mathrm{t}$; n.d., no data. Contained $\mathrm{Cu}$ in metric tons is computed as $(\mathrm{Mt} \times 1,000,000) \times(\mathrm{Cu}$ grade, in $\% \div 100)]$

\begin{tabular}{|c|c|c|c|c|c|c|c|c|c|c|c|}
\hline Name & Latitude & Longitude & Subtype & Age (Ma) & $\begin{array}{l}\text { Tonnage } \\
\text { (Mt) }\end{array}$ & $\begin{array}{l}\mathrm{Cu} \\
(\%)\end{array}$ & Mo (\%) & $A u(g / t)$ & $A g(g / t)$ & $\begin{array}{c}\text { Contained } \\
\mathrm{Cu}(\mathrm{t})\end{array}$ & Reference \\
\hline $\begin{array}{l}\text { Dipidio } \\
\text { (Dinkidi) } \\
\text { Group }\end{array}$ & 16.331 & 121.453 & $\mathrm{Cu}-\mathrm{Au}$ & 23.2 & 121 & 0.39 & n.d. & 0.97 & n.d. & 471,900 & $\begin{array}{l}\text { Climax Mining, Ltd. } \\
\text { (2010), Feebrey (2001), } \\
\text { Garrett (1996), Hagg- } \\
\text { man (1997), Hollings } \\
\text { and others (2011), } \\
\text { Kamenetsky and others } \\
\text { (1999), Leach (1999), } \\
\text { Wolfe and others (1999, } \\
\text { 2010), OceanaGold } \\
\text { Corporation (2009, } \\
\text { 2011), Singer and } \\
\text { others (2008), van der } \\
\text { Heyden and others } \\
\text { (2008) }\end{array}$ \\
\hline Marian & 16.750 & 121.350 & $\mathrm{Cu}-\mathrm{Au}$ & $\begin{array}{l}\text { Late } \\
\quad \text { Oligocene } \\
\quad(\sim 25)\end{array}$ & 55 & 0.43 & n.d. & 0.24 & n.d. & 236,500 & $\begin{array}{l}\text { Baquiran (1975), } \\
\text { Knittel (1987), Mitchell } \\
\text { and Leach (1991), } \\
\text { Sillitoe and Gappe } \\
\text { (1984), Singer and } \\
\text { others (2008) }\end{array}$ \\
\hline San Fabian & 16.335 & 120.916 & $\mathrm{Cu}-\mathrm{Au}$ & $\begin{array}{l}\text { Early } \\
\text { Miocene } \\
(\sim 20.6)\end{array}$ & 314 & 0.27 & n.d. & 0.21 & n.d. & 847,800 & $\begin{array}{l}\text { MMAJ-JICA (1977), } \\
\text { Sillitoe and Gappe } \\
\text { (1984), Singer and } \\
\text { others (2008) }\end{array}$ \\
\hline
\end{tabular}


silica-undersaturated (quartz free) and silica-saturated stages of development of the deposit, which experienced two phases of tectonic brecciation, the latter of which was accompanied by development of a calcic zeolite alteration assemblage.

Exploration around the deposit area includes some 35 prospects, including a gold-rich copper porphyry associated with a collapse breccia at the D-Fox project and a low-grade alkali porphyry at the True Blue project (these are described in table F4). These exploration projects of OceanaGold Corporation (2011), located 3.2 and $0.6 \mathrm{~km}$ from the Dipidio project, are considered to be extensions of the Dipidio deposit.

\section{Marian}

The Marian gold mine in the Cordon Syenite Complex produced gold and silver (1978-1984) from an underground mine exploiting epithermal gold-rich quartz veins. The veins, which extended to depths of $100 \mathrm{~m}$, are hosted in syenite and tinguaite. The associated gold-rich Marian porphyry copper deposit is hosted in monzonite (Mitchell and Leach, 1991; Medusa Mining, Ltd., 2004).

\section{San Fabian}

The abandoned San Fabian porphyry system (1,500 by $400 \mathrm{~m}$ in area) was drilled by the Philex Mining Co. between 1960 and 1975, followed by additional mapping and sampling in the 1980s and 1990s. At San Fabian, andesitic dikes cut quartz diorite porphyry, tonalite, syenite and monzonite. Ore minerals include chalcopyrite, bornite, and minor chalcocite associated with pyrite in stringers and disseminations in chloritic, propylitic, sericitic, and argillic alteration zones.

\section{Prospects, Mineral Occurrences, and Related Deposit Types}

In addition to the prospects immediately around Dipidio, two prospect areas located more than $10 \mathrm{~km}$ away from the deposit may represent discrete porphyry centers (fig. F1, table F4). The Papaya prospect on the south wall of the Miocene Runruno caldera, $12 \mathrm{~km}$ west of Dipidio, includes a 7-km circular area of hydrothermal alteration associated with quartz monzonite intrusions and anomalous concentration of

Table F4. Significant prospects and occurrences in tract 142pCu7302, Cordon Alkalic Complex-Philippines.

$[\%$, percent; g/t, grams per metric ton; km, kilometers; m, meters. Ages all assumed to be Oligocene-Miocene based on associated map units or dated igneous rocks. Rank $3=$ drilled, with $>20 \mathrm{~m}$ of $0.2 \%$ or more $\mathrm{Cu}$. Rank $2=$ drilled or trenched with $<20 \mathrm{~m}$ of $0.2 \% \mathrm{Cu}$, or past or ongoing exploration. Rank $1=$ copper occurrence that may be related to porphyry-type mineralization based on stream sediment or magnetic anomaly or location along structural trend. *, considered an extension of identified resources]

\begin{tabular}{|c|c|c|c|c|c|}
\hline Name & Latitude & Longitude & Comments & Reference & Rank \\
\hline $\begin{array}{l}\text { True Blue Gold/ } \\
\text { Copper Project }\end{array}$ & 16.330 & 121.463 & $\begin{array}{l}\text { Exploration in the Dipidio area ( } 35 \text { prospects). Area } \\
\text { near the Dipidio open pit has been extensively explored. } \\
\text { Drilling at True Blue in } 2006 \text { identified a small intrusive } \\
\text { stock. }\end{array}$ & $\begin{array}{l}\text { OceanaGold Corpora- } \\
\text { tion }(2011)\end{array}$ & $*$ \\
\hline $\begin{array}{l}\text { D'Fox Gold/ } \\
\text { Copper Project }\end{array}$ & 16.310 & 121.484 & $\begin{array}{l}\text { May be an extension of Dipidio. Exploration of a gold- } \\
\text { rich copper porphyry associated with a collapse breccia } \\
1.5 \mathrm{~km} \text { southeast of Dipidio Gold project. Structural } \\
\text { intersection. Previous exploration drilling reported } 36 \mathrm{~m} \\
\text { of } 0.4 \% \mathrm{Cu}, 1.1 \mathrm{~g} / \mathrm{t} \mathrm{Au} \text {, and } 84 \mathrm{~m} \text { of } 0.4 \% \mathrm{Cu} \text { and } 1.0 \mathrm{~g} / \mathrm{t} \\
\mathrm{Au} \text {. }\end{array}$ & $\begin{array}{l}\text { OceanaGold Corpora- } \\
\text { tion }(2011)\end{array}$ & $*$ \\
\hline Papaya & 16.200 & 121.480 & $\begin{array}{l}\text { Circular alteration area }(7 \mathrm{~km} \text { in diameter) in an alkaline } \\
\text { Miocene volcano-plutonic complex; approximate loca- } \\
\text { tion } \sim 12 \mathrm{~km} \mathrm{~W} \text { of Dipidio. Anomalous } \mathrm{Au}(3.7 \mathrm{~g} / \mathrm{t}) \text {, } \\
\mathrm{Cu}(0.1 \%) \text {, Mo }(0.1 \%) \text { from channel samples in highly } \\
\text { altered (potassic-magnetite) monzonite. }\end{array}$ & $\begin{array}{l}\text { Climax Mining, Ltd. } \\
(2002)\end{array}$ & 2 \\
\hline Pao Yabbe & 16.167 & 121.333 & $\begin{array}{l}\text { Epithermal gold veins associated with alkalic volcanic } \\
\text { rocks, with possible porphyry-style mineralization } \\
\text { at depth. }\end{array}$ & $\begin{array}{l}\text { RoyalCo Resources, } \\
\text { Ltd. (2010) }\end{array}$ & 1 \\
\hline
\end{tabular}


copper, gold and molybdenum in stream sediment and channel samples (OceanaGold Corporation, 2011). Exploration at the Pao Yabbe exploration tenement (fig. F1) is focused on epithermal gold veins associated with alkalic volcanic rocks, with possible porphyry-style mineralization at depth (RoyalCo Resources, Ltd., 2010). Garwin and others (2005) described Runruno as an intermediate-sulfidation gold deposit and Pao as a high-sulfidation enargite-gold occurrence associated with alkalic volcanic rocks based on the work of Kavalieris and Gonzalez (1990). A gold-molybdenum deposit centered on a 3 -km-wide argillically altered volcanic center is in development at Runruno by Metals Exploration plc (2012). Drilling in an area $2 \mathrm{~km}$ to the south of Runruno (Magnetite Creek area) intercepted a brecciated monzonite-monzodiorite intrusion; assays on three drill holes returned intercepts for copper and gold (table F4). Climax Mining, Ltd., (2002) described a prospect area called Papaya-FHB Intrusive Complex as a $50-\mathrm{km}^{2}$ Miocene alkaline volcano-plutonic complex located about $12 \mathrm{~km}$ west of Dipidio; anomalous gold, copper, and molybdenum concentrations were obtained from channel samples in highly altered (potassic-magnetite) monzonite.

\section{Exploration History}

Alluvial gold mining led to recognition of the Dipidio area as a gold province in the 1970s (Joyce and Thomson, 2002). Dinkidi was discovered in 1988, based on recognition of the unusual topographic expression of an apparent collapse caldera (Haggman, 1997). The Marian gold mine was discovered during regional exploration in the 1970s. The Dipidio copper-gold project area includes the Dipidio (Dinkidi) open pit mine and 30 prospects within the FTAA (Financial or Technical Assistance Agreement) area (OceanaGold Corporation, 2011). The Dipidio area $\left(215 \mathrm{~km}^{2}\right)$ was explored under an FTAA granted to Climax Mining Limited in 1998 (Joyce and Thomson, 2002); the expected mine development (15 yearminimum mine life producing 15,000 t of copper concentrate and 12,000 ounces of gold per year in the first 10 years of operation) did not occur at that time. The mine development was placed on care and maintenance in 2008, with a review of feasibility to renew development in 2009 (OceanaGold Corporation, 2009). Global economic conditions, as well as local social and environmental opposition to mining, are factors that affected mine development until very recently (2012).

Exploration for epithermal gold and alkali-associated porphyry deposits using stream sediment, soil, rock chip sampling and limited drilling led to the identification of additional targets (True Blue, d'Fox are partially drilled). Exploration for deep porphyry copper-gold targets associated with highlevel epithermal gold systems is underway in several areas, including proximal to the Runruno gold-molybdenum deposit, which is currently in development with announced resources of $26 \mathrm{Mt}$ at $1.69 \mathrm{~g} / \mathrm{t}$ gold and $470 \mathrm{ppm}$ molybdenum (Metals Exploration plc, 2012).

\section{Sources of Information}

Principal sources of information used for the assessment are listed in table F5.

\section{Grade and Tonnage Model Selection}

The known deposits are copper-gold porphyry deposits. The porphyry $\mathrm{Cu}-\mathrm{Au}$ subtype model was selected. In addition to the known gold grades, porphyry copper deposits associated with alkaline source rocks typically are gold-rich.

\section{Estimate of the Number of Undiscovered Deposits}

\section{Rationale for the Estimate}

Based on the wide spatial distribution of the three known deposits in the tract, the presence of alkalic rocks, and active, but incompletely explored prospect areas, the assessment team estimated a 50-percent chance for one or more deposits like those in the model, a 10-percent chance for four or more, and a 5-percent chance of five or more undiscovered deposits (table F6). The expected number of undiscovered deposit associated with this distribution is two. The small tract area $\left(4,860 \mathrm{~km}^{2}\right)$ is a limiting factor on the number of deposits. In addition, the thicknesses of some of the stratigraphic units in the Caraballo Mountains are on the order of 3,000-4,000 m (Philippine Bureau of Mines and Geosciences, 1981), so the depth of cover may exceed the $1-\mathrm{km}$ protocol adopted for this study.

\section{Probabilistic Assessment Simulation Results}

Undiscovered resources for the tract were estimated by combining the team's estimate for numbers of undiscovered porphyry copper deposits with the porphyry copper-gold model of Singer and others (2008) using the EMINERS program (Root and others, 1992; Duval, 2012; Bawiec and Spanski, 2012). Selected simulation results are reported in table F7. Results of the Monte Carlo simulation are presented as a cumulative frequency plot (fig. F3). The cumulative frequency plot shows the estimated resource amounts associated with cumulative probabilities of occurrence, as well as the mean, for each commodity and for total mineralized rock. The simulation estimates that the median amount of copper in undiscovered deposits in the tract (1.2 Mt) is slightly less than the identified resources $(1.4 \mathrm{Mt})$; the mean estimated resources (4.9 Mt) exceed the identified resources (table F1). See table 6 for comparisons with identified copper and gold resources, and with other tracts. 
Table F5. Principal sources of information used for tract 142pCu7302, Cordon Alkalic Complex-Philippines.

[NA, not applicable]

\begin{tabular}{|c|c|c|c|}
\hline Theme & Name or title & Scale & Citation \\
\hline \multirow[t]{3}{*}{ Geology } & Digital geologic map of the Philippines & $1: 1,000,000$ & $\begin{array}{l}\text { Philippine Mines and Geosciences Bureau } \\
\text { (2004a) }\end{array}$ \\
\hline & $\begin{array}{l}\text { Geology and mineral resources of the Philippines, } \\
\text { v. } 1 \text { - Geology }\end{array}$ & $1: 1,000,000$ & $\begin{array}{l}\text { Philippine Bureau of Mines and Geosci- } \\
\text { ences (1981) [Philippine] Mines and } \\
\text { Geosciences Bureau (2010) }\end{array}$ \\
\hline & Geologic map of the Philippines & $1: 1,000,000$ & Philippine Bureau of Mines (1963) \\
\hline \multirow[t]{5}{*}{$\begin{array}{l}\text { Mineral } \\
\text { occurrences }\end{array}$} & $\begin{array}{l}\text { Porphyry copper deposits of the world-Database, } \\
\text { map, and grade and tonnage models }\end{array}$ & NA & Singer and others (2008) \\
\hline & $\begin{array}{l}\text { Geology and mineral resources of the Philippines, } \\
\text { v. } 2 \text { - Mineral Resources }\end{array}$ & NA & $\begin{array}{l}\text { Philippine Bureau of Mines and Geosci- } \\
\text { ences (1986) }\end{array}$ \\
\hline & $\begin{array}{l}\text { Digital data base of mineral occurrences of the } \\
\text { Philippines }\end{array}$ & NA & $\begin{array}{l}\text { Philippine Mines and Geosciences Bureau } \\
\text { (2004b) }\end{array}$ \\
\hline & Mining places in the Philippines ( $\mathrm{kml}$ file) & NA & GoogleEarth ${ }^{\circledR}(2013)$ \\
\hline & Philippine porphyry copper deposits & NA & Sillitoe and Gappe (1984) \\
\hline \multirow[t]{4}{*}{ Exploration } & $\begin{array}{l}\text { U.S. Geological Survey On-Line Mineral Resources } \\
\text { Spatial Data }\end{array}$ & NA & U.S. Geological Survey (2012) \\
\hline & Philippine Mines and Geosciences Bureau Web site & NA & http://www.mgb.gov.ph/ \\
\hline & Commercial databases & NA & http://www.infomine.com/ \\
\hline & Company Web sites and technical reports & NA & Numerous_-see references in table E4 \\
\hline
\end{tabular}

Table F6. Undiscovered deposit estimates, deposit numbers, tract area, and deposit density for tract 142pCu7302, Cordon Alkalic Complex-Philippines.

[ $N_{\mathrm{xX}}$, estimated number of deposits associated with the xxth percentile; $N_{\text {und }}$, expected number of undiscovered deposits; $s$, standard deviation; $C_{v} \%$, coefficient of variance; $N_{\text {known }}$, number of known deposits in the tract that are included in the grade and tonnage model; $N_{\text {total }}$ total of expected number of deposits plus known deposits; area, area of permissive tract in square kilometers $\left(\mathrm{km}^{2}\right)$; density, deposit density reported as the total number of deposits per $100,000 \mathrm{~km}{ }^{2} . N_{\text {und }} s$, and $C_{v} \%$ are calculated using a regression equation (Singer and Menzie, 2005)]

\begin{tabular}{|c|c|c|c|c|c|c|c|c|c|c|c|}
\hline \multicolumn{5}{|c|}{ Consensus undiscovered deposit estimates } & \multicolumn{5}{|c|}{ Summary statistics } & \multirow{2}{*}{$\begin{array}{c}\text { Tract Area } \\
\quad\left(\mathbf{k m}^{2}\right)\end{array}$} & \multirow{2}{*}{$\begin{array}{c}\text { Deposit density } \\
\left(N_{\text {total }} / 100,000 \mathrm{~km}^{2}\right)\end{array}$} \\
\hline$N_{90}$ & $N_{50}$ & $N_{10}$ & $N_{05}$ & $N_{01}$ & $N_{\text {und }}$ & $s$ & $C_{v} \%$ & $N_{\text {known }}$ & $N_{\text {total }}$ & & \\
\hline 0 & 1 & 4 & 5 & 5 & 1.7 & 1.7 & 100 & 3 & 4.7 & 4,860 & 97 \\
\hline
\end{tabular}

Table F7. Results of Monte Carlo simulation of undiscovered resources for tract 142pCu7302, Cordon Alkalic Complex—Philippines.

[Cu, copper; Mo, molybdenum; Au, gold; and Ag, silver; in metric tons; rock, in million metric tons]

\begin{tabular}{|c|c|c|c|c|c|c|c|c|}
\hline \multirow[b]{2}{*}{ Material } & \multicolumn{6}{|c|}{ Probability of at least the indicated amount } & \multicolumn{2}{|c|}{ Probability of } \\
\hline & 0.95 & 0.9 & 0.5 & 0.1 & 0.05 & Mean & $\begin{array}{c}\text { Mean or } \\
\text { greater }\end{array}$ & None \\
\hline Mo & 0 & 0 & 52,000 & 420,000 & 620,000 & 140,000 & 0.27 & 0.12 \\
\hline $\mathrm{Au}$ & 82 & 210 & 1,300 & 4,000 & 5,000 & 1,800 & 0.37 & 0.03 \\
\hline
\end{tabular}




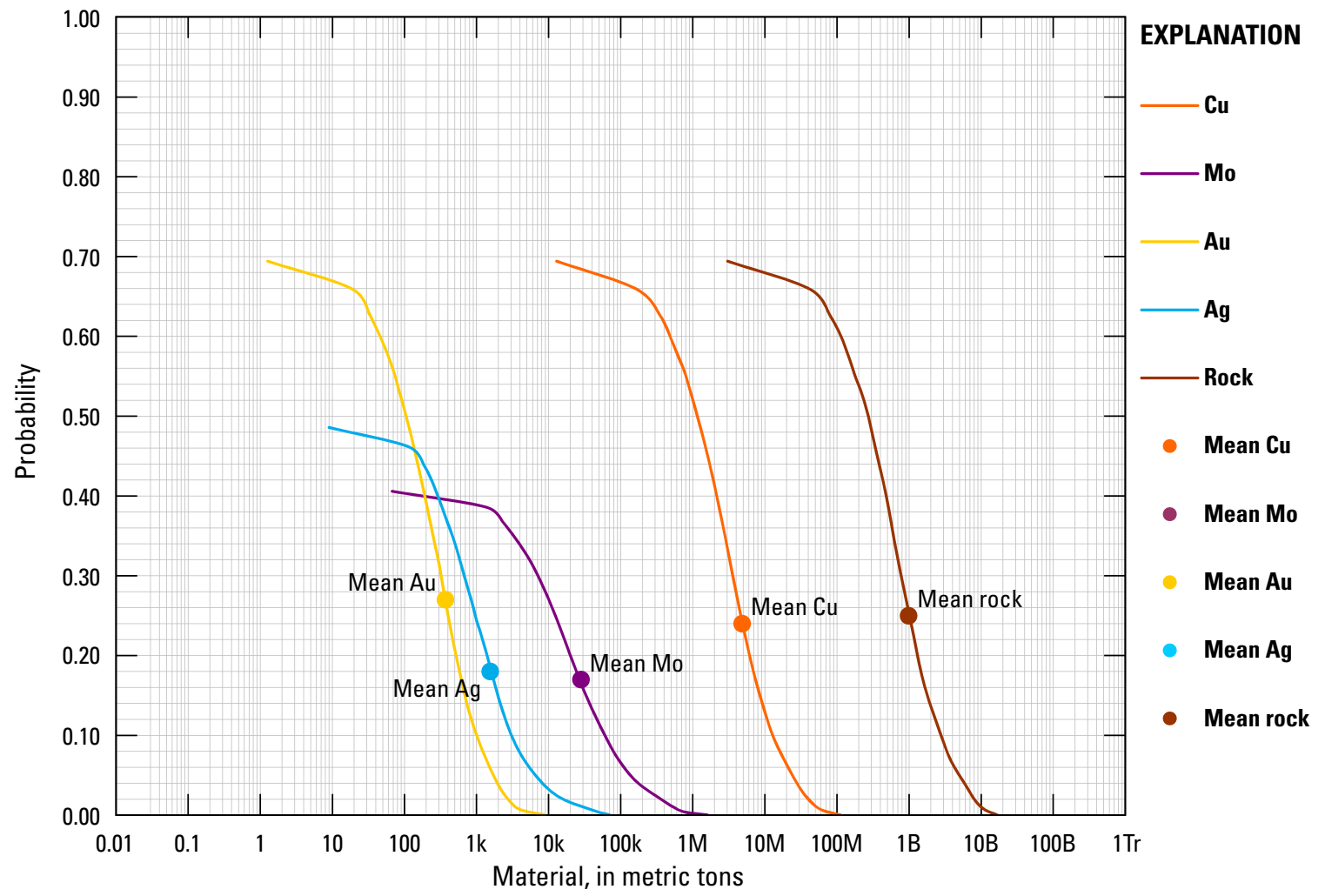

Figure F3. Cumulative frequency plot showing the results of Monte Carlo computer simulation of undiscovered resources in 142pCu7302, Cordon Alkalic Complex-Philippines. k, thousands; M, millions; B, billions; $T r$, trillions.

\section{References Cited}

Bawiec, W.J., and Spanski, G.T., 2012, Quick-start guide for version 3.0 of EMINERS-Economic Mineral Resource Simulator: U.S. Geological Survey Open-File Report 2009-1057, 26 p., accessed June 30, 2012, at http://pubs. usgs.gov/of/2009/1057. (This report supplements USGS OFR 2004-1344/.)

Baquiran, G.B., 1975, Notes on the geology and exploration of the Marian copper deposit, Cordon, Isabela: Journal of Geological Society of the Philippines, v. 29, no. 1, p. 1-9.

Berger, B.R., Ayuso, R.A., Wynn, J.C., and Seal, R.R., 2008, Preliminary model of porphyry copper deposits: U.S. Geological Survey Open-File Report 2008-1321, 55 p., accessed May 15, 2009, at http://pubs.usgs.gov/ of/2008/1321/.

Climax Mining, Ltd., 2002, Philippines: Climax Mining, Ltd., Quarterly report for the period ending 30 June 2002, 3 p.

Climax Mining, Ltd., 2010, Dinkidi project: Climax Mining, Ltd., Web site, accessed July 22, 2010, at http://www. climaxmining.com.au/dinkidi_project.html.
Cox, D.P., 1986, Descriptive model of porphyry $\mathrm{Cu}-\mathrm{Au}$, in Cox, D.P., and Singer, D.A., eds., 1986, Mineral deposit models: U.S. Geological Survey Bulletin 1693, p. 110. (Also available at http://pubs.usgs.gov/bul/b1693/.)

Duval, J.S., 2012, Version 3.0 of EMINERS-Economic Mineral Resource Simulator: U.S. Geological Survey Open-File Report 2004-1344, accessed June 30, 2012, at http://pubs. usgs.gov/of/2004/1344/.

Feebrey, G.A., 2001, Exploration reviews: Asia, Philippines: SEG (Society of Economic Geologists) Newsletter, April, no. 45, p. 35 .

Garrett, S., 1996, The geology and mineralization of the Dinkidi porphyry related Au-Cu deposit, in Porphyry related copper and gold deposits of the Asia Pacific region: Glenside, South Australia, Australian Mineral Foundation, Conference Proceedings, p. 6.0-6.15.

Garwin, S., Hall, R., and Watanabe, Y., 2005, Tectonic setting, geology, and gold and copper mineralization in Cenozoic magmatic arcs of southeast Asia and the west Pacific, in Hedenquist, T.W., Thompson, J.F.H., Goldfarb, R.J., and Richards, J.P., eds., One hundredth anniversary volume 1905-2005: Littleton, Colorado, Society of Economic Geologists, p. 891-930. 
Google Earth ${ }^{\circledR}, 2013$, Mining places in the Philippines: Google Earth ${ }^{\circledR}$ Web site, accessed April 5, 2013, at http:// www.google.com/url? sa $=\mathrm{t} \& \mathrm{rct}=\mathrm{j} \& \mathrm{q}=\& \mathrm{esrc}=\mathrm{s} \& \mathrm{frm}=1 \&$ sou rce $=$ web $\&$ cd $=2 \&$ sqi $=2 \&$ ved $=0$ CEAQFjAB \&url $=$ http $\% 3 \mathrm{~A}$ $\% 2 \mathrm{~F} \% 2 \mathrm{Fgeocommons} . c 0 \mathrm{\%} \% 2 \mathrm{Foverlays} \% 2 \mathrm{~F} 16366 . \mathrm{kml} \&$ ei=kfNeUZTVE8nO2gXb2IGYAQ\&usg=AFQjCNFLq8Cr nK4OBdTHR81Aka9fzvm3zg\&sig2=dDS9CIwjKLhyq28Ifqtmw\&bvm=bv.44770516,d.b2.

Haggman, J.A., 1997, Philippines exploration-Discovery of the Dinkidi gold-copper porphyry: Mining Engineering, $p$. 34-39.

Hollings, Pete, Wolfe, R., Coke, D.R., and Waters, P.J., 2011, Geochemistry of Tertiary igneous rocks of Northern Luzon, Philippines-Evidence for a back-arc setting for alkali porphyry copper-gold deposits and a case for slab roll-back?: Economic Geology, v. 106, p. 1257-1277.

Imai, A., 2005, Evolution of hydrothermal system at the Dizon porphyry $\mathrm{Cu}-\mathrm{Au}$ deposit, Zambales, Philippines: Resource Geology, v. 55, no. 2, p. 73-90.

John, D.A., Ayuso, R.A., Barton, M.D., Blakely, R.J., Bodnar, R.J., Dilles, J.H., Gray, Floyd, Graybeal, F.T., Mars, J.C., McPhee, D.K., Seal, R.R., Taylor, R.D., and Vikre, P.G., 2010, Porphyry copper deposit model, chap. B of Mineral deposit models for resource assessment: U.S. Geological Survey Scientific Investigations Report 2010-5070-B, 169 p., accessed September 8, 2010, at http://pubs.usgs.gov/ $\operatorname{sir} / 2010 / 5070 / \mathrm{b} /$.

Joyce, Paul, and Thomson, Robert, 2002, Dipidio gold-copper project-Moving towards development: accessed June 21, 2010, at http://www.smedg.org.au/Tiger/Dipidio.htm.

Kamenetsky, V.S., Wolfe, R.C., Eggins, S.M., Mernagh, T.P., and Bastrakov, E., 1999, Volatile exsolution at the Dinkidi $\mathrm{Cu}-\mathrm{Au}$ porphyry deposit, Philippines-A melt-inclusion record of the initial ore-forming process: Geology, v. 27, p. 691-694.

Kavalieris, I., and Gonzalez, J.M., 1990, Geology and mineralization of the Pao prospect-A high sulphidation epithermal gold system hosted in alkaline volcanics, North Luzon, Philippines, in Foots, J., and Brennan, T., eds., Proceedings of the Pacific Rim Congress 1990: Parkville, Victoria, Australian Institute of Mining and Metallurgy, v. 2, p. 413-418.

Knittel, U., 1987, The Cordon syenite complex-An undersaturated potassic igneous center in the Philippine Island Arc: Neues Jahrbuch Mineralogishe Abhandlungen, v. 157, no. 1, p. $57-80$.

Knittel, U., and Cundari, A., 1990, Mineralogical evidence for the derivation of metaluminous, potassic rocks from peralkaline precursors-The Cordon Syenite Complex (Philippines): Mineralogy and Petrology ,v. 41, p. 163-183.
Knittel, U., and Defant, M.J., 1988, Sr isotopic and trace element variations in Oligocene to Recent igneous rocks from then Philippine island arc - Evidence for Recent enrichment in the sub-Philippine mantle: Earth and Planetary Science Letters, v. 87, p. 87-99.

Leach, T.M., 1999, Evolution of selected porphyry coppergold systems in the Northwest Pacific Region and its relevance to exploration, in Weber, G., ed., Pacrim ' 99 Congress Proceedings, International Congress on earth science, exploration and mining around Pacific rim: Australasian Institute of Mining and Metallurgy Publication Series no. 4/99, p. 211-225.

Malaihollo, J.F.A., Hall, R., and Macpherson, C.G., 2002, SE Asia Radiometric ages - GIS database: Southeast Asia Research Group, Department of Earth Sciences, Royal Holloway University of London, accessed February 1, 2010, at http://searg.rhul.ac.uk/current_research./isotopic_ages/ SEAsia_GIS.pdf.

Medusa Mining, Ltd., 2004, Marian gold mine project, Luzon Island, Philippines: Medusa Mining, Ltd., Web site, accessed April 15, 2013, at http://www.medusamining.com. au/newsroom/asx/040714\%20Marian\%20Gold\%20Project. pdf.

Metal Mining Agency of Japan and Japan International Cooperation Agency [MMAJ-JICA], 1977, Report on geological survey of northeastern Luzon, Phase III: Metal Mining Agency of Japan and Japan International Cooperation Agency, Tokyo, $280 \mathrm{p}$.

Metals Exploration plc, 2012, Runruno project: Metals Exploration plc Web site, accessed June 10, 2012, at http://www. metalsexploration.com/.

Mitchell, A.H.G, and Leach, T.M., 1991, Epithermal gold in the Philippines-Island arc metallogenesis, geothermal systems and geology: London, Academic Press, $457 \mathrm{p}$.

OceanaGold Corporation, 2009, OceanaGold Corporation Annual Report for 2009: OceanaGold Corporation, accessed September 5, 2010, at http://www.OceanaGold Corporation. com/images/documents/OceanaGold Corporation_annual_ report_2009.pdf.

OceanaGold Corporation, 2011, OceanaGold Corporation: OceanaGold Corporation Web site, accessed September 5, 2011, at http://www.OceanaGold Corporation.com/.

OceanaGold Corporation, 2013, Dipidio Mine: OceanaGold Corporation Web site, accessed April 18, 2013, at http:// www.oceanagold.com/our-business/philippines/didipiomine/.

Philippine Bureau of Mines, 1963, Geological map of the Philippines: Philippine Bureau of Mines, 1 map on 8 sheets, scale 1:1,000,000. 
Philippine Bureau of Mines and Geosciences, 1981, Geology and mineral resources of the Philippines, v. 1-Geology: Philippine Bureau of Mines and Geosciences, 406 p.

Philippine Bureau of Mines and Geosciences, 1983, Geological map of Aritao quadrangle: Philippine Bureau of Mines and Geosciences, sheet 3268-4, scale 1:50,000.

Philippine Bureau of Mines and Geosciences, 1986, Geology and mineral resources of the Philippines, v. 2-Mineral Resources: Philippine Bureau of Mines and Geosciences, $446 \mathrm{p}$.

Philippine Geological Survey Division, 1964, Mineral distribution map of the Philippines-Base metals: Philippine Geological Survey Division, sheet 2 of 6 maps, scale $1: 2,500,000$.

Philippine Mines and Geosciences Bureau, 2004a, Digital geological map of the Philippines: Philippine Mines and Geosciences Bureau, scale 1:1,000,000. [Proprietary data.]

Philippine Mines and Geosciences Bureau, 2004b, Digital database of mineral occurrences of the Philippines: Philippine Mines and Geosciences Bureau. [Proprietary report.]

Philippine Mines and Geosciences Bureau, 2010, Geology of the Philippines ( $2 \mathrm{~d}$ ed.): Philippine Mines and Geosciences Bureau, $532 \mathrm{p}$.

Redden, R., and Moore, J., 2011, Technical report for the Dipidio project prepared for OceanaGold Corporation, July 29, 2011, 163 p.: accessed June 10, 2012, at http:// www.OceanaGold Corporation.com/our-business/ philippines/didipio-project.

Root, D.H., Menzie, W.D., and Scott, W.A., 1992, Computer Monte Carlo simulation in quantitative resource estimation: Natural Resources Research, v. 1, no. 2, p. 125-138.

RoyalCo Resources, Ltd., 2010, Pao Yabbe Project, Southern Sierra Madre [Philippines]: RoyalCo Resources, Ltd. Web page, accessed April 8, 2010, at http://www.royalco.com.au/ exploration.html.

Sillitoe, R.H., and Gappe, I.M., Jr., 1984, Philippine porphyry copper deposits-Geologic setting and characteristics: Committee for Co-ordination of Joint Prospecting for Mineral Resources in Asian Offshore Areas (CCOP), CCOP Technical Publication 14, 89 p.
Singer, D.A., and Menzie, W.D., 2005, Statistical guides to estimating the number of undiscovered mineral deposits-An example with porphyry copper deposits, in Cheng, Qiuming, and Bonham-Carter, Graeme, eds., Proceedings of IAMG-The annual conference of the International Association for Mathematical Geology: Toronto, Canada, York University, Geomatics Research Laboratory, p. $1028-1033$.

Singer, D.A., Berger, V.I., and Moring, B.C., 2008, Porphyry copper deposits of the World-Database and grade and tonnage models, 2008: U.S. Geological Survey Open-File Report 2008-1155, accessed June 1, 2011, at http://pubs. usgs.gov/of/2008/1155/.

U.S. Department of State, 2009, Small-scale digital international land boundaries (SSIB) - Lines, edition 10, and polygons, beta edition 1, in Boundaries and sovereignty encyclopedia (B.A.S.E.): U.S. Department of State, Office of the Geographer and Global Issues.

U.S. Geological Survey, 2012, On-line mineral resources spatial data: U.S. Geological Survey Web site, accessed February 10, 2012, at http://mrdata.usgs.gov/.

van der Heyden, A., Wyhe, J., and McIntyre, J., 2008, Independent technical report for the Dipidio goldcopper project prepared for OceanaGold Corporation: accessed June 10, 2012, at www.oceanagold.com/assets/ documents/.../080627ni43-101.pdf.

Wolfe, R.C., Cooke, D.R., and Joyce, P., 1999, Geology, mineralization and genesis of the alkaline Dinkidi $\mathrm{Cu}-\mathrm{Au}$ porphyry, North Luzon, Philippines, in Weber, G., ed., Pacrim '99 Congress Proceedings, International Congress on earth science, exploration and mining around Pacific rim: Australasian Institute of Mining and Metallurgy Publication Series no. 4/99, p. 509-516.

Wolfe, Rohan, Hollings, Pete, and Cooke, D.R., 2010 Mineralisation and geochemistry associated with the Dinkidi alkali $\mathrm{Cu}$-Au porphyry, Northern Luzon, Philippines: GeoCanada-Working with the Earth, accessed September 8, 2010, at www.geocanada2010.ca/uploads/abstracts_new/ view.php?item_id=531.

Wolfe, R.C., and Cooke, D.R., 2011, Geology of the Dipidio region and genesis of the Dinkidi alkalic porphyry $\mathrm{Cu}-\mathrm{Au}$ deposit and related pegmatites, Northern Luzon, Philippines: Economic Geology, v. 106, p. 1279-1315. 
This page left intentionally blank. 


\section{Appendix G. Porphyry Copper Assessment for Tract 142pCu7304, Sierra Madre Arc-Philippines}

By Jane M. Hammarstrom ', Arthur A. Bookstrom², Connie L. Dicken', Steve Ludington³, Gilpin R. Robinson, Jr.', and Michael L. Zientek ${ }^{2}$ with contributions from Sevillo (Bill) D. David, Jr. ${ }^{4}$ Claro J. Manipon ${ }^{4}$, Lilian A. Rollan ${ }^{4}$, and Yasushi Watanabe ${ }^{5}$

\section{Deposit Type Assessed: Porphyry copper}

Descriptive model: Porphyry copper (Cox, 1986; Berger and others, 2008; John and others, 2010; Sillitoe and Gappe, 1984) Grade and tonnage model: Porphyry copper, general model (Singer and others, 2008)

Table G1 summarizes selected assessment results.

Table G1. Summary of selected resource assessment results for tract 142pCu7304, Sierra Madre Arc-Philippines.

[km, kilometers; $\mathrm{km}^{2}$, square kilometers; $\mathrm{t}$, metric tons; identified copper rounded to two significant figures]

\begin{tabular}{|c|c|c|c|c|c|}
\hline $\begin{array}{c}\text { Date of } \\
\text { assessment }\end{array}$ & $\begin{array}{l}\text { Assessment depth } \\
(\mathrm{km})\end{array}$ & Tract area $\left(\mathbf{k m}^{2}\right)$ & $\begin{array}{l}\text { Identified copper } \\
\text { resources }(t)\end{array}$ & $\begin{array}{l}\text { Mean estimate of } \\
\text { undiscovered copper } \\
\text { resources }(t)\end{array}$ & $\begin{array}{l}\text { Median estimate of } \\
\text { undiscovered copper } \\
\text { resources }(t)\end{array}$ \\
\hline 2010 & 1 & 14,000 & 310,000 & $1,400,000$ & 0 \\
\hline
\end{tabular}

\section{Location}

Northern and Southern Sierra Madre of eastern Luzon and Polillo Island (fig. G1).

\section{Geologic Feature Assessed}

Sierra Madre Arc.

${ }^{1}$ U.S. Geological Survey, Reston, Virginia, United States.

${ }^{2}$ U.S. Geological Survey, Spokane, Washington, United States.

${ }^{3}$ U.S. Geological Survey, Menlo Park, California, United States.

${ }^{4}$ Philippine Department of Environment and Natural Resources, Mines and Geosciences Bureau, Quezon City, Philippines.

${ }^{5}$ Geological Survey of Japan, National Institute of Advanced Industrial Science and

Technology (AIST), Ibaraki, Japan. 
$\boldsymbol{A}$

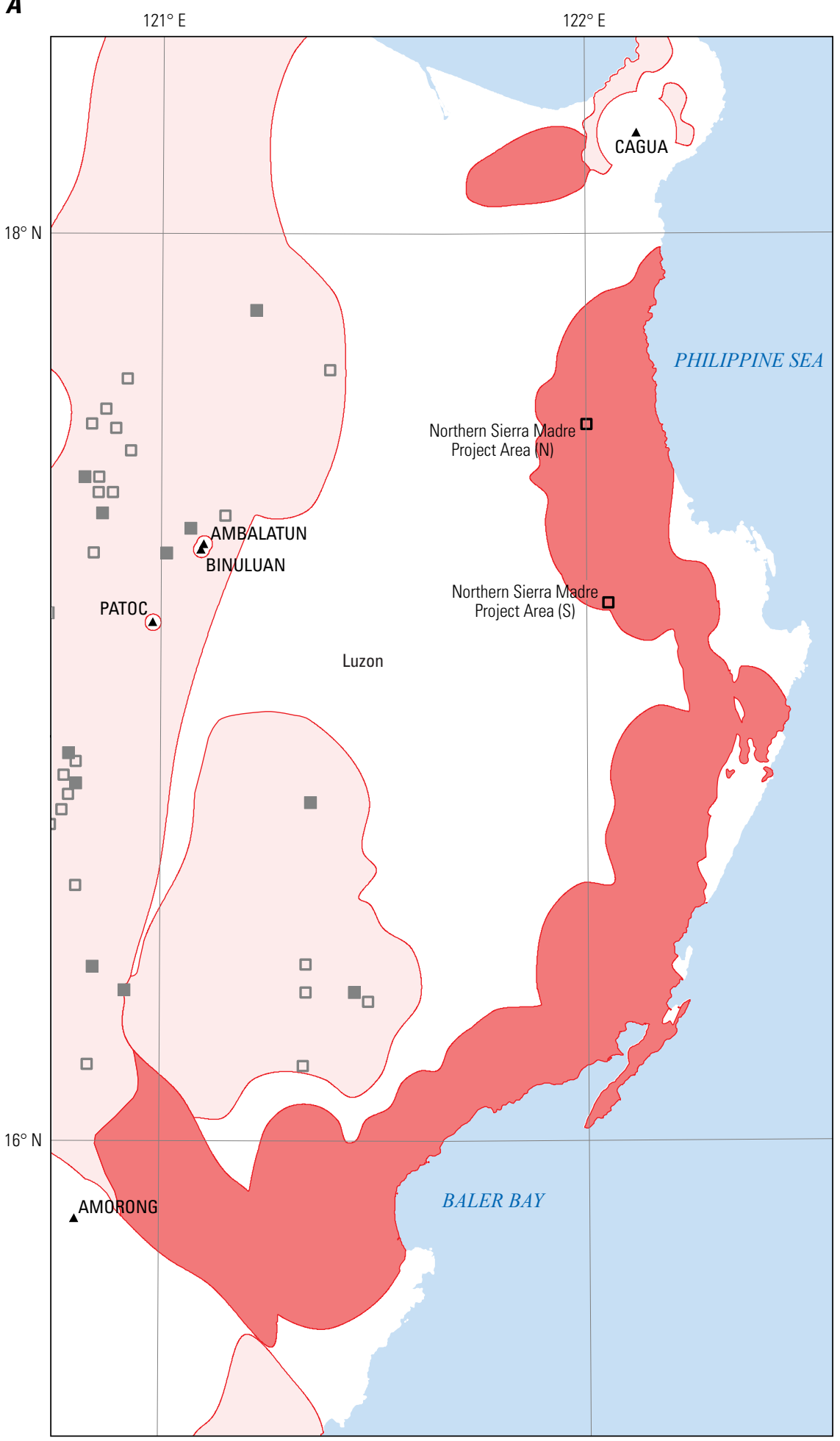

Political boundaies from U.S. Department of State (2009). Asia North Albers Equal Area Conic Projection.

Central meridian $121.5^{\circ}$ E., latitude of origin, $30^{\circ} \mathrm{N}$.

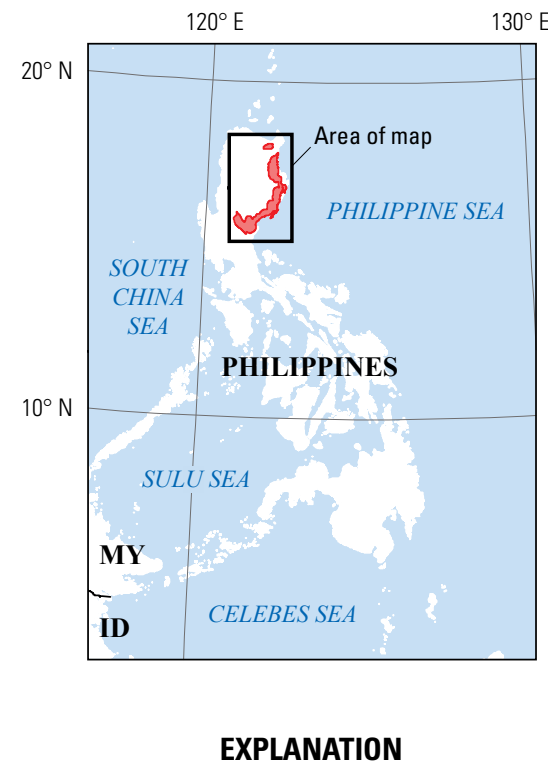

Assessed porphyry copper tract 150pCu7304 (Northern segment)

Other porphyry copper tracts

Porphyry copper deposit associated with other tracts

\section{Porphyry copper prospect;}

口 prospects associated with other tracts shown in gray

- Volcano

Figure G1. Maps showing tract location, deposits, and significant porphyry copper prospects for tract 142pCu7304, Sierra Madre Arc—Philippines. A, Northern Sierra Madre. B, Southern Sierra Madre. MY, Malaysia; ID, Indonesia. 
B

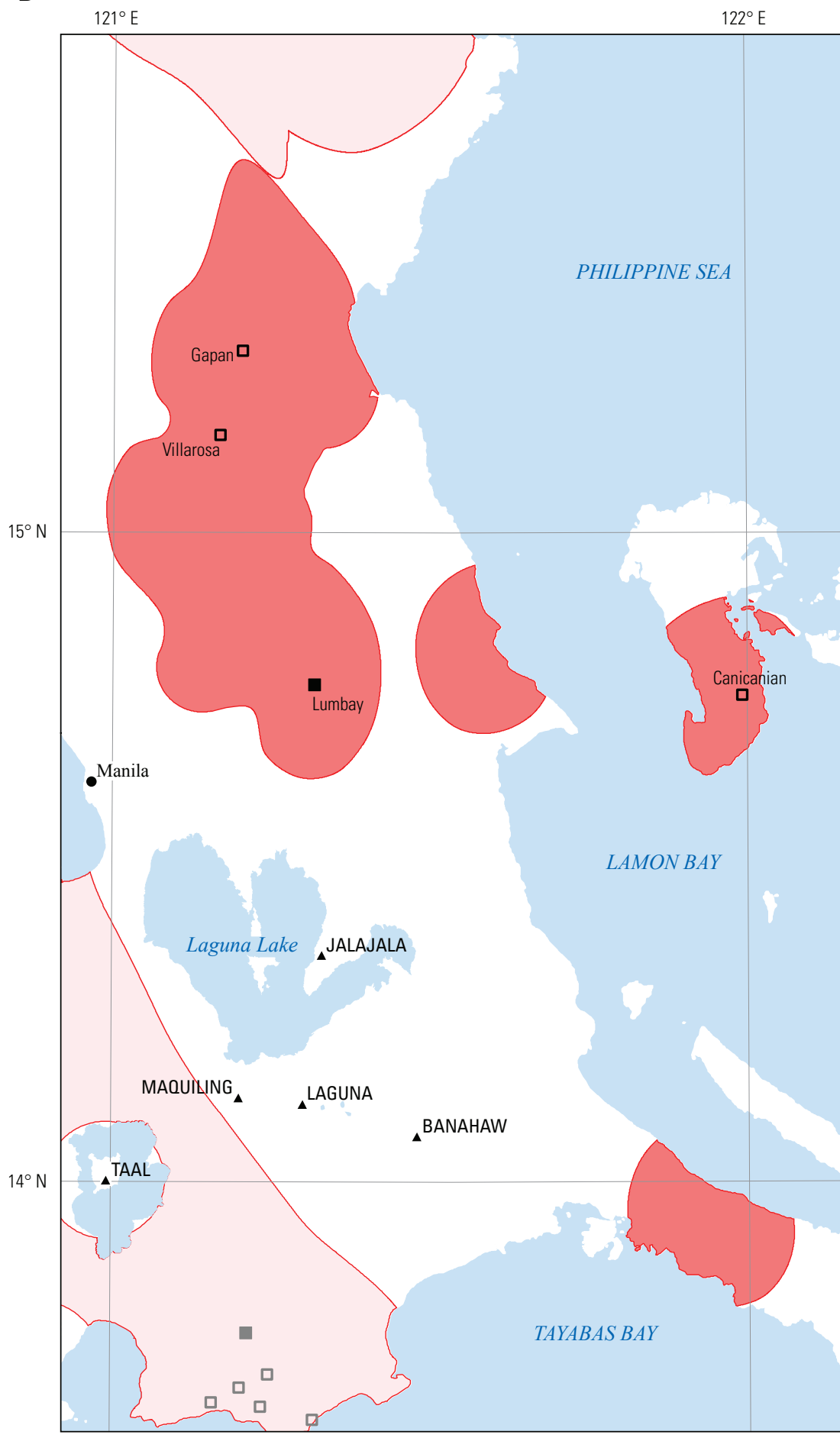

Political boundaries from U.S. Department of State (2009). Asia North Albers Equal Area Conic Projection. Central meridian $121^{\circ} 30^{\prime} \mathrm{E}$. , latitude of origin $30^{\circ} \mathrm{N}$.

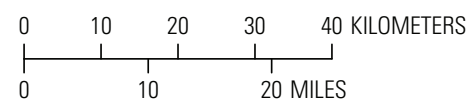

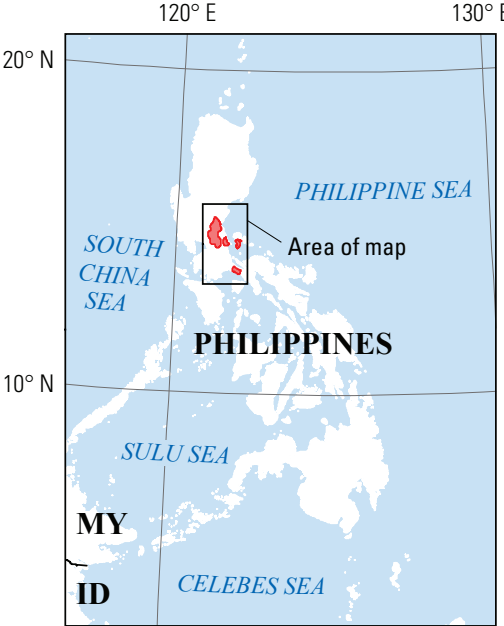

\section{EXPLANATION}

Assessed porphyry copper tract 142pCu7304 (Southern segment)

Other porphyry copper tracts

Porphyry copper deposit;

deposits associated with other tracts shown in gray

Porphyry copper prospect;

口 prospects associated with other tracts shown in gray

\ Volcano

Figure G1.-Continued 


\section{Delineation of the Permissive Tract}

\section{Tectonic Setting}

The Sierra Madre Arc borders the eastern coast of Luzon (fig. G1). The Eocene-Oligocene Sierra Madre Arc includes two segments both formed on oceanic basement. The northern segment is defined by the Northern Sierra Madre (fig. 4B). The southern segment extends from the Caraballo Mountains (fig. 4B) through the Southern Sierra Madre (fig. 4C), south and west of the Philippine Fault. Although the arc lies to the west of the East Luzon Trough, the polarity of the subduction (eastward or westward) and the extent of the arc are uncertain (Hall, 2002; Wolfe, 1988). The arc may continue to the Masbate-Negros Arc to the south (fig. $2^{6}$ ). Yumul and others (2003) indicate that the Southern Sierra Madre Arc has a northwestsoutheast orientation and includes Oligocene plutons on Polillo, Paleogene and Neogene intrusions and OligoceneMiocene volcanic rocks in the province of Camarines Norte, and volcanic rocks on Catuandanes Island (fig. 4A). Pollilo Island (fig. G1B), located about $30 \mathrm{~km}$ east of Luzon, may have been rifted from Luzon by strike-slip movement along the Philippine Fault or may be the northern end of an island arc accreted to the Mobile Belt (Knittel and Burton, 1985). Polillo Island is included here with the Southern Sierra Madre (although it does lie within present-day extent of the Philippine Arc shown in fig. 2A); the permissive rocks in Camarines Norte and on Catuandanes Island are included in the northern (Bicol) segment of the Oligocene to Holocene Philippine Arc (tract 142pCu7301).

\section{Geologic Criteria}

The permissive tract is delineated on the mapped extent of Paleogene and Neogene intrusive rocks and Paleogene and Oligocene andesitic volcanic rocks that lie to the west and south of the Philippine Fault within the Sierra Madre and Northeast Luzon Arcs as shown by Garwin and others (2005). The Philippine Fault is a younger structure (2-4 Ma) that crosscuts the older arc.

The tract was constructed by selecting map units coded as Paleogene intrusions and volcanic rocks, Oligocene volcanic rocks, and Oligocene-Miocene volcanic rocks (table G2) from the digital version of the 1:1,000,000-scale geologic map of the Philippines (Philippine Mines and Geosciences Bureau, 2004a). Permissive rocks used to delineate the tract are shown in figure G2. The preliminary tract was developed using ArcGIS tools to create a $10-\mathrm{km}$ buffer around intrusive rocks and a 2-km buffer around volcanic rocks. These distances are considered appropriate to allow for inaccuracies in mapped contacts and extensions under adjacent cover rock. Furthermore, Sillitoe and Gappe (1984) noted that 75 percent of the known (as of 1984) porphyry deposits in the Philippines were located less than $4 \mathrm{~km}$ from the margins of a pluton with phaneritic texture. The buffered map unit polygons were aggregated, smoothed, and edited by hand to include known but unmapped permissive igneous rocks and prospects. The final tract segments were clipped to coastlines (U.S. Department of State, 2009).

The mountains of the Northern Sierra Madre record two episodes of magmatism - (1) middle to late Eocene volcanic rocks and intermediate composition (mainly tonalite) plutons of the Eocene Coastal Batholith and (2) Oligocene to Miocene volcanic rocks and the Northern Sierra Madre Batholith. $\mathrm{K}$-Ar ages for tonalite, quartz diorite, diorite, and granodiorite in the Northern Sierra Madre batholith range from late Oligocene (31.1 $\pm 1.5 \mathrm{Ma})$ to early Miocene $(22.3 \pm 1.1 \mathrm{Ma})$ (as reported in Hollings and others, 2011, for data from Billedo, 1994, and Metal Mining Agency of Japan, 1987). A calcalkalic composite tonalite-granodiorite-quartz monzonite pluton dated at 34.4 Ma crops out on southern Polillo Island (Knittel and Burton, 1985). The Coastal Batholith and the intrusions on Polillo Island have initial ${ }^{87} \mathrm{Sr} /{ }^{86} \mathrm{Sr}$ ratios of 0.7035-0.7043; the compositions of the Polillo rocks are more evolved (higher silica contents, $\mathrm{K}_{2} \mathrm{O}>\mathrm{Na}_{2} \mathrm{O}$ ) than the rocks of the Coastal Batholith (Knittel and Defant, 1988; Knittel and Burton, 1985).

Permissive rocks in the Southern Sierra Madre include quartz diorites dated at 27 to $32 \mathrm{Ma}$ in the Caraballo Mountains, the 36.9-Ma Antipolo diorite, and the correlative Mayopa diorite, which are mapped as Paleogene and Neogene intrusions (table G2) and described in detail in the volume on geology and mineral resources of the Philippines (Philippine Bureau of Mines and Geosciences, 1981). 
$\boldsymbol{A}$

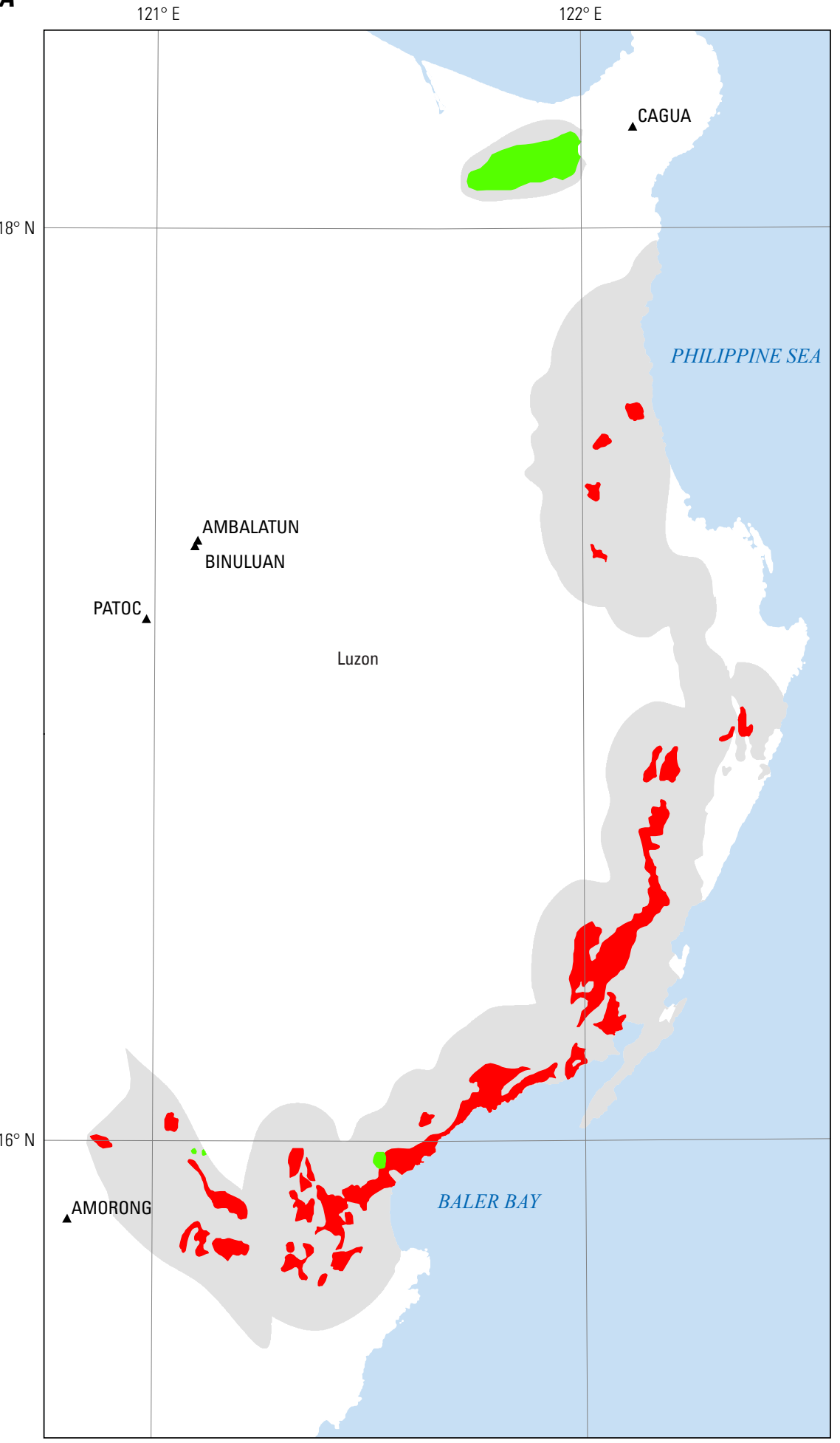

Political boundaies from U.S. Department of State (2009) Asia North Albers Equal Area Conic Projection.

Central meridian $121.5^{\circ}$ E., latitude of origin, $30^{\circ} \mathrm{N}$

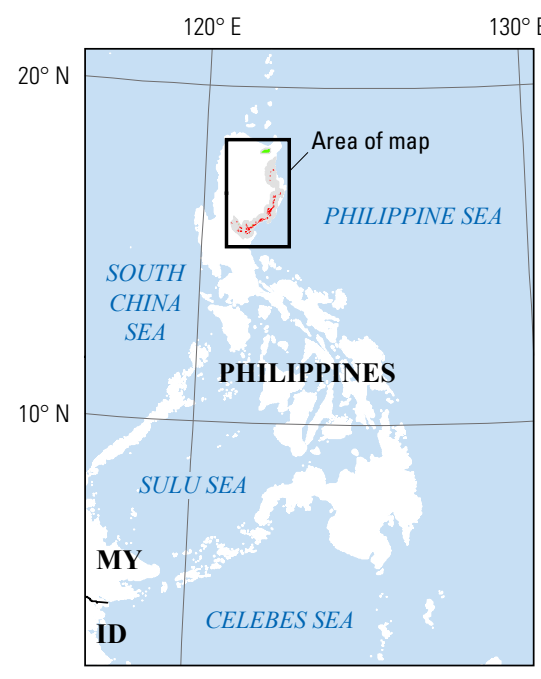

EXPLANATION

Assessed porphyry copper tract 142pCu7304 (Northern segment)

Permissive intrusive rock

Permissive volcanic rock

\ Volcano

Figure G2. Maps showing the distribution of permissive igneous rocks for tract 142pCu7304, Sierra Madre Arc-Philippines. A, Northern Sierra Madre. B, Southern Sierra Madre. See table G2 for a description of included rocks. MY, Malaysia; ID, Indonesia. 
B
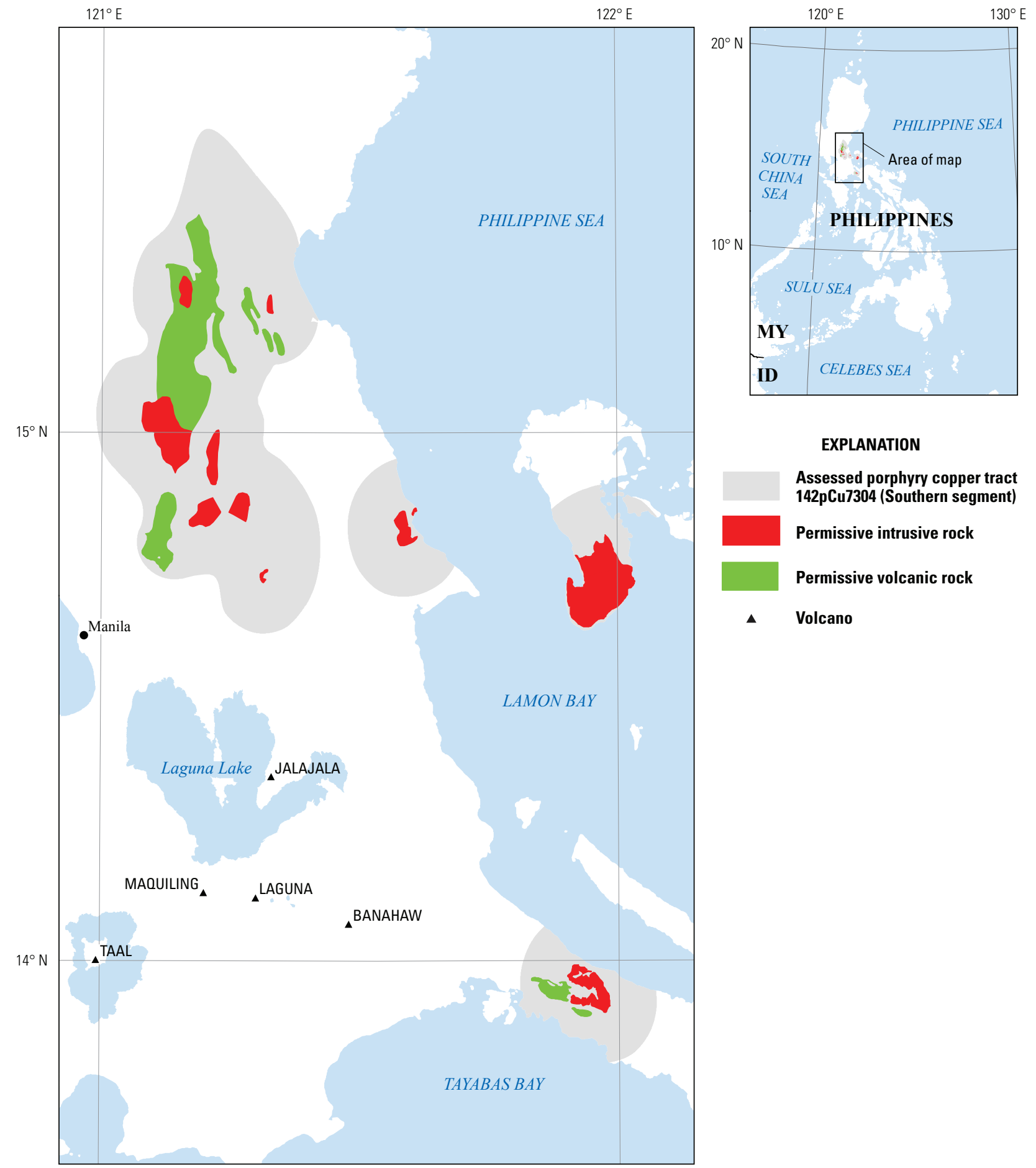

XPLANATION

Assessed porphyry copper tract 142pCu7304 (Southern segment)

Permissive intrusive rock

Permissive volcanic rock

A Volcano

Political boundaries from U.S. Department of State (2009) Asia North Albers Equal Area Conic Projection.

Central meridian $121^{\circ} 30^{\prime} \mathrm{E}$., latitude of origin $30^{\circ} \mathrm{N}$.

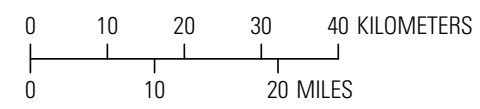

Figure G2.-Continued 
Table G2. Map units that define tract 142pCu7304, Sierra Madre Arc—Philippines.

[Map unit, age range, and principal lithologies are based on a digital version of the 1:1,000,000-scale geologic map of the Philippines (Philippine Bureau of Mines, 1963)]

\begin{tabular}{llll}
\hline \multicolumn{1}{c}{ Map unit } & $\begin{array}{c}\text { Map } \\
\text { symbol }\end{array}$ & \multicolumn{1}{c}{ Lithology } & Age range \\
\hline Neogene intrusive rocks & NI & $\begin{array}{l}\text { Largely intra-Miocene quartz diorite. Mostly batholiths and stocks, } \\
\text { some laccoliths; also sills, dikes, and other minor bodies. Includes } \\
\text { granodiorite and diorite porphyry facies and late Miocene dacite. }\end{array}$ & Neogene \\
& & $\begin{array}{l}\text { Pervasive in Paleogene and Mesozoic rock sequences, less wide- } \\
\text { spread in early Miocene rock sequences. }\end{array}$ & Paleogene \\
\hline Paleogene intrusive rocks & $\operatorname{Pg}_{1}$ & Mostly quartz diorite. & Oligocene-Miocene \\
\hline Neogene volcanic rocks & $\mathrm{IN}_{1}$ & $\begin{array}{l}\text { Mostly submarine andesite and/or basalt flows. Intercalated with } \\
\text { pyroclastics and clastic sedimentary rocks or reef limestone lenses. } \\
\text { Largely confined within the axial zone of Luzon, Visayas, and } \\
\text { Mindanao. }\end{array}$ & \\
\hline Paleogene volcanic rocks & $\mathrm{IPg}_{2}$ & $\begin{array}{l}\text { Essentially keratophyre and andesite flows. Often with pyroclastics } \\
\text { and chert of volcanic origin. Undifferentiated from early Miocene } \\
\text { sedimentary rocks in some areas. }\end{array}$ & Oligocene \\
\hline Paleogene volcanic rocks & $\operatorname{IPg}_{1}$ & $\begin{array}{l}\text { Limited dacite and andesite flows and dikes, generally intercalated } \\
\text { with or intrude Eocene clastics. Included with Eocene sedimentary } \\
\text { rocks in this map. }\end{array}$ & Paleocene(?)-Eocene \\
\hline
\end{tabular}

\section{Known Deposits}

The tract includes one deposit having identified resources (Lumbay, fig. G1, table G3).

\section{Lumbay (Kalawang)}

The Lumbay deposit in the Southern Sierra Madre, discovered in 1973, was an exploration project of Colossal Mining and Exploration (Alapan, 1980). It was listed as an abandoned prospect and described by Sillitoe and Gappe (1984) as having the ore geometry of a steep cylinder. Reserves reported in their report and included in Singer and others (2008) reflect 1973-77 drilling. Supergene enrichment at Lumbay is minor, with less than a 30-m depth of partial leaching. No information on recent activity in the area was available.

\section{Prospects, Mineral Occurrences, and Related Deposit Types}

\section{Sierra Madre (North)}

Indophil Resources (2002) described a grass roots exploration project in the Northern Sierra Madre covering an exploration area of $588 \mathrm{~km}^{2}$ for porphyry copper gold targets. The area on the western side of the Sierra Madre in Cagayan and Isabela Provinces includes seven copper occurrences, hydrothermal alteration associated with granodiorite, diorite, dacite and andesite, and copper and arsenic stream sediment anomalies (70-520 ppm copper). Two prospect areas identified in the Indophil Resources (2002) report are noted in table G4 and figure G1.

Table G3. Porphyry copper deposits in tract 142pCu7304, Sierra Madre Arc—Philippines.

[Ma, million years; Mt, million metric tons; $\mathrm{t}$, metric ton; $\mathrm{g} / \mathrm{t}$, gram per metric ton; \%, percent; $\mathrm{Cu}$-Au subtype, deposits that have $\mathrm{Au} / \mathrm{Mo}$ ratios $>30$ or average Au grades $>0.2 \mathrm{~g} / \mathrm{t}$; n.d., no data. Contained $\mathrm{Cu}$ in metric tons is computed as $(\mathrm{Mt} \times 1,000,000) \times(\mathrm{Cu}$, in $\% \div 100)]$

\begin{tabular}{lccccccccc}
\hline Name & Subtype & Age (Ma) & $\begin{array}{c}\text { Tonnage } \\
(\mathbf{M t})\end{array}$ & $\begin{array}{c}\mathbf{C u} \\
(\mathbf{\%})\end{array}$ & $\begin{array}{c}\text { Mo } \\
(\mathbf{\%})\end{array}$ & $\begin{array}{c}\text { Au } \\
(\mathbf{g} / \mathbf{t})\end{array}$ & $\begin{array}{c}\text { Ag } \\
(\mathbf{g} / \mathbf{t})\end{array}$ & $\begin{array}{c}\text { Contained } \\
\mathbf{C u}(\mathbf{t})\end{array}$ & Reference \\
\hline Lumbay & $\mathrm{Cu}-\mathrm{Au}$ & n.d. & 78 & 0.40 & 0.0008 & 0.03 & n.d. & 312,000 & $\begin{array}{l}\text { Alapan (1980), Malicdem (1975), Sillitoe } \\
\text { and Gappe (1984), Singer and others } \\
(2008)\end{array}$ \\
\hline
\end{tabular}


Kuroko-type copper deposits are known in volcanic rocks and Cyprus-type massive sulfide deposits are associated with ophiolites in northeastern Luzon (Philippine Bureau of Mines and Geosciences, 1986). These deposit types typically are not associated with permissive areas for porphyry copper deposits but may contribute to copper anomalies detected in streamsediment analyses.

\section{Sierra Madre (South)}

The southern part of the tract includes two copper occurrences that may be porphyry-related and a porphyry molybdenum prospect (table G4). The Canicanian prospect and nearby areas in southern Pollilo Island are described as porphyry molybdenum-rich, gold-poor copper prospects associated with hypabyssal quartz monzonite intrusions into tonalite and granodiorite (Philippine Bureau of Mines and Geosciences, 1986; Knittel and Burton, 1985). An anomaly defined by colocated soil molybdenum concentrations (greater than $40 \mathrm{ppm}$ ), phyllic alteration, and high induced polarization (IP) was drilled with 26 holes. Drill-based (noncompliant) resource estimates of $16.5 \mathrm{Mt}$ at 0.085 percent $\mathrm{MoS}_{2}$ reported by Knittel and Burton (1985) do not include any information on copper concentrations.

\section{Exploration History}

The tract may be underexplored for porphyry copper deposits. The major gold-copper districts in the eastern Philippines (Bicol, east Mindanao) and a lack of exploration in the Sierra Madre led Yumul and others (2003) to note that the Sierra Madre of northern Luzon is an attractive exploration target area for gold and copper deposits. Northeastern Luzon was mapped (unpublished) and a stream-sediment survey was conducted in the 1970s (Republic of the Philippines-Government of Japan Project, 1977). Polillo Island was explored for molybdenum by Inco Mining Corporation and S and L Mining Corporation following the Canicanian discovery in the early 1970s (Philippine Bureau of Mines and Geosciences, 1986; Knittel and Burton, 1985).

\section{Sources of Information}

Table G5 lists principal sources of information used in the assessment.

Table G4. Significant prospects and occurrences in tract 142pCu7304, Sierra Madre Arc—Philippines.

[n.d., no data; $\%$, percent; $\mathrm{g} / \mathrm{t}$, grams per metric ton; km, kilometers; $\mathrm{m}$, meters. Rank $2=$ drilled or trenched with $<20 \mathrm{~m}$ of $0.2 \% \mathrm{Cu}$ or $<0.2 \% \mathrm{Cu}$, or past or ongoing exploration. Rank $1=$ copper occurrence that may be related to porphyry-type mineralization based on stream sediment or magnetic anomaly or location along structural trend]

\begin{tabular}{|c|c|c|c|c|c|c|}
\hline Name & Latitude & Longitude & $\begin{array}{l}\text { Age } \\
\text { (Ma) }\end{array}$ & Comments & Reference & Rank \\
\hline \multicolumn{7}{|c|}{ Northern Sierra Madre } \\
\hline $\begin{array}{l}\text { Northern Sierra } \\
\text { Madre Project } \\
\text { Area (S) }\end{array}$ & 17.191 & 122.049 & n.d. & $\begin{array}{l}\text { Area of hydrothermal alteration, four copper occurrences, } \\
\text { north and south of Aubuan River. Location approximate, } \\
\text { in Indophil concession area EPA-55. }\end{array}$ & $\begin{array}{l}\text { Indophil Resources } \\
\text { (2002) }\end{array}$ & 1 \\
\hline $\begin{array}{l}\text { Northern Sierra } \\
\text { Madre Project } \\
\text { Area (N) }\end{array}$ & 17.583 & 122.000 & n.d. & $\begin{array}{l}\text { Area of hydrothermal alteration, two copper occurrences, } \\
\text { and elevated copper in stream sediments. Location } \\
\text { approximate, in central part of Indophil concession areas } \\
\text { EPA- } 52,53,54 \text {. }\end{array}$ & $\begin{array}{l}\text { Indophil Resources } \\
\text { (2002) }\end{array}$ & 1 \\
\hline \multicolumn{7}{|c|}{ Southern Sierra Madre } \\
\hline $\begin{array}{l}\text { Canicanian } \\
\text { prospect }\end{array}$ & 14.75 & 121.992 & 34.4 & $\begin{array}{l}\text { Porphyry Mo-Cu prospect, estimated resources } 16.5 \mathrm{Mt} \\
\text { at } 0.085 \% \mathrm{MoS}_{2} \text {. }\end{array}$ & $\begin{array}{l}\text { Knittel and Burton } \\
\text { (1985) }\end{array}$ & 2 \\
\hline Gapan & 15.281 & 121.201 & n.d. & $\begin{array}{l}\text { Porphyry copper prospect; diorite porphyry, chalcopyrite, } \\
\text { bornite. }\end{array}$ & $\begin{array}{l}\text { Philippine Mines } \\
\text { and Geosciences } \\
\text { Bureau (2004b) }\end{array}$ & 1 \\
\hline Villarosa & 15.151 & 121.167 & n.d. & Copper, gold occurrence associated with diorite. & $\begin{array}{l}\text { Philippine Mines } \\
\text { and Geosciences } \\
\text { Bureau (2004b) }\end{array}$ & 1 \\
\hline
\end{tabular}


Table G5. Principal sources of information used for tract 142pCu7304, Sierra Madre Arc—Philippines.

[NA, not applicable]

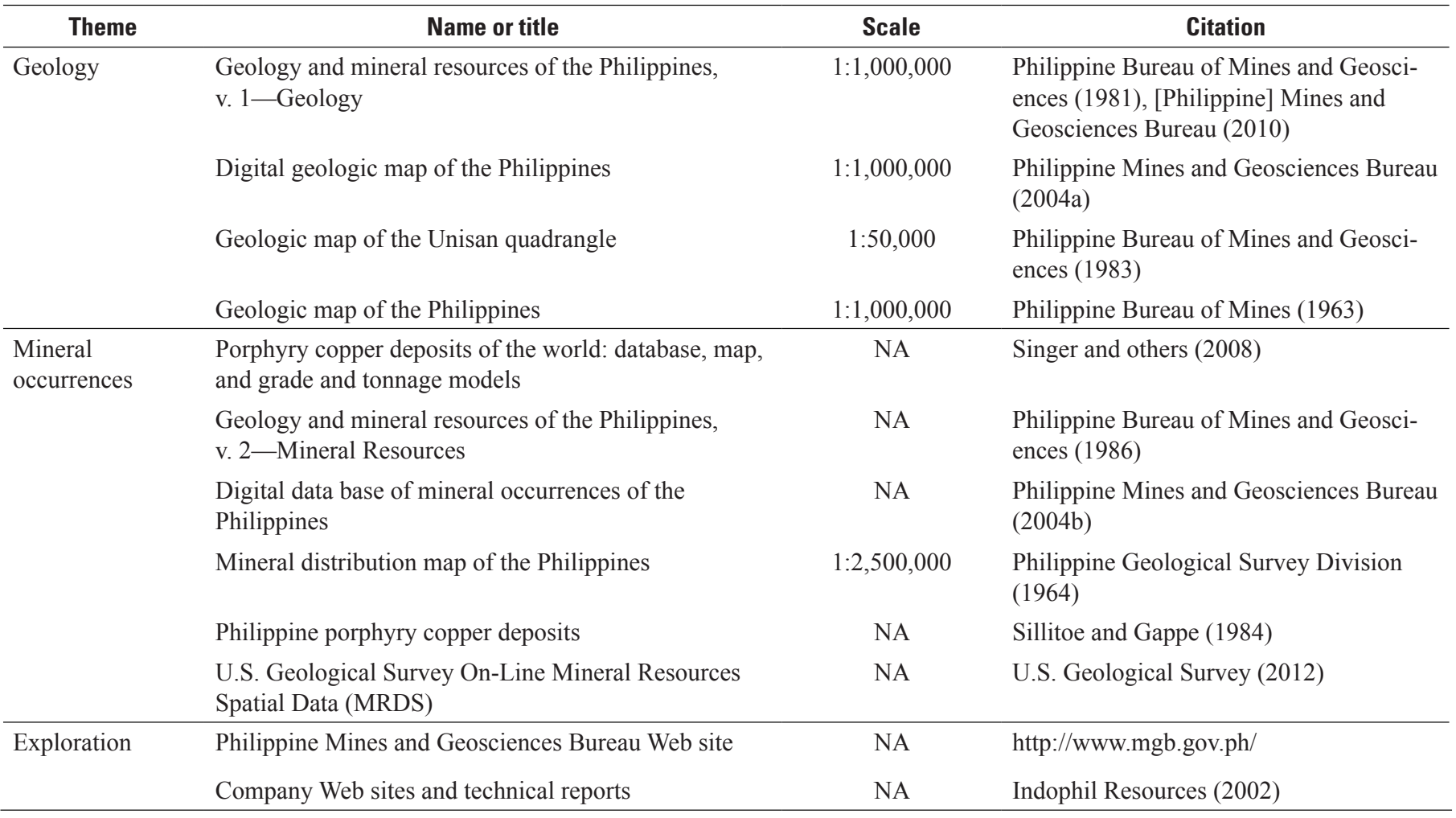

\section{Grade and Tonnage Model Selection}

The only identified resources within the tract are those associated with the Lumbay deposit in the Southern Sierra Madre. On the basis of reported gold and molybdenum grades (table G3), Lumbay is classified as a copper-gold porphyry deposit. The late Eocene arc rocks on Polillo Island, however, are associated with molybdenum-rich porphyry style mineralization. Due to uncertainties about the types of deposit likely to be present within the tract, the general porphyry coppergold-molybdenum model was used by default.

\section{Estimate of the Number of Undiscovered Deposits}

\section{Rationale for the Estimate}

The tract is permissive on the basis of (1) the presence of igneous rocks of appropriate composition and (2) a few prospect areas that have not been fully explored. Exposed batholiths indicate that parts of the area may be too deeply eroded to preserve deposits. Areas with coeval volcanic and intrusive rocks are most likely to be prospective. The tract area does not include any of the major epithermal gold districts of the Philippines; the assessment team regarded this observation as an unfavorable factor for undiscovered porphyry copper deposits. Two potential porphyry prospect areas were active in 2002 , but the team is unaware of follow-up work. On the basis of the information on the prospect areas, the lack of modern exploration, and the area of permissive igneous rock, the team estimated a 10-percent chance for one undiscovered deposit (table G6). A 1-percent chance for three or more deposits is based on three clusters of copper occurrences associated with hydrothermal alteration in andesite and granodiorite within the approximately 20 by $80 \mathrm{~km}$ prospect area in the Northern Sierra Madre and the likelihood that other such areas may exist within the tract. This distribution produces a mean estimate of less than one undiscovered deposit with a very high associated uncertainty $\left(C_{v}=210\right.$ percent $)$. 


\section{Probabilistic Assessment Simulation Results}

Undiscovered resources for the tract were estimated by combining the team's estimate for numbers of undiscovered porphyry copper deposits with the porphyry copper model of Singer and others (2008) using the EMINERS program (Root and others, 1992; Duval, 2012; Bawiec and Spanski, 2012). Selected simulation results are reported in table G7. Results of the Monte Carlo simulation are presented as a cumulative frequency plot (fig. G3). The cumulative frequency plot shows the estimated resource amounts associated with cumulative probabilities of occurrence, as well as the mean, for each commodity and for total mineralized rock. The mean expected amount of copper, $1.4 \mathrm{Mt}$, is about 4.5 times the amount of identified copper resources associated with the Lumbay deposit. The data for Lumbay, however, are historical and the existing data may not accurately reflect the total resource.

Table G6. Undiscovered deposit estimates, deposit numbers, tract area, and deposit density for tract 142pCu7304, Sierra Madre Arc-Philippines.

$\left[N_{\mathrm{XX}}\right.$, estimated number of deposits associated with the xxth percentile; $N_{\text {und }}$, expected number of undiscovered deposits; $s$, standard deviation; $C_{v} \%$, coefficient of variance; $N_{\text {known }}$, number of known deposits in the tract that are included in the grade and tonnage model; $N_{\text {total }}$, total of expected number of deposits plus known deposits; area, area of permissive tract in square kilometers $\left(\mathrm{km}^{2}\right)$; density, deposit density reported as the total number of deposits per $100,000 \mathrm{~km}^{2} . N_{\text {und }}, s$, and $C_{v} \%$ are calculated using a regression equation (Singer and Menzie, 2005)]

\begin{tabular}{|c|c|c|c|c|c|c|c|c|c|c|c|}
\hline \multicolumn{5}{|c|}{ Consensus undiscovered deposit estimates } & \multicolumn{5}{|c|}{ Summary statistics } & \multirow{2}{*}{$\begin{array}{c}\text { Tract Area } \\
\left(\mathbf{k m}^{2}\right)\end{array}$} & \multirow{2}{*}{$\begin{array}{c}\text { Deposit density } \\
\left(N_{\text {total }} / 100,000 \mathrm{~km}^{2}\right)\end{array}$} \\
\hline$N_{90}$ & $N_{50}$ & $N_{10}$ & $N_{05}$ & $N_{01}$ & $N_{\text {und }}$ & $s$ & $C_{v} \%$ & $N_{\text {known }}$ & $N_{\text {total }}$ & & \\
\hline 0 & 0 & 1 & 1 & 3 & 0.36 & 0.75 & 210 & 1 & 1.36 & 14,000 & 10 \\
\hline
\end{tabular}

Table G7. Results of Monte Carlo simulation of undiscovered resources for tract 142pCu7304, Sierra Madre Arc—Philippines.

[Cu, copper; Mo, molybdenum; $\mathrm{Au}$, gold; and Ag, silver; in metric tons; rock, in million metric tons]

\begin{tabular}{|c|c|c|c|c|c|c|c|c|}
\hline \multirow[b]{2}{*}{ Material } & \multicolumn{6}{|c|}{ Probability of at least the indicated amount } & \multicolumn{2}{|c|}{ Probability of } \\
\hline & 0.95 & 0.9 & 0.5 & 0.1 & 0.05 & Mean & $\begin{array}{l}\text { Mean or } \\
\text { greater }\end{array}$ & None \\
\hline $\mathrm{Cu}$ & 0 & 0 & 0 & $2,900,000$ & $6,800,000$ & $1,400,000$ & 0.15 & 0.69 \\
\hline Mo & 0 & 0 & 0 & 40,000 & 130,000 & 35,000 & 0.11 & 0.82 \\
\hline $\mathrm{Au}$ & 0 & 0 & 0 & 65 & 170 & 36 & 0.13 & 0.80 \\
\hline $\mathrm{Ag}$ & 0 & 0 & 0 & 350 & 1,500 & 420 & 0.10 & 0.86 \\
\hline Rock & 0 & 0 & 0 & 670 & 1,400 & 290 & 0.16 & 0.69 \\
\hline
\end{tabular}




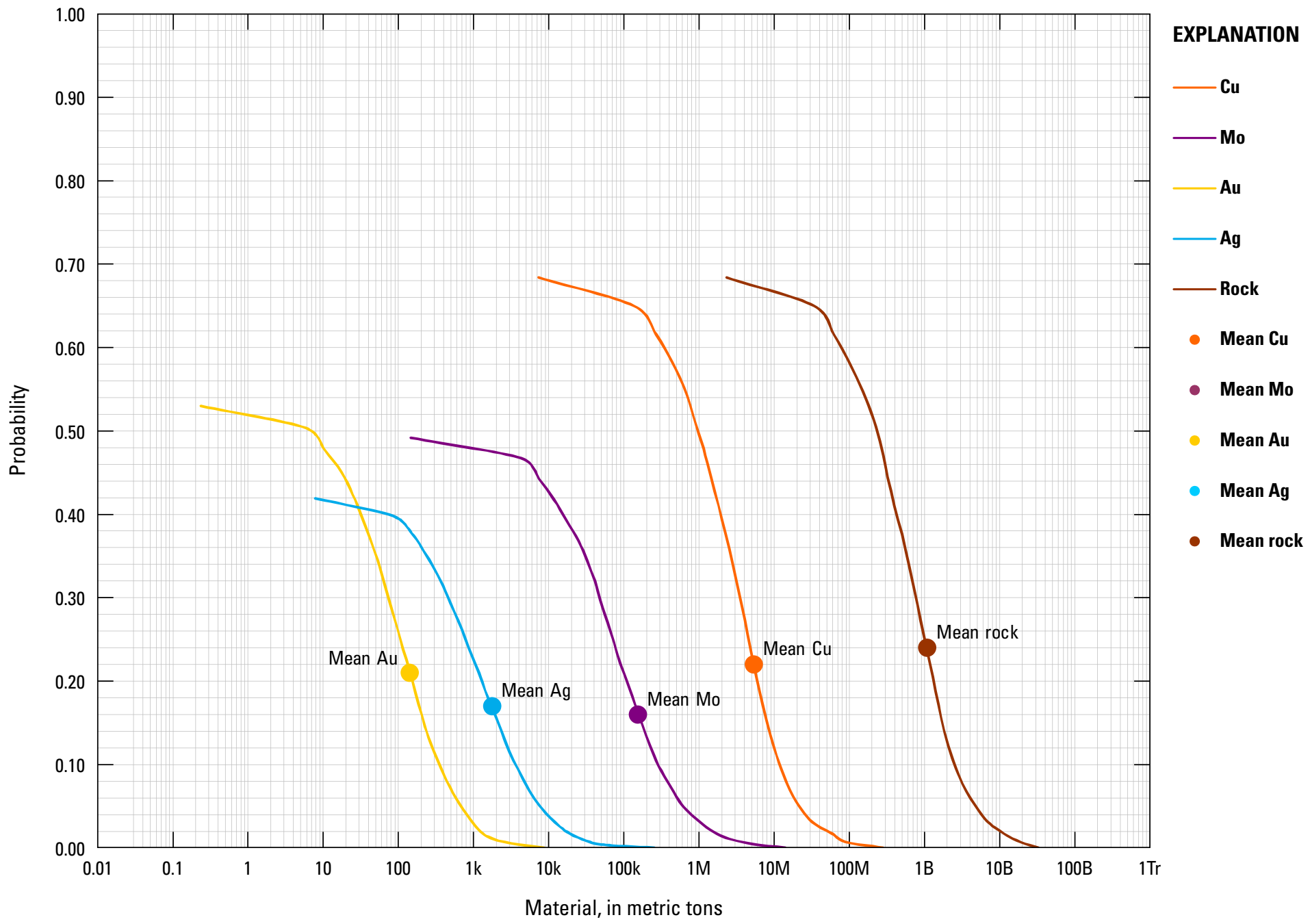

Figure G3. Cumulative frequency plot showing the results of Monte Carlo computer simulation of undiscovered resources in tract 142pCu7304, Sierra Madre Arc—Philippines. k, thousands; M, millions; B, billions; Tr, trillions. 


\section{References Cited}

Alapan, G.A., 1980, Notes on some aspects of hydrothermal alteration in the Lumbay project of Colossal Mining and Exploration Corporation: Journal of the Geological Society of the Philippines, v. 34, no. 2, p. 20-23.

Bawiec, W.J., and Spanski, G.T., 2012, Quick-start guide for version 3.0 of EMINERS-Economic Mineral Resource Simulator: U.S. Geological Survey Open-File Report 2009-1057, 26 p., accessed June 30, 2012, at http://pubs. usgs.gov/of/2009/1057/. (This report supplements USGS OFR 2004-1344.)

Berger, B.R., Ayuso, R.A., Wynn, J.C., and Seal, R.R., 2008, Preliminary model of porphyry copper deposits: U.S. Geological Survey Open-File Report 2008-1321, 55 p., accessed May 15, 2009, at http://pubs.usgs.gov/ of $/ 2008 / 1321 /$.

Billedo, E.B., 1994, Geologie de la Sierra Madre Septentrionale et de l'archipel de Polillo (ceinture mobile est Philippines) - Implications geodynamiques; documents et treveaux 20: Nice, Institue de geodynamique, Universite Nice Sophia Antipolis, Ph.D. dissertation, 244 p.

Cox, D.P., 1986, Descriptive model of porphyry $\mathrm{Cu}$, in Cox, D.P., and Singer, D.A., eds., 1986, Mineral deposit models: U.S. Geological Survey Bulletin 1693, p. 76. (Also available at http://pubs.usgs.gov/bul/b1693/.)

Duval, J.S., 2012, Version 3.0 of EMINERS-Economic Mineral Resource Simulator: U.S. Geological Survey Open-File Report 2004-1344, accessed June 30, 2012, at http://pubs. usgs.gov/of/2004/1344/.

Garwin, S., Hall, R., and Watanabe, Y., 2005, Tectonic setting, geology, and gold and copper mineralization in Cenozoic magmatic arcs of southeast Asia and the west Pacific, in Hedenquist, T.W., Thompson, J.F.H., Goldfarb, R.J., and Richards, J.P., eds., One hundredth anniversary volume 1905-2005: Littleton, Colorado, Society of Economic Geologists, p. 891-930.

Hall, R., 2002, Cenozoic geological and plate tectonic evolution of Southeast Asia and Southwest Pacific, computerbased reconstructions, model and animations: Journal of Asian Earth Sciences, v. 20, no. 4 (Special Issue), 431 p.

Hollings, Pete, Wolfe, Rohan, Cooke, D.R., and Waters, P.J., 2011, Geochemistry of Tertiary igneous rocks of northern Luzon, Philippines - Evidence for a back-arc setting for alkali porphyry copper-gold deposits and a case for slab roll-back?: Economic Geology, v. 106, p. 1257-1277.

Indophil Resources, 2002, Original Prospectus: Indophil Resources, accessed September 25, 2010, at http:// www.indophil.com/pdf/2001\%20annual $\% 20$ report $\% 20$ (prospectus).pdf.
John, D.A., Ayuso, R.A., Barton, M.D., Blakely, R.J., Bodnar, R.J., Dilles, J.H., Gray, Floyd, Graybeal, F.T., Mars, J.C., McPhee, D.K., Seal, R.R., Taylor, R.D., and Vikre, P.G., 2010, Porphyry copper deposit model, chap. B of Mineral deposit models for resource assessment: U.S. Geological Survey Scientific Investigations Report 2010-5070-B, 169 p., accessed September 8, 2010, at http://pubs.usgs.gov/ $\operatorname{sir} / 2010 / 5070 / b /$.

Knittel, Ulrich, and Burton, C.K., 1985, Polillo Island (Philippines)-Molybdenum mineralization in an island arc: Economic Geology, v. 80, p. 2013-2018.

Knittel, Ulrich, and Defant, M.J., 1988, Sr isotopic and trace element variations in Oligocene to Recent igneous rocks from the Philippine island arc-Evidence for Recent enrichment in the sub-Philippine mantle: Earth and Planetary Science Letters, v. 87, p. 87-99.

Malicdem, D.G., 1975, Notes on the geology and exploration of Colossal-Lepanto copper project, Gen. Nakar, Quezon: Journal of the Geological Society of the Philippines, v. 29, no. 1, p. 13-19.

Metal Mining Agency of Japan, 1987, Report on the mineral exploration, mineral deposits and tectonics of two contrasting geological environments in the Philippines, phase 3 (part 1), northern Sierra Madre area: Tokyo, Japan, Japan International Cooperation Agency, Government of Japan, $121 \mathrm{p}$.

Philippine Bureau of Mines, 1963, Geological map of the Philippines: Philippine Bureau of Mines, 1 map on 8 sheets, scale $1: 1,000,000$.

Philippine Bureau of Mines and Geosciences, 1981, Geology and mineral resources of the Philippines, v. 1-Geology: Philippine Bureau of Mines and Geosciences, $406 \mathrm{p}$.

Philippine Bureau of Mines and Geosciences, 1983, Geological map of Unisan quadrangle: Philippine Bureau of Mines and Geosciences, sheet 3361-1, scale 1:50,000.

Philippine Bureau of Mines and Geosciences, 1986, Geology and mineral resources of the Philippines, v. 2-Mineral Resources: Philippine Bureau of Mines and Geosciences, $446 \mathrm{p}$.

Philippine Geological Survey Division, 1964, Mineral distribution map of the Philippines - Base metals: Philippine Geological Survey Division, sheet 2 of 6 maps, scale $1: 2,500,000$.

Philippine Mines and Geosciences Bureau, 2004a, Digital geological map of the Philippines: Philippine Mines and Geosciences Bureau, scale 1:1,000,000. [Proprietary data.]

Philippine Mines and Geosciences Bureau, 2004b, Digital database of mineral occurrences of the Philippines: Philippine Mines and Geosciences Bureau. [Proprietary report.] 
Philippine Mines and Geosciences Bureau, 2010, Geology of the Philippines ( $2 \mathrm{~d}$ ed.): Philippine Mines and Geosciences Bureau, $532 \mathrm{p}$.

Republic of the Philippines-Government of Japan Project, 1977, Report on the geological survey of northeastern Luzon: Republic of the Philippines-Government of Japan Project unpublished report.

Root, D.H., Menzie, W.D., and Scott, W.A., 1992, Computer Monte Carlo simulation in quantitative resource estimation: Natural Resources Research, v. 1, no. 2, p. 125-138.

Sillitoe, R.H., and Gappe, I.M., Jr., 1984, Philippine porphyry copper deposits - Geologic setting and characteristics: Committee for Co-ordination of Joint Prospecting for Mineral Resources in Asian Offshore Areas (CCOP), CCOP Technical Publication 14, 89 p.

Singer, D.A., and Menzie, W.D., 2005, Statistical guides to estimating the number of undiscovered mineral deposits-An example with porphyry copper deposits, in Cheng, Qiuming, and Bonham-Carter, Graeme, eds., Proceedings of IAMG - The annual conference of the International Association for Mathematical Geology: Toronto, Canada, York University, Geomatics Research Laboratory, p. 1028-1033.
Singer, D.A., Berger, V.I., and Moring, B.C., 2008, Porphyry copper deposits of the World-Database and grade and tonnage models, 2008: U.S. Geological Survey Open-File Report 2008-1155, accessed June 1, 2011, at http://pubs. usgs.gov/of/2008/1155/.

U.S. Department of State, 2009, Small-scale digital international land boundaries (SSIB)_Lines, edition 10, and polygons, beta edition 1, in Boundaries and sovereignty encyclopedia (B.A.S.E.): U.S. Department of State, Office of the Geographer and Global Issues.

U.S. Geological Survey, 2012, On-line mineral resources spatial data: U.S. Geological Survey Web site, accessed February 10, 2012, at http://mrdata.usgs.gov/.

Wolfe, J.A., 1988, Arc magmatism and mineralization in North Luzon and its relationship to subduction at the East Luzon and North Manila Trenches: Journal of Southeast Asian Earth Sciences, v. 2, p. 79-93.

Yumul, G.P., Jr., Dimalanta, C.B., Maglambayan, V.B., and Tamayo, R.A., Jr., 2003, Mineralization controls in island arc settings - Insights from Philippine metallic deposits: Gondwana Research, v. 6, no. 4, p. 767-776. 
This page left intentionally blank. 


\section{Appendix H. Porphyry Copper Assessment for Tract 142pCu7311, Mindoro-Tablas-West Panay Area-Philippines}

By Jane M. Hammarstrom ', Arthur A. Bookstrom², Connie L. Dicken', Steve Ludington³, Gilpin R. Robinson, Jr.', and Michael L. Zientek ${ }^{2}$ with contributions from Sevillo (Bill) D. David, Jr., Claro J. Manipon ${ }^{4}$, Lilian A. Rollan ${ }^{4}$, and Yasushi Watanabe ${ }^{5}$

\section{Deposit Type Assessed: Porphyry copper, copper-gold subtype}

Descriptive model: Porphyry copper (Cox, 1986; Berger and others, 2008; John and others, 2010; Sillitoe and Gappe, 1984) Grade and tonnage model: Porphyry copper, copper-gold subtype (Singer and others, 2008)

Table H1 summarizes selected assessment results.

Table H1. Summary of selected resource assessment results for tract 142pCu7311, Mindoro-Tablas-West Panay Area—Philippines.

[km, kilometers; $\mathrm{km}^{2}$, square kilometers; $\mathrm{t}$, metric tons $]$

\begin{tabular}{cccccc}
\hline $\begin{array}{c}\text { Date of } \\
\text { assessment }\end{array}$ & $\begin{array}{c}\text { Assessment depth } \\
(\mathbf{k m})\end{array}$ & Tract area $\left(\mathbf{k m}^{2}\right)$ & $\begin{array}{c}\text { Identified copper } \\
\text { resources }(\mathbf{t})\end{array}$ & $\begin{array}{c}\text { Mean estimate of } \\
\text { undiscovered copper } \\
\text { resources }(\mathbf{t})\end{array}$ & $\begin{array}{c}\text { Median estimate of } \\
\text { undiscovered copper } \\
\text { resources }(\mathbf{t})\end{array}$ \\
\hline 2010 & 1 & 9,170 & 0 & $3,200,000$ \\
\hline
\end{tabular}

\section{Location}

Mindoro, Tablas (Romblon Island Group), and northeastern Palawan Islands and western Panay (Visayas ${ }^{6}$ (fig. H1).

\section{Geologic Feature Assessed}

Neogene Mindoro-Tablas-Western Panay Arc.

${ }^{1}$ U.S. Geological Survey, Reston, Virginia, United States.

${ }^{2}$ U.S. Geological Survey, Spokane, Washington, United States.

${ }^{3}$ U.S. Geological Survey, Menlo Park, California, United States.

${ }^{4}$ Philippine Department of Environment and Natural Resources, Mines and Geosciences Bureau, Quezon City, Philippines.

${ }^{5}$ Geological Survey of Japan, National Institute of Advanced Industrial Science and Technology (AIST), Ibaraki, Japan.

${ }^{6}$ The Visayas Islands include Panay, Negros, Cebu, Bohol, Leyte, and Samar. 

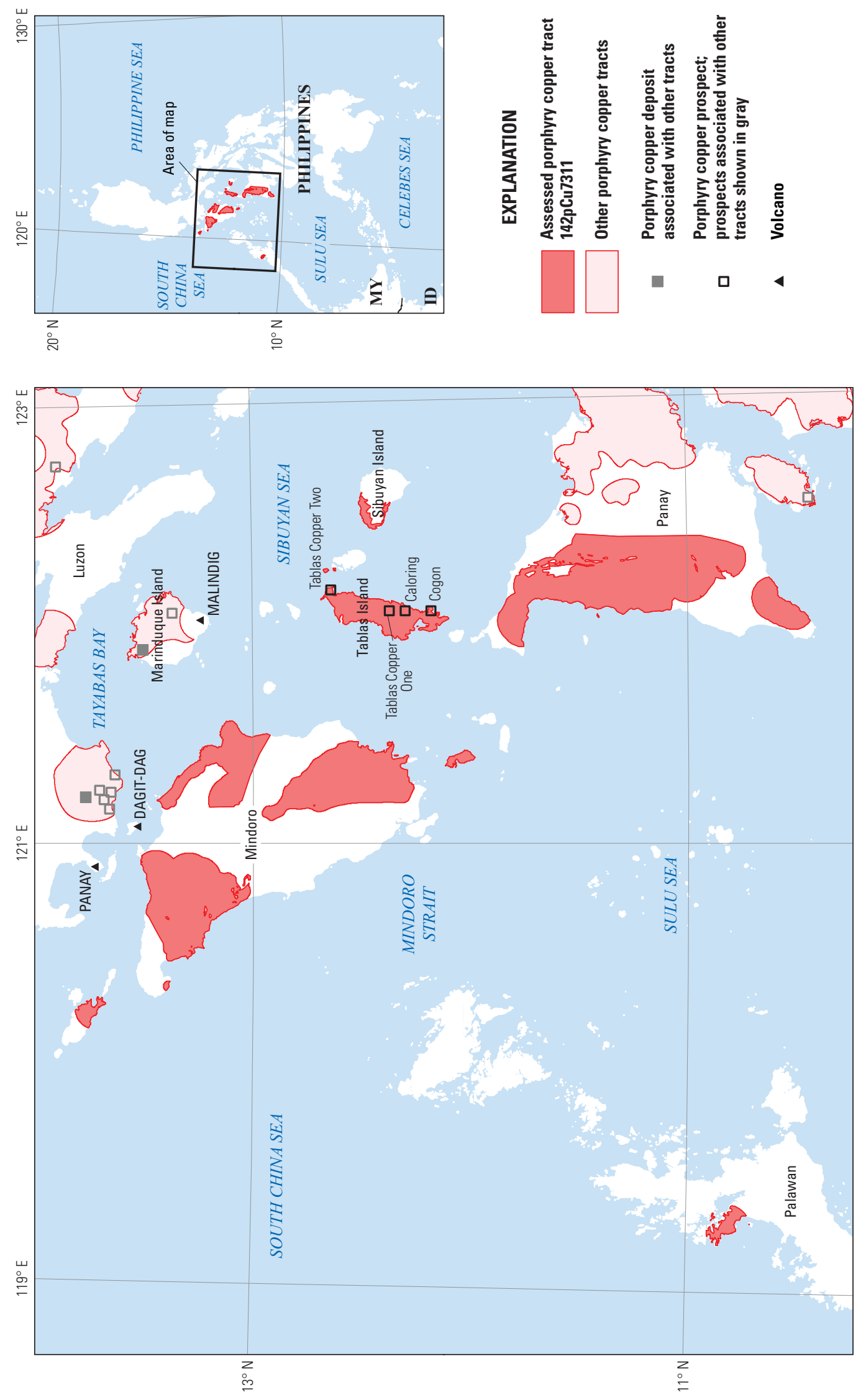

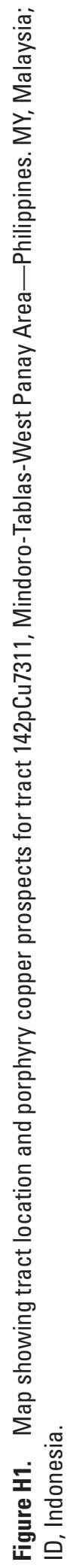




\section{Delineation of the Permissive Tract}

\section{Tectonic Setting}

This tract outlines Neogene igneous rocks in the collisional area between the Palawan microcontinent and the Philippine Mobile Belt (fig. $5 B^{7}$ ). The Palawan block formed along an Andean-type subduction zone along the Asian continental margin during the Cretaceous. The Palawan block rifted from the Asian continent, moved southward as the South China Sea opened in the late Eocene to early Miocene, and collided with the northwest-directed Philippine Mobile Belt at about 20-16 Ma (Yumul and others, 2009; Marchadier and Rangin, 1990).

Mitchell and Leach (1991) used the term "Tablas-western Panay-Cagayan Ridge arc" for the area and interpreted the arc as the middle Miocene continuation of the western segment of the Luzon Arc. Dimalanta and Yumul (2004) associated this arc with the subduction of the South China Sea Plate along the Manila-Negros Trench (fig. 5B). The area has been studied extensively to document the timing and nature of the collision of Palawan with the Philippine Mobile Belt.

The westernmost islands of the central Philippines are a complex collage of accretionary prism complexes, metamorphic rocks (schists and marbles), ophiolites, mélange zones, and igneous rocks. Yumul and others (2009) documented at least five collision/accretion events and concluded that the collision boundary runs through western to central Mindoro Island. In northwestern Panay, the collision zone separates the Buruanga Peninsula (Palawan microcontinent) from the Antique Range (fig. 4C) of the Philippine Mobile Belt (Zamoras and others, 2008).

Multiple lines of geologic and geophysical evidence indicate that the original orientation of these islands was northwest-southeast, like the orientation of Masbate, Leyte, and Samar (fig. 2A). The present northeast-southwest orientation of these islands reflects clockwise rotation of Panay, Negros, Cebu, and Bohol (fig. 4A) and counterclockwise rotation of Mindoro (Yumul and others, 2009; Rangin and others, 1985).

\section{Geologic Criteria}

The tract delineates syncollisional to postcollisional Neogene igneous rocks in an area that spans the collision zone. The tract was constructed by selecting map units coded as Neogene intrusions and volcanic rocks from the digital version of the 1:1,000,000-scale geologic map of the Philippines (Philippine Bureau of Mines and Geosciences, 2004a) that fall within the Mindoro-Tablas-Western Panay Arc as outlined by Garwin and others (2005). Permissive rocks used to delineate the tract are shown in figure $\mathrm{H} 2$ and listed in table $\mathrm{H} 2$. The preliminary tract was developed using ArcGIS tools to create a $10-\mathrm{km}$ buffer around intrusive rocks and a $2-\mathrm{km}$ buffer around volcanic rocks. These distances are considered appropriate to allow for inaccuracies in mapped contacts and extensions under adjacent cover rock. The buffered map unit polygons were aggregated, smoothed, and edited by hand to include known, but unmapped permissive igneous rocks and prospects. The tract boundaries based on the 1:1,000,000-scale digital geology were compared with permissive rock distributions on recently released larger-scale maps for the islands in the tract area to ensure that the permissive rocks shown in the more detailed maps fall within the tract (table H4). The final tract segments were clipped to coastlines (U.S. Department of State, 2009).

The tract includes Neogene intrusions and volcanic rocks on Mindoro Island, the Romblon Islands, Western Visayas (Panay), and a small area of exposed late Eocene to early Oligocene quartz monzonite in northern Palawan (fig. H2). Northeastern Mindoro Island has the island-arc characteristics of the Philippine Mobile Belt, whereas southwestern Mindoro is linked to the Palawan microcontinent. Romblon Province includes the islands of Tablas, Romblon, and Sibuyan as well as smaller islands. The Romblon islands primarily are composed of strongly deformed pre-Tertiary schists, marbles, and metavolcanic and ultramafic rocks intruded by quartz diorite and porphyritic andesite (Philippine Bureau of Mines and Geosciences, 2010b). Miocene (19.9 Ma, 18.5 Ma) and Pliocene (3.8 Ma, 4.4 Ma) medium-K calc-alkalic andesite and dacite on Tablas Island and Miocene quartz diorite (19.5 Ma) in northwestern Panay record syncollisional magmatism (Bellon and Rangin, 1991). Effects of the collision event (strike-slip faulting, fragmented ophiolite complexes, mélanges) are best displayed on the island of Panay (Rangin and others, 1991). The tract is composed of a number of separate parts because of the geography of the islands, all of which lie west of the Philippine Fault. No permissive rocks for porphyry copper deposits are mapped on Romblon Island, which is entirely metamorphic. Ophiolites are excluded from the tract area; many of the ophiolites have associated nickel prospects. 
Table H2. Map units that define tract 142pCu7311, Mindoro-Tablas-West Panay Area—Philippines.

[Map unit, age range, and principal lithologies are based on a digital version of the 1:1,000,000-scale geologic map of the Philippines (Philippine Bureau of Mines, 1963, and larger-scale maps listed in table H4)]

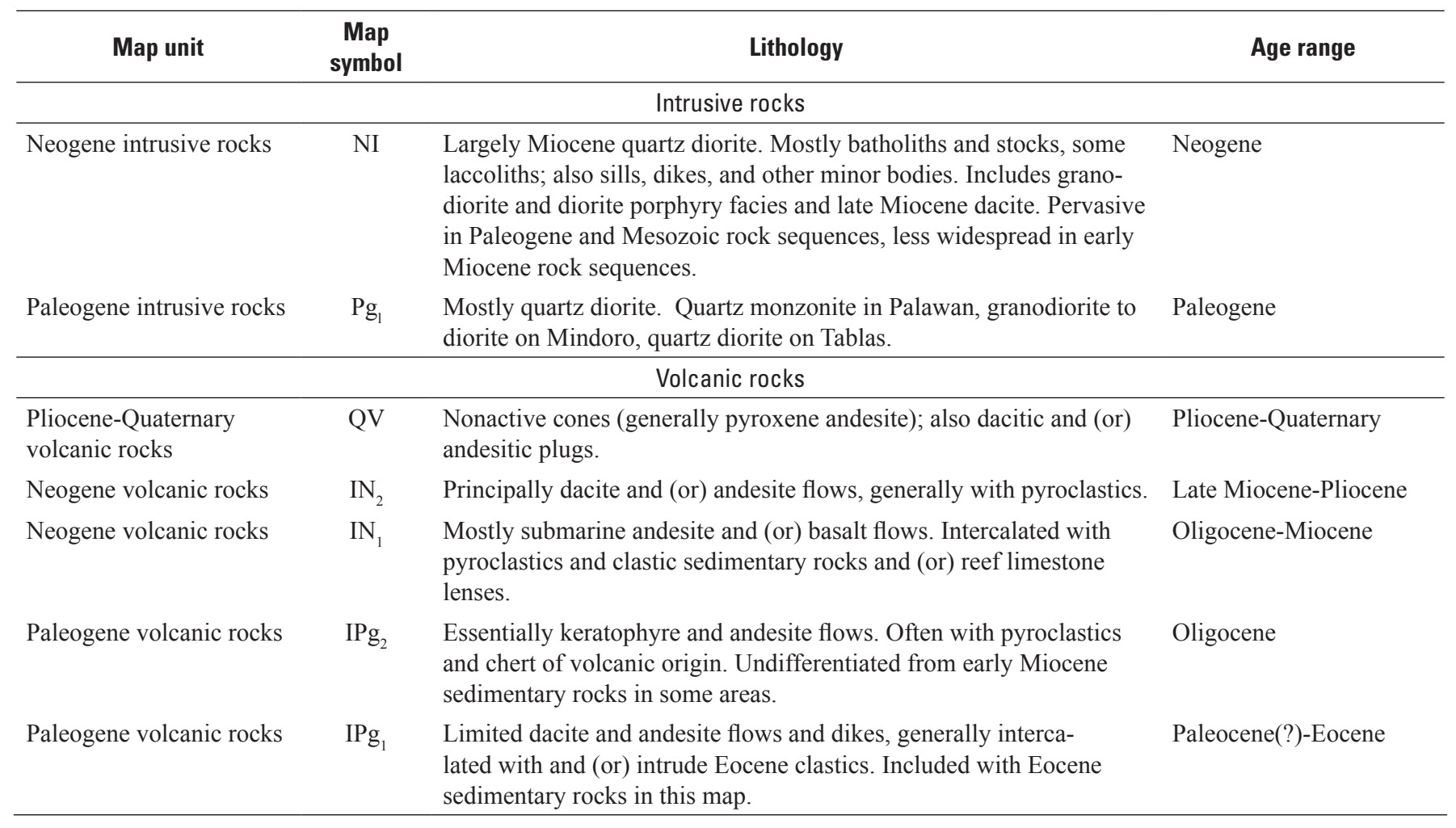



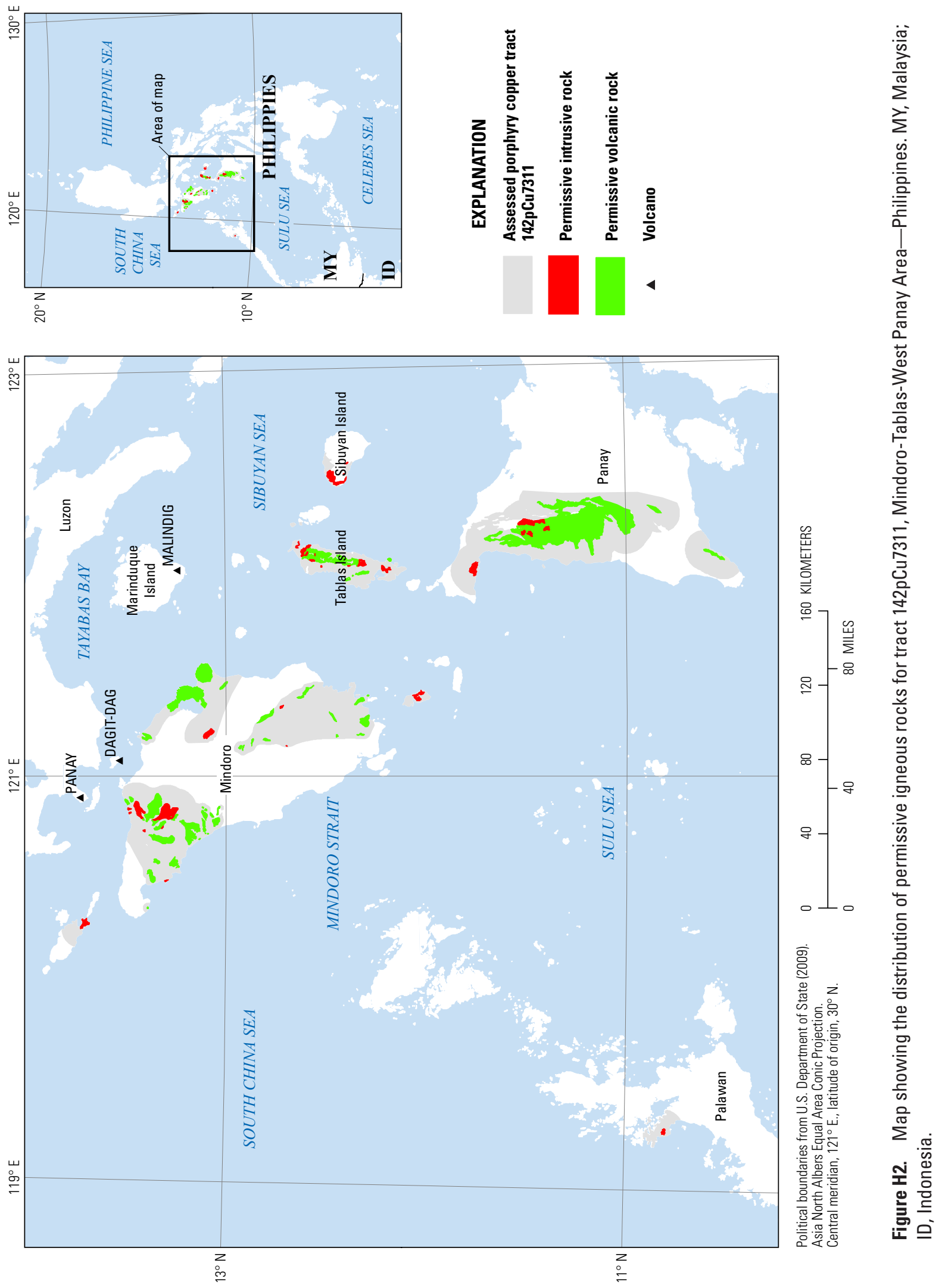
Table H3. Significant prospects and occurrences in tract 142pCu7311, Mindoro-Tablas-West Panay Area—Philippines.

[n.d., no data. Rank 1=copper occurrence that may be related to porphyry-type mineralization based on stream sediment or magnetic anomaly or location along structural trend]

\begin{tabular}{|c|c|c|c|c|c|c|}
\hline Name & Latitude & Longitude & Age & Comments & Reference & Rank \\
\hline \multicolumn{7}{|c|}{ Northern Sierra Madre } \\
\hline Caloring & 12.300 & 122.050 & n.d. & $\begin{array}{l}\text { Porphyry-associated chalcopyrite-bornite on } \\
\text { Tablas Island. }\end{array}$ & $\begin{array}{l}\text { Philippine Mines and } \\
\text { Geosciences Bureau (2004, } \\
\text { written commun.) }\end{array}$ & 1 \\
\hline Cogon & 12.183 & 122.050 & n.d. & $\begin{array}{l}\text { Porphyry-associated chalcopyrite-bornite on } \\
\text { Tablas Island. }\end{array}$ & $\begin{array}{l}\text { Philippine Mines and } \\
\text { Geosciences Bureau (2004, } \\
\text { written commun.) }\end{array}$ & 1 \\
\hline $\begin{array}{l}\text { Tablas Copper } \\
\text { One }\end{array}$ & 12.373 & 122.051 & n.d. & Copper prospect on Tablas Island & $\begin{array}{l}\text { Philippine Mines and Geo- } \\
\text { sciences Bureau (2010d) }\end{array}$ & 1 \\
\hline $\begin{array}{l}\text { Tablas Copper } \\
\text { Two }\end{array}$ & 12.641 & 122.148 & n.d. & Copper prospect on northeastern Tablas Island & $\begin{array}{l}\text { Philippine Mines and Geo- } \\
\text { sciences Bureau (2010d) }\end{array}$ & 1 \\
\hline
\end{tabular}

\section{Known Deposits}

None.

\section{Prospects, Mineral Occurrences, and Related Deposit Types}

Four prospects and occurrences are known on Tablas Island (fig. H1, table H3). Possible porphyry-related occurrences are present on Mindoro.

\section{Romblon Islands}

The Cogon and Caloring copper prospects on Tablas Island are reportedly porphyry-style occurrences having disseminated bornite and chalcopyrite associated with silicified diorite and andesite porphyry and metavolcanic rocks (fig. H1). Copperstaining is reported in quartz diorite and altered volcanic rocks in roadcuts and along shorelines in northeastern Tablas. Chalcopyrite and bornite also are reported in quartz veins in silicified serpentinite and quartz diorite on northwestern Sibuyan; it is not clear if these occurrences are porphyry related.

\section{Mindoro Island}

A number of copper-rich polymetallic vein deposits are present in northern Mindoro, as well as in the Mindoro gold district. The Mindoro gold-quartz veins are associated with greenschist-facies metasedimentary rocks (Mitchell and Leach, 1991) and do not appear to be porphyry related. Pre-Pliocene porphyry and skarn prospects in eastern Mindoro were noted by Mitchell and Leach (1991), but we have no locations for these prospects. The Lubang volcanogenic massive sulfide copper deposit is located in the far northwestern part of the tract (Philippine Mines and Geosciences Bureau, 2004b).

\section{Exploration History}

Prospect-scale exploration has taken place on Tablas and Mindoro Islands proximal to the porphyry-style and polymetallic vein occurrences. Ivanhoe Philippines, Inc., sought permits for mineral exploration for copper and gold on Tablas Island in 2010; applications were withdrawn following strong local opposition to mineral exploration (Mindanao Examiner, 2011). A geochemical soil survey for copper in northeastern Mindoro that followed up on vein and fissure-type copper associated with Paleogene dioritic intrusions in northeastern Mindoro concluded that the extent of mineralization was limited (Philippine Mines and Geosciences Bureau, 2010a). Some exploration and prospecting for mercury and manganese took place in Palawan; it is possible that indications of hydrothermal processes associated with porphyry copper were missed, but no copper occurrences are noted. Other than academic studies on the tectonics and stratigraphy within the North Palawan area, no exploration of any significance is known to have taken place.

According to the January 2012 mining tenement control maps for the area (Mindoro, Romblon, Tablas), no copper projects were active. Local opposition to metal mining and exploration is strong in the region, where several municipalities have sought a 25 -year moratorium on metals extraction and changes in the mining law. The islands included in the tract lie within Region $4 \mathrm{~b}$ of the Philippine Mines and Geosciences Bureau; the most recent information on exploration and development in the area can be accessed on their Web site at http://region4b.mgb.gov. $\mathrm{ph} / \mathrm{q}=$ geology_and_mineralresource_list. 


\section{Sources of Information}

The tract was based on permissive igneous rocks as shown on the 1:1,000,000-scale geologic map of the Philippines and larger scale maps of Tablas, Mindoro, Panay, and Palawan. Local and regional mineral occurrence databases and occurrences shown on geological and mineral occurrence maps also were used (Philippine Mines and Geosciences Bureau, 2004a, b). See table H4 for sources of information.

\section{Grade and Tonnage Model Selection}

On the basis of the gold-rich character of most porphyry deposits in the Philippines, recommendations of a regional analysis (Drew and Singer, 2005), and the possibility that the tract area may be a continuation of the western segment of the Luzon Arc that hosts numerous porphyry copper-gold deposits (Dizon, Taysan, Marcopper), the copper-gold subtype model was used for the assessment of the tract.

\section{Estimate of the Number of Undiscovered Deposits}

\section{Rationale for the Estimate}

The tract does not encompass a well-defined, mineralized magmatic arc. The relation between the collision events and magmatism is not fully understood; reported ages indicate that multiple pulses of magmatism occurred. The level

Table H4. Principal sources of information used for tract 142pCu7311, Mindoro-Tablas-West Panay Area—Philippines.

[NA, not applicable]

\begin{tabular}{|c|c|c|c|}
\hline Theme & Name or title & Scale & Citation \\
\hline \multirow[t]{6}{*}{ Geology } & $\begin{array}{l}\text { Geology and mineral resources of the Philippines, v. } \\
1 \text { - Geology }\end{array}$ & $1: 1,000,000$ & $\begin{array}{l}\text { Philippine Bureau of Mines and Geosciences } \\
\text { (1981), Philippine Mines and Geosciences } \\
\text { Bureau (2010e) }\end{array}$ \\
\hline & Digital geologic map of the Philippines & $1: 1,000,000$ & $\begin{array}{l}\text { Philippine Mines and Geosciences Bureau } \\
\text { (2004a) }\end{array}$ \\
\hline & Geology and mineral resources of Mindoro Island & $1: 400,000$ & $\begin{array}{l}\text { Philippine Mines and Geosciences Bureau } \\
\text { (2010a) }\end{array}$ \\
\hline & $\begin{array}{l}\text { Geology and mineral resources of map of Tablas } \\
\text { Island, Romblon Province }\end{array}$ & $1: 500,000$ & $\begin{array}{l}\text { Philippine Mines and Geosciences Bureau } \\
\text { (2010d) }\end{array}$ \\
\hline & $\begin{array}{l}\text { Geology and mineral resources of map of Romblon } \\
\text { Island }\end{array}$ & $1: 50,000$ & $\begin{array}{l}\text { Philippine Mines and Geosciences Bureau } \\
\text { (2010b) }\end{array}$ \\
\hline & $\begin{array}{l}\text { Geology and mineral resources of map of Sibuyan } \\
\text { Island, Romblon Province }\end{array}$ & $1: 50,000$ & $\begin{array}{l}\text { Philippine Mines and Geosciences Bureau } \\
\text { (2010c) }\end{array}$ \\
\hline \multirow[t]{4}{*}{$\begin{array}{l}\text { Mineral } \\
\text { occurrences }\end{array}$} & $\begin{array}{l}\text { Porphyry copper deposits of the world-Database, } \\
\text { map, and grade and tonnage models }\end{array}$ & NA & Singer and others (2008) \\
\hline & $\begin{array}{l}\text { Geology and mineral resources of the Philippines, v. } \\
\text { 2-Mineral Resources }\end{array}$ & NA & $\begin{array}{l}\text { Philippine Bureau of Mines and Geosciences } \\
\text { (1986) }\end{array}$ \\
\hline & $\begin{array}{l}\text { Digital data base of mineral occurrences of the Philip- } \\
\text { pines }\end{array}$ & NA & $\begin{array}{l}\text { Philippine Bureau of Mines and Geosciences } \\
\text { (2004b) }\end{array}$ \\
\hline & $\begin{array}{l}\text { Mineral resource map of Asia: Metal Mining Agency } \\
\text { of Japan }\end{array}$ & NA & Kamitani and Naito (1998) \\
\hline Exploration & $\begin{array}{l}\text { Philippine Mines and Geosciences Bureau Region 4B } \\
\text { Web site, tenement maps and reports }\end{array}$ & NA & http://region4b.mgb.gov.ph/ \\
\hline
\end{tabular}


of exposure is permissive for porphyry deposits because the tract area includes both intrusions and coeval volcanic rocks. The tract lacks the association with epithermal gold deposits that is characteristic of the major porphyry districts in the Philippines. Plans for copper and gold exploration on Tablas Island were halted due to social opposition, so no modern exploration data are available. Consideration of the remoteness, the fact that much of the tract has not been thoroughly explored, and that parts of the tract are covered led the assessment team to estimate a 50-percent chance of one or more deposits, a 10-percent chance for two or more deposits, and a 5 -percent chance of three or more deposits. The mean result is one undiscovered deposit with a relatively high degree of uncertainty $\left(C_{v}=91\right.$ percent $)$.

\section{Probabilistic Assessment Simulation Results}

Undiscovered resources for the tract were estimated by combining the consensus estimate for numbers of undiscovered porphyry copper deposits with the global copper-gold subtype porphyry copper model of Singer and others (2008) using the EMINERS program (Root and others, 1992; Duval, 2012; Bawiec and Spanski, 2012). Selected simulation results are reported in table H6. Results of the Monte Carlo simulation are presented as a cumulative frequency plot (fig. H3). The cumulative frequency plot shows the estimated resource amounts associated with cumulative probabilities of occurrence, as well as the mean, for each commodity and for total mineralized rock.

Table H5. Undiscovered deposit estimates, deposit numbers, tract area, and deposit density for tract 142pCu7311, Mindoro-Tablas-West Panay Area-Philippines.

[ $N_{\mathrm{XX}}$, estimated number of deposits associated with the xxth percentile; $N_{\text {und }}$, expected number of undiscovered deposits; $s$, standard deviation; $C_{v} \%$, coefficient of variance; $N_{\text {known }}$, number of known deposits in the tract that are included in the grade and tonnage model; $N_{\text {total }}$, total of expected number of deposits plus known deposits; area, area of permissive tract in square kilometers $\left(\mathrm{km}^{2}\right)$; density, deposit density reported as the total number of deposits per 100,000 km². $N_{\text {und }}, S$, and $C_{v} \%$ are calculated using a regression equation (Singer and Menzie, 2005)]

\begin{tabular}{|c|c|c|c|c|c|c|c|c|c|c|c|}
\hline \multicolumn{5}{|c|}{ Consensus undiscovered deposit estimates } & \multicolumn{5}{|c|}{ Summary statistics } & \multirow{2}{*}{$\begin{array}{l}\text { Tract Area } \\
\qquad\left(\mathbf{k m}^{2}\right)\end{array}$} & \multirow{2}{*}{$\begin{array}{c}\text { Deposit density } \\
\left(N_{\text {total }} / 100,000 \mathrm{~km}^{2}\right)\end{array}$} \\
\hline$N_{90}$ & $N_{50}$ & $N_{10}$ & $N_{05}$ & $N_{01}$ & $N_{\text {und }}$ & $s$ & $C_{v} \%$ & $N_{\text {known }}$ & $N_{\text {total }}$ & & \\
\hline 0 & 1 & 2 & 3 & 3 & 1.1 & 0.98 & 91 & 0 & 1.1 & 9,170 & 12 \\
\hline
\end{tabular}

Table H6. Results of Monte Carlo simulation of undiscovered resources for tract 142pCu7311, Mindoro-Tablas-West Panay-Philippines.

[Cu, copper; Mo, molybdenum; Au, gold; and Ag, silver; in metric tons; Rock, in million metric tons]

\begin{tabular}{|c|c|c|c|c|c|c|c|c|}
\hline \multirow[b]{2}{*}{ Material } & \multicolumn{6}{|c|}{ Probability of at least the indicated amount } & \multicolumn{2}{|c|}{ Probability of } \\
\hline & 0.95 & 0.9 & 0.5 & 0.1 & 0.05 & Mean & $\begin{array}{c}\text { Mean or } \\
\text { greater }\end{array}$ & None \\
\hline $\mathrm{Cu}$ & 0 & 0 & 670,000 & $7,300,000$ & $14,000,000$ & $3,200,000$ & 0.22 & 0.29 \\
\hline Mo & 0 & 0 & 0 & 35,000 & 73,000 & 17,000 & 0.15 & 0.67 \\
\hline $\mathrm{Au}$ & 0 & 0 & 66 & 590 & 990 & 230 & 0.25 & 0.29 \\
\hline $\mathrm{Ag}$ & 0 & 0 & 0 & 1,900 & 4,200 & 1,000 & 0.16 & 0.60 \\
\hline Rock & 0 & 0 & 150 & 1,500 & 2,800 & 630 & 0.23 & 0.29 \\
\hline
\end{tabular}




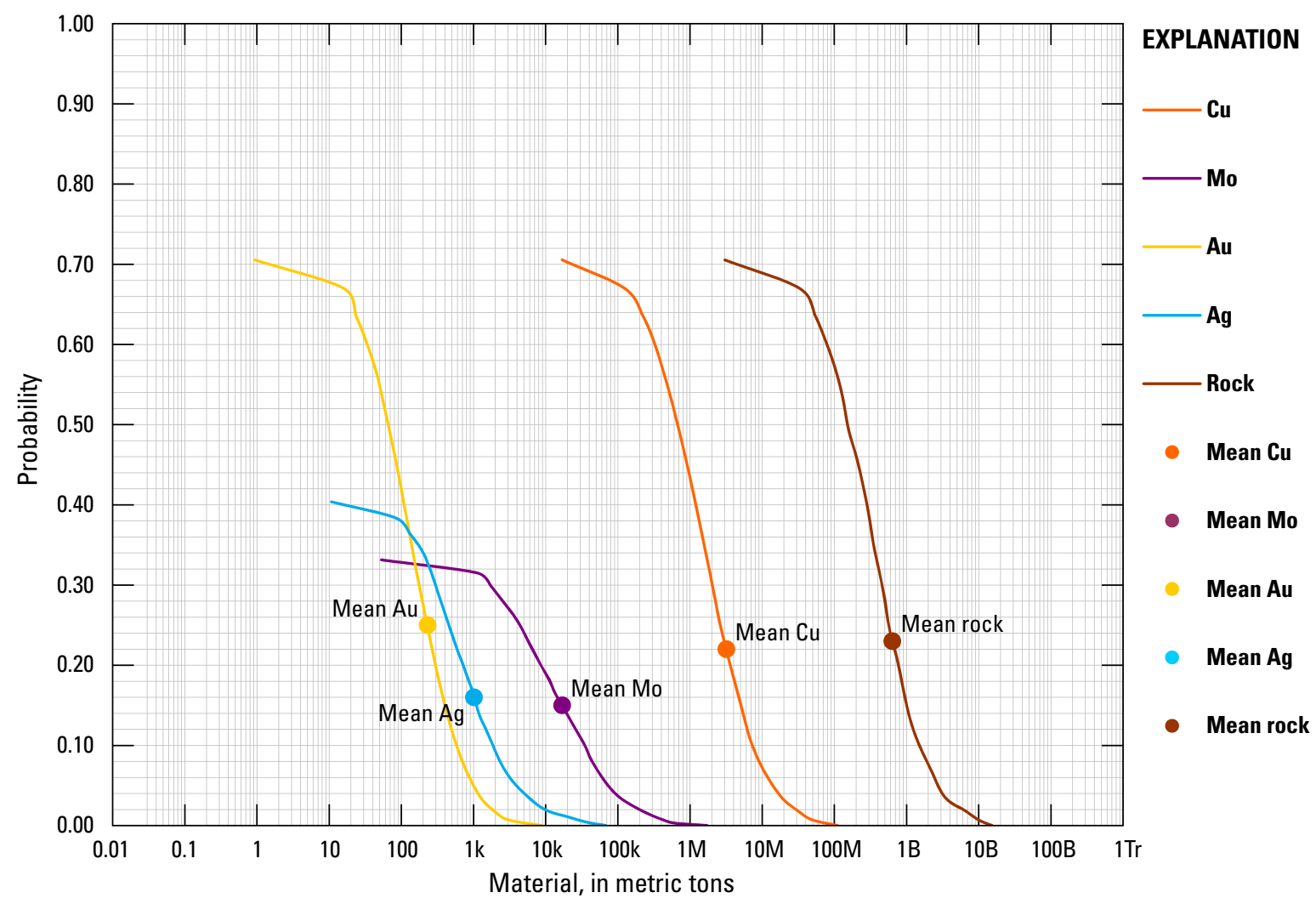

Figure H3. Cumulative frequency plot showing the results of Monte Carlo computer simulation of undiscovered resources in tract 142pCu7311, Mindoro-Tablas-West Panay Area-Philippines. k, thousands; M, millions; B, billions; Tr, trillions.

\section{References Cited}

Bawiec, W.J., and Spanski, G.T., 2012, Quick-start guide for version 3.0 of EMINERS-Economic Mineral Resource Simulator: U.S. Geological Survey Open-File Report 2009-1057, 26 p., accessed June 30, 2012, at http://pubs. usgs.gov/of/2009/1057/. (This report supplements USGS OFR 2004-1344.)

Bellon, H., and Rangin, C., 1991, Geochemistry and isotopic dating of Cenozoic volcanic arc sequences around Celebes and Sulu seas, in Silver, E.A., Rangin, C., von Breymann, M.T., eds., Proceedings of the Ocean Drilling Program, Scientific Results, v. 124, p. 321-338.

Berger, B.R., Ayuso, R.A., Wynn, J.C., and Seal, R.R., 2008, Preliminary model of porphyry copper deposits: U.S. Geological Survey Open-File Report 2008-1321, 55 p., accessed May 15, 2009, at http://pubs.usgs.gov/ of $/ 2008 / 1321 /$.

Coordinating Committee for Coastal and Offshore Geoscience Programmes in East and Southeast Asia (CCOP) and Geological Survey of Japan, 1997, Digital Geologic Map of East and Southeast Asia, 1:2,000,000: Geological Survey of Japan, Digital Geoscience Map G-2.
Cox, D.P., 1986, Descriptive model of porphyry Cu, in Cox, D.P., and Singer, D.A., eds., 1986, Mineral deposit models: U.S. Geological Survey Bulletin 1693, p. 76. (Also available at http://pubs.usgs.gov/bul/b1693/.)

Department of Environment and Natural Resources, 2008, Mineral resources information series (Metallic): Mines and Geosciences Bureau, Lands Geological Survey Division.

Dimalanta, C.B., and Yumul, G.P., Jr., 2004, Crustal thickening in an active margin setting (Philippines)-The whys and the hows: Episodes, v. 27, no. 4, p. 260-264.

Drew, L.J., and Singer, D.A., 2005, Identifying the appropriate porphyry-copper deposit grade-tonnage model for a largescale mineral resource assessment in South East Asia, in Chen, Qiuming, and Bonham-Carter, Graeme, eds., Proceedings of IAMG-The annual conference of the International Association for Mathematical Geology: Toronto, Canada, York University Geomatics Research Laboratory, p. 1034-1039.

Duval, J.S., 2012, Version 3.0 of EMINERS-Economic Mineral Resource Simulator: U.S. Geological Survey Open-File Report 2004-1344, accessed July 15, 2012, at http://pubs. usgs.gov/of/2004/1344/. 
Garwin, S., Hall, R., and Watanabe, Y., 2005, Tectonic setting, geology, and gold and copper mineralization in Cenozoic magmatic arcs of southeast Asia and the west Pacific, in Hedenquist, T.W., Thompson, J.F.H., Goldfarb, R.J., and Richards, J.P., eds., One hundredth anniversary volume 1905-2005: Littleton, Colorado, Society of Economic Geologists, p. 891-930.

John, D.A., Ayuso, R.A., Barton, M.D., Blakely, R.J., Bodnar, R.J., Dilles, J.H., Gray, Floyd, Graybeal, F.T., Mars, J.C., McPhee, D.K., Seal, R.R., Taylor, R.D., and Vikre, P.G., 2010, Porphyry copper deposit model, chap. B of Mineral deposit models for resource assessment: U.S. Geological Survey Scientific Investigations Report 2010-5070-B, 169 p., accessed September 8, 2010, at http://pubs.usgs.gov/ $\operatorname{sir} / 2010 / 5070 / \mathrm{b} /$.

Kamitani, M., and Naito, K., eds., 1998, Mineral resource map of Asia: Metal Mining Agency of Japan, 1 sheet, scale 1:35,000,000-scale. (Also available at www.mmaj.go.jp/ mric_web/deposit/index.htm.)

Marchadier Y., and Rangin, C., 1990, Polyphase tectonics at the southern tip of the Manila trench, Mindoro-Tablas islands, Philippines: Tectonophysics, v. 183, p. 273-287.

Mitchell, A.H.G, and Leach, T.M., 1991, Epithermal gold in the Philippines-Island arc metallogenesis, geothermal systems and geology: London, Academic Press, 457 p.

Mindanao Examiner, 2011, Romblon rejoices from withdrawal of mining form: The Mindanao Examiner, October 13, 2011, accessed June 1, 2012, at http://zamboangajournal. blogspot.com/2011/10/romblon-rejoices-from-withdrawalof.html.

Philippine Bureau of Mines, 1963, Geological map of the Philippines: Philippine Bureau of Mines, 1 map on 8 sheets, scale $1: 1,000,000$.

Philippine Bureau of Mines and Geosciences, 1981, Geology and mineral resources of the Philippines, v. 1-Geology: Philippine Bureau of Mines and Geosciences, $406 \mathrm{p}$.

Philippine Bureau of Mines and Geosciences, 1986, Geology and mineral resources of the Philippines, v. 2-Mineral Resources: Philippine Bureau of Mines and Geosciences, $446 \mathrm{p}$.

Philippine Mines and Geosciences Bureau, 2004a, Digital geological map of the Philippines: Philippine Mines and Geosciences Bureau, scale 1:1,000,000. [Proprietary data.]

Philippine Mines and Geosciences Bureau, 2004b, Digital database of mineral occurrences of the Philippines: Philippine Mines and Geosciences Bureau. [Proprietary report.]
Philippine Mines and Geosciences Bureau, 2010a, Geology and mineral resources of Mindoro Island: Philippine Mines and Geosciences Bureau, accessed June 15, 2012, at http://region4b.mgb.gov.ph/sites/default/files/Geology\%20 and $\% 20$ Mineral $\% 20$ Resources $\% 20$ Map $\% 20$ of $\% 20$ Mindoro.jpg, scale 1:400,000.

Philippine Mines and Geosciences Bureau, 2010b, Geology and mineral resources of Romblon Island: Philippine Mines and Geosciences Bureau, accessed June 15, 2012, at http://region4b.mgb.gov.ph/sites/default/files/Romblon $\% 20$ Island $\% 20$ Geology\%20and\%20Mineral\%20Resources $\% 20$ map.jpg, scale 1:50,000.

Philippine Mines and Geosciences Bureau, 2010c, Geology and mineral resources of Sibuyan Island, Romblon Province: Philippine Mines and Geosciences Bureau, accessed June 15, 2012, at http://region4b.mgb.gov.ph/sites/ default/files/Sibuyan\%20Island\%20Geology\%20and\%20 Mineral\%20Resources\%20Map.jpg, scale 1:50,000.

Philippine Mines and Geosciences Bureau, 2010d, Geology and mineral resources map of Tablas Island, Romblon Province: Philippine Mines and Geosciences Bureau, accessed June 15, 2012, at http://region4b.mgb.gov.ph/sites/default/ files/Tablas\%20Island\%20Geology\%20and\%20Mineral\%20 Reservation\%20Map.jpg, scale 1:500,000.

Philippine Mines and Geosciences Bureau, 2010e, Geology of the Philippines ( $2 \mathrm{~d}$ ed.): Philippine Mines and Geosciences Bureau, $532 \mathrm{p}$.

Rangin, C., Stephan, J.F., Butterlin, J., Bellon, H., Müller, C., Chorowicz, and Baladad, D., 1991, Collision neogene d'arc volcaniques dans le centre des Philippines-Stratigraphie et structure de la chaine d'antique (Ile de Panay): Bulletin de la Société géologique de France, v. 162, no. 3, p. 465-477.

Root, D.H., Menzie, W.D., and Scott, W.A., 1992, Computer Monte Carlo simulation in quantitative resource estimation: Natural Resources Research, v. 1, no. 2, p. 125-138.

Sillitoe, R.H., and Gappe, I.M., Jr., 1984, Philippine porphyry copper deposits - Geologic setting and characteristics: Committee for Co-ordination of Joint Prospecting for Mineral Resources in Asian Offshore Areas (CCOP), CCOP Technical Publication 14, $89 \mathrm{p}$.

Singer, D.A., and Menzie, W.D., 2005, Statistical guides to estimating the number of undiscovered mineral deposits-An example with porphyry copper deposits, in Cheng, Qiuming, and Bonham-Carter, Graeme, eds., Proceedings of IAMG-The annual conference of the International Association for Mathematical Geology: Toronto, Canada, York University, Geomatics Research Laboratory, p. 1028-1033. 
Singer, D.A., Berger, V.I., and Moring, B.C., 2008, Porphyry copper deposits of the World-Database and grade and tonnage models, 2008: U.S. Geological Survey Open-File Report 2008-1155, accessed June 1, 2011, at http://pubs. usgs.gov/of/2008/1155/.

U.S. Department of State, 2009, Small-scale digital international land boundaries (SSIB) - Lines, edition 10, and polygons, beta edition 1, in Boundaries and sovereignty encyclopedia (B.A.S.E.): U.S. Department of State, Office of the Geographer and Global Issues.
Yumul, G.P. Jr., Dimalanta, C.B., Marquez, E.J., and Queño, K.L., 2009, Onland signatures of the Palawan microcontinental block and Philippine Mobile Belt collision and crustal growth process-A review: Journal of Asian Earth Sciences, v. 34, p. 610-623.

Zamoras, L.R., Montes, M.G.A., Queaño, K.L., Marquez, E.J., Dimalanta, C.B., Gabo, J.A.S., and Yumul, G.P, Jr., 2008, Buruanga peninsula and Antique Range-Two contrasting terranes in northwest Panay, Philippines featuring an arccontinent collision zone: Island Arc, v. 17, p. 433-457. 
This page left intentionally blank. 


\section{Appendix I. Porphyry Copper Assessment for Tract 142pCu7306, Bohol-Cebu Area-Philippines}

By Jane M. Hammarstrom ', Arthur A. Bookstrom², Connie L. Dicken', Steve Ludington ${ }^{3}$, Gilpin R. Robinson, Jr.', and Michael L. Zientek ${ }^{2}$ with contributions from Sevillo (Bill) D. David, Jr. ${ }^{4}$ Claro J. Manipon ${ }^{4}$, Lilian A. Rollan ${ }^{4}$, and Yasushi Watanabe ${ }^{5}$

\section{Deposit Type Assessed: Porphyry copper}

Descriptive model: Porphyry copper (Cox, 1986; Berger and others, 2008; John and others, 2010; Sillitoe and Gappe, 1984) Grade and tonnage model: Porphyry copper, general model (Singer and others, 2008)

Table I1 summarizes selected assessment results.

Table I1. Summary of selected resource assessment results for tract 142pCu7306 Bohol-Cebu Area—Philippines.

[km, kilometers; $\mathrm{km}^{2}$, square kilometers; t, metric tons; identified resources rounded to two significant figures]

\begin{tabular}{cccccc}
\hline $\begin{array}{c}\text { Date of } \\
\text { assessment }\end{array}$ & $\begin{array}{c}\text { Assessment depth } \\
(\mathbf{k m})\end{array}$ & Tract area $\left(\mathbf{k m}^{2}\right)$ & $\begin{array}{c}\text { Identified copper } \\
\text { resources }(\mathbf{t})\end{array}$ & $\begin{array}{c}\text { Mean estimate of } \\
\text { undiscovered copper } \\
\text { resources }(\mathbf{t})\end{array}$ & $\begin{array}{c}\text { Median estimate of } \\
\text { undiscovered copper } \\
\text { resources }(\mathbf{t})\end{array}$ \\
\hline 2010 & 1 & 9,170 & 0 & $3,200,000$ \\
\hline
\end{tabular}

\section{Location}

Bohol Island and Cebu Island (fig. I1).

\section{Geologic Feature Assessed}

Cretaceous, Paleogene, and Miocene magmatic belt on Bohol and Cebu Islands.

${ }^{1}$ U.S. Geological Survey, Reston, Virginia, United States.

${ }^{2}$ U.S. Geological Survey, Spokane, Washington, United States.

${ }^{3}$ U.S. Geological Survey, Menlo Park, California, United States.

${ }^{4}$ Philippine Department of Environment and Natural Resources, Mines and Geosciences Bureau, Quezon City, Philippines.

${ }^{5}$ Geological Survey of Japan, National Institute of Advanced Industrial Science and Technology (AIST), Ibaraki, Japan. 

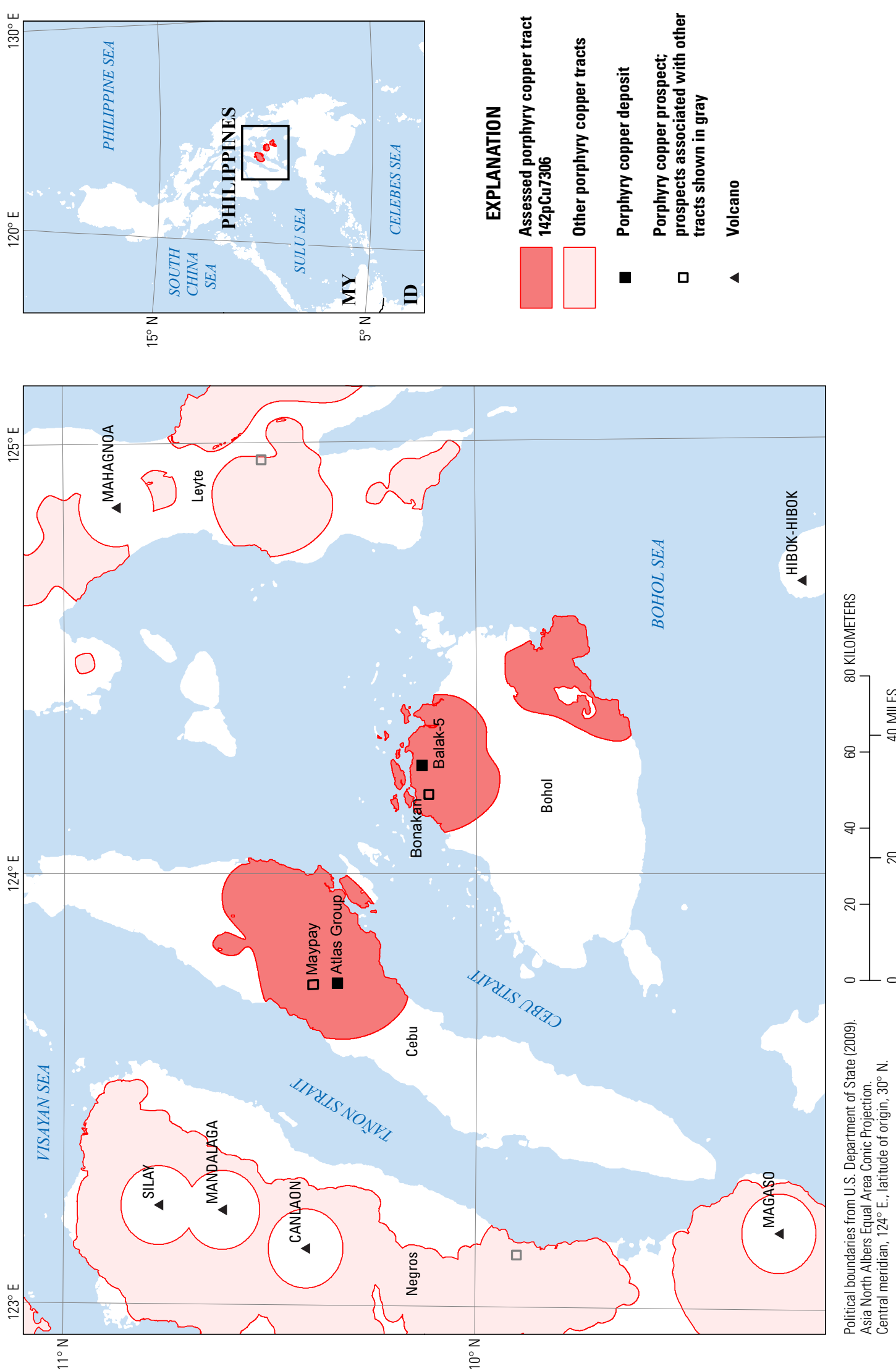

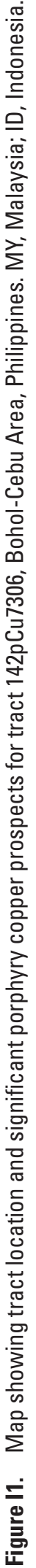




\section{Delineation of the Permissive Tract}

\section{Tectonic Setting}

The relation of igneous rocks on Bohol and Cebu Islands to magmatic arcs and subduction zones is uncertain. Miocene diorite plutons and andesitic and dacitic volcanic rocks, possibly related to an early Miocene trench that lay to the east of Bohol, are described as the Northwestern Bohol Arc by Mitchell and Leach (1991). They suggested that middle Miocene andesites on Cebu might be part of a single arc system that extended to western Mindanao to the south; alternatively, an east-facing Miocene arc may have been continuous with the Sulu-Zamboanga arc system (fig. $2^{6}$ ). Miocene andesitic volcanic rocks also are present in southeastern Bohol.

Cretaceous and Paleogene igneous rocks (quartz diorite, andesite) are present on both islands. Isolated areas of Cretaceous arc rocks were documented farther north in the Philippines on Catuandanes Island and in southeastern Luzon on Rapu Rapu Island (fig. 4A) (Dimalanta and Yumul, 2004), where a northwest-striking (present-day orientation) Late Cretaceous arc may be related to subduction of the Philippine Sea Plate along a proto-East Luzon Trough (Yumul and others, 2003). The nature and extent of Cretaceous arc magmatism on Cebu and the relation to younger arc rocks requires further studies. As noted by Mitchell and Leach (1991), pre-Tertiary unmetamorphosed arc volcanic rocks have been recognized only on Cebu Island, and on some maps, CretaceousPaleogene ages were incorrectly assigned to Tertiary rocks because of hydrothermal alteration and lack of fossils. For the purposes of this assessment, the occurrence of the disparate age groups on the two islands is considered informally as the Bohol-Cebu magmatic belt.

\section{Geologic Criteria}

Tract 142pCu7306 delineates pre-Pliocene quartz diorite intrusions and andesitic rocks that occur in a northwesttrending belt extending from southeastern Bohol to the central highlands of Cebu (fig. I2). The permissive tract was constructed by selecting igneous rocks from a digital version of the 1:1,000,000-scale geologic map of the Philippines (Philippine Bureau of Mines and Geosciences, 2004a). The map units were classified by age groups, and subdivided into intrusive and volcanic subgroups. Larger scale maps for central Cebu and southeastern Bohol (listed in table I5) were rectified and compared with the smaller-scale digital maps (table I2). Map unit lithologies were examined, and rock types that were not considered permissive for porphyry copper deposits, such as ultramafic rocks and ophiolite complexes, were excluded.
Using GIS tools, a 10-km buffer was created around intrusive rocks and a $2-\mathrm{km}$ buffer was created around volcanic rocks. These distances are considered appropriate to allow for inaccuracies in mapped contacts and extensions under adjacent cover rock. The buffered map unit polygons were aggregated, smoothed, and edited by hand to include known but unmapped permissive igneous rocks and prospects. Site locations for dated and classified igneous rocks were also used to constrain tract boundaries (Malaihollo and others, 2002). The final tract segments were clipped to coastlines (U.S. Department of State, 2009).

\section{Bohol Island}

The Paleocene-late Eocene Ubay Volcanics in northeastern Bohol include dacite, pyroxene andesite, and basalt. They have been intruded by diorite. Hydrothermally altered rocks are described in a limited area in the northwestern part of the island. Small diorite bodies (Talibon diorite) are present along a northeasterly trend in northern Bohol. The diorite (late Eocene-early Oligocene) intrudes coeval porphyritic hornblende andesite. A Miocene andesite (Janga andesite) crops out on southeastern Bohol Island (Philippine Bureau of Mines and Geosciences, 1981).

\section{Cebu Island}

The northeast-trending composite Lutopon Diorite (diorite, quartz diorite, andesite, dacite, gabbro) intruded Cretaceous sedimentary and volcanic rocks on central Cebu Island. The age of the complex is problematic and may record a long magmatic history. Reported radiometric ages include the following: 101-Ma K-Ar and 107-Ma Rb-Sr ages from the Biga and Frank ore bodies at the Atlas Mine (Walther and others, 1981) and a 59.7 \pm 1.2 -Ma whole-rock K-Ar age for diorite from the Lutopan pit at the Atlas Mine (Wolfe, 1973; Malaihollo and others, 2002). Middle Miocene diorite and quartz monzonite stocks dated at $12.5 \pm 0.6 \mathrm{Ma}$ and mid- to late Miocene andesite flows and pyroclastic rocks are exposed in the central highland areas of Cebu Island. Geochemical data for seven samples of hornblende quartz diorite, quartz diorite porphyry, and postmineral andesite at the Atlas Mine were reported by Divis (1983); these samples ranged from 61 to 68 percent in $\mathrm{SiO}_{2}$ content and contained elevated metal concentrations (12-523 ppm copper, 380-10,800 ppm tin).

Figure I3 illustrates the geology in the Atlas Mine area, as shown by Divis (1983) and the Philippine Bureau of Mines and Geosciences (1986). The Pardo 1:50,000-scale geological map, which covers the mine area, shows that the mapped Cretaceous Lutopan Diorite (dated at the Lutopan pit as Paleocene or Eocene) intrudes the Cretaceous Managa Group, which includes the Pandan Formation and Cansi Volcanics shown in figure I3. 
Table 12. Map units that define tract 142pCu7306, Bohol-Cebu Area-Philippines.

[Map unit, age range, and principal lithologies are based on a digital version of the 1:1,000,000-scale geologic map of the Philippines (Philippine Bureau of Mines, 1963). Named units are from the 1:50,000-scale maps for Buanoy, Danao, Balamban, Liloan, and Pardo quadrangles on Cebu Island and the Anda, Jagna, and Sierra Bullones quadrangles in southeastern part of Bohol Island]

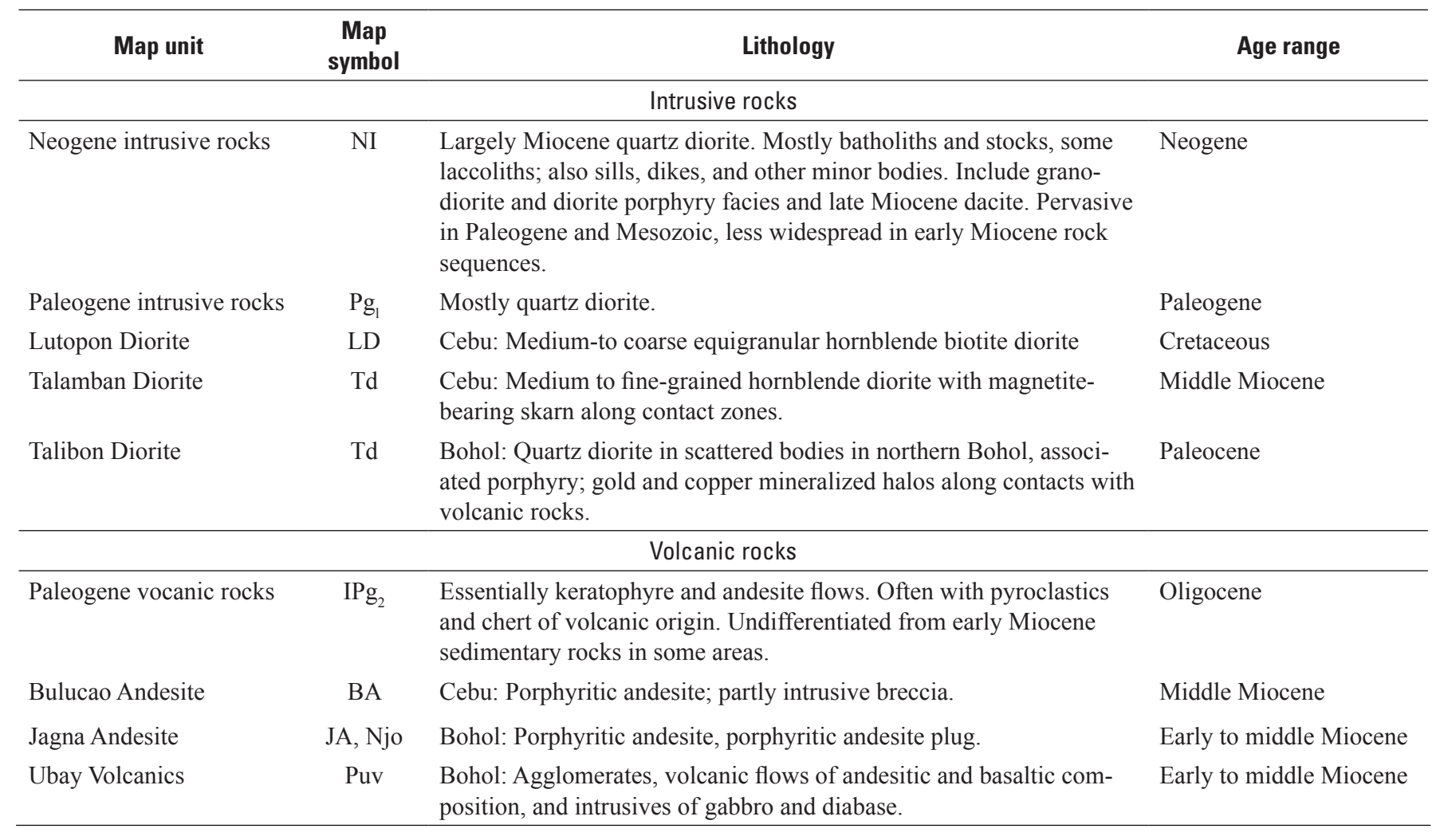



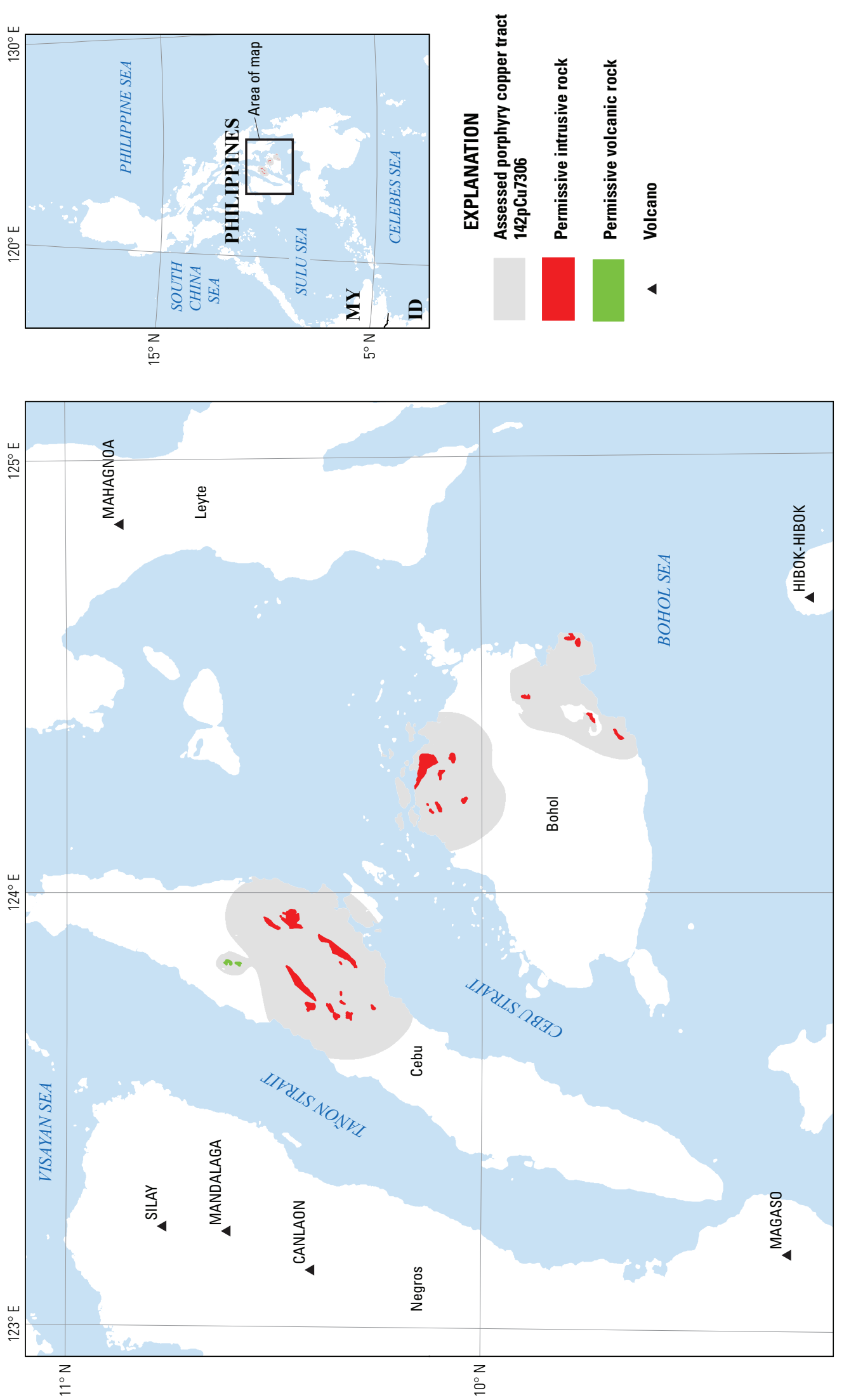

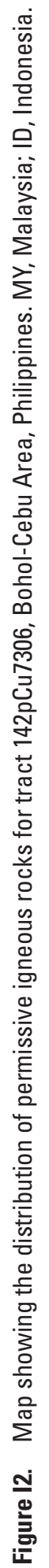




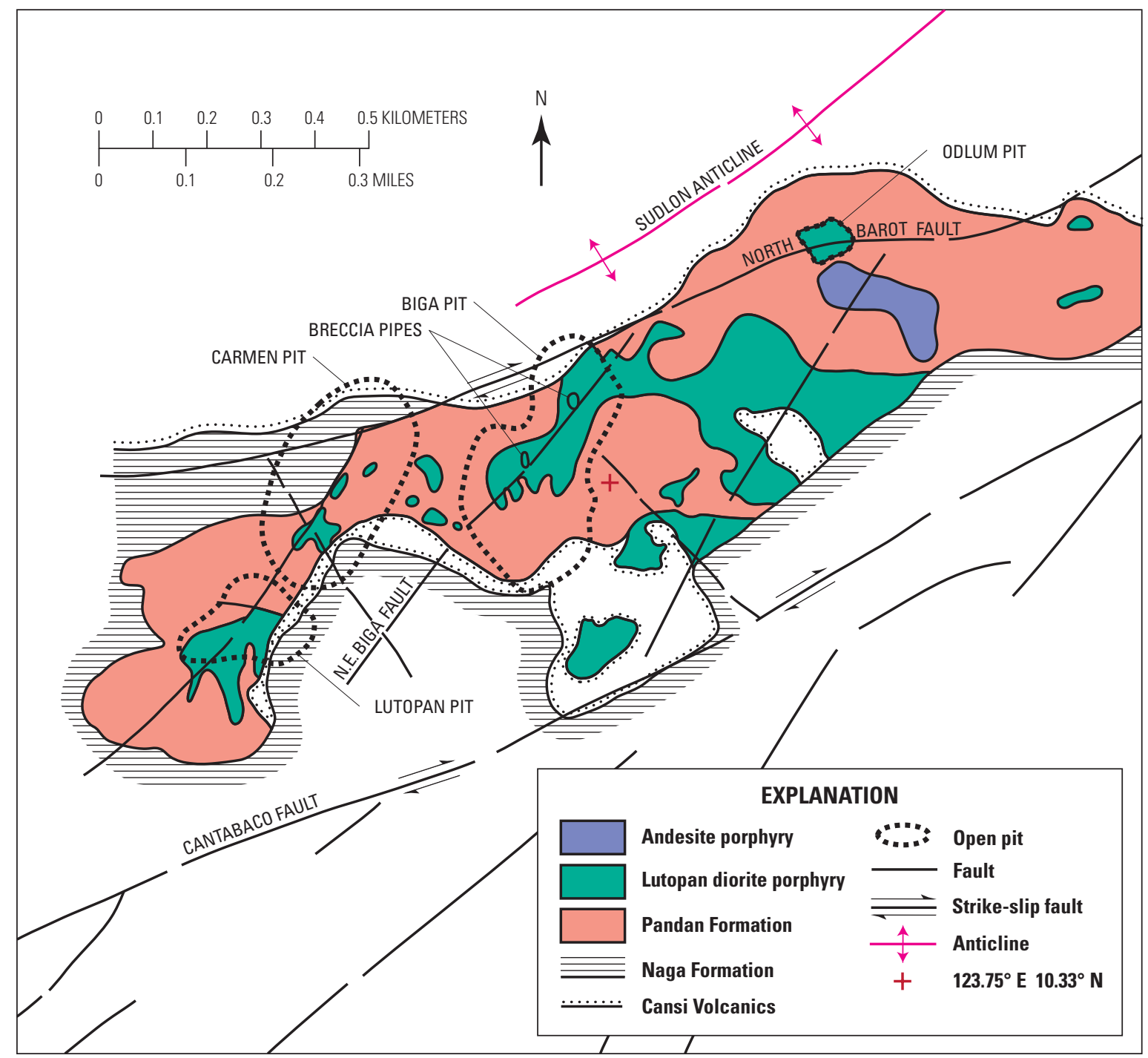

Figure 13. Sketch map of the historical Atlas Mine on Cebu Island, modified from Divis (1983) and Philippine Bureau of Mines and Geosciences (1986).

\section{Known Deposits}

The tract contains two deposits with reported grades and tonnages, the Balak deposit on Bohol Island and the Atlas Group of deposits on Cebu Island (fig. I1, table I3.)

\section{Bohol Island}

The Balak deposit has supergene reserves of $5 \mathrm{Mt}$ of 0.80 percent copper. Drilling in the 1970 s reported intercepts greater than $90 \mathrm{~m}$ with grades for copper (less than or equal to 0.43 percent $)$, molybdenum ( 0.035 percent) and gold $(0.6 \mathrm{~g} / \mathrm{t})$. Minerals reported at Balak include alunite, chalcopyrite, hematite, pyrite, malachite, cuprite, copper, neotocite, limonite, sericite, and tourmaline.

\section{Cebu Island}

The oldest porphyry copper deposit recognized to date in the Philippines is the Atlas Group (fig. I1), which is associated with Cretaceous (?) and Paleogene quartz diorite, hornblende diorite porphyry intrusions, dacite porphyry, breccia, and volcaniclastic rocks on Cebu. The deposit lies within a 2-km wide horst (Divis, 1983). The major ore bodies in the deposit, Lutopan, Biga, and Carmen (fig. I3) are bounded by parallel east-northeast-striking faults that define the horst (Philippine Bureau of Mines and Geosciences, 1986). A dacite porphyry sill was mapped in the upper part of a mushroom-shaped diorite porphyry in the Lutopan pit at the Atlas Mine.

Garwin and others (2005) classified the Atlas deposit as a porphyry copper-gold-molybdenum system. Ore minerals include both hypogene (chalcopyrite, bornite) and supergene (chalcocite, covellite, azurite/malachite, chrysocolla) copper minerals. 
Table 13. Porphyry copper deposits in tract 142pCu7306, Bohol-Cebu Area-Philippines.

[Ma, million years; Mt, million metric tons; $\mathrm{t}$, metric ton; $\mathrm{g} / \mathrm{t}$, gram per metric ton; \%, percent; contained $\mathrm{Cu}$ in metric tons is computed as tonnage $(\mathrm{Mt} \times 1,000,000) \times(\mathrm{Cu}$ grade, in $\% \div 100$ ); NA, not applicable; n.d., no data]

\begin{tabular}{|c|c|c|c|c|c|c|c|c|c|}
\hline Name & Latitude & Longitude & Subtype & $\begin{array}{l}\text { Age } \\
\text { (Ma) }\end{array}$ & $\begin{array}{c}\text { Tonnage } \\
\text { (Mt) }\end{array}$ & $\begin{array}{l}\text { Cu } \\
(\%)\end{array}$ & Mo (\%) & $A u(g / t) A g(g / t)$ & $\begin{array}{c}\text { Contained } \\
\text { Cu (t) }\end{array}$ \\
\hline
\end{tabular}

\begin{tabular}{|c|c|c|c|c|c|c|c|c|c|}
\hline \multicolumn{10}{|c|}{ Bohol Island } \\
\hline Balak-5 & 10.133 & 124.250 & NA & n.d. & 5 & 0.80 & n.d. & 40,000 & $\begin{array}{l}\text { Hope (1971), Kinkel and others } \\
\text { (1956), Sillitoe and Gappe (1984) }\end{array}$ \\
\hline
\end{tabular}

\begin{tabular}{|c|c|c|c|c|c|c|c|c|c|c|c|}
\hline \multicolumn{12}{|c|}{ Cebu Island } \\
\hline $\begin{array}{l}\text { Atlas } \\
\text { Group }\end{array}$ & 10.339 & 123.746 & NA & 108 & 1,420 & 0.448 & 0.018 & 0.24 & 1.8 & $6,400,000$ & $\begin{array}{l}\text { Arcilla and others (1990), Atlas Con- } \\
\text { solidated Mining and Development } \\
\text { Corporation (2010, 2012), Clark } \\
\text { and Arancibia (1996), Divis (1983), } \\
\text { Hutchinson (1996), Kinkel and } \\
\text { others (1956), Madamba (1972), } \\
\text { Motegi (1977), Philippine Bureau } \\
\text { of Mines and Geosciences (1986), } \\
\text { Reyes and others (1985), Sillitoe } \\
\text { and Gappe (1984), Singer and others } \\
\text { (2008), Walther and others (1981) }\end{array}$ \\
\hline
\end{tabular}

Production from the Atlas Mine on Cebu Island began in 1955. Mining was suspended in 1995; the Carmen Copper Corporation (a subsidiary of Atlas Consolidated Mining and Development Corporation) reopened the mine in 2007 with reported reserves of $873.8 \mathrm{Mt}$ at 0.41 percent copper (Atlas Consolidated Mining and Development Co., 2010, 2012). In 2008, the Biga pit (fig. I3) was converted to a tailings pond. Most of the ore produced in 2011 came from the Lutopan pit. In 2012, both the Lutopan and Carmen pits were mined (Atlas Consolidated Mining and Development Corporation, 2013). Singer and others (2008) reported total resources and reserves for the Atlas (also known as the Biga or Toledo deposit) ore bodies, including the Biga, Carmen 1, Carmen 2, and Lutopan pit areas, as 1,420 Mt having average grades of 0.45 percent copper, 0.018 percent molybdenum, $0.24 \mathrm{~g} / \mathrm{t}$ gold, and $1.8 \mathrm{~g} / \mathrm{t}$ silver with $8 \mathrm{ppb}$ platinum and $56 \mathrm{ppb}$ palladium in Biga ore concentrate.

\section{Prospects, Mineral Occurrences, and Related Deposit Types}

Porphyry copper-related prospects are plotted as open squares on fig. I1 and described in table I4.

\section{Bohol Island}

Five porphyry prospects were identified within a $25-\mathrm{km}^{2}$ area during exploration in the 1950s to 1970 s, which led to delineation of the resource at Balak-5. Porphyry copper prospects are related to the Talibon diorite and the Ubay volcanics. The Bonakan copper-gold prospect (fig. I1) has reported grades of 1.02 percent copper and $4.18 \mathrm{~g} / \mathrm{t}$ gold in narrow gold-bearing veins in andesite.

Alluvial gold was worked in areas south and west of the porphyry area; advanced argillic alteration is associated with some porphyry prospects and in areas unrelated to known epithermal or porphyry prospects.

\section{Cebu Island}

The Toledo Copper Complex exploration area (Atlas Consolidated Mining and Development Corporation, 2012) includes several prospects within and outside of the structural corridor that hosts the Lutopan, Biga, and Carmen pits, along parallel faults. Most of these are within approximately $2 \mathrm{~km}$ of the areas of identified resources. These are active exploration areas (mapping, grid soil sampling) for the identification of drill targets. Bornite is present in a $4.5 \mathrm{~km}$ long by $1.5 \mathrm{~km}$ wide zone of hydrothermal alteration (biotite-quartz-sericite-clay) along a diorite contact at the Maypay porphyry copper-gold prospect, located $6 \mathrm{~km}$ north of the Carmen ore body (fig. I1). Structurally controlled, east-northeast-striking en echelon quartz veins in altered volcanic rocks may be the source of the artisanal gold mined in the Maypay area (Atlas Consolidated Mining and Development Corporation, 2012).

Other porphyry prospects on Cebu are based on wildcat drilling in the 1960s, mapping, and grid sampling in the West Lutopan area, but we do not have information on exact locations or the age of the mineralized intrusions. According 
to the Atlas Consolidated Mining and Development Corporation Web site (2012), separate, concealed porphyry copper targets are present $1 \mathrm{~km}$ south of the Biga ore body, $2 \mathrm{~km}$ south along the Biga Northeast Fault, $0.5 \mathrm{~km}$ and $1 \mathrm{~km}$ south of the Lutopan ore body, and $5 \mathrm{~km}$ west-northwest of the Lutopan ore body (see fig. I3 for the 1977-era locations of the historical pits and mapped faults). Based on spatial rules, these targets would all probably be considered as extensions of the identified resources. An approximate location for the Maypay prospect, which could represent a separate deposit, is plotted in figure I1.

\section{Exploration History}

Exploration activities on Cebu include two ongoing projects of the Atlas Consolidated Mining and Development Corporation (2012). One project is an assessment of mine waste dumps (1.2 billion metric tons) from 1955 to 1993 for copper recovery. Historical cutoff grades ( 0.5 and 0.3 percent copper) suggest that recoverable copper may be present in the piles. The second project is exploration of six partially explored prospects for extensions and satellites of the Lutopan, Carmen, and Biga resources.

\section{Sources of Information}

Principal sources of information used by the assessment team are listed in table I5. Descriptions of the rocks on Bohol and $\mathrm{Cebu}$, as described in the revised edition of the geology of the Philippines (Philippines Mines and Geosciences Bureau, 2010), also are available on the Region 7 Web site at http:// dvasia.ph/viewgeology.php?region=Region\%20VII.

\section{Grade and Tonnage Model Selection}

The Atlas and Balak deposits are copper-goldmolybdenum deposits. Statistical tests indicate that both global general and copper-gold subtypes are acceptable models for the simulation. No reliable average grades for molybdenum, gold, or silver are available for Balak; however, the reported drill intercepts indicate that both molybdenum and gold are present. Therefore, the general porphyry copper model of Singer and others (2008) was used for the simulation of undiscovered resources.

\section{Estimate of the Number of Undiscovered Deposits}

\section{Rationale for the Estimate}

The small size of the permissive tract area $\left(2,600 \mathrm{~km}^{2}\right)$ defined by the extent of onshore exposures of permissive rocks on islands limits the number of individual porphyry systems that could be present. The horst in central Cebu accommodated erosion that exposed the Atlas deposit; Cretaceous sedimentary rocks elsewhere in central Cebu can be as much as $2 \mathrm{~km}$ thick and may conceal buried deposits at depths greater than the 1-km depth adopted for the assessment. Based on assessment protocols, deposits that have overlapping alteration zones within $2 \mathrm{~km}$ of each other are grouped as a single deposit. Most of the known prospects on Cebu Island are likely to be extensions of the Atlas system. However, the team, considered the possibility of a discrete ore body on Cebu, as well as the area of permissive rock and prospects on

Table 14. Significant prospects and occurrences in tract 142pCu7306 Bohol-Cebu Area-Philippines.

[n.d., no data; \%, percent; g/t, grams per metric ton; $\mathrm{km}$, kilometers; $\mathrm{m}$, meters. Rank $2=$ drilled or trenched with $<20 \mathrm{~m}$ of $0.2 \% \mathrm{Cu}$, or past or ongoing exploration. Rank $1=$ copper occurrence that may be related to porphyry-type mineralization based on stream sediment or magnetic anomaly or location along structural trend]

\begin{tabular}{lcccccc}
\hline Name & Latitude & Longitude & Age & \multicolumn{1}{c}{ Comments } & Reference \\
\hline Bonakan & 10.117 & 124.183 & n.d. & $\begin{array}{l}\text { Bonakan Cu-Au prospect (1.02\% Cu, 4.18 g/t } \\
\text { Au); narrow gold-bearing veins in andesite. }\end{array}$ & $\begin{array}{l}\text { Philippine Mines and Geo- } \\
\text { sciences Bureau (2004b) }\end{array}$ & $\begin{array}{l}2 \\
\text { Cebu Island }\end{array}$ \\
\hline Maypay & 10.026 & 123.726 & n.d. & $\begin{array}{l}\text { Porphyry copper-gold prospect located } 6 \mathrm{~km} \\
\text { north of the Carmen pit of the Atlas Mine. } \\
\text { Chalcopyrite and bornite associated with }\end{array}$ & $\begin{array}{l}\text { Atlas Consolidated Mining } \\
\text { and Development Corpo- } \\
\text { ration (2012), Philippine } \\
\text { biotite-quartz-sericite-pyrite-clay alteration. }\end{array}$ & $\begin{array}{l}\text { Mines and Geosciences } \\
\text { Bureau (2004b) }\end{array}$ \\
\hline
\end{tabular}


Table 15. Principal sources of information used for tract 142pCu7306 Bohol-Cebu Area-Philippines.

[NA, not applicable]

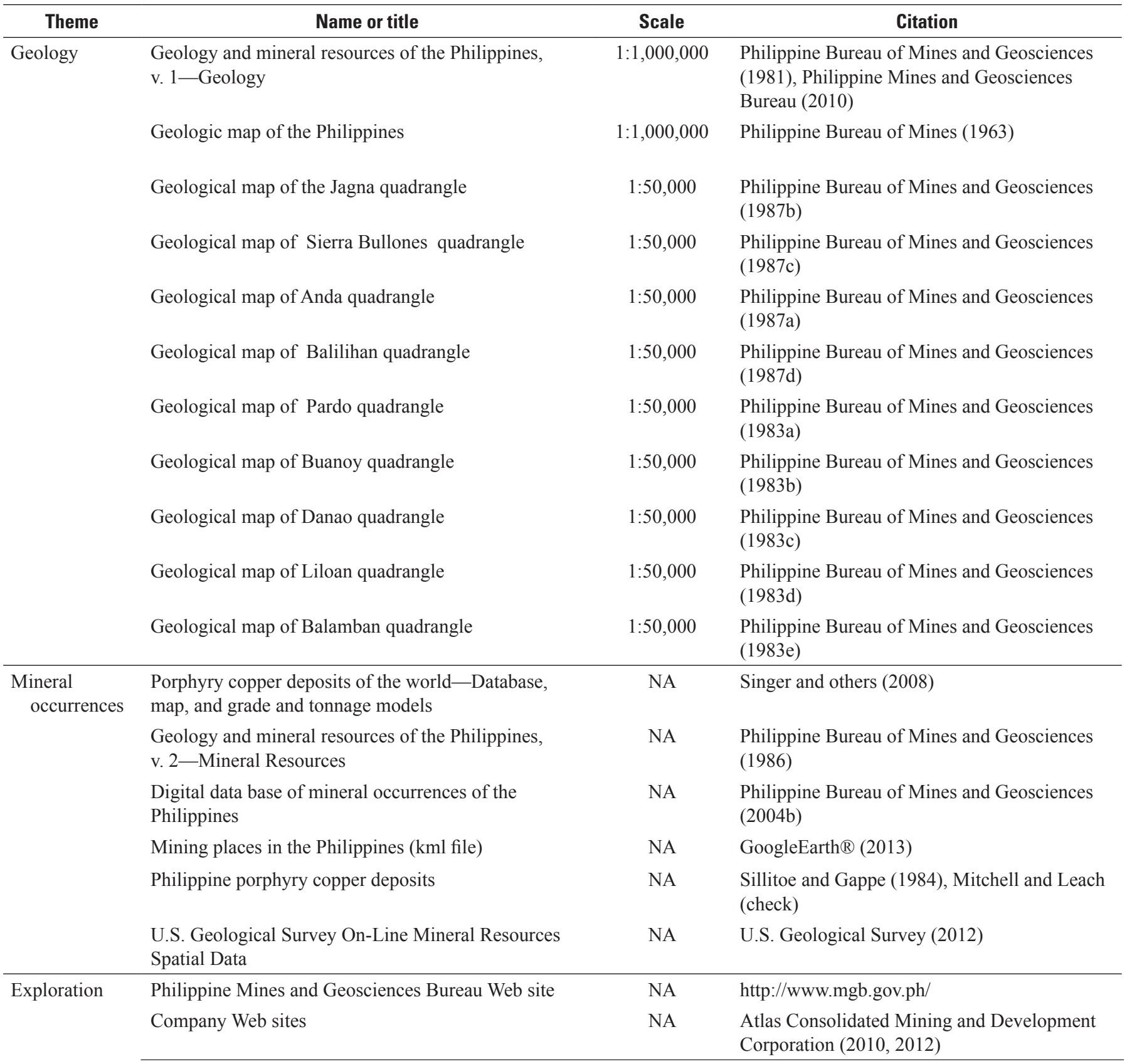


Bohol (table I4) and estimated a 50-percent chance of one or more undiscovered deposit within the Bohol-Cebu tract and a 10-percent chance of three or more deposits (table I6). This estimate results in a mean of 1.3 undiscovered deposits with a relatively high coefficient of variation (90 percent), reflecting a high degree of uncertainty.

\section{Probabilistic Assessment Simulation Results}

Undiscovered resources for the tract were estimated by combining the consensus estimate for numbers of undiscovered porphyry copper deposits with the global general porphyry copper model of Singer and others (2008) using the EMINERS program (Root and others, 1992; Duval, 2012; Bawiec and Spanski, 2012). Selected simulation results are reported in table I7. Results of the Monte Carlo simulation are presented as a cumulative frequency plot (fig. I4). The cumulative frequency plot shows the estimated resource amounts associated with cumulative probabilities of occurrence, as well as the mean, for each commodity and for total mineralized rock. Both the mean and the median predicted amounts of undiscovered copper within the tract are less than the identified resources at the two known deposits (table I1). See table 6 for comparisons with identified copper and gold resources and with other tracts.

Table I6. Undiscovered deposit estimates, deposit numbers, and tract area for tract 142pCu7306 Bohol-Cebu Area—Philippines.

$\left[N_{\mathrm{xx}}\right.$, estimated number of deposits associated with the xxth percentile; $N_{\text {und }}$, expected number of undiscovered deposits; $s$, standard deviation; $C_{v} \%$, coefficient of variance; $N_{\text {known }}$, number of known deposits in the tract that are included in the grade and tonnage model; $N_{\text {total }}$, total of expected number of deposits plus known deposits; area, area of permissive tract in square kilometers $\left(\mathrm{km}^{2}\right)$; density, deposit density reported as the total number of deposits per $100,000 \mathrm{~km}^{2} . N_{\text {und }}, s$, and $C_{v} \%$ are calculated using a regression equation (Singer and Menzie, 2005)]

\begin{tabular}{|c|c|c|c|c|c|c|c|c|c|c|c|}
\hline \multicolumn{5}{|c|}{ Consensus undiscovered deposit estimates } & \multicolumn{5}{|c|}{ Summary statistics } & \multirow{2}{*}{$\begin{array}{l}\text { Tract Area } \\
\quad\left(\mathbf{k m}^{2}\right)\end{array}$} & \multirow{2}{*}{$\begin{array}{c}\text { Deposit density } \\
\left(N_{\text {total }} / 100,000 \text { km² }^{2}\right)\end{array}$} \\
\hline$N_{90}$ & $N_{50}$ & $N_{10}$ & $N_{05}$ & $N_{01}$ & $N_{\text {und }}$ & $s$ & $C_{v} \%$ & $N_{\text {known }}$ & $N_{\text {total }}$ & & \\
\hline 0 & 1 & 3 & 3 & 3 & 1.3 & 1.2 & 90 & 2 & 3.3 & 2,600 & 127 \\
\hline
\end{tabular}

Table 17. Results of Monte Carlo simulation of undiscovered resources for tract 142pCu7306 Bohol-Cebu Area-Philippines.

[Cu, copper; Mo, molybdenum; Au, gold; and Ag, silver; in metric tons; Rock, in million metric tons]

\begin{tabular}{|c|c|c|c|c|c|c|c|c|}
\hline \multirow[b]{2}{*}{ Material } & \multicolumn{6}{|c|}{ Probability of at least the indicated amount } & \multicolumn{2}{|c|}{ Probability of } \\
\hline & 0.95 & 0.9 & 0.5 & 0.1 & 0.05 & Mean & $\begin{array}{l}\text { Mean or } \\
\text { greater }\end{array}$ & None \\
\hline Mo & 0 & 0 & 0 & 290,000 & 590,000 & 140,000 & 0.17 & 0.51 \\
\hline $\mathrm{Au}$ & 0 & 0 & 9 & 320 & 580 & 130 & 0.23 & 0.45 \\
\hline
\end{tabular}




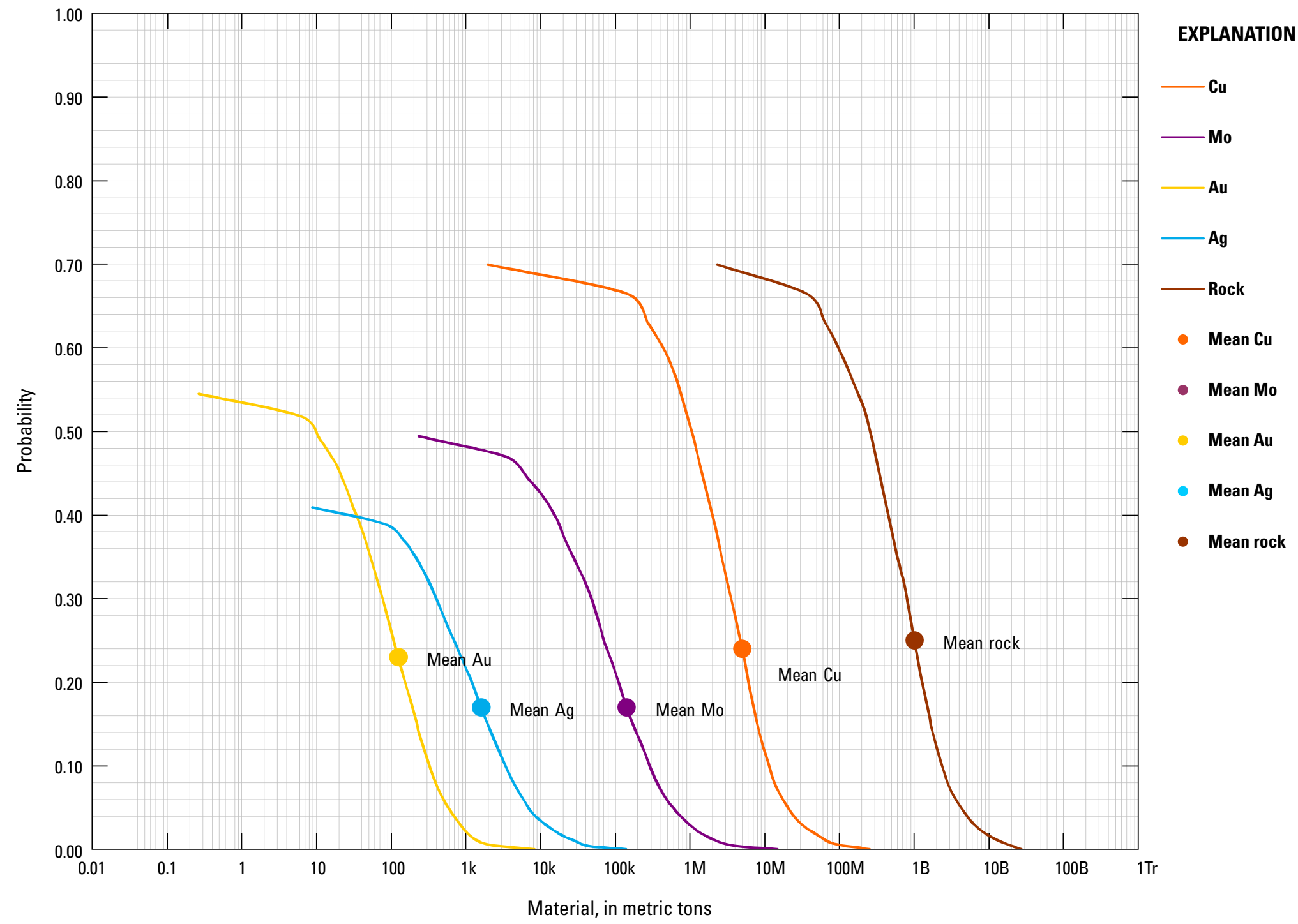

Figure 14. Cumulative frequency plot showing the results of Monte Carlo computer simulation of undiscovered resources in 142pCu7306, Bohol-Cebu Area, Philippines. k, thousands; M, millions; B, billions; Tr, trillions. 


\section{References Cited}

Arcilla, C.A., Harris, G.W., and Reyes, A.N., 1990, Goldbornite occurrence in an island arc porphyry copper deposit—The Carmen ore body, Cebu Philippines:presented at the submitted to 8th International Association on the Genesis of Ore Deposits (IAGOD) Symposium, Ottawa, Canada, $27 \mathrm{p}$.

Atlas Consolidated Mining and Development Corporation, 2010, Carmen Copper Project: Atlas Consolidated Mining and Development Corporation Web page, accessed March 1, 2010, at http://www.atlasphilippines.com/index. php?option $=$ com $\_$content\&task $=$view\&id $=34 \&$ Itemid $=49$.

Atlas Consolidated Mining and Development Corporation, 2012, Carmen Copper Corporation's Toledo Copper Mine: Atlas Consolidated Mining and Development Corporation Web page, accessed June 1, 2012, at http://atlasphilippines.com/.

Atlas Consolidated Mining and Development Corporation, 2013, Atlas Exploration projects: Atlas Consolidated Mining and Development Corporation Web site, accessed April 23, 2013, at http://www.atlasphilippines.com/projects/ atlas-exploration-projects.

Bawiec, W.J., and Spanski, G.T., 2012, Quick-start guide for version 3.0 of EMINERS-Economic Mineral Resource Simulator: U.S. Geological Survey Open-File Report 2009-1057, 26 p., accessed June 30, 2012, at http://pubs. usgs.gov/of/2009/1057/. (This report supplements USGS OFR 2004-1344.)

Berger, B.R., Ayuso, R.A., Wynn, J.C., and Seal, R.R., 2008, Preliminary model of porphyry copper deposits: U.S. Geological Survey Open-File Report 2008-1321, 55 p., accessed May 15, 2009, at http://pubs.usgs.gov/ of $/ 2008 / 1321 /$.

Clark, A.H., and Arancibia, O.N., 1996, The occurrence, paragenesis and implications of magnetite-rich alterationmineralization in calc-alkaline porphyry copper deposits, in Clark, A.H., ed., Giant ore deposits-II: Proceedings of the Second Giant Ore Deposits Workshop, Kingston, Ontario, Canada, p. 583-640.

Cox, D.P., 1986, Descriptive model of porphyry $\mathrm{Cu}$, in Cox, D.P., and Singer, D.A., eds., 1986, Mineral deposit models: U.S. Geological Survey Bulletin 1693, p. 76. (Also available at http://pubs.usgs.gov/bul/b1693/.)

Dimalanta, C.B., and Yumul, G.P., Jr., 2004, Crustal thickening in an active margin setting (Philippines)-The whys and the hows: Episodes, v. 27, no. 4, p. 260-264.

Divis, A.F., 1983, The geology and geochemistry of Philippine porphyry copper deposits, in Hayes, D.E., ed., The tectonic and geologic evolution of Southeast Asian Seas and Islands-Part 2: Washington, D.C., American Geophysical Union, p. 173-216.
Duval, J.S., 2012, Version 3.0 of EMINERS-Economic Mineral Resource Simulator: U.S. Geological Survey Open-File Report 2004-1344, accessed July 15, 2012, at http://pubs. usgs.gov/of/2004/1344/.

Garwin, S., Hall, R., and Watanabe, Y., 2005, Tectonic setting, geology, and gold and copper mineralization in Cenozoic magmatic arcs of southeast Asia and the west Pacific, in Hedenquist, T.W., Thompson, J.F.H., Goldfarb, R.J., and Richards, J.P., eds., One hundredth anniversary volume 1905-2005: Littleton, Colorado, Society of Economic Geologists, p. 891-930.

Hope, A.R., 1971, The application of results of geochemical prospecting to a porphyry copper/molybdenum property in the Philippines: 3rd Symposium on Mineral Resources Development, Manila, Nov. 1971, Section 1.

Hutchinson, C.S., 1996, South-East Asian oil, gas, coal and mineral deposits: Oxford, Clarendon Press, 265 p.

John, D.A., Ayuso, R.A., Barton, M.D., Blakely, R.J., Bodnar, R.J., Dilles, J.H., Gray, Floyd, Graybeal, F.T., Mars, J.C., McPhee, D.K., Seal, R.R., Taylor, R.D., and Vikre, P.G., 2010, Porphyry copper deposit model, chap. B of Mineral deposit models for resource assessment: U.S. Geological Survey Scientific Investigations Report 2010-5070-B, 169 p., accessed September 8, 2010, at http://pubs.usgs.gov/ sir/2010/5070/b/.

Kinkel, A.R., Santos-Yñigon, L.M., Sanmaniego, S., and Crispin, O., eds., 1956, Copper deposits of the Philippines: Manila, Philippines, Bureau of Mines of the Philippines, Special Project Series Publication no. 16-Copper, 305 p.

Madamba, F.A., 1972, Geology and mineralization of the Atlas copper deposits in Cebu island, Philippines: Journal of the Geological Society of the Philippines, v. 25, no. 2, p. 13-19.

Malaihollo, J.F.A., Hall, R., and Macpherson, C.G., 2002, SE Asia Radiometric ages - GIS database: Southeast Asia Research Group, Department of Earth Sciences, Royal Holloway University of London, accessed February 1, 2010, at http://searg.rhul.ac.uk/current_research/isotopic_ages/ SEAsia_GIS.pdf.

Mitchell, A.H.G, and Leach, T.M., 1991, Epithermal gold in the Philippines-Island arc metallogenesis, geothermal systems and geology: London, Academic Press, 457 p.

Motegi, M., 1977, Porphyry copper deposits in PhilippinesTheir tectonic setting and present status of development: Mining Geology, v. 27, p. 221-230.

Philippine Bureau of Mines, 1963, Geological map of the Philippines: Philippine Bureau of Mines, 1 map on 8 sheets, scale $1: 1,000,000$.

Philippine Bureau of Mines and Geosciences, 1981, Geology and mineral resources of the Philippines, v. 1-Geology: Philippine Bureau of Mines and Geosciences, $406 \mathrm{p}$. 
Philippine Bureau of Mines and Geosciences, 1983a, Geological map of Pardo quadrangle: Philippine Bureau of Mines and Geosciences, map 3750-4, scale 1:50,000.

Philippine Bureau of Mines and Geosciences, 1983b, Geological map of Buanoy quadrangle: Philippine Bureau of Mines and Geosciences, map 3751-3, scale 1:50,000.

Philippine Bureau of Mines and Geosciences, 1983c, Geological map of Danao quadrangle: Philippine Bureau of Mines and Geosciences, map 3851-4, scale 1:50,000.

Philippine Bureau of Mines and Geosciences, 1983d, Geological map of Liloan quadrangle: Philippine Bureau of Mines and Geosciences, map 3750-4, scale 1:50,000.

Philippine Bureau of Mines and Geosciences, 1983e, Geological map of Balamban quadrangle: Philippine Bureau of Mines and Geosciences, map 3751-1, scale 1:50,000.

Philippine Bureau of Mines and Geosciences, 1986, Geology and mineral resources of the Philippines, v. 2-Mineral Resources: Philippine Bureau of Mines and Geosciences, $446 \mathrm{p}$.

Philippine Bureau of Mines and Geosciences, 1987a, Geological map of Anda quadrangle: Philippine Bureau of Mines and Geosciences, map 3849-2, scale 1:50,000.

Philippine Bureau of Mines and Geosciences, 1987b, Geological map of Jagna quadrangle: Philippine Bureau of Mines and Geosciences, map 3848-4, scale 1:50,000.

Philippine Bureau of Mines and Geosciences, 1987c, Geological map of Sierra Bullones quadrangle: Philippine Bureau of Mines and Geosciences, map 3849-3, scale 1:50,000.

Philippine Bureau of Mines and Geosciences, 1987d, Geological map of Balilihan quadrangle: Philippine Bureau of Mines and Geosciences, map 3749-2, scale 1:50,000.

Philippine Geological Survey Division, 1964, Mineral distribution map of the Philippines-Base metals: Philippine Geological Survey Division, sheet 2 of 6 maps, scale $1: 2,500,000$.

Philippine Mines and Geosciences Bureau, [n.d.], Geology and mineral distribution map of the Philippines: Philippine Mines and Geosciences Bureau, 1 map on 4 sheets, scale 1:1,400,000.

Philippine Mines and Geosciences Bureau, 2004a, Digital geological map of the Philippines: Philippine Mines and Geosciences Bureau, scale 1:1,000,000. [Proprietary data.]

Philippine Mines and Geosciences Bureau, 2004b, Digital database of mineral occurrences of the Philippines: Philippine Mines and Geosciences Bureau. [Proprietary report.]
Philippine Mines and Geosciences Bureau, 2010, Geology of the Philippines (2nd ed.): Philippine Mines and Geosciences Bureau, $532 \mathrm{p}$.

Reyes, A.N., Cinco, J.C., Jr., Guardiario, J.D.A., Jr., 1985, Geology of the Atlas porphyry copper district, Cebu, Philippines: Asian Mining '85, Manila, p. 79-90.

Root, D.H., Menzie, W.D., and Scott, W.A., 1992, Computer Monte Carlo simulation in quantitative resource estimation: Natural Resources Research, v. 1, no. 2, p. 125-138.

Sillitoe, R.H., and Gappe, I.M., Jr., 1984, Philippine porphyry copper deposits-Geologic setting and characteristics: Committee for Co-ordination of Joint Prospecting for Mineral Resources in Asian Offshore Areas (CCOP), CCOP Technical Publication 14, 89 p.

Singer, D.A., and Menzie, W.D., 2005, Statistical guides to estimating the number of undiscovered mineral depositsAn example with porphyry copper deposits, in Cheng, Qiuming, and Bonham-Carter, Graeme, eds., Proceedings of IAMG-The annual conference of the International Association for Mathematical Geology: Toronto, Canada, York University, Geomatics Research Laboratory, p. 1028-1033.

Singer, D.A., Berger, V.I., and Moring, B.C., 2008, Porphyry copper deposits of the World-Database and grade and tonnage models, 2008: U.S. Geological Survey Open-File Report 2008-1155, accessed June 1, 2011, at http://pubs. usgs.gov/of/2008/1155/.

U.S. Department of State, 2009, Small-scale digital international land boundaries (SSIB) - Lines, edition 10, and polygons, beta edition 1, in Boundaries and sovereignty encyclopedia (B.A.S.E.): U.S. Department of State, Office of the Geographer and Global Issues.

U.S. Geological Survey, 2012, On-line mineral resources spatial data: U.S. Geological Survey Web site, accessed February 10, 2012, at http://mrdata.usgs.gov/.

Walther, H.W., Förster, H., Harre, W., Kreuzer, H., Lenz, H., Müller, P., and Raschka, H., 1981, Early Cretaceous porphyry copper mineralization on Cebu Island, Philippines, dated with $\mathrm{K}-\mathrm{Ar}$ and $\mathrm{Rb}-\mathrm{Sr}$ methods: Geologische Jahrbuch, Reihe D, Hf. 48, p. 21-35.

Wolfe, J.A., 1973, Interpretation of potassium argon dates in the Philippines: The Mines Magazine, no. 63, p. 25-28.

Yumul, G.P., Jr., Dimalanta, C.B., Maglambayan, V.B., and Tamayo, R.A., Jr., 2003, Mineralization controls in island arc settings-Insights from Philippine metallic deposits: Gondwana Research, v. 6, no. 4, p. 767-776. 
This page left intentionally blank. 


\section{Appendix J. Porphyry Copper Assessment for Tract 142pCu7301, Luzon Arc-Philippines and Taiwan (Republic of China)}

By Jane M. Hammarstrom ', Arthur A. Bookstrom², Connie L. Dicken', Steve Ludington³, Gilpin R. Robinson, Jr.', and Michael L. Zientek ${ }^{2}$ with contributions from Sevillo (Bill) D. David, Jr., Claro J. Manipon ${ }^{4}$, Lilian A. Rollan ${ }^{4}$, and Yasushi Watanabe ${ }^{5}$

\section{Deposit Type Assessed: Porphyry copper, copper-gold subtype}

Descriptive model: Porphyry copper (Cox, 1986; Berger and others, 2008; John and others, 2010; Sillitoe and Gappe, 1984) Grade and tonnage model: Porphyry copper, copper-gold subtype (Singer and others, 2008)

Table J1 summarizes selected assessment results.

Table J1. Summary of selected resource assessment results for tract 142pCu7301, Luzon Arc_-Philippines and Taiwan (Republic of China).

[km, kilometers; $\mathrm{km}^{2}$, square kilometers; t, metric tons; identified resources rounded to two significant figures]

\begin{tabular}{|c|c|c|c|c|c|c|}
\hline $\begin{array}{c}\text { Date of } \\
\text { assessment }\end{array}$ & $\begin{array}{l}\text { Assessment } \\
\text { depth }(\mathrm{km})\end{array}$ & Tract segment & Tract area $\left(\mathbf{k m}^{2}\right)$ & $\begin{array}{l}\text { Identified } \\
\text { copper } \\
\text { resources }(t)\end{array}$ & $\begin{array}{l}\text { Mean estimate of } \\
\text { undiscovered copper } \\
\text { resources }(t)\end{array}$ & $\begin{array}{l}\text { Median estimate of } \\
\text { undiscovered copper } \\
\text { resources }(t)\end{array}$ \\
\hline \multirow[t]{5}{*}{2010} & 1 & $\begin{array}{l}\text { (a) Northern } \\
\text { (Taiwan) }\end{array}$ & 1,058 & 0 & $31,000,000$ & $22,000,000$ \\
\hline & & $\begin{array}{l}\text { (b) Luzon Central } \\
\text { Cordillera }\end{array}$ & 15,970 & $12,000,000$ & & \\
\hline & & (c) Western Luzon & 6,071 & $5,100,000$ & & \\
\hline & & (d) Eastern Luzon & 599 & 0 & & \\
\hline & & Total & 23,700 & $17,000,000$ & $31,000,000$ & $22,000,000$ \\
\hline
\end{tabular}

\section{Location}

The tract extends for approximately 1,200 km from western Luzon Island in the Philippines to southeastern Taiwan (Republic of China) (fig. J1).

\section{Geologic Feature Assessed}

Oligocene to Holocene Luzon Arc.

\footnotetext{
${ }^{1}$ U.S. Geological Survey, Reston, Virginia, United States.

${ }^{2}$ U.S. Geological Survey, Spokane, Washington, United States.

${ }^{3}$ U.S. Geological Survey, Menlo Park, California, United States.

${ }^{4}$ Philippine Department of Environment and Natural Resources, Mines and Geosciences Bureau, Quezon City, Philippines.

${ }^{5}$ Geological Survey of Japan, National Institute of Advanced Industrial Science and Technology (AIST), Ibaraki, Japan.
} 
A

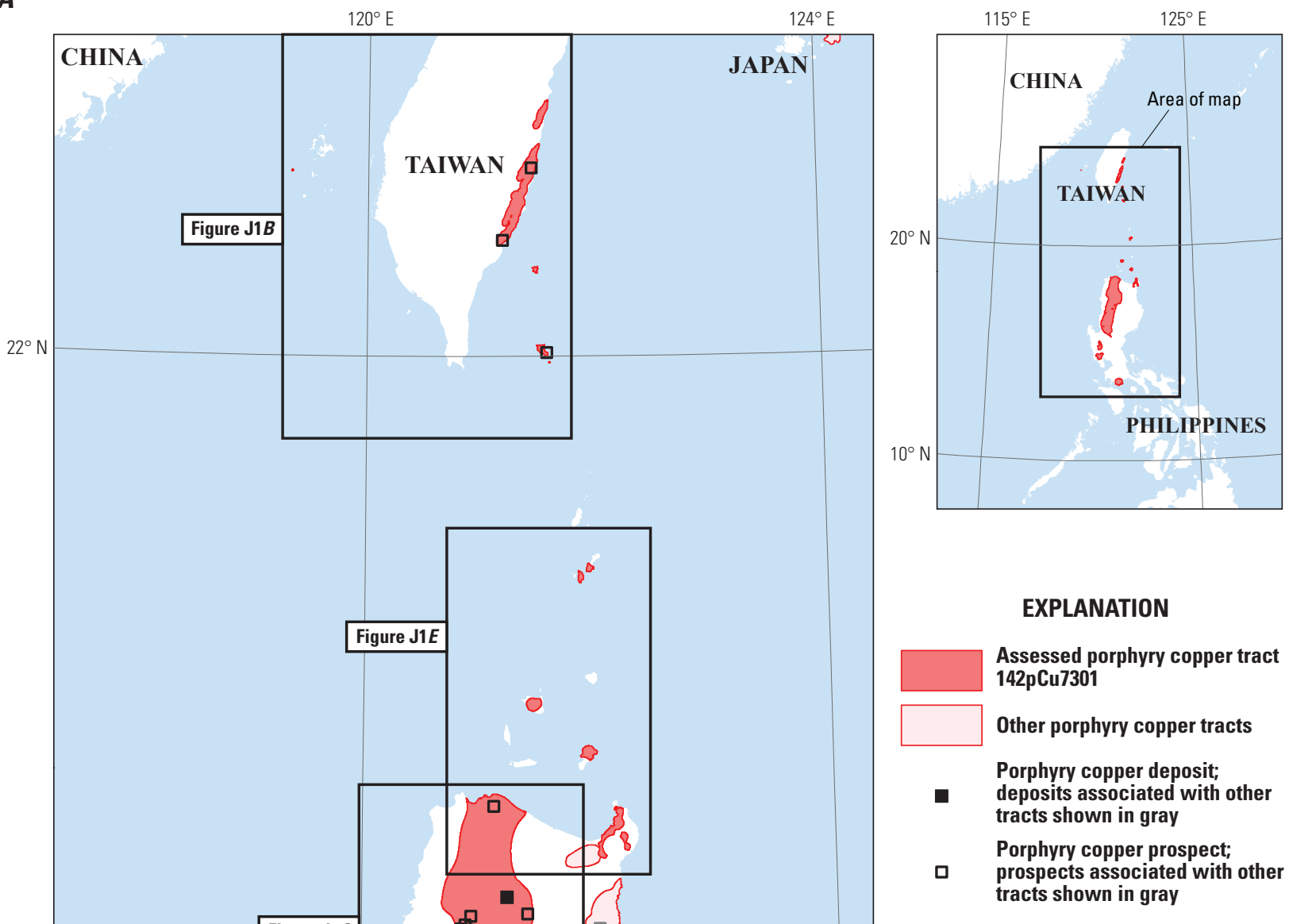

PHILIPPINES

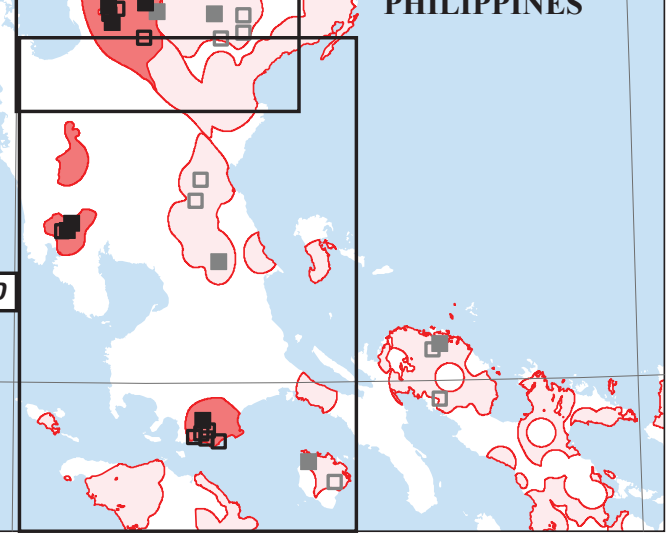

Political boundaries from U.S. Department of State (2009)

Asia North Albers Equal Area Conic Projection.

Central meridian, $121^{\circ} \mathrm{E}$., latitude of origin, $30^{\circ} \mathrm{N}$

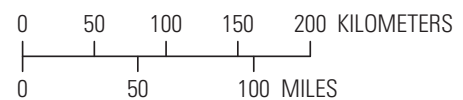

Figure J1. Maps showing tract location, deposits, and significant prospects for tract 142pCu7301, Luzon ArcPhilippines and Taiwan (Republic of China). A, Overview. B, Taiwan segment. C, Luzon Central Cordillera segment. $D$, Western segment. E, Eastern segment. TW, Taiwan (Republic of China). 
B

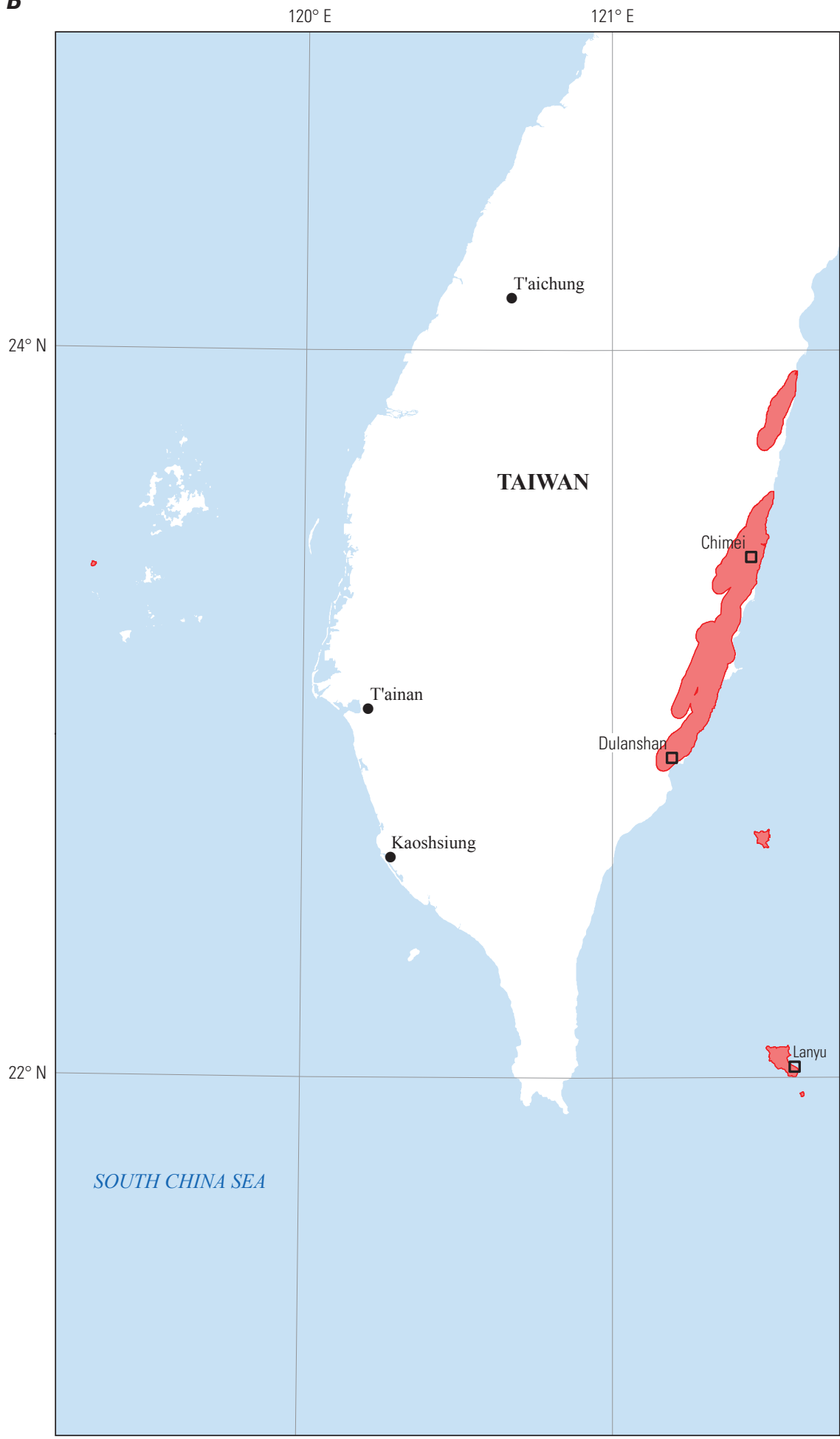

Political boundaries from U.S. Department of State (2009).

Asia North Albers Equal Area Conic Projection.

Central meridian, $121^{\circ} \mathrm{E}$., latitude of origin, $30^{\circ} \mathrm{N}$.

Figure J1.-Continued

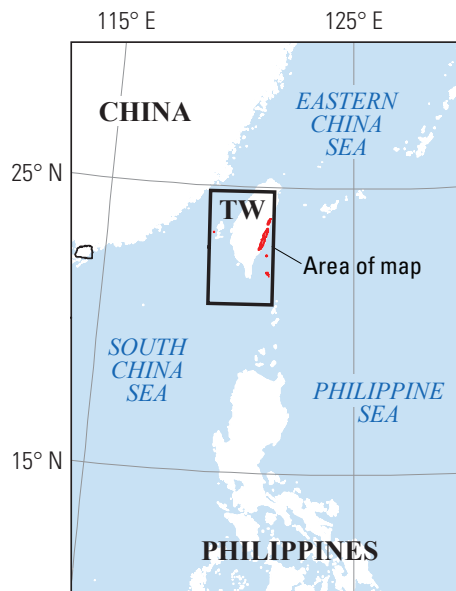

\section{EXPLANATION}

Assessed porphyry coppe tract 142pCu7301 (Taiwan segment) 
C

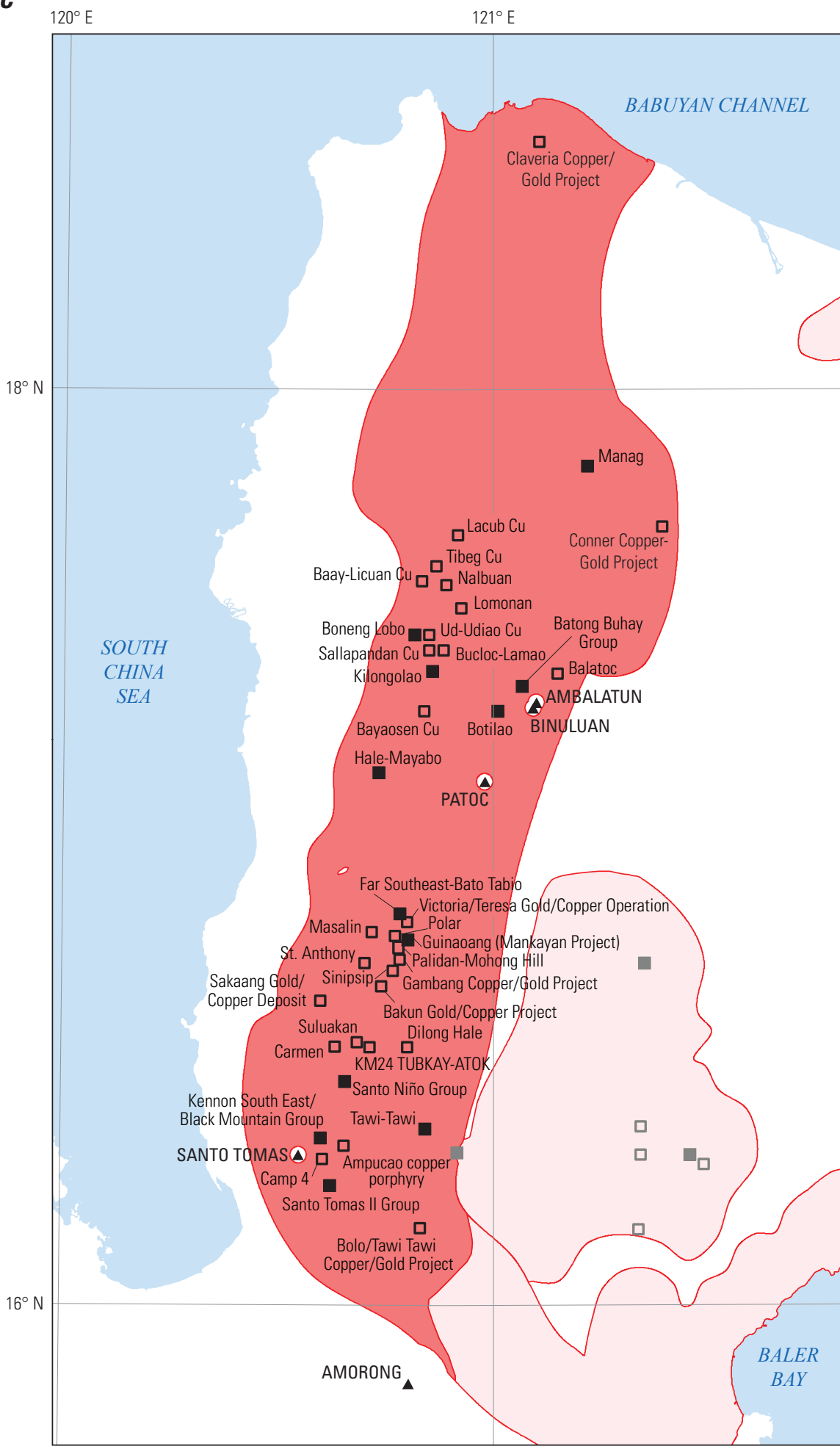

Political boundaries from U.S. Department of State (2009) Asia North Albers Equal Area Conic Projection.

Central meridian, $121^{\circ} \mathrm{E}$., latitude of origin, $30^{\circ} \mathrm{N}$

Figure J1.-Continued

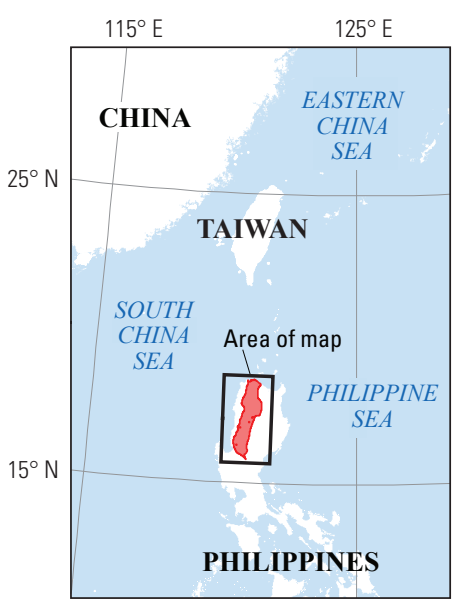

\section{EXPLANATION}

Assessed porphyry copper tract 142pCu7301 (Luzon Central Cordillera segment) Other porphyry copper tracts

Porphyry copper deposit; deposits associated with other tracts shown in gray

Porphyry copper prospect; prospects associated with other tracts shown in gray

- Volcano 
D
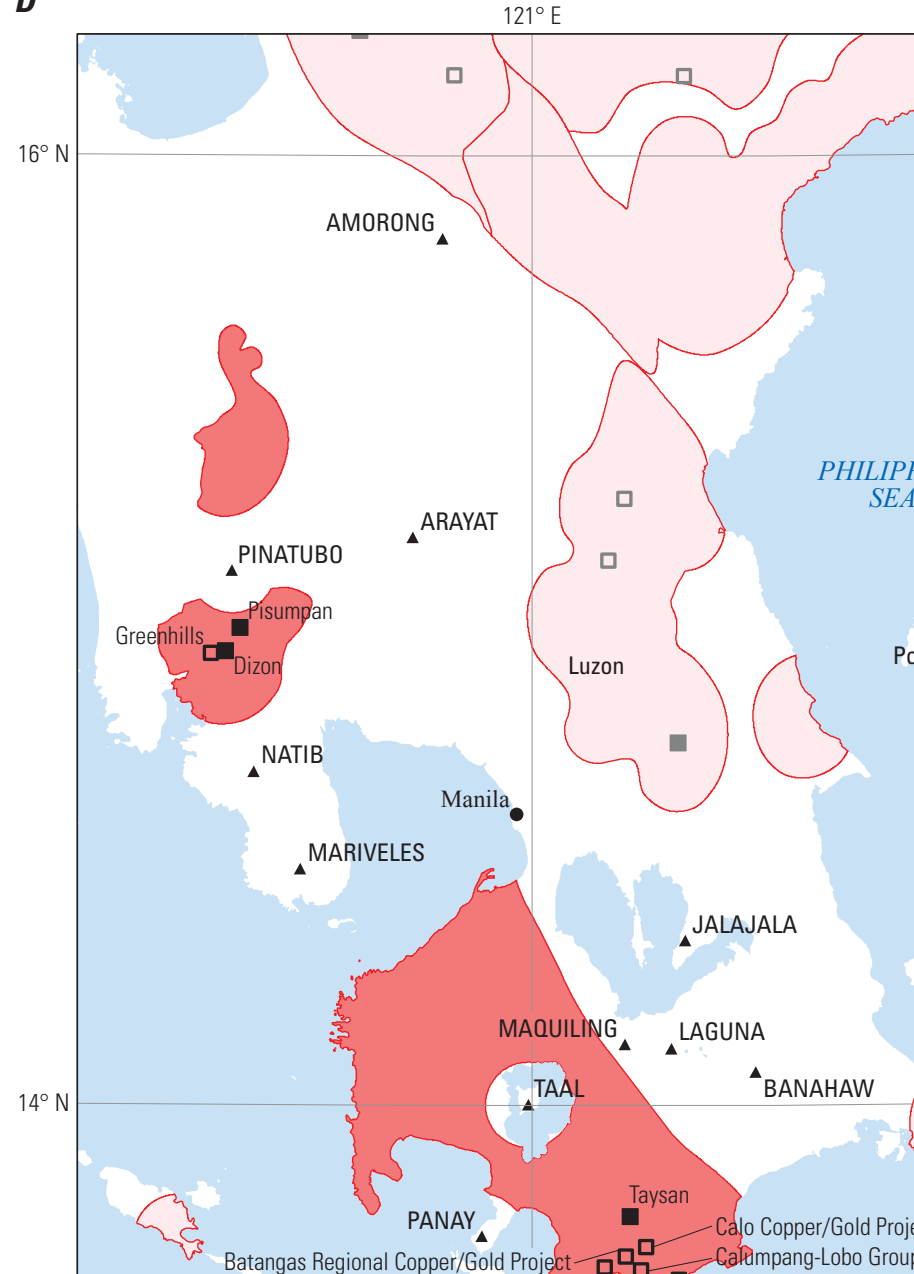

Batangas Regional Copper/Gold Project

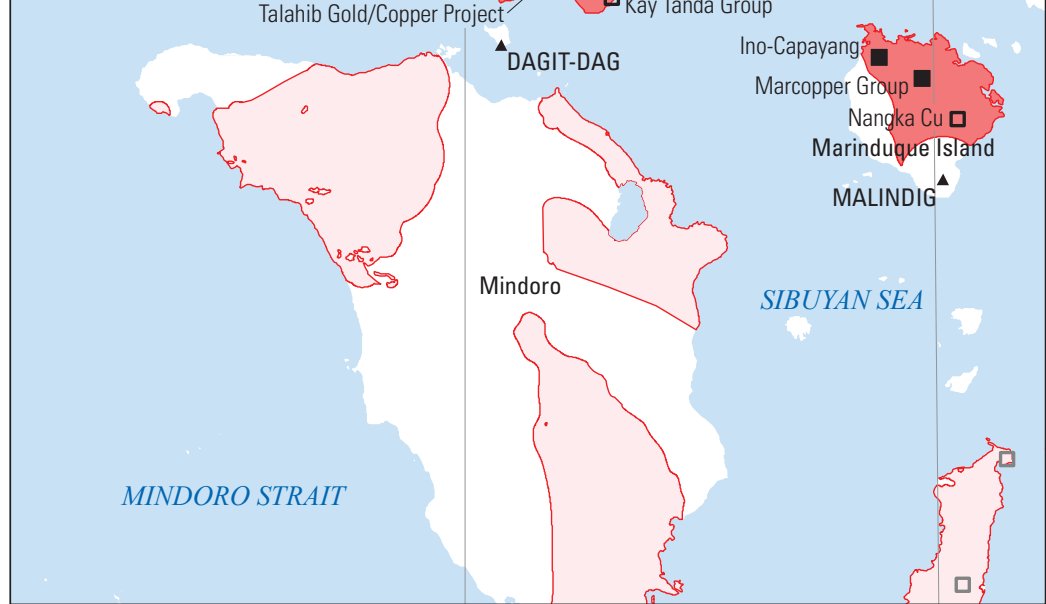

Political boundaries from U.S. Department of State (2009) Asia North Albers Equal Area Conic Projection. Central meridian, $121^{\circ} \mathrm{E}$., latitude of origin, $30^{\circ} \mathrm{N}$

Figure J1.-Continued

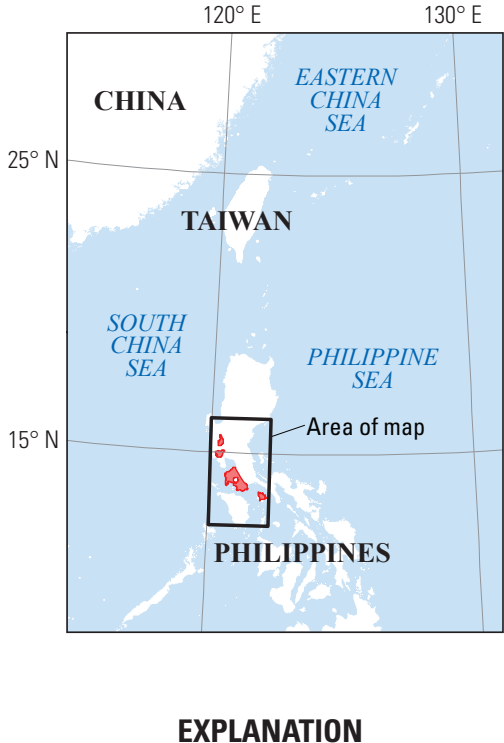

Assessed porphyry copper tract 142pCu7301 (Western Luzon segment)

Other porphyry copper tracts

Porphyry copper deposit; deposits associated with other tracts shown in gray

Porphyry copper prospect;

prospects associated with other tracts shown in gray

Volcano 
$\boldsymbol{E}$
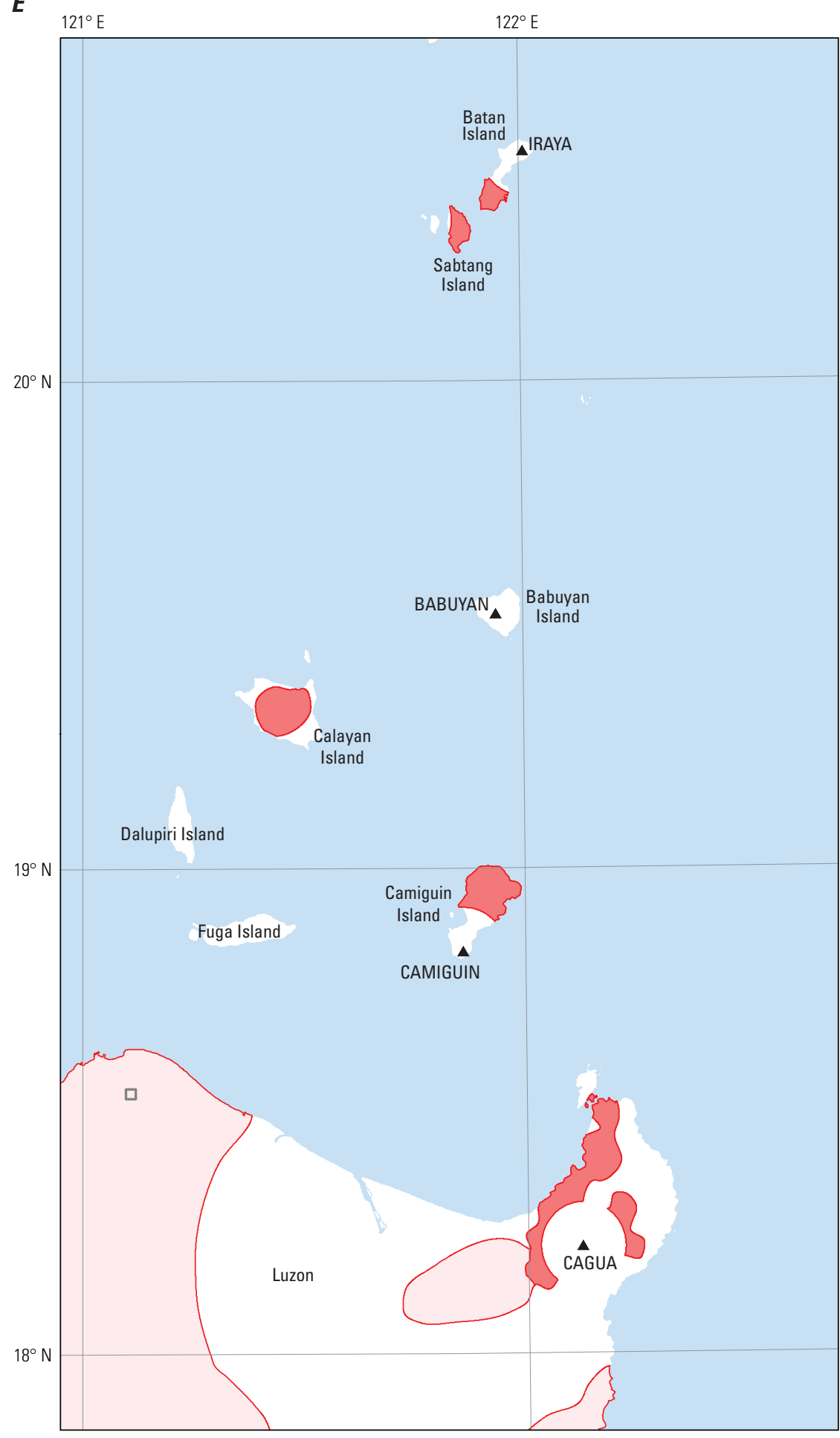

Political boundaries from U.S. Department of State (2009). Asia North Albers Equal Area Conic Projection. Central meridian, $121^{\circ} \mathrm{E}$., latitude of origin, $30^{\circ} \mathrm{N}$

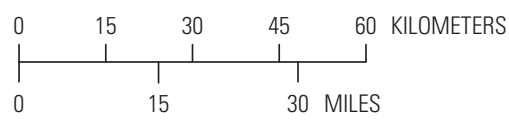

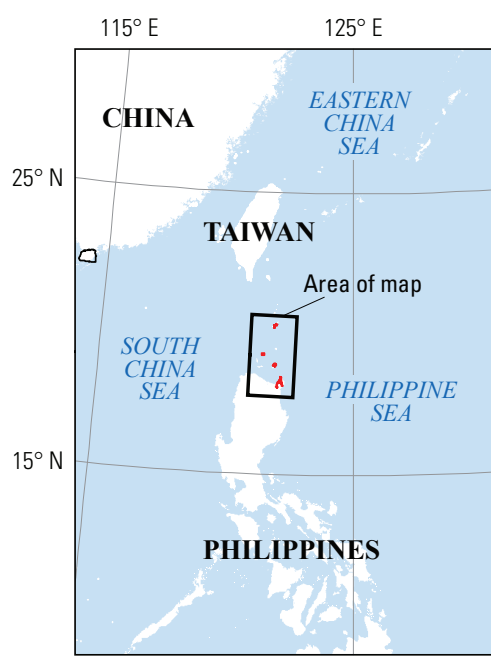

\section{EXPLANATION}

Assessed porphyry copper tract 142pCu7301 (Eastern Luzon segment)

Other porphyry copper tracts

Porphyry copper prospect associated with other

- Volcano

Figure J1.-Continued 


\section{Delineation of the Permissive Tract}

\section{Tectonic Setting}

The Neogene Luzon Arc is a composite arc system extending from Marinduque Island through western Luzon Island in the Philippines to the Coastal Range of eastern Taiwan (fig. $4 A^{6}$ ). The arc became active in the early Miocene and is now underlain by an east-dipping Benioff zone related to the Manila Trench. In northern Luzon, an early to middle Miocene reversal in arc polarity may have shifted the locus of arc activity from east to west as the geodynamics switched from subduction of the proto-Philippine Sea Plate along the proto-East Luzon Trough to subduction of the South China Sea Plate along the Manila Trench (fig. 7) (Yumul and others, 2008a; Bautista and others, 2001). The 900-km-long Manila Trench marks Plio-Pleistocene eastward subduction of the South China Sea ocean basin on the Eurasian Plate beneath the Luzon Arc of the Philippine Mobile Belt. The Manila Trench trends approximately north-south from the Taiwan collision zone to Mindoro in the south, where the Palawan block collides with southwestern Luzon Island (figs. 5B, 7). Subduction of the Scarborough Seamounts (the aseismic mid-ocean ridge of the South China Sea) at 5-4 Ma may have caused a change in subduction angle (buoyancy) that interrupted subduction, caused regional uplift and erosion, and led to a gap in magmatic activity expressed as an approximately $50-\mathrm{km}$-wide gap between the western and eastern volcanic zones of the double island arc between Luzon and Taiwan to the north.

The Luzon Arc represents a chain of stratovolcanoes and volcanic necks that erupted tholeiitic, calc-alkalic to shoshonitic, and adakitic rocks (Yumul and others, 2008b). The oldest rocks associated with the Luzon Arc are 30-9 Ma igneous rocks on Taiwan and Miocene rocks in the Baguio mineral district (fig. $4 B$ ) on northern Luzon.
The four Luzon Arc segments are based on arc segments described by Yang and others (1996) and Garwin and others (2005) - Taiwan, Luzon Central Cordillera, Western Luzon, and Eastern Luzon. The Eastern Luzon Arc segment was excluded from the probabilistic assessment of undiscovered porphyry copper resources; this arc segment is considered to be too volcanically active to be permissive for porphyry copper deposits within $1 \mathrm{~km}$ of the surface.

\section{Geologic Criteria}

The permissive tracts were constructed by selecting igneous rocks from a digital version of the 1:1,000,000-scale geologic map of the Philippines (Philippine Bureau of Mines and Geosciences, 2004a) and the 1:500,000-scale digital geologic map of Taiwan (Ministry of Economic Affairs, 2006). The map units were classified by age groups, and subdivided into intrusive and volcanic rocks. Permissive rocks used to delineate the tract are shown in figure $\mathrm{J} 2$ and listed in table $\mathrm{J} 2$. A $10-\mathrm{km}$ buffer was created around intrusive rocks, and a 2-km buffer was created around volcanic rocks. These distances are considered appropriate to allow for inaccuracies in mapped contacts and extensions under adjacent cover rock. The buffered map unit polygons were aggregated, smoothed, and edited by hand to honor fault boundaries and include known but unmapped permissive igneous rocks and prospects. Site locations for dated and classified igneous rocks were also used to constrain tract boundaries (Malaihollo and others, 2002). The final tract segments were clipped to coastlines (U.S. Department of State, 2009).

In some areas, the 1:50,000-scale geological maps of the Philippines were scanned and georectified to check the tract areas that were developed using the smaller scale digital map. Larger scale geologic maps are available in topical studies, such as a geologic map of the Baguio district (Waters and others, 2011), and on some Web sites for exploration project areas (RoyalCo Resources, Ltd., 2010). 
A

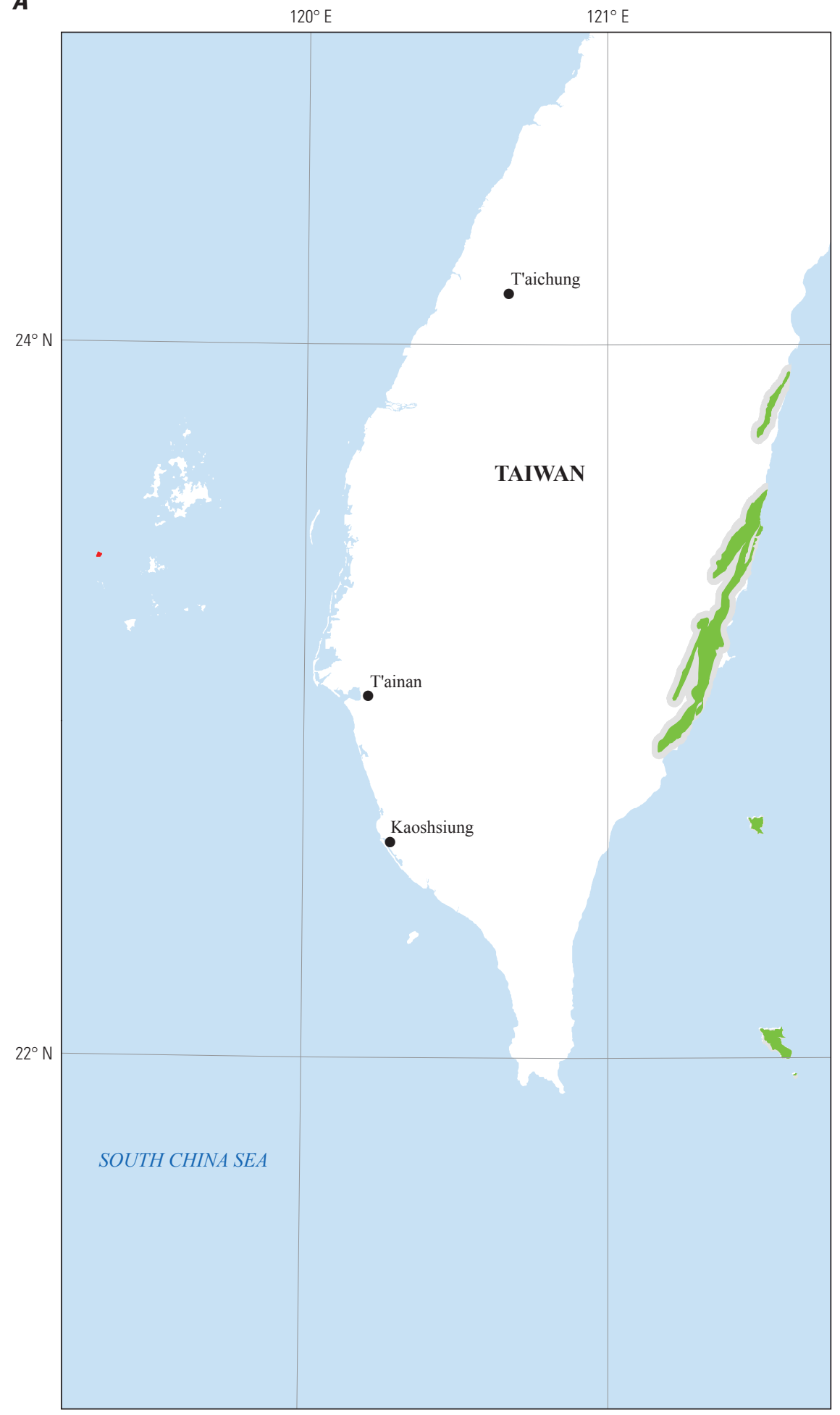

Political boundaries from U.S. Department of State (2009)

Asia North Albers Equal Area Conic Projection.

Central meridian, $121^{\circ} \mathrm{E}$., latitude of origin, $30^{\circ} \mathrm{N}$

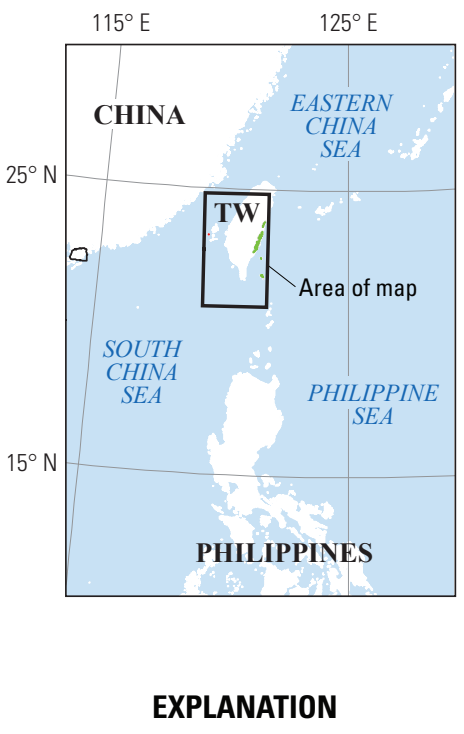

Assessed porphyry copper tract 142pCu7301 (Taiwan segment)

Permissive intrusive rock

Permissive volcanic rock

Figure J2. Map showing the distribution of permissive igneous rocks for tract 142pCu7301, Luzon Arc, the Philippines and Taiwan (Republic of China). A, Taiwan segment. $B$, Luzon Central Cordillera segment. $C$, Western segment. $D$, Eastern segment. TW, Taiwan (Republic of China). 
B

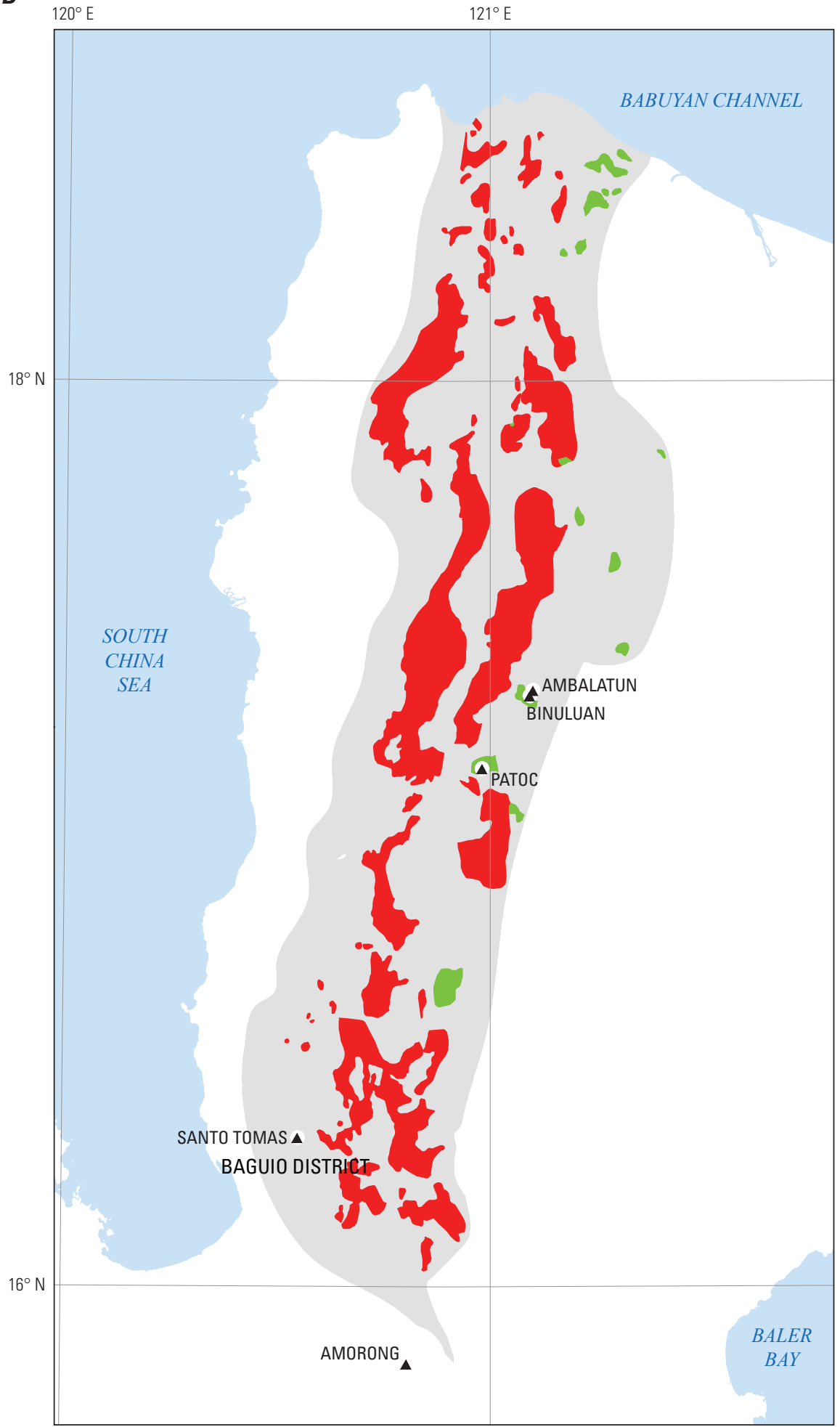

Political boundaries from U.S. Department of State (2009). Asia North Albers Equal Area Conic Projection. Central meridian, $121^{\circ} \mathrm{E}$., latitude of origin, $30^{\circ} \mathrm{N}$.

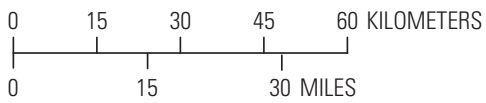

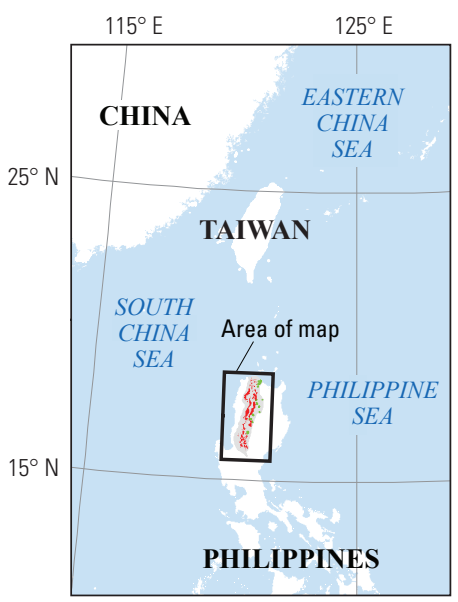

\section{EXPLANATION}

Assessed porphyry copper tract 142pCu7301 (Luzon Central Cordillera segment)

Permissive intrusive rock

\section{Permissive volcanic rock}

$\Delta \quad$ Volcano

Figure J2.-Continued 
C

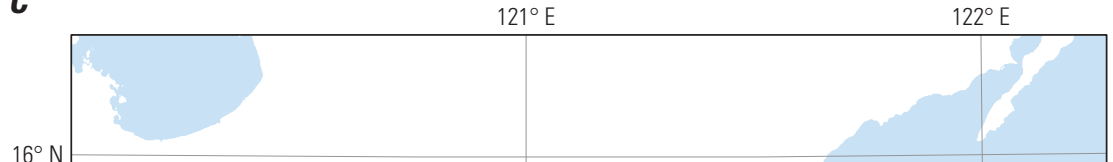

$16^{\circ} \mathrm{N} \quad$ AMORONG

3

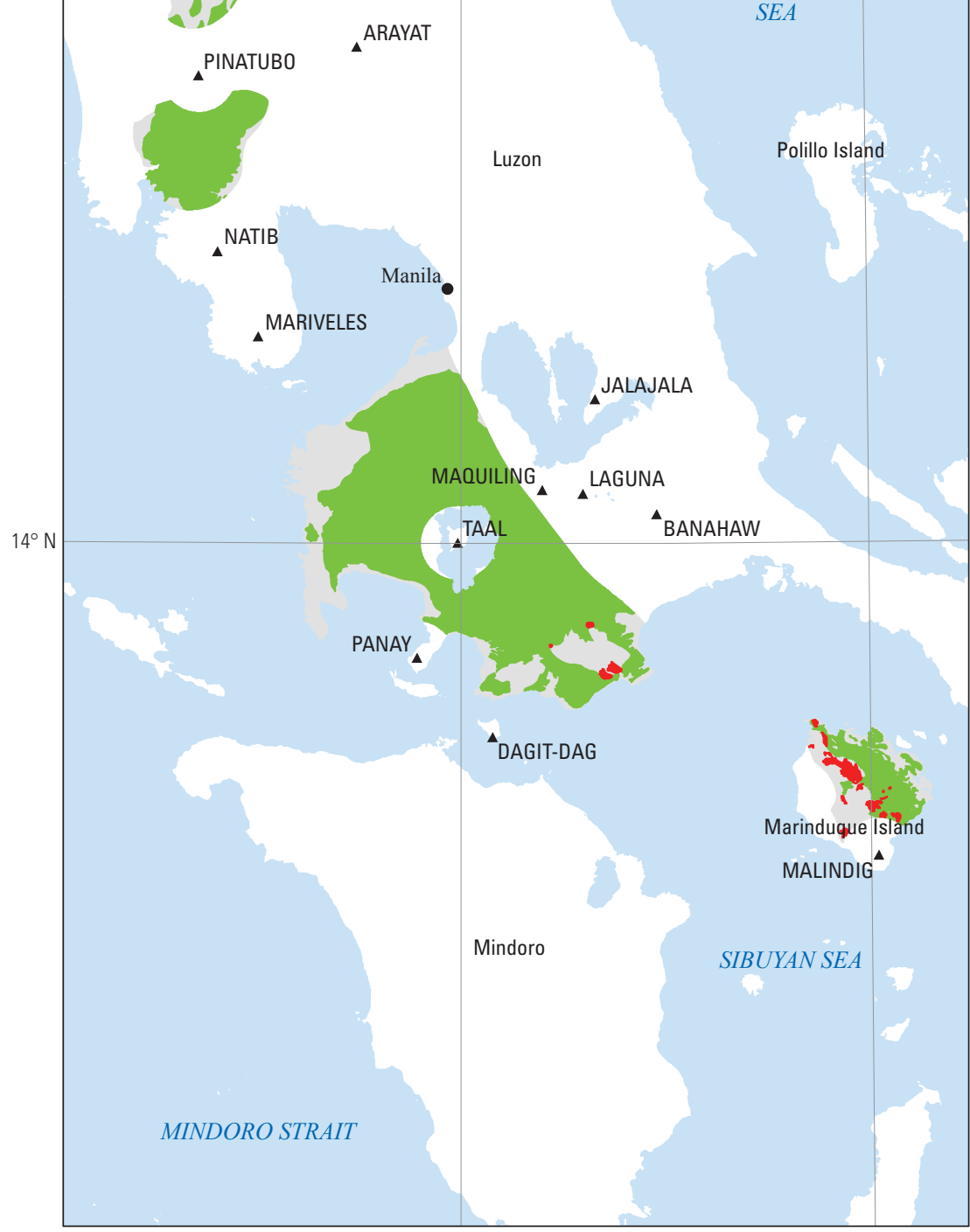

Political boundaries from U.S. Department of State (2009). Asia North Albers Equal Area Conic Projection.

Central meridian, $121^{\circ} \mathrm{E}$., latitude of origin, $30^{\circ} \mathrm{N}$.

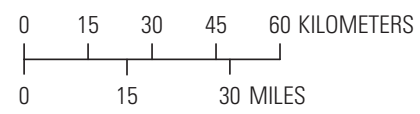

Figure J2.-Continued

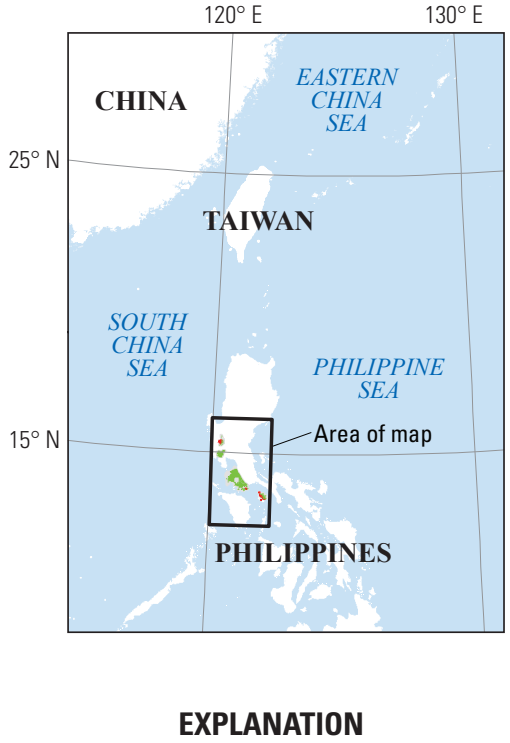

Assessed porphyry copper tract 142pCu7301 (Western Luzon segment)

Permissive intrusive rock

Permissive volcanic rock

- Volcano 
D

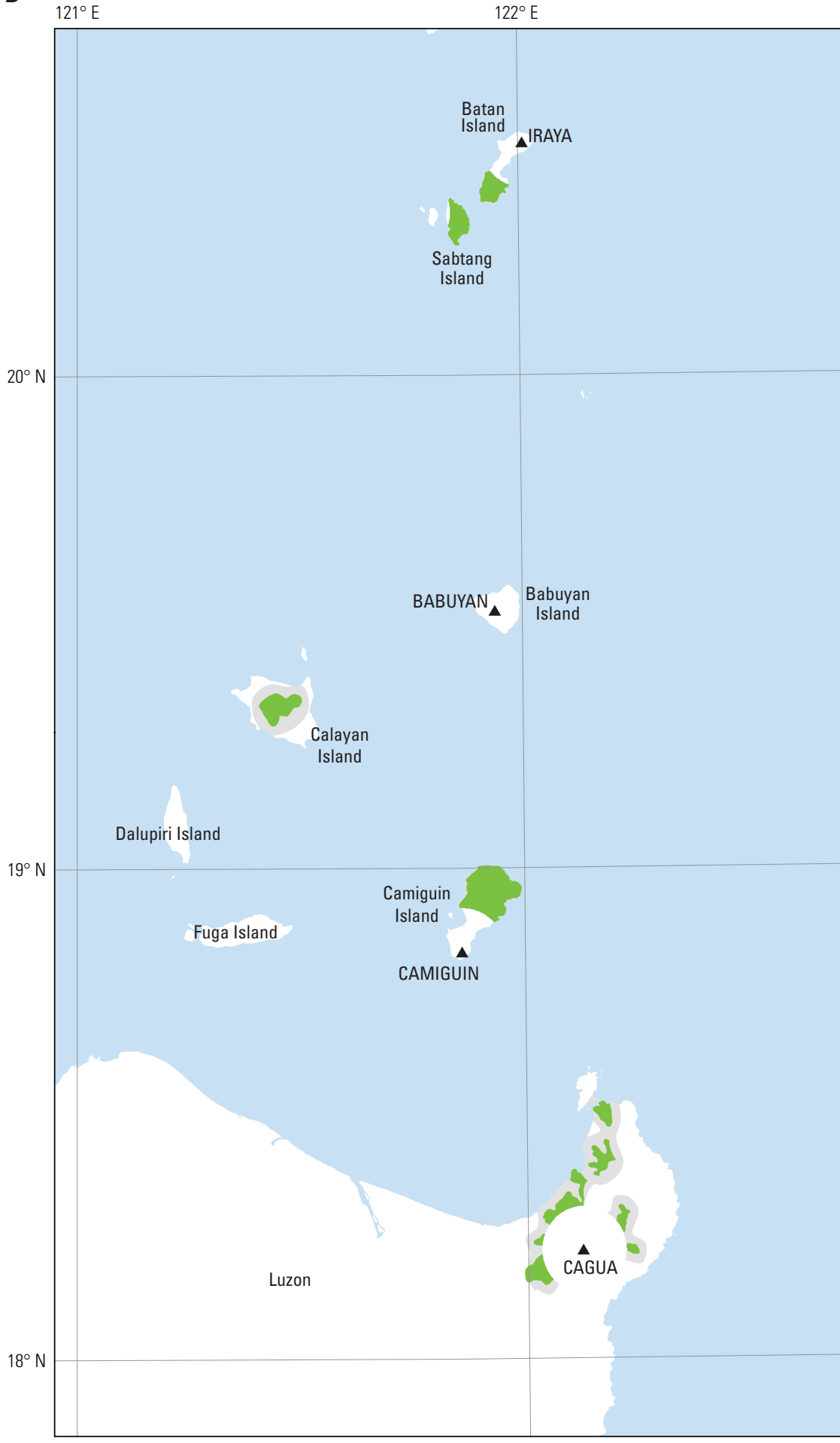

Political boundaries from U.S. Department of State (2009).

Asia North Albers Equal Area Conic Projection.

Central meridian, $121^{\circ} \mathrm{E}$., latitude of origin, $30^{\circ} \mathrm{N}$

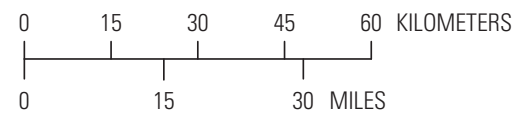

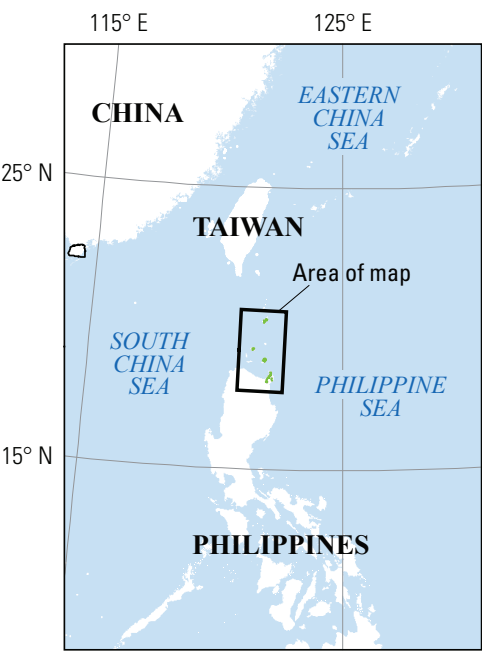

EXPLANATION

Assessed porphyry copper tract 142pCu7301 (Eastern Luzon segment)

Permissive volcanic rock

- Volcano

Figure J2.-Continued 
Table J2. Map units that define tract 142pCu7301, Luzon Arc_-Philippines and Taiwan (Republic of China).

[Map unit, age range, and principal lithologies are based on a digital version of the 1:1,000,000-scale geologic map of the Philippines (Philippine Bureau of Mines, 1963) and the 1:500,000-scale map of Taiwan. NA, not applicable]

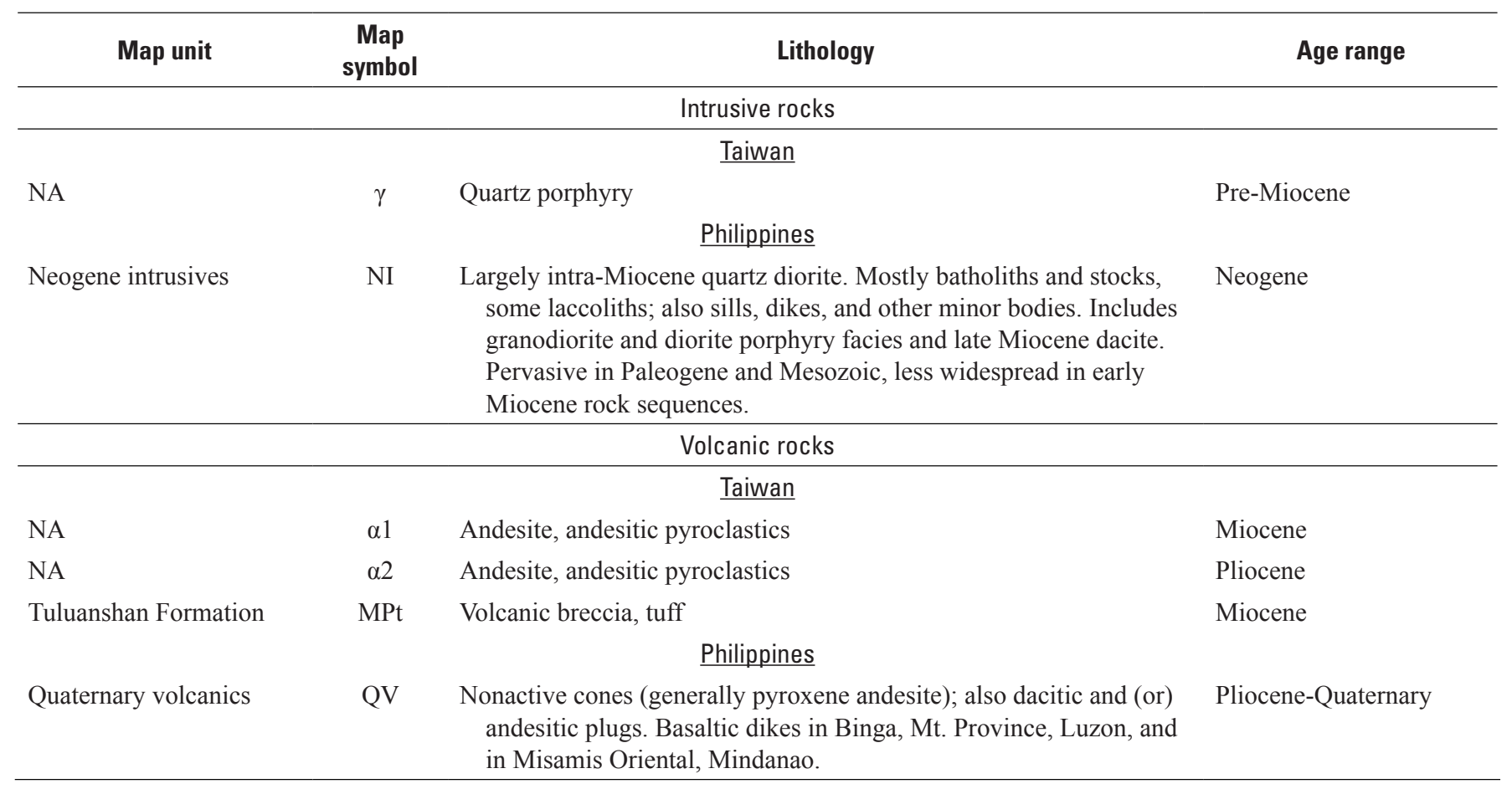

\section{Northern Luzon Arc (Taiwan)}

The Taiwan segment represents the northernmost part of the Luzon Arc in the Coastal Range of eastern Taiwan (fig. $3 A$ ) and offshore islands. Taiwan is at the convergent boundary between the Eurasian Plate subducting (eastward) under the northern Luzon Arc on the Philippine Sea Plate (fig. 10B). The Longitudinal Valley (fig. $4 A$ ) of eastern Taiwan marks the suture zone between the two plates. The northern Luzon Arc consists of the Chimei Igneous Complex and the offshore volcanic islands of Lan Yu and Lu Dao (fig. 4A); arc orientation changes from north-northwest to north-northeast (fig. 7) between these two islands (Shyu and others, 1996). The tract delineates Miocene andesitic volcanic rocks of the Tulanshan Formation and the Chimei Intrusive Complex in the Coastal Range of eastern Taiwan (fig. J2A). Facies distributions of volcanic rocks suggest that the Chimei area is a volcanic center. The 30- to 9-Ma Chimei Complex includes hydrothermally altered diorite, diabase, and andesite.

\section{Luzon Central Cordillera}

The Luzon Central Cordillera extends for about $300 \mathrm{~km}$ along northern Luzon Island (fig. $3 A$ ). The tract segment is bounded on the west and east by deep basins and, locally, by faults at basin margins. The eastern tract boundary lies along the contact of Tertiary rocks with Quaternary basinal sedimentary rocks of the Cagayan Valley to the east of the tract (Philippine Mines and Geosciences Bureau, 2010). The southern boundary is the Philippine Fault and the northern boundary is the Luzon coast.

The geology of the Central Cordillera is characterized as a north-trending zone containing Cretaceous to Paleogene submarine lava flows of spilite and basalt with some keratophyre and andesite (fig. J2B). These rocks have been intruded by Neogene to Miocene quartz diorite, granodiorite, and diorite porphyry bodies that form north-south elongate batholiths and stocks but also locally form laccoliths, sills and dikes. This central zone also is flanked by Oligocene to Miocene transgressive conglomerate, graywacke, shale, and reef limestone that is locally interlayered with mafic to intermediate volcanic flows and pyroclastic rocks. These rocks are, in turn, overlain by Upper Miocene to Pliocene marine clastics and pyroclastic rocks (Philippine Mines and Geosciences Bureau, 2010). This part of the tract delineates early Miocene through Pliocene composite diorite to tonalite intrusions and coeval hypabyssal rocks selected from a digital versions of the 1:1,000,000-scale geologic map the Philippines (Philippine Bureau of Mines, 1963).

\section{Western Luzon Arc}

The western part of the Luzon Arc includes two areas north and south of Pinatubo volcano and extends for about $300 \mathrm{~km}$ along the southwestern coast of Luzon Island and through Marinduque Island (figs. $3 A, 4 C$ ). The tract delineates Neogene quartz diorites that crop out west and south of the 
Philippine Fault and Pliocene-Quaternary volcanic rocks on the flanks of Quaternary volcanic centers (fig. J2C). A 10-km buffer area around mapped intrusions extends the tract under cover of Neogene andesitic flows, tuffs, and volcaniclastic rocks. Porphyry copper deposits in the tract are associated with Miocene-Pliocene rocks in windows in Quaternary volcanic cover. The tract excludes ultramafic rocks, Holocene Natib $(1,253 \mathrm{~m})$ and Mariveles $(1,388 \mathrm{~m})$ stratovolcanoes on the Bataan Peninsula (fig. 4C), and the active (1993) central part of Pinatubo volcano (1,486 m elevation). The volcanic cover at young, uneroded volcanoes with summits at elevations of $1 \mathrm{~km}$ or higher, such as the volcanoes in the Luzon area, would bury any associated porphyry system. Volcanic summits are excluded from surrounding volcanic cover by placing a 10-km "hole" around the topographic high point. The tract also excludes small bodies mapped as Neogene quartz diorite on the northern margins of a large ultramafic body that may represent older arc material, based on a 44.2-Ma age on tonalite; no volcanic rocks were mapped near the quartz diorite.

The southern part of the Mount Pinatubo area hosts several porphyry copper deposits (Dizon, Pisumpan, and Pinpin). Very young and active stratovolcano complexes, such as Pinatubo, can localize porphyry copper deposits when mantle-derived mafic melts carrying sulfur, other volatiles, and copper are injected repeatedly into shallow crustal felsic magma reservoirs triggering eruptions and fracturing that accommodates deposition of metals from hydrothermal fluids, as described by Hattori and Keith (2001) and Sillitoe (1973).

\section{Eastern Luzon Arc}

The eastern chain of the double island arc system $(50 \mathrm{~km}$ east of the Luzon Central Cordillera) forms the Eastern Luzon Arc segment (fig. 3A). The eastern chain is younger than, and geochemically distinct from, the western chain; the chains merge into a single chain between Luzon and Taiwan. In northeastern Luzon, the eastern arc segment is the active calcalkalic Cagua Volcano (elevation 1,133 m) (fig. J2D).

\section{Known Deposits}

Deposit locations (fig. J1) and identified resources are listed in table $\mathrm{J} 3$ by arc segment, along with references for individual deposits. No deposits are known in the Taiwan and Eastern Luzon tract segments.

Table J3. Porphyry copper deposits in tract 142pCu7301, Luzon Arc—Philippines and Taiwan (Republic of China).

[Ma, million years; Mt, million metric tons; $t$, metric ton; $g / t$, gram per metric ton; \%, percent; $\mathrm{Cu}-\mathrm{Au}$ subtype, deposits that have Au/Mo ratios $>30$ or average Au grades $>0.2 \mathrm{~g} / \mathrm{t}$; NA, not applicable; n.d., no data. Contained $\mathrm{Cu}$ in metric tons is computed as tonnage $(\mathrm{Mt} \times 1,000,000) \times(\mathrm{Cu}$ grade, $\% \div 100)]$

\begin{tabular}{|c|c|c|c|c|c|c|c|c|c|c|c|}
\hline Name & Latitude & Longitude & Subtype & $\begin{array}{l}\text { Age } \\
\text { (Ma) }\end{array}$ & $\begin{array}{c}\text { Tonnage } \\
\text { (Mt) }\end{array}$ & $\begin{array}{l}\mathrm{Cu} \\
(\%)\end{array}$ & $\begin{array}{l}\text { Mo } \\
(\%)\end{array}$ & $\begin{array}{c}\mathrm{Au} \\
(\mathrm{g} / \mathrm{t})\end{array}$ & $\begin{array}{c}\mathrm{Ag} \\
(\mathrm{g} / \mathrm{t})\end{array}$ & $\begin{array}{c}\text { Contained } \\
\text { Cu (t) }\end{array}$ & Reference \\
\hline \multicolumn{12}{|c|}{ Luzon Central Cordillera } \\
\hline Manag & 17.834 & 121.221 & $\mathrm{Cu}-\mathrm{Au}$ & n.d. & 20 & 0.50 & n.d. & 1.10 & n.d. & 100,000 & $\begin{array}{l}\text { Sillitoe and Gappe } \\
\text { (1984), Singer and } \\
\text { others (2008) }\end{array}$ \\
\hline Boneng Lobo & 17.467 & 120.817 & $\mathrm{Cu}-\mathrm{Au}$ & 10.5 & 225 & 0.28 & 0.005 & 0.26 & 4 & 636,750 & $\begin{array}{l}\text { Almogela (1974), Imai } \\
\text { (2002), Jacinto (1977), } \\
\text { Sillitoe and Gappe } \\
\text { (1984), Singer and } \\
\text { others (2008) }\end{array}$ \\
\hline Kilongolao & 17.387 & 120.858 & NA & n.d. & 50 & 0.35 & n.d. & n.d. & n.d. & 175,000 & $\begin{array}{l}\text { Almogela (1974), } \\
\text { Fernandez (1986), Sil- } \\
\text { litoe and Gappe (1984), } \\
\text { Singer and others } \\
(2008)\end{array}$ \\
\hline $\begin{array}{l}\text { Batong } \\
\text { Buhay Group }\end{array}$ & 17.354 & 121.067 & $\mathrm{Cu}-\mathrm{Au}$ & 7.0 & 87 & 0.60 & 0.002 & 0.31 & 2 & 520,531 & $\begin{array}{l}\text { Fernandez (1986), } \\
\text { Philippine Mines and } \\
\text { Geosciences Bureau } \\
\text { (2007), Saegart } \\
\text { and Lewis (1976), } \\
\text { Sillitoe and Gappe } \\
\text { (1984), Singer and } \\
\text { others (2008) }\end{array}$ \\
\hline
\end{tabular}


Table J3. Porphyry copper deposits in tract 142pCu7301, Luzon Arc_-Philippines and Taiwan (Republic of China).—Continued

[Ma, million years; Mt, million metric tons; t, metric ton; $\mathrm{g} / \mathrm{t}$, gram per metric ton; \%, percent; $\mathrm{Cu}$-Au subtype, deposits that have Au/Mo ratios $>30$ or average Au grades $>0.2 \mathrm{~g} / \mathrm{t}$; NA, not applicable; n.d., no data. Contained $\mathrm{Cu}$ in metric tons is computed as tonnage $(\mathrm{Mt} \times 1,000,000) \times(\mathrm{Cu}$ grade, $\% \div 100)]$

\begin{tabular}{|c|c|c|c|c|c|c|c|c|c|c|c|}
\hline Name & Latitude & Longitude & Subtype & $\begin{array}{l}\text { Age } \\
\text { (Ma) }\end{array}$ & $\begin{array}{c}\text { Tonnage } \\
\text { (Mt) }\end{array}$ & $\begin{array}{l}\text { Cu } \\
(\%)\end{array}$ & $\begin{array}{l}\text { Mo } \\
(\%)\end{array}$ & $\begin{array}{c}\mathrm{Au} \\
(\mathrm{g} / \mathrm{t})\end{array}$ & $\begin{array}{c}\mathrm{Ag} \\
(\mathrm{g} / \mathrm{t})\end{array}$ & $\begin{array}{c}\text { Contained } \\
\mathrm{Cu}(\mathrm{t})\end{array}$ & Reference \\
\hline Botilao & 17.300 & 121.010 & NA & n.d. & 82 & 0.52 & n.d. & 0.19 & n.d. & 426,400 & $\begin{array}{l}\text { Almogela (1974), Sil- } \\
\text { litoe and Gappe (1984), } \\
\text { Singer and others } \\
\text { (2008) }\end{array}$ \\
\hline $\begin{array}{l}\text { Hale-Mayabo } \\
\text { (Dilong } \\
\text { project) }\end{array}$ & 17.167 & 120.733 & $\mathrm{Cu}-\mathrm{Au}$ & n.d. & 35 & 0.50 & 0.005 & 0.35 & 2.5 & 175,000 & $\begin{array}{l}\text { Almogela (1974), } \\
\text { Fernandez (1986), Sil- } \\
\text { litoe and Gappe (1984), } \\
\text { Singer and others } \\
(2008)\end{array}$ \\
\hline Far Southeast & 16.866 & 120.783 & $\mathrm{Cu}-\mathrm{Au}$ & 1.4 & 657 & 0.65 & n.d. & 0.94 & 0.93 & $4,270,500$ & $\begin{array}{l}\text { Arribas and others } \\
\text { (1995), Claveria (2001), } \\
\text { Claveria and others } \\
\text { (1999), Disini and } \\
\text { others (1998), Garcia } \\
\text { (1991), Hedenquist } \\
\text { (1999), Hedenquist and } \\
\text { others (1998), Lepanto } \\
\text { Consolidated Min- } \\
\text { ing Company (2008), } \\
\text { Malicdem (1975), } \\
\text { Sajona and others } \\
\text { (2002), Shinohara and } \\
\text { Hedenquist (1997), } \\
\text { Singer and others } \\
\text { (2008) }\end{array}$ \\
\hline $\begin{array}{l}\text { Guinaoang } \\
\text { (Mankayan } \\
\text { Project) }\end{array}$ & 16.864 & 120.782 & $\mathrm{Cu}-\mathrm{Au}$ & 3.5 & 400 & 0.38 & n.d. & 0.42 & n.d. & $1,520,000$ & $\begin{array}{l}\text { Almogela (1974), } \\
\text { Bezant Resources plc } \\
(2007), \text { Chang and oth- } \\
\text { ers (2011), Fernandez } \\
\text { (1986), Sillitoe and } \\
\text { Angeles (1985), Singer } \\
\text { and others (2008), } \\
\text { Togashi and others } \\
\text { (1989) }\end{array}$ \\
\hline $\begin{array}{l}\text { San Antonio- } \\
\text { Philex }\end{array}$ & 16.750 & 120.700 & $\mathrm{Cu}-\mathrm{Au}$ & n.d. & 170 & 0.44 & 0.001 & 0.07 & 1.2 & 748,000 & $\begin{array}{l}\text { Jacinto (1975), Sillitoe } \\
\text { and Gappe (1984), } \\
\text { Singer and others } \\
(2008)\end{array}$ \\
\hline $\begin{array}{l}\text { Santo Niño } \\
\text { Group }\end{array}$ & 16.490 & 120.656 & NA & 9.5 & 286 & 0.35 & 0.008 & 0.20 & 1.7 & 986,700 & $\begin{array}{l}\text { Apostol (1974), Bryner } \\
\text { (1969), Divis (1983), } \\
\text { Govett and Hale (1967), } \\
\text { Imai (2002), MMAJ- } \\
\text { JICA (1977), Motegi } \\
\text { (1977), Sillitoe and } \\
\text { Gappe (1984) }\end{array}$ \\
\hline
\end{tabular}


Table J3. Porphyry copper deposits in tract 142pCu7301, Luzon Arc—Philippines and Taiwan (Republic of China)._Continued

[Ma, million years; Mt, million metric tons; $\mathrm{t}$, metric ton; $\mathrm{g} / \mathrm{t}$, gram per metric ton; \%, percent; $\mathrm{Cu}-\mathrm{Au}$ subtype, deposits that have Au/Mo ratios $>30$ or average Au grades $>0.2 \mathrm{~g} / \mathrm{t}$; NA, not applicable; n.d., no data. Contained $\mathrm{Cu}$ in metric tons is computed as tonnage $(\mathrm{Mt} \times 1,000,000) \times(\mathrm{Cu}$ grade, $\% \div 100)]$

\begin{tabular}{|c|c|c|c|c|c|c|c|c|c|c|c|}
\hline Name & Latitude & Longitude & Subtype & $\begin{array}{l}\text { Age } \\
\text { (Ma) }\end{array}$ & $\begin{array}{l}\text { Tonnage } \\
\text { (Mt) }\end{array}$ & $\begin{array}{l}\mathrm{Cu} \\
(\%)\end{array}$ & $\begin{array}{l}\text { Mo } \\
(\%)\end{array}$ & $\begin{array}{c}\text { Au } \\
(\mathrm{g} / \mathrm{t})\end{array}$ & $\underset{(\mathbf{g} / \mathbf{t})}{\mathbf{A g}}$ & $\begin{array}{c}\text { Contained } \\
\mathrm{Cu}(\mathrm{t})\end{array}$ & Reference \\
\hline Tawi-Tawi & 16.387 & 120.842 & NA & 4.6 & 225 & 0.39 & 0.008 & 0.30 & 1.7 & 877,500 & $\begin{array}{l}\text { Mitchell and Leach } \\
\text { (1991), MMAJ-JICA } \\
\text { (1977), Sillitoe and } \\
\text { Gappe (1984), Singer } \\
\text { and others (2008), } \\
\text { Solfotara Mining Corp. } \\
\text { (2010, 2012) }\end{array}$ \\
\hline $\begin{array}{l}\text { Kennon } \\
\text { South East/ } \\
\text { Black Moun- } \\
\text { tain Group }\end{array}$ & 16.367 & 120.600 & NA & 2.1 & 62 & 0.38 & 0.013 & 0.33 & 4 & 234,360 & $\begin{array}{l}\text { Almogela (1974), Clark } \\
\text { and Arancibia (1996), } \\
\text { Divis (1983), Fernandez } \\
\text { (1986), Imai (2002), } \\
\text { Mitchell and Leach } \\
\text { (1991), MMAJ-JICA } \\
\text { (1977), Philippine } \\
\text { Bureau of Mines and } \\
\text { Geosciences (1986), } \\
\text { Singer and others } \\
\text { (2008) }\end{array}$ \\
\hline $\begin{array}{l}\text { Santo Tomas } \\
\text { II Group }\end{array}$ & 16.263 & 120.623 & $\mathrm{Cu}-\mathrm{Au}$ & 1.5 & 449 & 0.38 & 0.001 & 0.70 & 1.5 & $1,683,750$ & $\begin{array}{l}\text { Apostol (1974), Bryner } \\
\text { (1969), Imai (2001), } \\
\text { Imai and others (1992), } \\
\text { MMAJ-JICA (1977), } \\
\text { Motegi (1977), Philip- } \\
\text { pine Bureau of Mines } \\
\text { and Geosciences (1986), } \\
\text { Sillitoe (1997), Singer } \\
\text { and others (2008), Tak- } \\
\text { enouchi (1980), Tarkian } \\
\text { and Koopmann (1995) }\end{array}$ \\
\hline
\end{tabular}

\begin{tabular}{|c|c|c|c|c|c|c|c|c|c|c|c|}
\hline \multicolumn{12}{|c|}{ Western Luzon Arc } \\
\hline Pisumpan & 15.008 & 120.367 & $\mathrm{Cu}-\mathrm{Au}$ & 2.1 & 20 & 0.41 & n.d. & 0.60 & 3 & 82,000 & $\begin{array}{l}\text { Fernandez (1986), Sil- } \\
\text { litoe and Gappe (1984), } \\
\text { Singer and others } \\
\text { (2008) }\end{array}$ \\
\hline Dizon & 14.959 & 120.336 & $\mathrm{Cu}-\mathrm{Au}$ & 2.7 & 187 & 0.36 & 0.003 & 0.93 & 2 & 673,200 & $\begin{array}{l}\text { Almogela (1974), } \\
\text { Anonymous (1997), } \\
\text { Hutchinson (1996), Imai } \\
\text { (2002), Imai (2005), } \\
\text { Imai and others (1992), } \\
\text { Malihan (1982), Sillitoe } \\
\text { (1989), Sillitoe and } \\
\text { Gappe (1984), Singer } \\
\text { and others (2008) }\end{array}$ \\
\hline
\end{tabular}


Table J3. Porphyry copper deposits in tract 142pCu7301, Luzon Arc_-Philippines and Taiwan (Republic of China).—Continued

[Ma, million years; Mt, million metric tons; t, metric ton; $\mathrm{g} / \mathrm{t}$, gram per metric ton; \%, percent; Cu-Au subtype, deposits that have Au/Mo ratios $>30$ or average Au grades $>0.2 \mathrm{~g} / \mathrm{t}$; NA, not applicable; n.d., no data. Contained $\mathrm{Cu}$ in metric tons is computed as tonnage $(\mathrm{Mt} \times 1,000,000) \times(\mathrm{Cu}$ grade, $\% \div 100)]$

\begin{tabular}{|c|c|c|c|c|c|c|c|c|c|c|c|}
\hline Name & Latitude & Longitude & Subtype & $\begin{array}{l}\text { Age } \\
\text { (Ma) }\end{array}$ & $\begin{array}{c}\text { Tonnage } \\
\text { (Mt) }\end{array}$ & $\begin{array}{l}\text { Cu } \\
(\%)\end{array}$ & $\begin{array}{l}\text { Mo } \\
(\%)\end{array}$ & $\underset{(g / t)}{A u}$ & $\underset{(g / t)}{A g}$ & $\begin{array}{c}\text { Contained } \\
\text { Cu (t) }\end{array}$ & Reference \\
\hline Taysan & 13.764 & 121.211 & $\mathrm{Cu}-\mathrm{Au}$ & 7.3 & 968 & 0.22 & 0.003 & 0.09 & 0.68 & $2,129,600$ & $\begin{array}{l}\text { Anonymous (2006), } \\
\text { Crazy Horse Resources, } \\
\text { Inc. (2012), Delos and } \\
\text { Kajiwara (1995), Imai } \\
\text { (2002), Leach (1999), } \\
\text { McPHAR Geophysical } \\
\text { Services (2006), Sillitoe } \\
\text { and Gappe (1984), } \\
\text { Singer and others } \\
\text { (2008) Wolfe and others } \\
\text { (1978) }\end{array}$ \\
\hline $\begin{array}{l}\text { Ino-Capay- } \\
\text { ang }\end{array}$ & 13.500 & 121.883 & NA & n.d. & 50 & 0.50 & 0.005 & 0.03 & 1.3 & 250,000 & $\begin{array}{l}\text { Saegart and Lewis } \\
\text { (1976), Sillitoe and } \\
\text { Gappe (1984), Singer } \\
\text { and others (2008) }\end{array}$ \\
\hline $\begin{array}{l}\text { Marcop- } \\
\text { per Group } \\
\text { (Tapian, San } \\
\text { Antonio) }\end{array}$ & 13.446 & 121.975 & $\mathrm{Cu}-\mathrm{Au}$ & 20.5 & 372 & 0.55 & 0.004 & 0.11 & 0.7 & $2,046,000$ & $\begin{array}{l}\text { Clark (1993), Loudon } \\
\text { (1976), Loudon } \\
\text { (1981), Metal Min- } \\
\text { ing Agency of Japan } \\
\text { (1998), Sillitoe and } \\
\text { Gappe (1984), Singer } \\
\text { and others (2008,) } \\
\text { Takenouchi (1980), } \\
\text { Walther and others } \\
\text { (1981) }\end{array}$ \\
\hline
\end{tabular}

\section{Luzon Central Cordillera}

The Luzon Central Cordillera contains 13 copper-gold porphyry deposits that range in age from 11 to $1 \mathrm{Ma}$ (table J3). Deposits and prospects are associated with quartz diorite intrusions and tend to be localized along or near fault intersections (fig. J3). This relation was quantified by Carranza and Hale (2002) in their analysis of the spatial relations among mapped porphyry plutons, known deposits, and strike-slip fault discontinuities in Benguet Province (fig. J3). Their study, which used a digital elevation model (DEM) to interpret fault and fracture patterns combined with weights of evidence modeling, concluded that more than 75 percent of the known porphyry deposits and prospects occurred in belts and clusters localized by regional strike-slip fault systems and within $4 \mathrm{~km}$ of a large pluton and that 50 percent of the known deposits are located within $3 \mathrm{~km}$ of one another. The clustering and spatial relations of deposits and prospects to the coarser scale fault patterns from the 1:1,000,000-scale geologic map of the Philippines shown in fig. J3 suggest that these relations may continue farther north in western Luzon and provide an exploration guide there as well.
Mankayan District

The Mankayan district of northern Luzon (fig. J3) contains a variety of deposit types including the Far Southeast and Guianoang-Tirad porphyry copper-gold deposits the Lepanto high-sulfidation epithermal copper-gold deposit, and intermediate sulfidation-state epithermal veins deposits (Chang and others, 2011). The largest porphyry deposit in the segment is the concealed Far Southeast-Bato Tabio deposit with greater than $4 \mathrm{Mt}$ of contained copper (table J3). The most recent resource estimate based on 1995 data for 114 drill holes is $657 \mathrm{Mt}$ of ore having an average grade of 0.65 percent copper and $0.84 \mathrm{~g} / \mathrm{t}$ gold (cutoff grade of 0.7 percent copper equivalent). The deposit, which is covered by $600 \mathrm{~m}$ of volcaniclastic rocks, is hosted by a Pliocene-Pleistocene quartz diorite porphyry stock at the intersection of west-northwest and north-northwest-striking fault systems (Lepanto Consolidated Mining Company, 2008).

The Mankayan district is the premier example of an established genetic relation between a porphyry copper deposit (Far Southeast) and a spatially associated epithermal deposit (Lepanto). Recognition of coupled K-silicate and advanced 
argillic (quartz-alunite) alteration in the district established new guidelines for exploration for concealed porphyry deposits based on careful documentation of paleohydrologic regimes that control alteration and ore deposition in some settings (Hedenquist and others, 1998).

\section{Baguio District}

The world class Baguio district at the southern end of the Cordillera (fig. J3) includes the 2-1.5 Ma diorite-hosted Santo Tomas II palladium-bearing porphyry copper-gold deposit that was mined by block caving from 1958-2003. The Santo Tomas II Group (fig. J1C) includes 2 prospects within $2 \mathrm{~km}$ of the deposit. The Kennon and Black Mountain Southeast Group of deposits that are associated with the approximately 3-Ma Black Mountain intrusive complex (Imai, 2001; Philippine Bureau of Mines and Geosciences, 1986; Sillitoe and Gappe, 1984; Waters and others, 2011).

\section{Western Luzon Arc}

\section{Zambales Area, Luzon Island}

The 187-Mt Dizon deposit (fig. J1D), $14 \mathrm{~km}$ from the current summit of Pinatubo volcano in the same arc, was mined until the eruption of 1991. The 2.7-Ma Dizon deposit is hosted by Pliocene andesitic to dacitic volcanic rocks and quartz diorite porphyry (Malihan, 1982). At Dizon, supergene enrichment occurred to a maximum depth of $50 \mathrm{~m}$; supergene ore accounts for $8 \mathrm{Mt}$ of 0.6 percent copper. In 17 years of mining, the Dizon deposit produced more than $100 \mathrm{Mt}$ of tailings, which contain $0.3 \mathrm{~g} / \mathrm{t}$ gold, $0.6 \mathrm{~g} / \mathrm{t}$ silver, 0.074 percent copper, and 4 percent magnetite (Dizon Copper and Silver Mines, Inc., 2012); the company is exploring possible recovery of gold and copper from tailings.

Pisumpan and nearby Pinpin (each $20 \mathrm{Mt}$ at 0.4 percent copper and approximately $1 \mathrm{~g} / \mathrm{t}$ gold) are hosted by Quaternary dacitic rocks (Hattori and Keith, 2001). No supergene zone was observed at Pisumpan (Sillitoe and Gappe, 1984).

\section{Batangas Area, Luzon Island}

Taysan (fig. J1D) is a porphyry copper-gold deposit along the western edge of the Taysan batholith in potassically altered hornblende diorite, quartz diorite, and porphyry- associated hydrothermal breccia (Wolfe and others, 1978; Crazy Horse Resources, Inc., 2012). The deposit has been drilled intermittently since 1968 and in 2012 was a prefeasibility-stage project of Crazy Horse Resources, Inc., (2012) with an expected mine life of 24 years. Based on drilling through 2011, total resources (measured, indicated, and inferred) are reported to be $968 \mathrm{Mt}$ averaging 0.22 percent copper, $0.09 \mathrm{~g} / \mathrm{t}$ gold, and $0.67 \mathrm{~g} / \mathrm{t}$ silver (at a 0.1 percent copper cutoff grade), and about 3 percent magnetite.

\section{Marinduque Island}

Mining at the 20.9 Ma Marcopper mine on Marinduque Island started in 1969 at the Mount Tapian deposit, which was mined out in 1990. The mining operation continued at the San Antonio ore body, north of the former operations (fig. J1D). Mining operations ceased in 1996 as a result of a tailings impoundment breach which discharged $20 \mathrm{Mt}$ of tailings into the Boac River. Total resources for the Marcopper deposit, including the Tapian and San Antonio ore bodies are $372 \mathrm{Mt}$ at 0.55 percent copper, 0.0035 percent molybdenum, and $0.11 \mathrm{~g} / \mathrm{t}$ gold (table J3). The deposit is within a granodiorite porphyry phase along the margins of Miocene quartz diorite stock. The upper 30 to $60 \mathrm{~m}$ of the deposit was oxidized; hypogene ore minerals included chalcopyrite associated with pyrite and magnetite and minor amounts of bornite and covellite (Loudon, 1976; Philippine Bureau of Mines and Geosciences, 1986).

An open-pit mine was operated at Ino-Capayang (fig. J1D) from 1978 to 1980 . The ore zone geometry is described as a steep cylinder, containing 2 volume percent total sulfides. $\mathrm{K}$-silicate alteration is well-developed, with minor development of sericite-chlorite-clay (SCC) alteration, and supergene enrichment to a maximum depth of $80 \mathrm{~m}$ (Sillitoe and Gappe, 1984).

\section{Prospects, Mineral Occurrences, and Related Deposit Types}

The tract contains 36 porphyry copper prospects and occurrences. These are listed in table J4, with comments, references, and a ranking of likely significance ( $4=$ high, $1=$ low). 


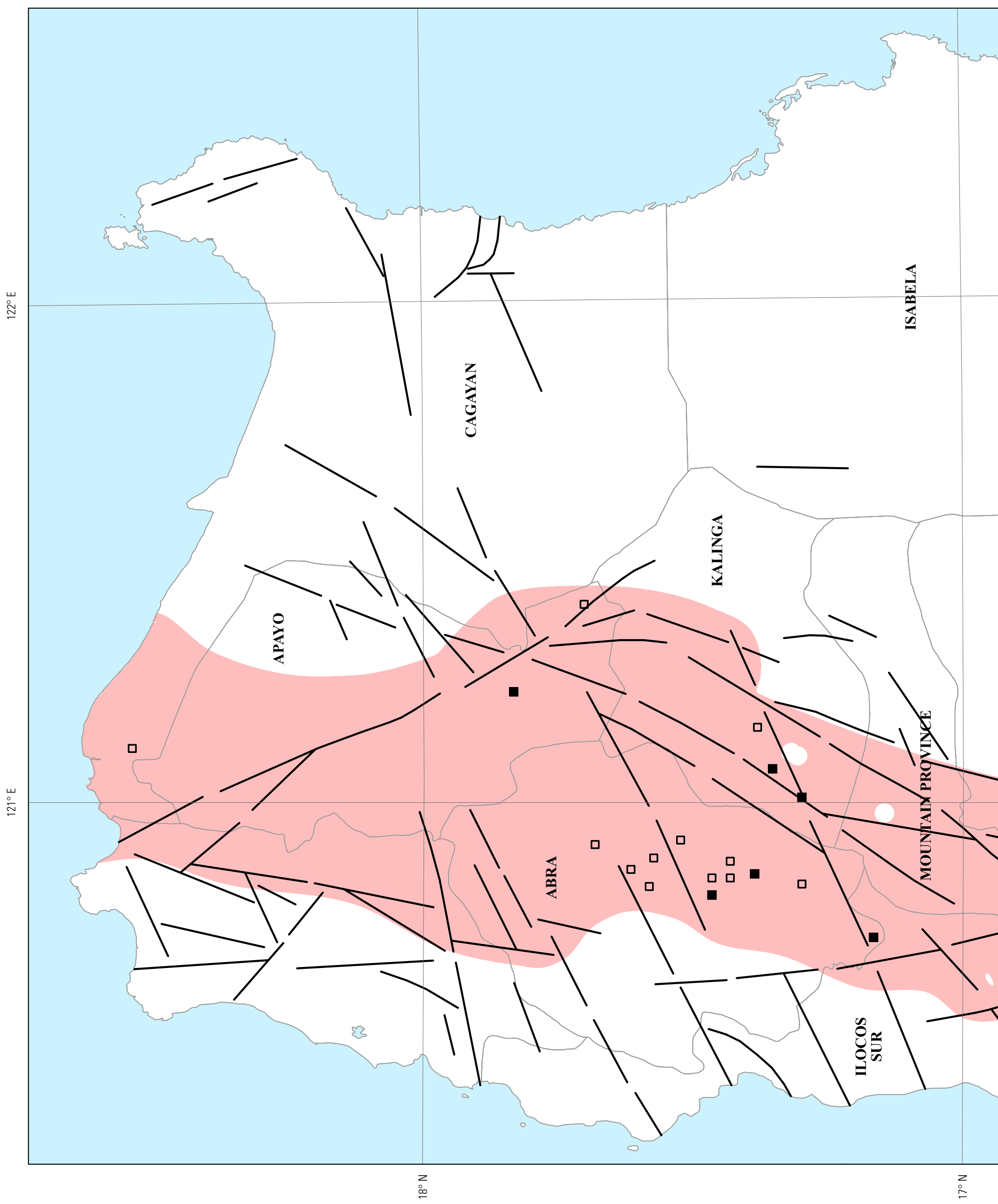



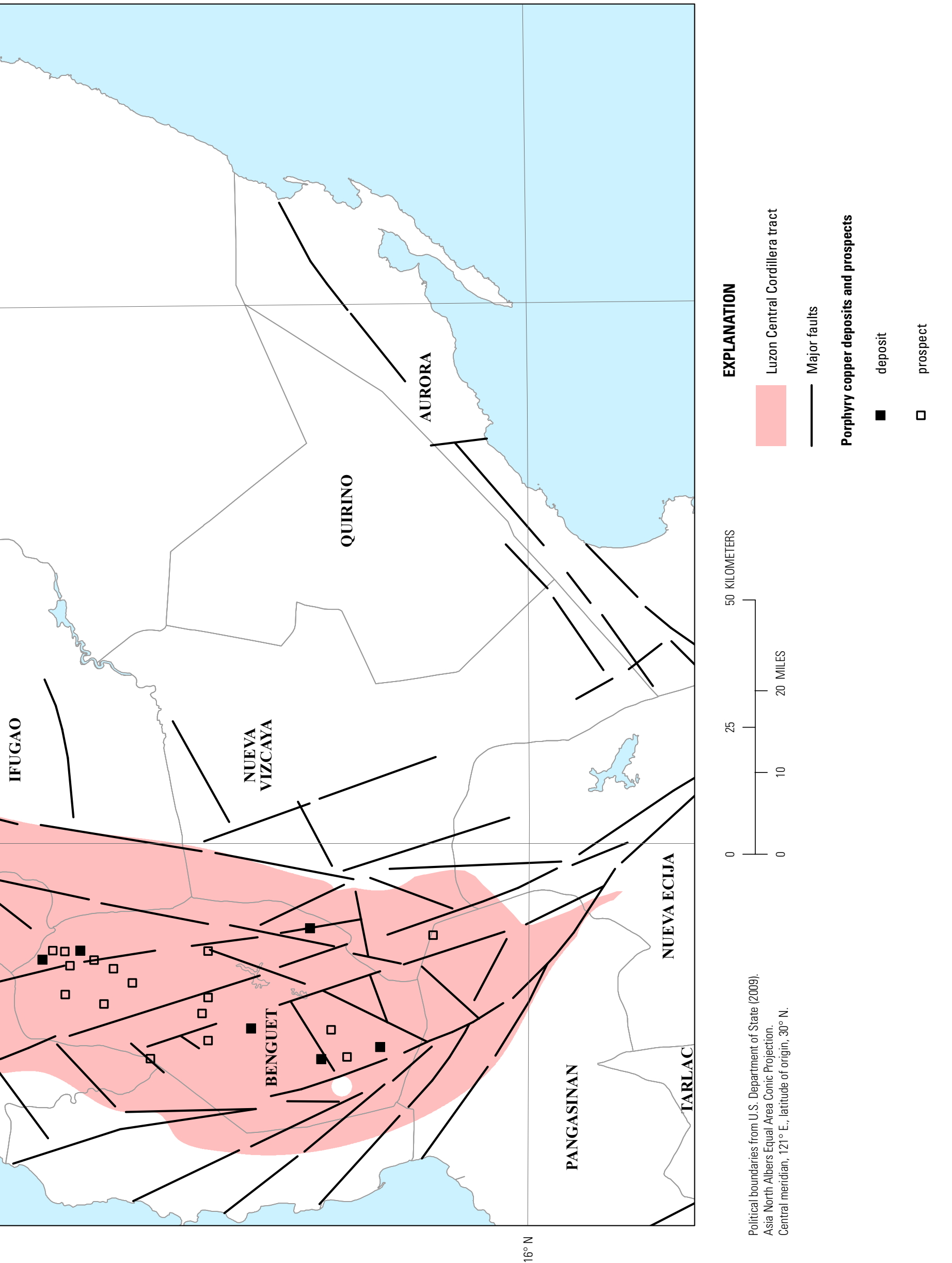

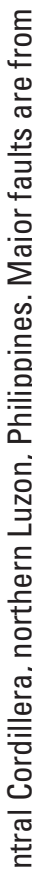

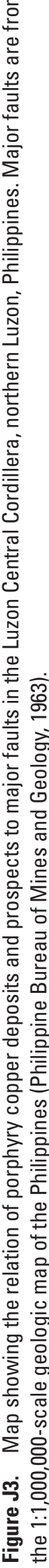


Table J4. Significant prospects and occurrences in tract 142pCu7301, Luzon Arc_-Philippines and Taiwan (Republic of China).

[n.d., no data; \%, percent; g/t, grams per metric ton; km, kilometers; m, meters; ha, hectares. MRDS, Mineral Resources Data System record available at http://mrdata. usgs.gov; LS, low-sulfidation epithermal; HS, high-sulfidation epithermal; SCC, sericite-chlorite-clay; IP, induced polarization. Rank 4=prospect listed in global database of Singer and others (2008) or $<16,000$ t of ore established by drilling. Rank $3=$ drilled, with $>20 \mathrm{~m}$ of $0.2 \%$ or more Cu. Rank $2=$ drilled or trenched with $<20 \mathrm{~m}$ of $0.2 \% \mathrm{Cu}$, or past or ongoing exploration. Rank $1=$ copper occurrence that may be related to porphyry-type mineralization based on stream sediment or magnetic anomaly or location along structural trend]

\begin{tabular}{|c|c|c|c|c|c|c|}
\hline Name & Latitude & Longitude & Age & Comments & Reference & Rank \\
\hline \multicolumn{7}{|c|}{ Northern Luzon Arc (Taiwan) } \\
\hline Chimei & 23.433 & 121.450 & 21.5 & $\begin{array}{l}\text { Resource: } 10 \mathrm{Mt} \text { at } 0.3 \text { to } 0.9 \% \mathrm{Cu} ; 7.3 \\
\mathrm{Mt} \text { at } 0.3 \% \mathrm{Cu}, 0.4-0.5 \mathrm{~g} / \mathrm{t} \mathrm{Au}\end{array}$ & $\begin{array}{l}\text { Fan (1986), Song and Lo (2002), Tan } \\
\text { (1976), Tan and Yu (1970), Wei and } \\
\text { Tan (2001) }\end{array}$ & 4 \\
\hline Dulanshan & 22.883 & 121.192 & n.d. & Copper prospect $\mathrm{Cu}, \mathrm{Au}$ & Wei and Tan (2001) & 1 \\
\hline Lanyu & 22.030 & 121.580 & n.d. & Copper prospect $\mathrm{Cu}, \mathrm{Au}$ & Wei and Tan (2001) & 1 \\
\hline \multicolumn{7}{|c|}{ Luzon Central Cordillera } \\
\hline Sinipsip & 16.733 & 120.767 & n.d. & $\begin{array}{l}\text { Exploration } 1974-1977,0.08 \mathrm{Mt} \text { at } 0.02 \\
\text { to } 0.51 \% \mathrm{Cu}, 0.035 \% \mathrm{Mo}(73 \mathrm{~m}),<0.02 \\
\mathrm{~g} / \mathrm{t} \mathrm{Au}\end{array}$ & $\begin{array}{l}\text { Almogela (1974), Fernandez (1986), } \\
\text { Sillitoe and Gappe (1984), Singer and } \\
\text { others (2008) }\end{array}$ & 4 \\
\hline Suluakan & 16.577 & 120.684 & n.d. & $\begin{array}{l}\text { Porphyry Cu-Au exploration project } \\
\text { ( } 324 \mathrm{ha} \text { ) of Philippine Metals Corp. } \\
\text { in Ilocos Sur and Abra to reevaluate } \\
\text { historical exploration data (drill logs, } \\
\text { assays, samples, and maps) to target } \\
\text { new drilling and develop a current } \\
\text { resource estimate. Prospected } 1975- \\
1981 \text { with estimate of } 123 \mathrm{Mt}, 0.35 \% \\
\mathrm{Cu}, 0.007 \% \mathrm{Mo}, 0.13 \mathrm{~g} / \mathrm{t} \mathrm{Au} \text {. and } 2.4 \\
\mathrm{~g} / \mathrm{t} \mathrm{Ag.}\end{array}$ & $\begin{array}{l}\text { Carranza and Hale (2002), Sillitoe and } \\
\text { Gappe (1984) }\end{array}$ & 4 \\
\hline Balatoc & 17.382 & 121.149 & n.d. & $\begin{array}{l}\text { Exploration area }\left(50.7 \mathrm{~km}^{2}\right) \text { in andesite } \\
\text { porphyry intruded by Neogene diorite. } \\
\text { Along western flank of a northern } \\
\text { extension of the Philippine Fault. Clus- } \\
\text { ter of prospects associated with epith- } \\
\text { ermal gold veins. Historical small-scale } \\
\text { copper production. Historical reserve } \\
\text { estimates } 80 \mathrm{Mt} \text { at } 0.60 \% \mathrm{Cu}, 0.2 \mathrm{~g} / \mathrm{t} \\
\text { Au. Location for municipality of Pasil. }\end{array}$ & Indophil Resources (2010) & 4 \\
\hline $\begin{array}{l}\text { Palidan- } \\
\text { Mohong Hill }\end{array}$ & 16.821 & 120.798 & 1.7 & $\begin{array}{l}\text { Porphyry lithocap prospect in the } \\
\text { Mankayan district } \sim 3 \mathrm{~km} \text { southwest } \\
\text { of the Guinaoang porphyry deposit; } \\
\text { estimated resources of } 100 \mathrm{Mt} \text { at } 0.4 \\
\text { percent } \mathrm{Cu}, 0.5 \mathrm{~g} / \mathrm{t} \mathrm{Au} \text {; alunite in the } \\
\text { lithocap dated at } 1.66 \mathrm{Ma} \text {. }\end{array}$ & Chang and others (2011) & 4 \\
\hline $\begin{array}{l}\text { Gambang } \\
\text { Copper/Gold } \\
\text { Project }\end{array}$ & 16.767 & 120.782 & n.d. & $\begin{array}{l}\text { Exploration since } 1995 \text { (stream sedi- } \\
\text { ment and soil geochemical sampling, } \\
\text { geological mapping, and geophysi- } \\
\text { cal survey) delineated seven target } \\
\text { areas with porphyry copper-gold style } \\
\text { mineralization }\end{array}$ & RoyalCo Resources, Ltd. (2010) & 3 \\
\hline Dilong Hale & 16.567 & 120.800 & n.d. & $\begin{array}{l}\text { Porphyry } \mathrm{Cu}-\mathrm{Au} \text { exploration project } \\
\text { ( } 324 \mathrm{ha} \text { ) in Ilocos Sur and Abra to } \\
\text { re-evaluate historical exploration data } \\
\text { (drill logs, assays, samples, and maps) } \\
\text { to target new drilling and develop a cur- } \\
\text { rent resource estimate. }\end{array}$ & Philippine Metals Corp. (2010) & 2 \\
\hline
\end{tabular}


Table J4. Significant prospects and occurrences in tract 142pCu7301, Luzon Arc—Philippines and Taiwan (Republic of China).—Continued

[n.d., no data; \%, percent; g/t, grams per metric ton; km, kilometers; m, meters; ha, hectares. MRDS, Mineral Resources Data System record available at http://mrdata. usgs.gov; LS, low-sulfidation epithermal; HS, high-sulfidation epithermal; SCC, sericite-chlorite-clay; IP, induced polarization. Rank 4=prospect listed in global database of Singer and others (2008) or $<16,000$ t of ore established by drilling. Rank $3=$ drilled, with $>20 \mathrm{~m}$ of $0.2 \%$ or more Cu. Rank $2=$ drilled or trenched with $<20 \mathrm{~m}$ of $0.2 \% \mathrm{Cu}$, or past or ongoing exploration. Rank $1=$ copper occurrence that may be related to porphyry-type mineralization based on stream sediment or magnetic anomaly or location along structural trend]

\begin{tabular}{|c|c|c|c|c|c|c|}
\hline Name & Latitude & Longitude & Age & Comments & Reference & Rank \\
\hline $\begin{array}{l}\text { Ampucao } \\
\text { (Acupan } \\
\text { South) }\end{array}$ & 16.350 & 120.654 & 0.5 & $\begin{array}{l}\text { Prospect associated with Miocene- } \\
\text { Pliocene Ampucao dacite exploration } \\
\text { drilling in southern part of the Acupan } \\
\text { mine area (closed 1992) showed inter- } \\
\text { cepts averaging } 0.1-0.2 \% \mathrm{Cu}, 0.9-1.0 \\
\text { g.t } \mathrm{Au} \text {; associated with northwest- and } \\
\text { northeast-trending splays of the Philip- } \\
\text { pine fault. Alteration styles present } \\
\text { include K-silicate, SCC, and propylitic. } \\
\text { Prospect is } 10 \mathrm{~km} \text { from nearest known } \\
\text { porphyry (Santo Tomas II). }\end{array}$ & $\begin{array}{l}\text { Benguet Corp. (2010), Cooke and } \\
\text { Bloom (1990) }\end{array}$ & 2 \\
\hline $\begin{array}{l}\text { Conner } \\
\text { Copper-Gold } \\
\text { Project }\end{array}$ & 17.703 & 121.395 & n.d. & $\begin{array}{l}\text { Tenement Exploration permit } 037 \text {; } \\
7,337 \text { ha claim area. Area of quartz } \\
\text { diorite intruding altered basalt flows. } \\
\text { Later hornblende andesitic dikes intrude } \\
\text { quartz diorite and metavolcanic rocks. } \\
\text { Possible LS epithermal gold system } \\
\text { associated with porphyry copper. } \\
\text { Google Earth }{ }^{\circledR} \text { location } ~ \text { center of } \\
\text { claim area. }\end{array}$ & Claveria (2001) & 1 \\
\hline $\begin{array}{l}\text { Baay-Licuan } \\
\mathrm{Cu}\end{array}$ & 17.583 & 120.833 & n.d. & Mining claim area & $\begin{array}{l}\text { Philippine Mines and Geosciences } \\
\text { Bureau (2004b) }\end{array}$ & 1 \\
\hline $\begin{array}{l}\text { Bakun Gold/ } \\
\text { Copper Project }\end{array}$ & 16.700 & 120.740 & n.d. & Copper prospect & $\begin{array}{l}\text { Philippine Mines and Geosciences } \\
\text { Bureau }(2004 \mathrm{~b})\end{array}$ & 1 \\
\hline Bayaosen $\mathrm{Cu}$ & 17.300 & 120.839 & n.d. & Copper prospect & $\begin{array}{l}\text { Philippine Mines and Geosciences } \\
\text { Bureau (2004b) }\end{array}$ & 1 \\
\hline Bucloc-Lamao & 17.433 & 120.883 & n.d. & Copper prospect & $\begin{array}{l}\text { Philippine Mines and Geosciences } \\
\text { Bureau (2004b) }\end{array}$ & 1 \\
\hline Camp 4 & 16.321 & 120.604 & 4.0 & $\begin{array}{l}\text { Two porphyry } \mathrm{Cu}-\mathrm{Au} \text { prospects associ- } \\
\text { ated with the Camp } 4 \text { intrusive com- } \\
\text { plex: Kidao prospect: diorite porphyry } \\
\text { and breccias; potassic alteration zones } \\
\text { at surface; rock chip assays avg. } 0.27 \% \\
\mathrm{Cu}, 0.25 \mathrm{~g} / \mathrm{t} \mathrm{Au}, 2 \mathrm{~km}^{2} \text { geochemical } \\
\text { anomaly for } \mathrm{Cu}, \mathrm{Au} \text {. Ubulan prospect, } \\
\text { low-grade mineralization indicated by } \\
\text { drilling a hornblende diorite porphyry } \\
\text { in the } 1960 \mathrm{~s} \text {. }\end{array}$ & $\begin{array}{l}\text { Carranza and Hale (2002), Durkee } \\
\text { and Pederson (1961), Waters and } \\
\text { others (2011) }\end{array}$ & 2 \\
\hline Carmen & 16.567 & 120.633 & n.d. & Copper prospect & $\begin{array}{l}\text { Philippine Mines and Geosciences } \\
\text { Bureau (2004a) }\end{array}$ & 1 \\
\hline $\begin{array}{l}\text { Claveria } \\
\text { Copper/Gold } \\
\text { Project }\end{array}$ & 18.538 & 121.108 & n.d. & $\begin{array}{l}\text { Exploration project at Praxedes, } \\
\text { Cagayan Province. Magnetic anomaly } \\
\text { several km long associated with high- } \\
\text { grade copper-gold float (up to } 9 \% \mathrm{Cu} \\
\text { and } 31 \mathrm{~g} / \mathrm{t} \mathrm{Au} \text { ) in magnetite skarn. } \\
\text { Location from Google Earth }{ }^{\circledR} \text {. }\end{array}$ & Oceana Gold (2010) & 1 \\
\hline $\begin{array}{l}\text { KM24 } \\
\text { Tubkay-Atok }\end{array}$ & 16.567 & 120.713 & n.d. & $\begin{array}{l}\text { Copper occurrence in metavolcanic } \\
\text { rock }\end{array}$ & U.S. Geological Survey (2012) & 1 \\
\hline
\end{tabular}


Table J4. Significant prospects and occurrences in tract 142pCu7301, Luzon Arc—Philippines and Taiwan (Republic of China).—Continued

[n.d., no data; \%, percent; g/t, grams per metric ton; km, kilometers; m, meters; ha, hectares. MRDS, Mineral Resources Data System record available at http://mrdata. usgs.gov; LS, low-sulfidation epithermal; HS, high-sulfidation epithermal; SCC, sericite-chlorite-clay; IP, induced polarization. Rank 4=prospect listed in global database of Singer and others (2008) or $<16,000 \mathrm{t}$ of ore established by drilling. Rank $3=$ drilled, with $>20 \mathrm{~m}$ of $0.2 \%$ or more Cu. Rank $2=$ drilled or trenched with $<20 \mathrm{~m}$ of $0.2 \% \mathrm{Cu}$, or past or ongoing exploration. Rank $1=$ copper occurrence that may be related to porphyry-type mineralization based on stream sediment or magnetic anomaly or location along structural trend]

\begin{tabular}{|c|c|c|c|c|c|c|}
\hline Name & Latitude & Longitude & Age & Comments & Reference & Rank \\
\hline Lacub $\mathrm{Cu}$ & 17.683 & 120.917 & n.d. & Copper occurrence in Miocene diorite & U.S. Geological Survey (2012) & 1 \\
\hline Lomonan & 17.525 & 120.925 & n.d. & Copper prospect & $\begin{array}{l}\text { Philippine Mines and Geosciences } \\
\text { Bureau (2004b) }\end{array}$ & 1 \\
\hline Masalin & 16.818 & 120.718 & n.d. & $\begin{array}{l}\text { Benguet. Copper prospect. Quartz } \\
\text { diorite. Chalcopyrite, bornite. }\end{array}$ & Carranza and Hale (2002) & 1 \\
\hline Nalbuan & 17.575 & 120.890 & n.d. & Copper prospect & $\begin{array}{l}\text { Philippine Mines and Geosciences } \\
\text { Bureau (2004b) }\end{array}$ & 1 \\
\hline Polar & 16.810 & 120.772 & n.d. & Copper-gold prospect & Carranza and Hale (2002) & 1 \\
\hline $\begin{array}{l}\text { Sakaang } \\
\text { Gold/Copper } \\
\text { Deposit }\end{array}$ & 16.668 & 120.599 & n.d. & Copper prospect & $\begin{array}{l}\text { Philippine Mines and Geosciences } \\
\text { Bureau (2004b) }\end{array}$ & 1 \\
\hline $\begin{array}{l}\text { Sallapandan } \\
\mathrm{Cu}\end{array}$ & 17.433 & 120.850 & n.d. & Copper prospect & $\begin{array}{l}\text { Philippine Mines and Geosciences } \\
\text { Bureau (2004b) }\end{array}$ & 1 \\
\hline Tibeg $\mathrm{Cu}$ & 17.617 & 120.867 & n.d. & Copper prospect & $\begin{array}{l}\text { Philippine Mines and Geosciences } \\
\text { Bureau (2004b) }\end{array}$ & 1 \\
\hline Ud-Udiao $\mathrm{Cu}$ & 17.467 & 120.850 & n.d. & Copper prospect & $\begin{array}{l}\text { Philippine Mines and Geosciences } \\
\text { Bureau (2004b) }\end{array}$ & 1 \\
\hline $\begin{array}{l}\text { Victoria/Teresa } \\
\text { Gold/Copper } \\
\text { Operation }\end{array}$ & 16.840 & 120.800 & n.d. & Copper prospect & $\begin{array}{l}\text { Lepanto Consolidated Mining Com- } \\
\text { pany (2008) }\end{array}$ & 1 \\
\hline $\begin{array}{l}\text { Bolo/Tawi } \\
\text { Tawi Copper/ } \\
\text { Gold Project }\end{array}$ & 16.170 & 120.830 & n.d. & Exploration project (Solfotara Mining) & Solfotara Mining Corp. (2010) & 1 \\
\hline
\end{tabular}

\begin{tabular}{|c|c|c|c|c|c|c|}
\hline $\begin{array}{l}\text { Batangas } \\
\text { Regional } \\
\text { Copper/Gold } \\
\text { Project }\end{array}$ & 13.680 & 121.200 & n.d. & $\begin{array}{l}\text { Exploration project southeast of } \\
\text { Taysan deposit; Lobo and Archangel } \\
\text { epithermal gold prospects; Balibago } \\
\text { porphyry Cu-Au system (partially } \\
\text { unroofed, silica-chlorite-sericite-clay } \\
\text { alteration, copper oxides, Cu soil } \\
\text { anomalies). Regional northeast Balabat } \\
\text { structural trend includes prospects } \\
\text { associated with Pliocene volcanoplu- } \\
\text { tonic complex capped with Quater- } \\
\text { nary volcanic rocks (Cu-Au skarns, } \\
\text { intrusive-related porphyry Cu, LS to HS } \\
\text { epithermal veins and breccias). }\end{array}$ & Ruelo and others (2003) & 2 \\
\hline
\end{tabular}


Table J4. Significant prospects and occurrences in tract 142pCu7301, Luzon Arc—Philippines and Taiwan (Republic of China).—Continued

[n.d., no data; \%, percent; g/t, grams per metric ton; km, kilometers; m, meters; ha, hectares. MRDS, Mineral Resources Data System record available at http://mrdata. usgs.gov; LS, low-sulfidation epithermal; HS, high-sulfidation epithermal; SCC, sericite-chlorite-clay; IP, induced polarization. Rank 4=prospect listed in global database of Singer and others (2008) or $<16,000 \mathrm{t}$ of ore established by drilling. Rank $3=$ drilled, with $>20 \mathrm{~m}$ of $0.2 \%$ or more Cu. Rank $2=$ drilled or trenched with $<20 \mathrm{~m}$ of $0.2 \% \mathrm{Cu}$, or past or ongoing exploration. Rank $1=$ copper occurrence that may be related to porphyry-type mineralization based on stream sediment or magnetic anomaly or location along structural trend]

\begin{tabular}{|c|c|c|c|c|c|c|}
\hline Name & Latitude & Longitude & Age & Comments & Reference & Rank \\
\hline $\begin{array}{l}\text { Calo Copper/ } \\
\text { Gold Project }\end{array}$ & 13.700 & 121.244 & n.d. & $\begin{array}{l}\text { Reconnaissance drilling ( } 7 \text { widely } \\
\text { spaced holes) in } 2006 \text { to test cluster of } \\
\text { IP anomalies reported up to } \sim 500 \mathrm{~m} \text { of } \\
\text { volcanic cover, weak porphyry-related } \\
\text { alteration, and altered diorite clasts. } \\
\text { Drill intersections of } 213 \mathrm{~m} \text { of } 0.18 \% \\
\mathrm{Cu} \text { and } 0.30 \mathrm{~g} / \mathrm{t} \mathrm{Au} \text { below advanced } \\
\text { argillic alteration cap. Exotic copper in } \\
\text { volcanic cover above IP anomalies. }\end{array}$ & Mindoro Resources, Ltd. (2010) & 2 \\
\hline Greenhills & 14.955 & 120.305 & n.d. & $\begin{array}{l}\text { Zambales copper prospect. Andesite } \\
\text { porphyry. Chalcopyrite, bornite. }\end{array}$ & $\begin{array}{l}\text { Philippine Mines and Geosciences } \\
\text { Bureau (2004a) }\end{array}$ & 1 \\
\hline $\begin{array}{l}\text { Kay Tanda } \\
\text { Group } \\
\text { (Archangel) }\end{array}$ & 13.630 & 121.314 & Miocene & $\begin{array}{l}\text { Altered volcanic rocks intruded by } \\
\text { andesitic, dacitic, and dioritic intru- } \\
\text { sions; partly unexposed. Cluster of } \\
\text { epithermal gold-silver and porphyry } \\
\text { copper prospects along a 6- km long } \\
\text { northeast structural trend. Kay Tanda } \\
\text { epithermal Au-Ag deposit telescoped } \\
\text { on a porphyry system at depth. }\end{array}$ & $\begin{array}{l}\text { Mindoro Resources, Ltd. (2010), Cox } \\
\text { (2010) }\end{array}$ & 2 \\
\hline $\begin{array}{l}\text { Calampang- } \\
\text { Lobo Group }\end{array}$ & 13.658 & 121.233 & 10.5 & $\begin{array}{l}\text { Exploration based on IP anomalies } \\
\text { interpreted as buried porphyry targets. } \\
\text { Copper mined in } 1960 \mathrm{~s} \text {. Drilled sum- } \\
\text { mer of } 2010 \text { to test } \mathrm{Cu}-\mathrm{Au} \text {-Mo soil } \\
\text { anomaly. Pica prospect drilled in } 2005 \\
\text { intersected } 213 \mathrm{~m} \text { at } 0.18 \% \mathrm{Cu}, 0.30 \\
\mathrm{~g} / \mathrm{t} \text {. Includes Calumpang Copper/Gold } \\
\text { Project, a geophysical target northeast } \\
\text { of Pica. }\end{array}$ & $\begin{array}{l}\text { Imai (2002), Mindoro Resources, Ltd. } \\
\text { (2010) }\end{array}$ & 2 \\
\hline $\begin{array}{l}\text { Talahib Gold/ } \\
\text { Copper Project }\end{array}$ & 13.657 & 121.156 & n.d. & $\begin{array}{l}\text { Reconnaissance exploration in an } \\
\text { area of altered andesitic volcanic } \\
\text { rocks intruded by altered diorite and } \\
\text { microdiorite intrusion. Stream sedi- } \\
\text { ment anomalies for } \mathrm{Cu}, \mathrm{Au}, \mathrm{Pb} \text {, and } \\
\mathrm{Zn} \text {. Altered diorite outcrop sampling } \\
(0.74 \% \mathrm{Cu}, 0.15 \mathrm{~g} / \mathrm{t} \mathrm{Au}) \text {; anomalous } \mathrm{Cu} \\
\text { and } \mathrm{Au} \text { in channel samples of hydro- } \\
\text { thermal breccia. }\end{array}$ & Mindoro Resources, Ltd. (2010) & 2 \\
\hline
\end{tabular}


Taiwan

Chimei is a porphyry prospect in Miocene hornblende diorite porphyry, characterized by stockwork and disseminated chalcopyrite and stockwork quartz (fig. J1B). The resource at Chimei is estimated at $10 \mathrm{Mt}$ of ore with $0.3-0.9$ percent copper; the reliability and basis for this estimate are uncertain and may not be based on drilling, so it is cited as a prospect rather than a deposit (Fan, 1986). Alteration includes sericitization, argillization, chloritization, and pyritization. Exploration in the 1970s showed anomalous copper in stream sediments and soils in a $15-\mathrm{km}^{2}$ area near Chimei (Tan and Yu, 1970). Other porphyry prospects in the Taiwan arc segment include Dulanshan (23-1.8 Ma age range) and Lanya (less than $2 \mathrm{Ma}$ ) (fig. J1B).

\section{Luzon Central Cordillera}

Twenty-seven porphyry copper prospects are known in the Luzon Central Cordillera (table J4, fig. J1B,C). About a quarter of these prospects have had some recent exploration to reevaluate historical data; the others are reportedly porphyry copper-type occurrences (C. Manipon, written commun., 2004). The porphyry copper deposits and prospects in the Baguio district are subjacent to major producing epithermal gold-silver deposits, such as Acupan and gold and base-metal skarn deposits such the Thanksgiving deposit (Cooke and Bloom, 1990; Waters and others, 2011).

\section{Western Luzon Arc}

The Western Luzon arc segment contains six recently active exploration projects, with some reported drill intercepts (table J4). Weak indications of porphyry copper alteration and copper anomalies in stream sediments are associated with the Kay Tanda and Calampang-Lobo prospect areas (fig. J1D), where buried porphyry systems are exploration targets. The Archangel epithermal gold-silver deposit at Kay Tanda was interpreted as a younger system telescoped on a Miocene porphyry system (Cox, 2010).

\section{Exploration History}

The Luzon Central Cordillera has a long history of exploration and development. Most exploration and discovery of large gold and copper deposits in the Luzon Central Cordillera occurred in the 1970s and 1980s. The Far SoutheastBato Tabio deposit was known in the 13th Century; gold and copper were mined in the early 1900s. Some of the porphyry copper and gold deposits in the southern part of the Cordillera were discovered in the 1950s and 1960s. Exploration activity included trenching, sampling, geological mapping, prospect-scale geophysical exploration and drilling. Two areas of 30-year-old stream-sediment geochemical surveys were noted during the assessment. New exploration depends heavily on magnetics and drilling to target buried deposits. Stream sediment and soil sampling, as well as reevaluation of historic exploration data, have been ongoing since 2002 to target drilling. The Assessment Team considered the high frequency of mining claim applications to indicate relatively intense levels of mineral exploration in the southern parts of the tract (see also, Kamitani and Naito, 1998; Sillitoe, 1995; and regional mining tenement maps for the Philippines available at http:// www.mgb.gov.ph/lmtp.aspx).

\section{Sources of Information}

Table J5 lists the sources of information used in the assessment.

\section{Grade and Tonnage Model Selection}

Most of the known deposits in the tract are classified as $\mathrm{Cu}-\mathrm{Au}$ subtype, as defined by greater than $0.2 \mathrm{~g} / \mathrm{t}$ gold or Au:Mo ratios greater than 30. Statistical tests ( $t$-tests) of deposits in the tract against the porphyry $\mathrm{Cu}-\mathrm{Au}$ subtype model indicated that the model is appropriate for the assessment (table 4).

\section{Estimate of the Number of Undiscovered Deposits}

\section{Rationale for the Estimate}

In 2005, an assessment team made preliminary estimates of nine undiscovered deposits for the Luzon Central Cordillera. In 2010, another team considered the area in the context of the entire Luzon Arc system, along with an update of the deposits and prospects data compilation. The Taiwan, Luzon Central Cordillera, and Western Luzon tract segments of the Luzon Arc system all contain prospects, at least one of which might, if fully explored, be a deposit. The tract segments on Luzon span numerous fault intersections that might provide conduits for porphyry-related magmas and hydrothermal fluids. Outcropping plutons in the Central Luzon Cordillera define an axis of voluminous porphyry-related magmatism that might also be present at depth, beneath postmineralization cover rocks.

The 2010 tract estimate of a mean of 10 undiscovered deposits (table J6) represents the mean for a 90 -percent chance of 2 or more deposits, a 50-percent chance of 9 deposits, and a 10-percent chance of 20 or more deposits (table J6). Recent exploration focus on buried targets that have yet to be tested by drilling, and changes in Philippine mining policies that are more open to exploration than in the recent past were considered in the analysis. 
Table J5. Principal sources of information used for tract 142pCu7301, Luzon Arc—Philippines and Taiwan (Republic of China).

[NA, not applicable]

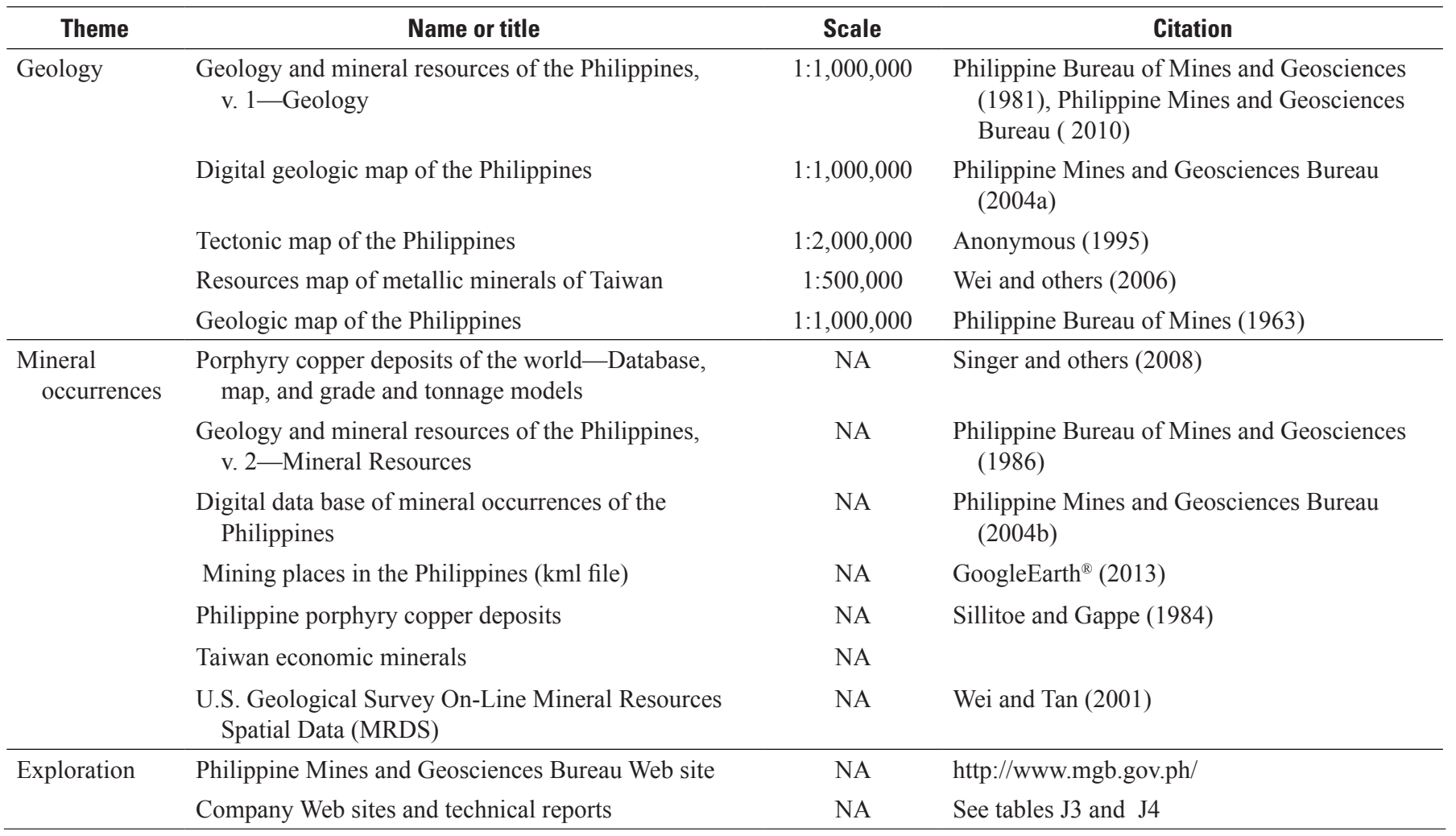

Table J6. Undiscovered deposit estimates, deposit numbers, tract area, and deposit density for tract 142pCu7301, Luzon ArcPhilippines and Taiwan (Republic of China).

$\left[N_{\mathrm{XX}}\right.$, estimated number of deposits associated with the xxth percentile; $N_{\text {und }}$, expected number of undiscovered deposits; $s$, standard deviation; $C_{v} \%$, coefficient of variance; $N_{\text {known }}$, number of known deposits in the tract that are included in the grade and tonnage model; $N_{\text {total }}$ total of expected number of deposits plus known deposits; area, area of permissive tract in square kilometers $\left(\mathrm{km}^{2}\right)$; density, deposit density reported as the total number of deposits per $100,000 \mathrm{~km}^{2} . N_{\text {und }}, s$, and $C_{v} \%$ are calculated using a regression equation (Singer and Menzie, 2005)]

\begin{tabular}{|c|c|c|c|c|c|c|c|c|c|c|c|}
\hline \multicolumn{5}{|c|}{ Consensus undiscovered deposit estimates } & \multicolumn{5}{|c|}{ Summary statistics } & \multirow{2}{*}{$\begin{array}{c}\text { Tract Area } \\
\quad\left(\mathbf{k m}^{2}\right)\end{array}$} & \multirow{2}{*}{$\begin{array}{c}\text { Deposit density } \\
\left(N_{\text {total }} / 100,000 \mathrm{~km}^{2}\right)\end{array}$} \\
\hline$N_{90}$ & $N_{50}$ & $N_{10}$ & $N_{05}$ & $N_{01}$ & $N_{\text {und }}$ & $s$ & $C_{v} \%$ & $N_{\text {known }}$ & $N_{\text {total }}$ & & \\
\hline 2 & 9 & 20 & 20 & 20 & 10 & 6.4 & 63 & 18 & 28 & 23,700 & 118 \\
\hline
\end{tabular}




\section{Probabilistic Assessment Simulation Results}

Undiscovered resources for the tract were estimated by combining consensus estimates for numbers of undiscovered porphyry copper deposits with the porphyry copper model of Singer and others (2008) using the EMINERS program (Root and others, 1992; Duval, 2012; Bawiec and Spanski, 2012). Selected simulation results are reported in table J7. Results of the Monte Carlo simulation are presented as a cumulative frequency plot (fig. J4). The cumulative frequency plot shows the estimated resource amounts associated with cumulative probabilities of occurrence, as well as the mean, for each commodity and for total mineralized rock. The mean amount of copper (31 Mt) estimated for undiscovered deposits represents about twice the identified resources $(17 \mathrm{Mt})$. The median expected value is $22 \mathrm{Mt}$ (table J7).

Table J7. Results of Monte Carlo simulation of undiscovered resources for tract 142pCu7301, Luzon Arc_-Philippines and Taiwan (Republic of China).

[Cu, copper; Mo, molybdenum; Au, gold; and Ag, silver; in metric tons; Rock, in million metric tons]

\begin{tabular}{|c|c|c|c|c|c|c|c|c|}
\hline \multirow[b]{2}{*}{ Material } & \multicolumn{6}{|c|}{ Probability of at least the indicated amount } & \multicolumn{2}{|c|}{ Probability of } \\
\hline & 0.95 & 0.9 & 0.5 & 0.1 & 0.05 & Mean & $\begin{array}{c}\text { Mean or } \\
\text { greater }\end{array}$ & None \\
\hline Mo & 0 & 0 & 75,000 & 520,000 & 720,000 & 180,000 & 0.30 & 0.13 \\
\hline $\mathrm{Au}$ & 21 & 160 & 1,700 & 5,100 & 6,400 & 2,300 & 0.40 & 0.04 \\
\hline
\end{tabular}

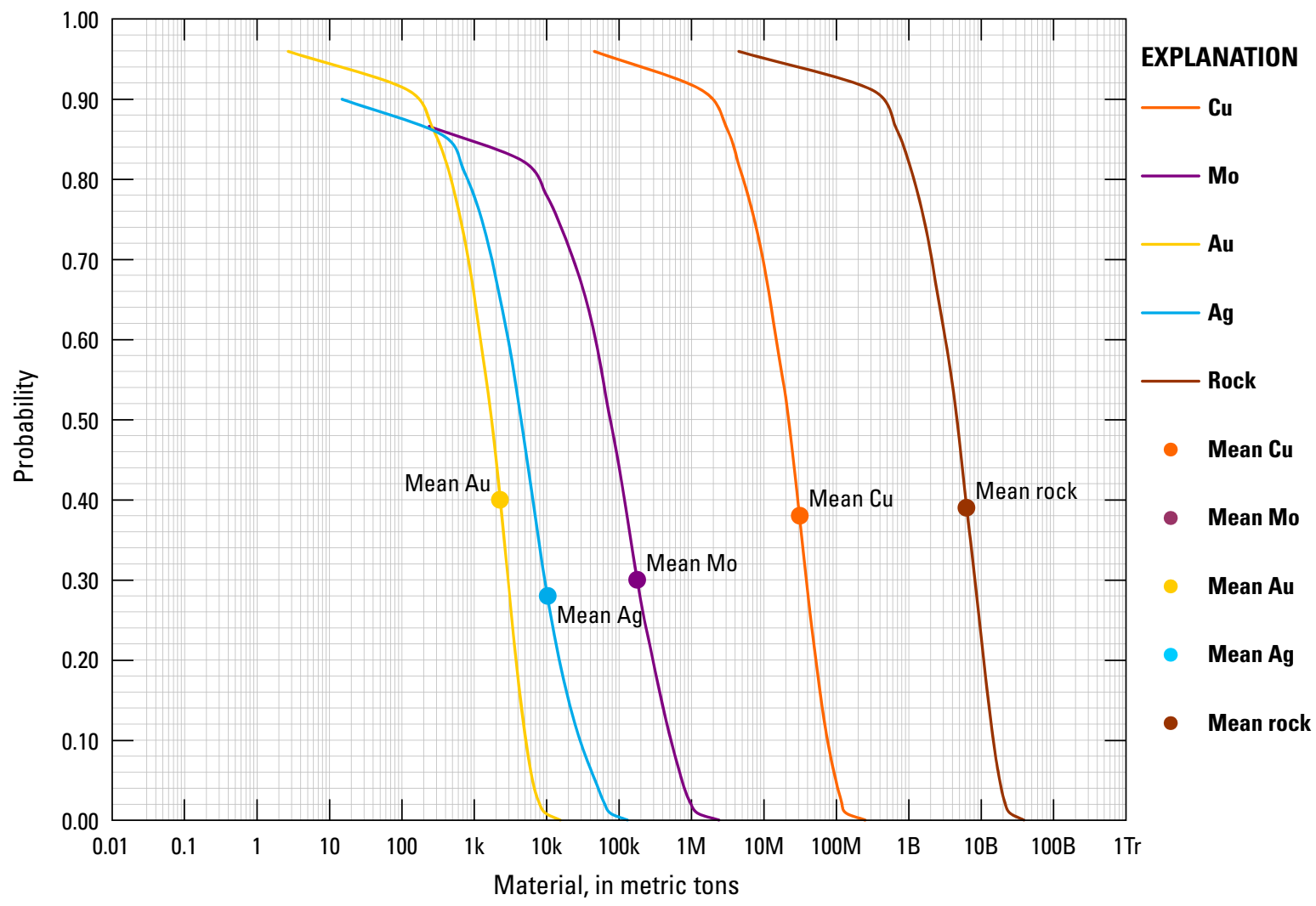

Figure J4. Cumulative frequency plot showing the results of Monte Carlo computer simulation of undiscovered resources in tract 142pCu7301, Luzon Arc, the Philippines and Taiwan (Republic of China). k, thousands; M, millions; B, billions; Tr, trillions. 


\section{References Cited}

Almogela, D.H., 1974, Geologic environment and economic possibilities of porphyry copper deposits in the Philippines: Journal of the Geological Society of the Philippines, v. 28, no. 3 , p. $1-16$.

Anonymous, 1995, Tectonic map of the Philippines: scale 1:2,000,000.

Anonymous, 1997, The Dizon copper-gold project, Philippines: Mining Magazine (London), v. 146, no. 4, p. 268-279.

Anonymous, 2006, Mindoro stays the course in the Philippines: The Northern Miner, August 18-24, 2006, p. B7-B8.

Apostol, E.L., 1974, Porphyry copper deposits in Baguio district, Luzon, Philippines: Journal of the Geological Society of the Philippines, v. 28, no. 2, p. 32-43.

Arribas, A., Jr., Hedenquist, J.W., Itaya, T., Okada, T., Concepción, R.A., and Garcia, J.S., Jr., 1995, Contemporaneous formation of adjacent porphyry and epithermal $\mathrm{Cu}-\mathrm{Au}$ deposits over $300 \mathrm{ka}$ in northern Luzon, Philippines: Geology, v. 23, p. 337-340.

Bautista, B.C., Bautista, M.L.P., Oike, K., Wu, F.T., and Punongbayan, R.S., 2001, A new insight on the geometry of subducting slabs in northern Luzon, Philippines: Tectonophysics, v. 339, p. 279-310.

Bawiec, W.J., and Spanski, G.T., 2012, Quick-start guide for version 3.0 of EMINERS - Economic Mineral Resource Simulator: U.S. Geological Survey Open-File Report 2009-1057, 26 p., accessed June 30, 2012, at http://pubs. usgs.gov/of/2009/1057/. (This report supplements USGS OFR 2004-1344.)

Berger, B.R., Ayuso, R.A., Wynn, J.C., and Seal, R.R., 2008, Preliminary model of porphyry copper deposits: U.S. Geological Survey Open-File Report 2008-1321, 55 p., accessed May 15, 2009, at http://pubs.usgs.gov/ of/2008/1321/.

Benguet Corporation, 2010, Ampucao project: Benguet Corporation Web site, accessed September 26, 2010, at http://www.benguetcorp.com/index.php?option=com content\&view=article\&id=126\&Itemid=95.

Bezant Resources plc, 2007, Presentation of June 2007: Bezant Resources plc, 22 p., accessed July 15, 2011, at http://www.bezantresources.com/TZG\%20PP\%20final.pdf.

Bezant Resources plc, 2011, Positive independent conceptual study completed on the Mankayan copper-gold project, Philippines: Bezant Resources plc Web site , accessed April 5, 2013, at http://online.hemscottir.com/ir/bzt/ ir.jsp?page $=$ news-item\&item $=583915836281158$.
Bryner, L., 1969, Ore deposits of the Philippines-An introduction to their geology: Economic Geology, v. 64, p. 644-666.

Carranza, J.M., and Hale, M., 2002, Where are porphyry copper deposits spatially localized? A case study in Benguet Province, Philippines: Natural Resources Research, v. 11, no. 1, p. 45-59.

Chang, Z., Hedenquist, J.W., White, N.C., Cooke, D.R., Roach, M., Deyell, C.L., Garcia, J., Jr., Gemmell, J.B., McKnight, S., and Cuison, A.L., 2011, Exploration tools for linked porphyry and epithermal deposits_Example from the Mankayan intrusion-centered $\mathrm{Cu}-\mathrm{Au}$ district, Luzon, Philippines: Economic Geology, v. 106, p. 1365-1398.

Clark, A.H., and Arancibia, O.N., 1996, The occurrence, paragenesis and implications of magnetite-rich alterationmineralization in calc-alkaline porphyry copper deposits, in Clark, A.H., ed., Giant ore deposits-II: Proceedings of the Second Giant Ore Deposits Workshop, Kingston, Ontario, Canada, p. 583-640.

Claveria, R.J., 2001, Mineral paragenesis of the Lepanto copper and gold and Victoria gold deposits, Mankayan mineral district, Philippines: Resource Geology, v. 51, no. 2, p. 97-106.

Claveria, R.J., Cuison, A.G., and Andam, B.V., 1999, The Victoria gold deposit in the Mankayan mineral district, Luzon, Philippines, in Weber, G., ed., Pacrim '99 Congress Proceedings, International Congress on earth science, exploration and mining around Pacific rim: Australasian Institute of Mining and Metallurgy Publication Series no. 4/99, p. $73-80$.

Cooke, D.R., and Bloom, M.S., 1990, Epithermal and subjacent porphyry mineralization, Acupan, Baguio District, Philippines-A fluid-inclusion and paragenetic study, in Hedenquist, J.W., N.C., and Siddelley, G., eds., Epithermal gold mineralisation of the Circum-Pacific-Geology, geochemistry, origin and exploration I: Journal of Geochemical Exploration, v. 35, p. 297-340.

Cox, D.P., 1986, Descriptive model of porphyry Cu-Au, in Cox, D.P. and Singer, D.A., eds., Mineral deposit models: U.S. Geological Survey Bulletin 1693, p. 110. (Also available at http://pubs.usgs.gov/bul/b1693/.)

Cox, D.M., 2010, NI43-101 Report, Mineral resource estimate upgrade on the Kay Tanda project, Luzon, Philippines: Report prepared for Mindoro Resources Limited, 128 p., accessed July 20, 2012, at http://www.mindoro.com/s/ TechReports.asp.

Crazy Horse Resources, Inc., 2012, Taysan copper-gold project: Web site accessed March 15, 2012, at http://crazyhorseresources.com/s/TaysonProject.asp. 
Defant, M.J., Jacques, D., Maury, R.C., de Boer, J., and Joron, J.-L., 1989, Geochemistry and tectonic setting of the Luzon arc, Philippines: Geological Society of America Bulletin, v. 101, p. 663-672.

Delos Santos, M.S., Jr., and Kajiwara, Y., 1995, The geology, mineralization and hydrothermal alteration of the Taysan porphyry copper deposit, Batangas, Philippines [abs.]: Resource Geology, v. 45, no. 4, p. 279.

Disini, A.F., Robertson, B.M., and Claveria, R.J.R., 1998, The Mankayan Mineral District, Luzon Philippines, in Porter, T.M., ed., Porphyry and hydrothermal copper \& gold deposits-A global perspective, Conference Proceedings: Australian Mineral Foundation, Glenside South Australia, p. $75-88$.

Divis, A.F., 1983, The geology and geochemistry of Philippine porphyry copper deposits, in Hayes, D.E., ed., The tectonic and geologic evolution of Southeast Asian Seas and Islands-Part 2: Washington, D.C., American Geophysical Union, p. 173-216.

Dizon Copper and Silver Mines, Inc., 2012, Web site: accessed April 25, 2013, at http://www.dizonmines.com/index.html.

Durkee, E.F., and Pederson, S.L., 1961, Geology of northern Luzon, Philippines: Bulletin of the American Association of Petroleum Geologists, v. 45, p. 137-168.

Duval, J.S., 2012, Version 3.0 of EMINERS-Economic Mineral Resource Simulator: U.S. Geological Survey OpenFile Report 2004-1344, available at http://pubs.usgs.gov/ of/2004/1344/.

Fan, P.F., 1986, Porphyry copper deposits in East and Southeast Asia: Memoir of the Geological Society of China, no. 7, p. 249-257.

Fernandez, J.C., 1986, Geology and mineral resources of the Philippines, v. 2, Mineral Resources: Manila, Philippines, Bureau of Mines and Geosciences, Ministry of Natural Resources, $446 \mathrm{p}$.

Garcia, J.S., Jr., 1991, Geology and mineralization characteristics of the Mankayan mineral district, Benguet, Philippines: Geological Survey of Japan Report, no. 277, p. 21-30.

Garwin, S., Hall, R., and Watanabe, Y., 2005, Tectonic setting, geology, and gold and copper mineralization in Cenozoic magmatic arcs of southeast Asia and the west Pacific, in Hedenquist, T.W., Thompson, J.F.H., Goldfarb, R.J., and Richards, J.P., eds., One hundredth anniversary volume 1905-2005: Littleton, Colorado, Society of Economic Geologists, p. 891-930.

Govett, G.J.S., and Hale, W.E., 1967, Geochemical orientation and exploration near a disseminated copper deposit, Luzon, Philippines: Transactions of the Institution of Mining and Metallurgy, London, Series B, v. 76, p. B190-B191.
Hattori, K.H., and Keith, J.D., 2001, Contribution of mafic melt to porphyry copper mineralization-Evidence from Mount Pinatubo, Philippines and Bingham Canyon, Utah, USA: Mineralium Deposita, v. 36, p. 799-806.

Hedenquist, J.W., 1999, Far Southeast-Lepanto porphyryepithermal $\mathrm{Cu}-\mathrm{Au}$ deposits, Philippines: Coupled hydrothermal processes between the porphyry and high-sulfidation environments, in Weber, G., ed., Pacrim '99 Congress Proceedings, International Congress on earth science, exploration and mining around Pacific Rim: Australasian Institute of Mining and Metallurgy Publication Series no. 4/99, p. 61-63.

Hedenquist, J.W., Arribas, A., Jr., and Reynolds, T.J., 1998, Evolution of an intrusion-centered hydrothermal systemFar Southeast-Lepanto porphyry and epithermal $\mathrm{Cu}-\mathrm{Au}$ deposits, Philippines: Economic Geology, v. 93, p. 373-404.

Hutchinson, C.S., 1996, South-East Asian oil, gas, coal and mineral deposits: Oxford, Clarendon Press, 265 p.

Imai, A., 2005, Evolution of hydrothermal system at the Dizon porphyry $\mathrm{Cu}-\mathrm{Au}$ deposit, Zambales, Philippines: Resource Geology, v. 55, no. 2, p.73-90.

Imai, A., 2001, Generation and evolution of ore fluids for porphyry $\mathrm{Cu}-\mathrm{Au}$ mineralization of the Santo Tomas II (Philex) deposit, Philippines: Resource Geology, v. 51, no. 2, p. 71-96.

Imai, A., 2002, Metallogenesis of porphyry $\mathrm{Cu}$ deposits of the Western Luzon Arc, Philippines-K-Ar ages, $\mathrm{SO}_{3}$ contents of microphenocrystic apatite and significance of intrusive rocks: Resource Geology, v. 52, no. 2, p.147-161.

Imai, A., Muyco, J.D., Domingo, E.G., Almeda, R.L., Villones, R.I., Yumul, G.P., Jr., Damasco, F.V., Baluda, R.I., Malihan, T.D., Datuin, R.T., Punongbayan, R.S., Listanco, E.L., and Santos, R.A., 1992, Porphyry copper and gold mineralization in the Philippines: 29th IGC Field Trip Guide Book, Volume 6, Mineral deposits of Japan and Philippines, The Society of Resource Geology, Tokyo, p. C36-1-C36-30.

Indophil Resources, 2010, Indophil Resources: Indophil Resources Web site, accessed March 1, 2010, at http://www. indophil.com/.

Jacinto, R.P., 1975, Exploration of the low-grade copper deposit at Tabbac, Kibungan, Benguet Province, Philippines: Journal of the Geological Society of the Philippines, v. 29 , no. 2 , p. $1-4$.

Jacinto, R.P., 1977, Alteration and mineralization of LoboBoneng area, Atok, Benguet, Philippines: 5th Symposium on Mineral Resources Development, Baguio City, Nov. 1977, section 1-A, paper 6. 
John, D.A., Ayuso, R.A., Barton, M.D., Blakely, R.J., Bodnar, R.J., Dilles, J.H., Gray, Floyd, Graybeal, F.T., Mars, J.C., McPhee, D.K., Seal, R.R., Taylor, R.D., and Vikre, P.G., 2010, Porphyry copper deposit model, chap. B of Mineral deposit models for resource assessment: U.S. Geological Survey Scientific Investigations Report 2010-5070-B, 169 p., accessed September 8, 2010, at http://pubs.usgs.gov/ $\operatorname{sir} / 2010 / 5070 / \mathrm{b} /$.

Kamitani, M., and Naito, K., eds., 1998, Mineral resource map of Asia: Metal Mining Agency of Japan, [1 sheet 1:35,000,000-scale], www.mmaj.go.jp/mric_web/deposit/ index.htm.

Leach, T.M., 1999, Evolution of selected porphyry coppergold systems in the Northwest Pacific Region and its relevance to exploration, in Weber, G., ed., Pacrim '99 Congress Proceedings, International Congress on earth science, exploration and mining around Pacific rim: Australasian Institute of Mining and Metallurgy Publication Series no. $4 / 99$, p. $211-225$.

Lepanto Consolidated Mining Company, 2008, Far Southeast: Lepanto Consolidated Mining Company Web page, accessed June 15, 2012, at http://www.lepantomining.com/ far_southeast.html.

Loudon, A.G., 1976, Marcopper porphyry copper deposit, Philippines: Economic Geology, v. 71, p. 721-732.

Loudon, A.G., 1981, Marcopper porphyry copper deposit, Philippines: Journal of Geological Society of the Philippines, v. 35 , no. 2, p. 1-23.

Malaihollo, J.F.A., Hall, R., and Macpherson, C.G., 2002, SE Asia Radiometric ages-GIS database: Southeast Asia Research Group, Department of Earth Sciences, Royal Holloway University of London, accessed January 15, 2010, at http://searg.rhul.ac.uk/current_research/isotopic_ages/ SEAsia_GIS.pdf.

Malihan, T.D., 1982, The gold-rich Dizon porphyry copper Mine in the Western Central Luzon Island: Proceedings of Pacific Rim Congress 87, Australia, p. 303-307.

Malicdem, D.G., 1975, Notes on the geology and exploration of Colossal-Lepanto copper project, Gen. Nakar, Quezon: Journal of the Geological Society of the Philippines, v. 29, no.1, p. 13-19.

McPHAR Geophysical Services, 2006, Tayson project: McPHAR Geophysical Services, 1 p., accessed May 15, 2010, at http://www.mcphar.com.ph/case-taysan.asp.
Mindoro Resources, Ltd., 2010, Mindoro Resources: Mindoro Resources Web site, accessed March 1, 2010, at http://www. mindoro.com/s/Home.asp.

Ministry of Economic Affairs, 2006, Resources Map of Metallic Minerals of Taiwan: [Taiwan] Ministry of Economic Affairs, Central Geological Survey, scale 1:500,000.

Metal Mining Agency of Japan and Japan International Cooperation Agency (MMAJ-JICA), 1977, Report on geological survey of northeastern Luzon, phase III: Metal Mining Agency of Japan and Japan International Cooperation Agency, Tokyo, 280 p.

Motegi, M., 1977, Porphyry copper deposits in PhilippinesTheir tectonic setting and present status of development: Mining Geology, v. 27, p. 221-230.

Oceana Gold Corporation, 2010, Oceana Gold Corporation: Oceana Gold Corporation Web site, accessed September 26, 2010, at http://www.oceanagold.com/.

Philippine Bureau of Mines, 1963, Geological map of the Philippines: Philippine Bureau of Mines, 1 map on 8 sheets, scale $1: 1,000,000$.

Philippine Bureau of Mines and Geosciences, 1981, Geology and mineral resources of the Philippines, v. 1-Geology: Philippine Bureau of Mines and Geosciences, $406 \mathrm{p}$.

Philippine Bureau of Mines and Geosciences, 1986, Geology and mineral resources of the Philippines, v. 2-Mineral resources: Manila, Philippines, Philippine Bureau of Mines and Geosciences, $446 \mathrm{p}$.

Philippine Metals Corporation, 2010, Philippine Metals Corporation: Philippine Metals Corporation Web site, accessed September 26, 2010, at http://www.philippinemetals.com/s/ Home.asp.

Philippine Mines and Geosciences Bureau, 2004a, Digital geological map of the Philippines: Philippine Mines and Geosciences Bureau, scale 1:1,000,000. [Proprietary data.]

Philippine Mines and Geosciences Bureau, 2004b, Digital database of mineral occurrences of the Philippines: Philippine Mines and Geosciences Bureau. [Proprietary report.]

Philippine Mines and Geosciences Bureau, 2007, Priority Mineral development projects of the Philippines: Philippine Mines and Geosciences Bureau, 27 p., accessed January 15, 2010, at http://www.mgb.gov.ph/revitalization_files/revitaliz ation_23projectsprofile.pdf.

Philippine Mines and Geosciences Bureau, 2010, Geology of the Philippines (2nd ed.): Philippine Mines and Geosciences Bureau, $532 \mathrm{p}$. 
Ruelo, H.B., Climie, J.A., Abrasaldo, E.M., and Lab-oyan, F.T., 2003, Mindoro Resources, Ltd., Batangas Projects, Batangas Province, Philippines, Results of phase I drilling program, Lobo project, and reconnaissance exploration of Batangas projects: Mindoro Resources, Ltd., accessed September 10, 2010, at http://www.mindoro.com/i/pdf/ Batangas_TechReport_03-10-10.pdf.

Root, D.H., Menzie, W.D., and Scott, W.A., 1992, Computer Monte Carlo simulation in quantitative resource estimation: Natural Resources Research, v. 1, no. 2, p. 125-138.

RoyalCo Resources, Ltd., 2010, Gambang Project, Luzon Central Cordillera [Philippines]: RoyalCo Resources, Ltd., Web page, accessed April 8, 2010, at http://www.royalco. com.au/exploration.html.

Saegart, W.E., and Lewis, D.E., 1976, Characteristics of Philippine porphyry copper deposits and summary of current production and resources: American Institute of Mining, Metallurgical, and Petroleum Engineers Annual Meeting, February 22-26, 1976, Las Vegas, preprint no. 76-1-79, $46 \mathrm{p}$.

Sajona, F., Izawa, E., Motomura, Y., Imai, A., Sakakibara, H., and Watanabe, K., 2002, Victoria carbonate-base metal gold deposit and its significance in the Mankayan mineral district, Luzon, Philippines: Resource Geology, v. 52, no. 4, p. 315-328.

Shinohara, H., and Hedenquist, J.W., 1997, Constraints on magma degassing beneath the Far Southeast porphyry $\mathrm{Cu}-$ Au deposit: Philippines Journal of Petrology, v. 38, no. 12, p. 1741-1752.

Shyu, C.T., Chih, M.C., Hsu, S.K., Wang, Chengsung, and Karp, Boris, 1996, Northern Luzon Arc_-Location and tectonic features from magnetic data off eastern Taiwan: Terrestrial, Atmospheric and Oceanic Sciences, v. 7, no. 4, p. 535-548.

Sillitoe, R.H., 1973, The tops and bottoms of porphyry copper deposits: Economic Geology, v. 68, p. 799-815.

Sillitoe, R.H., 1997, Characteristics and controls of the largest porphyry copper-gold and epithermal gold deposits in the circum-Pacific region: Australian Journal of Earth Sciences, v. 44 , p. 373-388.
Sillitoe, R.H., and Angeles, C.A., Jr., 1985, Geological characteristics and evolution of a gold-rich porphyry copper deposit at Guinaobagan, Luzon, Philippines, in Jones, M.P., chairperson, Asian Mining '85 Conference, February 11-14, 1985, Manila, Philippines Conference Proceedings, p. $15-26$.

Sillitoe, R.H., and Gappe, I.M., Jr., 1984, Philippine porphyry copper deposits - Geologic setting and characteristics: Committee for Co-ordination of Joint Prospecting for Mineral Resources in Asian Offshore Areas (CCOP), CCOP Technical Publication 14, 89 p.

Singer, D.A., and Menzie, W.D., 2005, Statistical guides to estimating the number of undiscovered mineral deposits - An example with porphyry copper deposits, in Cheng, Qiuming, and Bonham-Carter, Graeme, eds., Proceedings of IAMG-The annual conference of the International Association for Mathematical Geology: Toronto, Canada, York University, Geomatics Research Laboratory, p. 1028-1033.

Singer, D.A., Berger, V.I., and Moring, B.C., 2008, Porphyry copper deposits of the World-Database and grade and tonnage models, 2008: U.S. Geological Survey Open-File Report 2008-1155, accessed June 1, 2011, at http://pubs. usgs.gov/of/2008/1155/.

Singer, D.A., Berger, V.I., Menzie, W.D., and Berger, B.R., 2005, Porphyry copper density: Economic Geology, v. 100, no. 3, p. 491-514.

Solfotara Mining Corporation, 2010, Solfotara Mining Corporation: Solfotara Mining Corporation Web page, accessed April 8, 2010, at http://solfotara.com/.

Solfotara Mining Corporation, 2012, Tawi-Tawi copper-gold porphyry deposit: Solfotara Mining Corporation Web page, accessed May 1, 2012, at http://solfotara.com/.

Song, S.R., and Lo, H.J., 2002, Lithofacies of volcanic rocks in the central Coast Range, eastern Taiwan-Implications for island arc evolution: Journal of Asian Earth Sciences, v. 21, p. $23-38$.

Takenouchi, S., 1980, Preliminary studies on fluid inclusions of the Santo Tomas II (Philex) and Tapian (Marcopper) porphyry copper deposits in the Philippines: Mining Geology Special Issue, no. 8, p. 141-150. 
Tan, L.P., and Yu, F.S., 1970, Geochemical exploration of the Chimei copper deposit, Taiwan: Proceedings of the Geological Society of China, no. 13, p. 90-107.

Tarkian, M., and Koopmann, G., 1995, Platinum-group minerals in the Santo Tomas II (Philex) porphyry copper-gold deposit, Luzon Island, Philippines: Mineralium Deposita, v. 30 , p. $39-47$.

Togashi, Y., Domingo, E.G., Sta. Cruz, J.R., Nakagawa, M., and Murao, S., 1989, K-Ar ages of igneous rocks from the Philex (Santo Tomas II) auriferous porphyry copper deposit, Philippines [abs]: Mining Geology, v. 39, p. 59.

U.S. Department of State, 2009, Small-scale digital international land boundaries (SSIB) _ Lines, edition 10, and polygons, beta edition 1, in Boundaries and sovereignty encyclopedia (B.A.S.E.): U.S. Department of State, Office of the Geographer and Global Issues.

U.S. Geological Survey, 2012, On-line mineral resources spatial data: U.S. Geological Survey Web site, accessed February 10, 2012, at http://mrdata.usgs.gov/.

Waters, P.J., Cooke, D.R., Gonzales, R.I, and Phillips, D., 2011, Porphyry and epithermal deposits and ${ }^{40} \mathrm{Ar} /{ }^{39} \mathrm{Ar}$ geochronology of the Baguio District, Philippines: Economic Geology, v. 106, p. 1335-1363.
Wei, J., and Tan, L., eds., 2001, Taiwan non-metallic economic minerals; Taiwan economic minerals, v. 2: [Taiwan] Ministry of Economic Affairs, Central Geological Survey, 324 p. [In Chinese.]

Wei, Chi-Sheng, Yen, Chih-Min, Lin, Yung-Hsiang, Chen, PoPsun, Wang, Yunshuen, and Fei, Li-Yuan, compilers, 2006, Resources map of metallic minerals of Taiwan: [Taiwan] Ministry of Economic Affairs, Central Geological Survey, scale 1:500,000.

Wolfe, J.A., Manuzon, M.S., and Divis, A.F., 1978, The Taysan porphyry copper deposit, Southern Luzon Island, Philippines: Economic Geology, v. 73, p. 608-617.

Yang, T.F., Lee, T., Chen, C.H., Cheng, S.N., Knittel, U., Punongbayan, R.S., and Rasda, A.R., 1996, A double island arc between Taiwan and Luzon-Consequence of ridge subduction: Tectonophysics, v. 258, p. 85-101.

Yumul, G.P., Jr., Dimalanta, C.B., Maglambayan, V.B., and Marquez, E.J., 2008a, Tectonic setting of a composite terrane-A review of the Philippine island arc system: Geosciences Journal, v. 12, no. 1, p. 7-17.

Yumul, G.P., Jr., Dimalanta, C.B., Tam, T.A., III, and Ramos, E.G.L., 2008b, Baguio mineral district-An oceanic arc witness to geological evolution on northern Luzon, Philippines: Island Arc, v. 17, p. 432-442. 
This page left intentionally blank. 


\section{Appendix K. Porphyry Copper Assessment for Tract 142pCu7313, Gyeongsang Basin Area-Republic of Korea (South Korea)}

By Jane M. Hammarstrom'1, Steve Ludington², Michael DeMarr'1, and Connie L. Dicken¹

\section{Deposit Type Assessed: Porphyry copper}

Descriptive model: Porphyry copper (Berger and others, 2008; Cox, 1986; John and others, 2010)

Table K1 summarizes selected assessment results.

Table K1. Summary of selected resource assessment results for tract 142pCu7313, Gyeongsang Basin Area-Republic of Korea (South Korea).

[km, kilometers; $\mathrm{km}^{2}$, square kilometers; $\mathrm{t}$, metric ton; NA, not applicable]

\begin{tabular}{|c|c|c|c|c|c|}
\hline $\begin{array}{c}\text { Date of } \\
\text { assessment }\end{array}$ & $\begin{array}{l}\text { Assessment depth } \\
(\mathbf{k m})\end{array}$ & Tract area $\left(\mathbf{k m}^{2}\right)$ & $\begin{array}{l}\text { Identified copper } \\
\text { resources }(t)\end{array}$ & $\begin{array}{l}\text { Mean estimate of } \\
\text { undiscovered copper } \\
\text { resources }(t)\end{array}$ & $\begin{array}{l}\text { Median estimate of } \\
\text { undiscovered copper } \\
\text { resources }(t)\end{array}$ \\
\hline 2012 & 1 & 46,300 & 0 & NA & NA \\
\hline
\end{tabular}

\section{Location}

Gyeongsang ${ }^{3}$ Basin and adjacent areas in southern South Korea (fig. K1).

\section{Geologic Feature Assessed}

Korean segment (Gyeongsang Arc) of the Cretaceous-Paleogene continental margin arc along the East Asian craton.

${ }^{1}$ U.S. Geological Survey, Reston, Virginia, United States.

${ }^{2}$ U.S. Geological Survey, Menlo Park, California, United States.

${ }^{3}$ Also spelled as Gyeongsong and Kyongsang. 


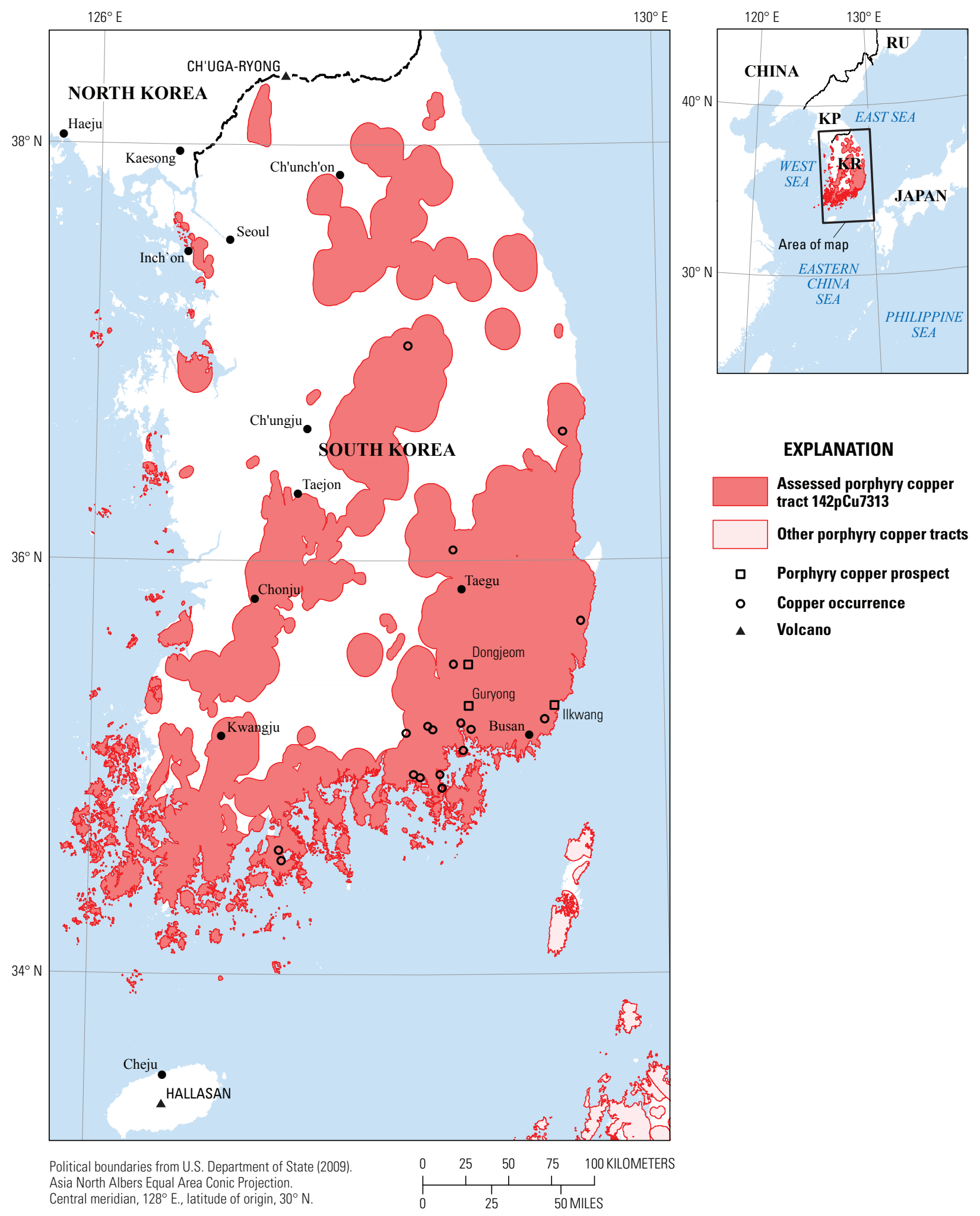

Figure K1. Map showing tract location and significant prospects and occurrences (open squares) for tract 142pCu7313, Gyeongsang Basin Area—Republic of Korea (South Korea). RU, Russia; JP, Japan; KP, Democratic People's Republic of Korea (North Korea); KR, Republic of Korea (South Korea). 


\section{Delineation of the Permissive Tract}

\section{Tectonic Setting}

Before the opening of the Sea of Japan in the Miocene, Korea was part of an active, Andean-type continental margin along East Asia that encompassed what is now southeastern China, western Japan, and the Sikhote-Alin area of Russia (fig. $9^{4}$ ). Northward (oblique) subduction of the Izanagi Plate (see fig. 10A) during the Cretaceous caused back-arc strike-slip basins to form, including the Gyeongsang Basin (Maruyama and others, 1997). The nonmarine Gyeongsang Basin preserves late Cretaceous volcano-sedimentary complexes and calc-alkalic I-type subvolcanic intrusions (Bulgugsa or Bulguksa magmatism) that have been interpreted as marking the trace of a subduction-related continental arc system that extends from eastern China through southeastern Korea to the Japan Arc (Zhang and others, 2012). The Bulgugsa granitoids were emplaced at relatively shallow levels (approximately $3 \mathrm{~km}$ ) and cooled rapidly from intrusion to about $72 \mathrm{Ma}$, after which cooling rates slowed as the basin was inverted by regional uplift and exhumation, as indicated by fission track cooling rates and sedimentalogical studies (Lim and Lee, 2005; Chough and others, 2000). Tertiary inversion of the strike-slip basin in South Korea is attributed to collision of the Indian Plate with Eurasia (Chough and others, 2000).

\section{Geologic Criteria}

The Late Cretaceous igneous and volcanic rocks of South Korea are exposed in the Gyeongsang Basin and along the Ogcheon Belt (fig. 11A). Rocks of the Gyeongsang Supergroup, a 9-km-thick sequence of volcanic and sedimentary rocks, including the 2,000-3,000-m-thick volcanicdominant Yucheon Group, fill the basin. The Yucheon Group is comprised of andesitic and rhyolitic subgroups of high-K calc-alkalic volcanic rocks. The granitoids range in age from 120-40 Ma, occur as small stocks and volcano-plutonic complexes, and predominantly are porphyritic, I-type diorites to granodiorites that have textures and miarolitic cavities indicative of a shallow level of emplacement (Zhang and others, 2012).

The permissive tract was constructed by selecting Cretaceous igneous rocks from a digital version of the 1:1,000,000-scale geologic map of Korea. Map units used to delineate the tract are shown in figure $\mathrm{K} 2$ and listed in table $\mathrm{K} 2$. A $10-\mathrm{km}$ buffer was created around intrusive rocks, and a 2-km buffer was created around volcanic rocks. These distances are considered appropriate to allow for inaccuracies in mapped contacts and extensions under adjacent cover rock.

\section{Known Deposits}

None.

\section{Prospects, Mineral Occurrences, and Related Deposit Types}

The tract includes the Dongjeom porphyry copper prospect, the Guryong copper-molybdenum prospect, and the Ilkwang copper-tungsten breccia-pipe (fig. K1, table K3), as well as skarns, polymetallic deposits, and copper occurrences. No economic porphyry copper deposits have been documented to date. Yang and Bodnar (1994) concluded that exposed permissive rocks in the Gyeongsang Basin represent the root zones of porphyry copper systems; any ores that existed higher in the system have eroded off. They interpreted fluid- and silicate-melt inclusion data of the granitoids as indicative of a higher pressure of emplacement (1.9-2.5 kbar) than that of typical porphyry systems. Those pressures, along with a lack of water saturation until very late in the crystallization history suggests that the only subeconomic, low-grade, deeper parts of porphyry systems are preserved. 


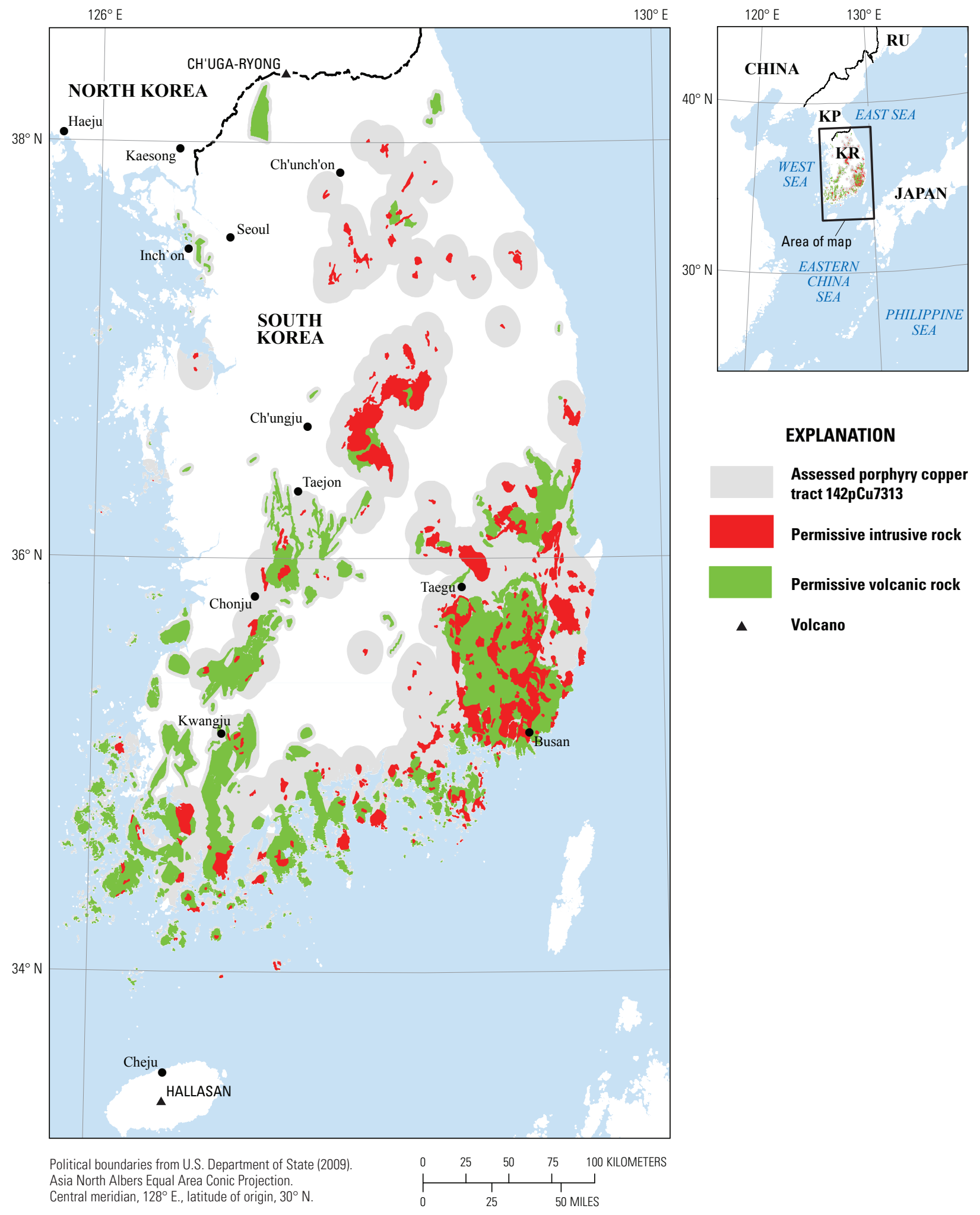

Figure K2. Map showing igneous rocks used to delineate tract 142pCu7313, Gyeongsang Basin AreaRepublic of Korea (South Korea). RU, Russia; JP, Japan; KP, Democratic People's Republic of Korea (North Korea); KR, Republic of Korea (South Korea). 
Table K2. Map units that define tract 142pCu7313, Gyeongsang Basin Area-Republic of Korea (South Korea).

[Map unit, age range, and principal lithologies are based on a digital compilation of maps listed in table K4]

\begin{tabular}{llll}
\hline \multicolumn{2}{c}{ Lithology unit } & \multicolumn{2}{c}{ Age range } \\
\hline \multicolumn{3}{c}{ Bulgugsa granite } & Intrusive rocks \\
\hline Kgr & \multicolumn{2}{c}{ Colcanic rocks } \\
\hline \multicolumn{3}{c}{ Yucheon and Jaedok Groups of the } & Cretaceous and Paleogene \\
\hline
\end{tabular}

Table K3. Significant prospects and occurrences in tract 142pCu7313, Gyeongsang Basin Area-Republic of Korea (South Korea).

[\%, percent; $\mathrm{m}$, meters; Ma, million years. Rank $2=$ drilled or trenched with $<20 \mathrm{~m}$ of $0.2 \% \mathrm{Cu}$ or past or ongoing exploration. Rank $1=$ copper occurrence that may be related to porphyry-type mineralization based on stream sediment or magnetic anomaly or location along structural trend]

\begin{tabular}{|c|c|c|c|c|c|c|}
\hline Name & Latitude & Longitude & Age (Ma) & Comments & Reference & Rank \\
\hline $\begin{array}{l}\text { Dongjeom } \\
\text { (Red Hill, } \\
\text { Baegwol) }\end{array}$ & 35.503 & 128.633 & Cretaceous & $\begin{array}{l}\text { Low-grade }(\leq 0.1 \% \mathrm{Cu}) \text { porphyry copper } \\
\text { prospect associated with a } 1,400 \text { by } 500 \mathrm{~m} \\
\text { exposed granodiorite porphyry stock. Explored } \\
\text { by drilling, IP, geochemical surveys in } \\
\text { the } 1970 \mathrm{~s} \text {. }\end{array}$ & Sillitoe (1980) & 2 \\
\hline Ilkwong & 35.301 & 129.233 & 69 & $\begin{array}{l}\mathrm{Cu}-\mathrm{W} \text { tourmaline breccia pipe associated with } \\
\text { an } 81 \mathrm{Ma} \text { quartz monzonite stock. Level of } \\
\text { emplacement appropriate for porphyry; no } \\
\text { potassic alteration. }\end{array}$ & $\begin{array}{l}\text { Fletcher (1977), } \\
\text { Yang and } \\
\text { Bodnar (2004) }\end{array}$ & 1 \\
\hline Guryong & 35.301 & 128.634 & $\sim 85$ & $\begin{array}{l}\text { Cu-Mo in hydrothermally altered (pyrophyl- } \\
\text { lite) andesite. Quartz veinlets with chalcopyrite, } \\
\text { molybdenite, and pyrite in a propylitized zone } \\
\text { at depth. }\end{array}$ & Sillitoe (1980) & 1 \\
\hline
\end{tabular}

\section{Dongjeom (Red Hill, Baegwol)}

The Red Hill porphyry copper prospect at Dongjeom (fig. K1) is a partly covered, fine-grained biotite-hornblende granodiorite stock that intrudes mudstones of the Cretaceous Gyeongsang Supergroup (Sillitoe, 1980). Potassic and sericitic alteration affected the stock; propylitic alteration developed in the mudstone. The potassic alteration zone is sulfide-rich (as much as 10 percent sulfides), mainly pyrite, with chalcopyrite, pyrrhotite, and molybdenite; calcite, chlorite, and tourmaline also are present (Sillitoe, 1980). Five holes were drilled in the 1970s, following an exploration plan for a vein-type deposit; evaluation of drill core and surface exposures led to a reinterpretation as a porphyry-type deposit, albeit of low average grade ( 0.1 percent copper or less, local higher-grade zones) with negligible supergene enrichment (Sillitoe, 1980).

\section{Guryong}

Guryong is not a recognizable porphyry copper prospect but rather represents one of a number of pyrophyllite deposits developed in advanced argillic alteration zones in Cretaceous andesite near intrusions in South Korea (Sillitoe, 1980). Some characteristics of the upper parts of porphyry systems are present at Guryong, as well as minor amounts of copper and molybdenum minerals. Quartz stockworks cut argillic alteration; molybdenite occurs with pyrite and chalcopyrite in quartz veinlets and as disseminations in the argillic alteration zone and to a lesser extent in an underlying propylitic zone. However, the observed apparent stratigraphic control and downward decrease in alteration and sulfide content are atypical of porphyry systems. Sillitoe (1980) suggested that the annular intrusion at Guryong might indicate cauldron subsidence, which would have perturbed the more stable subvolcanic conditions necessary to develop porphyry systems.

\section{Ilkwang}

Ilkwang is a 100 by $70 \mathrm{~m}$ altered copper-tungsten breccia pipe in an elliptical Cretaceous stock that shares some characteristics with tourmaline-bearing breccia pipes associated with porphyry copper systems elsewhere (Yang and Bodnar, 2004). The deposit was mined from 1937 to 1945 , and produced 3,500 metric tons of copper and 40 metric tons of tungsten. 
The Ilkwang stock was dated at $81 \pm 3 \mathrm{Ma}$ (K-Ar on hornblende), whereas sericite in altered breccia fragments from the pipe were dated at $69 \mathrm{Ma}$ (Fletcher, 1977). Fluid inclusion and stable isotope data indicate that the deposit formed from magmatic hydrothermal fluids that evolved from high to low pressure as crystallization and water pressure buildup within the pipe eventually fractured and formed the breccia. Ilkwang was apparently formed at lower pressure or shallower emplacement depths than most of the noneconomic granitoids in the basin (Yang and Bodnar, 2004).

\section{Andong Area}

Copper-bearing polymetallic vein occurrences in the Andong area (fig. K3) in the northern part of the Gyeongsang Basin were described as Cretaceous hydrothermal copperlead-zinc-silver deposits that may represent a type of vein system transitional between epithermal and porphyry types of deposits (So and others, 1997). The quartz- and calcite veins fill fractures in Cretaceous sedimentary rocks; the veins may be related to spatially associated Cretaceous quartz porphyry (Bulgugsa series granitoids). A K-Ar age of 91.4 4 .2 Ma was obtained on sericite alteration from one of the veins. Hightemperature (greater than $320^{\circ} \mathrm{C}$ ), high-salinity early stage fluid inclusions, and decreasing sulfur and oxygen isotopes with decreasing temperature through the multistage vein paragenesis were interpreted as a magmatic hydrothermal system that was progressively mixed with meteoric water. The economically significant stage I veins evolved from pyrite (with pyrrhotite, chalcopyrite, sphalerite, and minor wolframite and magnetite) through base-metal sulfide to sulfosalt-bearing veins.

The exact location of the two mines developed along the veins, the Dongwha ( 3.2 percent copper and $160 \mathrm{ppm} \mathrm{Ag}$ ) and Daesong mines studied by So and others (1997), could not be confirmed. On the basis of their sketch map, however, the mines appear to be in the vicinity of the prospects in the Andong area, as shown on figure $\mathrm{K} 3$.

\section{Other Deposits}

South Korea is best known for production of tungsten, molybdenum, and lead-zinc from skarns associated with Cretaceous felsic intrusions. The Sangdong tungsten-molybdenum deposit, one of the largest tungsten resources in the world, produced tungsten until 1992, when low metal prices led to mine closure; the mine was approved to reopen in 2010, and a feasibility study was completed in April 2012 (Woulfe Mining Corp., 2012). These types of skarns typically are associated with coarse-grained equigranular batholiths rather than with porphyritic intrusions, and may indicate a deeper level of emplacement than porphyry-copper-related skarns, in accord with the results of Yang and Bodnar's 1984 study.
A copper-molybdenum prospect near the eastern coast of South Korea called Kampo (Gumnyong) was described by Sillitoe (1980) as an alteration zone in mainly rhyolitic volcanic and volcaniclastic rocks associated with a hornblendebiotite granodiorite of probable Cretaceous age. The location of this prospect could not be confirmed, but it was reportedly drilled in the 1970s.

The southwestern corner of South Korea (Jeollanam- $\mathrm{do}^{5}$ Province and Gasa Island, figs. 8, K3) host epithermal goldsilver veins in clay deposits (advanced argillic alteration) associated with Cretaceous tuffs, rhyolites, and andesite (Eunsun (Silver Hill), Moisan deposits); these do not appear to have any association with porphyry copper deposits. Mining at Eunsun ceased in 2004. Exploration in the area from about 2003 to 2004 failed to discover additional high-grade precious metal veins (Asia Gold Corp., 2004).

\section{Exploration History}

The Korea Mining Promotion Corporation and other groups explored for porphyry copper and molybdenum deposits in the 1970s (Sillitoe, 1980). A few prospects were drilled, and geophysical and geochemical surveys were done. In 2009, the Korean Institute of Geoscience and Mineral Resources (KIGAM, previously called the Korea Institute of Geology, Mining and Materials) (KIGAM, 2012) initiated a 3-year domestic exploration project for epithermal gold deposits in hydrothermally altered Cretaceous volcanic rocks in Jeollanam-do Province, southwesternmost South Korea (fig. K3). KIGAM is also doing an assessment of domestic reserves of metallic mineral resources that includes streamsediment surveys and drilling for extensions of tungsten skarns in Gangwon-do Province (fig. K3) (KIGAM, 2011).

\section{Sources of Information}

Table K4 lists the sources of information used in the assessment.

\section{Qualitative Assessment}

Although Cretaceous continental margin arcs host significant porphyry copper deposits in many parts of the word, the Gyeongsang Basin area has not proven to be prospective for the deposit type. The basin preserves permissive rocks in volcanoplutonic complexes. However, existing data suggest that the uplift and erosion that accompanied basin inversion may have eroded any porphyry systems, if they ever existed. None of the available data suggest that undiscovered porphyry copper deposits that would have grades and tonnages described by the global models used for this assessment are likely to be present within the upper kilometer of the surface. Therefore, no estimate of numbers of undiscovered deposits was made. 


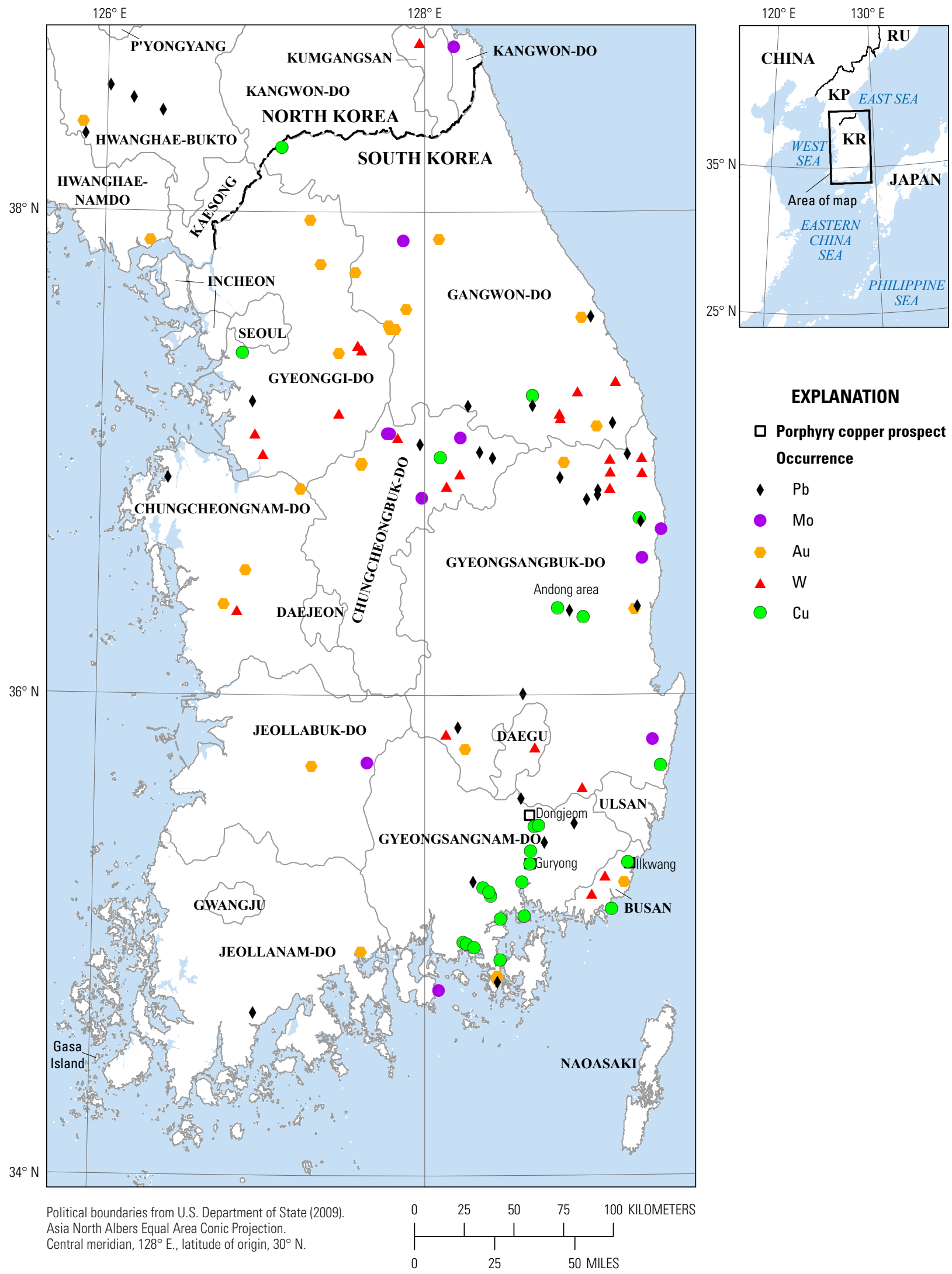

Figure K3. Map showing the distribution of copper, molybdenum, gold, tungsten and lead occurrences in South Korea. See table K4 for data sources. RU, Russia; JP, Japan; KP, Democratic People's Republic of Korea (North Korea); KR, Republic of Korea (South Korea). 
Table K4. Principal sources of information used for tract 142pCu7313, Gyeongsang Basin Area-Republic of Korea (South Korea).

[NA, not applicable]

\begin{tabular}{|c|c|c|c|}
\hline Theme & Name or title & Scale & Citation \\
\hline \multirow[t]{3}{*}{ Geology } & Geological map of Korea & $1: 1,000,000$ & $\begin{array}{l}\text { Korea Institute of Geology, Mining and } \\
\text { Materials (1995a) }\end{array}$ \\
\hline & Isotope age map of plutonic rocks in Korea & $1: 1,000,000$ & $\begin{array}{l}\text { Korea Institute of Geology, Mining and } \\
\text { Materials (1995b) }\end{array}$ \\
\hline & $\begin{array}{l}\text { Late Cretaceous volcanic rocks and associated granites } \\
\text { in Gyeongsang Basin, SE Korea }\end{array}$ & NA & Zhang and others (2012) \\
\hline \multirow{4}{*}{$\begin{array}{l}\text { Mineral } \\
\text { occurrences }\end{array}$} & Metallogenic map of Korea & $1: 1,000,000$ & Hwang and Kim (1983) \\
\hline & $\begin{array}{l}\text { U.S. Geological Survey On-Line Mineral Resources } \\
\text { Spatial Data }\end{array}$ & NA & U.S. Geological Survey (2012) \\
\hline & $\begin{array}{l}\text { Evidence for porphyry-type mineralization in } \\
\text { South Korea }\end{array}$ & NA & Sillitoe (1980) \\
\hline & $\begin{array}{l}\text { Mineralization characteristics and structural controls } \\
\text { of hydrothermal deposits in the Gyeongsang Basin, } \\
\text { South Korea }\end{array}$ & NA & Koh and others (2003) \\
\hline Exploration & $\begin{array}{l}\text { Evidence for porphyry-type mineralization in } \\
\text { South Korea }\end{array}$ & NA & Sillitoe (1980) \\
\hline
\end{tabular}

\section{References Cited}

Asia Gold Corporation, 2004, Management's discussion and analysis of financial condition and results of operation: Asia Gold report dated March 31, 2004, 8 p.

Berger, B.R., Ayuso, R.A., Wynn, J.C., and Seal, R.R., 2008, Preliminary model of porphyry copper deposits: U.S. Geological Survey Open-File Report 2008-1321, 55 p., accessed May 15, 2009, at http://pubs.usgs.gov/ of/2008/1321/.

Chough, S.K., Kwon, S.-T., Ree, J.-H., and Choi, D.K., 2000, Tectonic and sedimentary evolution of the Korean peninsula - A review and new view: Earth-Science Reviews, v. 52, p. 175-235.

Cox, D.P., 1986, Descriptive model of porphyry $\mathrm{Cu}$, in Cox, D.P., and Singer, D.A., eds., 1986, Mineral deposit models: U.S. Geological Survey Bulletin 1693, p. 76. (Also available at http://pubs.usgs.gov/bul/b1693/.)
Fletcher, C.J.N., 1977, The geology, mineralization, and alteration of Ilkwang Mine, Republic of Korea-A Cu-Wbearing tourmaline breccia pipe: Economic Geology, v. 72, p. 753-768.

Hwang, D.H., and Kim, S.E., 1983, Metallogenic map of Korea: Seoul, Korea Institute of Energy and Resources, scale 1:1000,000.

John, D.A., Ayuso, R.A., Barton, M.D., Blakely, R.J., Bodnar, R.J., Dilles, J.H., Gray, Floyd, Graybeal, F.T., Mars, J.C., McPhee, D.K., Seal, R.R., Taylor, R.D., and Vikre, P.G., 2010, Porphyry copper deposit model, chap. B of Mineral deposit models for resource assessment: U.S. Geological Survey Scientific Investigations Report 2010-5070-B, 169 p., accessed September 8, 2010, at http://pubs.usgs.gov/ $\operatorname{sir} / 2010 / 5070 / \mathrm{b} /$.

Kamitani, M., Okumura, K., Teraoka, Y., Miyano, S., and Watanabe, Y., 2007, Mineral resources map of East Asia: Geological Survey of Japan, AIST, 2 sheets and explanatory notes, scale 1:3,000,000. 
Koh, Sang-Mo, Ryoo, Chung-Ryul, and Song, Min-Sub, 2003, Mineralization characteristics and structural controls of hydrothermal deposits in the Gyeongsang Basin, South Korea: Resource Geology, v. 53, no. 3, p. 175-192.

Korea Institute of Geology, Mining and Materials (KIGAM), 1995a, Geological map of Korea: Taejeon, Korea, KIGAM, scale 1:1,000,000. [In Korean and English.]

Korea Institute of Geology, Mining and Materials (KIGAM), 1995b, Isotope age map of volcanic rocks in Korea: Taejeon, Korea, KIGAM, scale 1:1,000,000. [In Korean and English.]

Korea Institute of Geology, Mining and Materials (KIGAM), 1995 c, Isotope age map of plutonic rocks in Korea: Taejeon, Korea, KIGAM, scale 1:1,000,000. [In Korean and English.]

Korea Institute of Geology, Mining and Materials (KIGAM), 1995d, Isotope age map of ore deposits in Korea:

Taejeon, Korea, KIGAM, scale 1:1,000,000. [In Korean and English.]

Korea Institute of Geosciences and Mineral Resources (KIGAM), 2012, KIGAM: KIGAM Web site: accessed May 1, 2012, at http://www.kigam.re.kr/.

Korea Institute of Geosciences and Mineral Resources (KIGAM), 2011, Annual Report 2011: KIGAM, accessed May 1, 2012, at http://www.kigam.re.kr/Contents/ mboard.asp?strBoardID=B028.

Lim, H.S., and Lee, Y.I., 2005, Cooling history of the Upper Cretaceous Palgongsan granite, Gyeongsang Basin, SE Korea and its tectonic implication for uplift on the active continental margin: Tectonophysics, v. 403, p. 151-165.
Maruyama, Shigenori, Isozaki, Yukio, Kimura, Gaku, and Taerbayshi, Masuru, 1997, Paleogeographic maps of the Japanese Islands-Plate tectonic synthesis from $750 \mathrm{Ma}$ to the present: The Island Arc, v. 6, p. 121-142.

Sagong, Hee, Kwon, Sung-Tack, and Ree, Jin-Han, 2005, Mesozoic episodic magmatism in South Korea and its tectonic implication: Tectonics, v. 24, p. 1-18.

Sillitoe, R.H., 1980, Evidence for porphyry-type mineralization in South Korea: Mining Geology Special Issue 8, p. 205-214.

So, C.S., Choi, S.H., and Shelton, K.L., 1997, Geochemistry and genesis of hydrothermal $\mathrm{Cu}$ deposits in the Gyeongsang Basin (Andong Area), Korea-A link between porphyry and epithermal systems: Neues Jahrbuch für Mineralogie Abhandlungen v. 171, no. 3, p. 281-307.

U.S. Department of State, 2009, Small-scale digital international land boundaries (SSIB) - Lines, edition 10, and polygons, beta edition 1, in Boundaries and sovereignty encyclopedia (B.A.S.E.): U.S. Department of State, Office of the Geographer and Global Issues.

Woulfe Mining Corp., 2012, Sangdong: Woulfe Mining Corp. Web site, accessed November 27, 2012, at http://www.woulfemining.com/s/Sangdong.asp.

Yang, Kyounghee, and Bodnar, R.J., 2004, Orthomagmatic origin for the Ilkwang $\mathrm{Cu}-\mathrm{W}$ breccia-pipe deposits, southeastern Kyongsang Basin, South Korea: Journal of Asian Earth Sciences, v. 24, p. 259-270.

Zhang, Yan-Bin, Zhai, M., Hou, Q.-L., Li, T.-SA., Liu, F., and Hu, B., 2012, Late Cretaceous volcanic rocks and associated granites in Gyeongsang Basin, SE Korea-Their chronological ages and tectonic implications for cratonic destruction of the North China craton: Journal of Asian Earth Sciences, v. 47 , p. 252-264. 
This page left intentionally blank. 


\section{Appendix L. Porphyry Copper Assessment for Tract 142pCu7314, Western Honshu Area-Japan}

By Yashushi Watanabe' with contributions from Dennis Cox ${ }^{2}$, Jane M. Hammarstrom², and Michael DeMarr ${ }^{3}$

\section{Deposit Type Assessed: Porphyry copper}

Descriptive model: Porphyry copper (Cox, 1986; John and others, 2010)

Table L1 summarizes selected assessment results.

Table L1. Summary of selected resource assessment results for tract 142pCu7314, Western Honshu Area-Japan.

[km, kilometers; $\mathrm{km}^{2}$, square kilometers; $\mathrm{t}$, metric ton; NA, not applicable]

\begin{tabular}{|c|c|c|c|c|c|}
\hline $\begin{array}{c}\text { Date of } \\
\text { assessment }\end{array}$ & $\begin{array}{l}\text { Assessment depth } \\
(\mathrm{km})\end{array}$ & Tract area $\left(\mathbf{k m}^{2}\right)$ & $\begin{array}{l}\text { Identified copper } \\
\text { resources }(t)\end{array}$ & $\begin{array}{l}\text { Mean estimate of } \\
\text { undiscovered copper } \\
\text { resources }(t)\end{array}$ & $\begin{array}{l}\text { Median estimate of } \\
\text { undiscovered copper } \\
\text { resources }(t)\end{array}$ \\
\hline 2005 & 1 & 27,600 & 0 & NA & NA \\
\hline
\end{tabular}

\section{Location}

Western Honshu Island.

\section{Geologic Feature Assessed}

Cretaceous to Paleogene calc-alkalic magnetite-series igneous rocks that formed part of the continental arc along the East Asia craton margin.

${ }^{1}$ Geological Survey of Japan, National Institute of Advanced Industrial Science and Technology (AIST), Ibaraki, Japan.

${ }^{2}$ U.S. Geological Survey, Menlo Park, California, United States.

${ }^{3}$ U.S. Geological Survey, Reston, Virginia, United States. 

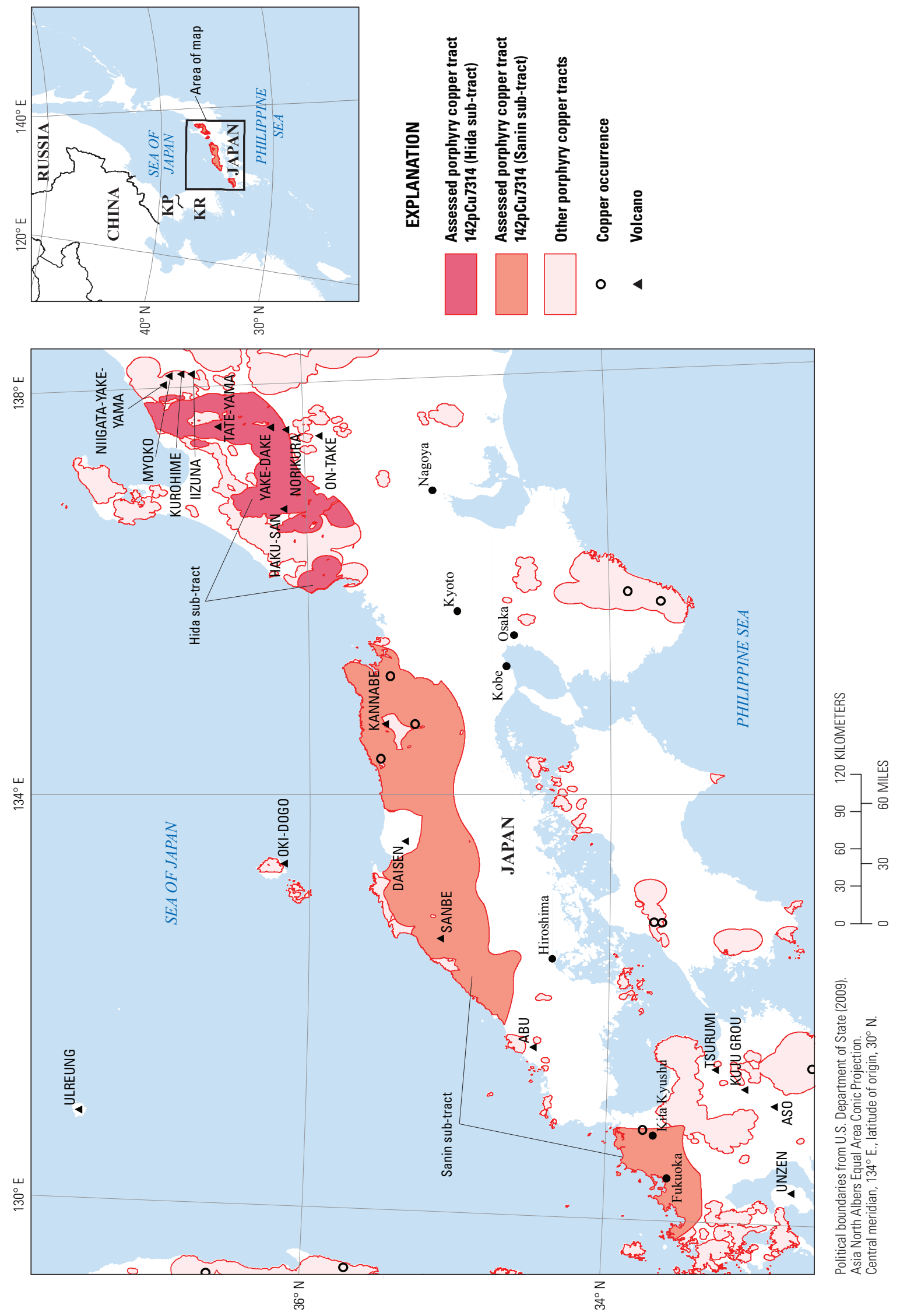

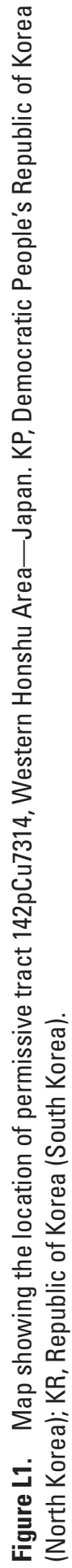




\section{Delineation of the Permissive Tract}

\section{Tectonic Setting}

Japan was part of an active Cretaceous Andean-type continental margin along East Asia that encompassed what is now southeastern China, western Japan, and the SikhoteAlin area of Russia (fig. $9^{4}$ ). Subduction of the (now extinct) Izanagi Plate (fig. 10A) brought the paleo-Pacific Plate into contact with proto-Japan. Subsequently, an extensional regime developed along the northern Asian continental margin in Eocene time as convergence rates decreased. Continued extension led to the Miocene opening of the Japan Sea as a back-arc basin and resulted in a separation of Japan from the continent. Clockwise rotation of southwestern Japan and counterclockwise rotation of northeastern Japan in the Miocene led to the modern configuration of the archipelago (fig. 10B), which is situated on four different tectonic plates: Eurasia, Okhotsk (North America), the Philippine Sea Plate, and the Pacific Sea Plate (Maruyama and others, 1997). The Japan Arc evolved from a Cretaceous Eurasian continental margin arc through a continental rifting stage (approximately $24 \mathrm{Ma}$ ), followed by an arc rifting stage (16-13 Ma) to the modern island arc (less than $14 \mathrm{Ma}$ ). The tract delineates Cretaceous and Paleogene granitoids and volcanic rocks that formed when Japan was part of the Eurasian continental margin.

\section{Geologic Criteria}

The tract delineates a permissive area for porphyry copper deposits consisting of Cretaceous to Paleogene calc-alkalic magnetite-series granodiorite and granite, as depicted on geologic maps of Japan (Yamada and others, 1990; Ishihara and others, 1992). This tract is large having dimensions of about 70 by $600 \mathrm{~km}$, and is separated into the eastern Hida and western Sanin segments by the Sea of Japan (fig. L1). The eastern margin of the tract is cut by the Itoigawa-Shizuoka tectonic line (ISTL on fig. 12A), a major fault that separates tectonic provinces (Ishihara and others, 1992). The tract is part of the Cretaceous to Paleogene Inner Zone Southwest Japan metallogenic belt (Nokleberg and others, 2004). The belt is interpreted as forming during the generation of granitoids along the East Asia magmatic arc related to subduction of the Kula and Pacific Plates. Mineral deposits in the belt are interpreted as forming during siliceous granitoid magmatism.

The permissive tract was constructed by selecting Cretaceous to Eocene igneous rocks from a digital version of the 1:1,000,000-scale geologic map of Japan (fig. L2, table L2).
A 10-km buffer was created around intrusive rocks, and a $2-\mathrm{km}$ buffer was created around volcanic rocks. These distances are considered appropriate to allow for inaccuracies in mapped contacts and extensions under adjacent cover rock. The buffered map polygons were edited by hand to restrict the tract to areas of magnetite-series rocks west of the ItoigawaShizuoka tectonic line.

The 65- to 30-Ma host granitoids in the Sanin sub-tract (figs. L1, L2) have initial strontium isotope ratios of 0.704 to 0.706 . The granitoids consist of magnetite-series granite and granodiorite associated with rhyolite-dacite lava and felsic pyroclastic rock (Rezanov and others, 1994). Some of the granitoids are associated with cauldrons and intense sericitic and pyrophyllitic hydrothermal alteration (Imaoka and others, 2001). The granitoids associated with polymetallic vein deposits or occurrences in the eastern part of the Sanin segment are quartz diorite, granodiorite, and biotite granite whereas granitoids associated with molybdenum-tungsten vein and skarn deposits in the Hida and Sanin segments are biotite granite and granodiorite that are rich in mafic enclaves (Ishihara, 2002b). The exception is a stock in the Shirakawa region of molybdenum-mineralized granitoids (fig. L2) in Gifu Prefecture, where the Mirase molybdenite deposit occurs (Ishihara and Tani, 2004). The high concentration of molybdenum in the Hirase stock is attributed to a high degree of magmatic fractionation that produced $\mathrm{MoS}_{2}$-rich residual melts (Ishihara and Tani, 2004).

The Hida sub-tract (fig. L1) corresponds to the Hida belt of basement rock that consists of high-grade gneiss that is intruded by granitoids. This segment is intruded by latest Cretaceous to Paleogene magnetite-series granites and granodiorites and overlain by granitoids that are associated with rhyolite and andesite volcanic rock (Harayama, 1988).

The Sanin sub-tract corresponds to basement belts that represent several pre-Jurassic accretionary prisms (Isozaki, 1997). Late Cretaceous (79-58 Ma) andesite and rhyolite lavas and pyroclastic rock (Ishihara, 2002a), and latest Cretaceous to Paleogene (68-30 Ma) magnetite-series granitoids are present along the southern margin of the Sanin sub-tract (Rezanov and others, 1994; Ishihara, 2002a, b). Early Miocene tholeiitic volcanic rock that erupted in a rift graben (Inoue, 1994), Pliocene-Pleistocene sedimentary rocks (Uno, 1994), and Pliocene-Quaternary volcanic rocks (Uto and others, 1994) overlie the permissive ricks that define the Sanin sub-tract. The formation of the rift graben is interpreted to be related to spreading in the Sea of Japan.

\section{Known Deposits}

None. 

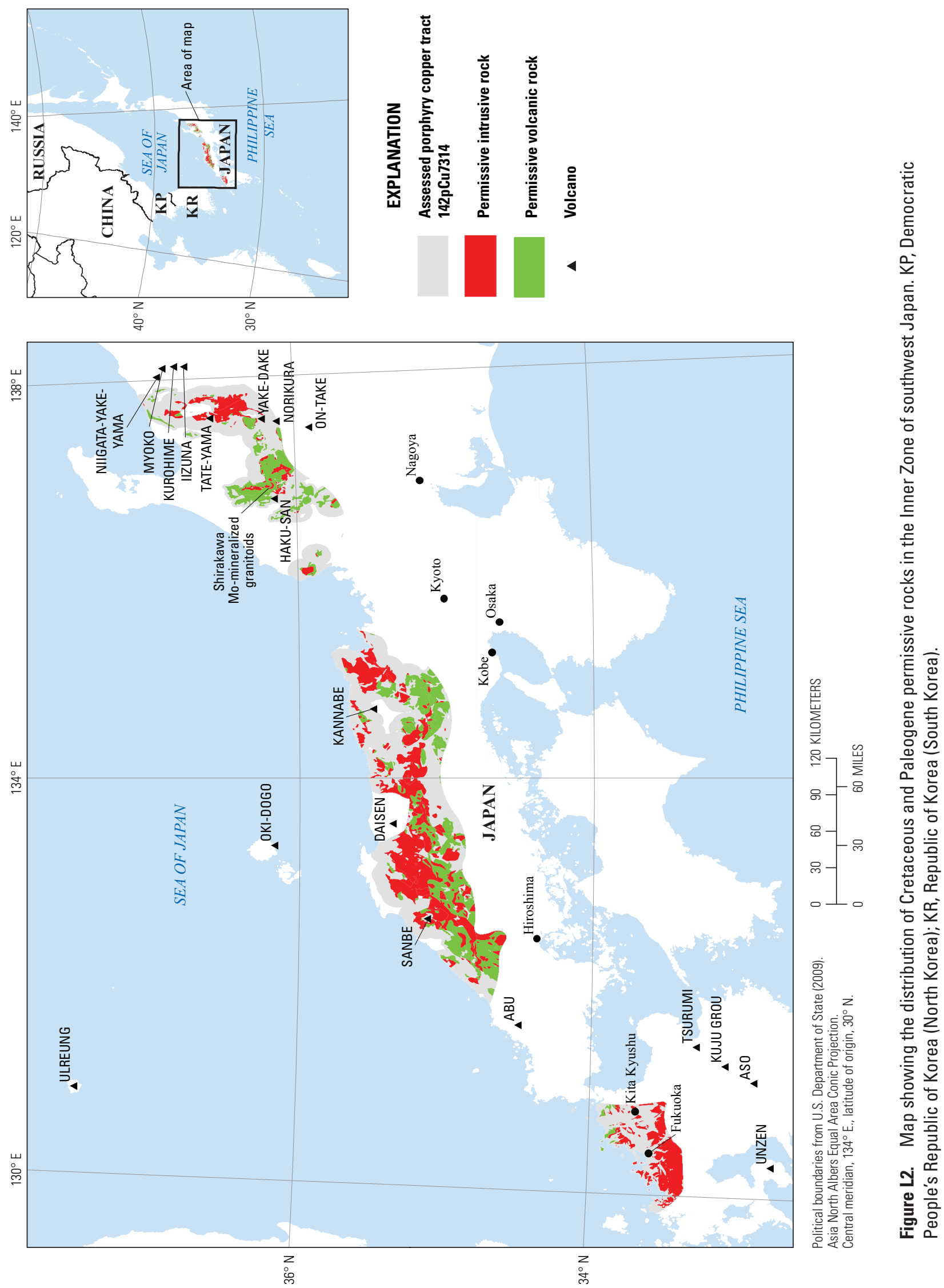
Table L2. Map units that define tract 142pCu7314, Western Honshu Area—Japan.

[Map unit, age range, and principal lithologies are based the 1995 digital geologic map of Japan. Felsic rocks predominate over mafic rocks; mafic rocks are spatially associated with felsic rocks at the 1:1,000,000 map scale]

\begin{tabular}{lll}
\hline \multicolumn{1}{c}{ Map unit } & \multicolumn{1}{c}{ Lithology } & \multicolumn{1}{c}{ Intrusive rocks } \\
\hline K1 & felsic, mafic intrusive rocks & Early Cretaceous \\
K1-K2 & felsic, mafic intrusive rocks & Early and Late Cretaceous \\
K2 & felsic, mafic intrusive rocks & Late Cretaceous \\
PG1 & felsic, mafic intrusive rocks & Paleocene to early Eocene \\
PG2 & felsic, mafic intrusive rocks & Eocene \\
PG3 & felsic, mafic intrusive rocks & Late Eocene to early Oligocene \\
PG4 & felsic, mafic intrusive rocks & Late Oligocene to early Miocene \\
\hline & & \\
\hline K1 & folcanic rocks & \\
K1-K2 & felsic, mafic volcanic rocks & Early Cretaceous \\
K2 & felsic, mafic volcanic rocks & Early and Late Cretaceous \\
PG1 & felsic, mafic volcanic rocks & Late Cretaceous \\
PG2 & felsic, mafic volcanic rocks & Paleocene to early Eocene \\
PG3 & felsic, mafic volcanic rocks & Eocene \\
PG4 & felsic, mafic volcanic rocks & Late Eocene to early Oligocene \\
\hline
\end{tabular}

\section{Prospects, Mineral Occurrences, and Related Deposit Types}

No porphyry copper prospects are known in the tract area. Other types of deposits known within the tract include molybdenum deposits (48-65 Ma) and lead-zinc-silver vein and skarn deposits (Ishihara and others, 1988). The largest metallic deposit in the tract is the Kamioka (fig. 8) clinopyroxene skarn with sphalerite, galena, chalcopyrite, magnetite, pyrite, and pyrrhotite, and minor molybdenite and scheelite.

The tract also includes an antimony vein deposit, a few gold-silver mesothermal vein deposits, and four major sericite and pyrophyllite deposits that are hosted in granite (Sudo and Murao, 2004).

\section{Exploration History}

The tract has been explored in detail for more than 1,000 years. Shallow drilling, to about $100 \mathrm{~m}$, has occurred in and around sericite mines, and to $500 \mathrm{~m}$ at other types of mines. The Metal Mining Agency of Japan conducted exploration projects for lead and zinc skarn deposits in Hida (fig. 8) and in other areas. Many detailed geologic, geochemical and geophysical studies have been conducted at scales of 1:50,000 and larger.

\section{Sources of Information}

Principal sources of information used by the assessment team for delineation of $142 \mathrm{pCu} 7314$ are listed in table L3.

\section{Qualitative Assessment}

Qin and Ishihara (1998) discussed the potential for porphyry copper deposits in Japan and concluded that although such deposits could possibly exist, the absence of thick crust, an extensional setting that produced volcanogenic massive sulfide deposits rather than a compressional setting that would favor porphyry formation, low copper abundance in granitoids, and the overall low percentages of magnetite-series relative to ilmenite-series granitoids compared with productive arcs elsewhere, all are negative factors for porphyry systems. They suggested that the most likely target areas are volcanoplutonic magnetite series rocks in uplifted areas of the Inner Zone of southwestern Japan.

The lack of porphyry copper deposits most likely reflects the fact that the oxygen and sulfur fugacities of magnetiteseries magmas in Japan were not high enough to form porphyry copper deposits, as shown by Takagi and Tsukimura (1997) and Takagi (2004) based on considerations of volatile compositions of source magmas.

This assessment was developed by the Geological Survey of Japan in consultation with the U.S. Geological Survey. The Assessment Team chose not to record an estimate of the number of undiscovered porphyry copper deposits in the tract because the available data do not support the assumption that undiscovered porphyry copper deposits are likely to be present within the upper kilometer of the surface that would have grades and tonnages described by the global models used for this assessment. 
Table L3. Principal sources of information used for tract 142pCu7314, Western Honshu Area-Japan.

[NA, not applicable]

\begin{tabular}{|c|c|c|c|}
\hline Theme & Name or title & Scale & Citation \\
\hline \multirow[t]{3}{*}{ Geology } & Computer-generated geologic map of Japan & $1: 1,000,000$ & Yamada and others (1990) \\
\hline & Geological map of Japan (digital) & $1: 1,000,000$ & Geological Survey of Japan (1995) \\
\hline & Regional geology of Japan & $1: 1,000,000$ & Karakida and others (1992) \\
\hline \multirow[t]{8}{*}{$\begin{array}{l}\text { Mineral } \\
\text { occurrences }\end{array}$} & $\begin{array}{l}\text { Geology, geochemistry, and origin of high sulfidation } \\
\mathrm{Cu}-\mathrm{Au} \text { mineralization in the Nansatsu district, Japan. }\end{array}$ & NA & Hedenquist and others (1994) \\
\hline & Metallogenic map of Japan & $1: 2,000,000$ & Ishihara and others (1992) \\
\hline & Ore deposits related to granitic magmatism in Japan. & NA & Ishihara and Sasaki (1991) \\
\hline & $\begin{array}{l}\text { Overview of epithermal gold mineralization in Kyushu, } \\
\text { Japan. }\end{array}$ & NA & Izawa and Watanabe (2001) \\
\hline & Geologic setting of the Kuroko deposits, Japan. & NA & Ohmoto and others (1983) \\
\hline & Mineral resources map of Tohoku & $1: 500,000$ & Sudo and Igarashi (1997) \\
\hline & Mineral resources map of Tohoku & $1: 500,000$ & Sudo and Morao (2004) \\
\hline & $\begin{array}{l}\text { U.S. Geological Survey On-Line Mineral Resources } \\
\text { Spatial Data }\end{array}$ & NA & U.S. Geological Survey (2012) \\
\hline Geochemistry & Unpublished data & NA & $\begin{array}{l}\text { Geological Survey of Japan Assessment Team, } \\
\text { this report }\end{array}$ \\
\hline \multirow[t]{2}{*}{ Exploration } & Unpublished data & NA & $\begin{array}{l}\text { Geological Survey of Japan Assessment Team, } \\
\text { this report }\end{array}$ \\
\hline & $\begin{array}{l}\text { Korea Institute of Geosciences and Mineral Resources } \\
\text { (KIGAM) Web site }\end{array}$ & NA & $\begin{array}{l}\text { Korea Institute of Geosciences and Mineral } \\
\text { Resources (KIGAM) (2012) }\end{array}$ \\
\hline
\end{tabular}

\section{References Cited}

Cox, D.P., 1986, Descriptive model of porphyry $\mathrm{Cu}$, in Cox, D.P. and Singer, D.A., eds., Mineral deposit models: U.S. Geological Survey Bulletin 1693, p. 76. (Also available at http://pubs.usgs.gov/bul/b1693/.)

Geological Survey of Japan, ed., 1995, Geological map of Japan 1:1,000,000, (3d ed.): Geological Survey of Japan Digital Geoscience Map G-1, scale 1:1,000,000, 2nd CD-ROM version.

Harayama, S., 1988, Cretaceous to Paleogene granitic rocks in the Hida Mountain Range, in Uemura, T. and Yamada, T., eds., Regional Geology of Japan, Part 4, Chubu I Kyoritsu: Tokyo, Shuppan Co., Ltd., p. 30-32. [In Japanese.]

Hedenquist, J.W., Matsuhisa, Y., Izawa, E., White, N.C., Giggenbach, W.F., and Aoki, M., 1994, Geology, geochemistry, and origin of high sulfidation $\mathrm{Cu}-\mathrm{Au}$ mineralization in the Nansatsu district, Japan: Economic Geology, v. 89, p. $1-30$.
Imaoka, T., Nakashima, K., Itaya, T. and Okada, T., 2001, Timing and duration of hydrothermal activity in the Oligocene Hamada Cauldron, SW Japan-Evidence from K-Ar ages of sericite: Resource Geology, v. 51, p. 55-62.

Inoue, T., 1994, Reconstruction of a volcano from the early Miocene Ito volcanic rocks, Arashima Basin, western Japan: Journal of the Geological Society of Japan, v. 100, no. 8, p. 600-617. [In Japanese, English abstract.]

Ishihara, S., 2002a, Chemical characteristics of the mineralized granitoids (II)-Polymetallic province of the west-central Hyogo Prefecture, Japan: Bulletin of the Geological Survey of Japan, v. 53, p. 673-688. [In Japanese, English abstract.]

Ishihara, S., 2002b, Chemical characteristics of the mineralized granitoids (I) - Mo and W provinces of the Inner Zone of Southwest Japan: Bulletin of the Geological Survey of Japan, v. 53, p. 657-672. [In Japanese, English abstract.]

Ishihara, S., and Sasaki, A., 1991, Ore deposits related to granitic magmatism in Japan-A magmatic viewpoint: Episodes, v. 14, p. 286-292. 
Ishihara, S., Sasaki, A. and Sato, K., 1992, Metallogenic map of Japan, plutonism and mineralization (vol. 2) - Cretaceous-Tertiary: Geological Survey of Japan Map Series no. 15-2, scale 1:2,000,000.

Ishihara, S., Shibata, K. and Uchiumi, S., 1988, K-Ar ages of ore deposits related to Cretaceous-Paleogene granitoidsSummary in 1987: Geological Survey of Japan Bulletin, v. 39 , no. 2 , p. $81-84$.

Ishihara, S. and Tani, K., 2004, Magma mingling/mixing vs. magmatic fractionation-Genesis of the Shirakawa Momineralized granitoids, central Japan: Resource Geology, v. 54, p. 373-382.

Isozaki, Y., 1997, Contrasting two types of orogen in PermoTriassic Japan-Accretionary versus collisional: Island Arc, v. 6 , p. $2-24$.

Izawa, E., and Watanabe, K., 2001, Overview of epithermal gold mineralization in Kyushu, Japan: Society of Economic Geologists Guidebook Series, v. 34, p. 11-15.

John, D.A., Ayuso, R.A., Barton, M.D., Blakely, R.J., Bodnar, R.J., Dilles, J.H., Gray, Floyd, Graybeal, F.T., Mars, J.C., McPhee, D.K., Seal, R.R., Taylor, R.D., and Vikre, P.G., 2010, Porphyry copper deposit model, chap. B of Mineral deposit models for resource assessment: U.S. Geological Survey Scientific Investigations Report 2010-5070-B, 169 p., accessed September 8, 2010, at http://pubs.usgs.gov/ $\operatorname{sir} / 2010 / 5070 / \mathrm{b} /$.

Karakida, Y., Hayasaka, S., and Hase, Y., eds., 1992, Regional Geology of Japan, part 9: Kyushu: Tokyo, Kyoritsu Shuppan Co., Ltd., 371 p. [In Japanese.]

Maruyama, Shigenori, Isozaki, Yukio, Kimura, Gaku, and Taerbayshi, Masuru, 1997, Paleogeographic maps of the Japanese Islands_-Plate tectonic synthesis from 750 Ma to the present: The Island Arc, v. 6, p. 121-142.

Nokleberg, W.J., Badarch, Gombosuren, Berzin, N.A., Diggles, M.F., Hwang, Duk Hwan, Khanchuk, A.I., Miller, R.J. Naumova, V.V., Obolenskiy, A.A., Ogasawara, Masatsugu, Parfenov, L.M., Prokopiev, A.V., Rodionov, S.M., and Hongquan, Yan, eds., 2004, Digital files for Northeast Asia geodynamics, mineral deposit location, and metallogenic belt maps, stratigraphic columns, descriptions of map units, and descriptions of metallogenic belts: U.S. Geological Survey Open-File Report 2004-1252 (CD-ROM). (Also available at http://pubs.usgs.gov/of/2004/1252/.)
Ohmoto, H, Tanimura, S., Date, J., and Takahashi, T., 1983, Geologic setting of the Kuroko deposits, Japan: Economic Geology Monograph 5, p. 9-54.

Qin, Kezhang, and Ishihara, Shunso, 1998, On the possibility of porphyry copper mineralization in Japan: International Geology Review, v. 40, no. 6, p. 539-551.

Rezanov, A. I., Kagami, H. and Iizumi S., 1994, Rb-Sr isochron ages of Cretaceous-Paleogene granitoids rocks in the central part of the Chugoku district, Southwest Japan: Journal of the Geological Society of Japan, v. 100, no. 9, p. 651-657. [In Japanese, English abstract.]

Sudo, S., and Igarashi T., 1997, Mineral resources map of Tohoku: Geological Survey of Japan, scale 1:2,000,000.

Sudo, S., and Murao, S., 2004, Mineral resources map of Chugoku Shikoku: Geological Survey of Japan, scale 1:500,000.

Takagi, Tetsuichi, 2004, Origin of magnetite- and ilmeniteseries granitic rocks in the Japan Arc: American Journal of Science, v. 304, p. 169-202.

Takagi, Tetsuichi, and Tsukitmura, Katsuhiro, 1997, Genesis of oxidized- and reduced-type granites: Economic Geology, v. 92 , p. $81-86$.

Uno, Y., 1994, Stratigraphy and distribution of rock facies of the Tsunozu Formation in the Gotsu-Yunotsu area, Shimane Prefecture: Journal of the Geological Society of Japan, v. 100, no. 11, p. 815-827. [In Japanese, English abstract.]

U.S. Department of State, 2009, Small-scale digital international land boundaries (SSIB) — Lines, edition 10, and polygons, beta edition 1, in Boundaries and sovereignty encyclopedia (B.A.S.E.): U.S. Department of State, Office of the Geographer and Global Issues.

U.S. Geological Survey, 2012, On-line mineral resources spatial data: U.S. Geological Survey Web site, accessed February 10, 2012, at http://mrdata.usgs.gov/.

Uto, K., Tagami, T., and Uchiumi, S., 1994, K-Ar and fissiontrack dating on volcanic rocks of Pliocene Teragi Group from eastern San'in region, Southwest Japan: Journal of the Geological Society of Japan, v. 100, no. 10, p. 787-798. [In Japanese, English abstract.]

Yamada, N., Saito, E., and Murata, Y., eds., 1990, Computergenerated geologic map of Japan: Geological Survey of Japan Map Series, no. 22, scale 1:2,000,000. [In Japanese.] 
This page left intentionally blank. 


\section{Appendix M. Porphyry Copper Assessment for Tract 142pCu7315, Subaerial Neogene Arcs of Japan}

By Yashushi Watanabe', with contributions from Dennis Cox², Takehiro Sakimoto', Jane M. Hammarstrom³, and Michael W. DeMarr ${ }^{3}$

\section{Deposit Type Assessed: Porphyry copper}

Descriptive model: Porphyry copper (Cox, 1986; John and others, 2010)

Table M1 summarizes selected assessment results.

Table M1. Summary of selected resource assessment results for tract 142pCu7315, Subaerial Neogene Arcs of Western Japan.

[km, kilometers; $\mathrm{km}^{2}$, square kilometers; $\mathrm{t}$, metric ton; NA, not applicable $]$

\begin{tabular}{cccccc}
\hline $\begin{array}{c}\text { Date of } \\
\text { assessment }\end{array}$ & $\begin{array}{c}\text { Assessment depth } \\
(\mathbf{k m})\end{array}$ & Tract area $\left(\mathbf{k m}^{2}\right)$ & $\begin{array}{c}\text { Identified copper } \\
\text { resources }(\mathbf{t})\end{array}$ & $\begin{array}{c}\text { Mean estimate of } \\
\text { undiscovered copper } \\
\text { resources }(\mathbf{t})\end{array}$ & $\begin{array}{c}\text { Median estimate of } \\
\text { undiscovered copper } \\
\text { resources }(\mathbf{t})\end{array}$ \\
\hline 2005 & 1 & 120,590 & 0 & NA & NA \\
\hline
\end{tabular}

\section{Location}

Most of Japan.

\section{Geologic Feature Assessed}

Subaerial parts of the Miocene and younger Kurile, Northeast Japan, Izu, Southwest Japan, and Ryukyu Arcs (fig. M1).

${ }^{1}$ Geological Survey of Japan, National Institute of Advanced Industrial Science and Technology (AIST), Ibaraki, Japan.

${ }^{2}$ U.S. Geological Survey, Menlo Park, California, United States.

${ }^{3}$ U.S. Geological Survey, Reston, Virginia, United States. 


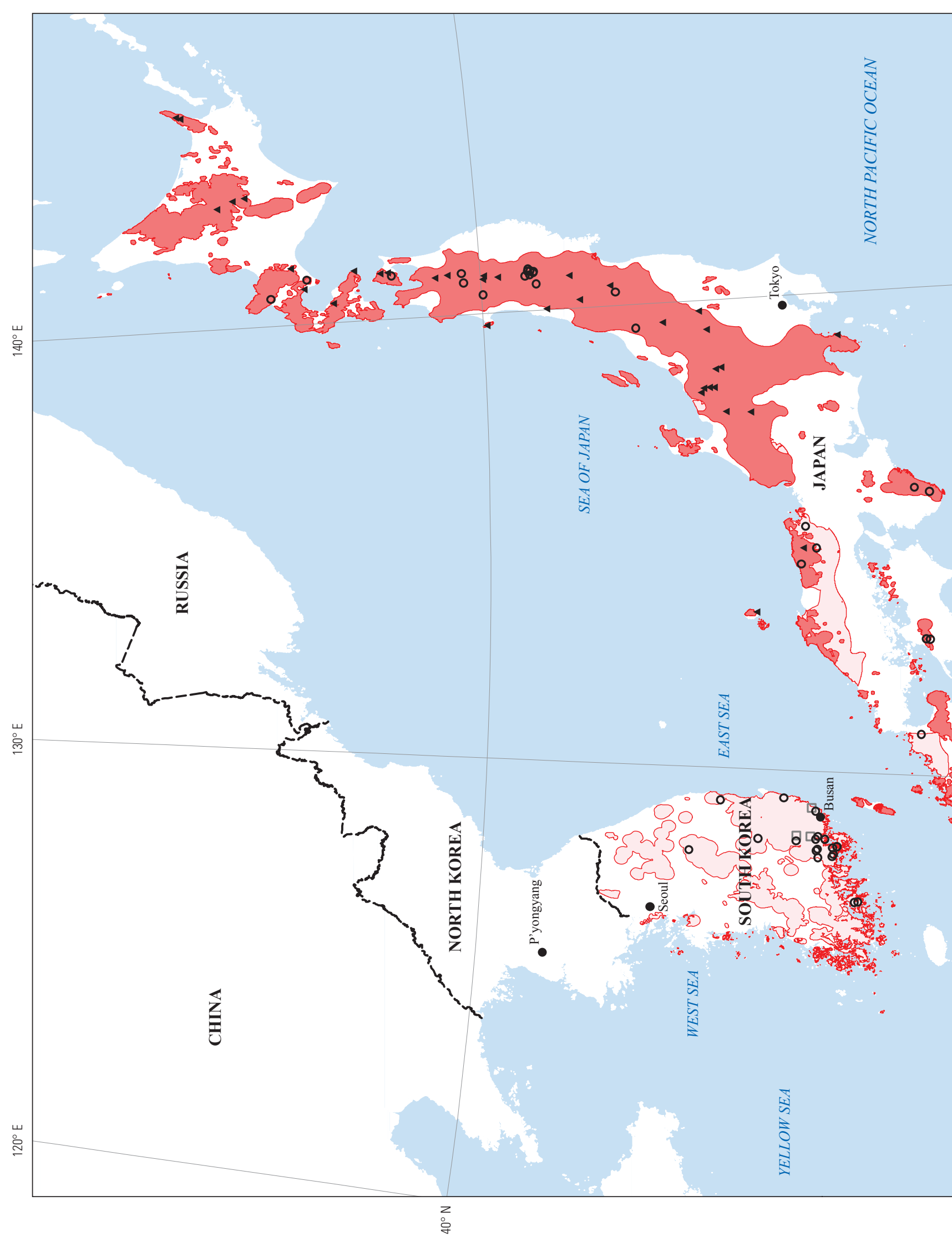




\section{Delineation of the Permissive Tract}

\section{Tectonic Setting}

The Neogene island arcs of Japan include the Japan Arc, the Ryukyu Arc, the Izu-Bonin Arc, and the Kurile Arc (fig. $2^{4}$ ). Rift-related bimodal arc volcanism accompanied the Miocene opening of the Sea of Japan, followed by subduction-related andesite-dacite volcanism starting in the late Miocene (Garwin and others, 2005). The northeastern and southwestern segments of the Japan Arc are separated by a fault zone (Itoigawa-Shizuoka tectonic line, ISTL on fig. 12A) that forms the boundary between the North American and Eurasian Plates (Garwin and others, 2005; Uyeda, 1991). The northeastern Japan Arc is related to subduction of the Pacific Plate beneath the North America Plate along the Japan Trench. The 1,800-km-long modern continental Japan Arc connects the Ryukyu Arc to the south with the Kurile Arc to the north (fig. 2B). The Ryukyu Arc resulted from subduction of the Philippine Sea Plate beneath Eurasia. The Kurile Arc formed by subduction of the Pacific Plate beneath the Okhotsk Plate along the Kurile Trench. The oceanic Izu-Bonin Arc results from northwestward subduction of the Pacific Plate along the Philippine Sea Plate (fig. 10B). During the middle Miocene, the Okhotsk (North America) continental block and the IzuBonin Arc collided with the Japan Arc. Most of the Izu-Bonin arc is submerged.

\section{Geologic Criteria}

The tract delineates the subaerial parts of the Miocene and younger-age Kurile, Northeast Japan, Izu, Southwest Japan, and Ryukyu Arcs, as depicted on the geologic map of Japan (Yamada and others, 1990). The tract is very large, about 1,800 km long by $100 \mathrm{~km}$ wide, and occurs in parts of Hokkaido Island, Northeast Japan, the Sanin district in Southwest Japan, and Kyushu Island (fig. M1).

The host rocks that are permissive for undiscovered deposits in the tract are Miocene to Quaternary volcanic rocks (fig. M2, table M2), including calc-alkaline andesite and dacite with minor rhyolite and basalt. The tract contains many Miocene and Pliocene shallow-level intrusions that are variable in size, ranging from a few meters to several kilometers in diameter. The shallow-level intrusions are generally fine-grained or porphyritic, and vary from andesite to rhyolite. Also occurring locally in the tract are late Miocene granitoid intrusions.

The permissive tract was constructed by selecting Miocene and younger igneous rocks from a digital version of the 1:1,000,000-scale geologic map of Japan. A 10-km buffer was created around intrusive rocks, and a 2-km buffer around volcanic rocks. These distances are considered appropriate to allow for inaccuracies in mapped contacts and extensions under adjacent cover rock. Volcanoes were not excluded from the tract; their locations are shown on fig. M2.

\section{Known Deposits}

None.

\section{Prospects, Mineral Occurrences, and Related Deposit Types}

Although no porphyry copper deposits or occurrences are known in the tract, abundant advanced argillic alteration occurs around late Miocene and Pliocene shallow intrusions in the Nagano and Kagoshima Prefectures (fig. 8). Many detailed geologic, geochemical, and geophysical studies have been conducted at a scale of 50,000 and larger. Porphyry granitoid systems probably are present beneath the epithermal deposits; some may contain copper. No porphyry molybdenum, porphyry tungsten, or porphyry tin deposits are known in Japan. The age range of host rocks for undiscovered deposits is middle Miocene to Quaternary.

The tract includes several metallogenic provinces that contain gold-silver epithermal vein, polymetallic and epithermal veins, sulfur-sulfide $\left(\mathrm{S}, \mathrm{FeS}_{2}\right)$, and related deposits (Nokleberg and others, 2004). Metallic mineral deposits of the Japan Arc include middle Miocene copper-lead-zinc (silvergold) Kuroko deposits and late Miocene to Pleistocene copperlead-zinc and gold-silver epithermal deposits (Watanabe, 2002). More than 40 Miocene, low-sulfidation epithermal gold and mercury deposits and prospects occur on northeast Hokkaido Island in the southwestern Kurile Arc. About 70 Kuroko deposits, including massive gypsum and barite deposits, occur in the 800-km-long Northeast Japan Arc (Sato, 1974). These 
deposits are associated with monogenetic rhyolite volcanism of the middle Miocene back-arc bimodal assemblage that formed in a submarine environment. A few middle (or early) Miocene epithermal gold-silver deposits in the Northeast Japan Arc are related to felsic volcanism (Watanabe, 1995, 1996, 2002). The metallic mineral deposits along the Izu Arc are Kuroko massive sulfide and epithermal gold-silver deposits. The northern end of the Ryukyu Arc hosts the Pliocene and Pleistocene Southern Kyushu epithermal low-sulfidation gold province.

\section{Exploration History}

The tract has been explored in detail for more than 400 years. Various epithermal gold-silver mines have been drilled at depths of hundreds to thousands of meters. Small volcanic islands in the middle and northeastern parts of the Kurile Arc have not been thoroughly explored. The middle and northeastern parts of the tract contain mainly polymetallic base-metal vein prospects of middle and late Miocene age and associated with intrusive rocks (Ishihara, 1994). The Metal Mining Agency of Japan conducted the following exploration projects in the tract (see fig. M2 for general locations): Northern Hokkaido area for gold (1989-2002), the Kunitomi area for base metals (1967-73), the Chitose area for gold (1978-86), the Shakotan area for base metals (1984-1988), the Southern Hokkaido area for gold (1998-2003), Kudo area for base metals (1977-86), the Oshima-Shimokita area for gold (1991-97), and the Northern Hidaka area for gold and rare metals (1992-96).

\section{Sources of Information}

Principal sources of information used by the assessment team for delineation of the tract are listed in table M3.

\section{Qualitative Assessment}

Well-developed, advanced argillic alteration occurs locally around late Miocene and Pliocene shallow intrusions in Japan. Many detailed studies of epithermal deposits are published at 1:50,000 and larger scales. Porphyry granitoid systems may be present beneath epithermal deposits and some may contain copper. No porphyry molybdenum, porphyry tungsten, or porphyry tin deposits are known in Japan.

This assessment was developed by geological surveys of local prefectures and by the Geological Survey of Japan in consultation with the U.S. Geological Survey. The Assessment Team chose not to record an estimate of the number of undiscovered porphyry copper deposits in the tract because the available data do not support the assumption that undiscovered porphyry copper deposits are likely to be present within the upper kilometer of the surface that would have grades and tonnages described by the global models used for this assessment. 


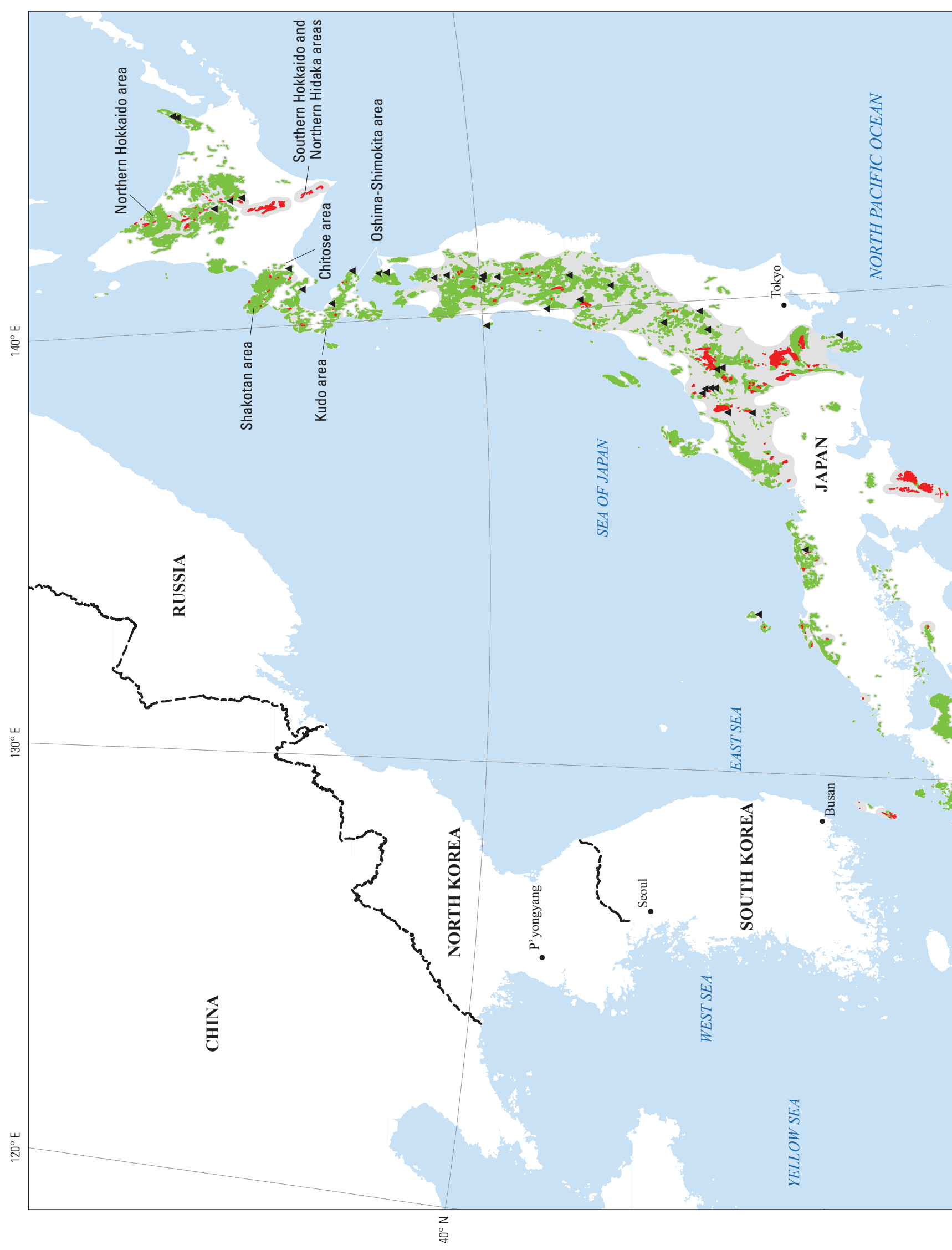


Table M2. Map units that define tract 142pCu7315, Subaerial Neogene Arcs of Western Japan.

[Map unit, age range, and principal lithologies are based the 1995 digital geologic map of Japan]

\begin{tabular}{lll}
\hline \multicolumn{1}{c}{ Map unit } & \multicolumn{1}{c}{ Lithology } & \multicolumn{1}{c}{ Age range } \\
\hline N1 & \multicolumn{1}{c}{ Intrusive rocks } \\
N2 & felsic, mafic intrusive rocks & Miocene \\
N3 & felsic, mafic intrusive rocks & Miocene \\
\hline \multicolumn{1}{c}{ felsic, mafic intrusive rocks } & Late Miocene to Pliocene \\
\hline N1 & \multicolumn{1}{c}{ Volcanic rocks } \\
N2 & felsic, mafic volcanic rocks & Miocene \\
N3 & felsic, mafic volcanic rocks & Miocene \\
Q1, Q2, Q3 & felsic, mafic volcanic rocks & Late Miocene to Pliocene \\
& felsic, mafic volcanic rocks; pyroclastic & Pleistocene \\
\hline
\end{tabular}

Table M3. Principal sources of information used for tract 142pCu7315, Subaerial Neogene Arcs of Western Japan.

[NA, not applicable]

\begin{tabular}{|c|c|c|c|}
\hline Theme & Name or title & Scale & Citation \\
\hline \multirow[t]{3}{*}{ Geology } & Computer-generated geologic map of Japan & $1: 1,000,000$ & Yamada and others (1990) \\
\hline & Geological map of Japan (digital) & $1: 1,000,000$ & Geological Survey of Japan (1995) \\
\hline & Regional geology of Japan & $1: 1,000,000$ & Karakida and others (1992) \\
\hline \multirow[t]{11}{*}{$\begin{array}{l}\text { Mineral } \\
\text { occurrences }\end{array}$} & $\begin{array}{l}\text { Geology, geochemistry, and origin of high sulfidation } \\
\mathrm{Cu}-\mathrm{Au} \text { mineralization in the Nansatsu district, Japan }\end{array}$ & NA & Hedenquist and others (1994) \\
\hline & Metallogenic map of Japan & $1: 2,000,000$ & Ishihara and others (1992) \\
\hline & Ore deposits related to granitic magmatism in Japan & NA & Ishihara and Sasaki (1991) \\
\hline & $\begin{array}{l}\text { Overview of epithermal gold mineralization in Kyushu, } \\
\text { Japan. }\end{array}$ & NA & Izawa and Watanabe (2001) \\
\hline & Mineral resources map of Kyushu & $1: 500,000$ & Sudo and others (2003) \\
\hline & Geologic setting of the Kuroko deposits, Japan & NA & Ohmoto and others (1983) \\
\hline & Mineralization in the Kuril Islands & NA & Ishihara (1994) \\
\hline & $\begin{array}{l}\text { Evolution in space and time of epithermal mineralization } \\
\text { in northeastern Hokkaido, Japan }\end{array}$ & NA & Yahata and others (1999) \\
\hline & $\begin{array}{l}\text { Quaternary gold mineralization and its geologic environ- } \\
\text { ments in Kyushu, Japan }\end{array}$ & NA & Izawa and Urashima (1987) \\
\hline & $\begin{array}{l}\text { U.S. Geological Survey On-Line Mineral Resources } \\
\text { Spatial Data }\end{array}$ & NA & U.S. Geological Survey (2012) \\
\hline & Unpublished data & NA & $\begin{array}{l}\text { Geological Survey of Japan Assessment Team, } \\
\text { this report }\end{array}$ \\
\hline Geochemistry & Unpublished data & NA & $\begin{array}{l}\text { Geological Survey of Japan Assessment Team, } \\
\text { this report }\end{array}$ \\
\hline Exploration & Unpublished data & NA & $\begin{array}{l}\text { Geological Survey of Japan Assessment Team, } \\
\text { this report }\end{array}$ \\
\hline
\end{tabular}




\section{References Cited}

Cox, D.P., 1986, Descriptive model of porphyry Cu, in Cox, D.P. and Singer, D.A., eds., Mineral deposit models: U.S. Geological Survey Bulletin 1693, p. 76. (Also available at http://pubs.usgs.gov/bul/b1693/.)

Garwin, S., Hall, R., and Watanabe, Y., 2005, Tectonic setting, geology, and gold and copper mineralization in Cenozoic magmatic arcs of southeast Asia and the west Pacific, in Hedenquist, T.W., Thompson, J.F.H., Goldfarb, R.J., and Richards, J.P., eds., One hundredth anniversary volume 1905-2005: Littleton, Colorado, Society of Economic Geologists, p. 891-930.

Geological Survey of Japan, ed., 1995, Geological map of Japan 1:1,000,000, (3d ed.): Geological Survey of Japan Digital Geoscience Map G-1, scale 1:1,000,000, 2nd CD-ROM version.

Hedenquist, J.W., Matsuhisa, Y., Izawa, E., White, N.C., Giggenbach, W.F., and Aoki, M., 1994, Geology, geochemistry, and origin of high sulfidation $\mathrm{Cu}-\mathrm{Au}$ mineralization in the Nansatsu district, Japan: Economic Geology, v. 89, p. $1-30$.

Ishihara, S., 1994, Mineralization in the Kuril Islands: Chishitsu News, no. 480, p. 54-59. [In Japanese.]

Ishihara, Shunso, and Sasaki, Akira, 1991, Ore deposits related to granitic magmatism in Japan-A magmatic viewpoint: Episodes, v. 14, p. 286-292.

Ishihara, Shunso, Sasaki, Akira, and Sato, Kohei, 1992, Metallogenic map of Japan-Plutonism and mineralization: Geological Survey of Japan, scale 1:2,000,000.

Ishihara, Shunso, Sasaki, Akira, and Sato, Kohei, 1992, Metallogenic map of Japan: Geological Survey of Japan, Map Series no. 15-2,3, scale 1:2,000,000.

Izawa, E., and Urashima, Y., 1987, Quaternary gold mineralization and its geologic environments in Kyushu, Japan, in Urashima, Y., ed., Gold deposits and geothermal fields in Kyushu: Tokyo, Society of Mining Geology Guidebook, no. 2, p. 1-12.

Izawa, E., and Watanabe, K., 2001, Overview of epithermal gold mineralization in Kyushu, Japan: Society of Economic Geologists Guidebook Series, v. 34, p. 11-15.

John, D.A., Ayuso, R.A., Barton, M.D., Blakely, R.J., Bodnar, R.J., Dilles, J.H., Gray, Floyd, Graybeal, F.T., Mars, J.C., McPhee, D.K., Seal, R.R., Taylor, R.D., and Vikre, P.G., 2010, Porphyry copper deposit model, chap. B of Mineral deposit models for resource assessment: U.S. Geological Survey Scientific Investigations Report 2010-5070-B, 169 p., accessed September 8, 2010, at http://pubs.usgs.gov/ $\operatorname{sir} / 2010 / 5070 / \mathrm{b} /$

Karakida, Y., Hayasaka, S., and Hase, Y., eds., 1992, Regional Geology of Japan, part 9-Kyushu: Tokyo, Kyoritsu Shuppan Co., Ltd., 371 p. [In Japanese.]
Nokleberg, W.J., Badarch, Gombosuren, Berzin, N.A., Diggles, M.F., Hwang, Duk Hwan, Khanchuk, A.I., Miller, R.J. Naumova, V.V., Obolenskiy, A.A., Ogasawara, Masatsugu, Parfenov, L.M., Prokopiev. A.V., Rodionov, S.M., and Hongquan, Yan, eds., 2004, Digital files for Northeast Asia geodynamics, mineral deposit location, and metallogenic belt maps, stratigraphic columns, descriptions of map units, and descriptions of metallogenic belts: U.S. Geological Survey Open-File Report 2004-1252 (CD-ROM). (Also available at http://pubs.usgs.gov/of/2004/1252/.)

Ohmoto, H., Tanimura, S., Date, J., and Takahashi, T., 1983, Geologic setting of the Kuroko deposits, Japan: Economic Geology Monograph 5, p. 9-54.

Sato, T., 1974, Distribution and geological setting of the Kuroko deposits: Mining Geology Special Issue, no. 6, p. 1-9.

Singer, D.A., Berger, V.I., and Moring, B.C., 2008, Porphyry copper deposits of the World - Database and grade and tonnage models, 2008: U.S. Geological Survey Open-File Report 2008-1155, accessed June 1, 2011, at http://pubs. usgs.gov/of/2008/1155/.

Sudo, S., Watanabe, Y., and Komura, K., 2003, Mineral Resources Map of Kyushu: Tsukuba, Geological Survey of Japan, scale 1:500,000.

U.S. Department of State, 2009, Small-scale digital international land boundaries (SSIB) — Lines, edition 10, and polygons, beta edition 1, in Boundaries and sovereignty encyclopedia (B.A.S.E.): U.S. Department of State, Office of the Geographer and Global Issues.

U.S. Geological Survey, 2012, On-line mineral resources spatial data: U.S. Geological Survey Web site, accessed February 10, 2012, at http://mrdata.usgs.gov/.

Uyeda, Seiya, 1991, The Japanese island arc and the subduction process: Episodes, v.14, p. 190-198.

Watanabe, Y., 1995, A tectonic model for epithermal Au mineralization in NE Hokkaido, Japan: Resource Geology, Special Issue, no. 18, p. 257-269.

Watanabe, Y.,1996, Genesis of vein-hosting fractures in the Kitami region, Hokkaido, Japan: Resource Geology, v. 46, p. 151-166.

Watanabe, Y., 2002, Late Cenozoic metallogeny of southwest Hokkaido, Japan: Resource Geology, v. 52, p. 191-210.

Yahata, M., Kubota, Y., Kurosawa, K., and Yamamoto, K., 1999, Evolution in space and time of epithermal mineralization in northeastern Hokkaido, Japan: Shigen-Chishitsu, v. 49, p. 191-202. [In Japanese, English abstract.]

Yamada, N., Saito, E., and Murata, Y., eds., 1990, Computergenerated geologic map of Japan: Geological Survey of Japan Map Series, no. 22, scale 1:2,000,000. [In Japanese.] 
This page left intentionally blank. 


\section{Appendix N. Description of Spatial Data Files}

Three ESRI shapefiles (.shp), a file geodatabase (.gdb) and an ESRI map document (.mxd) are included with this report. The file geodatabase contains four feature classes and two data tables. These may be downloaded from the USGS Web site as zipped file GIS_SIR2010-5090-P.zip.

The file geodatabase is $\mathbf{E} \_\mathbf{S E} \_\mathbf{A s i a} \_\mathbf{p C u}$ and contains the following four feature classes and two tables:

E-SE_Asia_pCu_Tracts-a polygon feature class that represents permissive tracts for East and South East Asia. Attributes include the tract identifiers, tract name, a brief description of the basis for tract delineation, and assessment results. Attributes are defined in the metadata that accompanies the feature class.

E_SE_Asia_pCu_Deposits_prospects-point feature class for locations of known deposits (identified resources that have well-defined tonnage and copper grade) and prospects. Feature class attributes include the assigned tract, alternate site names, information on grades and tonnages, age, mineralogy, associated igneous rocks, site status, comments fields, data sources, and references. Attributes are defined in the metadata that accompanies the feature class. Note that tonnage and grade information are numeric fields; entries of -9999 in these fields mean that no data are available. Entries of 0 in the Age_Ma field mean that no data are available.

E-SE_Asia_political_boundaries_-polygon feature class showing countries within and adjacent to the study area. The feature class is extracted from the country and shoreline boundaries maintained by the U.S. Department of State (2009).

SSIB_Borders-line feature class showing internal country boundaries. The feature class is maintained by the U.S. Department of State (2009).

Probabilistic assessment results are included in two tables in the GIS map document.

Means data table - shows the mean expected amount for each commodity by tract in East and South East Asia.

Quantiles data table - shows the probabilistic assessment results as quantiles for each commodity by tract.

Four shapefiles are included (E_SE_Asia_pCu_Tracts. shp, E_SE_Asia_pCu_Deposits_prospects.shp, E_SE Asia_political_boundaries.shp and SSIB_Borders.shp). The shapefiles have been created from the feature classes. They represent an exact copy of the feature class in shapefile format.

These four feature classes are included in an ESRI map document (version 10 Service Pack 5): E_SE_Asia_pCu. mxd. Probabilistic assessment results are included in two relate tables in the GIS package; Excel versions of these tables also are provided. Mean, shows the mean amount for each commodity by tract. Quantiles, shows probabilistic assessment results as quantiles for commodity by tract.

\section{Reference Cited}

U.S. Department of State, 2009, Small-scale digital international land boundaries (SSIB)-Lines, edition 10, and polygons, beta edition 1, in Boundaries and sovereignty encyclopedia (B.A.S.E.): U.S. Department of State, Office of the Geographer and Global Issues. 
This page left intentionally blank. 


\section{Appendix 0. Assessment Team}

Arthur A. Bookstrom, USGS Geology, Minerals, Energy, and Geophysics Science Center, Spokane, Wash., United States. Economic geologist with expertise on porphyry copper and mineral resource assessment. Dr. Bookstrom participated in the final quantitative assessment for the Philippines.

Dennis P. Cox, USGS Geology, Minerals, Energy, and Geophysics Science Center, Menlo Park, Calif., United States. Dr. Cox is an emeritus scientist with the USGS. Dr. Cox is an expert on porphyry copper deposits. He participated in project workshops in 2005.

Michael W. DeMarr, George Mason University, Fairfax, Va. Intern with USGS Eastern Mineral and Environmental Resources Science Center, Reston, Va. Assisted with the GIS compilation and analysis of the data for South Korea.

Connie L. Dicken, USGS Eastern Mineral and Environmental Resources Science Center, Reston, Va., United States. GIS task leader for the USGS Global Mineral Resource Assessment Project. Ms. Dicken compiled the GIS for the project.

Jane M. Hammarstrom, USGS Eastern Mineral and Environmental Resources Science Center, Reston, Va., United States. Co-chief, USGS Global Mineral Resource Assessment Project since 2007. Task leader, porphyry copper assessment. Mrs. Hammarstrom led the 2009 workshop in Busan, South Korea.

Steve Ludington, USGS Geology, Minerals, Energy, and Geophysics Science Center, Menlo Park, Calif., United States. Economic geologist with expertise on porphyry copper and mineral resource assessment. Dr. Ludington participated in the 2009 workshop in Busan, South Korea, and provided estimates for final quantitative assessment of the Philippines.

Claro C. Manipon, Mines and Geosciences Bureau, Department of Environment and Natural Resources, Republic of the Philippines. Mr. Manipon provided information on porphyry copper deposits and prospects in the Philippines and participated in the 2005 workshop in Kunming, China.

Lilian A. Rollan, Supervising science research specialist, Mines and Geosciences Bureau, Department of Environment and Natural Resources, Republic of the Philippines. CCOP representative for the Philippines at the 2009 Busan workshop.

Gilpin R. Robinson, Jr., USGS Eastern Mineral and Environmental Resources Science Center, Reston, Va., United States. Dr. Robinson is a geologist, geochemist, and mineralresources specialist working on mineral resource assessment and other projects, including geologic mapping, studies of the origin and genesis of metal and industrial-mineral deposits, and geochemical modeling.

Takehiro Sakimoto, Geological Survey of Japan, National Institute of Advanced Industrial Science and Technology (AIST). Dr. Sakimoto participated in the 2005 workshop for Japan.

Tetsuichi Takagi, Geological Survey of Japan, National Institute of Advanced Industrial Science and Technology (AIST). Dr. Takagi is an expert on the metallogeny of Japan and the origins of magnetite- and ilmenite series granitoids. CCOP representative for Japan at the 2009 Busan workshop.

Yashushi Watanabe, Geological Survey of Japan, National Institute of Advanced Industrial Science and Technology (AIST). Dr. Watanabe served as the Group Leader for the AIST Mineral Resources Research Group and was the CCOP representative for Japan and leader of the Japan assessment at the 2005 workshop in Kunming, China.

Michael L. Zientek, USGS Geology, Minerals, Energy, and Geophysics Science Center, Spokane, Wash., United States. Co-chief, USGS Global Mineral Resource Assessment Project since 2007. Dr. Zientek provided estimates for the final quantitative assessment of the Philippines. 
Menlo Park Publishing Service Center, California

Manuscript approved for publication January 24, 2013

Edited by Chet Zenone and James W. Hendley II

Layout and design by James E. Banton 

